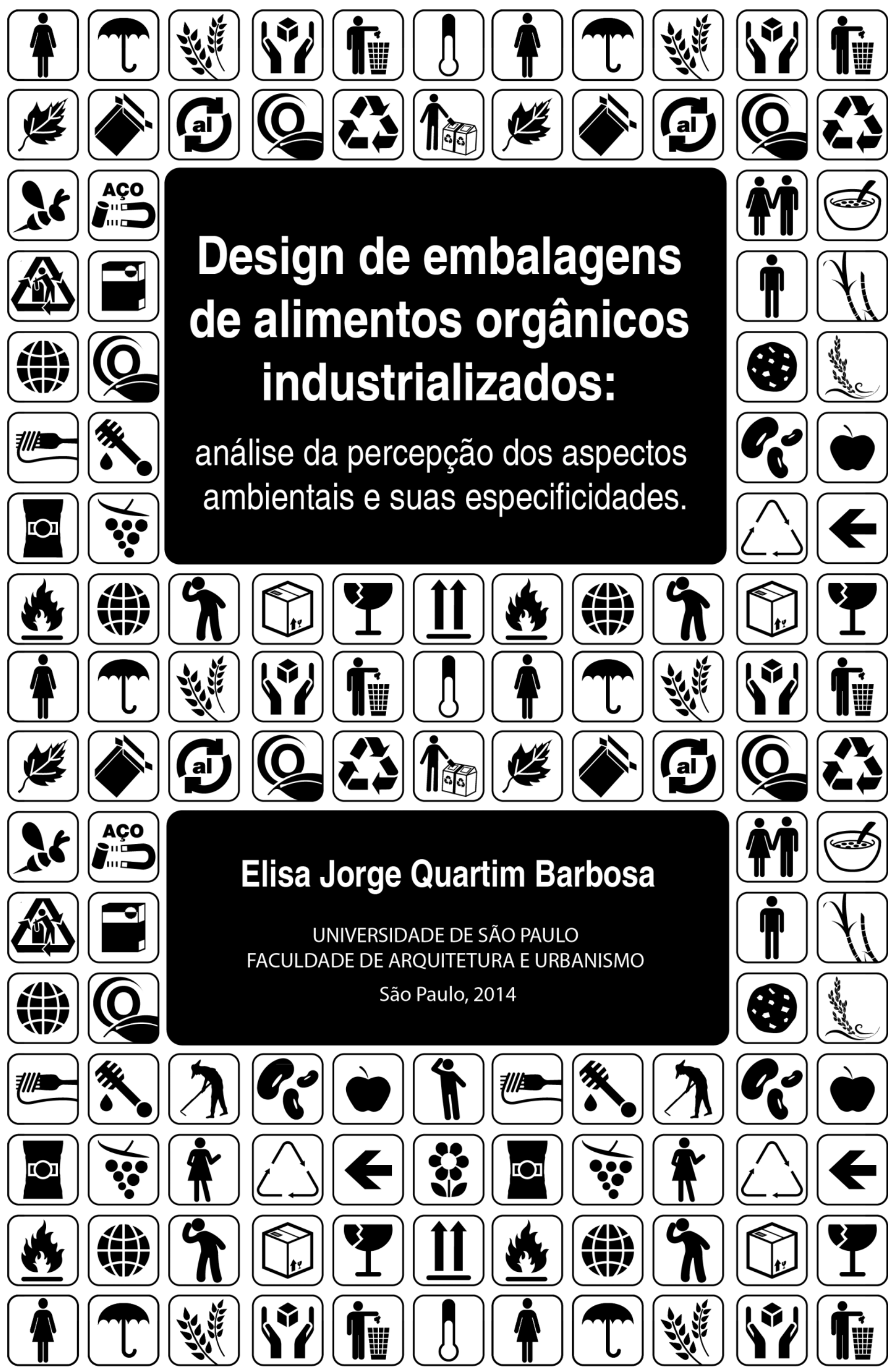




\section{Design de embalagens de alimentos orgânicos industrializados: análise da percepção dos aspectos ambientais e suas especificidades.}

Dissertação apresentada à Faculdade de Arquitetura e Urbanismo da Universidade de São Paulo como parte dos requisitos necessários à obtenção do título de Mestre em Arquitetura e Urbanismo

Área de concentração:

Design e Arquitetura

Orientadora:

Prof. ${ }^{a}$ Dra. Denise Dantas 
AUTORIZO A REPRODUÇÃO E DIVULGAÇÃO TOTAL OU PARCIAL DESTE TRABALHO, POR QUALQUER MEIO CONVENCIONAL OU ELETRÔNICO, PARA FINS DE ESTUDO E PESQUISA, DESDE QUE CITADA A FONTE.

E-MAIL DA AUTORA: elisaqb@gmail.com

\section{Barbosa, Elisa Jorge Quartim}

B238d Design de embalagens de alimentos orgânicos industrializados: análise da percepção dos aspectos ambientais e suas especificidades / Elisa Jorge Quartim Barbosa. -- São Paulo, 2014. 391 p.: il.

Dissertação (Mestrado - Área de Concentração: Design e Arquitetura) - FAUUSP.

Orientadora: Denise Dantas

1.Design 2.Embalagens de alimentos 3.Impactos ambientais 4.Alimentos industrializados orgânicos I.Título 


\section{Design de embalagens de alimentos orgânicos industrializados: análise da percepção dos aspectos ambientais e suas especificidades.}

Dissertação apresentada à Faculdade de Arquitetura e Urbanismo da Universidade de São Paulo como parte dos requisitos necessários à obtenção do título de Mestre em Arquitetura e Urbanismo

Aprovado em:

\section{Banca Examinadora}

Prof. Dr. Instituição:

Julgamento: Assinatura:

Prof. Dr. Instituição:

Julgamento: Assinatura:

Prof. Dr. Instituição: Assinatura: 
Dedico esse trabalho aos meus pais, Eliana e Luiz Antonio, e ao meu melhor amigo e companheiro, Sandro. 


\section{AGRADECIMENTOS}

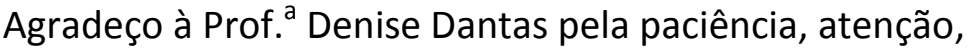
trabalho e seu verdadeiro apoio como orientadora.

Ao $\mathrm{CNPq}$, pelo financiamento dessa pesquisa que permitiu minha dedicação ao mestrado.

Agradeço à minha família pelo suporte emocional e afetivo e, em especial, à minha mãe, Eliana Quartim Barbosa, que sempre me deu força e carinho, e cedeu seu tempo várias vezes para ler e ajudar no fosse preciso o trabalho.

Ao meu companheiro de vida, Sandro Friedland, pelo carinho, apoio nos momentos em que tive de estar ausente, e pelas inumeráveis formas em que me ajudou, possibilitando a realização desse trabalho.

Ao Prof. Cláudio Portugal, por transmitir sua paixão pela pesquisa e design.

À Prof. ${ }^{a}$ Maria Cecília Loschiavo, por ter me mostrado um design mais humanizado logo no começo da pesquisa.

À Prof. ${ }^{a}$ Cyntia Malaguti, que me recebeu na disciplina Design de Embalagem como estagiária para o Programa de Aperfeiçoamento de Ensino da USP e me deu conselhos importantes para esta pesquisa.

À minha amiga e colega de jornada na FAU USP, Rosana Vasques, que compartilhou a sua experiência como pósgraduanda e mostrou informações fundamentais para a consolidação desta dissertação.

Às empresas Mãe Terra, Monama, Via Pax Bio e seus representantes, que abriram suas portas e forneceram informações valiosas para esta pesquisa.

A todos os entrevistados que aceitaram participar desta pesquisa e confiaram a mim suas declarações.

Aos autores e instituições, citados, cujos trabalhos são ricas fontes de conhecimento.

Aos colegas e professores da FAU USP pela amizade e troca de experiências.

A todos que de alguma forma contribuíram direta ou indiretamente com esse trabalho. 
Aceitar os limites da ciência é aceitar os limites do conhecimento humano, um passo fundamental em direção a uma nova postura de humildade perante a Natureza.

Marcelo Gleiser 
BARBOSA, E. J. Q. Design de embalagens de alimentos orgânicos industrializados: análise da percepção dos aspectos ambientais e suas especificidades. 2014. 391 p. Dissertação (Mestrado). Faculdade de Arquitetura e Urbanismo, Universidade de São Paulo, São Paulo, 2014.

\title{
RESUMO
}

Este estudo tem como objetivo verificar a coerência entre o design das embalagens de alimentos orgânicos industrializados, seu conteúdo e a filosofia dos produtores, conforme critérios técnicos, ambientais e percepção dos consumidores. Foram selecionados produtos nos principais pontos de venda paulistanos, presentes no mercado entre 2011 e 2013. Foram feitas entrevistas com os consumidores para verificar a percepção das informações sobre o produto e fabricantes, em relação às especificidades dos produtos orgânicos. Os resultados foram comparados com a avaliação técnica das embalagens, indicando possíveis deficiências de projeto e pontos positivos, de modo a subsidiar futuros projetos de embalagens com melhor identificação das características ambientais associadas a essa categoria.

Palavras-chave: Design. Embalagens de alimentos. Impactos ambientais. Alimentos industrializados orgânicos

\begin{abstract}
The present study aims to verify the consistency between the packaging design of processed organic food, its content and the producers' philosophy, according to technical and environmental criteria, and consumer perception. Products were selected on the main points of sale in São Paulo, commercially available between 2011 and 2013. Interviews with consumers were made to verify the perception of the product and manufacturers informations, in relation to the organic products specificities. The results were compared with the packaging technical evaluation, indicating possible design deficiencies and strengths in order to support future packaging designs with a better identify of environmental characteristics associated with that category.
\end{abstract}

Keywords: Design. Packaging food. Environmental impacts. Organic processed food. 


\section{LISTA DE FIGURAS}

Figura 1 - Selo do Sistema Brasileiro de Avaliação da Conformidade Orgânica (SisOrg). ................................. 39

Figura 2 - Certificadoras credenciadas pelo Ministério da Agricultura, Pecuária e Abastecimento. .................. 40

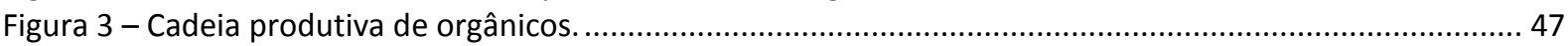

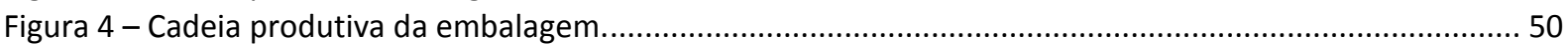

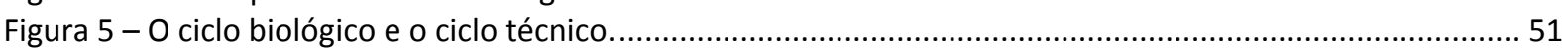

Figura 6 - Centros de atenção comparados com os centros geométricos ...................................................5 58

Figura 7 - Ponto de entrada e de atenção da visualização pelo usuário ......................................................5 58

Figura 8 - Padrão primário de varredura de campo que reage aos referentes verticais-horizontais. ...............58

Figura 9 - Padrão secundário de varredura que reage ao impulso perceptivo inferior-esquerdo...................... 58

Figura 10 - Diferenças entre Rotulagem Ambiental e Simbologia Técnica de Identificação de Materiais ........... 60

Figura 11 - Alguns exemplos de simbologia de identificação de material. ....................................................61

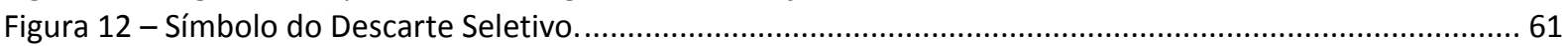

Figura 13 - Selos de pegadas de carbono, transgênicos e o comércio justo. . ....................................................62 62

Figura 14 - Exemplos de posições do valor percentual quando se utiliza o Ciclo de Möbius para fazer declarações sobre conteúdo mínimo de material reciclado na composição. ................................. 62

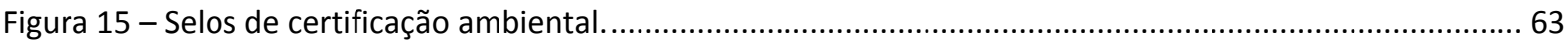

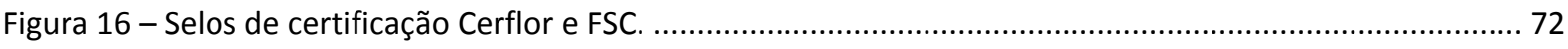

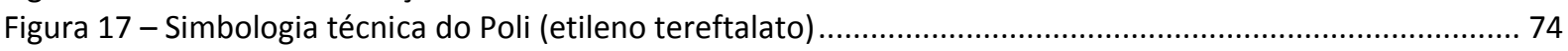

Figura 18 - Simbologia técnica do polietileno de alta e baixa densidade........................................................ 74

Figura 19 - Simbologia técnica do polipropileno e recomendada para o BOPP ........................................... 75

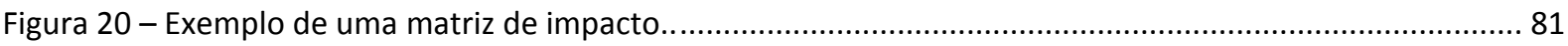

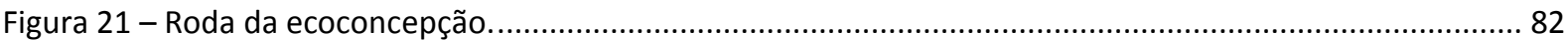

Figura 22 - Marca da Mãe Terra antes da compra da fábrica. .................................................................... 88

Figura 23 - Embalagens antigas da Mãe Terra, antes da compra da fábrica............................................... 88

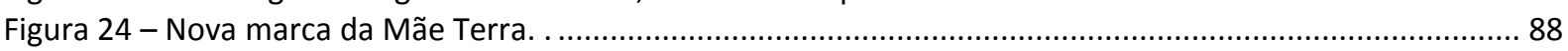

Figura 25 - Embalagens desenvolvidas após o design da identidade visual da Mãe Terra. ................................8 88

Figura 26 - Cerâmica indígena, referência para identidade visual da Mãe Terra............................................ 89

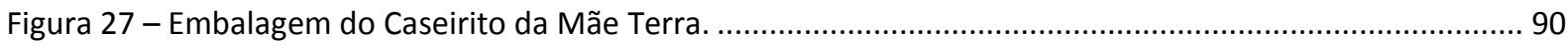

Figura 28 - Embalagem dos Cookies Integraisda Mãe Terra.. .................................................................... 91

Figura 29 - Embalagem do Açúcar Mascavo Extrasseco orgânico da Mãe Terra. . ............................................91

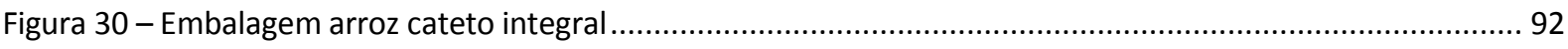

Figura 31 - Marca da Monama desenvolvido pela A10 Design. ............................................................ 93

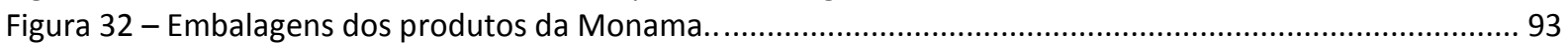

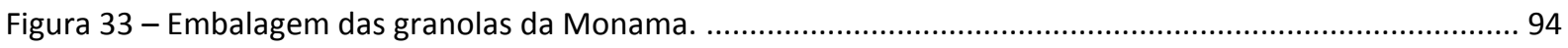

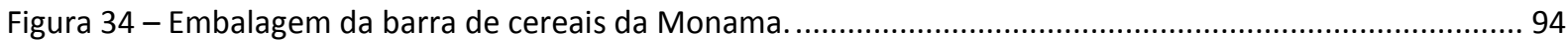

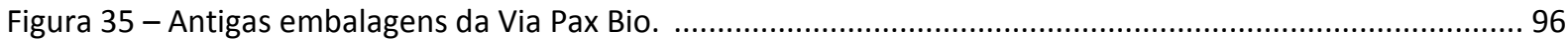

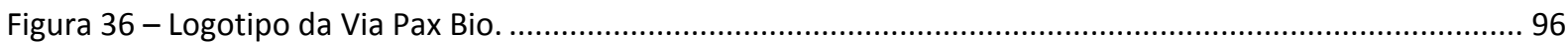

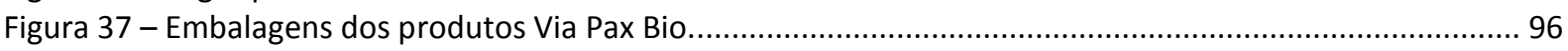

Figura 38 - Instalações do Sítio do Rio do Braço, onde fica a fábrica da Via Pax Bio. ..................................... 97

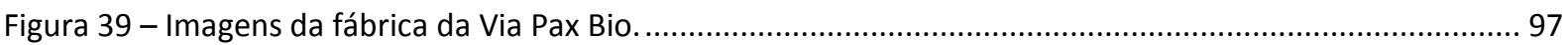

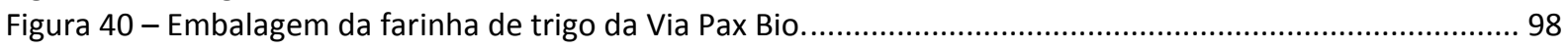

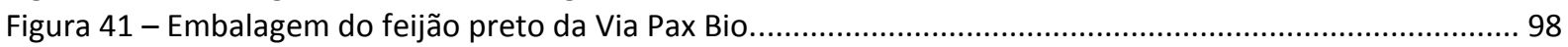

Figura 42 - Quadro de categorias para a análise do conteúdo................................................................. 113

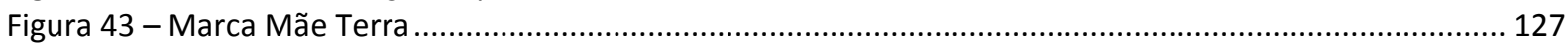

Figura 44 - Evolução da embalagem da linha de ingredientes da Mãe Terra. .............................................. 129

Figura 45- Painel frontal das embalagens da Mãe Terra ........................................................................ 129

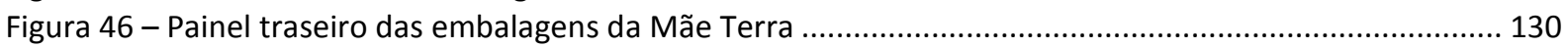

Figura 47 - Painéis laterais das embalagens da Mãe Terra ................................................................... 130

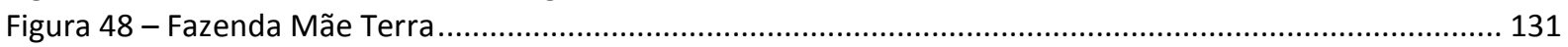

Figura 49 - Janela no painel frontal da embalagem da Mãe Terra ............................................................. 133

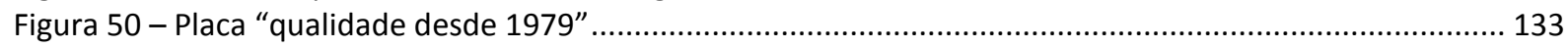

Figura 51 - Box de benefícios da farinha de soja Mãe Terra ...................................................................... 133

Figura 52 - Exemplo da tipografia usada nas embalagens da linha de ingredientes Mãe Terra ....................... 134

Figura 53 - Informações ocultas no painel traseiro das embalagens de arroz integral e farinha de trigo ......... 134

Figura 54- Identificação dos materiais na embalagem: orientação para o descarte nas embalagens do arroz integral, açúcar mascavo e farinha de trigo Mãe Terra .............................................................. 135

Figura 55 - Box Pensando Bem aplicado em quase todas as embalagens Mãe Terra .................................... 136 
Figura 56 - Box com carta de princípios da Mãe Terra. Como é apresentada no Caseirito e nas embalagens com mais espaço.

Figura 57 - Alguns produtos de pronto consumo da Mãe Terra ................................................................ 137

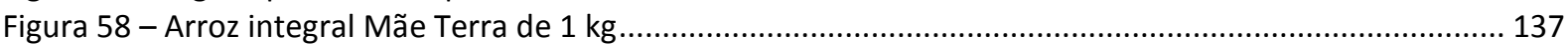

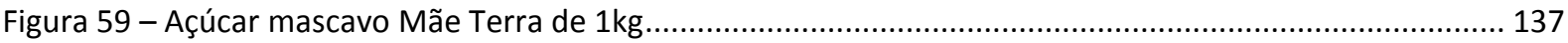

Figura 60 - Farinha de trigo integral Mãe Terra de 1 kg ....................................................................... 137

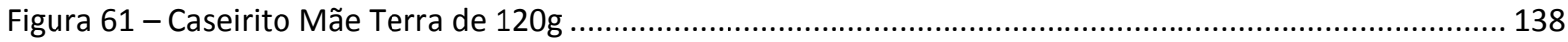

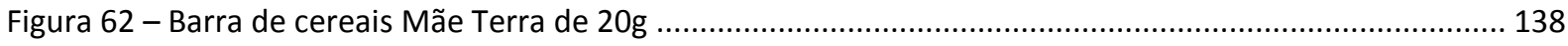

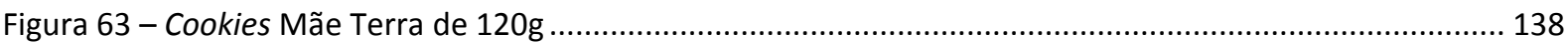

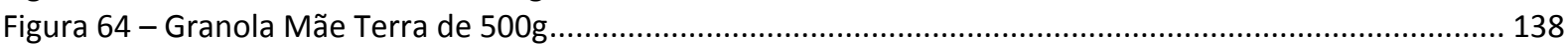

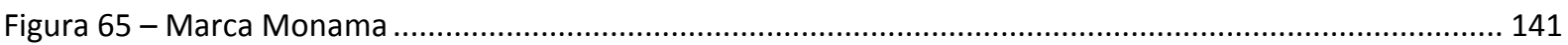

Figura 66 - Grafismos e ilustrações da embalagem de granola Monama. .................................................... 142

Figura 67 - Desdobramento da identidade visual nas embalagens de óleo de coco e chia ............................. 143

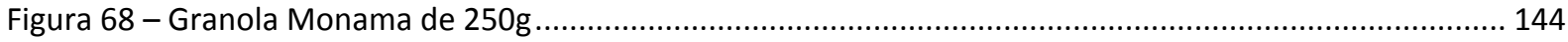

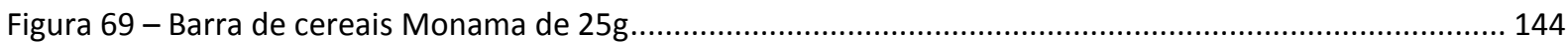

Figura 70 - Teto permite a circulação do ar e a passagem de luz natural ........................................................ 148

Figura 71 - Processo de filtragem do esgoto de todo o Sítio do Braço da Via Pax Bio..................................... 148

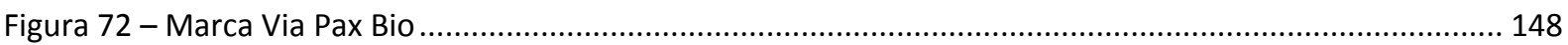

Figura 73 - Painel frontal das embalagens da Via Pax Bio ............................................................................ 150

Figura 74 - Painel traseiro das embalagens da Via Pax Bio .................................................................. 152

Figura 75 - Painel lateral direito das embalagens da Via Pax Bio ............................................................... 153

Figura 76 - Painel lateral esquerdo das embalagens da Via Pax Bio ........................................................ 153

Figura 77 - Tampa das embalagens da Via Pax Bio .................................................................................. 154

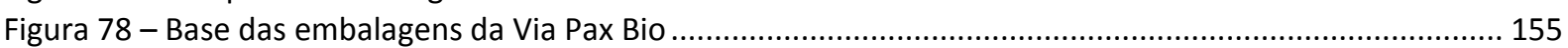

Figura 79 - Hierarquia de leitura das embalagens da linha de ingredientes da Via Pax Bio. ........................... 155

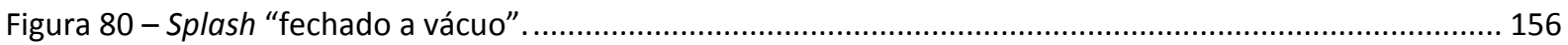

Figura 81 - Janela para visualizar o produto Via Pax Bio ....................................................................... 158

Figura 82 - Detalhe dos ícones na base da embalagem Via Pax Bio ............................................................ 159

Figura 83 - Geleia, néctar, óleo e polpa da Via Pax Bio em emblagens de vidro. Fonte: Via Pax Bio, 2012 ....... 161

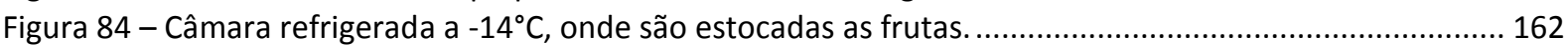

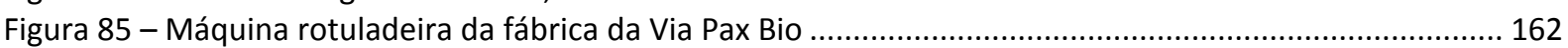

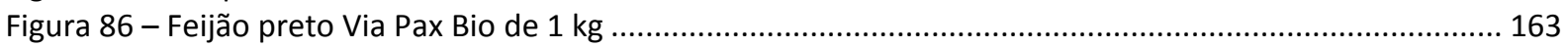

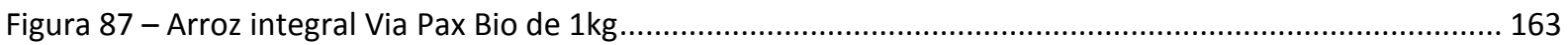

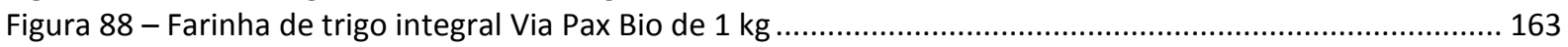

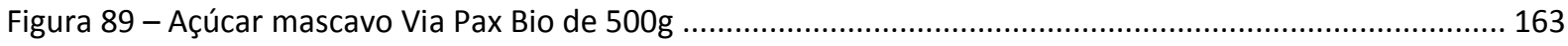

Figura 90 - A palavra 'orgânico', embaixo do nome do produto Identificação para diferenciar um produto orgânico do não orgânico.................................................................................................... 178

Figura 91 - Selo SisOrg substituindo a palavra "orgânico" nas novas embalagens da Mãe Terra .....................178

Figura 92 - A palavra "orgânico" embaixo da marca é usada para diferenciar o produto do não orgânico ...... 180

Figura 93 - Adesivo do selo SisOrg aplicado sobre a embalagem de granola e barra de cereais ....................... 180

Figura 94 - Faixa que identifica a palavra "orgânico" em todas as embalagens Via Pax Bio............................ 180

Figura 95 - Imagens das gravações das entrevistas do Grupo 1 (arroz integral e feijão preto). ...................... 181

Figura 96 - Imagens das gravações das entrevistas do Grupo 2 (farinha de trigo integral e açúcar mascavo) 181

Figura 97 - Imagens das gravações das entrevistas do Grupo 3 (cookie e barra de cereais). ............................ 181

Figura 98 - Imagens das gravações das entrevistas do Grupo 4 (macarrão instantâneo e granola). ............... 182

Figura 99 - Painel frontal da embalagem de arroz integral Mãe Terra ........................................................ 185

Figura 100 - Box da embalagem de arroz integral Mãe Terra ...................................................................... 185

Figura 101 - Painel traseiro da embalagem de arroz integral Mãe Terra ................................................. 185

Figura 102 - Painéis laterais da embalagem de arroz integral Mãe Terra ................................................. 186

Figura 103 - Bases da embalagem de arroz integral Mãe Terra ............................................................ 187

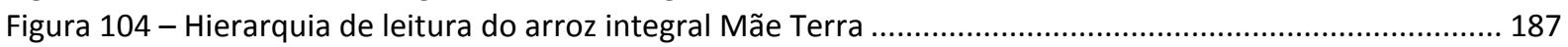

Figura 105 - Painel frontal da embalagem de arroz integral Via Pax Bio ...................................................... 192

Figura 106 - Painel traseiro da embalagem de arroz integral Via Pax Bio.................................................... 193

Figura 107 - Painéis laterais da embalagem de arroz integral Via Pax Bio .................................................... 193

Figura 108 - Tampa e base do arroz integral Via Pax Bio ....................................................................... 194

Figura 109 - Painel frontal da embalagem de feijão preto Via Pax Bio ....................................................... 196

Figura 110 - Painel traseiro da embalagem de feijão preto Via Pax Bio......................................................... 197

Figura 111 - Painéis laterais da embalagem de feijão preto Via Pax Bio...................................................... 197

Figura 112 - Tampa e base da embalagem de feijão preto Via Pax Bio ........................................................ 198 
Figura 113 - Painel frontal da embalagem de açúcar mascavo Mãe Terra ................................................. 203

Figura 114 - Box de benefícios da embalagem de açúcar mascavo Mãe Terra ................................................... 204

Figura 115 - Painel traseiro da embalagem de açúcar mascavo Mãe Terra..................................................... 204

Figura 116 - Base da embalagem de açúcar mascavo Mãe Terra ................................................................205

Figura 117 - Hierarquia de leitura do açúcar mascavo Mãe Terra ...................................................................205

Figura 118 - Tabela nutricional e tabela comparativa ........................................................................... 208

Figura 119 - Painel frontal da embalagem de açúcar mascavo Via Pax Bio ................................................... 210

Figura 120 - Painel traseiro da embalagem de açúcar mascavo Via Pax Bio .................................................. 210

Figura 121 - Painéis laterais da embalagem de açúcar mascavo Via Pax Bio .................................................. 210

Figura 122 - Tampa e base da embalagem de açúcar mascavo Via Pax Bio.................................................... 211

Figura 123 - Painel frontal da embalagem da farinha de trigo Via Pax Bio ..................................................... 213

Figura 124 - Painel traseiro da embalagem da farinha de trigo Via Pax Bio ................................................. 214

Figura 125 - Painéis laterais da embalagem da farinha de trigo Via Pax Bio................................................ 214

Figura 126 - Tampa e base da embalagem da farinha de trigo Via Pax Bio .................................................. 215

Figura 127 - Câmara refrigerada onde é estocada a farinha de trigo Via Pax Bio ......................................... 215

Figura 128 - Painel frontal da embalagem da farinha de trigo integral Mãe Terra .......................................... 218

Figura 129 - Box de benefícios da embalagem da farinha de trigo integral Mãe Terra ................................... 218

Figura 130 - Painel traseiro da embalagem da farinha de trigo integral Mãe Terra ........................................ 219

Figura 131 - Tabela nutricional da embalagem da farinha de trigo integral Mãe Terra .................................... 219

Figura 132 - Base da embalagem da farinha de trigo integral Mãe Terra ................................................... 220

Figura 133 - Hierarquia de leitura da farinha de trigo integral Mãe Terra ..................................................... 220

Figura 134 - Painel frontal da embalagem dos cookies integrais Mãe Terra .............................................. 224

Figura 135 - Painel traseiro da embalagem dos cookies integrais Mãe Terra .................................................. 225

Figura 136 - Hierarquia de leitura dos cookies integrais Mãe Terra ............................................................ 226

Figura 137 - Critérios para separação de barra de cereais como não orgânica. .............................................. 235

Figura 138 - Painel frontal da embalagem de barra de cereais Monama ...................................................... 235

Figura 139 - Painel traseiro da embalagem de barra de cereais Monama.................................................... 236

Figura 140 - Embalagens para comercialização com três barrinhas e caixa display com doze barrinhas. ....... 238

Figura 141 - Painel frontal da embalagem de barra cereal Mãe Terra .................................................... 241

Figura 142 - Painel traseiro da embalagem de barra cereal Mãe Terra ..........................................................2 242

Figura 143 - Painel frontal da embalagem de granola Monama .................................................................. 247

Figura 144 - Painel traseiro da embalagem de granola Monama ................................................................. 248

Figura 145 - Painéis laterais da embalagem de granola Monama ............................................................... 249

Figura 146 - Tampa e base da embalagem de granola Monama ............................................................ 250

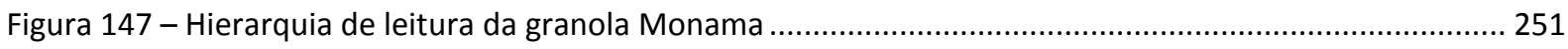

Figura 148 - Ícone que identifica o papel reciclado na embalagem da granola ............................................. 252

Figura 149 - Painel frontal da embalagens de granola Mãe Terra ................................................................ 256

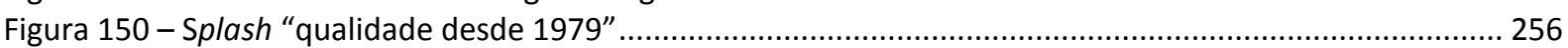

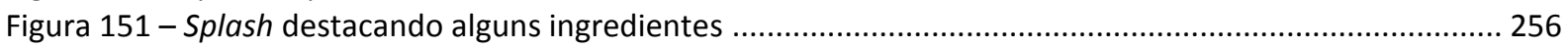

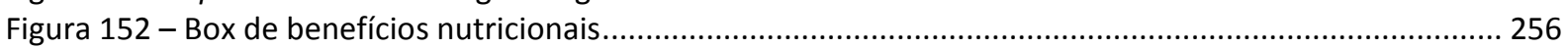

Figura 153 - Painel traseiro da embalagens de granola Mãe Terra .......................................................... 257

Figura 154 - Box como a Mãe Terra desenvolve seus produtos, antes e depois ...........................................257

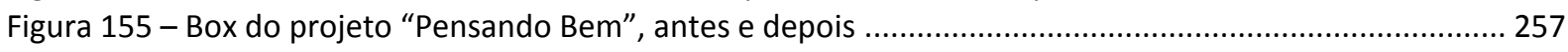

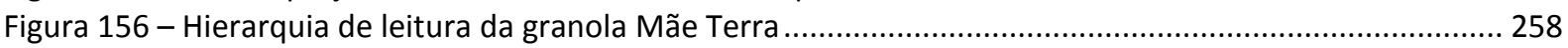

Figura 157 - Painel frontal da embalagem do macarrão instantâneo Caserito Mãe Terra ............................... 262

Figura 158 - Painel traseiro da embalagem do macarrão instantâneo Caserito Mãe Terra ............................. 263

Figura 159 - Painel superior e inferior da embalagem do macarrão instantâneo Caserito Mãe Terra .............. 264

Figura 160 - Hierarquia de leitura do Caseirito Mãe Terra..................................................................... 265

Figura 161 - Simbologia de identificação de materiais e reciclagem da 1a fase das embalagens Mãe Terra .... 272

Figura 162 - Simbologia de identificação de materiais e reciclagem da 2a fase das embalagens Mãe Terra .... 272

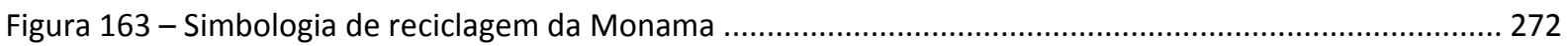

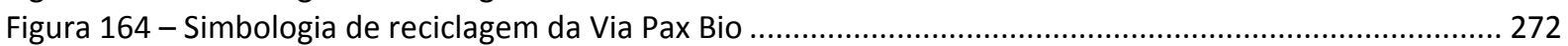

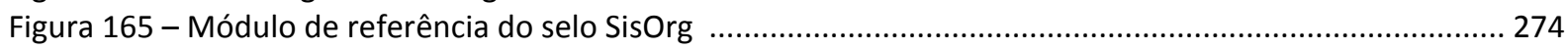

Figura 166 - Forma de apresentação das respostas aos questionamentos desta pesquisa............................ 280 


\section{LISTA DE TABELAS}

Tabela 1 - Número de estudos que comparam proteínas, nitratos, vitaminas e minerais entre a produção

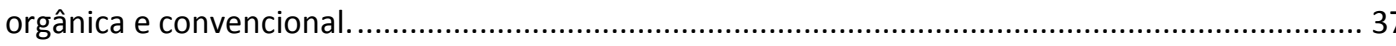

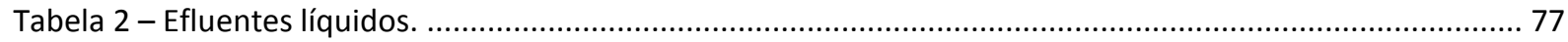

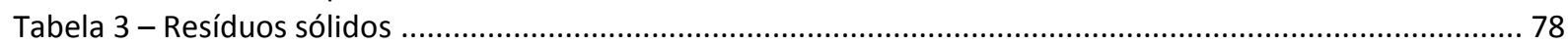

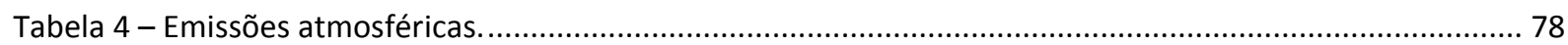

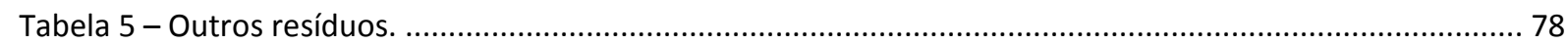

Tabela 6 - Participação dos materiais no total de resíduo urbano coletado no Brasil..................................... 79

Tabela 7 - Indicadores ambientais para o design de embalagem, estabelecidos por órgãos e associações. ....... 86

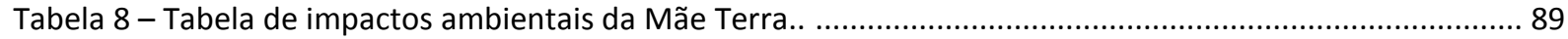

Tabela 9 - Tabela de 7 impactos ambientais do Açúcar Mascavo Extrasseco................................................. 91

Tabela 10 - Tabela de 7 impactos ambientais do Arroz Cateto Orgânico. .......................................................92

Tabela 11 - Materiais e métodos específicos por subproblema .................................................................... 102

Tabela 12 - Grupos de produtos selecionados para a entrevista ........................................................... 114

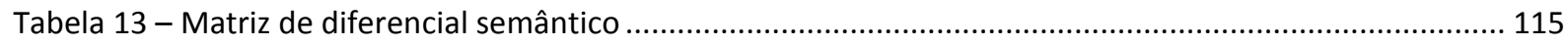

Tabela 14 - Codificação para identificar o perfil do consumidor e número total de consumidores por perfil .. 167

Tabela 15 - Símbolos de identificação de materiais apresentados nas entrevistas e resultados da entrevista

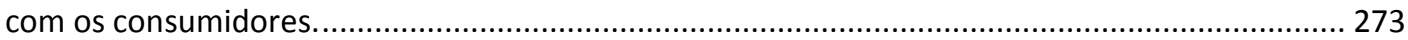

Tabela 16 - Selos de certificação apresentados nas entrevistas e resultados da entrevista com os consumidores. ..274

Tabela 17 - Avaliação do uso de recursos naturais baseada nas declarações das empresas............................ 281

Tabela 18 - Avaliação do uso de recursos naturais baseada nas análises das embalagens selecionadas.......... 282

Tabela 19 - Avaliação do uso de recursos naturais baseada na percepção dos consumidores. ....................... 283

Tabela 20 - Avaliação da produção baseada na percepção dos consumidores. ............................................ 284

Tabela 21 - Avaliação da produção baseada nas análises das embalagens selecionadas ................................ 284

Tabela 22 - Avaliação da produção baseada na percepção dos consumidores .............................................. 285

Tabela 23 - Avaliação da logística baseada nas declarações das empresas ....................................................285

Tabela 24 - Avaliação da logística baseada nas análises das embalagens selecionadas ................................... 286

Tabela 25 - Avaliação da logística baseada na percepção dos consumidores ............................................... 287

Tabela 26 - Avaliação do pós-consumo baseada nas declarações das empresas .......................................... 287

Tabela 27 - Avaliação do pós-consumo baseada nas análises das embalagens selecionadas ........................... 288

Tabela 28 - Avaliação do pós-consumo baseada na percepção dos consumidores ....................................... 289

Tabela 29 - Avaliação do pós-consumo baseada nas declarações das empresas ........................................... 290

Tabela 30 - Avaliação do pós-consumo baseada nas análises das embalagens selecionadas ...........................290

Tabela 31 - Avaliação do pós-consumo baseada na percepção dos consumidores .......................................... 291 


\section{LISTA DE GRÁFICOS}

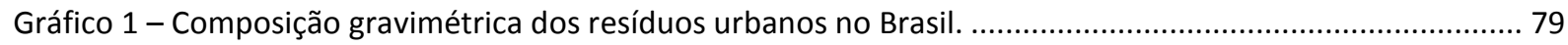

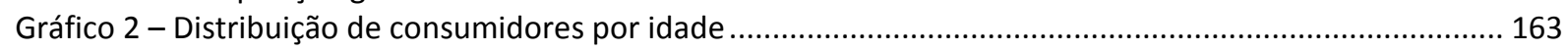

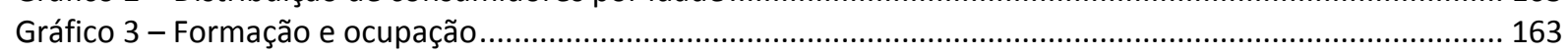

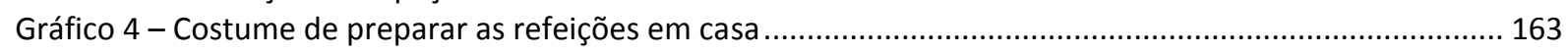

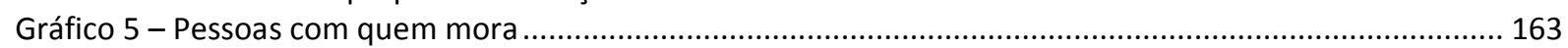

Gráfico 6 - Principais locais de compra de alimentos........................................................................... 164

Gráfico 7 - Costume de fazer lista de compras, ou algum planejamento, antes de ir às compras ................... 164

Gráfico 8 - Motivos para comprar algo fora do planejado ................................................................... 165

Gráfico 9 - Informações decisivas na embalagem para a compra de um produto........................................... 165

Gráfico 10 - Aspectos decisivos da embalagem para a compra de um produto ............................................ 165

Gráfico 11 - Avaliação do conhecimento do que é um orgânico ................................................................ 166

Gráfico 12 - Perfil do consumidor por conhecimento do orgânico por frequência de consumo...................... 167

Gráfico 13 - Percepção do que é um alimento orgânico. ........................................................................ 169

Gráfico 14 - Quantidade de pessoas que confundem orgânico com algo diferente......................................170

Gráfico 15 - Motivos para não ter comprado um alimento orgânico ......................................................... 173

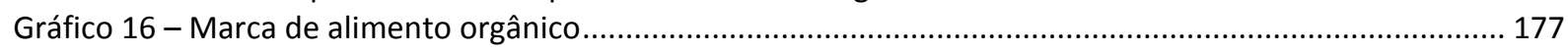

Gráfico 17 - Marcas de arroz integral separadas como mais saudáveis ....................................................... 182

Gráfico 18 - Critérios para a separação de arroz como mais saudável. . ..................................................... 183

Gráfico 19 - Critérios para a separação das marcas de arroz como menos saudável .................................... 183

Gráfico 20 - Marcas de arroz separadas como orgânicas .................................................................... 183

Gráfico 21 - Critérios para a separação do arroz como orgânico .................................................................. 184

Gráfico 22 - Critérios para a separação do arroz como não orgânico ........................................................ 184

Gráfico 23 - Respostas à pergunta “Você já comprou o arroz integral Mãe Terra ou de outro sabor?” $\ldots . . . . . . .188$

Gráfico 24 - Motivos para não ter comprado o arroz Mãe Terra. ................................................................. 188

Gráfico 25 - Aspectos positivos do arroz integral Mãe Terra .............................................................. 188

Gráfico 26 - Aspectos negativos do arroz integral Mãe Terra ................................................................... 189

Gráfico 27 - Matriz semântica arroz Mãe Terra ........................................................................................... 191

Gráfico 28 - Marcas de feijão preto separadas como mais saudáveis ........................................................... 194

Gráfico 29 - Critérios para separação do feijão preto como mais saudável. ................................................ 195

Gráfico 30 - Critérios para separação do feijão preto como menos saudável. .............................................. 195

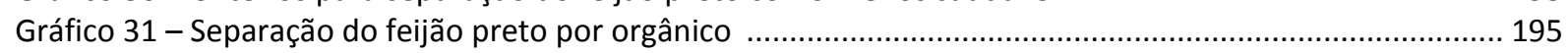

Gráfico 32 - Critérios para separação do feijão preto como orgânico ........................................................ 196

Gráfico 33 - Aspectos positivos do feijão preto Via Pax Bio ............................................................................ 199

Gráfico 34 - Aspectos negativos do feijão preto Via Pax Bio ......................................................................... 199

Gráfico 35 - Diferencial semântico do feijão preto Via Pax Bio.................................................................. 200

Gráfico 36 - Marcas de açúcar mascavo separadas como mais saudáveis ................................................... 201

Gráfico 37 - Critérios para separação do açúcar mascavo como mais saudável ........................................... 201

Gráfico 38 - Critérios para separação do açúcar mascavo como menos saudável ........................................ 201

Gráfico 39 - Marcas de açúcar mascavo separadas como orgânicas ........................................................ 202

Gráfico 40 - Critérios para a separação do açúcar mascavo como orgânico ..................................................... 202

Gráfico 41 - Critérios para a separação do açúcar mascavo como não orgânico ......................................... 203

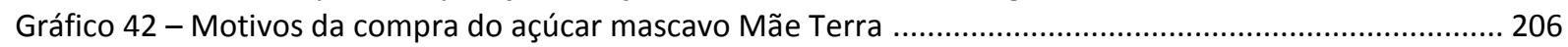

Gráfico 43 - Motivos por não ter comprado o açúcar mascavo Mãe Terra ................................................. 206

Gráfico 44 - Aspectos positivos do açúcar mascavo Mãe Terra ................................................................ 206

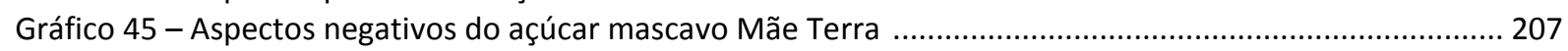

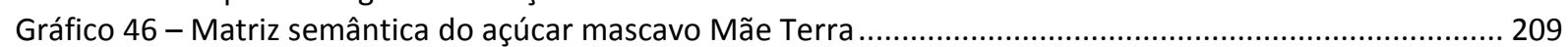

Gráfico 47 - Marcas de farinha de trigo separadas como mais saudáveis ....................................................... 211

Gráfico 48 - Critérios para separação da farinha de trigo integral como mais saudável. ................................. 212

Gráfico 49 - Critérios para a separação da farinha de trigo integral por menos saudável .............................. 212

Gráfico 50 - Marcas de farinha de trigo integral separadas como orgânicas ............................................... 212

Gráfico 51 - Critérios para separação de farinha de trigo integral como orgânica. ...................................... 213

Gráfico 52 - Critérios para separação de farinha de trigo integral como não orgânica. ................................. 213

Gráfico 53 - Aspectos positivos da farinha de trigo integral Via Pax Bio..................................................... 216

Gráfico 54 - Aspectos negativos da farinha de trigo integral Via Pax Bio....................................................... 216

Gráfico 55 - Diferencial semântico da farinha de trigo integral Via Pax Bio................................................. 217

Gráfico 56 - Marcas de cookie separadas como mais saudáveis ...................................................................... 221

Gráfico 57 - Critérios para separação de cookie como mais saudável. ....................................................... 222 
Gráfico 58 - Critérios para separação de cookie como menos saudável. .................................................... 222

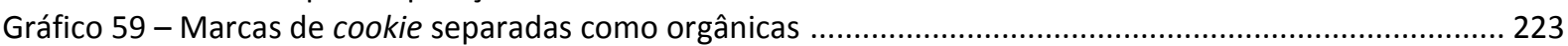

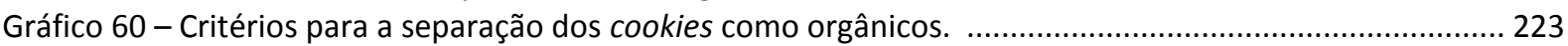

Gráfico 61 - Critérios para a separação de cookie como não orgânico. ...........................................................223

Gráfico 62 - Motivos da compra dos cookies integrais da Mãe Terra ....................................................... 228

Gráfico 63 - Aspectos positivos dos cookies integrais Mãe Terra ............................................................... 228

Gráfico 64 - Aspectos negativos dos cookies integrais Mãe Terra ..............................................................2229

Gráfico 65 - Matriz semântica dos cookies Mãe Terra ......................................................................... 232

Gráfico 66 - Marcas de barra de cereais separadas como mais saudável ....................................................... 233

Gráfico 67 - Critérios para a separação de barra de cereais como mais saudável. .......................................... 233

Gráfico 68 - Critérios para a separação de barra de cereais como menos saudável ........................................2234

Gráfico 69 - Marcas de barra de cereais separadas como orgânicas ...........................................................234

Gráfico 70 - Critérios para separação de barra de cereais como orgânicas ................................................ 235

Gráfico 71 - Aspectos positivos da barra de cereais Monama ................................................................. 238

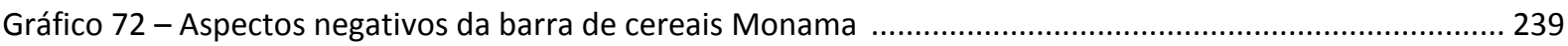

Gráfico 73 - Matriz semântica barra de cereais Monama ................................................................................ 240

Gráfico 74 - Marcas de granola separadas como mais saudáveis ................................................................ 244

Gráfico 75 - Critérios para separação de granola como mais saudável .........................................................245

Gráfico 76 - Critérios para separação de granola como menos saudável .......................................................2 246

Gráfico 77 - Marcas de granola separadas como orgânicas ...................................................................... 246

Gráfico 78 - Critérios para a separação da granola como orgânica ............................................................ 247

Gráfico 79 - Critérios para a separação da granola como não orgânica. ................................................... 247

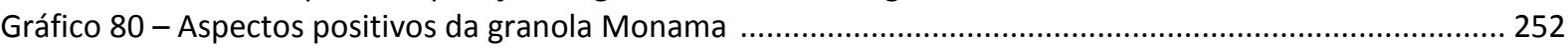

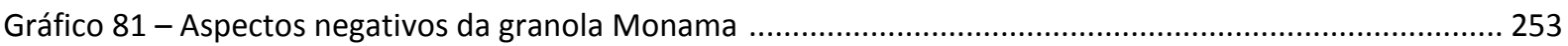

Gráfico 82 - Matriz semântica da granola Monama .......................................................................................25 255

Gráfico 83 - Marcas de macarrão instantâneo separadas como mais saudáveis .......................................... 259

Gráfico 84 - Critérios para separação de macarrão instantâneo como mais saudável ....................................260

Gráfico 85 - Critérios para separação de macarrão instantâneo como menos saudável ................................. 261

Gráfico 86 - Marcas de macarrão instantâneo separadas como orgânicas ................................................ 261

Gráfico 87 - Critérios para separação de macarrão instantâneo como orgânico ............................................ 261

Gráfico 88 - Critérios para a separação de macarrão instantâneo como não orgânico. ...................................262

Gráfico 89 - Motivos para não ter comprado o macarrão instantâneo Caseirito .............................................266

Gráfico 90 - Aspectos positivos do macarrão instantâneo Caseirito Mãe Terra ............................................. 267

Gráfico 91 - Aspectos negativos do macarrão instantâneo Caseirito Mãe Terra ........................................... 267

Gráfico 92 - Matriz semântica macarrão instantâneo Caseirito Mãe Terra ....................................................2 270

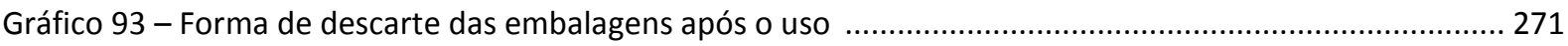

Gráfico 94 - Quando fica em dúvida de como separar para a reciclagem, o que faz? .................................. 271 


\section{LISTA DE ABREVIATURAS E SIGLAS}

ABRE - Associação Brasileira de Embalagem

ABTG - Associação Brasileira de Tecnologia Gráfica

ACV - Avaliação do Ciclo de Vida

ANVISA - Agência Nacional de Vigilância Sanitária

CETESB - Companhia de Tecnologia de Saneamento Ambiental,

EUROPEN - European Organization for Packaging and the Environment

Fiocruz - Fundação Oswaldo Cruz

$\mathrm{FiBL}$ - Research Institute of Organic Agriculture

IBD - Instituto Biodinâmico

IFOAM - International Federation of Organic Agriculture Movements

ISO - International Organization for Standadization

INMETRO - Instituto Nacional de Metrologia, Normalização e Qualidade Industrial

MAPA - Ministério da Agricultura, Pecuária e Abastecimento

PEAD - Polietileno de alta densidade

PEBD - Polietileno de baixa densidade

PET - Poli (tereftalato de etileno)

POPAI - Point of Purchase Advertising International

PP - Polipropileno

PS - Poliestireno

PVC - Poli (cloreto de vinila)

SisOrg - Sistema Brasileiro de Avaliação da Conformidade Orgânica

SPC - Sustainable Packaging Coalition

UNEP - United Nations Environment Programme

WWF - World Wide Fund for Nature 


\section{SUMÁRIO}

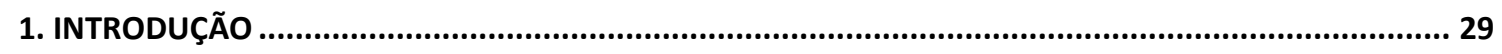

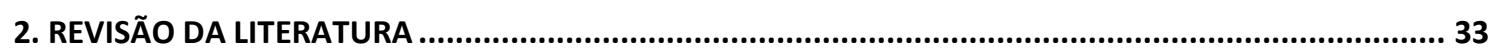

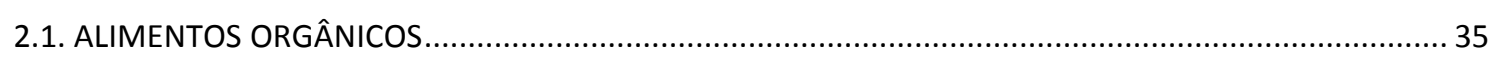

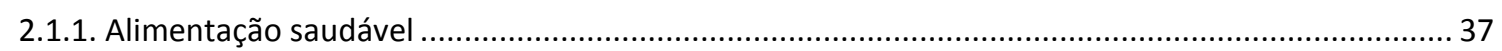

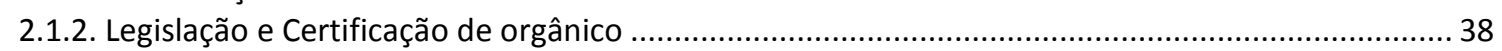

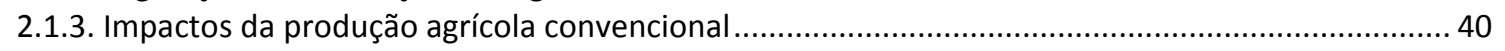

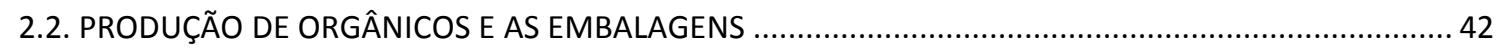

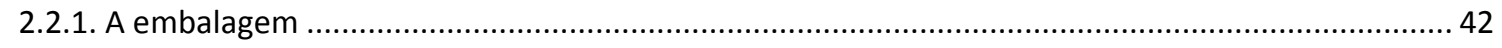

2.2.2. Aspectos reguladores das embalagens de alimentos orgânicos .................................................... 43

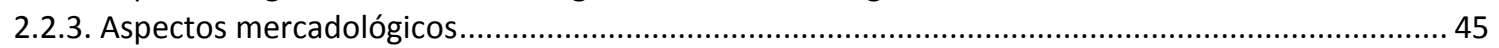

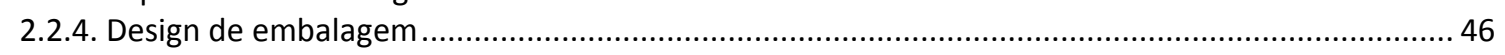

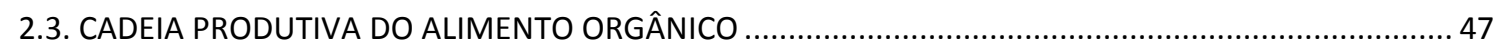

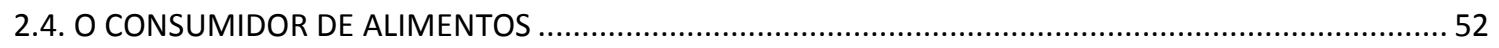

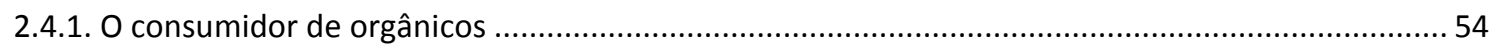

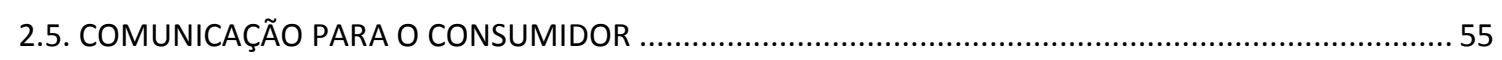

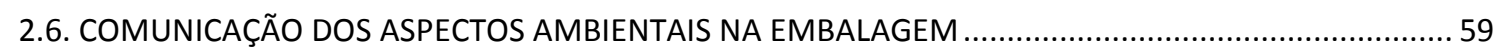

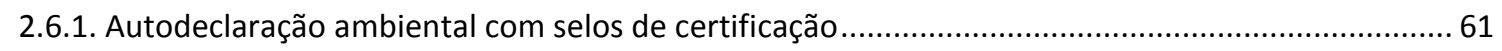

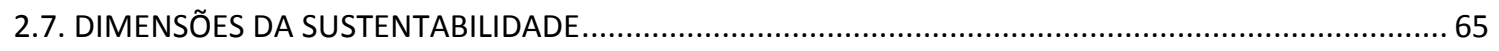

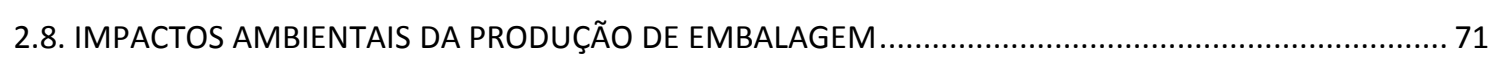

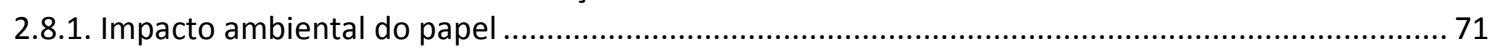

2.8.2. Impacto ambiental das embalagens flexíveis em filmes plásticos ................................................ 73

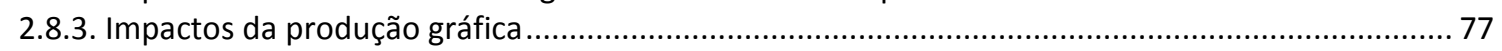

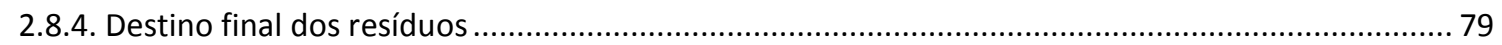

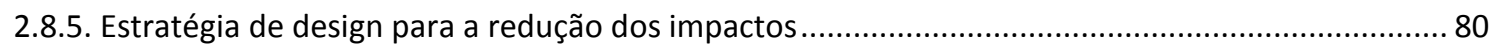

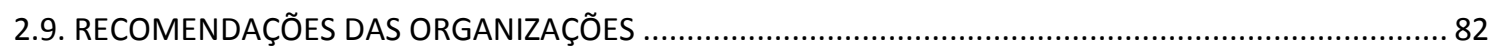

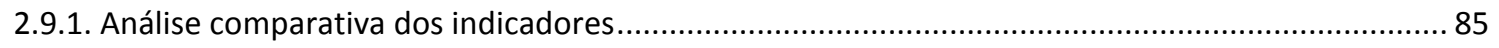

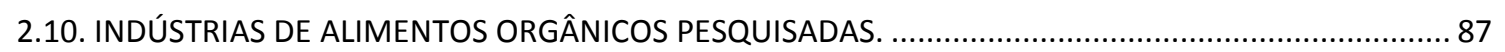

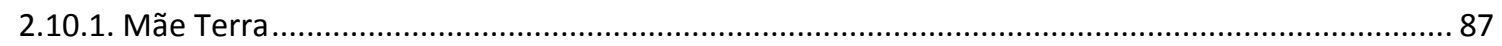

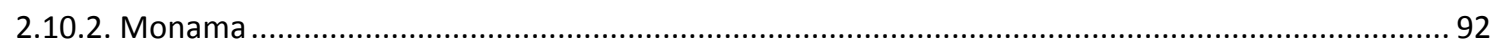

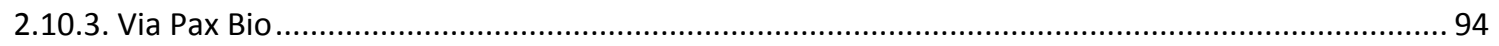

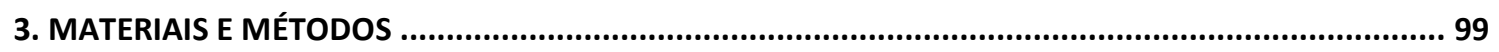

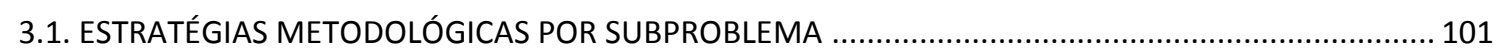

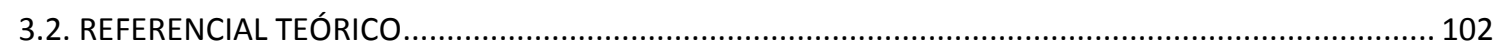

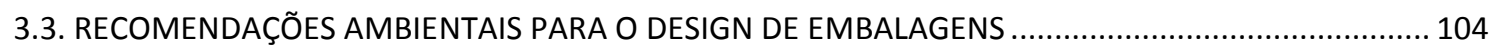

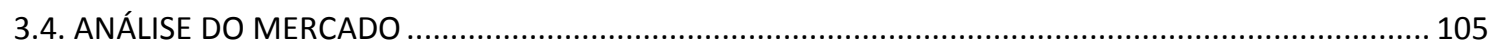

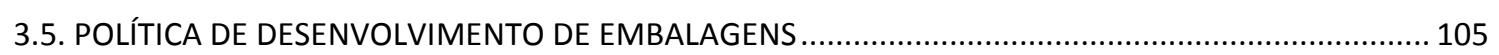

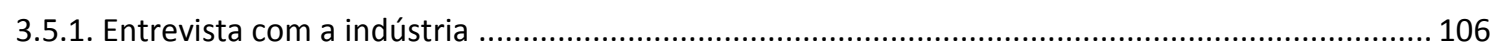

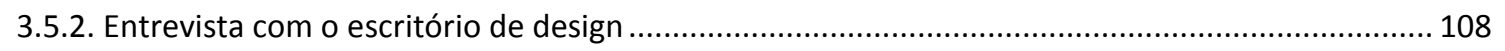

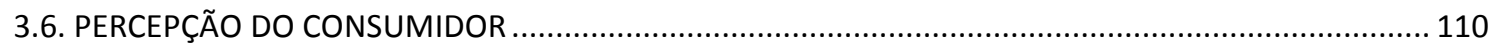

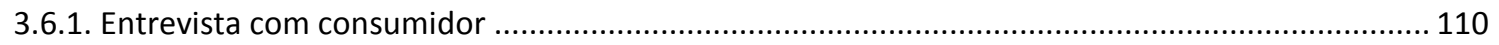

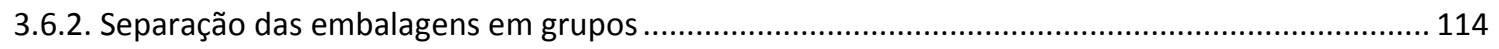

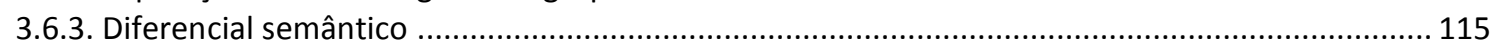

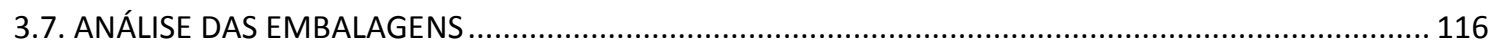

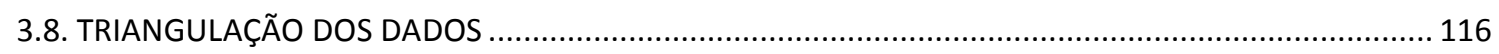




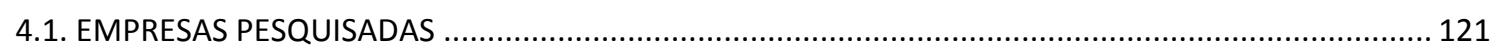

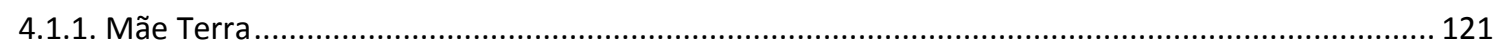

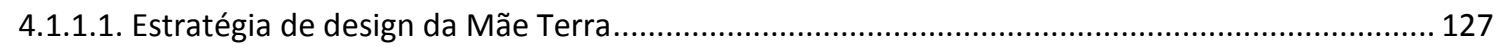

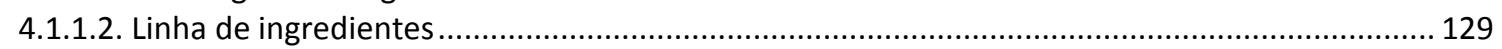

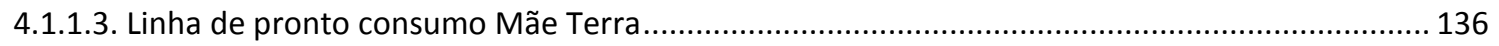

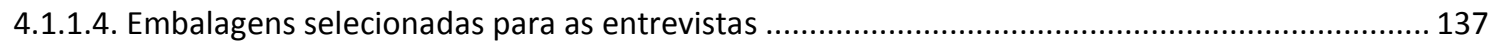

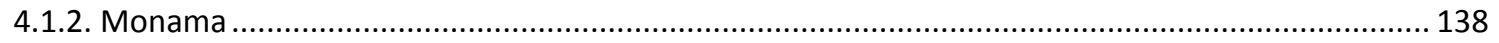

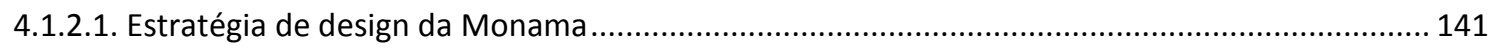

4.1.2.2. Extensão da linha de produtos Monama .............................................................................. 143

4.1.2.3. Embalagens selecionadas para as entrevistas .................................................................. 144

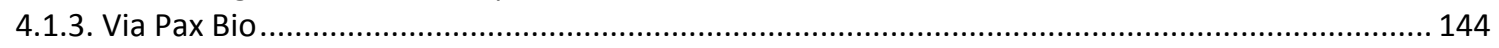

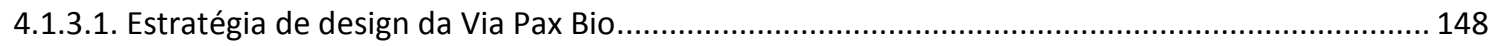

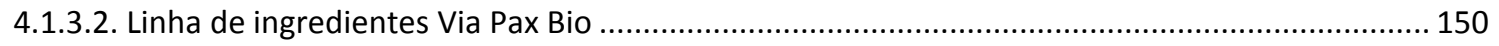

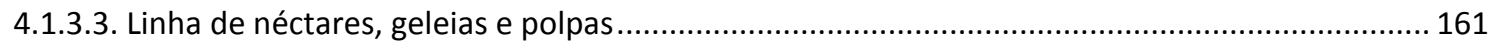

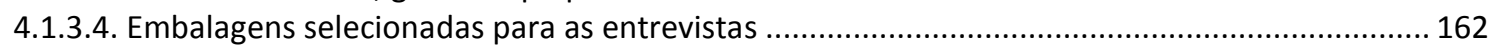

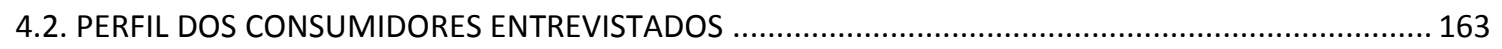

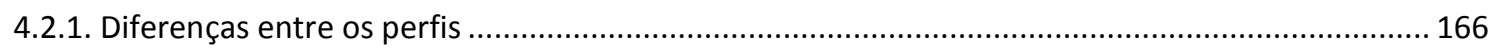

4.3. RECONHECIMENTO E IDENTIFICAÇÃO DOS ALIMENTOS ORGÂNICOS........................................... 167

4.3.1. Relacionando o alimento orgânico com alimentos saudáveis ................................................. 175

4.3.2. Relacionamento do orgânico com a marca....................................................................... 177

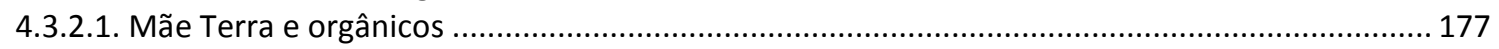

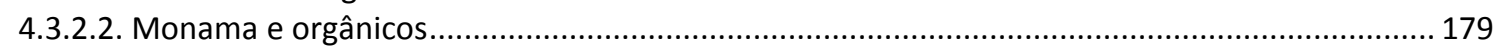

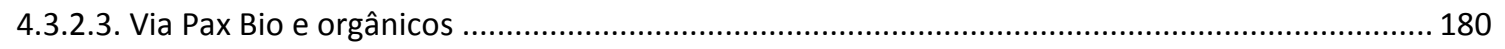

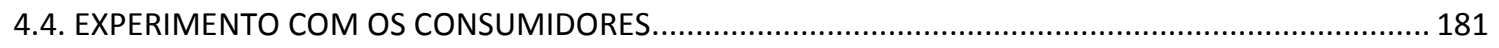

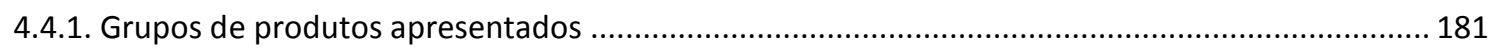

4.4.2. Arroz integral do Grupo 1 de não processados..................................................................... 182

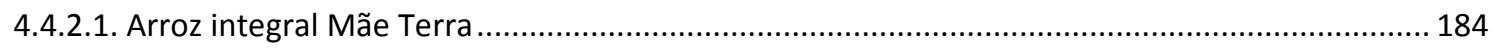

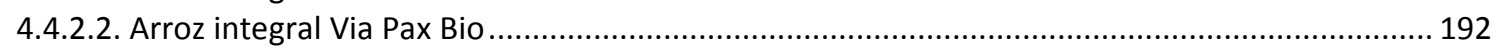

4.4.3. Feijão preto do Grupo 1 de não processados ...................................................................... 194

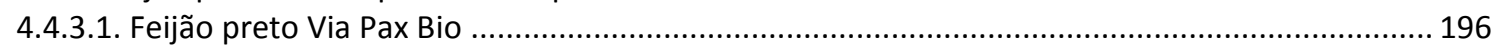

4.4.4. Açúcar mascavo do Grupo 2 de pouco processado ................................................................ 200

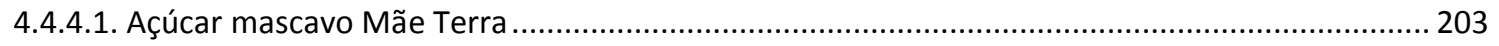

4.4.4.2. Açúcar Mascavo Via Pax Bio.................................................................................................. 209

4.4.5. Farinha de trigo integral do Grupo 2 de pouco processado .................................................... 211

4.4.5.1. Farinha de trigo integral Via Pax Bio ................................................................................. 213

4.4.5.2. Farinha de trigo Integral Mãe Terra .................................................................................. 217

4.4.6. Cookies do Grupo 3 de pronto consumo........................................................................................ 221

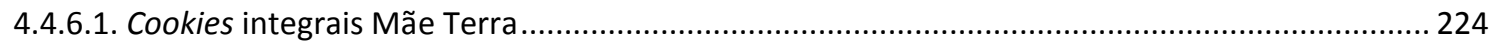

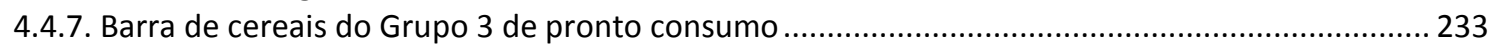

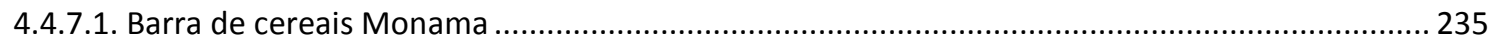

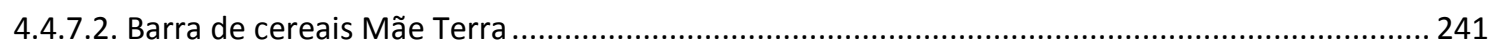

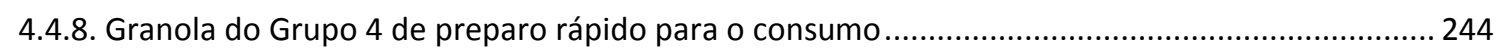

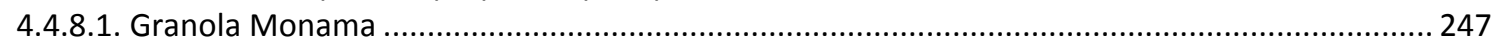

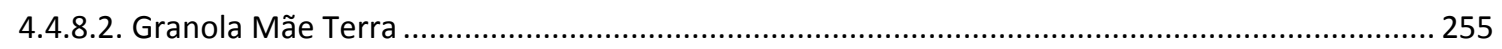

4.4.9. Macarrão instantâneo do Grupo 4 de preparo rápido para o consumo ..................................... 259

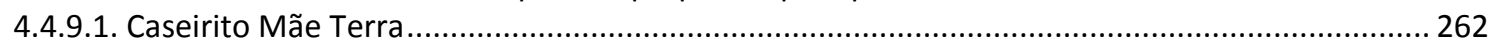

4.5. PÓS-CONSUMO, SIMBOLOGIA DE RECICLAGEM E CERTIFICAÇÃO................................................. 271

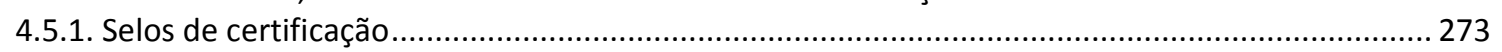

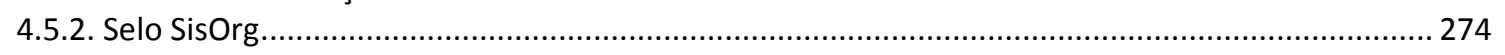

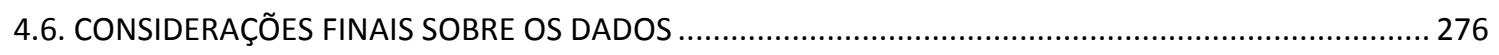

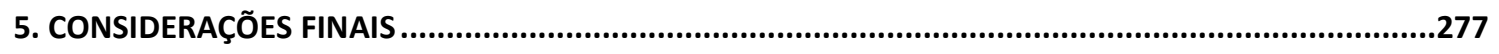

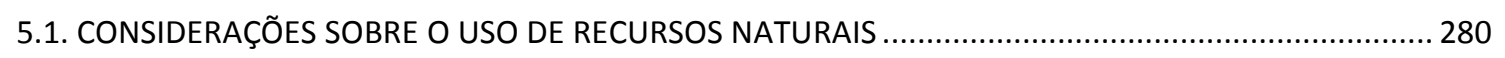

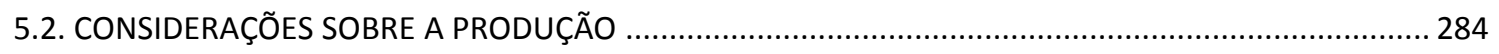




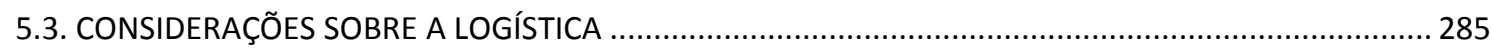

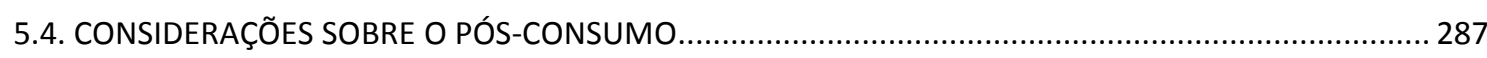

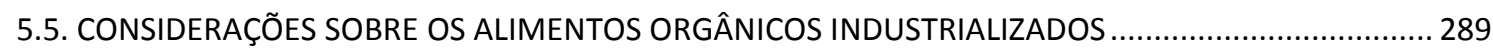

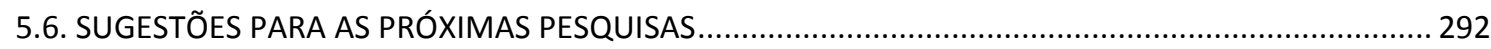

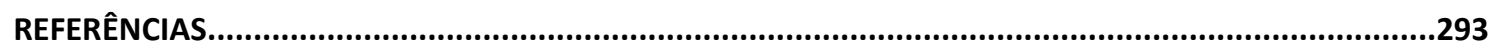

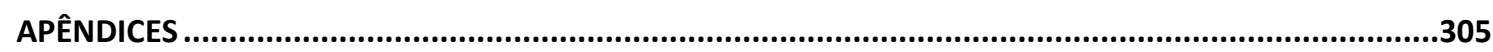

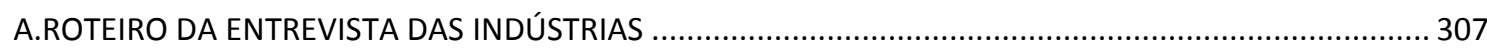

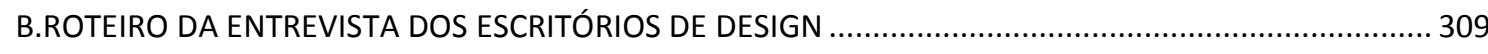

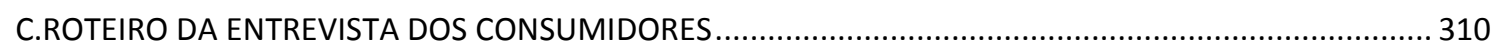

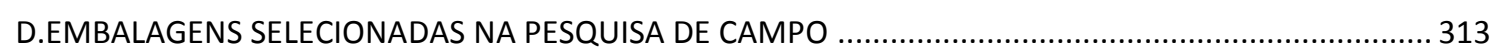

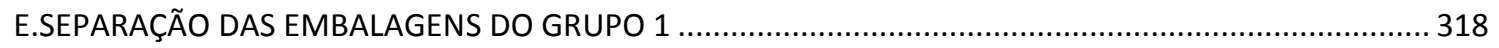

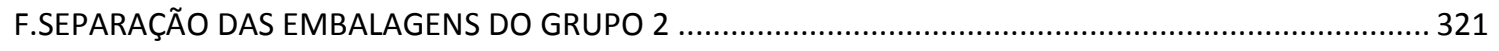

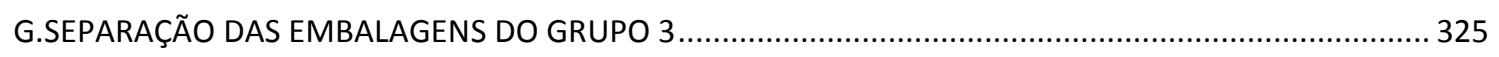

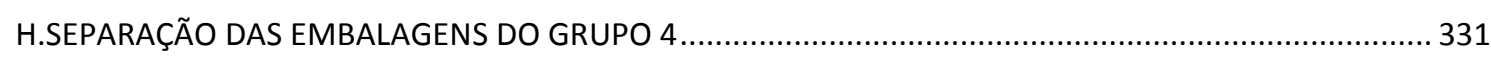

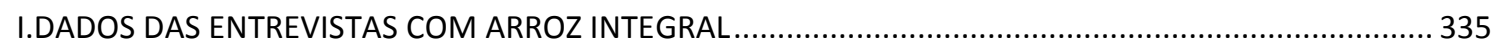

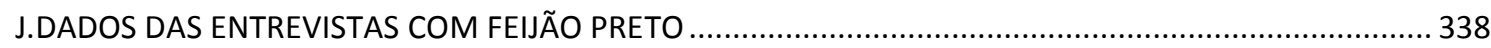

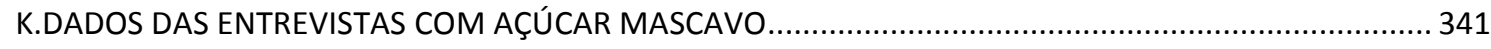

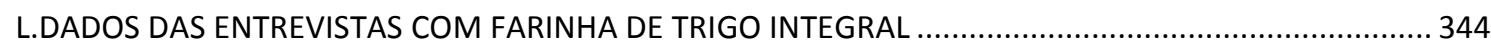

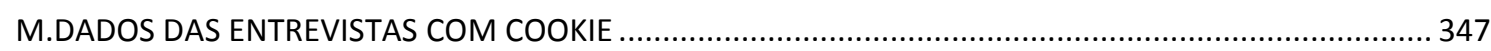

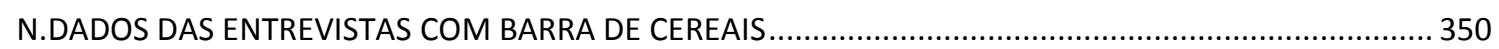

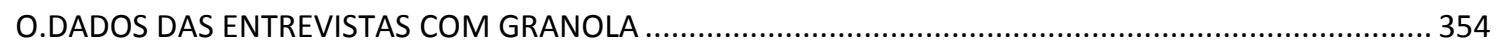

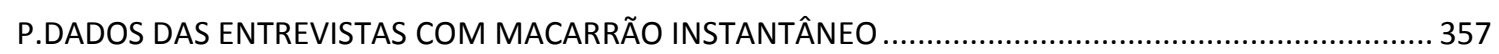

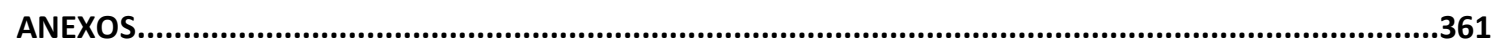

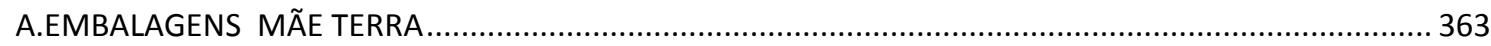

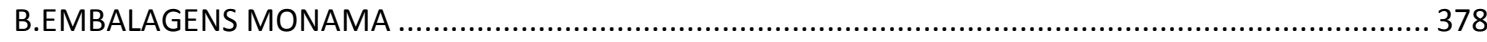

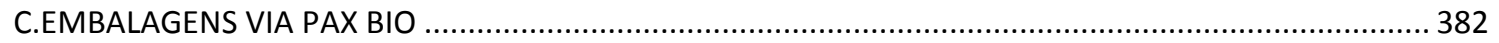




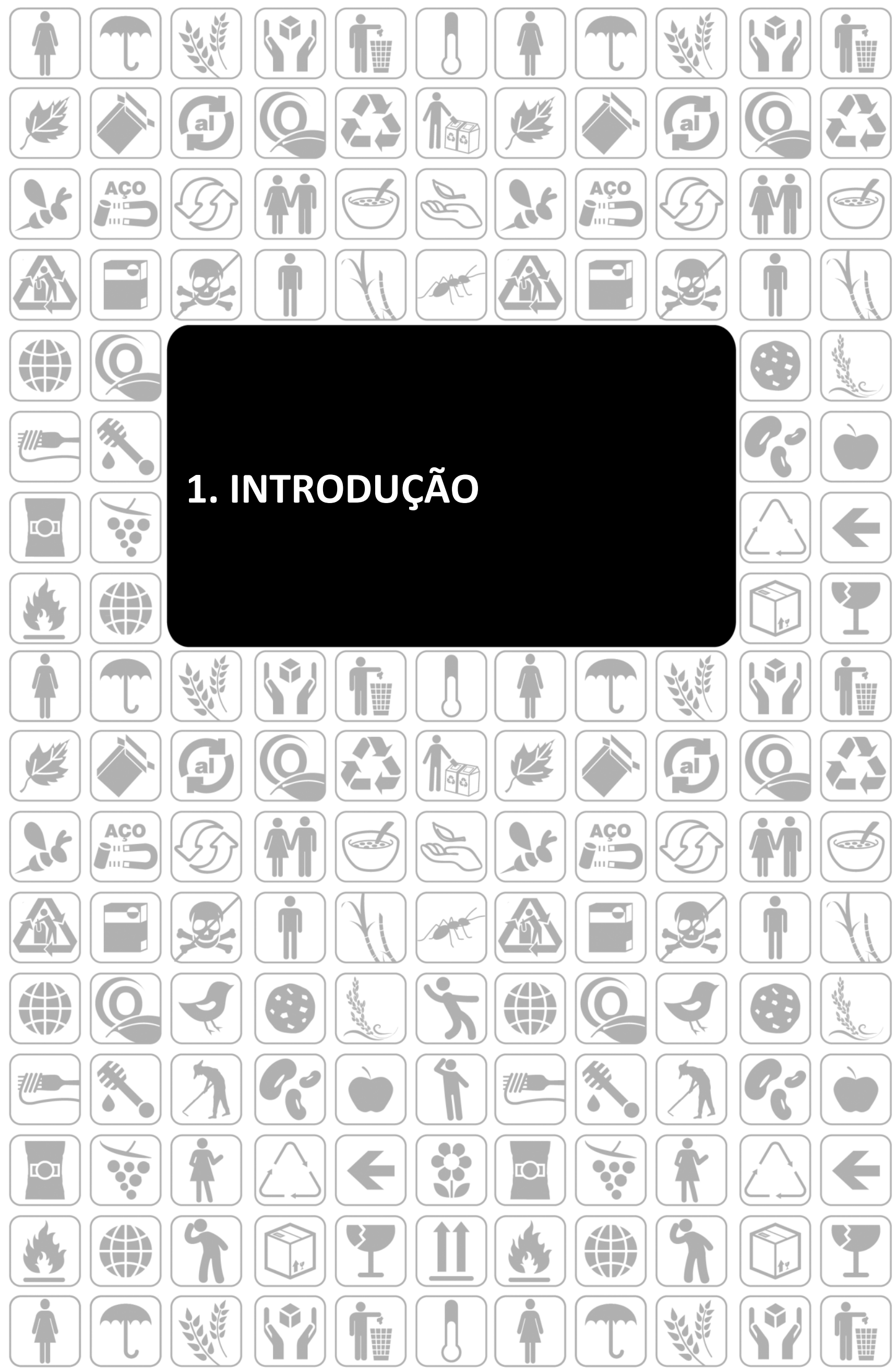




\section{INTRODUÇÃO}

A embalagem é parte integrante da crescente demanda por alimentos orgânicos que vem exercendo grandes mudanças nas indústrias de alimentos processados. Os produtos orgânicos possuem, em seu próprio conceito, a preocupação da redução do impacto da sua produção no meio ambiente, porém não se sabe se isso se reflete nas embalagens de seus produtos.

A embalagem, por ser um produto de rápido consumo e consequente descarte, pode causar grandes impactos ambientais caso não seja bem projetada, como a geração de resíduos e o grande consumo de matérias-primas não renováveis. Nessa pesquisa, também foi dada atenção ao que se refere aos impactos da escolha dos materiais de embalagem e o seu processo produtivo, nem sempre visível na embalagem.

Os alimentos orgânicos industrializados, por serem produzidos sem conservantes artificiais ou outros componentes químicos não orgânicos, podem ficar mais sensíveis a pragas e a variações ambientais. Por isso, precisam de embalagens de qualidade, projetadas para funcionar ao longo de todo o seu ciclo de vida, aproveitando melhor os recursos já existentes, e comunicando seus benefícios, porém sem esquecer os impactos ambientais que podem causar.

Este estudo tem o objetivo de verificar se há coerência entre o design das embalagens de alimentos orgânicos industrializados, presentes no mercado paulistano entre 2011 e 2013, e seu conteúdo, no que diz respeito aos critérios ambientais, entender a percepção dos consumidores em relação a essas embalagens, buscando identificar se há ou não deficiência de projeto nesse segmento que possa comprometer a compreensão do usuário em relação aos benefícios dessa categoria de produtos.

Foram feitas análises de como os requisitos ambientais de design foram aplicados no desenvolvimento de algumas embalagens de alimentos orgânicos selecionadas. Isto incluiu conhecer melhor o processo de produção de produtos selecionados e entrevistar os responsáveis pelo desenvolvimento de embalagens nas indústrias e no escritório de design e os consumidores de orgânicos.

Esta pesquisa, de natureza exploratória, utiliza métodos de abordagem qualitativa, sobretudo observações sistemáticas, não participantes, das embalagens de alimentos orgânicos, contando também com revisão da literatura, legislação, levantamento de campo, estudo comparativo e entrevistas semiestruturadas com os fabricantes, designers e consumidores.

A estratégia para análise dos dados foi a triangulação das informações, e a sua interpretação buscou traçar um panorama global que permita a posterior comparação dos dados obtidos com os diferentes agentes pesquisados. 


\section{OBJETO}

O objeto de estudo desta pesquisa são as embalagens de alimentos orgânicos industrializados que são produzidas e comercializadas em lojas de produtos naturais e em supermercados na cidade de São Paulo, após a aprovação do selo de certificação de orgânicos pelo Ministério da Agricultura, Pecuária e Abastecimento (MAPA) em 2011, com ênfase nos requisitos ambientais de design aplicados no seu desenvolvimento.

O recorte geográfico dos dados coletados nesta pesquisa abrangeu os produtos vendidos na cidade de São Paulo. Esta escolha decorreu pela cidade ser um grande mercado consumidor e possuir várias marcas desse tipo de produto à venda. No caso de produtos fabricados fora de São Paulo, mas com venda nos estabelecimentos comerciais do município, o estudo de caso inclui uma visita à indústria em sua cidade para uma melhor observação de seus processos produtivos.

\section{OBJETIVOS}

\section{Objetivos gerais}

Verificar qual é a política de desenvolvimento de embalagens em empresas selecionadas de alimentos orgânicos industrializados, presentes no mercado paulistano, e se estão de acordo com as recomendações ambientais das associações de embalagem selecionadas e da literatura especializada.

Verificar como se dá a percepção do consumidor das especificidades inerentes aos alimentos orgânicos, pelas suas embalagens.

\section{Objetivos específicos}

Avaliar, no mercado brasileiro, se as embalagens de alimentos industrializados orgânicos, das empresas selecionadas, têm algum tipo de preocupação ambiental.

Avaliar se a comunicação dos aspectos ambientais está adequada nas embalagens, com base no que é recomendável na literatura especializada e na legislação brasileira.

\section{QUESTÕES}

\section{Problema fundamental}

Considerando-se que na produção de alimentos orgânicos industrializados são observados princípios ambientais, o que se pode depreender sobre o design de suas embalagens, em termos da observância de recomendações ambientais, preconizadas pela literatura especializada e pelos órgãos reguladores, e sobre a percepção desses princípios por parte dos consumidores?

\section{Subproblemas}

Quais são as recomendações ambientais para o design de embalagens?

Quais são as recomendações ambientais para os produtos orgânicos?

Quais são as recomendações ambientais identificadas nas embalagens de alimentos orgânicos?

O consumidor é capaz de perceber as especificidades inerentes aos alimentos orgânicos, presentes na sua produção, apenas visualizando suas embalagens? 


\section{PRESSUPOSTOS CONCEITUAIS}

As embalagens de alimentos orgânicos podem não refletir os procedimentos de minimização do impacto ambiental da sua produção.

As embalagens de alimentos orgânicos industrializados podem não refletir para o consumidor as características específicas de produção de seu conteúdo, dificultando a identificação dos seus diferenciais ambientais.

\section{JUSTIFICATIVAS DO ESTUDO}

No Brasil, o mercado está se modificando na busca das melhores soluções para a preservação do meio ambiente e essa iniciativa pode ser percebida também por parte do setor de embalagens e na produção de alimentos. Um produto que se propõe a ser mais sustentável deve englobar os possíveis impactos ambientais da sua produção e consumo, portanto o design da embalagem, por estar no início desse processo, é essencial para que isso ocorra.

Os alimentos orgânicos são os produtos que mais se aproximam dos ciclos naturais de produção agrícola, buscando respeitar a natureza a partir do estabelecimento de protocolos e certificações. Eles seguem o princípio de minimizar o impacto ambiental na sua forma de produção. Para obter a certificação de orgânico, ele deve ser produzido em um ambiente de produção orgânica, onde se utiliza como base do processo produtivo os princípios agroecológicos que contemplam o uso responsável do solo, da água, do ar e dos demais recursos naturais, respeitando as relações sociais e culturais.

O design deve buscar caminhos para que essas mudanças, tecnológica e cultural, se tornem viáveis e considerem os aspectos ambientais presentes no desenvolvimento das embalagens. Há poucos estudos sobre as embalagens de alimentos orgânicos, por isso, esta dissertação busca auxiliar futuras pesquisas acadêmicas sobre este assunto e agregar informações ao campo do design.

As entrevistas e os estudos comparativos são importantes para um melhor mapeamento das políticas de desenvolvimento de embalagem ao longo da cadeia produtiva e, com este estudo, será possível verificar se há coerência entre o design das embalagens e seu conteúdo, no que diz respeito aos critérios ambientais, indicando a presença ou não de uma deficiência nesse segmento nos casos estudados. O tema foi escolhido por ser atual e pertinente para todo o planeta, interferindo diretamente na vida das pessoas. 
Esta dissertação está estruturada em cinco capítulos que estão organizados conforme descrito a seguir. O presente capítulo refere-se à introdução da dissertação, evidenciando seu problema de pesquisa, justificativa do estudo, objetivos e os pressupostos conceituais.

O capítulo 2 apresenta a revisão da literatura, onde são abordados os temas relacionados a esta pesquisa, como os alimentos orgânicos, sua forma de produção, comercialização e a importância do design integrado aos objetivos de redução do impacto ambiental. São apresentados os documentos que serviram de base teórica para a análise das embalagens e as empresas selecionadas para a pesquisa.

O capítulo 3 da dissertação apresenta os métodos utilizados para desenvolver esta pesquisa e como foi feita a análise dos resultados.

O capítulo 4 apresenta os dados das entrevistas com as indústrias, escritórios de design, consumidores e da análise das embalagens.

O capítulo 5 é dedicado às considerações finais da dissertação, apresentando suas contribuições teóricas e indicando novos caminhos para dar continuidade a esta pesquisa. 


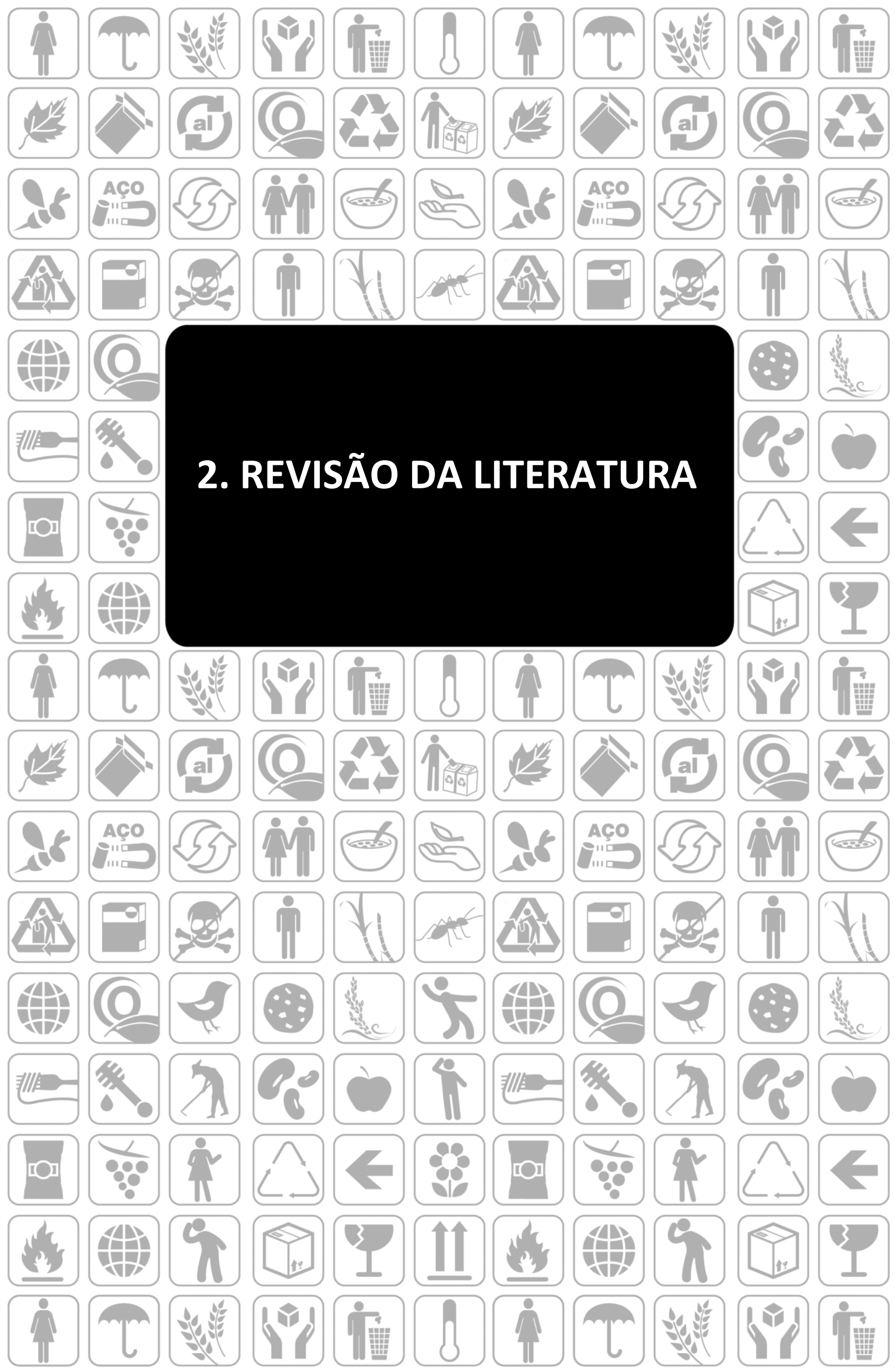




\section{REVISÃO DA LITERATURA}

Este capítulo faz uma revisão da literatura dos temas abordados ao longo desta pesquisa. Ele começa contextualizando o tema, onde primeiramente é definido o que é um alimento orgânico. Na segunda parte, são abordados os aspectos técnicos e reguladores da embalagem e o seu mercado hoje no Brasil. A terceira parte introduz a embalagem na cadeia produtiva do alimento orgânico. A quarta parte apresenta os tipos de consumidores de orgânicos e pesquisas já feitas em relação à sua percepção do produto orgânico. A quinta parte mostra as dimensões da sustentabilidade no contexto do design de embalagens. $\mathrm{Na}$ sexta parte, são apresentados alguns documentos nacionais e mundiais e organizações do mercado de embalagens com recomendações para o seu desenvolvimento. Finalizando, são apresentadas as empresas que foram pesquisadas nesta dissertação.

\subsection{ALIMENTOS ORGÂNICOS}

Para um alimento ser considerado orgânico, deve ser produzido em um ambiente onde se utilizam como base do processo produtivo os princípios agroecológicos que contemplam o uso responsável do solo, da água, do ar e dos demais recursos naturais, respeitando as relações sociais e culturais.

Uma das características fundamentais da produção orgânica é a preocupação com o meio ambiente. Os sistemas orgânicos de produção priorizam o uso responsável dos recursos naturais, contribuindo para o desenvolvimento sustentável.

Quando o alimento orgânico é processado em um ambiente industrial, ele necessita de uma embalagem para sua proteção no transporte e na comercialização. A embalagem deve expressar visualmente todas as características inerentes ao produto, para que o consumidor o adquira. Porém, após o seu consumo, caso seja descartada inadequadamente, a embalagem se torna um problema para o meio ambiente, contrastando com os princípios da produção orgânica.

\section{Alimentos industrializados}

Segundo Oliveira, Malta e Lima Filho (2007), em uma pesquisa com consumidores e especialistas, o alimento industrializado é aquele que passou por processamento industrial (larga escala) ou não (processamento doméstico), contendo elementos químicos e sendo percebido como menos saudável que o natural.

Com a evolução do alimento industrializado, o papel das indústrias alimentares modificou-se e o alimento passou a se apresentar de duas formas: por um lado, ele é artificial e, por outro, deve conservar um status natural. As indústrias recorrem a esse apelo do "natural" para manter a imagem de que aquele produto tem uma conexão com a natureza (HÉRNANDEZ, 2005).

A legislação brasileira informa o que é o alimento in natura:

[...] todo alimento de origem vegetal ou animal, para cujo consumo imediato se exija apenas a remoção da parte não comestível e os tratamentos indicados para a sua perfeita higienização e conservação. (BRASIL, 1969) 
Segundo uma perspectiva acadêmica, tem-se o conceito técnico de alimento natural como:

[...] item natural quer-se dizer aquele que não foi mudado de nenhuma forma significativa pelo contato com humanos. Ele pode ser colhido e transportado, mas tem sua essência quimicamente idêntica ao mesmo item em seu lugar natural. (ROZIN, 2004, p. 151)

Segundo especialistas e consumidores, o alimento considerado natural, ou in natura, é o alimento bruto (frutas, legumes, verduras e cereais), percebido como saudável desde que não tenha sido cultivado através do uso de produtos químicos, e que não passou por processo de industrialização (OLIVEIRA; MALTA; LIMA FILHO, 2007). Ou seja, é aquele minimamente processado, mais próximo de sua origem, isento de aditivos químicos como corantes artificiais, conservantes, espessantes, aromatizantes, entre outros.

A categoria de "natural" é utilizada pelas empresas como um símbolo, na tentativa de atrair a atenção do consumidor que busca uma alimentação mais saudável. Dentre as subcategorias de alimentos naturais, encontram-se os alimentos integrais e orgânicos, considerados ainda mais saudáveis.

Segundo o glossário temático Alimentação e nutrição, do Ministério da Saúde (2008), uma alimentação saudável é:

[...] padrão alimentar adequado às necessidades biológicas e sociais dos indivíduos e de acordo com as fases do curso da vida. [...] Deve ser acessível (física e financeiramente), saborosa, variada, colorida, harmônica e segura quanto aos aspectos sanitários. [...] Esse conceito considera as práticas alimentares culturalmente referenciadas e valoriza o consumo de alimentos saudáveis regionais (como legumes, verduras e frutas), sempre levando em consideração os aspectos comportamentais e afetivos relacionados às práticas alimentares. (MINISTÉRIO DA SAÚDE, 2008, p. 15)

Muitas vezes, o alimento saudável se confunde com outras categorias de produtos, cujo objetivo pode variar, como a perda de peso ou alguma dieta mais restrita de algum nutriente, como, por exemplo, os alimentos light e diet.

O alimento light é produzido de forma que sua composição reduza em, no mínimo, 25\% o valor calórico e/ou os seguintes nutrientes: açúcares, gordura saturada, gorduras totais, colesterol e sódio, comparado com o produto tradicional ou similar de marcas diferentes (BRASIL, 2008).

Já o alimento diet é quando determinados nutrientes, como proteína, carboidrato, gordura, sódio, entre outros, estão ausentes ou em quantidades muito reduzidas, não resultando, necessariamente, em um produto com baixas calorias (BRASIL, 2008), ou mais saudável.

Para um produto ser considerado como integral, espera-se que o primeiro ingrediente discriminado na embalagem seja integral, ou pelo menos esteja entre os primeiros, apesar de a legislação não fazer essa exigência. $O$ alimento integral mantém praticamente intactas as principais camadas dos grãos usados para a produção do produto, preservando não apenas a camada interna (endosperma, onde estão os carboidratos, proteínas e alguns micronutrientes do grão), mas também o farelo e o gérmen, onde se concentram as vitaminas, minerais e outros nutrientes pouco encontrados nos produtos refinados (MUNTER, 2007). O termo também pode ser usado para outros tipos de alimentos que mantêm todas as suas propriedades nutricionais, como o leite ou suco. 


\subsubsection{Alimentação saudável}

O alimento orgânico é considerado um alimento mais saudável, apesar da falta de estudos epidemiológicos relacionando o consumo de produtos orgânicos com a saúde humana, fazendo com que, cientificamente, isso ainda seja difícil de ser respondido (DAROLT, 2003).

A maioria dos estudos sobre a qualidade nutricional de alimentos orgânicos e convencionais faz comparativos de teores de nutrientes e outros elementos entre os dois sistemas. A comparação é difícil de ser realizada quando pensamos no ser humano, pois os hábitos de consumo e estilos de vida de consumidores orgânicos e convencionais também são diferenciados. Provavelmente, consumidores orgânicos que apresentam hábitos de vida mais saudáveis - de forma geral - teriam uma saúde mais equilibrada (DAROLT, 2003).

Segundo Williams (2002), um número limitado de estudos, com bom controle de variáveis, comparou as composições de nutrientes produzidos organicamente e convencionalmente, e um número ainda menor pesquisou produtos de origem animal. Na Tabela 1, foram compilados quantitativamente os principais estudos comparativos em termos nutricionais. 0 que se observa, de forma geral, é uma tendência na redução do teor de nitratos e aumento no teor de vitamina $\mathrm{C}$ em alimentos produzidos organicamente.

\begin{tabular}{lccc}
\hline NUTRIENTE & $\begin{array}{c}\text { AUMENTO EM } \\
\text { ORGÂNICOS }\end{array}$ & IGUAL & $\begin{array}{c}\text { DECRÉSCIMO EM } \\
\text { ORGÂNICOS }\end{array}$ \\
\hline Proteina (qualidade) & 3 & 0 & 0 \\
\hline Nitratos & 5 & 10 & 3 \\
\hline Vitamina C & 21 & 12 & 3 \\
\hline$\beta$-caroteno & 5 & 5 & 2 \\
\hline Vitamina B & 2 & 12 & 6 \\
\hline Cálcio (ca) & 21 & 20 & 4 \\
\hline Magnésio (Mg) & 17 & 24 & 6 \\
\hline Ferro (Fe) & 15 & 14 & 3 \\
\hline Zinco (Zn) & 4 & 9 & \\
\hline
\end{tabular}

Tabela 1- Número de estudos que comparam proteínas, nitratos, vitaminas e minerais entre a produção orgânica e convencional. Fonte: Williams, 2002

Percebe-se que os estudos comparados, em relação aos teores de elementos nutritivos (vitaminas, minerais etc.), são pouco conclusivos. Por outro lado, temos que destacar que, praticamente, não foram encontrados estudos que mostram que o alimento convencional é superior ao orgânico.

O que se destaca no alimento orgânico em relação ao convencional é a ausência de resíduos de agrotóxicos. O sistema de produção convencional de alimentos tem deixado resíduos de agrotóxicos em níveis preocupantes para a saúde pública. Pesquisa realizada pela Agência Nacional de Vigilância Sanitária (Anvisa) em parceria com a Fundação Oswaldo Cruz (Fiocruz), em 2011, mostrou que 28\% das frutas, verduras e legumes produzidos em sistema convencional e vendidos em supermercados em quatro estados (São Paulo, Paraná, Minas Gerais e Pernambuco) apresentavam irregularidades graves, ou seja, com agrotóxicos acima do limite permitido pela legislação e produtos não autorizados pela alta toxicidade.

Quando comparado aos alimentos transgênicos, que utiliza grãos e sementes geneticamente modificados, a agricultura orgânica respeita o princípio da precaução e não os utiliza. $\mathrm{O}$ seu 
consumo pode desencadear processos alérgicos, resistência aos antibióticos, aumento das substâncias tóxicas que as plantas possuem para se defender de seus predadores, como os insetos, e resistência à ação de agrotóxicos, provocando o aumento do seu uso (IDEC, 2010).

Em relação aos impactos no meio ambiente, em comparação ao alimento convencional, um estudo realizado na Europa Central comparou por 21 anos a biodiversidade e qualidade de solo entre sistemas orgânico e convencional. Os resultados apontaram para uma melhor estruturação de solo e infiltração de água nos sistemas orgânico e biodinâmico. Nestas parcelas, houve de $30 \%$ a $40 \%$ mais presença de micorrizas (fungos que se encontram em simbiose com as raízes das plantas) quando comparadas ao sistema convencional. Outra constatação foi a maior presença de biomassa microbiana e atividade enzimática, entre $30 \%$ e $85 \%$ superior quando comparado às parcelas de cultivo convencional (MÄDER et al., 2002).

Com o aumento do uso indiscriminado de agrotóxicos e fertilizantes químicos na agricultura convencional, consumidores de alimentos cada vez mais buscam alternativas para poder se alimentar de forma mais saudável e encontram nos alimentos orgânicos essa opção.

\section{Mercado consumidor de alimentos orgânicos}

Os alimentos e bebidas provenientes da agricultura orgânica são cada vez mais comuns nos mercados consumidores brasileiros. Novos canais de distribuição e de comercialização possibilitaram que os produtos orgânicos alcançassem maior número de consumidores, tornando a demanda mais regular. De acordo com pesquisa realizada pela International Federation of Organic Agriculture Movements (IFOAM) em 2012, apesar da desaceleração da economia europeia - que é a maior consumidora do setor - entre o ano de 2011 e 2012, o mercado mundial de agricultura orgânica registrou crescimento de aproximadamente 6,36\%.

No Brasil, segundo dados do Censo Agropecuário de 2006, do Instituto Brasileiro de Geografia e Estatística (IBGE), o país conta com 4,93 milhões de hectares de área destinada ao cultivo de produtos orgânicos, $1,8 \%$ do total investigado, sendo que $60 \%$ da produção são exportados, principalmente para o Japão, Estados Unidos e União Europeia, e para outros 30 países. Dentre os produtos orgânicos exportados, destacam-se produtos in natura e processados de soja, açúcar, arroz, café, cacau, provenientes da pecuária e da criação de pequenos animais e do extrativismo, principalmente o palmito.

O Brasil encontra-se entre os maiores produtores de orgânicos do mundo, conforme o relatório The world organic agriculture, elaborado pelo Research Institute of Organic Agriculture (FiBL) e pela IFOAM em 2010. Segundo dados da Organic Monitor, as vendas globais de produtos orgânicos no mundo atingiram USD 50,9 bilhões em 2008, dobrando 0 valor de USD 25 bilhões verificado em 2003.

\subsubsection{Legislação e Certificação de orgânico}

Em 2009, entrou em vigor no Brasil a Lei da Agricultura Orgânica, bem como seus regulamentos, e a rotulagem dos alimentos orgânicos obedece a seus critérios. O Art. 3 da Lei da Agricultura Orgânica determina que, para a comercialização, os produtos orgânicos devem seguir um critério de avaliação da conformidade, visando a garantir a qualidade do produto quanto às normas de produção. Nesta linha, a Lei dispõe sobre a certificação por auditoria, ressalvada a possibilidade de venda direta do produtor ao consumidor, onde essa certificação pode ser facultativa. 
A produção do alimento deve seguir o decreto $n^{0} 7.794$, de 2012 , Art. $3 \circ$, que estabelece diretrizes para a Política Nacional de Agroecologia e Produção Orgânica (PNAPO), que são:

I. Promoção da soberania e segurança alimentar e nutricional e do direito humano à alimentação adequada e saudável, por meio da oferta de produtos orgânicos e de base agroecológica isentos de contaminantes que ponham em risco a saúde;

II. Promoção do uso sustentável dos recursos naturais, observadas as disposições que regulem as relações de trabalho e favoreçam o bem-estar de proprietários e trabalhadores;

III. Conservação dos ecossistemas naturais e recomposição dos ecossistemas modificados, por meio de sistemas de produção agrícola e de extrativismo florestal baseados em recursos renováveis, com a adoção de métodos e práticas culturais, biológicas e mecânicas, que reduzam resíduos poluentes e a dependência de insumos externos para a produção;

IV. Promoção de sistemas justos e sustentáveis de produção, distribuição e consumo de alimentos, que aperfeiçoem as funções econômica, social e ambiental da agricultura e do extrativismo florestal, e priorizem o apoio institucional aos beneficiários da Lei no 11.326, de 2006;

V. Valorização da agrobiodiversidade e dos produtos da sociobiodiversidade e estímulo às experiências locais de uso e conservação dos recursos genéticos vegetais e animais, especialmente àquelas que envolvam o manejo de raças e variedades locais, tradicionais ou crioulas;

VI. Ampliação da participação da juventude rural na produção orgânica e de base agroecológica;

VII. Contribuição na redução das desigualdades de gênero, por meio de ações e programas que promovam a autonomia econômica das mulheres.

Desde janeiro de 2011, é obrigatório apresentar o selo do Sistema Brasileiro de Avaliação da Conformidade Orgânica (SisOrg) na embalagem, criado pelo Decreto no 6323 de 27 de dezembro de 2007, para que o produto possa ser comercializado em lojas e mercados (MAPA, 2012).

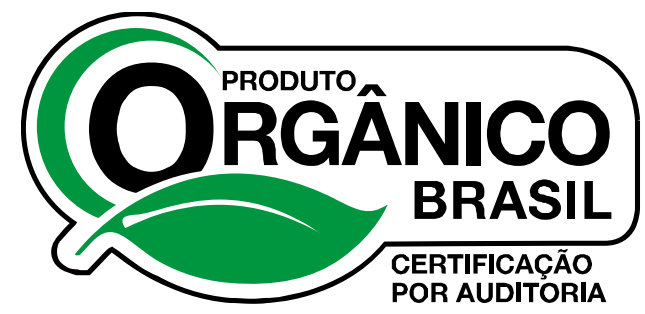

Figura 1 - Selo do Sistema Brasileiro de Avaliação da Conformidade Orgânica (SisOrg). Fonte: MAPA, 2009

A certificação pode ser realizada de três formas: por auditoria; por sistema participativo de garantia; e pelo controle social na venda direta. Para a certificação por auditoria, o produto deve ser auditado por uma empresa credenciada pelo Instituto Nacional de Metrologia, Normalização e Qualidade Industrial (INMETRO) e registrada no Ministério da Agricultura, Pecuária e Abastecimento (MAPA). Atualmente, quatro certificadoras estão credenciadas pelo Ministério: Tecpar, IBD, Ecocert e IMO. 

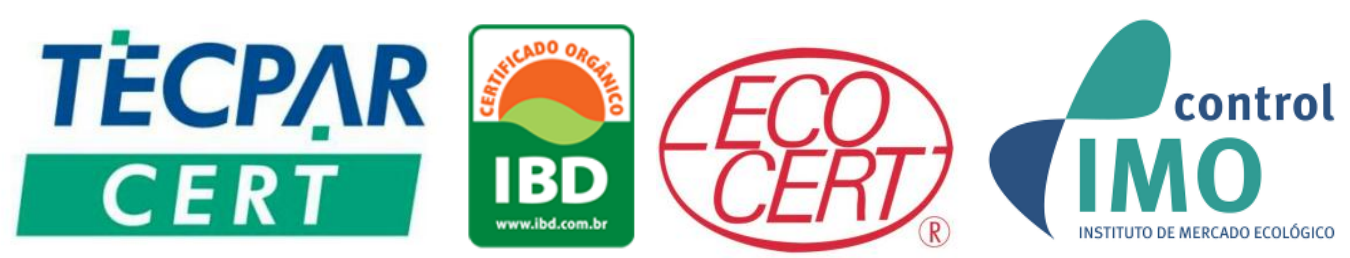

Figura 2 - Certificadoras credenciadas pelo Ministério da Agricultura, Pecuária e Abastecimento. Fonte: MAPA, 2012

A legislação brasileira abriu uma exceção na obrigatoriedade de certificação dos produtos orgânicos para a agricultura familiar pelos Sistemas Participativos de Garantia (SPG). Exigese, porém, o credenciamento em uma organização de controle social cadastrada em órgão fiscalizador oficial (IPD, 2011). Os grupos de agricultores autorizados a credenciar os produtos são: Rede Ecovida de Agroecologia, Associação de Agricultura Natural de Campinas e Região (ANC) e Associação de Agricultores Biológicos do Estado do Rio de Janeiro (ABIO).

No caso do alimento ser certificado, é permitido o uso do selo da certificadora a ser estampado no rótulo do alimento. Adicionalmente a este selo, produtos certificados devem apresentar o selo do SisOrg. As empresas e produtores orgânicos que ainda não possuem o selo oficial de garantia do MAPA em seus produtos correm o risco de sofrer penalidades, como multas e apreensões da mercadoria. É por meio do selo SisOrg e dos selos das certificadoras que o consumidor pode identificar um produto orgânico.

Para obter a certificação, o interessado precisa cumprir um conjunto de ritos legais estipulado pela Lei Federal 10.831 (BRASIL, 2003), regulamentada pelo Decreto Federal 6.323 (BRASIL, 2007), além das Instruções Normativas 19 e 50 (BRASIL, 2009) do Ministério da Agricultura, Pecuária e Abastecimento. Após a certificação, a legislação exige o registro do produtor no Cadastro Nacional de Produtores Orgânicos do MAPA.

Para um produto se apresentar, na embalagem, como orgânico, ele deve ser certificado. Apenas dessa forma podem informar no rótulo a expressão orgânico ou produto orgânico, desde que contenha $95 \%$ ou mais de ingredientes orgânicos certificados. Os alimentos orgânicos que apresentem de 70\% a 95\% de ingredientes orgânicos certificados podem informar na rotulagem a expressão produto com ingredientes orgânicos, lembrando que as matérias-primas e aditivos devem estar listados no rótulo.

Na legislação, não consta nada sobre a embalagem além da forma como o selo SisOrg deve ser aplicado no rótulo e que tipo de informação textual deve ter, ficando livre a escolha do tipo de embalagem para a comercialização.

\subsubsection{Impactos da produção agrícola convencional}

A produção orgânica tornou-se uma alternativa de produção de alimentos em relação à agricultura convencional. Nos últimos 50 anos, o rendimento agrícola tem aumentado no mundo. Logo após a Segunda Guerra Mundial, com o objetivo de recuperação econômica após a guerra, era indispensável aumentar a produção agrícola para responder às necessidades de uma população cada vez mais numerosa. Inicia-se neste período com mais força a agricultura dita intensiva, que privilegia o rendimento e seleciona as variedades de melhor desempenho, aumentando as monoculturas (KAZAZIAN, 2005).

A industrialização da agricultura foi um triunfo da tecnologia. Nos últimos 50 anos, a produção de gêneros importantes mais do que dobrou; a de cereais triplicou. Nas últimas 
três décadas, o número de calorias alimentares disponíveis por pessoa na Terra (mesmo que não fornecidas) aumentou 13\%, apesar do rápido crescimento demográfico.

Quase todo o aumento da produção mundial de alimentos resultou de plantações mais produtivas e de amadurecimento mais rápido, não do aumento da área cultivada, pois essencialmente toda a terra arável já está sendo lavrada. Embora ainda haja terras potencialmente agriculturáveis no mundo, custaria mais para prepará-la, não justificando o aumento dos preços das safras. Por conseguinte, a intensificação é convencionalmente considerada o único meio viável de continuar expandindo a produção global de alimento para sustentar uma população crescente (NAYLOR, 1996 apud HAWKEN; LOVINS, 2007, p. 177).

A introdução de organismos geneticamente modificados, ou transgênicos, na agricultura usa essa mesma lógica de redução de espécies. O objetivo alegado é criar variedades mais resistentes às doenças, aos pesticidas ou aos transportes, que possam crescer em climas desfavoráveis e cuja composição possa ser empobrecida ou enriquecida. O maior objetivo desses alimentos é produzir a um custo menor e com cada vez mais facilidade, mesmo que isso leve a uma perda da biodiversidade, à degradação do meio ambiente e à dependência econômica dos grandes produtores de insumos, como os agrotóxicos e fertilizantes químicos. Os transgênicos possibilitam o aumento das monoculturas, que têm como consequência a redução da biodiversidade de grãos e alimentos do mundo.

\begin{abstract}
As monoculturas também deixam ociosa a maior parte da rica diversidade da biota do solo. A natureza não desperdiça recursos sustentando organismos subutilizados, portanto, se eles nada têm a fazer, acabam morrendo. Tratar o solo como lixo - não como uma comunidade viva, mas como um meio estéril - torna-o árido e incapaz de prestar os serviços naturais. Dispondo de um hábitat livre e sem concorrência, os insetos e outros elementos patogênicos florescem (HAWKEN; LOVINS, 2007, p. 183).
\end{abstract}

A agricultura orgânica, ao contrário, mantém o solo sadio, observando cuidadosamente os níveis controláveis de pragas para aumentar suas colheitas.
Na visão orgânica, baseada no ecossistema, a erradicação total de pestes é um erro tático, pois todo o sistema salutar precisa de certa quantidade de pragas que sirvam de alimento aos predadores para que eles fiquem por perto e as conservem em equilíbrio (HAWKEN; LOVINS, 2007, p. 183).

A agricultura orgânica busca diversificar e integrar a produção de espécies vegetais e animais com o objetivo de criar ecossistemas mais equilibrados (MAPA, 2012), sem depender de produtos químicos externos.

\footnotetext{
A dependência química das monoculturas requer enormes quantidades de fertilizantes para substituir os serviços ecológicos gratuitos que a natureza oferece nos sistemas naturais (HAWKEN; LOVINS, 2007, p. 184).
}

A produção agrícola mundial atual deveria ser suficiente para alimentar todo mundo, porém 800 milhões de pessoas ainda sofrem dea fome. A forma de organização dos mercados e as perdas nos processos de produção, armazenamento, transporte e consumo impedem o acesso à quantidade necessária de alimentos, contribuindo para o aparecimento de desnutrição, anemia e outras carências nutricionais.

Segundo o Instituto Akatu (2004), no Brasil, 70 mil toneladas de alimentos vão para o lixo diariamente, num país onde, a cada cinco minutos, uma criança morre de problemas relativos à fome. São 288 crianças por dia. Essas perdas, porém, podem ser reduzidas com manuseio adequado, embalagens apropriadas, melhor distribuição, classificação e padronização desses alimentos (AKATU, 2004). 
Por outro lado, existe um contingente crescente de pessoas com mais acesso aos alimentos, constantemente estimuladas pelas propagandas e embalagens, cujo objetivo é aumentar a venda de alimentos industrializados. Sem uma consciência adequada do consumidor, o resultado é o consumo em excesso, gerando a obesidade e as doenças a ela associadas, como infarto, derrame, hipertensão e alguns tipos de câncer (AKATU, 2004).

Portanto, segundo Kazazian (2005, p. 86), "não é um problema de quantidade, mas de má distribuição". A embalagem tem por princípio facilitar esta distribuição, aumentando o acesso a alimentos para áreas cada vez mais distantes. A pós-colheita, considerando as embalagens, é tão importante quanto a produção de alimentos. Para que não haja desperdício, e seja sustentável, os processos de classificação, embalagem, manuseio e transporte devem ser adequados a cada tipo de produto agrícola (NEGRÃO; CAMARGO, 2008).

\subsection{PRODUÇÃO DE ORGÂNICOS E AS EMBALAGENS}

\subsubsection{A embalagem}

Vários autores apresentam considerações acerca do real significado do termo embalagem, porém todos tendem a convergir para um sentido único, onde a embalagem se apresenta como parte integrante de um sistema produtivo, considerada como um recipiente de contenção, invólucro ou qualquer forma de acondicionamento, destinada a cobrir, empacotar, envasar, proteger, manter os produtos, ao mesmo tempo em que é uma ferramenta de divulgação, promoção e apresentação do produto (GURGEL, 2007; MESTRINER, 2002; NEGRÃO; CAMARGO, 2008).

A embalagem hoje está no foco das discussões dos impactos ambientais, por sua característica efêmera, porém produzida, na maioria das vezes, com um material durável. A embalagem, quando descartada inadequadamente, se acumula no meio ambiente gerando problemas para a sociedade.

Do ponto de vista da sustentabilidade, o desenvolvimento de uma embalagem deve ser avaliado por meio de uma abordagem mais ampla e holística, considerando todo o seu ciclo de vida, desde a extração de matérias-primas até a disposição final. Isto inclui a preocupação com a redução dos fatores que afetam diretamente o meio ambiente, além de ser economicamente viável e atender as necessidades dos consumidores.

A embalagem de um produto preenche algumas funções como as tecnológicas, mercadológicas, aspectos logísticos, aspectos econômicos e alguns aspectos interativos como o uso e descarte (GURGEL, 2007; MESTRINER, 2002; NEGRÃO; CAMARGO, 2008).

As funções tecnológicas incluem a função de contenção e proteção mecânica, física e química. As funções mercadológicas estão relacionadas com as atividades de vendas, principalmente no que diz respeito à embalagem de apresentação, onde está inclusa a função de comunicação do conceito mercadológico (GURGEL, 2007).

A logística da embalagem tem a função de prever e detectar pontos de fragilidade e indesejáveis em toda a sua cadeia produtiva, pós-uso e descarte, analisando as necessidades específicas de cada produto e adequadas à linha de produção. De acordo com a fragilidade 
do produto, é necessário proteger contra choques, quedas ou até mesmo criar estruturas que suportem o peso das embalagens superpostas.

O custo da embalagem deve ser considerado, e é um dos pontos que mais influem em seu desenvolvimento. Além dos custos de produção, poderá também ser incluso o seu custo ambiental.

Além de cumprir a função de conter, transportar e comercializar, podem ser agregados benefícios e novas funções. Por exemplo, durante o uso ou após o produto ser utilizado, a embalagem poderá apresentar novas funções complementares, como a capacidade de se tornar um brinquedo ou de ser reutilizada (GURGEL, 2007).

Ainda segundo Gurgel (2007), as embalagens podem ser classificadas como embalagem de contenção, apresentação, comercialização, movimentação e transporte. Esta pesquisa explora apenas a embalagem de comercialização, que deve, inicialmente, chamar a atenção do consumidor pelas suas características óticas, como a visibilidade e a legibilidade. Uma vez atraída a atenção, a embalagem deverá apresentar singularidades dos produtos orgânicos que transformem a atenção em interesse. O consumidor, ao avaliar seus desejos, deverá observar na embalagem imagens associativas, que estimulem ainda mais esses desejos, sendo capaz de levá-lo a abdicar da utilização futura do produto e satisfazer seu desejo no presente. Torna-se necessário que a embalagem apresente características de ação "fechadoras de vendas" e exerça efeitos favoráveis na transmissão do conceito do produto (GURGEL, 2007).

Segundo Dougherty (2011), a embalagem tende a ser dividida em duas categorias básicas: a efêmera e a durável. A embalagem efêmera é leve e biodegradável, feita para durar até o consumo de seu produto, durante o tempo que for necessário, muitas vezes, por garantia, até mais que o necessário. Ela deve ser adequada aos ciclos disponíveis de reciclagem e aproveitamento dos materiais.

A embalagem durável, feita com um material mais resistente, procura ter outras funções antes de ser descartada. Para que isso seja viável, precisa ter uma forte percepção de valor para que as pessoas queiram interagir com ela inúmeras vezes durante um longo período de tempo. Sistemas de embalagens duráveis requerem uma padronização industrial, para que muitos fabricantes possam compartilhar um sistema de coleta centralizado, ou ciclos rigidamente controlados de distribuição e coleta.

Existe ainda a possibilidade de se comercializar o produto orgânico, principalmente os não industrializados, como as frutas e hortaliças, sem embalagem de comercialização, reutilizando a embalagem de transporte de forma quase ilimitada. Isso é possível quando os produtos são comercializados diretamente do produtor, sem intermediários.

\subsubsection{Aspectos reguladores das embalagens de alimentos orgânicos}

A embalagem de alimentos orgânicos deve seguir a mesma legislação de comercialização dos alimentos convencionais, específicos para cada produto, adicionando-se as disposições da Instrução Normativa MAPA no 16, de 11 de junho de 2004. 


\begin{tabular}{|c|c|}
\hline \multicolumn{2}{|c|}{ Legislação sobre rotulagem de alimentos orgânicos } \\
\hline $\begin{array}{l}\text { Lei } n=5.700 \text {, } \\
\text { de } 1 \text { de setembro de } 1991 .\end{array}$ & Dispõe sobre a utilização de símbolos nacionais. \\
\hline $\begin{array}{l}\text { Lei } n=8.078 \text {, } \\
\text { de } 11 \text { de setembro de } 1990 .\end{array}$ & Dispõe sobre a proteção do consumidor e dá outras providências. \\
\hline $\begin{array}{l}\text { Lei } n=10.674 \text {, } \\
\text { de } 16 \text { de maio de } 2003 \text {. }\end{array}$ & $\begin{array}{l}\text { Dispõe sobre a obrigatoriedade de informar sobre a presença de } \\
\text { glúten nos alimentos. }\end{array}$ \\
\hline $\begin{array}{l}\text { Lei no } 10.831 \text {, } \\
\text { de } 23 \text { de dezembro de } 2003 .\end{array}$ & Dispõe sobre a agricultura orgânica e dá outras providências. \\
\hline $\begin{array}{l}\text { Decreto no } 6.323 \text {, } \\
\text { de } 27 \text { de dezembro de } 2007 .\end{array}$ & $\begin{array}{l}\text { Regulamenta a Lei da Agricultura Orgânica (no 10.831/2003) e dá } \\
\text { outras providências. }\end{array}$ \\
\hline $\begin{array}{l}\text { Decreto no } 2.317 \\
\text { de } 4 \text { de setembro de } 1997 .\end{array}$ & Dispõe sobre bebidas em geral. \\
\hline $\begin{array}{l}\text { Decreto no 9.906/90, } \\
\text { de } 17 \text { de setembro de } 1946 .\end{array}$ & Dispõe sobre vinhos e derivados. \\
\hline $\begin{array}{l}\text { Instrução Normativa MAPA no 16, } \\
\text { de } 11 \text { de junho de } 2004 .\end{array}$ & Dispõe sobre a regulamentação e outras providências. \\
\hline $\begin{array}{l}\text { Instrução Normativa MAPA no } 55 \text {, } \\
\text { de } 18 \text { de outubro de } 2002 \text {. }\end{array}$ & Dispõe sobre a rotulagem de bebidas. \\
\hline $\begin{array}{l}\text { Resolução ANVISA RDC no } 259 \text {, } \\
\text { de } 20 \text { de setembro de } 2002 \text {. }\end{array}$ & Dispõe sobre as informações obrigatórias de rotulagem. \\
\hline $\begin{array}{l}\text { Resolução ANVISA RDC no } 360 \text {, } \\
\text { de } 23 \text { de dezembro de } 2003 .\end{array}$ & Dispõe sobre a rotulagem nutricional obrigatória. \\
\hline $\begin{array}{l}\text { Resolução ANVISA RDC no 359, } \\
\text { de } 23 \text { de dezembro de } 2003 .\end{array}$ & Dispõe sobre a definição de porções de alimentos embalados. \\
\hline $\begin{array}{l}\text { Resolução ANVISA no } 20 \text {, } \\
\text { de } 22 \text { de março de } 2007 .\end{array}$ & Sobre embalagens. \\
\hline $\begin{array}{l}\text { Resolução ANVISA no } 23 \text {, } \\
\text { de } 15 \text { de março de } 2000 .\end{array}$ & $\begin{array}{l}\text { Dispõe sobre o Regulamento Técnico e sobre o manual básico para } \\
\text { registro e isenção de registro na área de alimentos. }\end{array}$ \\
\hline $\begin{array}{l}\text { Resolução ANVISA no } 2.562 \text {, } \\
\text { de } 7 \text { de outubro de } 2005 .\end{array}$ & Sobre aditivos e corantes. \\
\hline $\begin{array}{l}\text { Portaria INMETRO no } 157 \text {, } \\
\text { de } 19 \text { de agosto de } 2002 .\end{array}$ & $\begin{array}{l}\text { Dispõe sobre a forma de expressar e o tamanho dos caracteres da } \\
\text { indicação quantitativa. }\end{array}$ \\
\hline $\begin{array}{l}\text { Portaria MAPA no } 371 \text {, } \\
\text { de } 4 \text { de setembro de } 1997 .\end{array}$ & $\begin{array}{l}\text { Dispõe sobre Regulamento Técnico para rotulagem de alimentos } \\
\text { embalados. }\end{array}$ \\
\hline
\end{tabular}

No Brasil, a Associação Brasileira de Normas Técnicas (ABNT) é o foro normativo responsável por elaborar normas técnicas para todo o setor industrial nacional. Podemos citar ainda a Agência Nacional de Vigilância Sanitária (ANVISA) e o Ministério da Agricultura, Pecuária e Abastecimento (MAPA) como outros órgãos importantes no desenvolvimento de embalagens de alimentos. O Instituto Nacional de Metrologia, Normatização e Qualidade Industrial (INMETRO) é o órgão responsável pela metrologia legal no país, que supervisiona e regulamenta unidades de medida, métodos de medição e seus respectivos instrumentos seguindo exigências técnicas e legais obrigatórias (NEGRÃO; CAMARGO, 2008).

O Código do Consumidor, de 1990, também ressalta a importância de se oferecer ao consumidor informações claras e ostensivas sobre os produtos colocados no mercado de consumo, o que significa dizer que construir o rótulo do alimento orgânico é tarefa de certa complexidade para quem produz, e importante para quem vai consumir.

As informações de rotulagem devem estar escritas no idioma do país de consumo, com caracteres de tamanho adequado. Alimentos com um único ingrediente, como açúcar e farinha, não precisam apresentar lista de ingredientes. Alimentos que se apresentam em forma sólida ou granulada devem ser comercializados em unidades de massa, e os semissólidos podem utilizar a unidade massa ou volume, entre outras exigências (CARRANO, 2008). Os elementos que devem compor a rotulagem de alimentos orgânicos são: 


\begin{tabular}{|c|c|}
\hline Denominação de venda & $\begin{array}{l}\text { É o nome que indica a origem e as características do produto, que pode ser, } \\
\text { por exemplo: óleo de soja ou leite UHT desnatado. }\end{array}$ \\
\hline Lista de ingredientes & $\begin{array}{l}\text { É a descrição de todos os ingredientes por ordem decrescente da proporção, } \\
\text { bem como os aditivos alimentares que devem ser informados por último. }\end{array}$ \\
\hline Quantidade & $\begin{array}{l}\text { Peso líquido ou conteúdo líquido, sendo representado pela quantidade } \\
\text { expressa em unidades de medida como: mililitro (ml), litro (l), grama (g), quilo } \\
\text { (kg) ou outras unidades aplicáveis. }\end{array}$ \\
\hline Identificação da origem & Nome e endereço do fabricante. \\
\hline $\begin{array}{l}\text { Serviço de Atendimento ao } \\
\text { Cliente (SAC) }\end{array}$ & $\begin{array}{l}\text { Visa a facilitar o contato entre o fornecedor e o consumidor quando } \\
\text { necessário. }\end{array}$ \\
\hline Identificação do lote & $\begin{array}{l}\text { É o código que permite identificar o lote de fabricação do produto para o caso } \\
\text { de se necessitar rastrear o processo de produção. }\end{array}$ \\
\hline Prazo de validade & $\begin{array}{l}\text { É a indicação da data até a qual o produto é garantido para o consumo, sendo } \\
\text { certo que ela deve estar presente de forma visível e legível ao consumidor. }\end{array}$ \\
\hline $\begin{array}{l}\text { Instruções sobre o preparo e uso } \\
\text { do alimento }\end{array}$ & $\begin{array}{l}\text { É a informação de rótulo que deve conter instruções sobre o uso adequado do } \\
\text { produto. }\end{array}$ \\
\hline Advertência & $\begin{array}{l}\text { Alimentos industrializados que contêm glúten devem ter esta informação na } \\
\text { rotulagem como advertência aos consumidores portadores de intolerância ao } \\
\text { glúten e problemas de saúde correlatos. }\end{array}$ \\
\hline Alimentos para fins especiais & $\begin{array}{l}\text { São alimentos formulados para necessidades físicas, metabólicas, fisiológicas } \\
\text { e/ou doenças específicas, como, por exemplo, controle de peso e de ingestão } \\
\text { de açúcar. }\end{array}$ \\
\hline Selos de inspeção & $\begin{array}{l}\text { Carimbos, certificados de que é um produto orgânico, de garantia de } \\
\text { qualidade e informações do gênero devem constar na rotulagem quando } \\
\text { exigidos pela lei. }\end{array}$ \\
\hline $\begin{array}{l}\text { Alimentos em condições } \\
\text { especiais para conservação }\end{array}$ & $\begin{array}{l}\text { Devem informar esta característica na rotulagem, como, por exemplo, } \\
\text { armazenamento em freezer, congelador ou geladeira. }\end{array}$ \\
\hline Informações nutricionais & $\begin{array}{l}\text { A informação nutricional é uma declaração obrigatória do fornecedor a ser } \\
\text { exposta na rotulagem do alimento, quanto aos nutrientes nele existentes. A } \\
\text { ANVISA orienta que produtores informem também sobre o conteúdo de } \\
\text { colesterol, cálcio e ferro. }\end{array}$ \\
\hline
\end{tabular}

O fabricante pode fazer constar no rótulo qualquer informação ou representação gráfica a título de rotulagem facultativa, desde que esta seja pertinente ao produto e ao fabricante. Não são admitidas na rotulagem informações ou outras representações gráficas que possam torná-la falsa, incorreta, insuficiente, ou que leve o consumidor ao equívoco, erro, confusão ou engano em relação à verdadeira natureza, composição, procedência, tipo, qualidade, quantidade, validade, rendimento, forma de uso do alimento e impacto ambiental (CARRANO, 2008).

Também está vedado destacar a presença ou ausência de elementos intrínsecos ao produto, realçar qualidades sobre propriedades terapêuticas e aconselhar seu consumo como estimulante para melhorar a saúde (CARRANO, 2008).

\subsubsection{Aspectos mercadológicos}

A embalagem de um produto deve se adequar ao mercado no qual o produto será inserido, principalmente considerando o mercado de orgânicos e todas as suas singularidades. Inicialmente, Gurgel (2007) destaca que a embalagem deverá agregar valor ao produto, ajudando na formação das vantagens competitivas. Para isso, ela deve facilitar a identificação e a diferenciação da marca no segmento de mercado específico do produto.

A embalagem deve atrair, envolver e manter um relacionamento com os usuários para se destacar em relação aos produtos convencionais e barrar as alternativas da concorrência, capturando e expondo o conceito do alimento orgânico e da marca da indústria produtora. 
O ambiente de comercialização condiciona o design da embalagem, devendo ser observada a posição onde o produto será exposto, ao lado de outros produtos, apresentando valores que proporcionem uma efetiva situação privilegiada com relação à concorrência. Devem também ser considerados os investimentos necessários para a implantação de novos materiais e segmentação geográfica ajustada à rentabilidade desejada pelo varejista e ao tamanho da empresa.

Mestriner (2002) acrescenta que devem ser consideradas as características, tamanho e linguagem visual do segmento de mercado em que o produto participa, observando o público-alvo e comportamento do consumidor em relação à categoria de produto, no caso, os alimentos orgânicos. No item 2.4 desta dissertação, é apresentada uma pesquisa que mostra como é o consumidor de orgânicos.

\subsubsection{Design de embalagem}

Segundo Mestriner (2002), o design de embalagem compreende a atividade de desenhar para a indústria, segundo uma metodologia de projeto, que leva em consideração a sua função do produto, características técnicas da matéria-prima e do sistema produtivo utilizado em sua confecção, as características e necessidades do mercado e do consumidor.

O design de embalagens deve integrar todas as áreas de desenvolvimento, produção, uso e descarte para que a embalagem possa cumprir eficientemente todas as suas funções. 0 design é componente integrador do Sistema de Embalagem, por estar presente desde o início da concepção do produto, durante o qual o tipo e a forma da embalagem são definidos considerando todas as etapas.

O conceito chave para o design de embalagem é a relação entre design e mercado (varejistas, donos de marcas e fabricantes de embalagem e consumidores). $O$ seu desenvolvimento deve estar integrado com as principais áreas de uma empresa, como a de marketing, departamento jurídico, produção, compra, design do produto e publicidade, incluindo os seus fornecedores, sendo o consumidor o foco de todo o desenvolvimento de um produto, até o seu descarte final (MESTRINER, 2007; STEWART, 2009).

Quando um indivíduo interage com a embalagem, o resultado desejado pode ser algum tipo de mudança em crença ou no comportamento. Segundo Dougherty (2011), essas mudanças impulsionam as vendas, desenvolvem o valor da marca e ajudam a determinar o sucesso ou o fracasso de um produto.

Aumentar o índice de resposta é uma das ações mais ecológicas que podem ser feitas pelos designers. $O$ bom design é mais sustentável que o design ruim porque ele realmente atinge os resultados desejados sem a distribuição desmedida de mensagens.

Uma abordagem dos fatores humanos também pode tornar os projetos de design mais eficazes, ajudando a visualizar e melhorar a experiência do usuário e com o foco nos aspectos físicos e psicológicos ao usar os produtos. Um exercício de segmentação do consumidor pode levar os designers a pensarem exatamente sobre as pessoas com as quais eles tentam se comunicar

A embalagem deve ser desenvolvida e pensada seguindo as necessidades dos indivíduos. Não apenas como um objeto de consumo, mas como algo a ser inserido na vida humana de forma positiva e benéfica. Mesmo depois, seguindo para o processo de descarte, deverá ter 
sido pensada para continuar a refletir tal propósito. Por ter a embalagem tamanha proximidade de relação com o indivíduo, é preciso usar de forma correta sua força de comunicação, a qual deveria servir como uma importante ferramenta no processo de desenvolvimento social.

\subsection{CADEIA PRODUTIVA DO ALIMENTO ORGÂNICO}

Em qualquer setor, é de grande importância conhecer cada etapa que compõe sua cadeia produtiva e verificar como são estabelecidos os relacionamentos entre os agentes envolvidos (ORMOND et al., 2002). Esta análise permite identificar os elos mais fortes e os mais vulneráveis, que são informações importantes para fundamentar o desenvolvimento de uma embalagem.

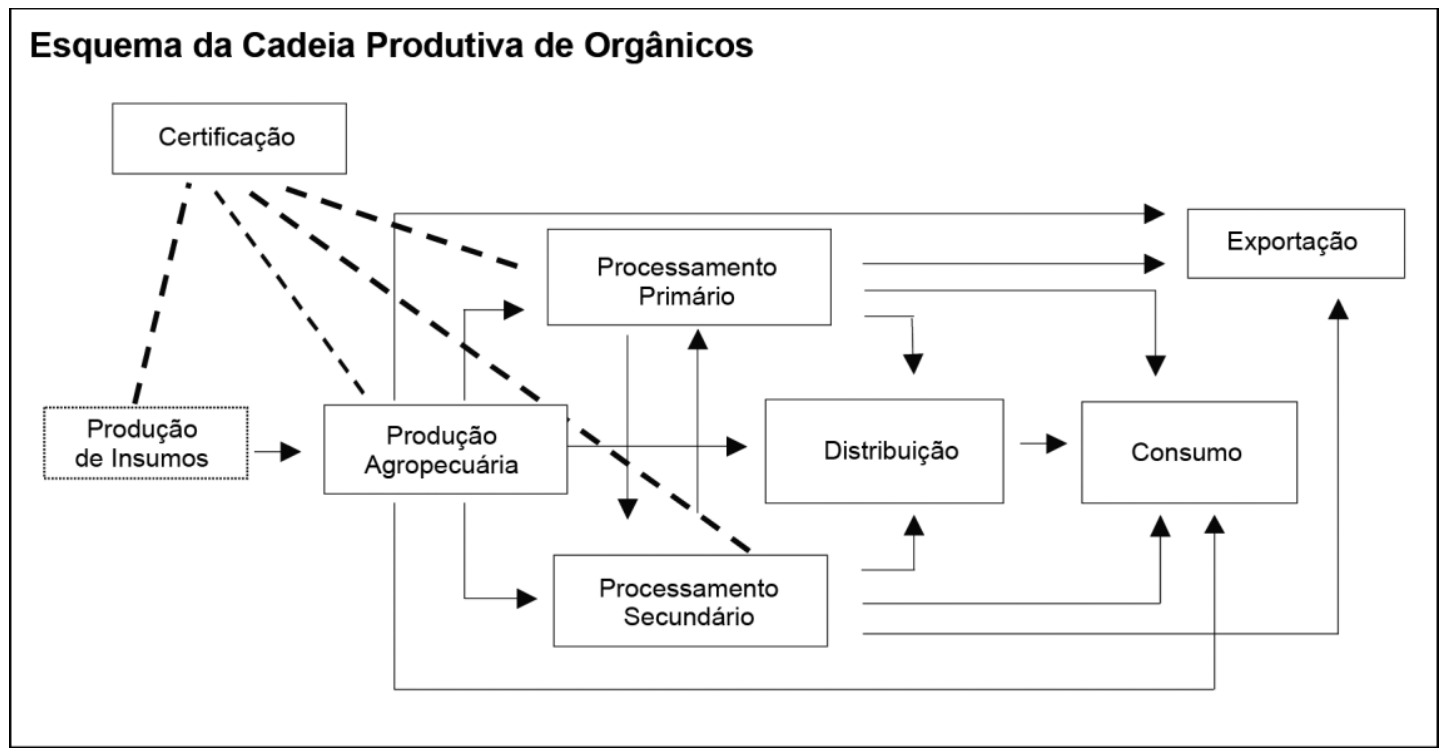

Figura 3 - Cadeia produtiva de orgânicos. Fonte: Ormond et al., 2002

O esquema anterior, desenvolvido por Ormond e seus colaboradores (2002), identifica as principais funções, e agentes, que compõem a cadeia produtiva de produtos orgânicos, mostrando as formas de relacionamentos entre eles.

\section{Certificação}

As instituições certificadoras têm importante papel nessa cadeia produtiva, uma vez que a sua credibilidade é determinante da confiança que distribuidores e consumidores devotam ao produto oferecido.

\section{Produção de insumos}

Consiste na produção de mudas, sementes, adubos, fertilizantes, controladores de pragas e doenças, defensivos, embalagens e outros itens necessários ao manejo orgânico de uma área ou propriedade. A maior parte desses agentes é formada por produtores ou pequenas empresas dedicadas exclusivamente a esse nicho de mercado.

\section{Produção agropecuária}

É a fase no processo em que são separadas as matérias-primas para sua geração ou elaboração de um produto em sua produção. Dentro desta fase, é coletado todo o tipo de matérias-primas, descartes, excedentes gerados de produção, recursos gerados da reciclagem, entre outros (MANZINI; VEZZOLI, 2005). Fabricantes de matéria-prima para a embalagem, proprietários rurais e empresas agropecuárias compõem esse segmento. 
Segundo Ormond e colaboradores (2002), em geral, os produtores rurais se dedicam à produção de commodities e são verticalizados, atuando também no processamento secundário. Os pequenos proprietários, em sua maioria, dedicam-se à produção de hortifrutigranjeiros e são ligados a associações de produtores, cooperativas ou empresas de processamento, responsáveis pela comercialização. Eventualmente, fazem comercialização direta em feiras de produtores.

As fases da cadeia produtiva descritas pelos autores (ORMOND et al., 2002) também esquematizam o ciclo de vida de um produto que demostra a sua entrada, permanência e saída, e o uso do produto no mercado (MANZINI; VEZZOLI, 2005).

\section{Produção ou processamento}

É a fase no processo que permite que os materiais passem por momentos de elaboração (beneficiamento, envase). Nessa fase, realizam-se o controle e o planejamento, para depois constituir sua fase final. No caso dos alimentos orgânicos, são dois tipos de processamento (ORMOND et al., 2002):

\section{Processamento primário}

Tratam-se de empresas, cooperativas ou associações de produtores que atuam na coleta de produção regional e fazem seleção, higienização, padronização e envase de produtos a serem consumidos in natura, sendo responsáveis pelo transporte e comercialização da produção. Não raro, fornecem insumos e assistência técnica, reproduzindo, em parte, o processo de integração de outras cadeias produtivas agroalimentares. Em geral, possuem marca própria. Podem atuar tanto no mercado interno quanto em exportação. Uma parte de suas vendas é feita diretamente ao consumidor através de entregas domiciliares, mas também vendem às indústrias para processamento secundário.

\section{Processamento secundário}

Uma gama variada de indústrias compõe esse segmento, desde grandes indústrias de alimentos a pequenas indústrias. Podem ser dedicadas integralmente a essa atividade, ter linhas de produção específicas ou utilizar linhas de produção convencionais para processar orgânicos. Boa parte tem o suprimento de matériaprima proveniente de sua própria produção, mas pode também captar de produtores ou processadores primários a matéria-prima necessária. Todos os produtos e aditivos utilizados têm necessariamente de ser orgânicos e as linhas de produção têm de passar por criteriosa limpeza, de forma a eliminar os vestígios de produtos não orgânicos, para evitar a contaminação.

Manzini e Vezzoli (2005, p. 95) ressaltam que "Outras atividades e processos atribuíveis a essa fase são: a pesquisa, o desenvolvimento, o projeto, os controles produtivos e, ainda, a gestão dessa atividade".

\section{Distribuição}

É a fase no processo onde o produto é submetido ao processamento primário e/ou secundário até ser entregue para o consumidor final. Nesta fase, os produtos são transportados em sua embalagem de transporte.

Desta fase fazem parte, em princípio, não somente o consumo e a energia para o transporte, mas também o uso de recursos para a produção dos próprios meios de transporte utilizados, não esquecendo as estruturas para sua estocagem ou armazenagem. (MANZINI; VEZZOLI, 2005, p. 95) 
Os principais pontos de venda dos produtos orgânicos são lojas de produtos naturais, lojas especializadas em hortifrútis e supermercados. Esses estabelecimentos detêm boa parte do conhecimento das preferências do consumidor e da quantidade demandada pelo mercado. Essas informações, quando repassadas aos seus fornecedores, permitem o planejamento da produção.

\section{Consumo}

O consumo, ou uso do produto, se dá por um período curto, no caso dos alimentos orgânicos. Estão incluídos os consumidores institucionais (restaurantes, lanchonetes, empresas etc.).

A fase da exportação deve se considerada nos casos em que isso acontece, o que não é o caso das empresas selecionadas. Além das fases descritas, ainda devem ser consideradas a fase do descarte e da produção de embalagem.

\section{Descarte}

Os resíduos gerados na produção agropecuária são, em geral, controlados. É um dos requisitos para a certificação de orgânicos, porém, após o consumo, a embalagem é absorvida pela mesma cadeia de reciclagem dos produtos convencionais.

A cadeia produtiva dos orgânicos pouco se diferencia das demais cadeias agroalimentares, a não ser pela presença da figura da certificação. Em muitos casos, pode não ter a figura do atacadista entre a produção e o elo seguinte, ausência que se dá em função da pequena escala de produção.

A função do atacadista foi substituída pelo processamento primário, como nas indústrias pesquisadas, que, na tentativa de criar escala de comercialização, incentiva produtores a produzir orgânicos, desempenhando papel semelhante ao das indústrias integradoras de outras cadeias (ORMOND et al., 2002).

\section{Sistema de embalagem de alimentos}

O sistema de embalagem é conjunto de operações de um sistema complexo e multidisciplinar, consequência da atuação de diversos especialistas, a fim de integrar o objeto acabado, conduzindo-o até o seu destino final, atendendo às necessidades dos consumidores a um custo adequado, respeitando a ética e o meio ambiente (MESTRINER, 2007). Cada parte afeta o desempenho do todo e as partes não têm razão para existir quando analisadas isoladamente.

A embalagem não é uma parte isolada, ela está integrada aos outros sistemas da cadeia produtiva de alimentos orgânicos. O alimento industrializado, para ser produzido e vendido, exige que existam outros produtos para sua fabricação, seu transporte e sua utilização, além da infraestrutura (KAZAZIAN, 2005). A embalagem faz parte desse sistema, envolvendo um grande número de variáveis e de agentes das cadeias produtivas.

Os altos custos dos fretes, as estradas mal cuidadas, o uso de veículos inadequados, o acondicionamento em embalagens inapropriadas e as técnicas obsoletas de carga e descarga fazem da logística de distribuição uma das principais causas de perda de qualidade dos produtos agrícolas, trazendo prejuízos para produtores e consumidores.

Segundo Negrão e Camargo (2008), entre as medidas objetivas adotadas na fase de póscolheita que poderiam reduzir tal percentual e manter a qualidade do produto, destacam-se, por exemplo: o uso de embalagens adequadas; a paletização da carga; a utilização de refrigeração; o transporte e a armazenagem apropriados. 


\section{Cadeia produtiva da embalagem}

Segundo Mestriner (2007), a cadeia produtiva da embalagem tem como base a matériaprima, que se origina basicamente de três fontes: madeira, minerais e petróleo. A embalagem é fabricada em indústrias especializadas, denominadas convertedoras. Uma vez fabricadas, elas são entregues aos fabricantes de produtos, que as utilizarão em suas linhas de envase.

Esses fabricantes são denominados envasadores. Uma vez colocados para a sua proteção e conservação em embalagens primárias, os produtos são acondicionados para o transporte e a distribuição em embalagens secundárias de embarque, ou transporte, como são denominadas. Os produtos são distribuídos até chegarem ao varejo do consumidor, que os utilizam e descartam suas embalagens. Após serem descartadas, elas vão para o lixo ou voltam ao processo - por meio da reciclagem.

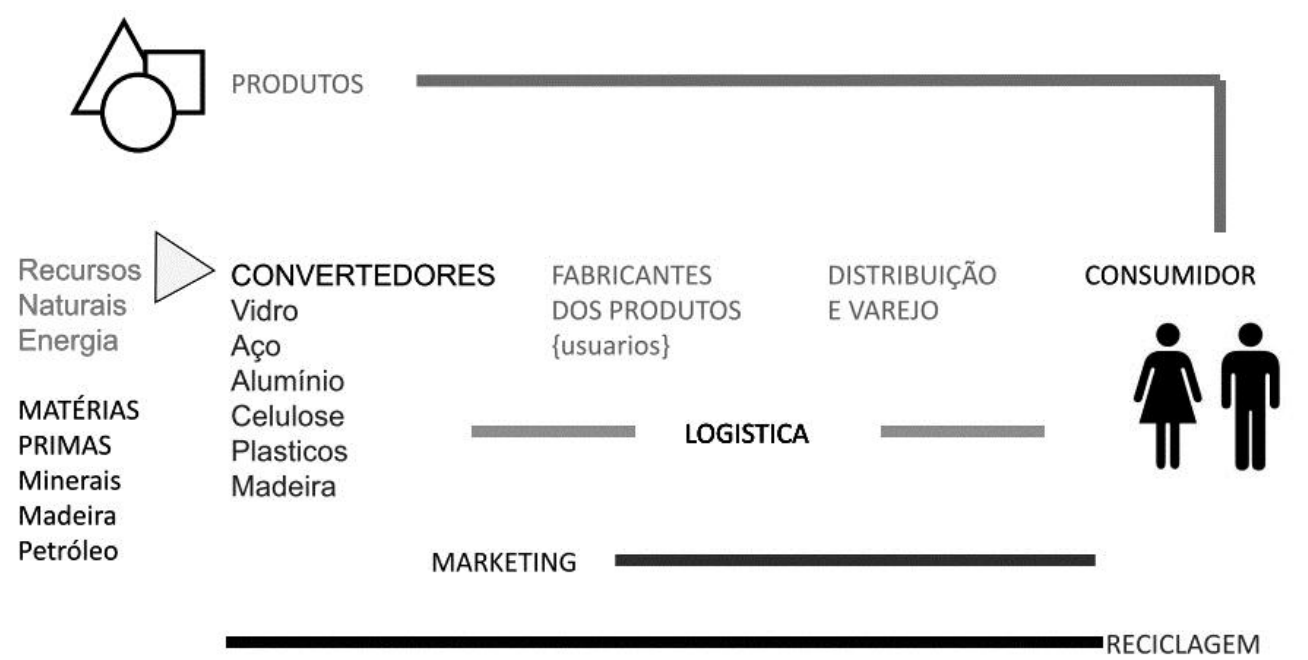

Figura 4 - Cadeia produtiva da embalagem. Fonte: ABRE, 2013

Para que isso aconteça, entram em ação várias empresas e um grande número de profissionais de especialidades diversas, que contribuem para que tudo funcione da melhor maneira possível, permitindo que o produto chegue a seu destino em perfeitas condições de consumo (MESTRINER, 2007).

Em cada etapa da cadeia produtiva, existe potencial para reduzir o consumo de recursos e melhorar o desempenho dos produtos. Para ter sucesso, todos os departamentos da organização e todos os atores da cadeia do produto devem ser envolvidos (MANZINI; VEZZOLI, 2005). Comunicação e cooperação entre os parceiros envolvidos constroem conexões entre a cadeia de suprimentos e a cadeia de valor. Nesse contexto, o designer pode ser um elemento integrador desse sistema.

\section{Sistemas abertos e fechados}

Produtos de um sistema industrial, como os alimentos orgânicos e as embalagens, em geral, são projetados para um sistema linear e unidirecional. Esse tipo de sistema é chamado como modelo do berço ao túmulo. Os recursos são extraídos, moldados em produtos, vendidos e, eventualmente, jogados "fora", em algum tipo de "túmulo" como um aterro sanitário ou incinerador, mas a realidade é que não há o "fora" (BRAUNGART; MCDONOUGH, 2008). São os ciclos de vida de um produto. 
O conceito de ciclo fechado, ou do "berço ao berço", foi explorado no livro Cradle to cradle: remaking the way we make things (2008), do engenheiro William McDonough e do designer e arquiteto Michael Braungart. No livro, eles exploram o conceito de forma mais tangível. A visão do Cradle to cradle olha para dois ciclos - o ciclo biológico e o ciclo técnico, que inclui a cadeia produtiva (Figura 5).
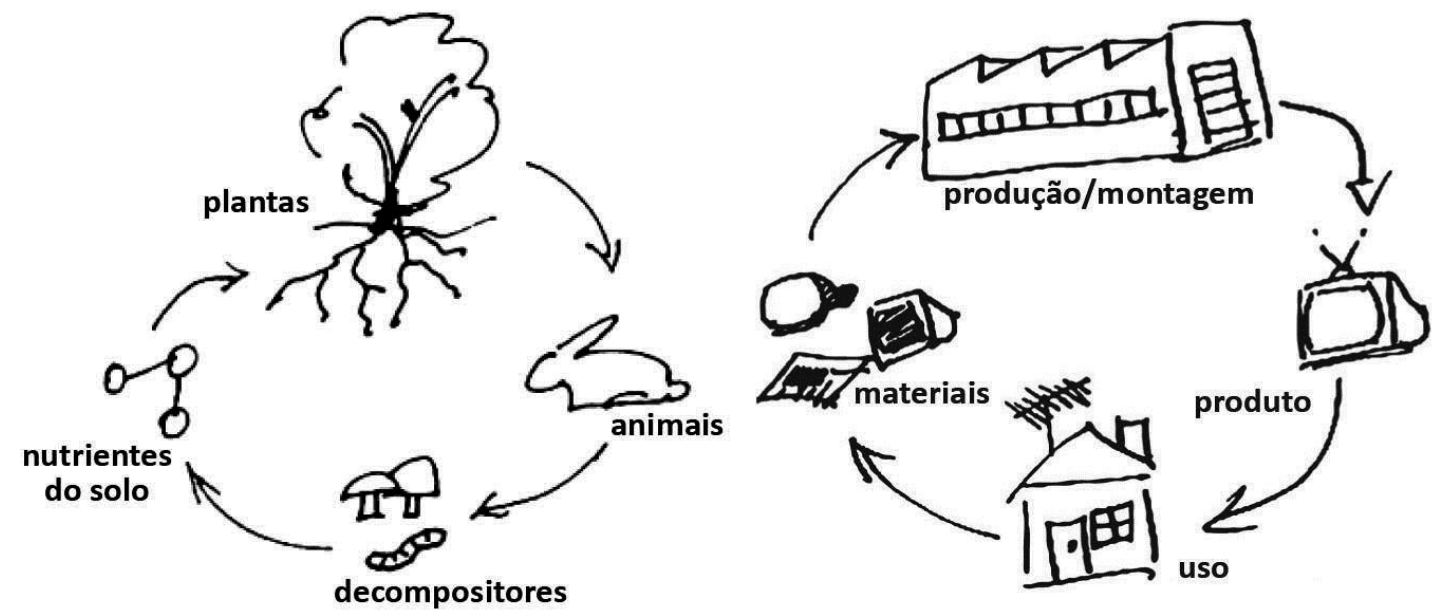

Figura 5 - O ciclo biológico e o ciclo técnico. Fonte: Braungart; McDonough, 2012

Um ponto de vista fundamental no conceito de Cradle to cradle é que o ciclo de vida do produto não deve terminar quando seus materiais são simplesmente despejados nos sistemas naturais. Dentro do ciclo de técnico, os produtos finais são utilizados como entrada para um novo ciclo de produção como "nutriente técnico", como a embalagem, criando um metabolismo técnico semelhante ao metabolismo biológico da terra, podendo ser continuamente reciclados e transformados em novas embalagens de valor igual e sem contaminar a biosfera. Estas operações de fabricação devem ser alimentadas por $100 \%$ de energias renováveis e maximizar a qualidade e a eficiência da água, respeitando as pessoas e os ecossistemas.

Além disso, as embalagens podem ser projetadas de modo que os materiais possam ser devolvidos com segurança para o ecossistema como "nutrientes biológicos", se biodegradando e construindo um solo saudável. O resíduo vira alimento para o sistema.

A interação entre os vegetais e os animais, combinada com os ritmos naturais do clima, da água e das marés, provê a base do ciclo de vida, ciclo este que é antigo, complexo e altamente interconectado. Quando se rompe um de seus componentes ficam afetados os oceanos, o solo, as chuvas, o calor, o vento, as moléstias e as tundras, para citar apenas alguns componentes. (HAWKEN; LOVINS, 2007, p. 141)

Com a integração da noção de circularidade e a variedade dos ritmos naturais, a empresa pode perceber outra relação com o tempo e, a partir disso, elaborar uma estratégia que lhe permita reduzir seus custos em matéria, pagar menos impostos, preparar-se para novas obrigações regulamentares. Assim, pode-se inovar por meio de novas estratégias de gestão e conseguir se aproximar de verdadeiros ecossistemas industriais sistêmicos em um modelo de produção autônomo (KAZAZIAN, 2005).

As partes de um sistema produtivo não podem ser consideradas individualmente, pelo contrário, todas devem ser tratadas ao mesmo tempo (JEDLIČKA, 2009). Na visão sistêmica da produção de alimentos, a embalagem adquire um papel estratégico e fundamental para as empresas, influenciando áreas como o marketing, distribuição, produção e até o serviço de atendimento ao consumidor. 
Um método desenvolvido para se quantificar, e futuramente reduzir, o uso de recursos ao longo do ciclo de vida é a Avaliação do Ciclo de Vida (ACV). Ele é um procedimento integrado, que quantifica o impacto de um produto ao longo do seu ciclo de vida, avaliando os aspectos ambientais e os impactos potenciais associados a um produto ou atividade, compreendendo etapas que vão desde a retirada da natureza das matérias-primas elementares que entram no sistema produtivo (berço) à disposição do produto final (túmulo) (ABCV, 2012; CHEHEBE, 1997; COLTRO, 2007; JEDLIČKA, 2009).

Esta metodologia permite a todos os envolvidos na produção de alimentos realizar mudanças pontuais, a fim de reduzir os seus impactos no meio ambiente. No contexto da sustentabilidade, todos os setores têm grande importância para se atingir as metas desejadas. Dessa forma, o design tem também sua responsabilidade e uma capacidade transformadora.

Para esta pesquisa, não será feita a ACV das embalagens para analisar o seu impacto ambiental. Interessa apenas saber se a empresa fez, mostrando a sua preocupação com o impacto ambiental. A análise das embalagens se baseará no que for divulgado pelas empresas, caso tenham feito.

Porém, a solução de design de embalagem deve ser considerada como uma solução pontual dentro de um sistema complexo; caso contrário, pode ter consequências inesperadas em outras áreas e apenas resolve uma situação que é limitada em seu alcance.

Esta pesquisa irá abordar áreas que o design influencia diretamente, como o relacionamento do designer com a empresa durante o desenvolvimento da embalagem.

\subsection{O CONSUMIDOR DE ALIMENTOS}

As escolhas feitas na hora do consumo, de certa forma, manifestam a forma como se vê o mundo, por isso é necessário conhecer o consumidor para o desenvolvimento das embalagens. O consumo envolve coesão social, produção e reprodução de valores; desta forma, não é uma atividade neutra, individual e despolitizada. O manual de consumo sustentável do Ministério do Meio Ambiente (MMA) indica que:

[...] trata-se de uma atividade que envolve a tomada de decisões políticas e morais praticamente todos os dias. Há, portanto, uma conexão entre valores éticos, escolhas políticas, visões sobre a natureza e comportamentos relacionados às atividades de consumo. (MMA et al., 2005, p. 14)

Grande parte da população escolhe o que vai comer com base em sua preferência pessoal, que recebe influência também de aspectos sociais, econômicos e culturais. A percepção do aumento de uso de recursos naturais e os impactos ambientais envolvidos estimularam o surgimento de novas formas de se consumir e novos perfis de consumidores, que, segundo o MMA (2005), são: consumo verde e consumo consciente, ético ou responsável. Surgiu também uma nova proposta de política ambiental que ficou conhecida como consumo sustentável.

\section{Consumo verde}

Segundo o MMA, consumo verde é aquele em que o consumidor, além de buscar melhor qualidade e preço, inclui, em seu poder de escolha, a variável ambiental, dando preferência a produtos e serviços que não agridam o meio ambiente, tanto na produção quanto na distribuição, no consumo e no descarte final.

Esta estratégia tem alguns benefícios importantes, como o fato de os cidadãos comuns sentirem, na prática, que podem ajudar a reduzir os problemas ambientais e sentem-se 
parte de um grupo crescente de pessoas preocupadas com o impacto ambiental de suas escolhas. Mas a estratégia de consumo verde tem algumas limitações. Os consumidores são estimulados a trocar uma marca $X$ por uma marca $Y$, para que os produtores percebam que suas escolhas mudaram. A possibilidade de escolha, portanto, acabou se resumindo a diferentes marcas e não entre consumismo e não consumismo (MMA et al., 2005).

\section{Consumo consciente, ético ou responsável}

Estas expressões surgiram como forma de incluir a preocupação com aspectos sociais, e não só ecológicos, nas atividades de consumo. Nestas propostas, os consumidores incluem, em suas escolhas de compra, um compromisso ético, uma consciência e uma responsabilidade quanto aos impactos sociais e ambientais que suas escolhas e comportamentos podem causar em ecossistemas e outros grupos sociais, na maior parte das vezes geográfica e temporalmente distantes (MMA et al., 2005).

O consumo consciente pode fazer a diferença e constituir-se na grande arma para ajudar a superar as questões referentes à produção, à sustentabilidade do planeta, à fome e à obesidade. Segundo o Instituto Akatu (2004), o consumidor consciente de alimentos:

- Busca a melhor relação entre preço, qualidade e comportamento social e ambiental da empresa ao comprar produtos e serviços;

- Preocupa-se com o impacto da produção e do consumo sobre a comunidade e o meio ambiente;

- Valoriza e divulga empresas socialmente responsáveis;

- Atua de forma construtiva com as empresas para o aprimoramento de suas relações com a sociedade e com o meio ambiente;

- Torna-se um multiplicador de informação, divulgando trabalhos, programas e campanhas realizados por organizações e empresas;

- Informa, propõe mudanças, políticas e campanhas;

- Usa a mídia como aliada para informar, mediar e pressionar;

- Cultiva a terra, consome a própria produção e ensina os vizinhos, amigos e a comunidade a fazer o mesmo;

- Utiliza o lixo orgânico como adubo para a horta caseira.

\section{Consumo sustentável}

Esta proposta tende a ser mais ampla que as anteriores, pois, além das inovações tecnológicas e das mudanças nas escolhas individuais de consumo, enfatiza ações coletivas e mudanças políticas, econômicas e institucionais para fazer com que os padrões e os níveis de consumo se tornem mais sustentáveis. Mais do que uma estratégia de ação a ser implementada pelos consumidores, consumo sustentável é uma meta a ser atingida. Poderíamos identificar seis características essenciais que devem fazer parte de qualquer estratégia de consumo sustentável (MMA et al., 2005):

- Faz parte de um estilo de vida sustentável em uma sociedade sustentável;

- Contribui para nossa capacidade de aprimoramento, enquanto indivíduo e sociedade;

- Requer justiça no acesso ao capital natural, econômico e social para as gerações presentes e futuras;

- O consumo material deve se tornar cada vez menos importante em relação a outros componentes da felicidade e da qualidade de vida; 
- É consistente com a conservação e melhoria do ambiente natural;

- Acarreta um processo de aprendizagem, criatividade e adaptação.

No Brasil, o movimento ainda se encontra em estágio inicial. No entanto, estima-se que um em cada três brasileiros já tenha praticado, em algum momento, consumo responsável, baseado em informações sobre o comportamento socioambiental das empresas.

Segundo o Monitor de responsabilidade social corporativa 2009 (apud VOLTOLINI, 2009), $59,3 \%$ dos consumidores são indiferentes às questões socioambientais, e o preço continua sendo, de longe, o fator mais valorizado (35\%) pelo consumidor brasileiro no momento de escolher o produto. Em seguida, vêm as características funcionais (19\%) e confiança na marca (16\%). A análise sobre o comportamento socioambiental da empresa fabricante aparece com 9\% de importância na decisão de compra.

A pesquisa Sustentabilidade: aqui e agora, realizada pelo MMA, em parceria com o Instituto Synovate e o Wal-Mart Brasil (2010), identificou que 74\% dos entrevistados ficam mais estimulados a comprar produtos que foram fabricados de maneira ambientalmente correta.

Nesse cenário, preocupações mais recentes, como as mudanças climáticas e o esgotamento de recursos naturais, levarão mais consumidores a exigir operações mais responsáveis para com a sociedade e o planeta.

Os produtores de alimentos orgânicos que souberem comunicar bem os diferenciais ambientais de seus produtos poderão se posicionar como marcas éticas em uma nova economia mais sustentável.

\subsection{1. $O$ consumidor de orgânicos}

Em 2010, foi feita uma pesquisa, realizada pela Organic Services e a Vital Food, sobre o comportamento e a percepção do consumidor de alimentos orgânicos. A pesquisa foi feita em sete capitais (São Paulo, Rio de Janeiro, Curitiba, Brasília, Belo Horizonte, Goiânia e Belém), num total de 1.907 entrevistas, das quais 765 feitas via internet e 1.139 nos principais pontos de venda de orgânicos em cada uma das cidades acima mencionadas.

Na pesquisa, foi constatado que $69 \%$ dos consumidores de orgânicos são mulheres, sendo que $29 \%$ delas têm de 31 a 45 anos de idade e $39 \%$ de 46 a 60 anos. O fato de a maior parte das consumidoras ser de mulheres de meia idade pode ser um indicativo de maior preocupação com a saúde a partir de determinado estágio da vida.

O público consumidor de orgânicos é economicamente ativo, tem nível elevado de escolaridade (um terço tem graduação, pós-graduação ou escolaridade acima disso). Em números, $40 \%$ têm pelo menos o curso superior completo. Quanto à renda, $44 \%$ ganham acima de $\mathrm{R} \$ \mathbf{m i l}$ (21\% entre $\mathrm{R} \$ 6$ mil e $\mathrm{R} \$ 10$ mil e $23 \%$ mais de $\mathrm{R} \$ 10 \mathrm{mil}$ ).

Sobre a imagem dos orgânicos, a pesquisa mostra que está fortemente ligada à saúde e à ausência de agrotóxicos, hormônios e adubos químicos. Além disso, $88 \%$ concordam que alimentos orgânicos têm alto valor nutritivo; $48 \%$ compram por questões de saúde; e $36 \%$ compram pelo fato de o alimento não conter agrotóxico.

O consumidor de orgânicos é relativamente bem informado, pois $44 \%$ declararam que sabem bastante sobre o modo de produção orgânica; $52 \%$ sabem um pouco a respeito; e $4 \%$ 
dos consumidores de orgânicos já ouviram falar do termo orgânico, mas não têm certeza do que significa.

Mesmo consumindo alimentos orgânicos, mais de $50 \%$ da amostra considera que conhece pouco a respeito, quase $1 / 3$ não reconhece nenhum selo de certificadora e mais da metade não se lembra de nenhuma marca. Dos que lembram, 72\% reconhecem algum selo certificador e $29 \%$ não reconhecem selo nenhum. Além disso, $51 \%$ não se lembraram de nenhuma marca de orgânicos, espontaneamente, e $49 \%$ citaram pelo menos uma marca. Vale lembrar que a pesquisa foi feita antes da obrigação do selo SisOrg criado pelo MAPA.

Outro dado da pesquisa abordou o tema de vegetais transgênicos, proibidos por lei nos cultivos orgânicos. Na visão dos consumidores pesquisados, $63 \%$ afirmaram que alimentos orgânicos não podem ter elementos transgênicos, mas uma parcela relativamente alta $17 \%$ e $4 \%$, respectivamente - concordou que pode haver transgênicos em orgânicos ou concorda plenamente com a presença de transgênicos em alimentos orgânicos.

O consumidor de orgânicos é fiel, já que $58 \%$ compram orgânicos semanalmente; $12 \%$ pelo menos a cada 15 dias; $8 \%$ mensalmente; e $22 \%$ ocasionalmente, mesmo com o fato de $3 / 4$ dos pesquisados acharem os orgânicos caros demais. Entre os alimentos mais consumidos, estão as frutas, legumes e verduras, com $94 \%$ do total.

Já as principais dificuldades para comprar orgânicos, na visão dos consumidores que responderam à pesquisa, são preço alto, pouca variedade e dificuldade para encontrar produtos orgânicos. De todo modo, justamente pela dificuldade de encontrar orgânicos, os consumidores fiéis buscam outras opções de locais para a compra como outros supermercados, lojas de orgânicos e feiras orgânicas. Entre os produtos à disposição do consumidor, os itens mais procurados são, em primeiro lugar, as frutas; depois, verduras, legumes e cereais básicos.

Quanto aos pontos de venda no varejo, os supermercados (72\%) são, de longe, o principal meio de venda da produção orgânica. Em seguida, vêm as lojas especializadas (41\%); as feiras de orgânicos (35\%); mercado local (9\%); feiras em geral (9\%); e, por último, pela internet ou telefone (5\%).

O consumidor de orgânicos busca lojas que ofereçam produtos de qualidade, com praticidade e preço baixo. As feiras de orgânicos detêm o maior grau de satisfação dos consumidores. De forma geral, eles querem consumir mais alimentos orgânicos, mas a maior dificuldade para isto é o preço: $79 \%$ da amostra não aceita pagar mais de $30 \%$ a mais por produtos orgânicos.

\subsection{COMUNICAÇÃO PARA O CONSUMIDOR}

Segundo Gurgel (2007), a aparência da embalagem engloba: os aspectos visuais, a forma, a cor, as ilustrações, o texto, a marca e outras características do grafismo. Os estímulos emanados de uma embalagem deverão chamar a atenção de forma que seja possível memorizar a marca, a cor e a forma do produto. Além disso, as informações textuais e visuais da embalagem devem estar visíveis e legíveis e as cores, relacionadas com a tendência do meio ambiente, a cor do produto e a família de produtos a qual pertence. 
A embalagem também pode gerar emoções nos usuários, inspirando confiança, para estimulá-los a uma ação de compra em decorrência das especificidades presentes no produto em detrimento das utilidades futuras de outros bens que possam ser adquiridos.

A embalagem é um instrumento comunicacional e seu aspecto semiológico é destacado por diversos autores (FERRARA, 1993; GURGEL, 2007; LAUTENSCHLÄGER, 2001; SANTAELLA, 2005). O designer (emissor) identifica uma necessidade e elabora um projeto gráfico e estrutural contendo uma mensagem que deve ser apreendida pelo consumidor (receptor). 0 projeto comunicacional da embalagem, na dimensão sintática do mesmo, procura estabelecer relações formais entre os elementos da embalagem. Já na dimensão semântica, relacionada ao significado, a embalagem transmite conceitos e emoções através de seus símbolos visuais (NEGRÃO; CAMARGO, 2008).

É o design que transforma uma mercadoria formada por ingredientes e processos industriais em um produto cheio de significados, mais desejado pelo consumidor (MESTRINER, 2007). É função do designer analisar, interpretar e propor signos que solucionem as necessidades físicas e visuais, otimizando recursos para obter a embalagem adequada, esperando com isto estabelecer um processo de comunicação e satisfazer as necessidades tanto do fabricante do produto como do consumidor do mesmo (GIOVANNETTI, 2000).

O resultado de todas as experiências, impressões, percepções e dos sentimentos que as pessoas apresentam condiciona a interpretação da mensagem que as embalagens devem transmitir no ponto de venda, como a familiaridade, credibilidade e condição favorável à compra. Essa imagem é algo intangível e deve ser desenvolvida, coordenada e sustentada sempre se considerando que a percepção visual da embalagem é algo subjetivo, com importantes fatores emocionais. No caso das pequenas indústrias, onde não há tanta verba para investir em propaganda, a embalagem é o único meio de divulgação de seus produtos.

Quando uma empresa produz mais de um produto, a identidade visual de uma família de produtos é expressa em sua embalagem, resumindo-se em um conjunto de características comuns a todos os produtos e com mensagens visuais que retratem o conceito a ser transmitido, no caso desta pesquisa, as características inerentes aos alimentos orgânicos.

A atratividade de uma embalagem depende do seu visual e, em alguns casos, oferece estímulos aos outros sentidos, como audição, olfato e paladar. Extraímos as principais características de uma imagem para a identificação de um padrão conhecido usando a visão para o exame dos detalhes (GURGEL, 2007).

Segundo Baxter (1998), a percepção humana é amplamente dominada pela visão e depende, basicamente, do aspecto visual da embalagem e do rótulo. A percepção é um processo dinâmico pelo qual aquele que percebe atribui um significado a matérias brutas oriundas do meio ambiente. A percepção e a capacidade de organizar a informação visual que se percebe dependem de processos naturais, das necessidades e propensões do sistema nervoso humano.

A interação de um designer com um material - ou produto - é provavelmente mais bemdescrita como experiência sinestésica. Sinestesia é um termo da psicologia que descreve a experiência física de sensações conjuntas (ASHBY; JONHSON, 2011, p. 15).

Segundo Ashby e Jonhson (2011), percepção é o resultado da interpretação daquilo que é observado. Dois observadores do mesmo produto o perceberão de maneiras diferentes, que resultarão na reação de cada um ao objeto físico que veem e às imagens e experiências mentais acumuladas que levam com eles: 
- Atributos de um produto que se referem ao design industrial;

- Atributos estéticos são aqueles relacionados diretamente aos sentidos: visão, tato, gosto, olfato e audição; o sentido da visão inclui a forma, a cor e a textura de um material ou produto;

- Atributos de associação são aqueles que remetem a uma época, lugar, evento, pessoa ou cultura;

- Atributos percebidos descrevem a reação a um material ou produto (ex.: sofisticado, moderno, engraçado etc.). Essas reações são a soma do que se percebe a princípio, e são muito influenciadas por contexto e experiência;

- Atributos emocionais descrevem a sensação que um material ou produto provoca no sujeito da experiência.

O dispositivo de informação constitui o conjunto de elementos da mensagem visual dos rótulos de embalagens que, dispostos de maneira planejada, fornecem as informações ao consumidor. Por isso, a percepção das informações dependerá dos fatores cognitivos e motivacionais do consumidor, dos tipos de códigos utilizados e da forma como a informação é apresentada na embalagem.

A estrutura visual da embalagem é formada por partes intercambiáveis. Podem ser isoladas e observadas de maneira independente, para logo em seguida serem reunidas na sua totalidade. Donis A. Dondis, a partir da Gestalt, observa que:

Para analisar e compreender a estrutura total de uma linguagem visual, é conveniente concentrar-se nos elementos visuais individuais, um por um, para um conhecimento mais aprofundado de suas qualidades específicas. (DONDIS, 1999, p. 53)

A Gestalt baseia-se no fato de a visão humana reconhecer determinados padrões. Os programas do cérebro extraem certos padrões visuais e ordena em uma imagem com significado, que se forma em função dos estímulos visuais recebidos durante o crescimento do indivíduo. $O$ ser humano tem bastante facilidade em perceber padrões regulares que podem ser desmembrados, como sugere Gurgel (2007), pela proximidade, similaridade continuidade e imagem e fundo. O ser humano, mesmo sendo um ser racional e social, ainda mantém inalterado o seu lado intuitivo.

\footnotetext{
Atingir esse lado primitivo e intuitivo do consumidor é muito importante, com a consideração dos padrões da Gestalt, a identificação da figura e do fundo, o balanceamento da harmonia, a complexidade, a estabilização das ambiguidades das imagens, o despertar dos sentimentos de ternura, e as regras de fugir da rejeição e elevar a atratividade de uma embalagem. (GURGEL, 2007, p. 147)
}

É também necessário perceber como o olhar do consumidor se movimenta. O centro de atenções de uma embalagem não é o centro geométrico da figura, pois devemos considerar as implicações da divisão áurea, uma vez que nem sempre o centro é o mais estético dos pontos. Também é necessário considerar que a entrada da visualização do consumidor, de modo geral, se processa da esquerda para a direita, por ser o sentido de leitura ocidental (GURGEL, 2007). 


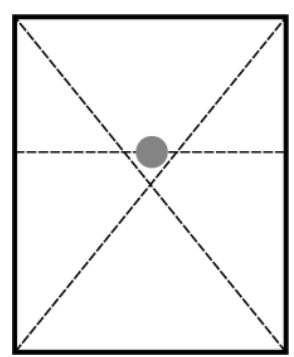

Figura 6 - Centros de atenção comparados com os centros geométricos Fonte: Gurgel, 2007

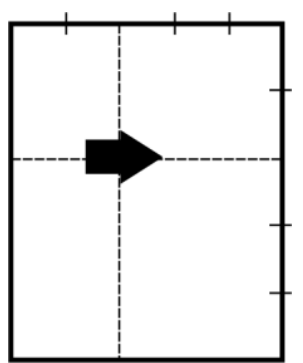

Figura 7 - Ponto de entrada e de atenção da visualização pelo usuário Fonte: Gurgel, 2007

Além de ser influenciado pelas relações dos elementos da estrutura visual da embalagem, segundo Dondis (1999), o olho favorece a zona inferior esquerda de qualquer campo visual criando uma tensão visual. Portanto, existe um padrão primário de varredura do campo que reage aos referentes verticais-horizontais, e um padrão secundário de varredura que reage ao impulso perceptivo inferior-esquerdo, conforme podemos ver nas figuras a seguir.

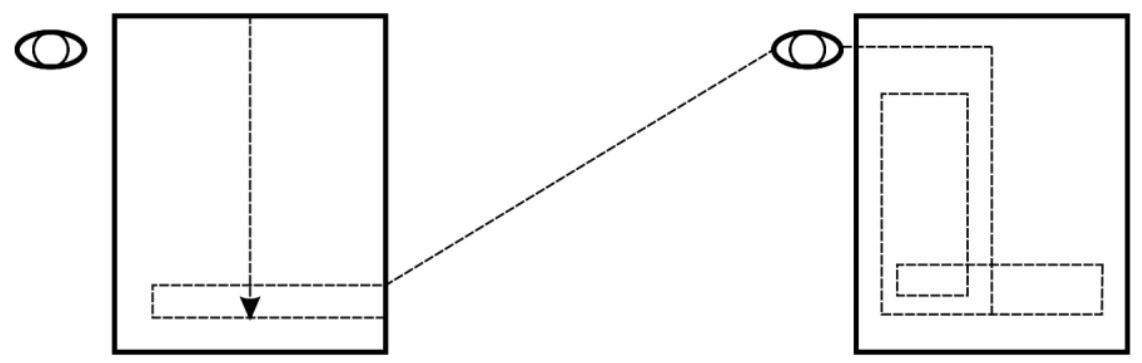

Figura 8 - Padrão primário de varredura de campo que reage aos referentes verticais-horizontais. Fonte: Dondis, 1997
Figura 9 - Padrão secundário de varredura que reage ao impulso perceptivo inferior-esquerdo. Fonte: Dondis, 1997

Quanto à composição dos elementos gráficos de uma embalagem, ela poderá ser simétrica ou assimétrica, podendo apresentar unidade, harmonia, simplicidade, atmosfera, proporção, equilíbrio, movimento, destaque, contraste e ritmo.

No entanto, a percepção está diretamente ligada à capacidade que o observador, ao interagir com o meio, tem de receber, interpretar e transmitir informações. Segundo Lautenschläger (2001), o homem seleciona, organiza e dá sentido ao que vê, e o meio sugere distinções e relações transmitindo para o consumidor as características de confiabilidade do produto, explícitas pelas formas de cada elemento que o compõe. Cada produto passa, assim, a ter sua própria linguagem e transmite ao usuário sensações de beleza, funcionalidade, resistência, durabilidade e segurança, sem a necessidade de uma interface de manuseio com o próprio produto.

A semiótica estuda as relações dos signos e sua interpretação. Concretamente, a função do designer de embalagens é analisar, interpretar e propor signos que solucionem as necessidades físicas e visuais, otimizando recursos para obter a embalagem adequada, esperando com isto estabelecer um processo de comunicação e satisfazer as necessidades tanto do fabricante do produto como do consumidor do mesmo (GIOVANNETTI, 2000).

Muitas vezes, os produtos são mal utilizados, podendo até ocorrer acidentes por causa de informações apresentadas de forma não clara na embalagem. A falta de compreensão das informações pode ter sido causada pela má visibilidade, legibilidade ou compressão dos signos visuais. 


\begin{abstract}
A legibilidade desempenha papel decisivo na qualidade das mensagens visuais e é o atributo de um caractere alfanumérico que permite a cada pessoa identificá-lo, em relação a outros caracteres. A legibilidade das letras, números, símbolos e expressões dependem de elementos como tamanho, proporção, cores, entre outros. (LAUTENSCHLÄGER, 2001 apud GONÇALVES; PASSOS; BIEDRZYCKI, 2008, p. 277)
\end{abstract}

Então, pode-se afirmar que diferenciação de um produto ou o ato de estabelecer um conjunto de elementos significativos traz vantagens competitivas para distinguir um tipo de produto, no caso os orgânicos, em relação aos convencionais.

Mediante uma linguagem visual, se estabelece o diálogo entre a embalagem e o consumidor, informando do que se trata o produto e motivando a compra. Para isso, são usadas formas, cores, símbolos e signos que tornam as embalagens suportes de informação e veículos de mensagens portadoras de significados.

\title{
2.6. COMUNICAÇÃO DOS ASPECTOS AMBIENTAIS NA EMBALAGEM
}

As declarações ambientais apresentam-se como importantes aliadas da comunicação dos valores ambientais de um produto para o consumidor, pois, ao mesmo tempo em que valorizam o desenvolvimento do setor produtivo, convidam a sociedade a repensar seus hábitos de consumo.

Para orientar estas declarações ambientais na embalagem, a Associação Brasileira de Embalagem (ABRE) criou a cartilha de Diretrizes de rotulagem ambiental para embalagens (2012). A cartilha é um referencial formal para a indústria brasileira de embalagem e de bens de consumo e se baseia na série de normas ISO 14020.

Essas normas, estabelecidas pela International Organization for Standadization (ISO), fazem parte da série de normas voltadas para a gestão ambiental nas empresas, a ISO 14001. As ações de rotulagem ambiental, ISO 14020, visam a criar a consciência para a importância dos aspectos ambientais de um produto ou serviço e uma mudança de comportamento do fabricante. Além de descrever os princípios gerais, a norma ISO regulamenta o uso dos rótulos e declarações ambientais, definidos em três tipos:

- Rotulagem Ambiental do Tipo I (ISO 14024), procedimentos de certificação para a concessão do rótulo;

- Rotulagem do Tipo II (ISO 14021), autodeclarações ambientais;

- Declarações Ambientais do Tipo III (ISO 14025) declaração com Avaliações de Ciclo de Vida.

\section{Rotulagem ambiental do Tipo I - certificação ambiental}

Na definição da ABNT, rotulagem ambiental é uma certificação que atesta, por meio de uma marca inserida na embalagem - daí o uso do termo selo -, que determinado produto/serviço apresenta menor impacto ambiental em relação a outros produtos disponíveis no mercado.

Essa norma estabelece os princípios e procedimentos para o desenvolvimento de programas de rotulagem ambiental do Tipo I, incluindo a seleção de categorias de produtos, critérios ambientais e características funcionais dos produtos, e parâmetros para avaliar e demonstrar sua conformidade. Essa norma também estabelece os procedimentos de certificação para a concessão do rótulo. 


\section{Rotulagem do Tipo II - autodeclarações ambientais}

Essa norma especifica os requisitos para autodeclarações ambientais no que se refere aos produtos, incluindo textos, símbolos e gráficos. Além da metodologia de avaliação e verificação geral para autodeclarações ambientais e métodos específicos de avaliação e verificação para as declarações selecionadas na própria norma, ela descreve também os termos usados comumente em declarações ambientais e fornece qualificações para o uso deles.

A autodeclaração ambiental oferece às empresas a flexibilidade e autonomia de comunicar sem a necessidade de certificação por terceiros. Porém, junto a essa vantagem, vem a responsabilidade de rotular com verdade e respaldo científico, verificável e acessível a todos (ABRE, 2012).

Antes da autodeclaração ambiental, a ABRE recomenda algumas medidas de avaliação que a verifiquem por meio de resultados confiáveis e reproduzíveis. Tal avaliação deverá ser registrada, disponibilizada para consulta futuras e deve valer durante todo o período que o produto estiver no mercado, considerando também a vida útil dele. Toda autodeclaração ambiental deve ser verificável, ou seja, as informações que comprovam sua veracidade devem estar facilmente acessíveis por qualquer parte interessada.

As autodeclarações de atributos mais comuns relativos às embalagens são: redução no uso de recursos, reutilizável, reciclável, com conteúdo reciclado (pré ou pós-consumo) e compostável.

\section{Declarações ambientais do Tipo III - declaração com Avaliação do Ciclo de Vida}

A declaração ambiental do Tipo III exige a avaliação de ciclo de vida segundo as normas da série ISO 14040. As declarações ambientais podem assumir a forma de textos, símbolos ou gráficos impressos no produto ou no rótulo da embalagem ou em literatura do produto, boletins técnicos, propaganda, publicidade, telemarketing, bem como na mídia digital ou eletrônica, como a internet.

A ABRE (2013) indica que, no setor de embalagens, é comum confundir Simbologia Técnica de Identificação de Materiais e Rotulagem Ambiental. Elas se diferem quanto à função e objetivo, conforme quadro abaixo:

\begin{tabular}{|c|c|}
\hline Rotulagem Ambiental & Simbologia Técnica de Identificação de Materiais \\
\hline $\begin{array}{l}\text { É uma ferramenta de comunicação que objetiva } \\
\text { aumentar o interesse do consumidor por produtos } \\
\text { de menor impacto, possibilitando a melhoria } \\
\text { ambiental contínua orientada pelo mercado. Esse } \\
\text { tipo de rotulagem agrega um diferencial e, por isso } \\
\text { mesmo, deve ser usado com ética e transparência } \\
\text { para não confundir, iludir e tampouco distorcer } \\
\text { conceitos de sustentabilidade. }\end{array}$ & $\begin{array}{l}\text { Parte integrante da norma } 14021 \text {, foi criada para } \\
\text { facilitar a identificação e separação dos materiais, } \\
\text { fortalecendo a cadeia de reciclagem. Todas as } \\
\text { embalagens devem conter esta identificação } \\
\text { técnica, mesmo que na prática nem todas sejam } \\
\text { enviadas para reciclagem, por não existirem } \\
\text { processos técnicos ou economicamente viáveis na } \\
\text { região em que foram descartadas. }\end{array}$ \\
\hline
\end{tabular}

Figura 10 - Diferenças entre Rotulagem Ambiental e Simbologia Técnica de Identificação de Materiais

A Simbologia Técnica de Identificação de Materiais não é garantia de que o material será reciclado. Sendo assim, os símbolos devem ser empregados somente para a denominação do material, evitando-se a inclusão de adjetivos como Reciclável, pois passaria a configurar rotulagem ambiental. A ausência de simbologia ou o uso incorreto podem prejudicar o processo de reciclagem de outros materiais e o desperdício de materiais recicláveis. 


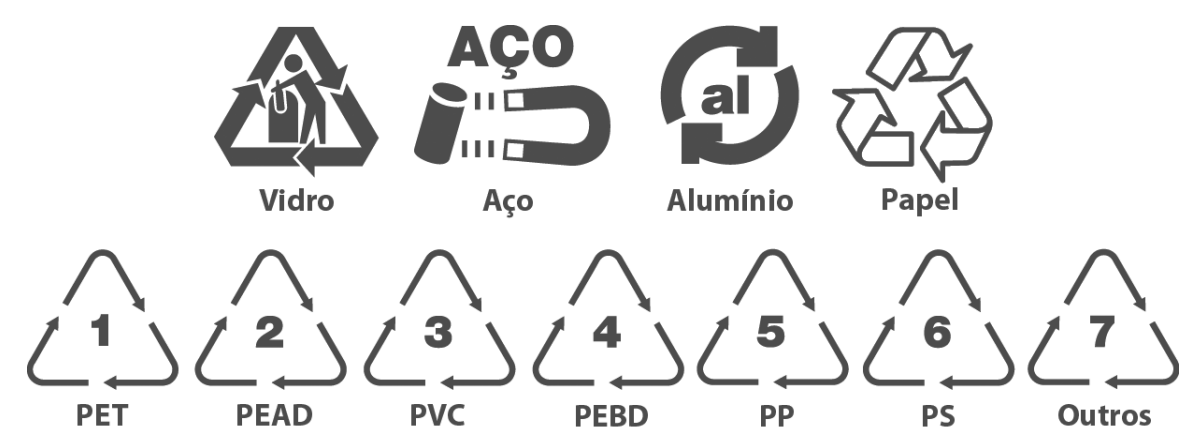

Figura 11 - Alguns exemplos de simbologia de identificação de material. Fonte: ABRE, 2012

\section{Simbologia Técnica de Descarte Seletivo}

Visando a contribuir para a comunicação com o consumidor na orientação sobre o descarte seletivo das embalagens, em 2009 foi incorporado aos anexos da norma ISO 14021 o símbolo do Descarte Seletivo, que pode ser inserido como simbologia técnica acompanhado da simbologia de identificação de material.

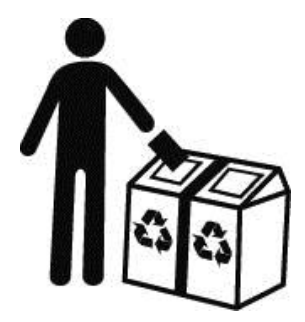

Figura 12 - Símbolo do Descarte Seletivo. Fonte: ABRE, 2012

\subsubsection{Autodeclaração ambiental com selos de certificação}

Os selos de certificação, como o dos produtos orgânicos, são quase sempre apontados como uma solução para a divulgação de aspectos técnicos e complexos em uma embalagem. Em grande medida porque oferecem uma informação mais segura e confiável para o consumidor tomar uma decisão de consumo responsável, sem ter de se tornar um expert em ecologia. Conferida por uma organização certificadora idônea, após análise rigorosa dos seus aspectos específicos, a imagem de um selo, com destaque na embalagem de um produto, contribuiria para atender a tendência da mente humana de buscar o mínimo esforço na hora de juntar informações para uma tomada de decisão. Funciona também como uma chancela de aprovação.

A assimilação dos dados apresentados nos selos exige tempo, esforço e demanda cognitiva. Comunicado de forma rápida e compreensível a uma primeira olhada, segundo Voltolini (2012), o selo de certificação seria uma espécie de "marca verde", dispensando o consumidor do trabalho de organizar informações complexas.

Os primeiros selos obrigatórios surgiram na Europa, nos anos 1940, com caráter de advertência. Eles tinham a função de destacar a presença de substâncias químicas potencialmente danosas à saúde do consumidor (VOLTOLINI, 2012). Hoje, os selos também têm a função de enfatizar questões específicas como a pegada de carbono, os alimentos orgânicos, a presença de transgênicos e o comércio justo. 


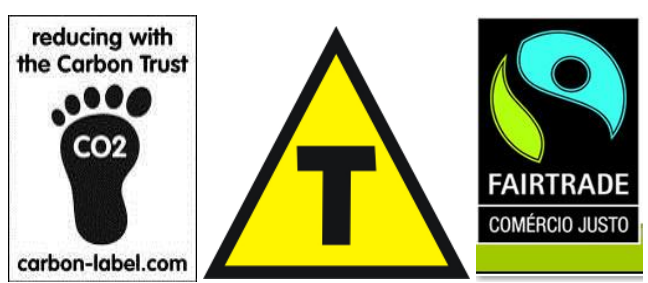

Figura 13 - Selos de pegadas de carbono, transgênicos e o comércio justo.

Fontes: Carbon Trust, 2012; Diário Oficial, 2011; Fairtrade International, 2012

Os selos podem ser divididos em atributos simples ou múltiplos. Os selos com atributos simples são aqueles que evidenciam uma característica ambiental do produto de forma individualizada. Um bom exemplo é o das embalagens que utilizam parte de recursos reciclados em sua composição e declaram isso no rótulo.

Segundo Bouabci (2010), a principal crítica a esse tipo de selo é que informações divulgadas desse modo podem confundir o consumidor. Um exemplo é o de percentual de material reciclado utilizado e posições do valor percentual quando se utiliza o Ciclo de Möbius para fazer declarações sobre conteúdo mínimo de material reciclado na composição.

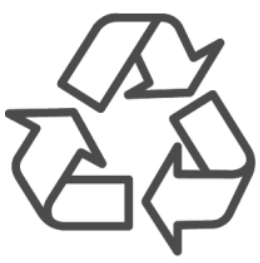

$65 \%$
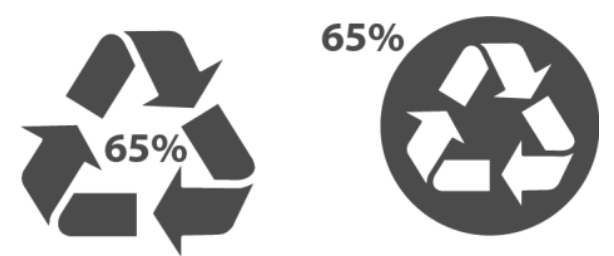

Figura 14 - Exemplos de posições do valor percentual quando se utiliza o Ciclo de Möbius para fazer declarações sobre conteúdo mínimo de material reciclado na composição. Fonte: ISO 14021, 1999

\section{Selos com atributos múltiplos}

Diferente dos selos com atributos simples, os atributos múltiplos buscam estabelecer uma visão mais integral do impacto gerado por produtos, como: eficiência energética, conservação, emissão de gases de efeito estufa, otimização no uso de recursos, destinação final, entre outros. A gradação atribuída pela certificadora leva em conta uma média geral dos critérios para atribuir ou não o selo ao produto. As críticas a esse tipo de selo normalmente fazem menção à pouca precisão do processo em virtude de trabalhar com médias ponderadas.

Em comum, esses selos são independentes, possuem critérios rígidos e avaliações contínuas. Todos desfrutam de alta credibilidade e representam um guia seguro para os consumidores, não sofrendo os efeitos da desconfiança que costuma recair sobre os selos autorreguladores, adotados sem verificação externa, por empresas ou segmentos empresariais. Para assegurarem o direito de seus consumidores a produtos ambientalmente responsáveis, os países promotores desses selos passaram a exigir também o mesmo compromisso dos produtos importados como contrapartida em acordos de comércio internacional. A seguir, alguns exemplos de selos de atributos múltiplos. 


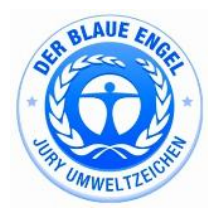

Alemanha Der Blaue Engel

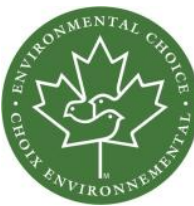

Canadá Ecologo

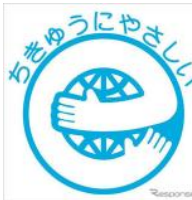

Japão

Eco Mark

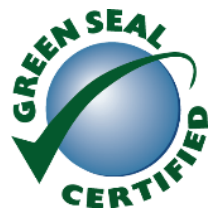

EUA

Green Seal

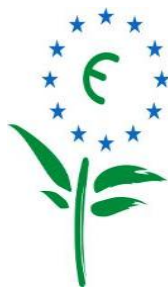

União Européia

Ecolabel

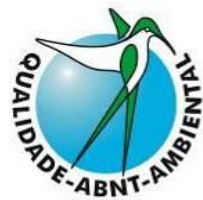

Brasil

Programa Brasileiro de Rotulagem Ambiental

Figura 15 - Selos de certificação ambiental. Fontes: Der Blaue Engel, 2012; Ecologo, 2012; Eco Mark, 2012; Green Seal, 2012; Ecolabel, 2012; ABNT, 2012

No Brasil, os programas de rotulagem ambiental foram desenvolvidos com base na experiência mundial. Em 1993, nasceu o Programa Brasileiro de Rotulagem Ambiental da ABNT, também chamado Qualidade Ambiental, conhecido pelo logotipo de um beija-flor verde e branco sobre o globo terrestre azul, tomando como base as normas ISO 14020 e ISO 14024. Trata-se de um programa de 3a Parte ${ }^{1}$, positivo, voluntário, estruturado a partir de critérios variados e habilitado a oferecer o selo do Tipo I.

Sua metodologia se apoia na Análise do Ciclo de Vida (ACV), contemplando os seguintes elementos: extração e processamento de matéria-prima, fabricação, transporte e distribuição, usos do produto, reutilização, manutenção, reciclagem, descarte final, ingredientes ou restrições a materiais utilizados e desempenho ambiental do processo de produção.

A evolução no uso de certificações pode e deve ser vista como um passo importante na busca por processos industriais mais sustentáveis. Se usadas com seriedade, representam uma oportunidade real de engajamento do setor privado na solução de problemas ambientais em escala apropriada, além de um instrumento tangível de medição de impacto.

A possível relevância dos selos de certificação e o seu impacto junto aos consumidores são confirmados pelo Monitor de Responsabilidade Social Corporativa 2010. Segundo o estudo, $36 \%$ dos consumidores brasileiros creem que uma etiqueta na embalagem do produto represente a melhor forma de uma empresa comunicar as suas práticas ambientais.

Embora tais pistas não sejam as únicas e a sua eficácia varie conforme os diferentes segmentos da economia, a pesquisa ratifica a importância de selos de certificação como um fator crítico no reconhecimento, por parte do consumidor, de quem é responsável, como e porquê. (VOLTOLINI, 2012, p. 48)

Para comunicar, com legitimidade, ações ambientais das empresas, os selos de certificação fornecem pistas cognitivamente mais eficazes para os consumidores que dificilmente seriam capazes de identificar as informações por outros meios.

\section{Confiabilidade dos selos}

A multiplicidade de selos pode gerar uma preocupação sobre a seriedade das certificadoras e a real impressão de que muitas querem apenas passar a imagem de sustentável, não por crença no processo de mudança, mas apenas como uma oportunidade de negócio.

\footnotetext{
${ }^{1}$ A rotulagem é feita por partes independentes da fabricação ou da venda dos produtos, normalmente instituições ligadas ao governo, ao setor privado ou sem fins lucrativos.
} 
Algumas empresas usam artifícios enganosos e declarações vagas para atrair consumidores. Uma forma comum de declaração vaga é a autodeclaração ambiental sem embasamento técnico ou científico que rotula o produto ou a embalagem como ambientalmente benéfico ou benigno. Autodeclarações ambientais como "ambientalmente seguro", "amigo do meio ambiente", "amigo da Terra", "não poluente", "verde", "amigo da natureza", "amigo da camada de ozônio" não devem ser utilizadas. As declarações vagas estão em todos os lugares e o ato de induzir o consumidor ao erro quanto às práticas ambientais de uma empresa ou os benefícios ambientais de um produto ou serviço são denominados greenwashing.

Greenwashing é um termo utilizado para designar um procedimento de marketing utilizado por uma organização com o objetivo de prover uma imagem ecologicamente responsável dos seus produtos ou serviços. Com o objetivo de descrever, entender e quantificar o crescimento do greenwashing no mercado, a consultora de marketing ambiental canadense TerraChoice desenvolveu uma metodologia de pesquisa em que, através dos padrões observados, classificou tais apelos falsos ou duvidosos em sete categorias, chamadas de The seven sins of greenwashing ${ }^{2}$ : custo ambiental camuflado; falta de prova; incerteza; culto a falsos rótulos; irrelevância; do "menos pior"; e mentira (TERRACHOICE, 2010).

Com o intuito de verificar o fenômeno do greenwashing no mercado brasileiro, o instituto de pesquisas MarketAnalysis realizou, entre os dias 11 de fevereiro e 2 de março de 2010, a mesma pesquisa na região da Grande Florianópolis, no estado de Santa Catarina, seguindo o padrão metodológico descrito e disponibilizado no relatório desenvolvido pela TerraChoice.

Na pesquisa feita no Brasil, entre todos os pecados cometidos, o da incerteza se apresenta como o mais praticado nas embalagens dos produtos. Comparando o Brasil à média dos outros países pesquisados, enquanto nos outros países há forte presença do pecado do custo ambiental camuflado (40\%), aqui o da incerteza prevalece sobre os demais cometidos (46\%) (TERRACHOICE, 2010).

O Brasil é o país que apresentou o maior número de produtos "sem pecado" (dentre os analisados): 80 produtos. Enquanto os EUA apresentaram 15; o Canadá, 10; a Austrália, 5; e o Reino Unido não apresentou nenhum produto livre dos pecados da rotulagem ambiental (TERRACHOICE, 2010).

Sem dúvida alguma, o fator mais importante no processo de escolha de uma certificação está no motivo que ampara a decisão. Se o vetor é simplesmente conquistar o consumidor, a falta de cuidado com os processos em algum momento vai gerar ruído e colocar a reputação da marca em jogo. Se, do contrário, a intenção for a busca genuína pela sustentabilidade, com a devida atenção à complexidade, os elementos se combinarão naturalmente e levarão a empresa ao lugar ideal.

Segundo Dougherty (2011), o melhor antídoto contra o greenwashing é a transparência. A sustentabilidade não é uma noção vaga e maleável, ela é específica e mensurável. A transparência ajuda os designers a elaborarem mensagens de significado verdadeiro e os coloca no papel de agente de mudança. Os designers ajudam a simplificar, esclarecer questões complexas e educar o público sobre o caminho no qual as empresas estão. Assim, pode-se ajudar a construir histórias convincentes a partir dos planos e do verdadeiro desempenho das empresas.

${ }^{2}$ Os sete pecados da rotulagem ambiental (tradução TERRACHOICE; MARKET ANALYSIS, 2010) 
Porém, se as ações de uma empresa contradizem os valores que elas promovem, a marca é afetada. O desenvolvimento da marca ecológica deixa as empresas sujeitas a acusações de greenwashing se elas promovem demais e atuam de menos.

Segundo Dougherty (2011), o desenvolvimento da marca pode ter três fatores:

- A autenticidade é a medida de quanto os valores que uma empresa projeta se alinham bem com a realidade de suas ações;

- A contenção é uma questão de prevenir exageros prejudiciais com pretensões ecológicas exageradas ou irrelevantes;

- O acompanhamento é uma questão de articular estratégias para cumprir a promessa de uma marca ecológica. $O$ designer ajuda as empresas a fazerem promessas, mas também pode ajudar a pensar em formas de cumpri-las.

Os designers podem ter um importante papel como mediador na prevenção do greenwashing, podendo agir como gestores da marca e chamando a atenção para as contradições antes que as críticas e notícias nocivas sejam publicadas (DOUGHERTY, 2011).

\subsection{DIMENSÕES DA SUSTENTABILIDADE}

A busca de parte da sociedade para clarear o conceito de sustentabilidade, de se propor um significado de preferência tangível e prático, tem suscitado reflexões desde as mais filosóficas, como o questionamento de ordem ética e moral, até as mais palpáveis, como a escolha do material no desenvolvimento de um produto. Há a necessidade de se traduzir em palavras o que representa o desenvolvimento sustentável, assim como os seus produtos resultantes, sendo um passo fundamental para que mudanças sejam efetivadas transformando e desenvolvendo o sistema vigente para que se torne mais efetivo e de fácil assimilação.

A palavra sustentabilidade é definida no dicionário Aurélio (2006) como a "qualidade do que é sustentável" ou como "um estado que se deseja atingir". Porém, a discussão sobre a ideia ou o que é a sustentabilidade teve seu fortalecimento a partir da divulgação do relatório Os limites do crescimento (1972), elaborado pelo MIT a pedido do Clube de Roma, na década de 1970. O relatório trazia modelos matemáticos que mostravam que o desenvolvimento da humanidade estava em risco devido ao fato de a Terra não suportar mais a exploração dos recursos naturais por sua crescente população humana.

A sustentabilidade estava, em seu início, mais relacionada à questão ambiental, e com a capacidade de suporte do planeta e manutenção dos recursos naturais. Os alertas dos ambientalistas trouxeram para o debate da sustentabilidade outros profissionais envolvidos nos processos produtivos, como os economistas, engenheiros e designers. Com novas abordagens, esses profissionais começaram a examinar possibilidades entre o dilema da conservação ambiental, produção e crescimento econômico.

A questão de se haveria recursos suficientes ou não foi levantada no âmbito da ciência econômica, mobilizando diversas áreas do conhecimento a refletir sobre a questão da sustentabilidade, também no âmbito social. Começa-se a questionar quais seriam os impactos que a escassez de recursos naturais, ou a possível alteração no modelo econômico vigente, teriam sobre a sociedade. De que forma a sustentabilidade se relaciona com a pobreza, com a desigualdade social, com o acesso ao consumo, com a democracia ou com os direitos humanos. Surgem as primeiras discussões sobre um termo que deriva da sustentabilidade, mas que passa a incluir também os aspectos sociais: o desenvolvimento sustentável. 
A World Comission on Environment and Development (WCED) se reuniu em 1987 na tentativa de conceituar o desenvolvimento sustentável e seus objetivos. Dessa reunião, surgiu o Relatório Brundtland, conhecido como Nosso futuro comum, que trouxe a primeira versão global do termo: desenvolvimento sustentável é o que atende as necessidades do presente sem comprometer a capacidade das gerações futuras atenderem as suas. Esse documento tornou possível uma série de debates acerca do que seriam as necessidades presentes e como estabelecer as necessidades das gerações futuras.

Cientistas sociais e políticos, filósofos, antropólogos, economistas e pensadores das mais diversas disciplinas passaram a propor pilares que sustentariam o novo conceito de sustentabilidade. $\mathrm{O}$ mais difundido foi o famoso triple bottom line, social-econômicoambiental, proposto pelo inglês John Elkington (2001), onde argumenta que o desenvolvimento sustentável é resultado de processos produtivos que consideram as três dimensões (ambiental, social e econômico) de maneira integrada.

Esse conceito representou uma ruptura fundamental na forma que até então era feita, que sempre considerou o crescimento econômico como o único objetivo de um empreendimento. Segundo Veiga (2012, p. 13):

[...] nada permite inferir da leitura do Relatório Brundtland que o desenvolvimento sustentável teria apenas três dimensões. Ainda menos que ele poderia ter sido manchado por essa mecânica metáfora sobre 'pilares' a serem 'equilibrados'. Ao contrário: nas raras vezes em que o relatório usa o termo 'dimensões', apresenta longas listas, e que terminam com significativos 'etc.'.

Tão forte foi a influência do triple bottom line que, cinco anos depois, foi incorporado no documento da cúpula de Johanesburgo, convocada com a ambição de transformar a Declaração do Rio numa espécie de projeto executivo. Então, em vez de contribuir para o entendimento do meio ambiente como a base material do desenvolvimento humano promovendo a necessidade de integração de todas as dimensões, abriu-se a porta para o entendimento de que o meio ambiente é apenas um terço do desenvolvimento sustentável, ignorando outras possíveis dimensões (VEIGA, 2012).

Ignacy Sachs, a partir de 1974, renovou o conceito de ecodesenvolvimento, incluindo os países em desenvolvimento nesta nova proposta e ampliando seus objetivos para atender as necessidades básicas da população envolvida e sua autonomia, incluindo aspectos políticos, culturais, sociais, éticos, além do econômico.

Em seu livro Ecodesenvolvimento: crescer sem destruir (SACHS, 1986), critica a importação do modelo de desenvolvimento de países industrializados para os países em desenvolvimento. O processo, denominado pelo autor de crescimento imitativo ou mimético, traz custos ambientais e sociais muito elevados para os países que o implantam, como o aumento das diferenças sociais, dependência cultural, males estruturais e danos ambientais, em função da exploração sem controle de seus recursos e patrimônio natural.

Aprofundando a discussão conceitual, Sachs (2008) propõe cinco pilares para a sustentabilidade: além dos três (ambiental, social, econômico) propostos por Elkington (2001), ele acrescenta os pilares cultural, ecológico, territorial, política nacional e política internacional.

1. Ambiental: respeitar e realçar a capacidade de autodepuração dos ecossistemas naturais.

2. Social: alcançar um patamar razoável de homogeneidade social, com distribuição de renda justa, emprego, com qualidade de vida e acesso aos recursos e serviços sociais. 
3. Cultural: equilíbrio entre respeito à tradição e inovação, capacidade de autonomia para elaboração de um projeto nacional integrado e autoconfiança, combinada com abertura para o mundo.

4. Econômica: desenvolvimento econômico intersetorial, segurança alimentar, modernização contínua dos instrumentos de produção, autonomia na pesquisa científica e tecnológica, e inserção na economia internacional.

5. Ecológica: preservação do potencial do capital natural na sua produção de recursos renováveis e limitação do uso dos recursos não renováveis.

6. Territorial: configurações urbanas e rurais balanceadas, melhoria do ambiente urbano, superação das disparidades inter-regionais e estratégias de desenvolvimento ambientalmente seguras para áreas ecologicamente frágeis.

7. Política (Nacional): democracia definida em termos de apropriação universal dos direitos humanos, desenvolvimento da capacidade do Estado para implementar o projeto nacional e um nível razoável de coesão social.

8. Política (Internacional): eficácia do sistema de prevenção de guerras da Organização das Nações Unidas (ONU), baseado no princípio da igualdade, controle institucional efetivo do sistema internacional financeiro e de negócios, aplicação do Princípio da Precaução na gestão do meio ambiente, prevenção das mudanças globais negativas, proteção da diversidade biológica (e cultural), gestão do patrimônio global, sistema efetivo de cooperação científica e tecnológica internacional e eliminação parcial do caráter commodity da ciência e tecnologia.

Independentemente das linhas e propostas sustentadas por estudiosos e militantes de diversos campos que interagem neste debate, o mais importante é notar que este ainda é um conceito em construção. O conceito de ecodesenvolvimento proposto por Sachs (1986) está de acordo com o proposto por Brundtland (1991), ou seja, satisfazer as necessidades da geração futura sem comprometer as necessidades da geração atual; no entanto é necessário um grande conhecimento sobre o ambiente em questão e as culturas nele inseridas, sendo imprescindível a participação da sociedade no planejamento das estratégias para se colocar em prática.

\section{Dimensões da sustentabilidade no design}

As preocupações com o meio ambiente contribuíram para a formação de uma nova consciência do papel do designer no mundo, possibilitando um aumento das discussões na área sobre ecologia humana, estratégias tecnológicas alternativas e responsabilidade social deste profissional.

No contexto ambiental e social, a atuação do designer Victor Papanek (1985), com seu livro Design for a real world, colocou em discussão as preocupações dos designers e indústrias interessados na ecologia, e incentivou a enfrentar os problemas sociais ao seu redor ao invés de agir apenas por interesses comerciais. $O$ autor acreditava que os designers poderiam proporcionar soluções para sistemas e produtos com a finalidade de uso coletivo, ou em comunidades, utilizando tecnologias apropriadas. Papanek defendeu um design centrado no homem, na ecologia e na ética, destacando a responsabilidade moral do design, que convida à sabedoria diante de sua produção e propõe a inspiração na experiência de outros países (notadamente aqueles em desenvolvimento), para melhor atender às necessidades básicas dos seres humanos e sua relação com o design.

A inserção das questões ambientais na atividade do design como uma necessidade surge ao longo do debate sobre desenvolvimento sustentável. A partir deste momento, definições 
como Design de Produtos Sustentáveis foram adotadas pela necessidade de os designers reconhecerem não só os impactos ambientais de sua atividade, mas também o impacto ético e social, não se limitando aos três pilares propostos por Elkington (2001).

Pensando mais na dimensão ambiental, Manzini (1993) fala que as tendências ambientais levam ao lema "menos matéria, menos energia e mais informação", mostrando a necessidade de elaborar uma cultura ecológica capaz de resolver não só os problemas mais evidentes da quantidade, como também os dilemas mais sutis da qualidade, pois é necessário orientar a evolução dos materiais em direção a equilíbrios aceitáveis entre o ambiente artificial e as leis da natureza a que estamos vinculados.

A sustentabilidade ambiental refere-se, conforme Manzini e Vezzoli (2002, p. 28):

[...] às condições sistêmicas segundo as quais [...] as atividades humanas não devem intervir nos ciclos naturais em que se baseia tudo o que a resiliência do planeta permite [...], não devem empobrecer seu capital natural, que será transmitido às gerações futuras.

Já o engenheiro William McDonough e o designer e arquiteto Michael Braungart, no livro Cradle to cradle: remaking the way we make things (2008), destacam a tendência de empresas e designers de projetarem produtos com mais controle. No entanto, "menos mau" não é o mesmo que ser bom e é uma é uma meta limitada.

Uma vez que os seres humanos são considerados como "maus", o zero é uma meta boa. Mas sermos "menos maus" significa aceitarmos as coisas como elas são, acreditarmos que os sistemas deficientemente planejados, indignos e destrutivos são o melhor que os seres humanos conseguem fazer. Esta é a falha derradeira da abordagem de "ser menos mau": uma falha da imaginação (MCDONOUGH; BRAUNGART, 2008, p. 67).

McDonough e Braungart (2008) também exploram a necessidade da produção de produtos dentro do conceito de ciclo fechado, ou do "berço ao berço", onde não há a geração de resíduos. O ciclo de vida do produto não deve terminar quando seus materiais são simplesmente despejados nos sistemas naturais, fornecendo abordagens alternativas, como transformá-lo em "nutriente técnico", criando um metabolismo semelhante ao metabolismo biológico da terra.

A sustentabilidade social, segundo Crul e Diehl (2006) em seu trabalho desenvolvido para a United Nations Environment Programme (UNEP) junto com a Delft University of Technology, também está associada a questões como: respeito à identidade e diversidade cultural; inclusão das minorias, marginalizados e deficientes; bem estar social; trabalho em condições adequadas e sem a necessidade de grandes deslocamentos; geração e equilíbrio na distribuição de renda; acesso à alimentação, água potável e serviços de saúde; escolarização e abolição do trabalho infantil, entre outros temas.

A sustentabilidade econômica apresenta uma ligação bastante forte com a social pela geração de trabalho e renda (CRUL; DIEHL, 2006). Além da lucratividade, é fundamental para as empresas a geração de valor tanto para ela quanto para os stakeholders ${ }^{3}$ e consumidores. É este valor que permite às empresas posicionarem-se de forma competitiva no mercado. Ao longo das últimas décadas, as organizações têm se preocupado mais com a sua responsabilidade nos impactos do ambiente e têm demonstrado que as iniciativas ambientais e melhorias podem trazer benefícios econômicos. É um objetivo a ser atingido, e

${ }^{3}$ Stakeholder (em português, parte interessada ou interveniente) é um termo usado em diversas áreas, como administração e arquitetura de software, referente às partes interessadas que devem estar de acordo com as práticas de governança corporativa executadas pela empresa. 
não, como hoje muitas vezes é entendido, uma direção a ser seguida. Em outras palavras, nem tudo que mostrar algumas melhorias em temas ambientais pode ser considerado realmente sustentável (MANZINI, 2005, p. 28).

Fiksel (1995), Brezet e Hemel (1997), Lewis e Gertsakis (2001) e Manzini e Vezzoli (2002) abordaram de diferentes formas como poderia ser a metodologia de design orientada por critérios ecológicos, onde o projeto seja integrado com outras áreas, apoiado por métodos de avaliação ambiental e do ciclo de vida, fazendo intervenções no desenvolvimento do produto, reduzindo (ou eliminando) os impactos ambientais. Essas abordagens nos sugerem transformar os produtos, desde sua concepção, em direção à sustentabilidade.

Por sua própria natureza holística, o design só pode existir em projetos integrados, uma vez que considera todos os aspectos do ciclo de vida do produto. Deve estar presente em todas as etapas do projeto, desde seu início, e não apenas como um elemento acessório primeiramente, prevendo-se o futuro do produto para reduzir o impacto ambiental por todo o ciclo de vida: fabricação, uso, fim de vida. Em seguida, considerando-se o produto como um sistema constituído cujo impacto pode às vezes ser maior que o do produto em si. 0 designer escolhe como finalidade a utilização, e não o produto, iniciando uma cooperação na cadeia de atores em uma abordagem transversal e multidisciplinar (KAZAZIAN, 2005).

\section{Impactos ambientais}

O aumento no consumo de recursos naturais vem causando sérios impactos ambientais. Segundo o relatório Living Planet Report 2012, da World Wide Fund for Nature (WWF), a demanda cada vez maior por recursos por uma população crescente está causando uma enorme pressão sobre a biodiversidade do planeta e ameaça nosso futuro em termos de segurança, saúde e bem-estar. Em 2050, seria necessário o equivalente a 2,9 planetas para suportar o crescimento da pegada ecológica da humanidade.

Os impactos ambientais podem ser divididos em três categorias principais: danos ecológicos, danos à saúde humana e esgotamento de recursos. Esses impactos são relevantes para as indústrias nas economias desenvolvidas e em desenvolvimento.

Quanto menos recursos naturais gastos para fazer um produto, mais barato ele se torna para as empresas e melhor para o meio ambiente, porque gastou menos matéria-prima e energia. Mesmo na escala de uma única empresa, as atividades industriais têm consequências para o meio ambiente. Na maioria dos casos, seus impactos são imputáveis aos resíduos que perturbam os equilíbrios naturais (KAZAZIAN, 2005).

\section{Impacto ambiental da embalagem}

A embalagem, como toda atividade industrial, gera impactos ambientais desde a extração da matéria-prima, processamento, transporte e disposição final. Por outro lado, é um elemento fundamental para minimizar outros problemas ambientais. Os alimentos passam por várias etapas até chegar ao consumidor final (item 2.3 desta dissertação), nas quais são gastos dinheiro, energia, matéria-prima, mão-de-obra, combustível etc. Uma embalagem inadequada pode inviabilizar as etapas seguintes, gerando perda de produto, o que representaria o desperdício dos insumos gastos nas etapas anteriores.

Todo esse impacto poderia ser diminuído ou eliminado por meio da redução do consumo desnecessário, correta separação e destinação do resíduo e um design de embalagem projetado para que tenha uma vida útil estendida ao longo do seu ciclo de vida. Um melhoramento contínuo, projetando sistemas de embalagem com responsabilidade 
ambiental, é necessário. As embalagens evitam os impactos causados pelo aumento de resíduos orgânicos, gerado pelo desperdício e deterioração dos alimentos, garantindo a qualidade e segurança alimentar dos consumidores.

Considerando-se sistemas completos, em vez de embalagens individuais, é possível remover embalagem de algumas categorias de produtos, porém não em todos os casos por razões de proteção do produto, apresentação, higiene ou segurança. Apesar disso, a eliminação da embalagem pode ser uma das primeiras mudanças a ser considerada pelo designer (STEWART, 2009).

\begin{abstract}
Uma excelente candidata ao desaparecimento é a embalagem elaborada em excesso ou desnecessária. A maior parte das embalagens industriais e uma parcela das dos produtos alimentícios pode ser prontamente reduzida em vinte ou até cinquenta por cento. (Hawken; Lovins, 2007, p. 166)
\end{abstract}

Não há estatísticas que quantifiquem convenientemente a contribuição específica do design da embalagem. Cada fabricação e transporte de materiais, envolvendo um acréscimo de energia baseado em combustíveis fósseis, contribuirá para a emissão de gases.

\title{
Papel do designer na redução dos impactos ambientais
}

Segundo Papanek (1995), a função do designer é apresentar opções reais e significativas às pessoas, permitindo que as mesmas participem mais plenamente nas decisões que thes dizem respeito. Ainda segundo ele, a ética é a base filosófica para fazer escolhas morais e seus valores. As decisões morais processam-se reconhecendo a existência de um dilema e sopesando conscienciosamente as alternativas, conferindo sentido ao se tomar decisões a respeito das alternativas existentes.

O design ético deve também ser salutar e benéfico em termos ambientais e ecológicos, precisa ser na escala humana e com responsabilidade social. Todos os objetos, grafismos e embalagens devem funcionar no sentido de suprir as necessidades do consumidor a um nível mais básico do que a mera aparência de "sustentável" (PAPANEK, 1995).

Dougherty (2011) faz uma analogia do papel do design, usando três formas de pensar: como manipulador de materiais, criador de mensagens e agente de mudanças, onde cada forma é incorporada à outra.

Os designers podem ajudar empresas preocupadas com valores ambientais a construir marcas fortes e ter sucesso no mercado. Pode ajudar as empresas a se posicionarem como líderes em questões ambientais podendo influenciar as operações de negócios nos anos seguintes (DOUGHERTY, 2011).

As marcas criadas e as causas promovidas podem ter impactos que vão muito além da embalagem. Mais do que buscar materiais e técnicas de fabricação melhores:

[...] o maior impacto do design não está nos materiais usados, o verdadeiro impacto reside na capacidade de comunicar, persuadir e mudar a forma de agir do público. Em essência, ser designer consiste em ser um agente para uma mudança positiva. (DOUGHERTY, 2011, p. 137)

O papel do designer é limitado em seu alcance direto, porém, como afirma Stewart (2009, p. 58 e 59$)$ :

Mesmo que a comunidade de design não seja a que vai resolver os problemas de desigualdade social ou prevenir o marketing de alimentos não saudáveis, ela é capaz de influenciar a escolha dos consumidores. Designers devem considerar formas de utilizar suas habilidades para o benefício da sociedade. 


\subsection{IMPACTOS AMBIENTAIS DA PRODUÇÃO DE EMBALAGEM}

Para cada embalagem, estão relacionadas várias formas de produção usando uma infinidade de materiais. Em todos os sistemas de produção de embalagem, são consumidos materiais para a produção da embalagem e são gerados resíduos.

Quando as indústrias adquirem matérias-primas, bens e serviços, como na produção de embalagens, pode ser usado um sistema de avaliação, perguntando aos fornecedores informações específicas do ciclo de vida e responsabilidade social, além da documentação da segurança do produto. As empresas e os designers envolvidos na escolha do material de uma embalagem têm assim uma oportunidade de usar uma abordagem mais proativa no ciclo de vida do produto e poder assim gerenciar seus impactos (UNEP, 2007).

Segundo Negrão e Camargo (2008), o material da embalagem a ser escolhido não deve responder ao projeto apenas em seu aspecto pragmático, mas equacionar uma série de outros requisitos, como custos, impacto ambiental e percepção do consumidor, entre outros.

Cada produto tem suas características químicas e físicas em diferentes níveis, o que o torna mais ou menos vulnerável à oxidação, desidratação, decomposição; podem ser sensíveis à luz, aos raios ultravioletas, apresentar pouca estabilidade térmica e volatilidade. Por isto, devemos conhecer suas condições ideais de acondicionamento, conservação e regulamentações impostas pelos órgãos competentes, pois a embalagem deve proteger seu conteúdo contra fenômenos que influenciem sua qualidade e vida útil (NEGRÃO; CAMARGO, 2008).

De maneira geral, o mercado de embalagens ainda utiliza quatro grandes grupos de materiais:

- Plásticos (polímeros);

- Papel (materiais celulósicos);

- Metal (alumínio e aço);

- Vidro.

Para este trabalho, foram pesquisados os impactos ambientais causados nos processos de produção das embalagens de alimentos orgânicos. As embalagens que foram analisadas neste estudo foram: a caixa de papel cartão impressa offset; embalagens flexíveis em filmes plásticos impressos em rotogravura.

\subsubsection{Impacto ambiental do papel}

O papel é um dos principais materiais usados para embalagem. O papel oferece muitos benefícios. Tem bom desempenho a um baixo custo. É rígido, opaco, de fácil impressão e versátil (TWEDE; GODDARD, 2009).

O papel pode ser feito com várias fibras naturais, como a celulose da madeira, algodão ou gramíneas, todas de fonte renovável. Ela é macerada em água e colocada para secar ao calor e pressão como uma chapa lisa. A água amacia a superfície externa das fibras de celulose, que então se fundem quando são colocadas em contato com outras fibras, usando pressão, sucção ou ambas, em modernas máquinas de fabricação de papel. A aglutinação das fibras é 
fortalecida e enrijecida durante o estágio de calandragem, quando o papel é passado através de um conjunto de rolos metálicos aquecidos (TWEDE; GODDARD, 2009).

O branqueamento do papel é uma área de preocupação pelos seus efeitos ambientais. O uso de produtos químicos contendo cloro leva à produção de pequenos restos de dioxina na água que é descartada da produção e até pequenas quantidades podem permanecer na polpa do papel. A dioxina causa danos à saúde quando é ingerida ou em contato com a pele (TWEDE; GODDARD, 2009). No fim de seu ciclo de vida, no seu descarte final, o cloro do papel também pode impactar o meio ambiente.

Indústrias de papel ao redor do mundo têm lançado extensos programas para reduzir o uso de cloro nos seus processos de produção. Nos casos onde o branqueamento é necessário, já se pensa no uso de produtos químicos alternativos como o oxigênio e o dióxido de cloro. 0 dióxido de cloro reduz significantemente a quantidade de emissão de cloro, e o oxigênio o faz de forma completa (TWEDE; GODDARD, 2009).

No Brasil, as fibras para a fabricação de papel são, em grande parte, de florestas plantadas desenvolvidas a partir de intervenções controladas por um sistema de produção para fins especificamente industriais, que atende a todas as exigências legais de um processo agrícola e a critérios de manejo florestal (BRACELPA, 2010).

É importante ressaltar que, da área total de florestas do setor de celulose e papel, cerca de 2,7 milhões de hectares são certificados por organizações independentes, como o programa nacional de Certificação Florestal (Cerflor) do INMETRO e o Forest Stewardship Council (FSC).

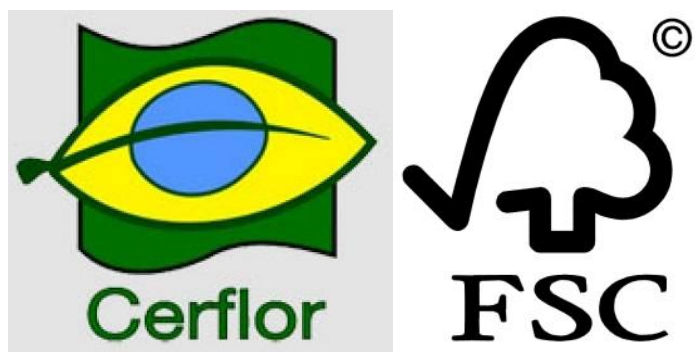

Figura 16 - Selos de certificação Cerflor e FSC. Fontes: INMETRO, 2012; FSC, 2012

No Brasil, essa indústria ajuda também a preservar, recuperar e proteger cerca de 2,9 milhões de hectares de florestas nativas, quando feito o manejo adequado, também colaborando para a manutenção da biodiversidade das florestas nativas. Quando esse manejo não é feito, dificilmente a biodiversidade sobrevive. Com o sistema de cultivo em mosaico, que mescla plantações com matas nativas, a floresta plantada passa a fazer parte de um complexo de ecossistemas, viabilizando a movimentação de espécies, características das Áreas de Proteção Permanente (APP) e das Áreas de Reserva Legal (ARL) por corredores ecológicos (BRACELPA, 2010).

Para continuar reduzindo o consumo de energia gerada a partir de fontes de grande impacto no meio ambiente, como os combustíveis fósseis, a indústria de celulose e papel investe constantemente em novas tecnologias e no desenvolvimento de processos produtivos sustentáveis. Com o crescente consumo energético de fontes renováveis, como biomassa, a indústria de celulose aproxima-se da autossuficiência em energia (BRACELPA, 2010).

O setor de celulose e papel tem a água como insumo indispensável, utilizando-a desde a criação de mudas de eucalipto, ou pinus, até o processo industrial. $O$ alto volume obriga a utilização de grandes fontes; para a produção de uma tonelada de celulose, são utilizados 30 mil litros, enquanto para a fabricação da mesma quantidade de papel são necessários 
aproximadamente 25 mil litros. Como prática para reduzir o uso de água, o seu reuso mostrase como um caminho viável. Além de aumentar a disponibilidade dos recursos hídricos para outras atividades, reduz os custos de produção, evita perdas de produto final ou intermediário e minimiza a carga de poluentes a serem tratados (BRACELPA, 2010).

Em todas as fases de produção, do cultivo das florestas até o produto final, são gerados resíduos e rejeitos. Os resíduos florestais do processo produtivo - galhos, topos e cascas são mantidos no campo, como proteção e adubação do solo. No sítio industrial, parte das cascas e dos cavacos (pequenos pedaços de madeira) desqualificados para a produção de celulose é encaminhada para a queima, em caldeiras que geram vapor para o processo produtivo, eliminando a utilização de combustível fóssil (BRACELPA, 2010).

Na produção, a separação da celulose da madeira gera o chamado licor preto - queimado em grandes caldeiras de recuperação -, que não apenas substitui o combustível fóssil, como permite o uso de turbinas elétricas, que geram toda a eletricidade utilizada nas modernas fábricas de celulose. Na produção de papel e de artefatos, todas as sobras de papel são recicladas na própria unidade ou encaminhadas para reciclagem em outras fábricas, na forma de aparas de papel (BRACELPA, 2010).

Há ainda uma grande quantidade de resíduos encaminhados a aterros sanitários, onde são depositados de forma adequada, ou encaminhados para outros segmentos industriais onde se tornam matéria-prima para, por exemplo, telhas e outros materiais da indústria da construção civil. Por utilizar matéria-prima de origem renovável, a indústria de celulose e papel não gera grande quantidade de resíduos perigosos (BRACELPA, 2010).

Papel para a embalagem pode incluir fibras recicladas na maioria das suas aplicações. O seu uso está crescendo por causa do aumento da reciclagem no mundo todo. É importante observar que fibras recicladas são mais curtas do que fibras de papel virgem e que o papel feito de fibras recicladas é mais fraco e mais fácil de rasgar. Em alguns casos, quanto mais fibras recicladas forem usadas, mais grosso o papel precisa ser para compensar a perda de resistência (TWEDE; GODDARD, 2009).

O volume de aparas transformadas no Brasil, em 2010, atingiu a marca de 4 milhões de toneladas, o que significa um crescimento de $3,2 \%$ sobre os 3,9 milhões de toneladas consumidas em 2009. A taxa de recuperação - volume de papel reciclado sobre o total de papel que entrou no mercado brasileiro - em 2010 foi de $44 \%$ e vem se mantendo estabilizada, nos últimos dez anos, em torno de $45 \%$. Praticamente todo material recolhido no Brasil é transformado em nosso próprio território (BRACELPA, 2010).

\subsubsection{Impacto ambiental das embalagens flexíveis em filmes plásticos}

Os polímeros de hoje são em sua maioria sintetizados do petróleo e resultantes de combinações de átomos simples de carbono, hidrogênio, oxigênio, cloro e, menos frequentemente, nitrogênio e flúor (ASHBY; JONHSON, 2011).

Como são preponderantemente produtos baseados em petróleo (fonte finita) e difíceis de descartar ao final da vida útil (não se degradam facilmente), isso implica no desenvolvimento de alternativas de recursos renováveis.

Para serem reciclados, os plásticos têm de ser separados por tipo, e cor, para que a reciclagem possa produzir um material com valor igual ao do material original. Plásticos 
contaminados ou misturados podem ser derretidos somente para o uso como materiais de baixo valor (TWEDE; GODDARD, 2009). Um dos empecilhos para a reciclagem de plásticos é a grande variedade de tipos.

Segundo Twede e Goddard (2009), a separação, a coleta e o transporte fazem com que a reciclagem de alguns plásticos não seja economicamente viável e podem resultar em mais impactos ambientais do que outras opções de descarte.

As embalagens plásticas flexíveis, ou convertidas, podem ser monomaterial, multicamada de polímero ou laminadas, ou multimateriais, dependendo do seu uso. Os principais materiais termoplásticos usados nas embalagens flexíveis são: polietileno (PE), polipropileno biorientado (BOPP), polipropileno (PP), poli (etileno tereftalato) (PET), celulose, papel alumínio e papéis. A composição do material da embalagem deve ser feito em função do conteúdo a ser acondicionado.

\section{Poli (etileno tereftalato) (PET)}

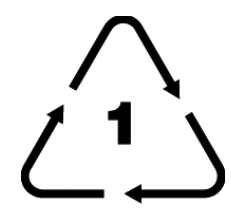

PET

Figura 17 - Simbologia técnica do Poli (etileno tereftalato)

É utilizado tanto em embalagens rígidas quanto flexíveis. Nas embalagens flexíveis, o PET é comumente usado na manufatura de recipientes de alimentos pré-cozidos e de recipientes para aplicações médicas esterilizáveis (ANYADIKE, 2009).

É um poliéster saturado, termoplástico, tem boa propriedade mecânica a temperaturas de até $160^{\circ} \mathrm{C}$. O PET é límpido como cristal, impermeável à água e ao $\mathrm{CO}_{2}$, mas deixa passar um pouco de oxigênio. Duro, forte, fácil de conformar, unir e esterilizar - permitindo reutilização (ASHBY; JONHSON, 2011).

O PET é oticamente transparente, límpido, translúcido, branco ou opaco. Tem como uso típico os recipientes de bebidas gaseificadas e utensílios de cozinha que podem ser levados ao forno (ASHBY; JONHSON, 2011).

Quando chega ao fim de sua primeira vida, pode ser reciclado como fibras e materiais peluciados usados em roupas e tapetes (ASHBY; JONHSON, 2011). A fabricação de garrafas de PET consome menos energia do que as de vidro (seu principal concorrente), no mesmo volume - e as de PET são mais leves.

\section{Polietileno (PE)}

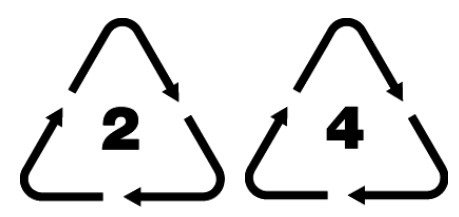

PEAD PEBD

Figura 18 - Simbologia técnica do polietileno de alta e baixa densidade 
O PE é produzido de várias formas. O polietileno de alta densidade (PEAD) é usado tanto para embalagens flexíveis quanto para embalagens rígidas. Nas aplicações das flexíveis, é aproveitada a manufatura de filmes soprados e moldados para muitos itens alimentícios. $O$ polietileno de baixa densidade (PEBD), por sua vez, é utilizado na manufatura de revestimentos industriais, barreiras de vapor, filmes para coberturas encolhíveis e esticáveis, enquanto o polietileno linear de baixa densidade (PELBD) é usado na manufatura de filmes esticáveis ou aderentes, bolsas de mercearias e sacaria industrial (ANYADIKE, 2009).

O polietileno é inerte e extremamente resistente à água doce e salgada, a alimentos e à maioria das soluções à base de água. Por isso, é amplamente utilizado em produtos domésticos e recipientes para alimentos. Ele é barato e particularmente fácil de moldar e fabricar. Aceita uma ampla gama de cores, pode ser transparente, translúcido ou opaco, tem um toque agradável, pode ser texturizado ou revestido com metal (ASHBY; JONHSON, 2011).

As propriedades dos diversos tipos de polietileno dependem da densidade, massa molecular, morfologia e grau de cristalinidade. A principal diferença de desempenho entre os tipos está na rigidez, resistência ao calor, resistência química e capacidade de suporte de cargas (TWEDE; GODDARD, 2009). O polietieleno (PE), conforme a sua densidade, pode ser classificado como polietileno de baixa densidade e polietileno de alta densidade.

\section{Polietileno de baixa densidade (PEBD)}

Usado para películas e embalagem, tem cadeias ramificadas que não se adensam bem, o que o torna menos denso do que a água. Tem uma fraca barreira a gás, porém sua resistência à transmissão de gás aumenta com a densidade (ANYADIKE, 2009).

\section{Polietileno de alta densidade (PEAD)}

Possui cadeias mais longas e menos ramificadas, o que os torna mais rígidos e mais resistentes. $O$ polietileno linear de baixa densidade (PELBD) é menos resistente a solventes orgânicos, porém mesmo essas deficiências podem ser superadas convertendo-se sua superfície em um fluoropolímero, podendo ser usado para substâncias mais corrosivas (ASHBY; JONHSON, 2011). Frequentemente, é laminado com outros filmes para combinar boa barreira à umidade e propriedades de selamento ao calor com outras propriedades desejáveis (ANYADIKE, 2009).

É atóxico e o processo de manufatura é relativamente eficiente em relação ao consumo de energia, o que os torna os polímeros comerciais que fazem uso menos intenso de energia. Pode ser produzido com recursos renováveis, como o álcool derivado da fermentação do açúcar ou do amido (ASHBY; JONHSON, 2011). Tecnicamente, é facilmente reciclado, se não for revestido com outros materiais, e pode ser incinerado e recuperar toda a energia que contém.

\section{Polipropileno (PP)}

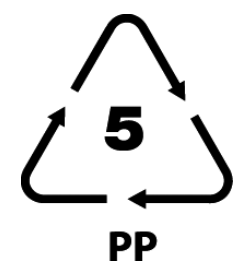

Figura 19 - Simbologia técnica do polipropileno e recomendada para o BOPP 
Usado na manufatura de embalagens médicas, revestimentos à prova de umidade e filmes resistentes à gordura. Assim como o PE, os comprimentos de suas moléculas e ramificações laterais podem ser ajustados por catalisadores inteligentes, o que dá controle preciso de resistência ao impacto e das propriedades que influenciam a moldagem e o repuxamento (ASHBY; JONHSON, 2011).

O PP grau padrão é barato e leve, mas tem baixa resistência. É mais rígido do que o PE e pode ser usado em temperaturas mais altas. As propriedades do PP são semelhantes às do $P E A D$, mas ele é mais rígido e funde a uma temperatura mais alta $\left(165-170^{\circ} \mathrm{C}\right)$ (ASHBY; JONHSON, 2011).

Mais fácil de moldar do que o PE, tem boa transparência e pode aceitar uma gama de cores mais vívida. Avanços em catalisadores prometem novos copolímeros de PP com combinações mais atraentes de tenacidade, estabilidade e facilidade de processamento (ASHBY; JONHSON, 2011).

O PP é inerte e, tecnicamente, fácil de reciclar. Pode ser incinerado para recuperar a energia que contém. O processo de manufatura do PP é relativamente eficiente em relação ao consumo de energia.

\section{Polipropileno biorientado (BOPP)}

A maior demanda é proveniente de filmes coextrudados, com cerca de dois terços de demanda de filme de embalagem BOPP. Aproximadamente $10 \%$ dos filmes de embalagem BOPP são metalizados; destes, dois terços são usados em embalagens de lanches e salgadinhos, confeitos, produtos de padaria e alimentos secos (ANYADIKE, 2009).

Segundo Anyadike (2009), as propriedades do BOPP são:

- Boas propriedades de barreira contra umidade;

- Baixa barreira a gás sem revestimento;

- Baixa resistência ao rasgo;

- Pode ser selado quando revestido ou coextrudado;

- Excelente claridade e rigidez;

- É de fácil uso de maquinaria;

- Mais barato por metro quadrado que outros filmes devido à sua densidade mais baixa e rendimento mais alto.

O filme BOPP metalizado tem propriedades de alta barreira ao vapor d'água e ao oxigênio, com a face metalizada e tratada, preparada para impressão e/ou laminação e a face oposta termosselável. Pode ser mono ou bitratado.

O Centro de Tecnologia de Embalagens (CETEA) fez uma pesquisa com a finalidade de confirmar a reciclagem de BOPP, realizada por Coltro, Gasparino e Queiroz (2008).

Segundo a pesquisa, uma vez que a espessura da camada de alumínio (da ordem de $30 \mathrm{~mm}$ ) presente nas embalagens de BOPP metalizadas é cerca de 1.000 vezes menor do que a espessura do filme de BOPP (da ordem de $20 \mu \mathrm{m}$ ) e não foi identificado nenhum problema tecnológico para a reciclagem deste material, é um material tecnicamente reciclável e vai para a mesma cadeia do PP.

Apesar da norma ABNT NBR 13.230 (ABNT, 2008) não fazer referência específica aos plásticos flexíveis, recomenda-se que os materiais de BOPP, metalizados ou não, apresentem 
o símbolo de reciclagem do PP, número 5, a fim de contribuir para a melhoria da identificação das embalagens plásticas disponíveis no mercado brasileiro, ainda carente e/ou com símbolo incorreto de identificação do material plástico, sendo que ambos os fatores prejudicam a cadeia de reciclagem do plástico no pós-consumo.

\section{Embalagem multicamada}

Uma estrutura multicamadas, quer laminada ou coextrudada, é necessária para fornecer às embalagens propriedades tanto de resistência quanto de barreira. Algumas dessas estruturas multicamadas, como nas embalagens de salgadinhos, podem ter sete ou mais diferentes camadas plásticas, cada uma executando funções de barreira estruturais ou adesivas (ANYADIKE, 2009).

As embalagens mais encontradas no mercado são as embalagens de polipropileno biorientado (BOPP) metalizado. Elas acondicionam uma ampla gama de produtos, pois agregam boas propriedades mecânicas e de barreira a gases de umidade. O processo de metalização consiste na impregnação do filme por uma fina camada de metal (alumínio). Essa aplicação é conseguida por meio do vapor de alumínio.

Todo o filme torna-se espelhado com uma excelente apresentação. Os produtos embalados em estruturas metalizadas oferecem um maior tempo de conservação, por melhorar as propriedades de barreira contra gases (ANYADIKE, 2009).

\subsubsection{Impactos da produção gráfica}

A Associação Brasileira de Tecnologia Gráfica e a Companhia de Tecnologia de Saneamento Ambiental (ABTG; CETESB, 2003), para facilitar a identificação dos resíduos ambientais mais significativos, reuniram as informações dividindo por tipo em efluente líquido, resíduo sólido, emissão atmosférica e outros. Cada um destes foi ainda subdividido por etapa do processo gráfico, onde ocorre sua geração.

\begin{tabular}{|c|c|c|}
\hline & Processo & Saída \\
\hline$\stackrel{0}{2 \pi}$ & $\begin{array}{l}\text { Processamento de } \\
\text { imagens }\end{array}$ & $\begin{array}{l}\text { Efluentes contendo resíduos de reveladores, } \\
\text { fixadores e prata }\end{array}$ \\
\hline 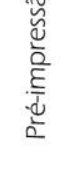 & Preparação de formas & $\begin{array}{l}\text { Efluentes podendo conter resíduos de solventes, } \\
\text { reveladores, soluções ácidas, alcalinas, lacas, metais } \\
\text { pesados e podendo gerar demanda química de } \\
\text { oxigênio (DQO) }\end{array}$ \\
\hline 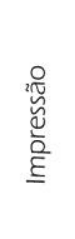 & $\begin{array}{l}\text { Limpeza de rolos e } \\
\text { formas, soluções de } \\
\text { molha }\end{array}$ & $\begin{array}{l}\text { Líquido contendo hidrocarbonetos e resíduos de } \\
\text { tinta que podem gerar odor, sólidos suspensos e, } \\
\text { dependendo da tinta, vestígios de metais pesados. } \\
\text { Podem gerar demanda química de oxigênio (DOO) } \\
\text { e conter resíduos de lubrificantes e graxas }\end{array}$ \\
\hline 峞高 & Diversas etapas & $\begin{array}{l}\text { Água contaminada com despejo oriundo da } \\
\text { lavagem de pisos, coleiros, molhas ácidas, solventes, } \\
\text { bem como resíduos de óleos e graxas }\end{array}$ \\
\hline
\end{tabular}

Tabela 2 - Efluentes líquidos. Fonte: ABTG; CETESB, 2003. 


\begin{tabular}{|c|c|c|}
\hline & Processo & Saída \\
\hline 怘 & $\begin{array}{l}\text { Processamento de } \\
\text { imagens }\end{array}$ & Embalagens vazias, filme usado, material vencido \\
\hline$\frac{\sum_{0}^{2}}{d \underline{c}}$ & Preparação de formas & $\begin{array}{l}\text { Chapas defeituosas, filmes revelados, materiais } \\
\text { vencidos. }\end{array}$ \\
\hline 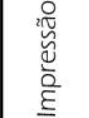 & Impressão & $\begin{array}{l}\text { Provas, papel maculado, latas de tinta vazias, panos } \\
\text { e estopas contaminados }\end{array}$ \\
\hline 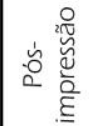 & Diversas etapas & $\begin{array}{l}\text { Produto danificado, sobras de papel, plástico, restos } \\
\text { adesivos }\end{array}$ \\
\hline$\overline{\widetilde{\pi}}$ & $\begin{array}{l}\text { Funcionamento da } \\
\text { empresa }\end{array}$ & $\begin{array}{l}\text { Resíduos ambulatoriais patogênicos, lixo orgânico, } \\
\text { restos de varrição, lâmpadas usadas, lodos de } \\
\text { tratamento de efluentes, lodos sépticos, resíduos de } \\
\text { manutenção (principalmente óleos e graxas) }\end{array}$ \\
\hline
\end{tabular}

Tabela 3 - Resíduos sólidos Fonte: ABTG; CETESB, 2003

\begin{tabular}{|c|l|l|}
\cline { 2 - 3 } \multicolumn{1}{c|}{} & \multicolumn{1}{c|}{ Processo } & \multicolumn{1}{c|}{ Saída } \\
\hline$\frac{\tilde{\pi}}{0}$ & Diversas etapas & $\begin{array}{l}\text { Emissão de compostos orgânicos voláteis (VOCs) } \\
\text { originários da evaporação de solventes }\end{array}$ \\
\hline
\end{tabular}

Tabela 4 - Emissões atmosféricas. Fonte: ABTG; CETESB, 2003

\begin{tabular}{|c|l|l|}
\cline { 2 - 3 } \multicolumn{1}{c|}{} & \multicolumn{1}{c|}{ Processo } & \multicolumn{1}{c|}{ Saída } \\
\hline$\frac{\tilde{\pi}}{0}$ & Diversas etapas & $\begin{array}{l}\text { Emissão de ruidos e vibrações, originados pelo fucio- } \\
\text { namento das máquinas de impressão e pós-impressão. }\end{array}$ \\
\hline
\end{tabular}

Tabela 5 - Outros resíduos. Fonte: ABTG; CETESB, 2003

Esses resíduos, dependendo de sua concentração e outros fatores, podem causar problemas ambientais e na saúde humana. Grande parte das tintas usadas na indústria gráfica possui, em sua composição, alguns elementos denominados metais pesados, como, por exemplo: cromo, chumbo, cádmio, entre outros.

Esses metais, além de serem bastante tóxicos, acumulam-se em nosso organismo, isto é, embora pequenas quantidades desses elementos possam não ser nocivas, sua sucessiva absorção pode atingir concentrações tóxicas em função da dosagem presente no corpo, possibilitando desenvolver danos ao sistema nervoso, deformações em fetos e, em casos extremos, até provocar a morte.

Este efeito cumulativo pode ocorrer uma vez que, lançados no meio ambiente por meio de efluentes líquidos, gasosos ou resíduos sólidos, direta ou indiretamente, atingem homens e animais (ABTG; CETESB, 2003).

Como é possível perceber, o lançamento indiscriminado no meio a mbiente dos resíduos da indústria gráfica pode ter sérias consequências, tanto para o ecossistema como para o ser humano. Em regiões onde a concentração destas empresas é significativa, como a Região Metropolitana de São Paulo, os problemas ambientais podem assumir proporções bastante preocupantes.

A constante preocupação das gráficas com o meio ambiente e a grande quantidade de impressos industrializados fazem com que essas operações evoluam para uma tecnologia cada vez mais correta. Para conseguir uma boa imagem no mercado, as gráficas estão adequando os seus processos, a fim de que eles se enquadrem em políticas ambientais 
corretas e com isso sejam concedidas as certificações de preservação ambiental, comprovando a existência da preocupação e responsabilidade para com o meio ambiente.

As principais certificações da indústria gráfica são: Forest Stewardship Council (FSC); Restriction of Certain Hazardous Substances (RoHS); Internacional Organization of Standardization (ISO 14001).

A principal maneira que a indústria gráfica tem para reduzir os impactos associados à utilização de um substrato para impressão é a de reduzir suas perdas no processo. Outra maneira é o usuário procurar se informar a respeito da origem das matérias-primas que garantem que os produtos provêm de bom manejo florestal e seguem critérios ambientais de produção (SINDIGRAF; CETESB, 2009).

\subsubsection{Destino final dos resíduos}

Hoje, o maior esforço da legislação ambiental e o foco dos programas de governo são indubitavelmente na direção da redução dos níveis de desperdício na embalagem e o descarte inadequado das embalagens, gerando lixo. No Brasil, aproximadamente um quinto do resíduo é composto por embalagens. São 25 mil toneladas de embalagens que vão parar, todos os dias, nos depósitos de resíduo (MMA, 2012).

De acordo com a definição da Lei Federal no 12.305/10 da Política Nacional dos Resíduos Sólidos (PNRS), os resíduos sólidos urbanos englobam os resíduos domiciliares, isto é, aqueles originários de atividades domésticas em residências urbanas, e os resíduos de limpeza urbana, quais sejam os originários da varrição, limpeza de logradouros e vias públicas, bem como de outros serviços de limpeza urbana.

Um parâmetro que bem expressa a característica do resíduo é sua composição gravimétrica, significando o peso e o valor percentual (com relação ao peso total) de cada componente da massa de resíduo (PEREIRA NETO, 2007). O Gráfico 1 apresenta a composição gravimétrica média dos resíduos urbanos coletados no Brasil e, juntamente com a Tabela 6, permite visualizar de um modo geral a participação de diferentes materiais na sua fração total (ABRELPE, 2012).

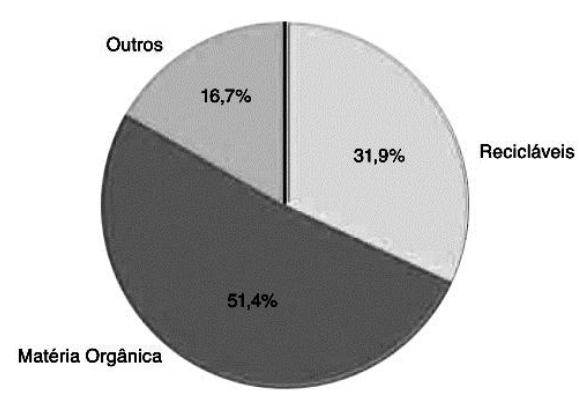

Gráfico 1 - Composição gravimétrica dos resíduos urbanos no Brasil. Fonte: Política Nacional de Resíduos Sólidos, 2012.

\begin{tabular}{l|c|c}
\hline Material & Participação (\%) & Quantidade (t/ano) \\
\hline Metais & 2,9 & 1.610 .499 \\
\hline Papel, Papelão e TetraPak & 13,1 & 7.275 .012 \\
\hline Plástico & 13,5 & 7.497 .149 \\
\hline Vidro & 2,4 & 1.332 .827 \\
\hline Matéria Orgânica & 51,4 & 28.544 .702 \\
\hline Outros & 16,7 & 9.274 .251 \\
\hline TOTAL & $\mathbf{1 0 0 , 0}$ & $\mathbf{5 5 . 5 3 4 . 4 4 0}$ \\
\hline
\end{tabular}

Tabela 6 - Participação dos materiais no total de resíduo urbano coletado no Brasil. Fontes: ABRELPE, 2011; Política Nacional de Resíduos Sólidos, 2012.

A composição, porém, é bastante diversificada nas diferentes regiões, uma vez que está diretamente relacionada com características, hábitos e costumes de consumo e descarte da população local. 
A coleta seletiva foi definida na Lei Federal no 12.305/2010, que instituiu a Política Nacional de Resíduos Sólidos, como a coleta de resíduos sólidos previamente separados de acordo com sua constituição e composição, objetivando sua reutilização ou reciclagem. Os materiais recolhidos são geralmente direcionados para uma central de triagem, unidades que usam mão de obra intensiva dos catadores de materiais recicláveis para a seleção, a classificação, o acondicionamento e o enfardamento dos materiais (PEREIRA NETO, 2007). A reciclagem reduz a quantidade levada para os aterros, com benefícios ambientais e econômicos.

A Política Nacional de Resíduos Sólidos, promulgada no dia 2 de agosto de 2010, promove mudanças no cenário dos resíduos. A lei tem como princípio a responsabilidade compartilhada entre governo, empresas e população. E tem como outro objetivo reduzir a quantidade de resíduo na fonte e encorajar a reutilização, reciclagem, o uso de materiais recicláveis, compostagem de materiais orgânicos e resgate de energia por meio de incineração.

Prioriza a ação ambiental como uma estrutura hierárquica. Na gestão e gerenciamento de resíduos sólidos, deve ser observada a seguinte ordem de prioridade: não geração, redução, reutilização, reciclagem, tratamento dos resíduos sólidos e disposição final ambientalmente adequada dos rejeitos (CEMPRE, 2011).

Nesse cenário, surgem novos e importantes desafios, como a maior conscientização dos consumidores para o descarte adequado de embalagens. Nas residências, é importante a separação dos materiais secos (plásticos, papéis, latas, vidros) dos úmidos (restos de comida e sujeiras contendo matéria orgânica em geral).

O papel do designer não é citado na lei, mas ele está diretamente ligado à prevenção de geração de resíduos através de projetos que tenham um melhor aproveitamento de materiais.

Todos os estudos de embalagem devem considerar o uso de materiais reciclados como componentes das embalagens e habilidade de a embalagem descartada ser reciclada com eficiência. Estes dois aspectos são distintamente diferentes. Se o uso de materiais reciclados for parte de nossas opções de design, haverá oportunidades e também restrições. Estas oportunidades e restrições são peculiares a cada classe de materiais. (STEWART, 2009, p. 144)

As medidas para reduzir resíduos começam desde o projeto dos produtos e permeiam todo o seu ciclo de vida, incluindo também o transporte e o descarte final. Para isso, o setor produtivo deverá informar o consumidor sobre as formas de evitar, reciclar e eliminar resíduos.

\subsubsection{Estratégia de design para a redução dos impactos}

O United Nations Environment Programme (UNEP), em seu documento Design for sustainability: a step-by-step approach (2009), apresenta uma estratégia possível para os designers reduzirem os seus impactos: a ferramenta de análise dos impactos ( $D 4 S$ impact assessment) e a roda da ecoconcepção (D4S strategy wheel).

Os principais objetivos da análise de impacto são:

- Entender os principais aspectos de sustentabilidade do ciclo de vida do produto;

- Identificar as prioridades da sustentabilidade do ciclo de vida do produto.

A análise de impacto consiste em cinco passos: 
1. Criar a árvore dos processos do ciclo de vida;

2. Definir o cenário do usuário e unidade funcional;

3. Identificar critérios de impacto para o design;

4. Preencher a matriz de impacto;

5. Priorizar os impactos do design.

\begin{tabular}{|c|c|c|c|c|c|}
\hline Assunto & $\begin{array}{l}\text { Matérias- } \\
\text { Primas }\end{array}$ & Fornecedores & Produção & Distribuição & Uso \\
\hline \multicolumn{6}{|l|}{ Materiais } \\
\hline \multicolumn{6}{|l|}{ Uso de energia } \\
\hline \multicolumn{6}{|l|}{ Resíduos Sólidos } \\
\hline \multicolumn{6}{|l|}{ Emissões tóxicas } \\
\hline \multicolumn{6}{|l|}{$\begin{array}{l}\text { Responsabilidade } \\
\text { Social } \\
\end{array}$} \\
\hline \multicolumn{6}{|l|}{$\begin{array}{c}\text { Gerenciamento } \\
\text { dos Recursos } \\
\text { Humanos }\end{array}$} \\
\hline \multicolumn{6}{|l|}{$\begin{array}{l}\text { Distribuição das } \\
\text { economias }\end{array}$} \\
\hline \multicolumn{6}{|l|}{ Água } \\
\hline \multicolumn{6}{|l|}{$\mathrm{Co}_{2}$} \\
\hline Custos & & & & & \\
\hline & & & & & \\
\hline
\end{tabular}

Figura 20 - Exemplo de uma matriz de impacto. Fonte: UNEP, 2009.

A roda da ecoconcepção (D4S strategy wheel) ilustra sete estratégias de design sustentável que cobrem algumas direções de melhoria em paralelo às etapas do ciclo de vida do produto.

1. Seleção de materiais de baixo impacto;

2. Redução do uso de materiais;

3. Otimização das técnicas de produção;

4. Otimização do sistema de distribuição;

5. Redução do impacto durante a utilização;

6. Otimização da vida inicial;

7. Otimização do sistema de fim de vida.

Junto às sete estratégias descritas acima, a roda da ecoconcepção também mostra o ' 0 ', a estratégia de um design completamente novo, tendo em conta o potencial de inovação. Nesta estratégia, o consumidor precisa da definição do desenvolvimento de um produto e/ou o serviço que melhor satisfaçam as suas necessidades de forma mais sustentável.

A roda da ecoconcepção pode ser utilizada para definir quais das estratégias de desenho são as mais adequadas para um produto selecionado. Os resultados da avaliação de impacto estão ligados a possíveis estratégias de melhoria do design. 


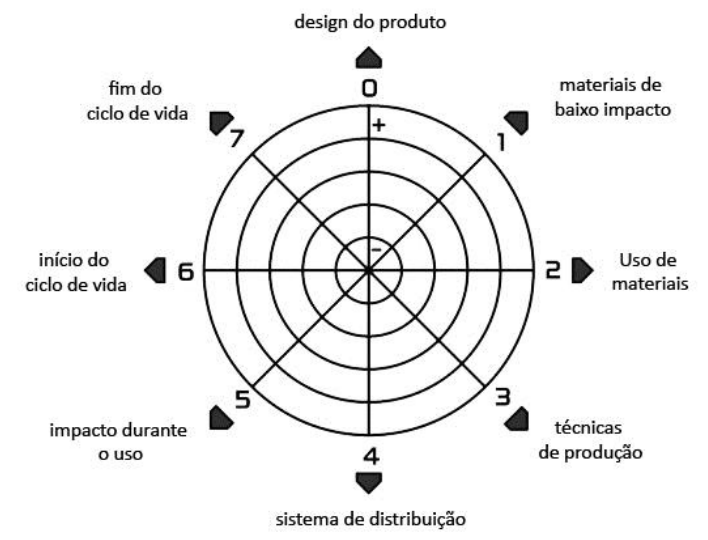

Figura 21 - Roda da ecoconcepção. Fonte: UNEP, 2009

A avaliação da roda pode levar a uma situação que haja conflito de escolha, onde a resolução do problema pode acarretar outro. Para facilitar o processo de tomada de decisão, a equipe responsável pelo design de embalagens pode selecionar duas estratégias com base na análise de impacto e duas com base nas estratégias da roda da ecoconcepção.

\subsection{RECOMENDAÇÕES DAS ORGANIZAÇÕES}

Com o advento das preocupações ambientais no desenvolvimento de embalagens, algumas organizações e associações do mercado de embalagens foram criadas com objetivo de orientar e sistematizar o desenvolvimento de embalagens, inserindo as questões ambientais como um dos temas chaves a serem discutidos e divulgados.

Para o presente trabalho, foram selecionadas organizações de várias localidades que desenvolveram materiais que orientam e dão diretrizes para desenvolver uma embalagem de forma mais sustentável.

Foram escolhidas organizações que representassem regiões diferentes do mundo, possibilitando uma visão mundial das recomendações para o desenvolvimento de embalagens comparadas ao que é recomendado no Brasil. Elas foram selecionadas devido à sua importância, representação e influência nas regiões em que atuam.

As associações pesquisadas foram: a Associação Brasileira de Embalagem (ABRE), do Brasil; a Sustainable Packaging Coalition (SPC), dos Estados Unidos; a European Organization for Packaging and the Environment (EUROPEN), da comunidade europeia; o documento The D4S: a step-by-step approach, da UNEP, produzido com a colaboração do programa de design para o meio ambiente da Delft University; e o documento Protocolo global sobre sustentabilidade de embalagens 2.0, traduzido pela $A B R E$, que reuniu os indicadores das associações já citadas e da ECR Europe e Grocerj/Manufacturers Association (GMA).

\section{Associação Brasileira de Embalagem (ABRE)}

O Brasil não possui uma organização especializada em promover o design sustentável de embalagens. As empresas brasileiras produtoras e consumidoras de embalagens são representadas pela ABRE. Para orientar o mercado de embalagens brasileiro, a ABRE produziu o documento Diretrizes de sustentabilidade para a cadeia produtiva de embalagem e bens de consumo (2012), por meio de seu Comitê de Meio Ambiente e Sustentabilidade. 


\section{Documento analisado: Diretrizes de sustentabilidade para a cadeia produtiva de embalagem e bens de consumo (2012)}

O objetivo é de promover junto a cada empresa a autoavaliação de indicadores ambientais de sustentabilidade. Para isso, elaborou uma ferramenta que possibilita que toda a cadeia produtiva trabalhe em uma mesma direção na busca da melhoria contínua do desempenho ambiental de seus produtos, processos produtivos e embalagens, ao longo de todas as etapas do seu ciclo de vida. Os indicadores ambientais foram desenvolvidos com base no conceito de ecodesign (design for environment), essencial para que a nossa sociedade tenha acesso a produtos, sem comprometer a disponibilidade de recursos naturais para as futuras gerações.

O desenvolvimento das diretrizes de sustentabilidade envolveu dois anos de discussão e trabalho do Comitê de Meio Ambiente e Sustentabilidade da ABRE, reunindo profissionais de empresas destas cadeias produtivas, bem como entidades e centros de pesquisa correlatos à área. Seu caráter é orientativo e será aprimorado a partir das experiências de aplicação dos indicadores.

\section{Sustainable Packaging Coalition (SPC)}

Nos EUA, a SPC reúne associados, muito deles indústrias multinacionais, que estão de acordo com as metas estabelecidas por eles para o desenvolvimento de embalagens sustentáveis. Para orientar os seus associados, foi desenvolvido o documento Sustainable packaging indicators and metrics framework (2009), um conjunto de indicadores e métricas, com o objetivo de orientar as empresas a medirem seu progresso em defesa dos critérios articulados por eles do que é uma embalagem sustentável.

Segundo a SPC, a embalagem sustentável:

- É benéfica, segura e saudável para indivíduos e comunidades, por todo seu ciclo de vida;

- Deve encontrar critérios de mercado para performance e custo;

- É pesquisada, manufaturada, transportada e reciclada usando energia renovável;

- Maximiza o uso de materiais renováveis e recicláveis;

- É produzida utilizando práticas e tecnologias de produção "limpas";

- É feita de materiais saudáveis ao longo do ciclo de vida;

- É fisicamente desenhada para otimizar uso de materiais e energia;

- É efetivamente recuperada e utilizada em ciclos fechados, biológicos ou industriais.

Documento analisado: Sustainable packaging indicators and metrics framework (2009)

A publicação Sustainable packaging indicators and metrics framework é o resultado de 18 meses do projeto que a SPC promoveu para desenvolver um conjunto de indicadores e métricas em comum que ajudem as empresas a medirem seu progresso em defesa dos critérios articulados na definição de embalagem sustentável da SPC.

A estrutura do documento é dividida em quatro sessões - introdução, compreensão dos indicadores e métricas, uso das linhas guias e os módulos de indicadores e métricas. Nele, existe um módulo para cada critério chave da definição de embalagem sustentável da SPC, especialmente sobre uso de material, uso de energia, materiais saudáveis, produção limpa e transporte, custo e performance, impactos na comunidade e no trabalhador. 
O documento sugere que as empresas devem selecionar os indicadores que sejam mais relevantes nas suas operações. A sessão de linhas guia para o usuário inclui uma discussão detalhada sobre a seleção e uso dos indicadores e métricas e dá sugestões de como começar.

\section{European Organization for Packaging and the Environment (EUROPEN)}

O documento selecionado da EUROPEN, representante das empresas da comunidade europeia, foi o Packaging in the sustainability agenda: a guide for corporate decision makers (2009). O documento foi projetado como uma fonte para ajudar as decisões dos líderes das empresas de forma balanceada e com visões atualizadas sobre o papel da embalagem no desenvolvimento sustentável.

\section{Documento analisado: Packaging in the sustainability agenda: a guide for corporate decision makers (2009)}

O guia Packaging in the sustainability agenda: a guide for corporate decision makers é sobre estratégia de embalagem. Um time representando toda a cadeia de embalagem foi estabelecido para colaborar junto com a EUROPEN para direcionar o guia de forma racional, fatual e desapaixonada. $\mathrm{O}$ documento foi projetado como uma fonte para ajudar as decisões dos líderes das empresas de forma balanceada e com visões atualizadas sobre o papel da embalagem no desenvolvimento sustentável. O guia tem o objetivo de ajudar a encontrar benefícios tangíveis como mais eficiência, melhor controle de custo e um melhor relacionamento com a grande variedade de stakeholders. Ainda examina alguns mal entendidos fundamentais sobre o papel da embalagem na nossa indústria. O guia explora várias abordagens e ferramentas usadas para calcular o impacto de um produto ao longo de seu ciclo de vida, salientando a importância de levar em conta uma variedade de indicadores de sustentabilidade. $O$ papel estratégico da embalagem em uma empresa é explorado informando como otimizar o seu desempenho em cada estágio da cadeia de suprimentos. Os últimos capítulos dão conselhos práticos de como os líderes de uma empresa podem implementar a estratégia de sustentabilidade na embalagem.

Segundo a EUROPEN, a embalagem traz uma grande contribuição para a economia, o meio ambiente e a sustentabilidade social através da proteção de produtos, prevenindo o desperdício, impedindo condução nos negócios de forma ineficiente e fornecendo aos consumidores os benefícios dos produtos que ela contém. Segundo a EUROPEN, não existe uma embalagem totalmente sustentável. Ela apenas pode ser produzida de forma mais sustentável. Na visão da contribuição da embalagem para o desenvolvimento sustentável, define-se que ela deve:

- Ser projetada de forma holística junto com o produto de forma a otimizar o seu desempenho ambiental;

- Ser feita com materiais de fontes responsáveis;

- Ser projetada para ser eficiente e segura ao longo do seu ciclo de vida;

- Estar de acordo com os critérios de mercado para o seu desempenho e custo;

- Estar de acordo com as escolhas e expectativas do consumidor;

- Ser recuperada de forma eficiente após o seu uso. 


\section{United Nations Environment Programme (UNEP)}

O documento da UNEP selecionado foi o The D4S: a step-by-step approach (2009), desenvolvido junto com a Delft University. A produção desse documento contou com vários parceiros, incluindo as entidades das Nações Unidas, organizações internacionais, governos nacionais, organizações não governamentais e setores privados da sociedade civil. A publicação foca em quatro abordagens práticas, mostrando as aplicações do design para desenvolver um produto inovador e sustentável.

\section{Documento analisado: The D4S: a step-by-step approach (2009)}

O documento foi produzido com a colaboração do programa de design para o meio ambiente da Delft University. As duas organizações têm sido ativas na área de promoção do design de produtos mais sustentáveis, desde a introdução desses conceitos nos anos de 1990. Essa publicação é o resultado de uma ampla cooperação e colaboração de especialistas de países como Holanda, Suécia, Itália, França, Alemanha, Japão, Austrália e da UNEP.

A publicação foca especificamente em quatro abordagens práticas e fornece uma coleção de estudos de caso mostrando as aplicações do design para a sustentabilidade e seus benefícios. Cada capítulo reflete o conhecimento e as lições aprendidas em múltiplos projetos e representam anos de projetos conectados. O documento aborda uma apresentação da situação global e os passos para a aplicação das áreas chaves para a intervenção do design sustentável.

Segundo a UNEP, são necessários nove passos simples para desenvolver um produto:

1. Selecione um produto;

2. Prepare um dossiê do produto;

3. Reveja seu produto no mercado, em termos das questões ambientais e sociais;

4. Reflita no produto a lista de abordagens do design sustentável;

5. Desenvolva uma visualização rápida dos impactos do produto;

6. Defina as abordagens de melhoramento e design;

7. Redefina conceitos, depois a criatividade;

8. Priorize ideias e conceitos;

9. Transforme-o em um projeto especial.

\subsubsection{Análise comparativa dos indicadores ${ }^{4}$}

Buscando o alinhamento frente aos conceitos e processos do desenvolvimento sustentável da embalagem e aplicação da Avaliação do Ciclo de Vida (ACV), tendo como premissa as diferentes interfaces técnicas, regulatórias e mercadológicas que balizam o seu desenvolvimento, o Comitê de Meio Ambiente e Sustentabilidade da Associação Brasileira de Embalagem (ABRE) traduziu para o português o Global protocol on packaging and sustainability publicado pelo The Consumer Goods Forum.

O Projeto Global de Embalagem começou como resultado de uma proposta feita ao Fórum Mundial de CEOs (Global CEO Forum) por Sir Terry Leahy e Paul Polman, em novembro de 2008. Eles identificaram a necessidade de uma linguagem comum para permitir o debate fundamentado sobre sustentabilidade. No entanto, compreendendo a magnitude dessa tarefa, propuseram que essa linguagem fosse primeiro endereçada a uma área mais

${ }^{4}$ A partir dos documentos acima citados (ABRE + ECR Europe + EUROPEN + Grocerj/Manufacturers Association (GMA) + Sustainable Packaging Coalition (SPC) + UNEP). 
delimitada e gerenciável dentro da agenda maior de sustentabilidade. Assim, a embalagem foi identificada como a área de foco deste Projeto.

\section{Documento analisado: Protocolo global sobre sustentabilidade de embalagens 2.0 (tradução de 2013)}

Durante o Fórum Mundial de CEOs, foi acordado que o projeto reuniria trabalhos existentes na indústria, em vez de criar novos, partindo do zero. O projeto conseguiu alcançar esse objetivo a partir dos aportes vindos de programas existentes nas seguintes organizações: ECR Europe, EUROPEN, Grocerj/Manufacturers Association (GMA) e Sustainable Packaging Coalition (SPC). Este documento resume o resultado do projeto até o momento.

A tabela a seguir faz uma comparação dos principais indicadores ambientais para o desenvolvimento de embalagens dos documentos pesquisados. Nota-se que cada um tem suas especificidades, sendo necessária uma avaliação de caso a caso para análise dos aspectos ambientais das embalagens.

\begin{tabular}{|c|c|c|c|c|c|c|}
\hline & Indicadores ambientais & ABRE & SPC & EUROPEN & $\begin{array}{l}\text { Protocolo } \\
\text { Global }\end{array}$ & UNEP \\
\hline \multirow{9}{*}{$\begin{array}{l}\text { Uso de recursos } \\
\text { naturais }\end{array}$} & Evita o consumo de recursos não renováveis & & & & $\mathrm{x}$ & \\
\hline & Consumo de recursos naturais & $\mathrm{x}$ & & $\mathrm{x}$ & $\mathrm{x}$ & $\mathrm{x}$ \\
\hline & $\begin{array}{l}\text { Avaliação e minimização do uso de substâncias perigosas ao } \\
\text { meio ambiente }\end{array}$ & & & & $\mathrm{x}$ & \\
\hline & Uso de água & $\mathrm{x}$ & $\mathrm{x}$ & & $x$ & $\mathrm{x}$ \\
\hline & Demanda acumulada de energia & $x$ & $x$ & & $x$ & $x$ \\
\hline & Uso de terra & & & & $\mathrm{x}$ & \\
\hline & Materiais virgens & & $\mathrm{x}$ & & & $\mathrm{x}$ \\
\hline & Materiais reciclados (pós e pré-consumo) & $\mathrm{x}$ & $\mathrm{x}$ & $\mathrm{x}$ & $\mathrm{x}$ & $\mathrm{x}$ \\
\hline & Materiais de fontes renováveis & $x$ & & & $x$ & $x$ \\
\hline \multirow{3}{*}{ Produção } & $\begin{array}{l}\text { Equilíbrio entre as embalagens primárias, secundárias e } \\
\text { terciárias }\end{array}$ & & & $\mathrm{x}$ & $\mathrm{x}$ & \\
\hline & Eficiência na produção para o não desperdício & & & $\mathrm{x}$ & $\mathrm{x}$ & \\
\hline & Avalia o ciclo de vida do produto & & & & $x$ & $\mathrm{x}$ \\
\hline \multirow{5}{*}{$\begin{array}{l}\text { Emissões e } \\
\text { resíduos gerados } \\
\text { na produção }\end{array}$} & Lançamento de efluentes & $\mathrm{x}$ & $x$ & $x$ & $\mathrm{x}$ & $\mathrm{x}$ \\
\hline & Emissões de gases de efeito estufa & $x$ & $\mathrm{x}$ & $\mathrm{x}$ & $\mathrm{x}$ & $\mathrm{x}$ \\
\hline & Emissões atmosféricas & $x$ & $x$ & $\mathrm{x}$ & $x$ & $\mathrm{x}$ \\
\hline & Geração e destinação de resíduos sólidos & $x$ & $x$ & $x$ & $x$ & $\mathrm{x}$ \\
\hline & Substâncias tóxicas e perigosas & $\mathrm{x}$ & $\mathrm{x}$ & & $\mathrm{x}$ & $\mathrm{x}$ \\
\hline \multirow{9}{*}{ Logística } & Meios de transporte & & & & $\mathrm{x}$ & $\mathrm{x}$ \\
\hline & Fácil identificação & & & $\mathrm{x}$ & & \\
\hline & Otimização no carregamento & & & $\mathrm{x}$ & & \\
\hline & Cubagem. Dimensionamento das embalagens & $\mathrm{x}$ & $\mathrm{x}$ & $\mathrm{x}$ & $\mathrm{x}$ & \\
\hline & Proteção do produto & $x$ & & & & \\
\hline & Proporção embalagem $\mathrm{x}$ produto & $\mathrm{x}$ & $\mathrm{x}$ & $x$ & $\mathrm{x}$ & \\
\hline & Energia utilizada no transporte & & $\mathrm{x}$ & & $\mathrm{x}$ & \\
\hline & Estoque eficiente & & & $\mathrm{x}$ & & \\
\hline & Recuperação de embalagens secundárias e terciárias & & & $\mathrm{x}$ & $\mathrm{x}$ & \\
\hline \multirow{5}{*}{ Pós-consumo } & $\begin{array}{l}\text { Compatibilidade dos componentes da embalagem na } \\
\text { reciclagem }\end{array}$ & $\mathrm{x}$ & & & & \\
\hline & Separação dos componentes da embalagem no pós-consumo & $\mathrm{x}$ & & $x$ & & $x$ \\
\hline & Reciclabilidade & $x$ & $x$ & & & $\mathrm{x}$ \\
\hline & Taxa de reutilização da embalagem & $x$ & $\mathrm{x}$ & & $\mathrm{x}$ & \\
\hline & Envio para aterros & & $\mathrm{x}$ & $\mathrm{x}$ & & \\
\hline \multirow{3}{*}{ Comunicação } & Conscientização ambiental & $\mathrm{x}$ & & & & \\
\hline & Comunicação para o descarte & $\mathrm{x}$ & $\mathrm{x}$ & $x$ & & \\
\hline & Simbologia técnica de identificação de materiais & $\mathrm{x}$ & & $\mathrm{x}$ & & \\
\hline
\end{tabular}

Tabela 7 - Indicadores ambientais para o design de embalagem, estabelecidos por órgãos e associações. 


\subsection{INDÚSTRIAS DE ALIMENTOS ORGÂNICOS PESQUISADAS.}

Considerando os objetivos propostos para esta pesquisa, entende-se a necessidade de um recorte no qual a seleção de casos atenderá aos critérios de maior cobertura possível do campo (FLICK, 2009). Foram selecionadas cinco principais marcas de alimentos orgânicos industrializados, escolhidas de acordo com a sua ampla distribuição e possível impacto ambiental, com uma diversidade de produtos e tipos diferentes de embalagens. $O$ recorte estabelecido permitiu a determinação a priori da estrutura da amostra, integrando a esta todos os casos disponíveis para análise nas empresas selecionadas.

Em pesquisa exploratória preliminar, feita em supermercados na cidade de São Paulo e em lojas especializadas em produtos naturais de março de 2011 a maio de 2012, as empresas que atenderam aos requisitos acima explicitados foram: Mãe Terra, Monama, Via Pax Bio, Native e Jasmine.

\subsubsection{Mãe Terra}

A Mãe Terra é uma empresa localizada em Osasco (SP) que, desde 1979, comercializa alimentos orgânicos e naturais compostos por ingredientes mais próximos de seu estado encontrado na natureza. Os produtos são minimamente processados para garantir seus nutrientes e para não terem alterações provocadas por aditivos, corantes, conservantes e adoçantes artificiais. Todos os produtos são criteriosamente escolhidos, procurando manter os nutrientes e outras características importantes do alimento in natura, ajudando no bom funcionamento do organismo (MÃE TERRA, 2012).

Seus produtos são fornecidos por cerca de cem agricultores, de várias regiões, que são responsáveis pelo fornecimento da matéria-prima para a empresa. Da Região Sul, são recebidos os grãos; do Norte e Nordeste, as castanhas e o cacau; e do Sudeste, o açúcar. A empresa não comercializa apenas produtos orgânicos, mas tem como meta ampliar o uso desse tipo de insumo.

Os produtos da Mãe Terra podem ser encontrados nas grandes redes de supermercados em São Paulo, como o Pão de Açúcar e o Carrefour, e em lojas de produtos naturais ou de venda de snacks (biscoitos, doces e salgadinhos).

Segundo o site da Mãe Terra (2012), a empresa acredita no:

[...] equilíbrio e bem-estar na alimentação e do cotidiano; na beleza integral encontrada na natureza e em cada um de nós; na felicidade, no cuidado consigo e com a família através dos alimentos naturais; na transformação da inter-relação de todas as coisas do planeta investindo cada vez mais em serviços inovadores e equipes de profissionais capacitados.

Mãe Terra foi criada em 1979, em São Paulo, como um pequeno restaurante natural chamado Sativa, que contava também com uma loja de produtos do mesmo segmento. Com o aumento da procura por seus produtos, começaram a investir na venda em grande escala, por atacado, para vários outros estados do Brasil. Com o tempo, foram trazendo novos produtos naturais ao mercado, com embalagens cada vez mais elaboradas e educativas, transmitindo a importância da alimentação saudável (MÃE TERRA, 2012).

Em 2007, a empresa foi comprada pelos sócios Alexandre Borges e Marília Rocca e houve uma mudança no rumo dos negócios (GLOBO RURAL, 2011). Nesse período, foi repensado o 
posicionamento da empresa no mercado e uma nova identidade visual. Para o design da marca e das embalagens, foi contratado o escritório Dezign com Z (2012).

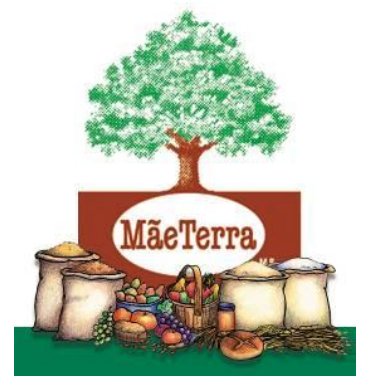

Figura 22 - Marca da Mãe Terra antes da compra da fábrica. Fonte: acervo Mãe Terra
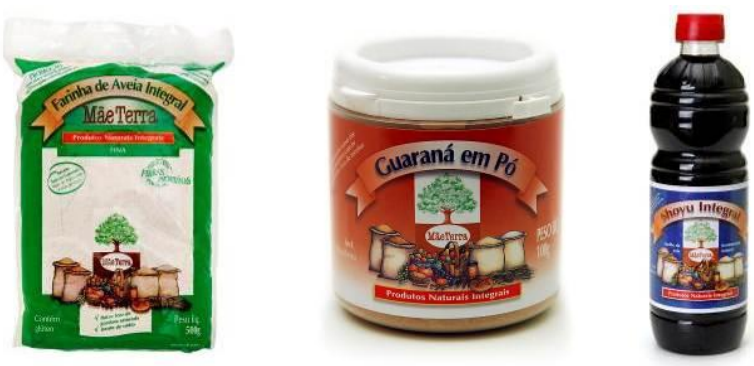

Figura 23 - Embalagens antigas da Mãe Terra, antes da compra da fábrica. Farinha de aveia integral, guaraná em pó, shoyu.

Fonte: acervo Mãe Terra

Em 2009, começou a comercializar produtos prontos para consumo, como salgadinhos sabor milho e pizza, sopas instantâneas, macarrão tipo lámen, barrinha de cereais, entre outros. A estratégia é fornecer alimentos isentos de aditivos e conservantes artificiais, mostrando que o natural tem sabor e pode ser prazeroso (GLOBO RURAL, 2011).

\section{Identidade visual}

As informações sobre o design da marca da Mãe Terra vieram do portfolio da Dezign com Z (2009) e das informações fornecidas pelos representantes da indústria e do escritório de design em entrevista concedida em junho de 2013. Na entrevista, o escritório indicou que, após uma pesquisa informal feita com os consumidores, percebeu-se que a árvore era um elemento que seus clientes reconheciam e confiavam, por isso foi mantida. Ao ser redesenhada, foram acrescentados outros elementos para enriquecer seu significado original e aproximar a marca dos ideais da empresa. Para representar a interdependência entre todos os seres vivos, foram acrescentados, na copa da árvore, o fruto e o pássaro.

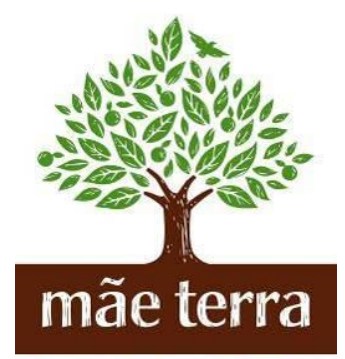

NATURAL DE VERDADE

Figura 24 - Nova marca da Mãe Terra. Fonte: acervo Mãe Terra.

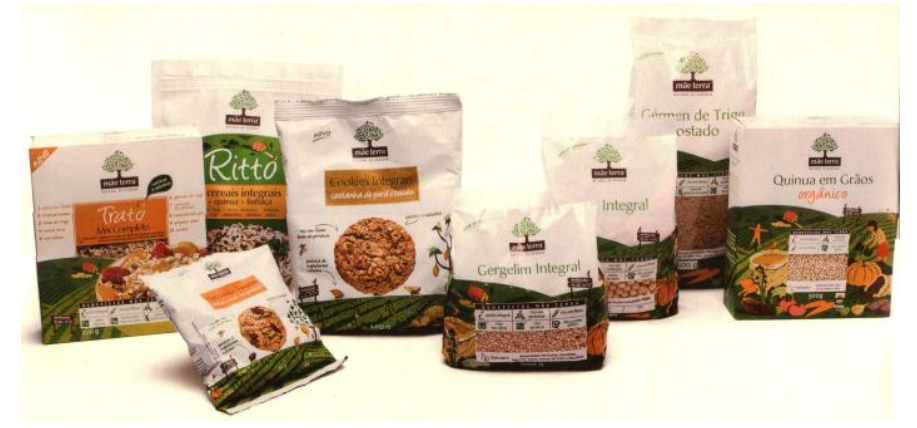

Figura 25 - Embalagens desenvolvidas após o design da identidade visual da Mãe Terra. Fonte: Dezign com Z, 2009

Como inspiração, para as ilustrações, foram escolhidos os grafismos das cerâmicas indígenas, que trazem a simbologia de um povo que vive em harmonia com a natureza. Aos desenhos das cerâmicas, foram adicionados os riscados da terra, espaço de plantio e colheita dos alimentos. Esse conceito visual foi desdobrado nas embalagens, materiais promocionais e no site. 


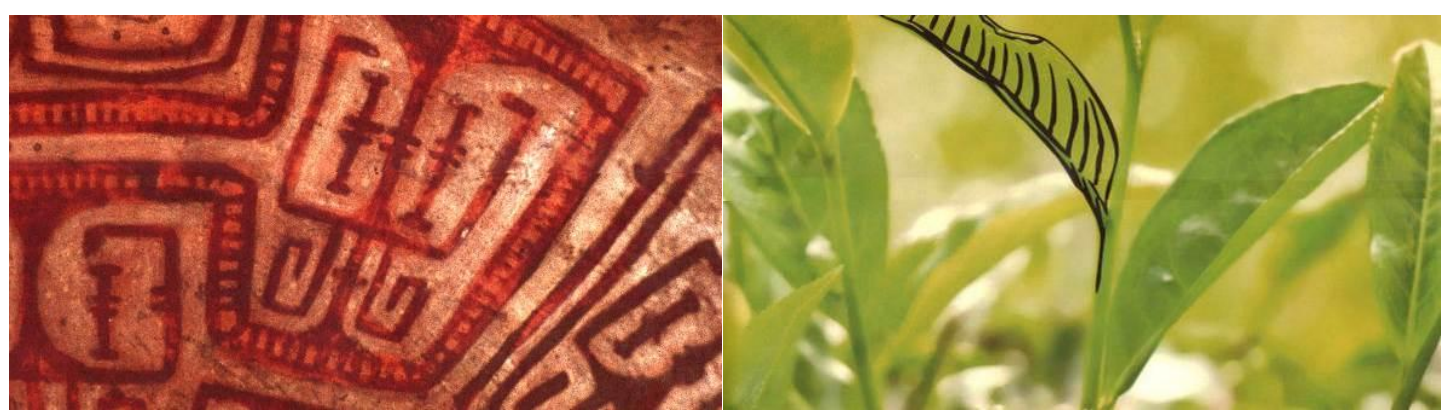

Figura 26 - Cerâmica indígena, referência para identidade visual da Mãe Terra. Fonte: Dezign com Z, 2009

\section{Aspectos ambientais da empresa}

O projeto Pensando Bem rastreia os sete impactos ambientais de diversos produtos, desde o plantio, produção, até a entrega nas lojas. Nesse rastreamento, são identificados pontos a serem melhorados e o que está bom, buscando formas de reduzir o impacto de seus processos na natureza. Os princípios e regras que norteiam o projeto Pensando Bem são: compromisso com a verdade; visão holística; apoio ao pequeno produtor; incentivo à cidadania global; atitude "mão na massa".

Os sete impactos rastreados foram: energia, água, $\mathrm{CO}^{2}$ e gases poluentes, insumos e resíduos, saúde do solo, biodiversidade, bem estar animal. No site, o rastreamento dos impactos da Mãe Terra está disponível em forma de tabela conforme é mostrado a seguir:

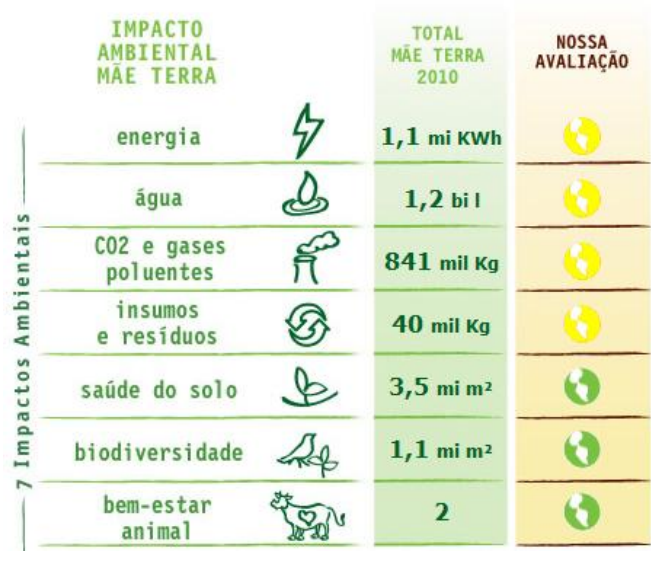

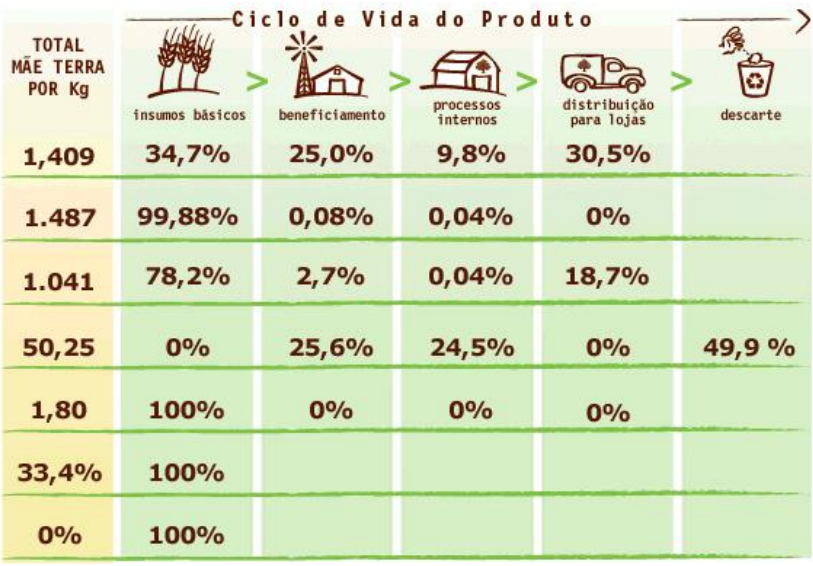

Tabela 8 - Tabela de impactos ambientais da Mãe Terra. Fonte: MÃE TERRA, 2012.

Os valores da Mãe Terra são divulgados em seu site na forma dos Sete princípios Mãe Terra e nas Sete paixões da Mãe Terra.

\begin{tabular}{|l|l|}
\hline Sete princípios Mãe Terra & Sete paixões da Mãe Terra \\
\hline Mais integral; & Paixão pelo natural de verdade; \\
Mais sabor; & Paixão pelo cuidar; \\
Orgânicos, quando possível; & Paixão por trabalhar com alegria; \\
Níveis moderados de sódio; & Paixão pela verdade; \\
Sem transgênicos; & Paixão por criar luz; \\
Sem açúcar branco e gordura trans; & Paixão pelo caminho do meio; \\
Sem corantes e aromatizantes artificiais. & Paixão por realizar com propósito. \\
\hline
\end{tabular}




\section{Produtos orgânicos}

A Mãe Terra produz 24 itens orgânicos até 2013, com certificação IBD, e trabalha para aumentar esse sortimento. Para eles, não basta que os alimentos sejam orgânicos (sem agroquímicos), eles também têm de ser naturais e integrais, sem corantes ou aromatizantes artificiais, sem açúcar branco e sem gorduras trans.

\section{Resíduos e embalagens}

Estão elaborando um manual de avaliação de embalagens plásticas e de papel que integra os sete impactos ambientais, tanto na fase de produção, quanto no descarte após a compra do produto pelo consumidor final. Esse documento irá auxiliar a Mãe Terra escolher quais embalagens usar em seus produtos. Um estudo sobre novos tipos de materiais e embalagens também está sendo conduzido. Segundo informação levantada em entrevista, o projeto desse manual está parado.

\section{Produtos selecionados - Mãe Terra}

Os produtos selecionados da Mãe Terra para análise das embalagens foram: Caseirito, Cookies Integrais, Açúcar Mascavo Extrasseco e Arroz Cateto Integral.

\section{Caseirito}

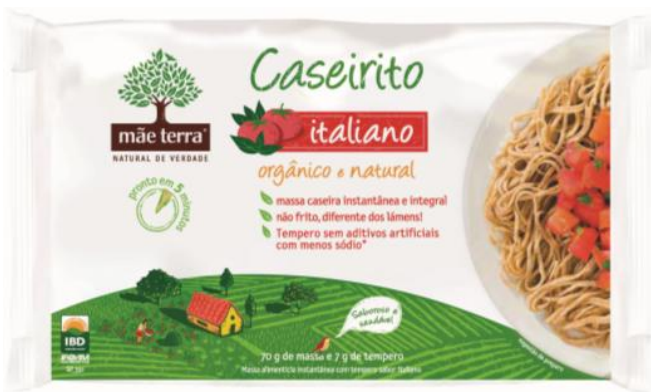

Figura 27 - Embalagem do Caseirito da Mãe Terra. Fonte: Mãe Terra, 2012 (ANEXO Q)

O Caseirito é o primeiro macarrão instantâneo, tipo lámen, natural do Brasil, feito com farinha integral de moinho de pedra (processo de moagem dos grãos integrais do trigo que preserva os seus benefícios). Ele vem com um sachê de tempero natural e fica pronto em cinco minutos.

Tem baixo teor de gordura, porque a massa não é frita, ao contrário dos macarrões instantâneos convencionais. Tem menos sódio, sem glutamato monossódico, rico em fibras e fonte de proteínas.

A massa integral do Caseirito é elaborada com os mesmos ingredientes, nas três versões do produto. A diferença está nos ingredientes naturais dos temperos que acompanham o produto, nos sabores funghi, legumes coloridos e italiano. A embalagem do Caseirito vem com 70 gramas de macarrão acompanhado do sachê de tempero, com sete gramas. 


\section{Cookies Integrais}

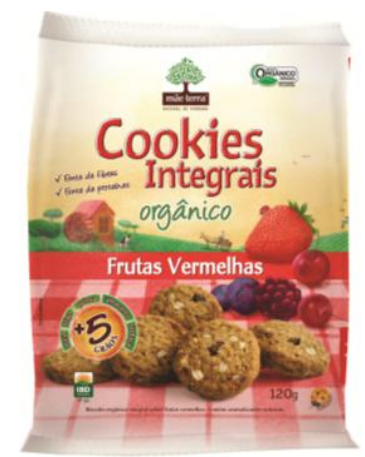

Figura 28 - Embalagem dos Cookies Integraisda Mãe Terra. Fonte: Mãe Terra, 2012 (ANEXO Q).

Os Cookies Integrais Orgânicos têm pedaços de frutas, cereais e castanhas. Feitos com cinco grãos integrais (quinua, amaranto, linhaça, aveia e trigo), são ricos em fibras e fontes de proteínas. Traz em sua composição $74 \%$ de cereais integrais. Sua receita é formulada com açúcar mascavo orgânico.

São vendidos em quatro sabores (banana e linhaça, aveia e mel com passas, coco e cacau, castanha-do-pará e cacau) e são isentos de corantes e conservantes artificiais. Estão disponíveis em embalagens com 120 gramas.

\section{Açúcar Mascavo Extrasseco}

O açúcar mascavo da Mãe Terra não tem aditivos químicos e é minimamente processado. Naturalmente, é fonte de ferro. É um dos produtos rastreados pelo projeto Pense Bem. A seguir, a tabela com os dados do rastreamento:

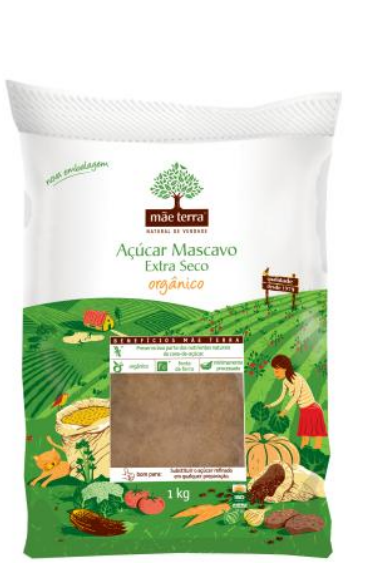

Figura 29 - Embalagem do Açúcar Mascavo Extrasseco orgânico da Mãe Terra. Fonte: Mãe Terra, 2012 (ANEXO Q).

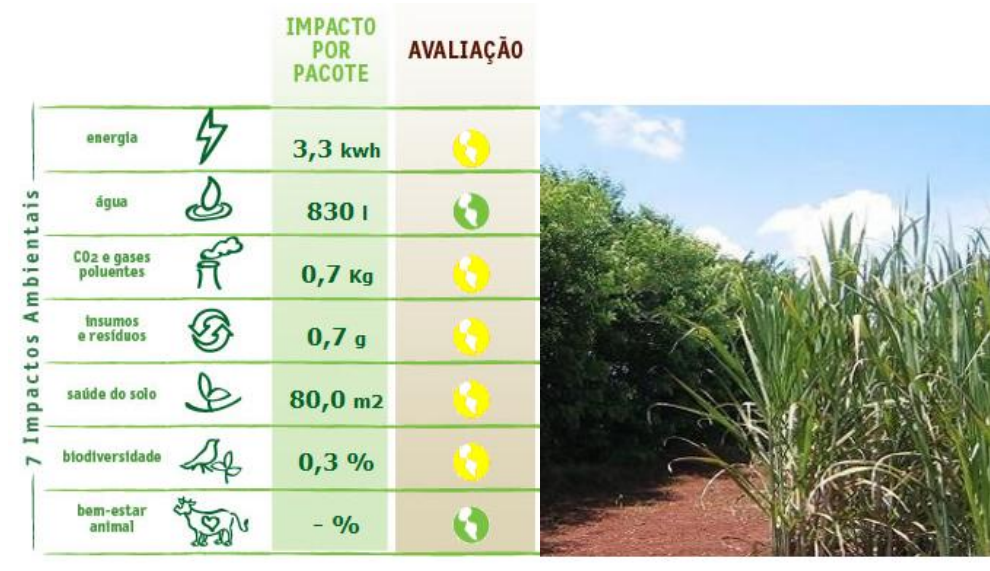

Tabela 9 - Tabela de 7 impactos ambientais do Açúcar Mascavo Extrasseco. Fonte: Mãe Terra, 2012.

\section{Arroz integral cateto}

Fonte de proteínas e fibras, o arroz integral cateto é usado para pratos como risotos. É um dos produtos rastreados pelo projeto Pense Bem. A seguir, a tabela com os dados do rastreamento. 


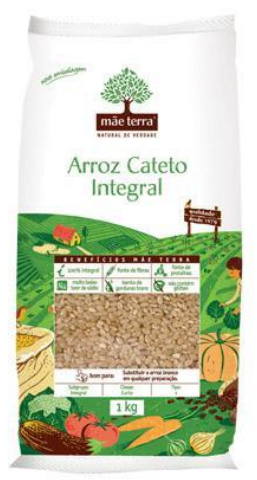

Figura 30 - Embalagem arroz cateto integral Fonte: Mãe Terra, 2012 (ANEXO Q)

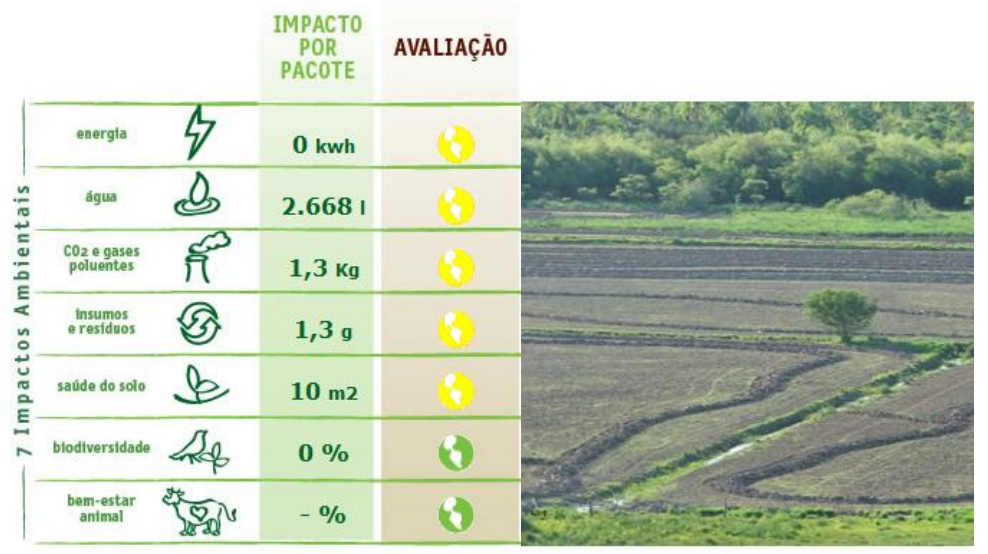

Tabela 10 - Tabela de 7 impactos ambientais do Arroz Cateto Orgânico. Fonte: Mãe Terra, 2012

\subsubsection{Monama}

Monama é uma marca de produtos orgânicos, cuja empresa é localizada em Itupeva (SP). Os produtos são especialmente elaborados para quem busca uma alimentação saudável. A matéria-prima é selecionada minuciosamente para atender a todas as especificações de um consumo saudável na alimentação de seus clientes.

Para abastecer a linha de produção, a Monama busca fornecedores em várias regiões do país como a Yamaguishi, de Jaguariúna (SP), e Palmas da Vida, de Conde (BA) (DINHEIRO RURAL, 2011).

A missão da Monama é alcançar um mundo melhor através da alimentação saudável aliada à produção orgânica e sustentável. Sua visão é ser referência no mercado de alimentos orgânicos brasileiro e seus valores são: união, família, saúde, nutrição e desenvolvimentos sócio, econômico e ambiental. Sua política é resumida no slogan "bom para o meio ambiente, melhor pra você!".

Indústria2 (2012), sócia-fundadora da empresa, conta que a oportunidade de negócio veio da sua própria história de vida. Na adolescência, Indústria2 teve um problema alimentar que Ihe impôs uma dieta à base de produtos sem glúten, percebendo assim que existe uma grande oferta de produtos alimentícios industrializados que causam males a seus consumidores. Na época, praticamente não havia produtos para comprar.

Em 2009, aos 21 anos, Indústria2 pesquisou sobre consumo, matérias-primas e fornecedores. Descobriu que a oferta estava aquém da demanda do mercado, e que os orgânicos constituíam um nicho a ser explorado. Com isso, Indústria2 estreou no mundo dos negócios em 2010 (DINHEIRO RURAL, 2011).

Indústria2 contou, no início, com o apoio dos pais, que investiram $\mathrm{R} \$ 1,5$ milhão no empreendimento. Da primeira fornada, surgiram as barras de cereais, cookies e snacks orgânicos elaborados a partir da mistura de grãos variados (DINHEIRO RURAL, 2011). Inicialmente, a empresa começou vendendo pela internet, porém o e-commerce não deu os resultados esperados logo no início da operação, mas o faturamento foi alavancado pelas vendas em supermercados. Hoje, a demanda do varejo representa $98 \%$ do faturamento e, até 2012, já havia faturado $R \$ 4,2$ milhões (EXAME, 2013). 


\section{Identidade visual}

A A10 foi o escritório de design convidado para desenvolver o nome, identidade visual e as embalagens da Monama. $O$ objetivo era comunicar principalmente o cuidado da marca com os produtos em todos os níveis do processo de produção.

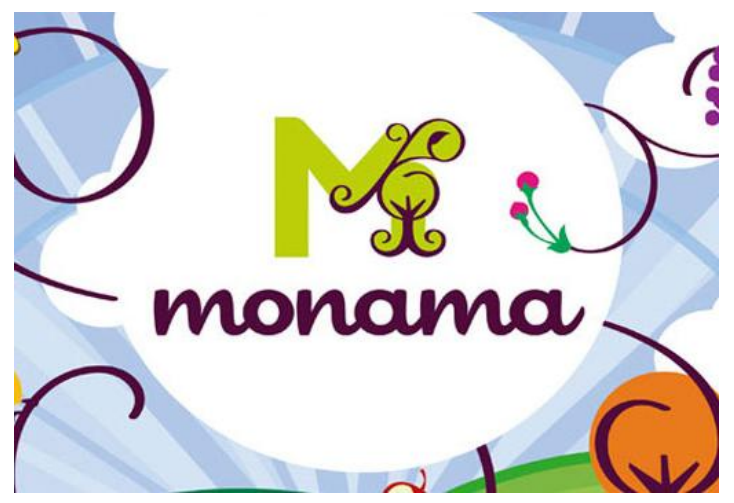

Figura 31 - Marca da Monama desenvolvido pela A10 Design. Fonte: A10 Design, 2012

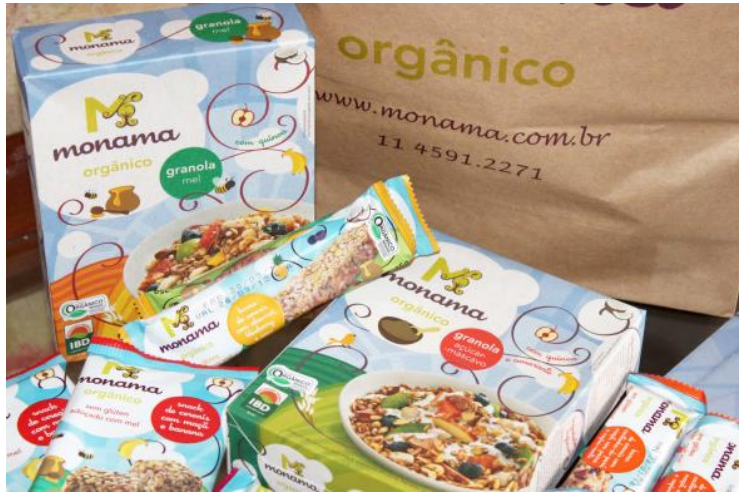

Figura 32 - Embalagens dos produtos da Monama. Fonte: Monama,2012.

Para o nome, a A10, junto com a empresa, foi buscar seu significado nas raízes e origens do consumo natural de alimentos. A palavra Monama tem origem na língua Tupi, onde apomonama significa misturar as pequenas coisas, associando à variedade de grãos encontrada nos produtos. Sob esse conceito, tanto a identidade quanto as embalagens informam os diferenciais como os sabores e dicas de consumo (A10 DESIGN, 2012).

\section{Produtos orgânicos}

A Monama acredita que, além de proporcionar uma dieta equilibrada em nutrientes e vitaminas, é preciso se preocupar com a origem de seus alimentos, oferecendo ao mercado produtos totalmente orgânicos. Segundo eles, o alimento orgânico está em sua forma mais pura, produzido sem fertilizantes químicos ou agrotóxicos e com práticas de uso consciente e responsável do solo, água, ar e de todos os recursos naturais. Apesar de o site informar que a empresa é $100 \%$ orgânica, alguns produtos não apresentam o selo de certificação SisOrg ou da certificadora.

\section{Produtos selecionados - Monama}

Os produtos selecionados da Monama para análise das embalagens foram a granola e a barra de cereais 


\section{Granola}

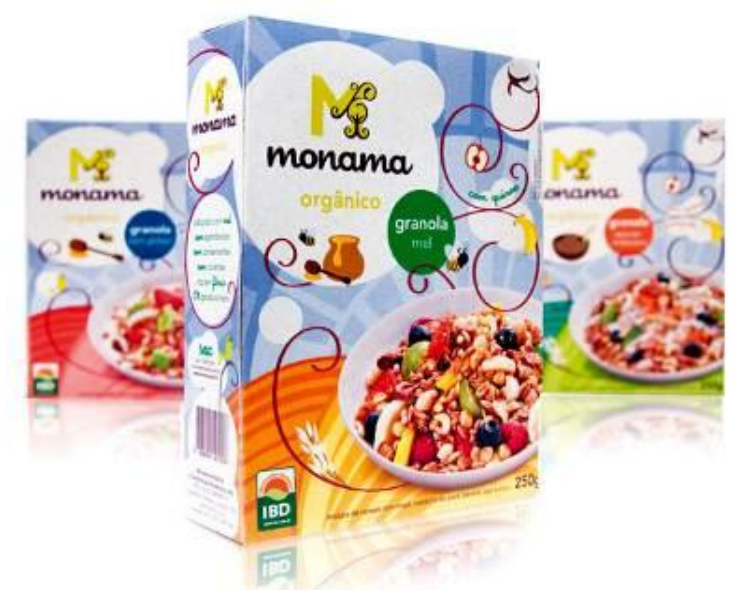

Figura 33 - Embalagem das granolas da Monama. Fonte: A10 Design, 2012. (ANEXO R)

As granolas Monama são feitas a partir de uma mistura equilibrada de cereais, frutas desidratadas, oleaginosas, mel ou açúcar mascavo. São fontes altamente concentradas de fibras, vitaminas e carboidratos, e auxiliam na regularização da função intestinal e no controle das taxas de açúcar e gordura no sangue. Não contêm conservantes e corantes ou gordura trans. São vendidas em embalagens de 250 gramas de quinoa e amaranto nas opções sem glúten, adoçados com mel ou açúcar mascavo. As granolas Monama possuem na sua composição ingredientes funcionais, como açaí, castanha-do-pará, quinoa, amaranto e farinha de linhaça.

\section{Barra de cereais}

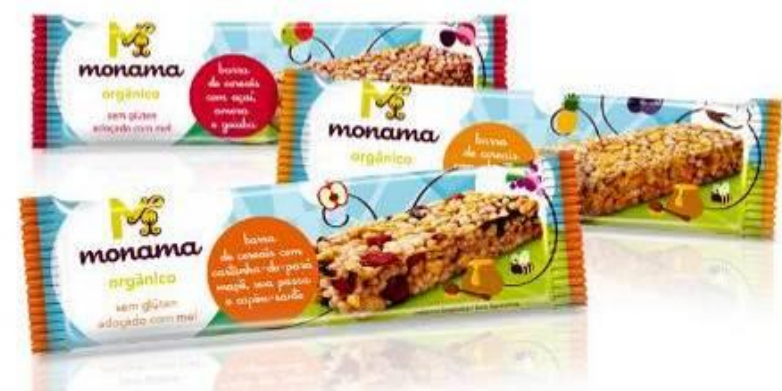

Figura 34 - Embalagem da barra de cereais da Monama. Fonte: A10 Design, 2012. (ANEXO R)

As barras de cereais da Monama possuem os mesmos benefícios da granola, porém em um formato e com uma embalagem mais conveniente para o consumo rápido. São vendidos em embalagens de 25 gramas nas opções abacaxi, blueberry e coco; cereais com castanha-dopará, maçã, uva passa e capim santo; açaí, amora e goiaba.

\subsubsection{Via Pax Bio}

A Via Pax Bio, empresa localizada em Joinville (SC), produz uma diversificada linha de produtos alimentícios orgânicos, industrializados por processos que preservam ao máximo as qualidades originais e nutricionais das matérias-primas, comercializando para todo 0 Brasil. Atualmente, a Via Pax Bio trabalha com 50 itens, entre açúcares, farinhas, geleias, doces, achocolatados, grãos, polpas, óleos e néctares. 
Os produtos da Via Pax Bio podem ser encontrados nas grandes redes de supermercados em São Paulo, como o Pão de Açúcar e Carrefour, e em lojas de produtos naturais ou de venda de snacks (biscoitos, balas e salgadinhos).

Desde o plantio até o produto acabado, os processos produtivos seguem princípios sustentáveis. Áreas de preservação e reservas legais são respeitadas; isolamento em relação a cultivos convencionais, de forma a evitar contaminação; defensivos utilizados são biológicos e os fertilizantes são compostos orgânicos; os produtos devem ser naturalmente amadurecidos, sem uso de radiações ionizantes e conservantes artificiais ou outro aditivos; os produtos finais são embalados a vácuo, para evitar contaminação, proporcionar proteção natural e maior durabilidade sem perder a qualidade nutritiva (SANTANDER, 2009).

Ela iniciou os primeiros plantios orgânicos na região serrana de Santa Catarina, em 1994. Nesta mesma época, uma rede de produtores começou a surgir, identificada e motivada com o trabalho da agricultura orgânica e biodinâmica que a Via Pax Bio vinha desenvolvendo. A partir daí, com o apoio da Associação Biodinâmica, iniciou-se um trabalho conjunto com estes produtores, que passaram a contar com acompanhamento técnico e adequação de suas propriedades a diversos cultivos, ajudando-os a se autosustentarem na agricultura orgânica (SANTANDER, 2009).

Dois anos mais tarde, a empresa foi fundada em Rancho Queimado (SC), com a proposta de processar produtos alimentícios dentro do conceito de agricultura orgânica e biodinâmica. Neste mesmo ano, a Via Pax Bio foi certificada pelo IBD, sendo uma das primeiras empresas brasileiras a receber esta certificação que atesta a procedência, o método de produção e o processamento de acordo com normas internacionais ${ }^{5}$, o que significa uma garantia em termos de qualidade do produto (SANTANDER, 2009).

Em 2006, Ivo Gramkow comprou de Marcelo de Cunto a Via Pax Bio. Executivo de grandes empresas, criado na roça, Gramkow batalhou para se formar economista e estudou posteriormente em escolas de gestão de prestígio global. Escoteiro, ambientalista e incentivador do associativismo, assim como a sua mulher Nilsa. Em 2003, resolveu encerrar uma carreira de 27 anos como executivo de grandes empresas. Durante dois anos, fez uma imersão na área de sustentabilidade, período em que trabalhou no sítio da família, hoje sede da Via Pax Bio. Gramkow passou a frequentar feiras, exposições e eventos sobre alimentos orgânicos. Também formado como técnico agrícola, Gramkow voltou às origens (SANTANDER, 2009).

Após a compra da Via Pax Bio, Gramkow desativou a fábrica em Florianópolis. Uma nova unidade de processamento de alimentos foi instalada no sítio Rio do Braço, em Joinville (SC). A região tinha sido degradada durante várias gerações, mas, desde a sua compra por Gramkow, resolveram abolir todo tipo de produto químico. Reflorestaram o terreno com espécies nativas e recuperaram o solo, que voltou a ser fértil (SANTANDER, 2009).

Além da Via Pax Bio, Gramkow foi presidente da Associação Brasileira de Orgânicos/Brasilbio e, em seus últimos dias, o empresário estava envolvido na organização da Semana dos Orgânicos e Bio Brasil Fair São Paulo. Em abril de 2011, Ivo Gramkow faleceu precocemente, deixando a empresa para sua esposa e três filhos. Após o acontecimento, em janeiro de 2012, a empresa passou a ser administrada por sua filha Helen Letícia Gramkow Carmignotto, assumindo o cargo de gerente geral (SANTANDER, 2009).

${ }^{5}$ De acordo com as normas da Federação Internacional de Movimentos de Agricultura Orgânica (IFOAM). 


\section{Identidade visual}

Em 2006, no período em que a Via Pax Bio foi comprada por Ivo Gramkow, ele pesquisou várias agências de publicidade locais para rever o seu posicionamento no mercado. A empresa decidiu contratar a Sintonia Comunicação para cuidar do marketing e da comunicação de sua marca. Um dos diferenciais que contribuiu para a decisão foi o fato de a Sintonia compartilhar, na prática, de um dos valores da Via Pax Bio, a sustentabilidade ambiental (SINTONIA COMUNICAÇÃO, 2012).
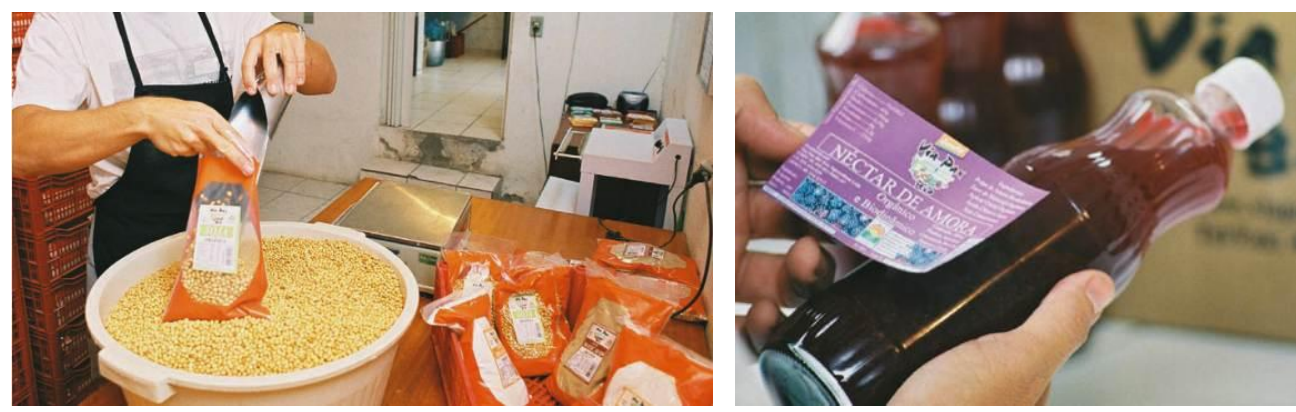

Figura 35 - Antigas embalagens da Via Pax Bio. Fonte: Empreendedorismo Rural, 2005

O nome Via Pax Bio tem sua origem ligada a três palavras do latim: Via, que significa caminho; Pax, que significa paz; e Bio, que significa vida. Para ilustrar essa tríade, a Via Pax Bio optou por trazer à sua marca a figura de um beija-flor que, na sua simbologia, transmite a ideia de paz, liberdade, harmonia e alimentação equilibrada (VIA PAX BIO, 2012). O beija-flor está posicionado com o bico elevado, alimentando-se, representando visão de futuro nesta posição (SINTONIA COMUNICAÇÃO, 2013).

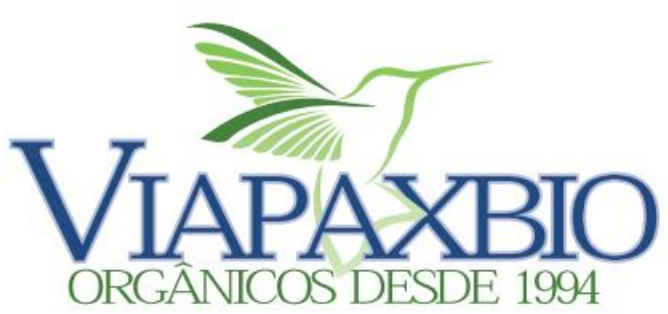

Figura 36 - Marca Via Pax Bio. Fonte: Via Pax Bio, 2012
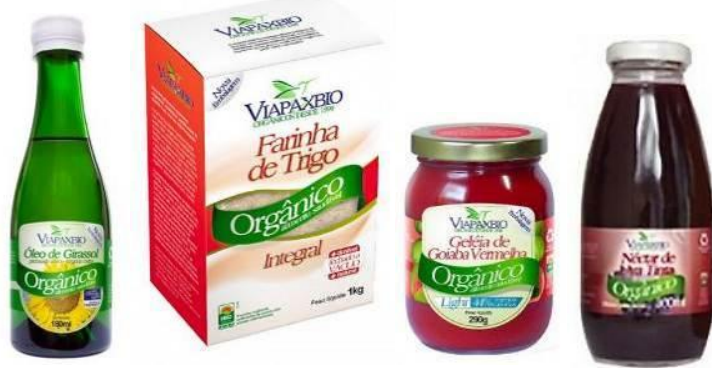

Figura 37 - Embalagens dos produtos Via Pax Bio. Fonte: Via Pax Bio, 2012

Segundo a Sintonia Comunicação, decidiu-se por agregar à marca a frase "Orgânicos desde 1994" para reforçar os argumentos diferenciais: o fato de ser uma marca de alimentos orgânicos.

Ainda segundo a Sintonia Comunicação (2012), houve uma verdadeira imersão de toda a equipe no tema dos orgânicos. Para alcançar os objetivos propostos, a Sintonia desenvolveu inicialmente o planejamento de marketing e criou a nova identidade visual da marca. As linhas de produtos e embalagens também passaram por criterioso estudo. Em pesquisa realizada nos pontos de venda, foi notado que a identificação dos produtos concorrentes, com sendo orgânico, ainda era bastante tímida. A proposta foi evidenciar esse atributo informando o consumidor (SINTONIA COMUNICAÇÃO, 2012). 


\section{Aspectos ambientais da empresa}

Um local especial foi escolhido para a instalação da nova sede da Via Pax Bio: o Sítio do Rio do Braço, em Joinville (SC), imóvel rural orgânico certificado, onde várias ações sustentáveis são desenvolvidas, tais como:

- Implantação de matas ciliares e projeto de adequação e recuperação ambiental global da propriedade;

- Desenvolvimento de Sistemas Agroflorestais (SAFs), com árvores nativas, agricultura orgânica, fruticultura e permacultura;

- Reconstituição gradativa e natural do habitat de pequenos animais, pássaros e répteis regionais;

- Paisagismo priorizando espécies nativas floríferas e frutíferas, fornecendo alimentos para a avi-fauna em todas as estações do ano;

- Passeios por trilhas que levam a uma encantadora viagem para o contato com a natureza e a biodiversidade local.

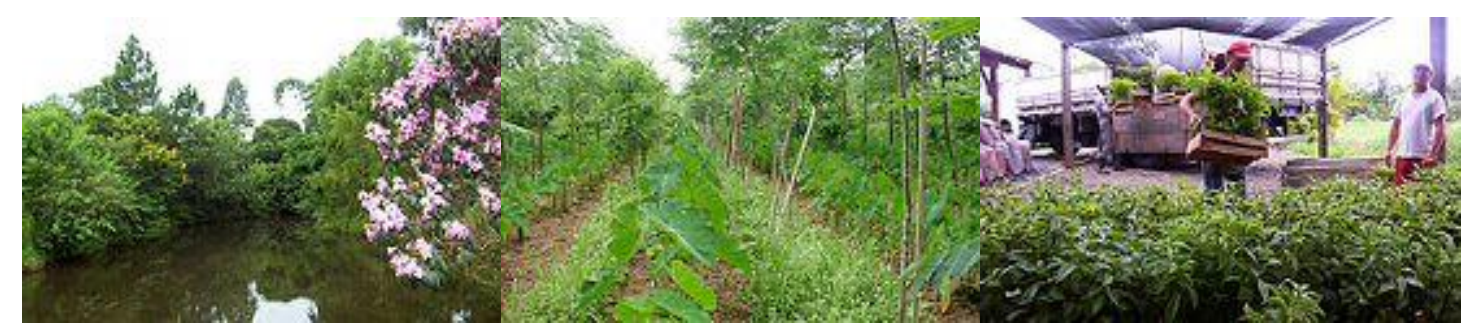

Figura 38 - Instalações do Sítio do Rio do Braço, onde fica a fábrica da Via Pax Bio. Fonte: Via Pax Bio, 2012

Para a montagem da processadora de alimentos, não houve necessidade de desmonte de morros nem de impermeabilização do solo. Não foi necessário aterramento, pois a fábrica foi edificada em cima de pilotis, que são colunas que sustentam a construção a dois metros da superfície do solo. Energia elétrica, água, esgoto e canalização de gás foram instalados debaixo do piso, permitindo fácil acesso para manutenção e flexibilidade para mudança de layout. $\mathrm{O}$ ar que circula por baixo do piso melhora as condições de conforto térmico do interior da fábrica.

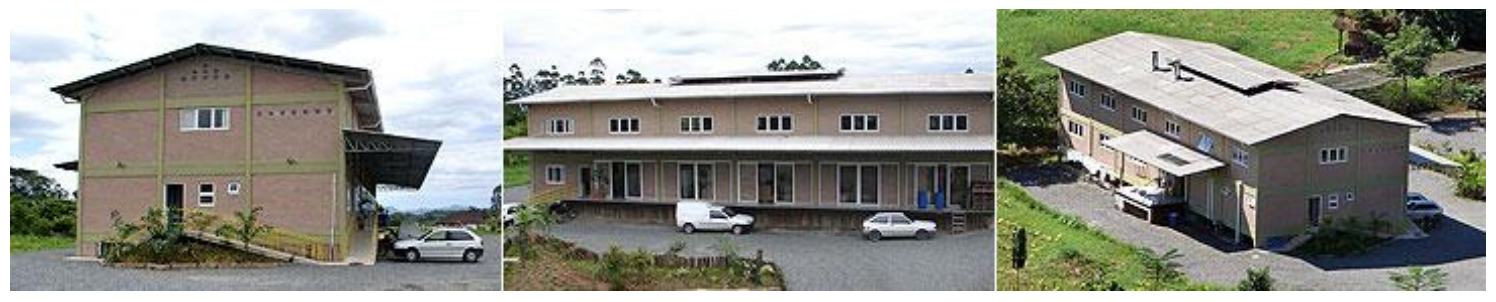

Figura 39 - Imagens da fábrica da Via Pax Bio. Fonte: Via Pax Bio, 2012

A instalação e a construção da indústria consideraram a sua posição em direção ao Norte Magnético para um melhor aproveitamento da iluminação natural em todos os ambientes.

A Via Pax Bio procurou utilizar na obra materiais de menor impacto ambiental, como tijolos fabricados por mão de obra familiar sem queima, tinta atóxica à base de água, telhas de fibrocimento e telhas transparentes e materiais reciclados nas divisórias dos banheiros, pisos e corrimões. Para a limpeza, são empregados detergentes orgânicos certificados.

A fábrica foi projetada para racionalizar o uso de energia elétrica e para aproveitar a água da chuva - o que, fora o menor impacto ambiental, gera economia. As telhas são transparentes e há amplas portas e janelas. A ventilação é natural por aberturas no teto e o pé-direito é bastante alto, o que torna a troca de calor mais eficiente e proporciona um ambiente agradável (VIA PAX BIO, 2012). 
Além de luminárias e equipamentos de alta eficiência e de sensores de presença, a empresa faz uso de energia solar, gás (GLP) e lenha a partir de parte das podas de manejo e galhos secos que caem das milhares de árvores nativas do SAF que circunda a fábrica - materiais oriundos das áreas de preservação permanente e reservas legais não são utilizados. Foi construído um sistema de captação de águas da chuva para uso nas descargas e as torneiras utilizadas são de classificação econômica. As fontes de energia utilizadas para funcionamento da fábrica e no processo de fabricação dos produtos seguem as premissas da sustentabilidade (VIA PAX BIO, 2012).

\section{Produtos orgânicos}

Entre 70 e 100 agricultores orgânicos fornecem matéria-prima para a empresa - dos estados de Santa Catarina, Rio Grande do Sul, Paraná, Bahia e São Paulo. No início, a empresa trabalhava apenas com agricultores do Planalto Catarinense (perto de Lages), sendo um dos objetivos da empresa promover a inclusão social com a geração de renda e preservação da saúde da população rural local. A Via Pax Bio foi uma das primeiras empresas orgânicas brasileiras certificadas de acordo com normas internacionais e certificação do IBD.

\section{Produtos selecionados - Via Pax Bio}

Os produtos selecionados da Via Pax Bio para análise das embalagens foram a farinha de trigo integral e o feijão preto.

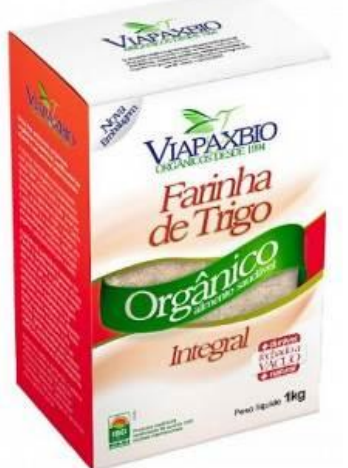

Figura 40 - Embalagem da farinha de trigo da Via Pax Bio. Fonte: Via Pax Bio, 2012

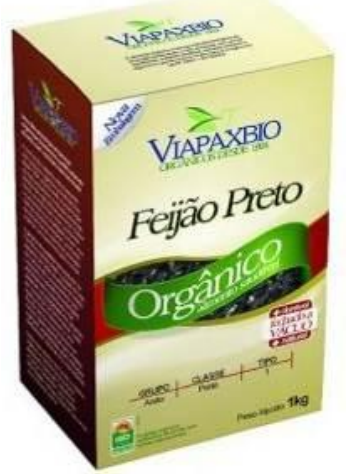

Figura 41 - Embalagem do feijão preto da Via Pax Bio. Fonte: Via Pax Bio, 2012

\section{Farinha de trigo integral}

A farinha de trigo integral Via Pax Bio é obtida da moagem dos grãos de trigo orgânico selecionados. Rica em proteína e fibras, a farinha integral confere mais valor nutritivo a pães, bolos e outras receitas. As farinhas são embaladas a vácuo para aumentar a durabilidade de forma natural (VIA PAX BIO, 2012).

\section{Feijão preto}

O feijão preto Via Pax Bio é cultivado preservando a água, os solos das propriedades e a saúde do agricultor e do consumidor. 0 controle das pragas e doenças é feito de forma natural e a integridade dos grãos é garantida naturalmente pela embalagem a vácuo (VIA PAX BIO, 2012). 


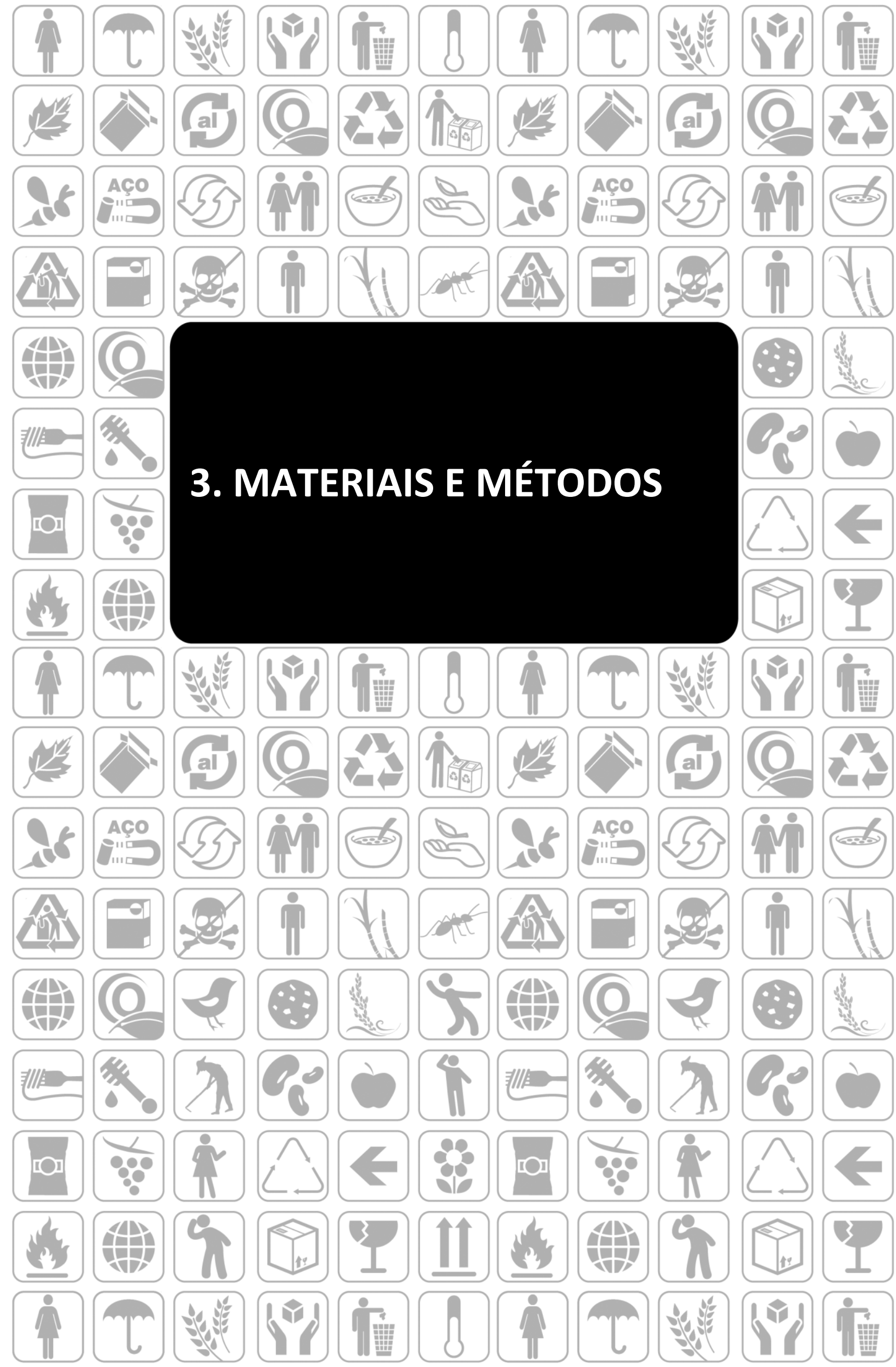




\section{MATERIAIS E MÉTODOS}

Esta pesquisa utiliza métodos de abordagem qualitativa, devido à subjetividade dos dados que não podem ser traduzidos em números, e sim interpretados, atribuindo-se a eles significados.

Para a obtenção dos dados, foi feito um estudo comparativo para descobrir padrões e perceber semelhanças e diferenças dos casos estudados, explicitando as especificidades do design das embalagens de alimentos orgânicos e suas percepções.

A fim de obter detalhes e peculiaridades, foram feitas entrevistas com pessoas que participaram do desenvolvimento das embalagens e também com consumidores de alimentos industrializados, visando a proporcionar uma visão geral das políticas de desenvolvimento de embalagens e a percepção dos consumidores.

\subsection{ESTRATÉGIAS METODOLÓGICAS POR SUBPROBLEMA}

De natureza exploratória, tem como foco principal a pergunta fundamental apresentada no capítulo de introdução desta dissertação, e abaixo:

Considerando-se que na produção de alimentos orgânicos industrializados são observados princípios ambientais, o que se pode depreender sobre o design de suas embalagens, em termos da observância de recomendações ambientais, preconizadas pela literatura especializada e pelos órgãos reguladores, e sobre a percepção desses princípios por parte dos consumidores?

A estratégia metodológica da pesquisa foi baseada na pergunta fundamental e nos subproblemas. Para cada um, foram determinados quais procedimentos metodológicos de pesquisa poderiam responder a questão para atingir o objetivo proposto, apresentados na tabela a seguir. 


\begin{tabular}{|c|c|c|c|c|}
\hline Subproblemas & $\begin{array}{l}\text { Quais são as } \\
\text { recomendações } \\
\text { ambientais para o } \\
\text { design de embalagens? }\end{array}$ & $\begin{array}{l}\text { Quais são as } \\
\text { recomendações } \\
\text { ambientais para os } \\
\text { produtos orgânicos? }\end{array}$ & $\begin{array}{l}\text { Quais são as } \\
\text { recomendações } \\
\text { ambientais } \\
\text { identificadas nas } \\
\text { embalagens de } \\
\text { alimentos orgânicos? }\end{array}$ & $\begin{array}{l}\text { O consumidor é capaz } \\
\text { de perceber as } \\
\text { especificidades } \\
\text { inerentes aos } \\
\text { alimentos orgânicos, } \\
\text { presentes na sua } \\
\text { produção, apenas } \\
\text { visualizando suas } \\
\text { embalagens? }\end{array}$ \\
\hline \multirow{2}{*}{$\begin{array}{l}\text { Dados } \\
\text { necessários à } \\
\text { resposta de } \\
\text { cada } \\
\text { subproblema }\end{array}$} & $\mathrm{A} 1$ & $\mathrm{~A} 2$ & A4 & A5 \\
\hline & $\begin{array}{l}\text { Indicadores de } \\
\text { sustentabilidade } \\
\text { divulgados por órgãos } \\
\text { especializados. }\end{array}$ & $\begin{array}{l}\text { Legislação brasileira } \\
\text { Critérios para } \\
\text { certificação. } \\
\text { Recomendações de } \\
\text { associações e } \\
\text { organizações de } \\
\text { orgânicos. }\end{array}$ & $\begin{array}{l}\text { Embalagens dos } \\
\text { produtos. } \\
\text { Normas ISO ABNT. } \\
\text { Recomendações de } \\
\text { órgãos especializados. } \\
\text { Legislação. }\end{array}$ & $\begin{array}{l}\text { Embalagens dos } \\
\text { produtos orgânicos. }\end{array}$ \\
\hline \multirow{2}{*}{$\begin{array}{l}\text { Fontes para } \\
\text { obtenção dos } \\
\text { dados de cada } \\
\text { problema }\end{array}$} & B1 & B2 & B4 & B5 \\
\hline & $\begin{array}{l}\text { Sites da internet. } \\
\text { Documentos dos } \\
\text { órgãos especializados. }\end{array}$ & $\begin{array}{l}\text { Livros; Sites da } \\
\text { internet; Artigos } \\
\text { científicos; Teses; } \\
\text { Produtores orgânicos; } \\
\text { Associações de } \\
\text { orgânicos; } \\
\text { Certificadoras. }\end{array}$ & $\begin{array}{l}\text { Documentos fornecidos } \\
\text { pela indústria. } \\
\text { Profissional da } \\
\text { indústria. }\end{array}$ & $\begin{array}{l}\text { Pesquisas já feita com } \\
\text { consumidores. }\end{array}$ \\
\hline \multirow{2}{*}{$\begin{array}{l}\text { Técnicas } \\
\text { específicas de } \\
\text { coletas de } \\
\text { dados de cada } \\
\text { subproblema }\end{array}$} & $\mathrm{C} 1$ & $\mathrm{C} 2$ & $\mathrm{C} 4$ & C5 \\
\hline & $\begin{array}{l}\text { Revisão da literatura } \\
\text { em livros, na internet, } \\
\text { legislação. }\end{array}$ & $\begin{array}{l}\text { Revisão da literatura } \\
\text { em livros, na internet, } \\
\text { legislação. }\end{array}$ & $\begin{array}{l}\text { Coleta de embalagens. } \\
\text { Fotografia da } \\
\text { embalagem. } \\
\text { Entrevista com } \\
\text { responsáveis pela } \\
\text { indústria e escritório de } \\
\text { design. }\end{array}$ & $\begin{array}{l}\text { Entrevista com } \\
\text { consumidores. }\end{array}$ \\
\hline $\begin{array}{l}\text { Técnicas de } \\
\text { tratamento de } \\
\text { dados de cada } \\
\text { subproblema }\end{array}$ & $\begin{array}{l}\text { Indexação dos } \\
\text { documentos } \\
\text { encontrados. } \\
\text { Detectar padrões. } \\
\text { Detectar quais são } \\
\text { aplicáveis em } \\
\text { embalagens de } \\
\text { alimentos orgânicos } \\
\text { industrializados. }\end{array}$ & $\begin{array}{l}\text { Indexação dos } \\
\text { documentos } \\
\text { encontrados. } \\
\text { Detectar padrões } \\
\text { Detectar quais são } \\
\text { aplicáveis em } \\
\text { embalagens de } \\
\text { alimentos orgânicos } \\
\text { industrializados. }\end{array}$ & $\begin{array}{l}\text { Análise da embalagem. } \\
\text { Análise das entrevistas. }\end{array}$ & $\begin{array}{l}\text { Organizar avaliações } \\
\text { em tabelas. } \\
\text { Análise das entrevistas. } \\
\text { Comparar os } \\
\text { resultados. }\end{array}$ \\
\hline
\end{tabular}

Tabela 11 - Materiais e métodos específicos por subproblema

\subsection{REFERENCIAL TEÓRICO}

Os documentos e livros selecionados como referencial teórico foram escolhidos segundo a importância de seu conteúdo com o tema da pesquisa, que agreguem informações ou respondam a algumas das perguntas levantadas por esta pesquisa.

\section{Metodologia}

Para estruturar metodologicamente a pesquisa, foram utilizados os seguintes livros: Fundamentos de metodologia científica (LAKATOS; MARCONI, 1996), Introdução à pesquisa qualitativa (FLICK, 2009) e Introdução à pesquisa em ciências sociais: a pesquisa qualitativa em educação (TRIVIÑOS, 1987). Foi também utilizado o Estudo de caso: planejamento e métodos (YIN, 2005) para decidir se esse seria o método utilizado para esta pesquisa. 


\section{Revisão da literatura}

A revisão da literatura foi feita ao longo da pesquisa. As informações foram separadas por temas e por autores. No caso dos livros, primeiramente foi feita uma leitura destacando pontos importantes com post-its para posteriormente passar essas informações com textos e imagens para o meio digital.

Para os temas relacionados à sustentabilidade, foi usado o documento 'Nosso futuro comum' (Our common future), publicado em 1987 pela Comissão Mundial sobre Meio Ambiente e Desenvolvimento, que reafirma uma visão crítica do modelo de desenvolvimento adotado pelos países industrializados e reproduzido pelas nações em desenvolvimento, e ressalta os riscos do uso excessivo dos recursos naturais sem considerar a capacidade de suporte dos ecossistemas. E textos de José Ely da Veiga e Ignacy Sachs, que fazem críticas posteriores a este documento, ampliando o conceito de sustentabilidade.

Quando abordado o tema de produção de produtos e embalagens com menor impacto ambiental, foi usado o Capitalismo natural (1999), de Paul Hawken, Amory Lovins, Hunter Lovins, que faz uma crítica ao sistema industrial atual e apresenta algumas estratégias para o futuro; e Cradle to cradle(2002), de William McDonough e Michael Braungart, que descreve como mudar o nosso sistema baseado no berço ao túmulo (sistemas que não consideram a utilização ou eliminação do produto) depois que o consumidor o utiliza, mostrando ser possivel integrar os sistemas industriais com os naturais.

Para os temas de ecodesign, foram usados os livros Haverá a idade das coisas leves (2005), de Thierry Kazazian, por fazer uma reflexão sobre todos os objetos que invadem nosso cotidiano e impactam o meio ambiente, mas que poderiam se tornar mais leves e duráveis; e o livro $O$ desenvolvimento de produtos sustentáveis, de Ezio Manzini e Carlo Vezzoli, publicado em 2002, por ter a proposta de contribuir para o desenvolvimento de uma cultura capaz de enfrentar a transição para a sustentabilidade e de promover o aparecimento de uma nova geração de produtos e serviços sustentáveis, e por fornecer um quadro geral do desenvolvimento de produtos sustentáveis.

Para os temas relacionados ao design de embalagem, foi usado o livro Packaging sustainability (2009), de Wendy Jedlička, que dá uma ampla visão de soluções para desenvolver embalagens mais sustentáveis e integrada aos sistemas de produção; e Administração da embalagem (2007), de Floriano do Amaral Gurgel, que apresenta as partes mais relevantes da produção de embalagem. Já o Guia de embalagens para produtos orgânicos (2011), do Instituto de Embalagens, faz um resumo das formas de produção de embalagem e o seu contexto na produção de orgânicos.

\section{Requisitos ambientais de design}

Para determinar quais dados deveriam ser obtidos, em termos da observância dos requisitos ambientais de design, e para se entender a percepção das especificidades inerentes aos alimentos orgânicos por parte dos consumidores, foram comparadas as recomendações de algumas organizações representativas no Brasil e no exterior do setor de embalagens e design, como a Associação Brasileira de Embalagens, a norte-americana Sustainable Packaging Coalition e a europeia EUROPEN, junto com a metodologia recomendada pela UNEP de Design for sustainability (D4S). 


\section{Entrevista}

Para estruturar e analisar os dados das entrevistas, foram utilizados os livros: $A$ entrevista na pesquisa qualitativa: mecanismos para validação dos resultados (ROSA; ARNOLDI, 2006), Pesquisa qualitativa com texto, imagem e som: um manual prático (BAUER; GASKEL, 2002) e Introdução à pesquisa em ciências sociais: a pesquisa qualitativa em educação (TRIVIÑOS, 1987) como referenciais teóricos.

\section{Diferencial semântico}

Foi utilizado o método de diferencial semântico criado por Osgood, Suci e Tannenbaun (1967) no livro The measurement of meaning para avaliar e quantificar as qualidades do conceito dos alimentos orgânicos e seu significado afetivo das percepções, frente aos produtos apresentados.

\section{Análise das embalagens}

A análise da estrutura visual das embalagens foi fundamentada nos livros Inteligência visual: como criamos o que vemos (HOFFMAN, 2001) e Sintaxe da linguagem visual (DONDIS, 1997), que apresentam a evidência científica acerca dos poderes construtivos da visão - como a percepção de linha, cor, forma, profundidade e movimento.

A base teórica para analisar os significados visuais das embalagens foi fundamentada nos estudos da semiótica desenvolvidos por Lucrécia Ferrara (1993), no livro Leitura sem palavras, e por Lucia Santaella (2005), no livro Semiótica aplicada, cuja vertente origina-se da arquitetura filosófica de Charles Sanders Pierce.

\section{Triangulação das informações}

A triangulação das informações foi feita para abranger a máxima amplitude na descrição, explicação e compreensão do estudo, usando diferentes fontes de dados, cuja base teórica veio do livro Introdução à pesquisa em ciências sociais: a pesquisa qualitativa em educação (TRIVIÑOS, 1987).

\subsection{RECOMENDAÇÕES AMBIENTAIS PARA O DESIGN DE EMBALAGENS}

Os indicadores usados para a análise dos aspectos ambientais do design de embalagem foram selecionados a partir de quatro organizações que são referência mundial ou na região em que atua. Essas organizações publicaram documentos que orientam e dão diretrizes de como desenvolver uma embalagem de forma mais sustentável, e são: a Associação Brasileira de Embalagem (ABRE), do Brasil; a Sustainable Packaging Coalition (SPC), dos Estados Unidos; a European Organization for Packaging and the Environment (EUROPEN), da União Europeia; e a United Nations Environment Programme (UNEP), uma organização mundial, junto com a Delft University of Technology.

A definição e escolha dos documentos foram feitas no primeiro ano da pesquisa, sendo que no último ano, 2013, foi acrescentado mais um documento, a tradução feita pela ABRE do Protocolo global. A pesquisa foi feita basicamente na internet, no site dos órgãos já citados.

Para a comparação dos indicadores, que podem ser vistos no Capítulo 2, foram selecionados os indicadores que mais se repetiam e aplicáveis nas embalagens de alimentos orgânicos. Alguns indicadores referentes ao contexto brasileiro foram mantidos, mesmo que não se repetissem em outros documentos, como a importância de se identificar os materiais das embalagens para a cadeia de reciclagem. 


\subsection{ANÁLISE DO MERCADO}

Considerando os objetivos propostos para esta pesquisa, entende-se a necessidade de um recorte no qual a seleção de casos atenderá aos critérios de maior cobertura possível do campo (FLICK, 2009). Foi feita uma pesquisa de campo exploratória, de forma sistemática, em supermercados, hipermercados e em lojas especializadas de produtos naturais, na cidade de São Paulo, durante 12 meses, de março de 2011 a maio de 2012, onde foi feito um mapeamento das marcas de produtos mais oferecidos.

Os requisitos para seleção de casos para o estudo comparativo foram: que tivessem uma boa distribuição em São Paulo, ou que pelo menos fossem vendidos em uma grande rede de supermercados, e que tivessem os seus produtos um grande impacto ambiental. Além disso, foram consideradas empresas com diversidade de produtos e tipos diferentes de embalagens, seja na forma ou material. $O$ recorte estabelecido permitiu a determinação a priori da estrutura da amostra, integrando a esta todos os casos disponíveis para análise nas empresas selecionadas.

As empresas que atenderam aos requisitos acima explicitados foram: Mãe Terra, Monama, Via Pax Bio, Native e Jasmine, sendo que as duas últimas empresas escolheram não participar da pesquisa, por motivos diversos, em comunicação realizada por e-mail e telefone.

Após o mapeamento, algumas embalagens das empresas selecionadas foram coletadas, fotografadas e identificadas por nome e data. Esse processo foi feito para que essas informações, caso fossem necessárias, não se perdessem. A mudança no design de embalagens pode ser muito rápida e, ao longo desta pesquisa, já se perceberam algumas mudanças em relação às primeiras embalagens.

Para a seleção das embalagens de cada empresa, estabeleceu-se que deveriam ser produtos de linhas diferentes, se possível com embalagens de materiais diferentes, buscando produtos similares entre as empresas para serem analisados em conjunto. $O$ resultado desse mapeamento pode ser visto no Capítulo 4 desta dissertação e nos Anexos A, B e C..

No ano de 2013, também foram coletadas embalagens de produtos concorrentes dos produtos já selecionados, para serem usados nas entrevistas com consumidores (ANEXO D).

\subsection{POLÍTICA DE DESENVOLVIMENTO DE EMBALAGENS}

Para conhecer melhor a política de desenvolvimento de embalagens, primeiramente foi feito um mapeamento do que é declarado pela empresa em seus materiais de divulgação, como sites e redes sociais. Alguns folhetos impressos também foram analisados, porém nem todas as empresas tinham esse tipo de material de divulgação.

Nesses documentos, foi avaliada a missão e valores divulgados, se tinham ou não um relatório de impacto ambiental disponível e que produtos orgânicos eram produzidos. Esse mapeamento foi feito durante o ano de 2011 até o final da pesquisa em 2013, pois algumas informações foram modificadas, principalmente nos sites. Também foi pesquisado o que a imprensa escreveu sobre cada empresa, em revistas e sites. 
Deste mapeamento, foram analisadas quais informações exigiam um melhor detalhamento nas entrevistas com os principais responsáveis pelo desenvolvimento de suas embalagens, com a indústria e com o escritório de design.

As entrevistas foram feitas em ordem, iniciando com a indústria, escritório de design e finalizando com o consumidor. Essa ordem teve o objetivo de agregar informações para a entrevista, podendo assim incluir perguntas que não haviam sido planejadas no roteiro inicial.

O áudio das entrevistas foi gravado e transcrito para o registro da pesquisa, respeitando a liberdade do entrevistado de recusar a gravação ou não. Procurou-se manter o maior grau de distanciamento e de invasão de privacidade, deixando claro, logo no início da entrevista, que o entrevistado deveria ficar à vontade para interromper a conversa em função de suas necessidades e agenda, o que não ocorreu de forma brusca em nenhum dos casos.

Todas as entrevistas foram feitas por apenas uma pessoa, devido à sua característica semiestruturada, pois algumas informações poderiam ser percebidas apenas com a presença do pesquisador.

\subsubsection{Entrevista com a indústria}

Foram feitas entrevistas em profundidade, semiestruturadas, com os responsáveis pelo processo de concepção nas empresas selecionadas para compreender se a política de desenvolvimento de embalagens inclui os aspectos ambientais definidos pelos órgãos pesquisados. Também foi questionado na entrevista como o design está inserido no processo de desenvolvimento das embalagens.

O entrevistado foi selecionado conforme o seu poder de decisão no desenvolvimento do design de uma embalagem, que poderia ser o responsável pelo marketing da empresa, do setor de design da empresa, caso existisse, e, se a empresa fosse pequena, com o proprietário ou gerente geral.

Para a seleção de qual profissional seria entrevistado, foi pesquisado, no site da empresa ou nas reportagens encontradas, o nome dos principais responsáveis pelo desenvolvimento de embalagens, podendo ser o responsável pelo marketing da empresa, do setor design da empresa, gerente geral ou proprietário. No caso da Mãe Terra, como a pesquisadora já conhecia os responsáveis pelo design das embalagens, foi pedido para que eles indicassem a pessoa para ser entrevistada.

O primeiro contato foi feito por e-mail, falando brevemente do que se tratava a entrevista e depois, caso fosse pedido, um contato por telefone.

As entrevistas foram realizadas de junho a setembro de 2012, dentro das indústrias, havendo assim a possibilidade da observação das instalações da mesma, mesmo que suas instalações estivessem localizadas em outra cidade, como no caso da Via Pax Bio, em Joinville (SC), Monama, em Itupeva (SP) e a Mãe Terra em Osasco, na divisa com o município de São Paulo.

O ambiente da entrevista foi selecionado pelos entrevistados, só foi pedido que esse local fosse silencioso o suficiente para a gravação do áudio e com uma mesa ou apoio para os materiais das entrevistas. As entrevistas duraram em média uma hora. 


\section{Roteiro das entrevistas com as indústrias}

As questões da entrevista foram formuladas de modo que o entrevistado pudesse discorrer e verbalizar seus pensamentos, tendências e reflexões sobre os temas apresentados. Para isso, o roteiro de entrevistas (APÊNDICE A) foi estruturado com perguntas abertas e algumas fechadas, deixando o entrevistado livre para falar o que achasse conveniente.

A entrevista foi iniciada com uma breve apresentação da natureza da pesquisa e identificando o pesquisador. Foi tomado o cuidado de não se falar inicialmente que o principal objetivo da entrevista estava nos aspectos ambientais do design de embalagem, seja nos contatos prévios ou antes do início da entrevista, apenas mencionando que a pesquisa era sobre o design de embalagens de alimentos.

No segundo módulo, foram feitas questões para conhecer o entrevistado e perceber, logo no início, a sua influência nas decisões do desenvolvimento de embalagens.

No terceiro módulo, as questões tinham o objetivo de perceber os setores e as áreas envolvidas no desenvolvimento de embalagens, para assim ter certeza se as perguntas estavam sendo feitas para a pessoa certa. Caso fosse detectado que existia outra pessoa mais indicada, era realizada uma segunda entrevista com essa pessoa indicada.

No quarto módulo, o objetivo foi perceber se a postura ambiental de um escritório de design influencia as decisões do design da embalagem.

No quinto módulo, foram feitas questões para perceber políticas ou projetos de logística e logística reversa.

O sexto módulo tinha como objetivo perceber o relacionamento da empresa com o consumidor e se isso era utilizado nas estratégias de design da embalagem. Caso fosse detectado, pretendia-se perceber se haveria algum projeto em andamento de rastreamento dos aspectos ambientais além do exigido pela certificação de orgânico, além de fazer perguntas adicionais.

A entrevista era finalizada com perguntas mais específicas sobre as embalagens selecionadas para a análise. Para essa fase, foram selecionadas quatro embalagens. Para a análise dos dados das entrevistas, foi utilizada a técnica da análise do discurso, onde foram identificados regularidades e padrões de respostas. $O$ roteiro completo pode ser visto no apêndice $A$.

\section{Entrevista com representante da indústria Mãe Terra}

Quando: 29 de maio de 2012

Horário: $18 \mathrm{~h} 00$ até $19 \mathrm{~h} 15$

Onde: Fábrica da Mãe Terra, Vila dos Remédios, Osasco, SP

A seleção de qual profissional seria entrevistado da Mãe Terra foi por indicação do responsável pelo design das embalagens da Mãe Terra. Após a indicação, foi enviado um e-mail solicitando um dia para a entrevista, que foi prontamente aceito, sem muitos questionamentos e mostrando interesse em ajudar.

O representante da indústria Mãe Terra é formado em administração, coordenador da área de Marketing da Mãe Terra há três anos. Coordena o desenvolvimento de embalagens junto com a equipe de Pesquisa e Desenvolvimento (P\&D), que cuida da estrutura das embalagens e dos materiais. 


\section{Entrevista com representante da indústria Monama}

Quando: 11 de julho de 2012

Horário: $12 \mathrm{~h} 29$ até $13 \mathrm{~h} 00$

Onde: Fábrica Monama, Jardim Santa Júlia, Itupeva, SP

Para a seleção de qual profissional seria entrevistado da Monama, foi feita uma pesquisa na internet. Após a pesquisa, foi enviado um e-mail solicitando um dia para a entrevista, que foi prontamente aceito, sem muitos questionamentos e mostrando interesse em ajudar. O local escolhido pela entrevistada para a gravação da entrevista foi a sala de reuniões da empresa.

O representante da indústria Monama é o fundador da Monama Orgânicos. Com uma formação multidisciplinar, estudou Administração em Moda, mas saiu antes de completar o curso, largando no último ano.

\section{Entrevista com representante da indústria Via Pax Bio}

Quando: 18 de setembro de 2012

Horário: $13 \mathrm{~h} 30$ até $14 \mathrm{~h} 00$

Onde: Fabrica da Via Pax Bio, Joinville, Santa Catarina

Para a seleção de qual profissional seria entrevistado da Via Pax Bio, foi feita uma pesquisa na internet. $O$ contato foi iniciado via e-mail e finalizado por telefone para explicações sobre o que era a pesquisa. Mostrou-se aberta para responder e ajudar em qualquer coisa que fosse necessário. O local escolhido pela entrevistada para a gravação da entrevista foi a sala de reuniões da empresa.

O representante da indústria Via Pax Bio é formado em veterinária, com mestrado em fisiologia do exercício do cavalo. Trabalhou por dois anos e meio em uma multinacional na área comercial. Desde janeiro de 2012, é gerente geral da Via Pax Bio.

\subsubsection{Entrevista com o escritório de design}

Foram feitas entrevistas em profundidade, semiestruturadas, com os responsáveis pelo design das embalagens das empresas selecionadas para compreender como a política de desenvolvimento de embalagens foi recebida pelo escritório de design, se inclui os aspectos ambientais definidos pelos órgãos pesquisados e como isto foi traduzido visualmente, textualmente e materialmente em suas embalagens.

O entrevistado foi selecionado conforme a indicação do profissional da indústria, em entrevista, que passou o contato. Antes da entrevista, foi feita uma pesquisa prévia sobre o escritório de design, portfolio, e se algumas das embalagens selecionadas eram apresentadas em seu site. O primeiro contato foi feito por e-mail, falando brevemente do que se tratava a entrevista e depois, caso fosse pedido, por telefone.

As entrevistas foram realizadas de julho a setembro de 2012. A entrevista com o escritório de design da Mãe Terra, a Sintonia Comunicação, aconteceu apenas em maio de 2013, pela dificuldade de conciliar as agendas. 
O local das entrevistas foi selecionado pelos entrevistados, apenas foi pedido que esse local fosse silencioso o suficiente para a gravação do áudio e com uma mesa ou apoio para os materiais das entrevistas. No caso da Sintonia Comunicação, a entrevista foi feita online via um programa de comunicação de voz e vídeo, o Skype. As entrevistas duraram em média uma hora.

\section{Roteiro das entrevistas com os escritórios de design}

As questões da entrevista foram formuladas de modo que o entrevistado pudesse discorrer e verbalizar seus pensamentos, tendências e reflexões sobre os temas apresentados. Para isso, o roteiro de entrevistas (APÊNDICE B) foi estruturado com perguntas abertas e algumas fechadas, deixando o entrevistado livre para falar o que achasse conveniente.

A entrevista foi iniciada com uma breve apresentação da natureza da pesquisa e identificando o pesquisador. Da mesma maneira que as entrevistas com os fabricantes, foi tomado o cuidado de não se falar inicialmente que o principal objetivo da entrevista estava nos aspectos ambientais do design de embalagem, seja nos contatos prévios ou antes do início da entrevista, apenas mencionando que a pesquisa era sobre o design de embalagens de alimentos.

No segundo módulo, foram feitas questões para conhecer o entrevistado e perceber, logo no início, a sua influência nas decisões do desenvolvimento de embalagens.

No terceiro módulo, sobre estratégias do desenvolvimento de embalagens, o objetivo foi perceber se é uma empresa especializada em design de embalagens e se os aspectos ambientais já fazem parte dos processos de desenvolvimento de embalagens da empresa.

No quarto módulo, sobre o relacionamento com a empresa, o objetivo foi perceber como é a relação de trabalho do escritório de design com a indústria e seu grau de integração.

A entrevista era finalizada com perguntas mais específicas sobre as embalagens selecionadas para a análise. Para essa fase, foram selecionadas quatro embalagens.

Para a análise dos dados das entrevistas, foi utilizada a técnica da análise do discurso, onde foram identificados regularidades e padrões de respostas. O roteiro completo pode ser visto no apêndice $B$.

\section{Entrevista com representante do escritório de design Petersen \& Avila}

Quando: 8 de junho de 2012

Horário: $16 \mathrm{~h} 00$ até $16 \mathrm{~h} 30$

Onde: escritório da Petersen \& Avila, Pinheiros, São Paulo

Diferentemente das outras empresas pesquisadas, já eram conhecidos os responsáveis pelo design das embalagens da Mãe Terra, mas não se sabia exatamente quais embalagens eles haviam feito. A forma do primeiro contato foi via e-mail, falando brevemente sobre o tema da pesquisa e solicitando uma entrevista, que foi feita após a entrevista com a empresa.

O local escolhido pelos entrevistados foi a mesa da sala de jantar, onde foi servido um chá orgânico para acompanhar a conversa.

Os representantes pelo design da Mãe Terra entrevistados são sócios da Petersen \& Avila e são formados em Publicidade e Propaganda e Comunicação Social, respectivamente. 


\section{Entrevista com representante do escritório de design A10 Design}

Quando: 4 de setembro de 2012

Horário: $14 \mathrm{~h} 30$ até $15 \mathrm{~h} 10$

Onde: Escritório da A10, Vila Olímpia, São Paulo

Para a seleção de qual profissional seria entrevistado da Monama, foi feita uma pesquisa na internet, onde foi encontrado o escritório responsável pelo design das embalagens da Monama. Primeiramente entrando em contato com a sócia-diretora da empresa, o contato foi via e-mail, solicitando um dia para a entrevista, o que foi prontamente aceito. Um contato anterior por telefone foi providenciado, comentando-se um pouco mais sobre a pesquisa, sem detalhar que seriam abordados aspectos ambientais.

No dia da entrevista a sócia-diretora não pôde participar em seu lugar foi entrevistado o designer responsável pelas embalagens da Monama. O local escolhido pelo entrevistado para a gravação da entrevista foi a sala de reuniões da empresa.

O representante pelo design da Monama é formado em desenho industrial pela FAAP em 2003. Trabalha na A10 há três anos e meio na área de embalagem de varejo.

\section{Entrevista com representante do escritório de design Sintonia Comunicação}

Quando: 2 de maio de 2013

Horário: $13 \mathrm{~h} 30$ até $14 \mathrm{~h} 30$

Onde: Via Skype

Para a seleção de qual profissional seria entrevistado da Sintonia Comunicação, antes da entrevista com a indústria foi feita uma pesquisa na internet, onde foi encontrada a informação de quem era o responsável pelo design das embalagens.

O contato foi iniciado via e-mail, indicado da Via Pax Bio. Após esse contato, houve algumas tentativas de conciliar a entrevista com a indústria e escritório de design no mesmo período em Joinville, o que não foi possível. Por isso, a entrevista acabou acontecendo via Skype, programa de comunicação online.

O representante pelo design da Via Pax Bio é formado em Publicidade e Propaganda, na PUC do Paraná. Proprietário e diretor de criação da Sintonia Comunicação.

\subsection{PERCEPÇÃO DO CONSUMIDOR}

\subsubsection{Entrevista com consumidor}

Para a compreensão da percepção dos consumidores quanto aos aspectos ambientais dos alimentos orgânicos e suas especificidades, foram feitas entrevistas em profundidade, semiestruturadas, para verificar se o consumidor percebe os elementos de comunicação associados a esse tipo de produto e se essa percepção está alinhada com os princípios gerais definidos pela empresa e pelos designers que fizeram o projeto das embalagens.

Além disso, a entrevista também procurou entender se os consumidores têm conhecimento sobre a reciclagem das embalagens, como são seus hábitos de compra e pós-consumo, quais são os elementos na embalagem que mais chamam a atenção e seu conhecimento sobre o tema alimento orgânico. 
A amostragem foi definida, primeiramente, em termos geográficos ${ }^{6}$. A área geográfica selecionada foi a região de São Paulo, por ser uma região com uma grande concentração de produtos orgânicos industrializados à venda, e com uma maior concentração de consumidores desse tipo de produto. Essa região também foi selecionada pela facilidade de acesso aos entrevistados pelo pesquisador.

A seleção dos entrevistados seguiu os seguintes critérios: consumidores de alimentos, adultos, da região da Grande São Paulo, que costumam fazer compras para a sua casa e que não tivessem um conhecimento prévio sobre o que era a pesquisa.

Foram selecionadas inicialmente pessoas que o pesquisador tinha algum conhecimento prévio, mas sem nenhum envolvimento com a pesquisa. Após a entrevista, foi pedida a indicação de outras pessoas para serem entrevistadas. O critério utilizado para selecionar o entrevistado foi baseado em seus hábitos de consumo, buscando ter equilíbrio entre consumidores de orgânicos frequentes e esporádicos.

Foi tomado o cuidado de não revelar qual era o principal objetivo da entrevista no primeiro contato, para não influenciar as respostas; falou-se apenas que se tratava de uma pesquisa sobre embalagens de alimentos. Porém, devido a isso, nem sempre era possível perceber o perfil do entrevistado antes da entrevista.

Para os consumidores de orgânicos, além da indicação por algum conhecido, foi usada a rede social Facebook para detectar quem tinha esse perfil. Foi feita a pergunta informal: "Quem aí prefere comer alimentos orgânicos?". Para as pessoas que responderam positivamente, e moravam em São Paulo, foi feito um contato para uma futura entrevista. As principais formas de contato foram via e-mail e Facebook.

Foram realizadas 32 entrevistas no período de julho a setembro de 2013, em um local calmo de escolha do entrevistado, sendo na maior parte das vezes em sua casa. Algumas aconteceram em locais públicos, como um café, e uma delas em sala reservada na biblioteca de uma faculdade. Do total, três foram descartadas, uma por falha nos equipamentos de gravação, e duas por terem sido apresentadas embalagens de grupos diferentes.

Também foi analisada a possibilidade de se fazer uma entrevista no próprio ponto de venda, porém, nesse tipo de ambiente, a duração da entrevista deveria ser mais curta e feita com um questionário de perguntas fechadas, e os dados resultantes seriam limitados.

A forma de registro dos dados visuais foi via filmagem com uma câmera e o áudio foi gravado com um gravador digital, sendo as gravações posteriormente transcritas. (APÊNDICE DVD)

\section{Roteiro da entrevista com os consumidores}

As questões da entrevista foram formuladas de modo que o entrevistado pudesse discorrer e verbalizar seus pensamentos, tendências e reflexões sobre os temas apresentados. Para isso, o roteiro de entrevistas (APÊNDICE C) foi estruturado com perguntas abertas e algumas fechadas, deixando o entrevistado livre para falar o que achasse conveniente.

\footnotetext{
${ }^{6}$ Por tratar-se de uma pesquisa qualitativa e tendo os produtos e empresas selecionados para esta sido geograficamente escolhidos o critério aqui se aplica como justificado, uma vez que não há necessidade de se trabalhar com amostragem estatística estratificada.
} 
Antes de iniciar a entrevista, o equipamento de gravação era preparado e as embalagens que seriam mostradas, colocadas sobre uma mesa, mas sem falar sobre o que era o tema da entrevista.

A entrevista era iniciada com uma breve apresentação da natureza da pesquisa e identificando o pesquisador. Foi tomado o cuidado de não se falar inicialmente que o principal objetivo da entrevista estava nos aspectos ambientais do design de embalagem, seja nos contatos prévios ou antes do início da entrevista, apenas mencionando que a pesquisa era sobre o design de embalagens de alimentos.

O primeiro módulo, introdutório, envolveu um esclarecimento breve da natureza da pesquisa e identificando o pesquisador, sem falar ainda muitos detalhes sobre a pesquisa.

No segundo módulo, foram feitas questões para conhecer o entrevistado e perceber o grau de influência na escolha dos alimentos de sua casa.

No terceiro módulo, foi pedido para o consumidor separar as embalagens em dois grupos, um de mais saudáveis e outro de menos saudáveis, isso para perceber se ele relacionava o alimento orgânico como mais saudável. Depois, logo após finalizar a primeira separação, foi pedido para que separasse em outros dois grupos, um de orgânicos e outro de não orgânicos.

No quarto módulo, foram feitas questões para um melhor detalhamento da percepção de um produto orgânico selecionado. Depois, foi pedido para que a pessoa preenchesse uma matriz de diferencial semântico, com palavras selecionadas de acordo com os valores da empresa.

No quinto módulo, foram feitas perguntas mais específicas sobre os alimentos orgânicos, para perceber o nível de conhecimento do entrevistado e se é consumidor de orgânicos ou não.

No sexto módulo, foram feitas perguntas sobre os hábitos de compra do entrevistado, percebendo a possível influência da embalagem na hora da compra.

No sétimo módulo, destinado a verificar a simbologia, foram apresentadas imagens de selos de certificação e a simbologia técnica de identificação de materiais e reciclagem. O objetivo foi perceber o conhecimento desses símbolos.

A entrevista foi finalizada com perguntas sobre o pós-consumo de embalagem. O objetivo era perceber o conhecimento e a prática do entrevistado sobre a separação de embalagens para a reciclagem em sua casa. $O$ roteiro completo pode ser visto no apêndice $C$.

\section{Análise dos dados da entrevista}

Após a transcrição das entrevistas, foi feita a análise do discurso e análise do conteúdo para cada uma separadamente.

Para análise do discurso, foram identificados padrões e funções no discurso baseados nos dados que emergiram da análise de conteúdo.

Para a análise do conteúdo, foram definidas categorias de unidades de texto, baseadas na teoria pesquisada, nos indicadores dos órgãos especializados e em outras que emergiram das respostas da pesquisa. A codificação criada para a análise do conteúdo pode se vista no próximo quadro: 


\begin{tabular}{|c|l|}
\hline+ & Percepção positiva \\
- & Percepção negativa \\
\hline S & Saudável \\
$\mathbf{O}$ & Orgânico \\
$\mathbf{A}$ & Aspectos ambientais \\
$\mathbf{e}$ & Embalagem \\
$\mathbf{p}$ & Produto \\
\hline
\end{tabular}

\begin{tabular}{|l|l|}
\hline \multicolumn{2}{|c|}{$\begin{array}{c}\text { Frequência de consumo de } \\
\text { alimentos orgânicos }\end{array}$} \\
\hline F1 & Sempre \\
F2 & Regularmente \\
F3 & Eventualmente \\
F4 & Raramente \\
F5 & Não consome \\
\hline
\end{tabular}

\begin{tabular}{|c|c|c|c|}
\hline Produtos & Al Alimentação & Ex Experiência com o produto & Le Leitura \\
\hline Co Cookie & Al1 Vegetariano & Ex1 Gosto & Le0 Necessidade de ler para classificar \\
\hline Ba Barrinha & Al2 Vegano & Ex2 Gosto da família & Le1 Não costuma ler detalhes da \\
\hline Ma Macarrão & Al3 Não come carne & Ex3 Compra & embalagem \\
\hline Gr Granola & vermelha & Ex4 Pesquisou sobre a empresa & Le2 Lê sempre a tabela nutricional \\
\hline Ar Arroz & Al4 Não come açúcar & Ex5 Não conhece & Le3 Lê sempre os ingredientes \\
\hline Fe Feijão & Al5 Peso & Ex6 Já comprou, mas não tem o & Le4 Lê sempre se foi enriquecido com \\
\hline Aç Açúcar & Al6 Colesterol & costume & minerais ou vitaminas. \\
\hline $\begin{array}{l}\text { Fa Farinha } \\
\text { Ge Geral }\end{array}$ & $\begin{array}{l}\text { Al7 Sódio } \\
\text { Al8 Evita açúcar }\end{array}$ & Ex7 Preço & $\begin{array}{l}\text { Le5 No supermercado, não costuma ler } \\
\text { tanto quanto na entrevista }\end{array}$ \\
\hline
\end{tabular}

\begin{tabular}{|c|c|c|c|c|}
\hline e Embalagem & $\begin{array}{l}\text { e1 Elemento } \\
\text { textual }\end{array}$ & e2 Marca & $\begin{array}{l}\text { e3 Elemento } \\
\text { Gráfico }\end{array}$ & p Produto \\
\hline $\begin{array}{l}\text { e1 Elemento textual } \\
\text { e2 Marca } \\
\text { e3 Elemento Gráfico } \\
\text { e4 Material } \\
\text { e5 Tipografia } \\
\text { e6 Cor } \\
\text { e7 Foto } \\
\text { e8 Ilustração } \\
\text { e9 Apelo visual } \\
\text { e10 Manuseio (Abrir / fechar) } \\
\text { e11 Tamanho } \\
\text { e12 Organização informações } \\
\text { e13 Legibilidade } \\
\text { e14 Sentidos } \\
\quad \text { (visão, tato, olfato) } \\
\text { e15 Remete a algo positivo ou negativo } \\
\text { e16 Aproveitamento embalagem } \\
\text { e17 Acabamento } \\
\text { e18 Reciclagem } \\
\text { e19 Tipo } \\
\text { e20 Quantidade de embalagem } \\
\text { e21 Segurança / resistência } \\
\text { e22 Design } \\
\text { e23 Anexos (lacre, adesivo) } \\
\text { e24 Empilhamento (Guardar) } \\
\text { e25 Público diferente } \\
\text { e26 Bandeja/berço }\end{array}$ & $\begin{array}{l}\text { e1A Saudável } \\
\text { e1B Orgânico } \\
\text { e1C Integral } \\
\text { e1D Light ou zero } \\
\text { e1E Tabela } \\
\quad \text { nutricional } \\
\text { e1F Sem algo } \\
\text { e1G Natural } \\
\text { e1H Fonte de } \\
\text { e1I Seção } \\
\text { e1J Nome } \\
\text { e1K Slogan } \\
\text { e1L Biodinâmico } \\
\text { e1M Info. Frente } \\
\text { e1N Artificial }\end{array}$ & $\begin{array}{l}\text { e2A Mãe Terra } \\
\text { e2B Via Pax Bio } \\
\text { e2C Monama } \\
\text { e2D Jasmine } \\
\text { e2E Native } \\
\text { e2F Taeq } \\
\text { e2G Carrefour } \\
\text { e2H Korin } \\
\text { e2l Outros }\end{array}$ & $\begin{array}{l}\text { e3A Selo SisOrg } \\
\text { e3B Outros selos } \\
\text { certificação } \\
\text { e3C Splash / bola } \\
\text { e3D Reciclagem } \\
\text { e3E Faixa } \\
\text { e3F Símbolo } \\
\text { transgênico }\end{array}$ & $\begin{array}{l}\text { p1 Tipo de produto } \\
\text { p2 Ingrediente } \\
\text { p3 Composição nutricional } \\
\text { p4 Experiência } \\
\text { p5 Sabor } \\
\text { p6 Preparo } \\
\text { p7 Produção } \\
\text { p8 Aparência } \\
\text { p9 Enriquecimento } \\
\text { p10 Qualidade } \\
\text { p11 Aditivos } \\
\text { p12 Química } \\
\text { p13 Qualidade } \\
\text { p14 Natural }\end{array}$ \\
\hline
\end{tabular}

Figura 42 - Quadro de categorias para a análise do conteúdo.

\section{Classificação do perfil do consumidor}

Para a classificação do perfil dos consumidores entrevistados, foram avaliadas as informações de frequência de consumo e conhecimento do que é um alimento orgânico. Quanto à frequência, foram classificados os que consomem sempre, raramente e que nunca consomem. Em relação ao conhecimento do que é um alimento orgânico, foram avaliadas as informações:

- Sabe definir;

- Separa corretamente;

- Identifica ou conhece o selo SisOrg;

- Identifica ou conhece a certificadora;

- Impacto menor no meio ambiente;

- Sabe a diferença dos selos de certificação;

- Conhece uma marca. 


\subsubsection{Separação das embalagens em grupos}

Os dados de uma entrevista não são suficientes para perceber se o entrevistado identifica ou não um alimento orgânico pela embalagem. As perguntas, mesmo abertas, poderiam influenciar as respostas. Por esse motivo, durante a entrevista foi feito um experimento, onde foi apresentado um grupo de embalagens do mesmo tipo de produto sobre uma mesa, podendo assim determinar quais são as variáveis que influenciam na escolha de um produto.

Após as perguntas relacionadas ao perfil do entrevistado, foi pedido para que ele separasse as embalagens em dois grupos, um de saudáveis e outro de menos saudáveis. O objetivo foi fazer com que o entrevistado se familiarizasse com os produtos apresentados, manuseando e lendo as informações, e também perceber se ele relaciona o alimento orgânico a um alimento mais saudável.

Após perguntar qual tinha sido o critério de seleção, foi pedido para o entrevistado que separasse novamente em dois grupos, mas, nessa segunda etapa, em orgânicos e não orgânicos. O objetivo dessa separação foi perceber o que o consumidor olha na embalagem para separar como orgânico e se ele busca no grupo de mais saudáveis, separados anteriormente.

\section{Grupo de produtos}

Foram apresentados dois grupos de tipos diferentes de alimentos, separados conforme a forma de processamento e consumo. $\mathrm{O}$ uso de grupos de produtos permitiu realizar a experimentação com maior precisão, reduzindo a influência de variáveis incontroláveis, conforme podemos ver abaixo ${ }^{7}$.

\begin{tabular}{|l|l|}
\hline \multicolumn{2}{|l|}{ Grupo 1 - Não processados } \\
\hline Arroz integral & Feijão preto \\
\hline Via Pax Bio, Organic, & Via Pax Bio, Camil \\
Volkmann, Korin, Tio João & exportação, Camil, Broto \\
Orgânico, Mãe Terra, Tio & Legal, Guto, Carrefour \\
João, Jasmine, Camil, & \\
Maninho & \\
\hline
\end{tabular}

\begin{tabular}{|l|l|}
\hline \multicolumn{2}{|l|}{ Grupo 2 - Pouco processados } \\
\hline Açúcar mascavo & Farinha de trigo integral \\
\hline Mãe Terra, Via Pax Bio, & Mãe Terra, Via Pax Bio, \\
Jasmine, Vitalin, Planeta & Mirella, Jasmine, Donna \\
Verde, Mais Vitta, Viver & Benta, Mais Vita \\
Carrefour, Athenas, Doces & \\
Puxa Puxa & \\
\hline
\end{tabular}

\begin{tabular}{|l|l|}
\hline \multicolumn{2}{|l|}{ Grupo 3 - Pronto consumo } \\
\hline Cookie & Barra de cereais \\
\hline Mãe Terra, Native, Jasmine & Monama, Native, Gran Pure \\
Orgânico, Jasmine Integral, & Granola, Gran Pure \\
Vitao, Biosoft, Gran Pure, & Chocolate, Bio2, Bio2 \\
Taeq organico, Taeq Aveia, & orgânico, Mãe Terra, Jasmine \\
Viver Carrefour, Kobber, & Cranberry, Jasmine Castanha, \\
Naturale, Quaker & Nature Valley, Kellness, \\
& Quaker, Kobber granola, \\
& Kobber, Taeq granola, Taeq \\
& light, Ritter, Tia Sônia \\
\hline
\end{tabular}

\begin{tabular}{|l|l|}
\hline \multicolumn{2}{|l|}{ Grupo 4 - Preparo rápido para o consumo } \\
\hline Granola & Macarrão instantâneo \\
\hline Mãe Terra, Monama, & Mãe Terra, Vilma Integral, \\
Native, Jasmine, Quaker, & Nissin, Nissin Mais, Vigor, \\
Kobber, Vitao, Trio, Biosoft, & Panco, Maggi, Adria, \\
Kellness, Cróqui & Carrefour \\
& \\
& \\
\hline
\end{tabular}

Tabela 12 - Grupos de produtos selecionados para a entrevista

O entrevistado era estimulado a falar o que quisesse durante a separação, podendo assim registrar quais tinham sidos os critérios usados para a separação. Todo o processo foi filmado e o som foi gravado pela filmadora e pelo gravador digital.

Após o término da separação dos produtos, os grupos foram fotografados da forma que o entrevistado havia separado, como registro, pois nem sempre era possível visualizar a

\footnotetext{
${ }^{7}$ As imagens das embalagens podem ser vistas no Apêndice D..
} 
separação apenas com o vídeo. Todo o áudio foi transcrito e algumas anotações foram acrescentadas após a observação do vídeo para um melhor entendimento.

\section{Forma de análise dos dados}

Além da análise do conteúdo e do discurso descrita anteriormente, nesta etapa também foi observada, e registrada, a movimentação do entrevistado, observando quais eram o produtos que os consumidores mais demoravam a separar, como organizavam os grupos e onde olhavam na embalagem.

\subsubsection{Diferencial semântico}

Para uma melhor avaliação de crenças, sentimentos, valores e atitudes em relação a cada embalagem apresentada, foi utilizado o método de diferencial semântico. Esse método baseia-se no pressuposto de que o significado de um objeto detém distinções sutis e difíceis de serem descritas e descobertas de outra forma, permitindo avaliar a percepção afetiva das pessoas sobre situações objetivas e subjetivas de seu dia a dia. (OSGOOD; SUCl; TANNENBAUN, 1967)

Os conceitos avaliados foram definidos com base no que é divulgado nas embalagens dos produtos e no site das empresas selecionadas e foram escolhidos de acordo com a melhor adequação ao problema de pesquisa.

A escala semântica consiste em uma escala bipolar, de onze pontos. Em cada extremo, são colocados dois adjetivos opostos, por meio dos quais os entrevistados avaliam o conceito, colocando uma marca na posição que mais se aproxima de seus sentimentos.

Cada intervalo de pontos representa uma determinada magnitude, expressa implícita ou explicitamente por quantificadores (exprimem o grau da resposta-significado), sendo o central o ponto neutro. Os intervalos receberam o valor numérico de $-5,-4,-3,-2,-1,0,+1,+2,+3,+4,+5$.

\begin{tabular}{|r|l|l|l|l|l|l|l|l|l|l|l|l|}
\hline & -5 & -4 & -3 & -2 & -1 & 0 & +1 & +2 & +3 & +4 & +5 & \\
\hline Artificial & & & & & & & & & & & & Natural \\
\hline Adoçado & & & & & & & & & & & & Sem açúcar \\
\hline Com gordura & & & & & & & & & & & Sem gordura \\
\hline Feito em grande quantidade & & & & & & & & & & & Feito com cuidado \\
\hline Enganoso & & & & & & & & & & & Verdadeiro \\
\hline Não integral & & & & & & & & & & & & Integral \\
\hline Insosso & & & & & & & & & & & Saboroso \\
\hline Inorgânico & & & & & & & & & & & & Orgânico \\
\hline Salgado & & & & & & & & & & & Pouco sódio \\
\hline Transgênico & & & & & & & & & & & & Não modificado \\
geneticamente
\end{tabular}

Tabela 13 - Matriz de diferencial semântico 
O total de pontos de respondentes individuais é computado, definindo os perfis em cada dimensão. São atribuídos pesos quantitativos a cada categoria, e eles são somados. Obtémse, desta forma, um perfil do sentido e do valor que o produto representa para o indivíduo. Ao final, os dados são apresentados em um gráfico com a análise comparativa, de modo a visualizar e comparar as respostas de cada entrevistado, por produto.

\subsection{ANÁLISE DAS EMBALAGENS}

A análise das embalagens pretendeu verificar se os atributos de design presentes nas embalagens são capazes de comunicar os aspectos ambientais inerentes às políticas de suas empresas, sendo feita com base nas informações não verbais representadas nas embalagens, e por seus elementos simbólicos e metafóricos, codificados em signos e sintaxes específicas. Foram considerados também os padrões primários de varredura do campo e a localização das informações, como o centro de atenções, a área de maior tensão visual e hierarquia de leitura.

A análise da estrutura perceptiva e funcional da embalagem ajudou a extrair dados que possibilitaram a interpretação da comunicação e pregnância das formas. Os valores, analogias e associações foram confrontados com o que foi transmitido pelos consumidores nas entrevistas.

O material da embalagem também foi analisado com base nos dados levantados na revisão da literatura (Capítulo 2), possibilitando prever os possíveis impactos ambientais na produção da embalagem e após o seu descarte. Ao final, os dados obtidos nas análises foram comparados com recomendações das organizações e associações especializadas, mencionadas no capítulo da revisão da literatura, verificando também se as informações estavam de acordo com o estabelecido pela legislação vigente.

A apresentação dos dados foi estruturada de acordo com sua categoria dentro dos requisitos ambientais presentes na literatura, por meio das análises propostas pelo pesquisador e suas interpretações de possíveis respostas aos subproblemas da pesquisa. A análise e interpretação dos dados estão apresentadas de forma concatenada a cada fragmento de dado e como um conjunto de relações.

Desta forma, os fatores foram vistos de modo integrado e interdependente. Os dados obtidos a partir da análise das embalagens foram organizados em tabelas, de acordo com sua categoria, de modo a se apresentar um panorama abrangente dos casos estudados.

\subsection{TRIANGULAÇÃO DOS DADOS}

A estratégia de análise final dos dados, combinando os diversos métodos, foi a de triangulação dos dados colhidos nas entrevistas com os consumidores, designers e indústrias e da análise das embalagens, após esses dados terem sido categorizados e analisados individualmente, sendo assim comparados e analisados.

A técnica da triangulação tem por objetivo básico abranger a máxima amplitude na descrição, explicação e compreensão do foco em estudo (TRIVIÑOS, 1987). A interpretação dos dados buscou traçar um panorama global, permitindo a posterior comparação dos dados obtidos com os diferentes agentes pesquisados. 


\section{Triangulações analisadas}

Entrevista com indústria X Entrevista com escritório de design

Entrevista com indústria X Entrevista com consumidor

Entrevista com consumidor X Análise da embalagem

Perfil consumidor X Percepção produto

Perfil consumidor $\mathrm{X}$ Conhecimento símbolos

Entrevista indústria X Entrevista escritório de design X Percepção consumidor X Análise da embalagem 


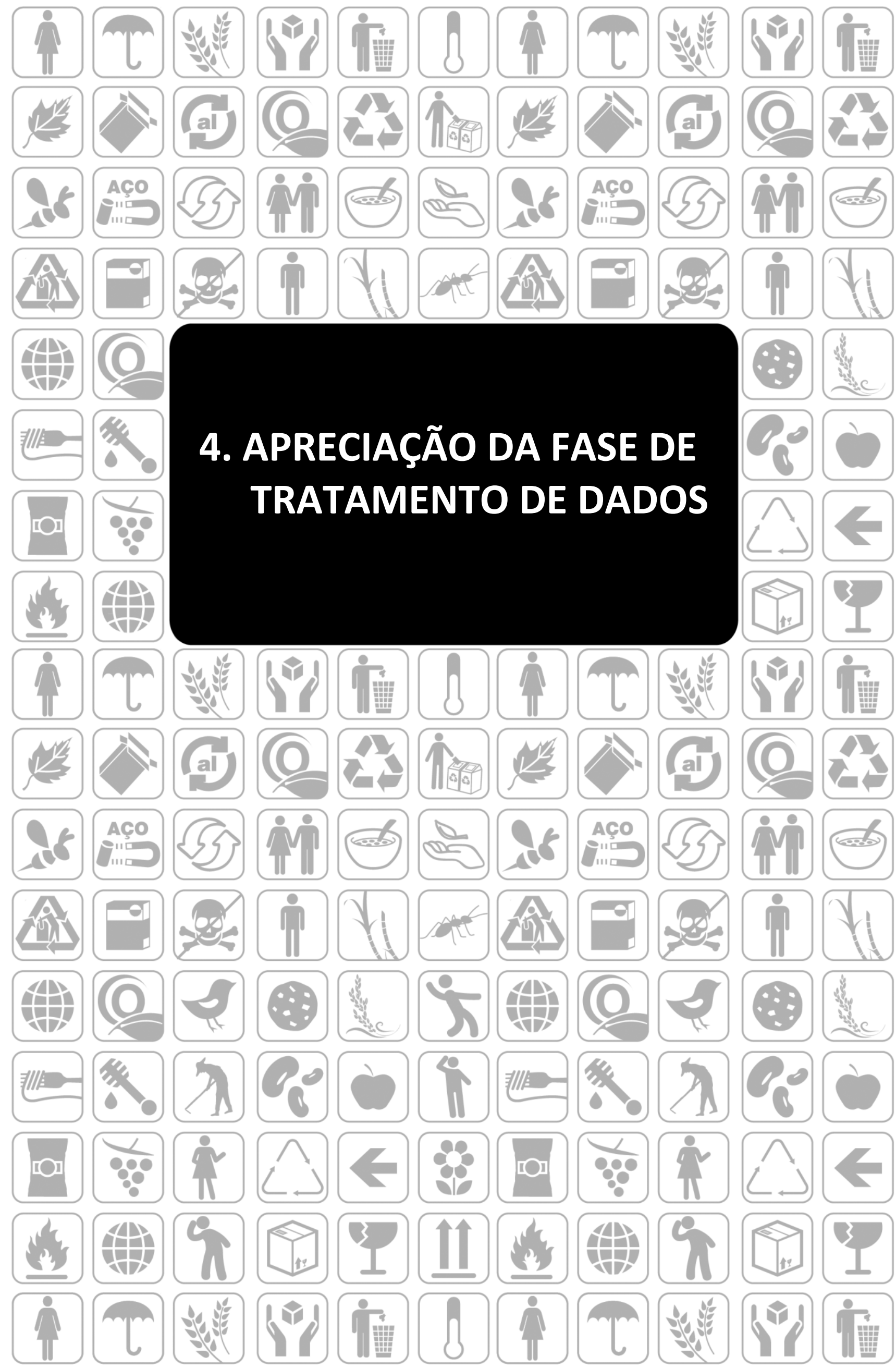




\section{APRECIAÇÃO DA FASE DE TRATAMENTO DE DADOS}

Este capítulo apresenta os dados obtidos nas entrevistas com os representantes das empresas selecionadas, com os representantes dos escritórios de design e os consumidores. Junto a cada tema apresentado, é feita uma análise do design das embalagens.

O capítulo começa apresentando as empresas pesquisadas e o perfil dos consumidores.

Após a apresentação dos entrevistados, primeiramente são apresentados os dados mais gerais das entrevistas sobre as especificidades dos alimentos orgânicos.

Depois dos dados gerais, são apresentados os dados mais específicos que resultaram do experimento feito com os consumidores em entrevista e das análises das embalagens.

O capítulo é finalizado com os dados sobre os hábitos de pós-consumo dos entrevistados e sobre o nível de conhecimento da simbologia técnica de materiais, símbolos que incentivem a reciclagem e os selos de certificação, com destaque para o selo de orgânicos do Sistema Brasileiro de Avaliação da Conformidade Orgânica (SisOrg).

\subsection{EMPRESAS PESQUISADAS}

As empresas aqui apresentadas para o estudo comparativo foram escolhidas com base na distribuição na cidade São Paulo, na diversidade de produtos, tipos diferentes de embalagens e na permissão de serem entrevistados. As empresas que atenderam aos requisitos foram a Mãe Terra, Monama e Via Pax Bio.

Nesta primeira parte do capítulo, é apresentada a visão das indústrias e dos escritórios de design em relação ao desenvolvimento de embalagens e relacionamento entre os setores envolvidos. É questionado também se as empresas conhecem os seus consumidores e se fazem pesquisas para conhecê-los. Os aspectos ambientais das empresas são abordados, questionando quais são as ações feitas nesse aspecto. No final da apresentação de cada empresa, são apresentadas as estratégias de design para a marca, identidade visual e embalagens.

\subsubsection{Mãe Terra}

Em entrevista com Indústria1 (2012), foi perguntado quais os três pontos que ele considera mais importantes no desenvolvimento das embalagens da Mãe Terra. Segundo ele, são:

- Comunicação eficiente;

- Reciclabilidade;

- Funcionalidade.

Segundo o entrevistado, os dois primeiros pontos são importantes, porém:

Não adianta ter uma embalagem que seja bonita e sustentável e que não funcione, não funcione no ponto de venda, não pare em pé em uma gôndola ou fique opaca ou não dá a barreira necessária ao produto, e o produto estraga antes do tempo. Até porque nossos produtos são naturais e não têm conservantes, a embalagem acaba sendo uma espécie de conservante. Quanto mais barreira ela oferecer contra as intempéries, mais o produto dura. (INDÚSTRIA1, 2012) 
Para Designer1 (2012), do escritório de design Petersen \& Avila, os três pontos mais importantes no desenvolvimento das embalagens são:

- Conhecer o consumidor final;

- Material da embalagem;

- Visualização no ponto de venda.

\title{
Briefing $^{8}$
}

Segundo Indústria1 (2012), o briefing deles tem um modelo simples e não segue nenhum modelo padrão de empresa, agência ou autor. Apresentado no programa Power Point, são colocadas informações que eles consideram relevantes, seguindo sempre o mesmo roteiro. Na entrevista, Indústria1 (2012) concordou em fornecer esse modelo para a pesquisa, mas o que foi enviado no lugar do briefing foi um estudo do mercado dos cookies.

Para Designer1 (2012), o briefing que eles recebem da Mãe Terra é considerado, por eles, a princípio, completo e organizado. Na primeira reunião, são apresentadas as decisões sobre informações que devem aparecer nas embalagens e sua localização, formato, pontos de destaque, e mais ou menos como deve ser a ilustração ou foto da embalagem. "E depois o projeto muda bastante, porque, porque é feito sempre uma comparação com os líderes de mercado e da concorrência" (DESIGNER1, 2012).

Ao longo do desenvolvimento da embalagem, a Petersen \& Avila busca investir em pesquisa, que não é cobrada no projeto. O escritório pesquisa melhores opções oferecidas por diferentes fornecedores de embalagens. Nos casos em que o cliente já tem um fornecedor, após uma visita às instalações, tenta substituir o material usado por um que tenha um impacto "um pouco menor" no meio ambiente, dentro da mesma verba que o cliente trabalha.

Na fase de produção, o escritório costuma acompanhar os processos. Em geral, é chamado na hora dos testes de impressão, para avaliar se as cores chegaram a um resultado próximo do planejado.

\begin{abstract}
Antigamente, o cliente investia na prova chamada prova prelo, que era aquela prova que fazia a chapa de impressão, e se tirava, digamos, um cromalin, e isso ia para a gráfica e era a referência para a pessoa acompanhar a máquina, a pressão das tintas, para poder fazer a impressão. Hoje em dia, esse investimento foi cortado porque entrou a questão da prova digital. [...] então muitas vezes a prova digital, por ser uma impressão em ponto, não é fiel, principalmente quando se trabalha o Pantone. Então a primeira prova a gente participa. (DESIGNER1, 2012)
\end{abstract}

A Petersen \& Avila não costuma fazer pesquisa como forma de avaliação de embalagem. Depois que elas estão no mercado, apenas acompanha o que é falado nas redes sociais ou o que é passado pelo cliente.

\section{Comunicação nas embalagens}

Quanto às informações das embalagens, além das informações obrigatórias da legislação, a Petersen \& Avila considera importante constar em todas as embalagens:

- Símbolo de reciclagem (norma da ISO/ABNT);

- Informações que dizem respeito à marca e ao produto;

- Atributos nutricionais;

- Informações sobre a Mãe Terra.

\footnotetext{
${ }^{8}$ Conjunto de informações, coleta de dados para o desenvolvimento de um trabalho. Palavra inglesa que significa resumo, em português. É um documento contendo a descrição da situação de uma marca ou empresa, seus problemas, oportunidades, objetivos e recursos para atingi-los.
} 
Indústria1 (2012) considera um desafio falar tudo o que eles acham importante na embalagem.

A gente tem que falar da empresa, porque a gente tem que se fazer conhecido. A gente tem que falar do produto, gerar interesse, a gente tem que falar dos aspectos nutricionais para gerar interesse. Ao mesmo tempo, a gente tem que ter uma embalagem leve, uma arte que tenha uma estética de leveza, que não seja apinhada de informações. Então muitas vezes é uma coisa de cobertor curto, puxa um lado, o pé descobre, puxa ou outro, a cabeça descobre. (INDÚSTRIA1, 2012)

Segundo ele, a embalagem deve passar:

[...] uma coisa leve, gostosa, saborosa, divertida. A gente quer ser inusitado. Quer ter uma linguagem própria, quer ter um estilo autoral de ser, de atitude mesmo, sabe? E a embalagem é importante para isso. Uma coisa de identidade, de personalidade. E cada vez mais a gente está refinando essa personalidade e as embalagens mais novas acabam ganhando mais essa nova personalidade, essa nova identidade. (INDÚSTRIA1, 2012)

Designer1, da Petersen \& Avila, é o principal responsável pelo design da Mãe Terra desde 2005, quando trabalhava na Dezign com Z, como diretor de criação. Nesse ano, a Mãe Terra foi comprada por um novo proprietário e precisava reformular todas as embalagens e a identidade visual. Para isso, ele fez uma pesquisa no mercado para saber quais eram as empresas de design que atendiam a Natura ${ }^{9}$. Essas empresas foram selecionadas para participar de uma concorrência.

Nesse momento, Designer1 refez o logo e as embalagens dos ingredientes Mãe Terra, sendo desenvolvido um conceito gráfico com ilustrações vetoriais, resgatando um pouco da linguagem que já existia nas embalagens antigas. Durante dois anos que trabalharam juntos na Dezign com Z, manteve um bom relacionamento com a Mãe Terra, mas, em 2009, Designer1 saiu da Dezign com Z para trabalhar em um outro escritório. “E, com a minha saída, a relação ficou um pouco perturbada porque a pessoa que ficou na conta não conseguiu acertar. [...] aí me procurou e fez a proposta de continuar a trabalhar como freela" (DESIGNER1, 2012). Indústria1 (2012) também comentou que procuraram o Designer1 por ele atender melhor o que buscavam no design de suas embalagens.

A Petersen \& Avila considera importante ter nas embalagens:

- Benefícios do produto para a saúde;

- Matéria-prima usada;

- Informações sobre a reciclagem da embalagem, de forma clara e respeitando os códigos padrões.

\section{Relacionamento com outros setores e escritórios de design}

Para as decisões estratégicas do desenvolvimento das embalagens, são envolvidos os setores de Marketing e P\&D. Quando é o desenvolvimento de um produto de forma integral, mais áreas são envolvidas, como nutrição, compras, comercial, sendo um trabalho mais multidisciplinar. Em projetos mais complexos, para a parte mais técnica, fornecedores são chamados. $O$ design estrutural da embalagem quem faz é o fornecedor; a equipe da Mãe Terra apenas define as dimensões, gramatura e resistência.

A gente tem uns fornecedores que são bastante parceiros e são sempre consultores, [...] é o business deles, então eles dão muitas dicas. Isso vai funcionar, isso não vai. Isso tem mais

${ }^{9}$ Indústria fabricante de cosméticos com forte apelo de sustentabilidade. 
barreira, isso não tem. Isso vai te dar um shelf life ${ }^{10}$ maior ou menor. Isso é mais reciclável, isso é menos. (INDÚSTRIA1, 2012)

O design de embalagens é trabalhado de duas formas diferentes: por escritórios de design e pela agência interna, formada por um profissional de design. O principal escritório de design até o momento da entrevista é a Petersen \& Avila.

O que norteou a escolha do escritório de design foi um alinhamento com a Mãe Terra, a compreensão do que eles querem e precisam, que é inovar e encantar o consumidor.

A gente tem que encantar com o que a gente tem, a embalagem é uma das formas. E mostrar que é uma coisa leve, gostosa, prazerosa. [...] Temos as nossas limitações, a gente tem um limite para inovar. Até porque o mercado brasileiro ainda não tem o mesmo nível de maturidade que o mercado americano e europeu. [...] e essa agência nos atende de forma adequada nesse sentido. (INDÚSTRIA1, 2012)

Boa parte do design é feito internamente, a Mãe Terra decide internamente o que quer em termos de estética, posicionamento, linguagem, cor. O escritório de design pode ajudar nesse processo, mas grande parte das decisões é feita na empresa, por Indústria1, pelo designer da equipe interna e pelo proprietário da Mãe Terra.

A gente sabe muito bem o que a gente quer. Claro que às vezes a gente erra a mão ou amadurece uma ideia, ou que podia ser a partir de algo que a gente já fez melhor, isso acontece. Mas a gente já tem isso muito claro na nossa cabeça. (INDÚSTRIA1, 2012)

O briefing da Mãe Terra já vem com os tópicos de destaque, mas a Petersen \& Avila costuma dar sugestões de informações para colocar na embalagem. Muitas vezes, a agência é convidada a participar das decisões estratégicas do desenvolvimento de produtos novos, como a degustação de produtos e sugestão de novos sabores. "[...] tem muito teste, então é muitas vezes aproveitado [sic] a nossa visita na empresa, para degustar, para nossa opinião, como consultor" (DESIGNER1, 2012).

\section{Consumidores da Mãe Terra}

Segundo Indústria1 (2012), a Mãe Terra busca estar próxima do consumidor. Como eles não investem em propaganda, os principais meios de comunicação são as embalagens e as mídias de redes sociais eletrônicas.

A embalagem é uma forma, já que a gente não tem publicidade. Tem outras, Facebook e etc. Mas essa empatia: a gente quer fazer a pessoa se sentir em casa, que a gente não é só mais uma empresa de alimentos. [...] A gente quer aproximar a empresa do consumidor. (INDÚSTRIA1, 2012)

Hoje em dia, com esse relacionamento muito próximo do consumidor dentro das redes sociais, principalmente via Facebook e e-mail, esse feedback vem ao natural. (DESIGNER1, 2012)

Parte desse feedback é sobre o design das embalagens, por exemplo:

A questão das cores, por exemplo, de ter pouco produto na parte frontal, às vezes tem muitos claims $^{11}$ de destaque que talvez esteja tapando o produto, e aí o cliente fala disso. Então esse retorno, hoje em dia, é uma coisa natural, já a gente percebe. (DESIGNER1, 2012)

Quanto ao conhecimento de seus consumidores, eles costumam fazer pesquisas, mas de forma formal. Eles estão sempre atentos ao que é falado nas redes sociais na internet, pois assim percebem se conseguiram ou não atingir o objetivo, que é criar empatia com o consumidor através da embalagem.

\footnotetext{
${ }^{10}$ Termo utilizado pelas indústrias alimentícias para definir a vida útil do produto, também chamado de "tempo de prateleira". ${ }^{11}$ Apelos.
} 
Encantar é muito forte para a gente e funciona. Assim, modéstia à parte, muitos consumidores olham para as embalagens e falam, 'pô, mas que bacana, que divertido, que encantador, adorei', a gente recebe muitas. [...] Eu acho isso admirável, a pessoa elogiar uma empresa. E é essa empatia que a gente quer criar. (INDÚSTRIA1, 2012)

Na época da compra da Mãe Terra, foi feita uma pesquisa que serviu para traçar um panorama do mercado de naturais para descobrir quem eram os seus consumidores, o seu perfil, o que eles esperavam do produto e em termo de qualidade de vida. Na época, os consumidores eram os idealistas, hippies e vegetarianos, que começaram a consumir este mercado nos anos 1960 e 1970, ou as mulheres de mais idade, que consomem por uma questão de saúde ou por indicação médica. Em termos de renda, na época, pertenciam principalmente às classes $A$ e $B$.

O público $C, D$ e E já começa a comprar produtos naturais. Claro que não é a linha toda, obviamente. O mix que você trabalha em um mercadinho de periferia é diferente de um que você trabalha em um Santa Luzia, Santa Maria, mas já consomem. (INDÚSTRIA1, 2012)

Hoje, a Mãe Terra tem o objetivo de atingir um consumidor mais amplo, não apenas o consumidor de naturais, sendo um desses públicos novos o infantil. O objetivo é dar uma opção de "guloseima mais saudável". Para isso, lançaram o primeiro salgadinho orgânico e natural do Brasil. Faz parte também dessa estratégia a plataforma do sítio Zuretinha, que trabalha a educação ambiental de forma lúdica.

Os homens e os jovens adultos também são outro público, não tradicional, com que estão trabalhando. Eles, em geral, consomem as barrinhas, as granolas e os cookies, principalmente os que fazem exercício e vão à academia.

A gente acredita muito na alimentação natural, mas nós não queremos vender naturais para quem é "natureba". Nada contra, aliás, os "naturebas": é um público supercativo, a gente tem um carinho e um respeito para esse público. Mas vender para quem é natureba é fácil. Certo? Não precisa de esforço nenhum. Você tem o seu produto natural e o cara sem esforço vai comprar. O nosso grande desafio, que vai até além das embalagens, é levar a alimentação saudável, mas natural, para o público amplo. (INDÚSTRIA1, 2012)

\section{Aspectos ambientais}

Para minimizar os impactos ambientais, a Mãe Terra desenvolveu o projeto Pensando Bem, que faz o rastreamento de produtos ao longo de toda a cadeia produtiva. No projeto, eles olham e avaliam o produto desde a sua produção até o pós-consumo, incluindo as embalagens. Os sete pilares do projeto são o uso da água, consumo de energia, emissão de gases de efeito estufa, biodiversidade, bem-estar animal, resíduos e saúde do solo.

Desenvolvido internamente, é um projeto contínuo, que se iniciou em 2009 e foi lançado em 2010, "às pressas", para concorrer ao prêmio Green Best 2011, que ganharam pelo júri popular. Para acelerar o processo, não incluíram todos os produtos. Foram priorizados os produtos que têm uma complexidade menor na cadeia produtiva e com uma relevância maior no portfolio, conseguindo assim medir de forma mais fácil os impactos. A divulgação é feita via site, que não havia sido atualizado até a entrevista, em junho de 2012.

Um consumidor comentou que relacionava a Mãe Terra como uma empresa mais consciente ambientalmente. "É uma empresa mais preocupada com o meio ambiente, trabalha com orgânicos, está introduzindo uma série de produtos que faltam no mercado, para os vegetarianos e tudo" $(C 28,2013)$.

A embalagem é uma das frentes de ação identificadas como prioritárias no projeto, quando foi feito o inventário para a visualização dos pontos fracos que deveriam ser atacados 
primeiro. Existe um projeto de se criar um manual de avaliação de embalagens plásticas e de papel, integrando os sete impactos ambientais do Pensando Bem, mas, apesar de estar no site, até o momento da entrevista esse manual ainda não havia sido feito.

Em relação à escolha dos materiais das embalagens para diminuir o impacto ambiental, a Petersen \& Avila sempre tenta usar algum material que seja reciclável e não tão agressivo para todos os seus clientes, porém nem sempre é possível porque os critérios ambientais não são prioritários para muitos de seus clientes. No caso da Mãe Terra, os materiais foram especificados pela sua equipe de Pesquisa e Desenvolvimento.

Às vezes um material alternativo não é tão bonito, e isso pesa muito no cliente, se o cliente precisa que o produto dele seja um pouco mais premium, ainda mais se é um cliente que não entende muito sobre esse tipo de virada, digamos assim. É bem complicado. (DESIGNER2, 2012)

O impacto ambiental durante a produção da embalagem também foi comentado pela Petersen \& Avila, principalmente na fase de teste e de prova de cor. No teste de impressão, são impressos vários metros de embalagens, gerando um desperdício grande de material.

Como a velocidade da máquina é muito grande, por isso tem a questão do desperdício. Depois que é ligado [sic], roda não sei quantas mil embalagens por hora, e aí é uma coisa que precisa ser trabalhada na empresa de impressão. (DESIGNER1, 2013)

\section{Pós-consumo}

A Mãe Terra incentiva a reciclagem das embalagens por meio do uso símbolo da reciclagem e, indiretamente, nas informações da seção Pensando Bem. A Mãe Terra também usa o Facebook como ferramenta de comunicação e educação dos sete impactos ambientais relacionados ao projeto Pensando Bem.

Enfim, não é muito sistemático. A gente acha que tem até um dever de casa de encorajar mais isso. Porque eu, na pessoa física, sou superadepto à reciclagem, e a empresa tem muito essa característica. Tem que ter. (INDÚSTRIA1, 2012)

Internamente, eles separam principalmente os resíduos da fábrica. No escritório, eles fazem um trabalho de educação mostrando vídeos de conscientização para seus funcionários, porém, segundo ele, "ainda existe uma cultura arraigada no escritório, como a cultura do copo plástico". Quanto à reciclagem das embalagens, Indústria1 (2012) ainda comenta:

Temos nossas pedras no sapato, sim. Temos embalagens que são menos recicláveis, a gente sabe disso. E trabalha dentro da nossa possibilidade de soluções mais sustentáveis porque esse é um dos pilares principais da empresa.

\section{Logística}

Quanto à logística dos produtos da Mãe Terra, uma parte da produção dos produtos é terceirizada, como o Caseirito, o salgadinho e a sopa. Os produtos que são feitos internamente são: a linha de ingredientes, os cookies, as granolas, o Fibrax e parte do Fitifibras. Os fornecedores de embalagens da Mãe Terra estão todos localizados perto da fábrica, em cidades como Diadema, Guarulhos e outra, perto de Campinas.

Eles trabalham com distribuidoras que revendem para clientes brasileiros pequenos, como padarias, bombonieres, ou vendem diretamente para os clientes do varejo e de lojas de produtos naturais. Os produtos são distribuídos para todos os estados brasileiros, principalmente via caminhão, pois segundo Indústria1 (2012), "não existe malha ferroviária que atenda esse tipo de produto". 
A Mãe Terra não tem um projeto de logística reversa ${ }^{12}$, porém está atenta a isso.

Vou conversar amanhã com uma empresa que está se tornando conhecida no mercado de logística reversa. [...] A gente já teve uma conversa lá no passado. Na época, não era viável para a gente fazer um programa de logística reversa, que o custo era muito alto. Mas amanhã eu vou retomar esse assunto e a gente vai ver se consegue lançar um projeto piloto. Tudo tem que ser meio assim, aos poucos. (INDÚSTRIA1, 2012)

\subsubsection{Estratégia de design da Mãe Terra}

\section{Marca Mãe Terra}

A marca da Mãe Terra é uma das informações que Indústria1 considera que devem ter destaque na embalagem.

A marca da Mãe Terra sempre grande. Isso é um trabalho que a gente tem feito de aumentar porque isso endossa, um carimbo, como um atestado de qualidade. As pessoas conhecem essa marca pela marca. (INDÚSTRIA1, 2012)

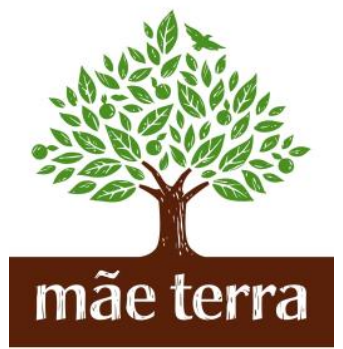

NATURAL DE VERDADE

Figura 43 - Marca Mãe Terra

Na época do design das embalagens de ingredientes da Mãe Terra, houve uma preocupação de não perder totalmente a identidade das antigas embalagens desenvolvidas antes da mudança dos donos da empresa.

Tinha uma preocupação muito grande de não perder a identidade que já era uma coisa, já existia um público já cativo da Mãe Terra. Era pequeno, mas já tinha consumidores de anos já, que sabiam a qualidade do produto. Então a preocupação teve, principalmente quando a gente refez o logo, não perder, por exemplo, a árvore, a árvore era um elemento que precisava acontecer. (DESIGNER1, 2012)

A importância da árvore como identidade da marca pode ser comprovada em um dos comentários dos consumidores: "A Mãe Terra, que eu já identifiquei a arvorezinha ali, e já ficou identificado" (CA15, 2013).

Mesmo quando afirmaram que não consomem os produtos da Mãe Terra, a marca foi vista como algo positivo e que vende produtos saudáveis.

Eu acho interessante essa marca desde a primeira vez que eu ouvi falar na Mãe Terra. É que eu tinha uma amiga nossa que tinha uma lojinha desses produtos, mas só que como era caro, a gente só comentava. Eu sempre achei bonitinho, Mãe Terra, sinal de coisa pura, coisa saudável. (CC30, 2013)

Quando as embalagens foram apresentadas para os consumidores, 10 das 29 vezes os consumidores declararam que já tinham comprado o produto apresentado por causa da marca, mostrando que é uma marca reconhecida influenciando a compra.

\footnotetext{
12 Área da logística que trata dos aspectos de retornos de produtos, embalagens ou materiais ao seu centro produtivo.
} 


\section{Relação da marca de produto saudável}

A relação da marca com a saúde começa com o slogan "Natural de verdade". Os atributos nutricionais são informações que a Mãe Terra procura destacar na embalagem de forma educativa.

Esse tipo de informação é bastante importante para a gente. Informações que eduquem o consumidor. A gente busca uma forma mais indireta, porque a embalagem não é uma apostila, mas a gente busca educar o consumidor por uma alimentação mais saudável, mais natural. (INDÚSTRIA1, 2012)

A forma indireta que a Mãe Terra busca para comunicar os atributos naturais e saudáveis é mostrar nas embalagens que é um produto gostoso, "encantando o cliente" com o design.

Porque não é fácil você vender o natural. Natural, muitas vezes, não tem aquela explosão de aromas. Não tem toda aquela propaganda publicitária, todos aqueles apelos. Então a gente tem que encantar com o que a gente tem, e a embalagem é uma das formas. E mostrar que é uma coisa leve, gostosa, prazerosa. (INDÚSTRIA1, 2012)

As informações dos atributos nutricionais que devem constar nas embalagens são passadas no briefing para o escritório de design, como um dos tópicos de destaque. "[...] eles foram um dos primeiros que entraram com essa cultura de colocar a parte de benefícios para saúde em destaque, então isso já vem mais ou menos pronto" (DESIGNER1, 2012).

Para desenvolver um produto novo e saudável, a Petersen \& Avila comentou que faz muita pesquisa antes de o produto sair.

[...] ele demora para sair também porque eles têm uma dificuldade muito grande na parte de parceiros e de matéria-prima, e de terceiros na produção de produto - então, também, para poder chegar num sabor ideal sem precisar usar nenhum aditivo químico. (DESIGNER1, 2012)

Essa relação da marca com um produto saudável também foi observada nas entrevistas com os consumidores: 25 dos 29 entrevistados relacionaram a marca Mãe Terra com algo saudável. Durante a separação, alguns comentaram qual o motivo para separar o produto como mais saudável:

\section{[...] apenas por ser uma marca que a gente já identifica a Mãe Terra, como uma marca de} produtos mais saudáveis, mais naturais. (CA02, 2013)

Eu acho que Mãe Terra não faria uma coisa que não fosse saudável. (CC06, 2013)

Estou separando esta aqui que é Mãe Terra porque eu acho que esta é uma marca que vende produto integral de boa qualidade e orgânico. (CA04, 2013).

\section{Análise da marca Mãe Terra}

Segundo o Dicionário de Símbolos de Jean Chevalier e Alain Gheerbrant (1998), a árvore é o símbolo da vida e das relações que se estabelecem entre a Terra e o Céu. A copa da árvore apresenta, além das folhas, outros símbolos como frutos e o pássaro, simbolizando a conexão entre a Terra (simbolizada pelo tronco da árvore) e o ar ou a natureza.

A cor verde da copa da árvore simbolicamente está ligada aos "campos e árvores que fornecem proteção e abrigo" e à natureza. A cor marrom é a cor da resistência psicológica e da persistência daqueles que nunca abandonam o caminho traçado (TISKI-FRANCKOWIAK, 2000).

O slogan "Natural de verdade" reforça a mensagem de que a empresa busca produtos próximos da natureza. Porém, perde legibilidade quando aplicado de forma reduzida. 
Como alguns elementos de design se repetem por toda a linha da Mãe Terra, principalmente na linha de ingredientes, primeiramente foram analisados os seus elementos gráficos e textuais em comum para posteriormente analisar a embalagem por painel e por produto no item 4.4 deste capítulo.

\subsubsection{Linha de ingredientes}

O padrão de linguagem das embalagens foi redesenhado no período em que a empresa foi comprada. A fazenda, que identifica a linha de ingredientes, é uma evolução da antiga Mãe Terra, e, segundo Indústria1 (2012):

Ela tem uma importância muito grande, ela já é uma evolução brutal da antiga Mãe Terra, antes da empresa ser comprada. Ela tinha uma embalagem extremamente pesada visualmente. Ela era de um verde escuro musgo. (INDÚSTRIA1, 2012)
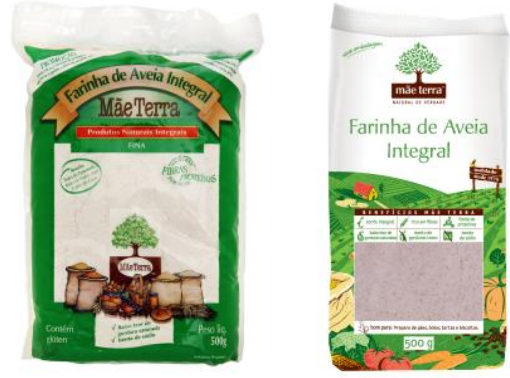

Figura 44 - Evolução da embalagem da linha de ingredientes da Mãe Terra. Fonte: acervo Mãe Terra

O design das embalagens da linha de ingredientes Mãe Terra segue a mesma estrutura visual. Poucas informações mudam de um produto para o outro. A diferenciação dos produtos da linha Mãe Terra é feita principalmente pelas informações textuais do produto.

A análise das diferenças entre os produtos serão apresentados no item 4.4 desta dissertação. As embalagens em tamanho real estão no Anexo A.

\section{Análise do painel frontal da linha de ingredientes Mãe Terra}

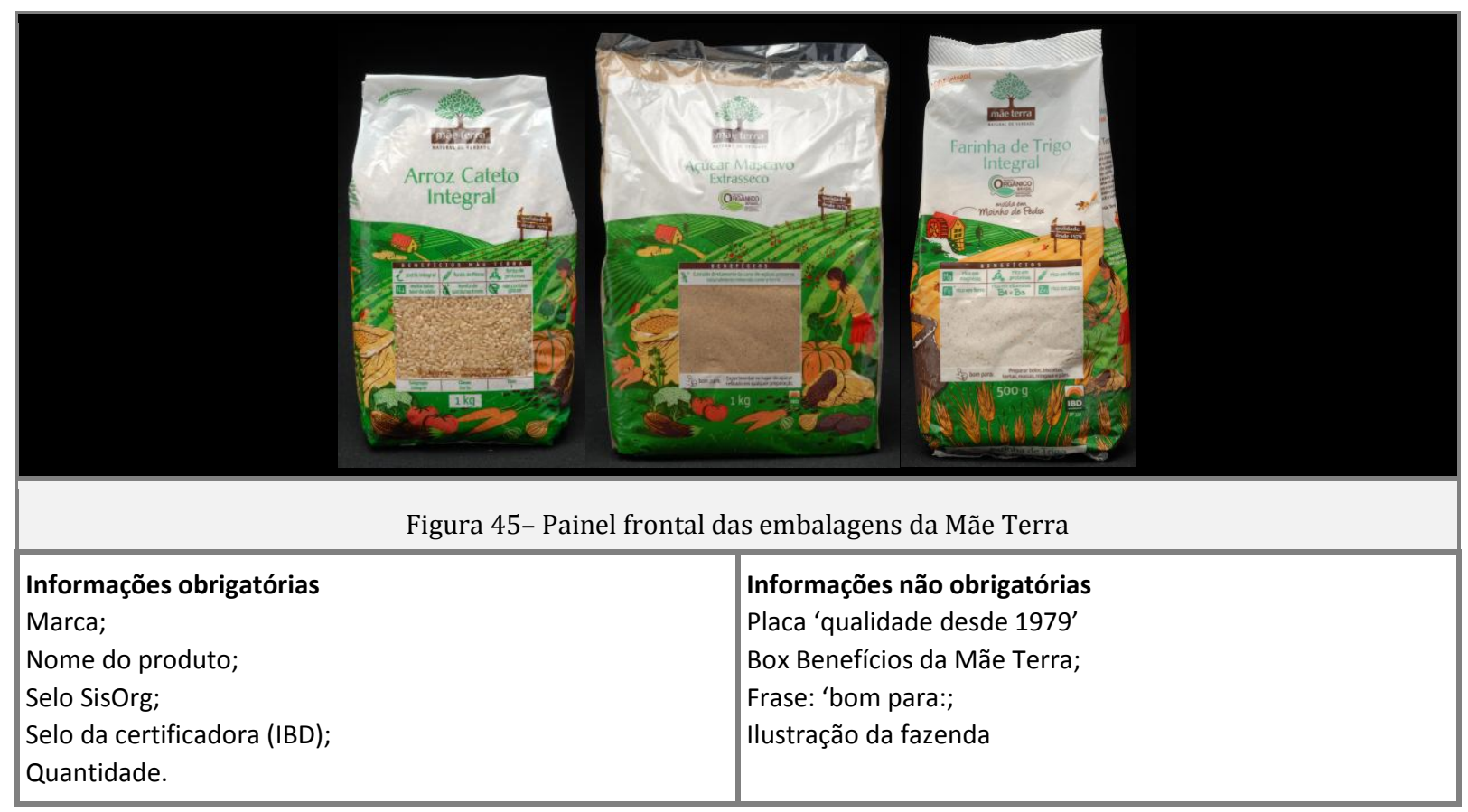


Segundo o sentido de leitura, de cima para baixo, da esquerda para a direita, a primeira informação do painel frontal é a marca Mãe Terra. Porém, a ilustração é a primeira informação visual a ser vista, pelas cores em contraste com o fundo branco. A marca é aplicada sobre o fundo banco, dando boa visibilidade e contraste de cor. O nome do produto em verde, com tipografia de serifas simples, contrasta com a cor do fundo, sendo bem legível.

O selo SisOrg abaixo do nome do produto tem o mesmo peso visualmente, não se destacando. Todos os textos estão na mesma tipografia do nome do produto.

Os elementos gráficos estão em equilíbrio, e as informações textuais e gráficas estão centralizadas em relação à embalagem.

\section{Análise do painel traseiro e dos painéis laterais da linha de ingredientes Mãe Terra}

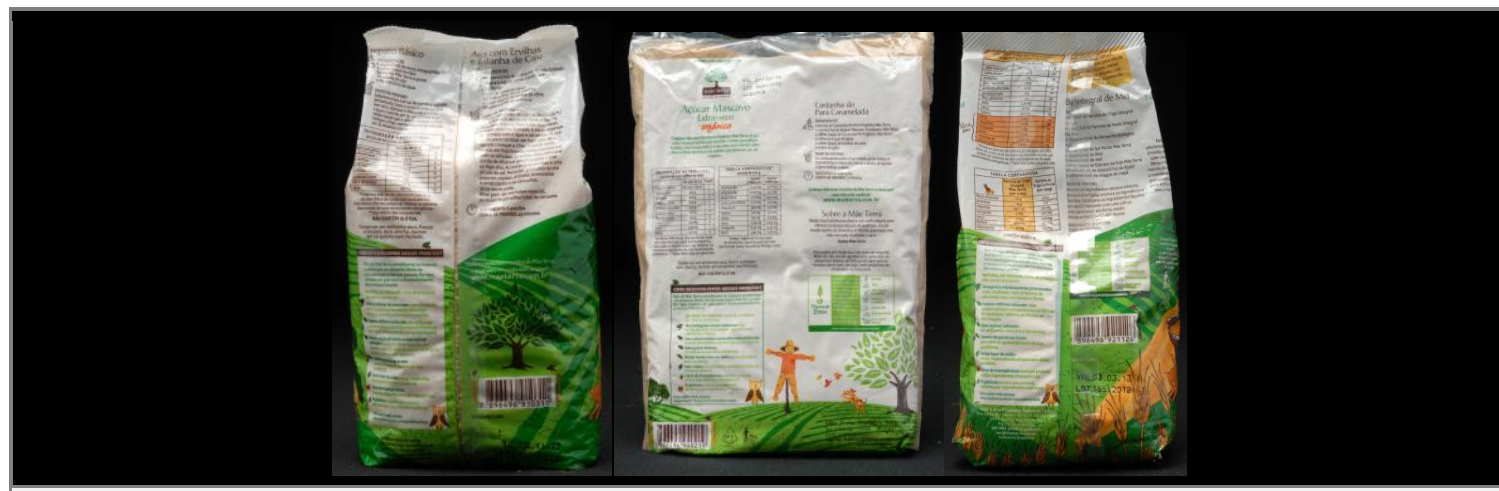

Figura 46 - Painel traseiro das embalagens da Mãe Terra

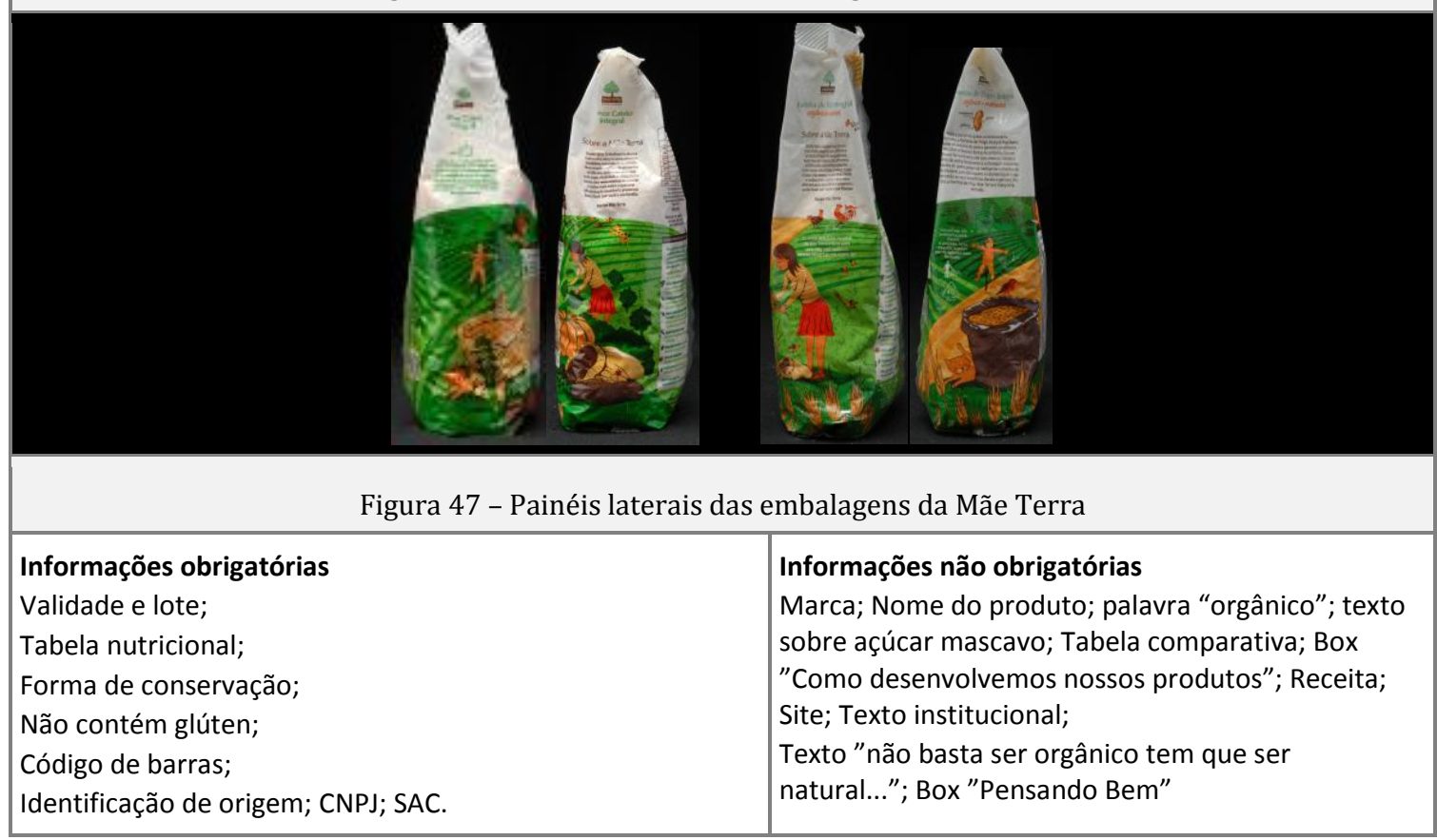

Nesses painéis, são apresentadas as informações nutricionais específicas para cada produto, modo de preparo e informações institucionais da empresa. A posição das informações visuais e textuais nas embalagens analisadas nesta pesquisa varia por produto e serão analisadas posteriormente junto com a hierarquia de leitura. 


\section{Apresentação dos dados das entrevistas}

Vários elementos visuais e textuais desenvolvidos para a linha de ingredientes são repetidos em todas as embalagens da Mãe Terra. A seguir, alguns elementos que se destacam.

\section{Ilustração}

Segundo Indústria1, é a ilustração da fazenda que identifica a linha de ingredientes:

A fazendinha, ela identifica a nossa linha de ingredientes. [...] É o que a gente chama de embalagem "Coca-Cola" [...] é marca registrada da Mãe Terra. (INDÚSTRIA1, 2012)

Segundo Designer1, ela foi uma solicitação do cliente. Inicialmente, a ideia era manter a mesa com produtos das embalagens antigas.

A primeira embalagem era uma mesa, com todos os produtos, os grãos colocados em cima.

Então eles queriam, na cena, tivesse isso de alguma forma. (DESIGNER1, 2012)

O escritório de design Dezign com Z apresentou a ideia de transformar a mesa de produtos em um horizonte de uma fazenda.

Então se substituiu a mesa por um horizonte, onde tinha abóbora, o pimentão a cebola, o tomate, e aí no fundo a gente trouxe a ideia do horizonte da fazenda, com a casinha, com a moça colhendo, com o cachorrinho, com os passarinhos e com as formigas, que eles adoram. Então toda essa conceitualização um pouco mais lúdica veio da empresa Design com Z. (DESIGNER1, 2012)

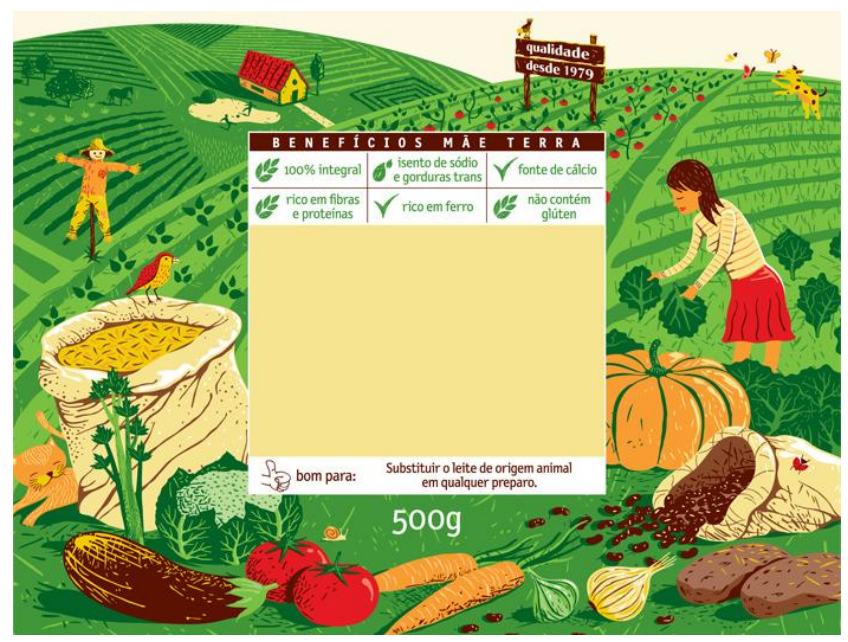

Figura 48 - Fazenda Mãe Terra (ilustração de Gustavo Perez)

\section{A ilustração foi desenvolvida por Gustavo Perez.}

[...] é um ilustrador do Rio de Janeiro, que eu trabalhei com ele na Tátil e ele participou da concorrência e depois ele finalizou todos os desenhos, dessa primeira linha do conceito básico. Porque ele fez a ilustração inicial, como eram vetores, que eram fáceis de você mudar. Depois desse design dessa embalagem, a gente aproveitou os desenhos e montou outro layout. (DESIGNER1, 2012)

Os consumidores, ao analisarem as embalagens, perceberam a ilustração como algo positivo, declarando que foi uma das coisas que mais chamaram a atenção em 10 de 29 vezes em que foi apresentado. 
Os desenhos de produtos saudáveis que você pode consumir com tranquilidade, olha, bastante [sic] legumes, animais, assim, é bem natureza, parece que te leva para essas fazendas onde todo mundo é feliz, até o espantalho está feliz aqui, tudo arado, bacana essa embalagem aqui, ela tem um efeito apelativo bonito, bem alegre, você compra e fala: 'Nossa, estou comprando um produto do campo mesmo'. (CB32, 2013)

Para alguns, a ilustração comunicou que o produto apresentado teve um cuidado especial na produção, característica dos produtos orgânicos. "Como os demais produtos, eu achei que está bacana mostrar que é de um cultivo diferenciado o fato da menina estar aqui e ter um trabalho com as mãos" (CA19, 2013).

A ilustração também passa credibilidade para o produto. Um dos consumidores, por ter uma imagem positiva da Mãe Terra, comentou que a ilustração corresponde à realidade.

Eu acho que chama a atenção a fazenda, que, nesse caso, corresponde, porque às vezes tem a fazenda, mas não tem nada a ver, não é nada orgânico, não é nada saudável, então tem aqui. Chama a atenção, mas como consumidora eu sei que chama a atenção e corresponde neste caso, que dizer, eu acredito que sim. (CA28, 2013)

Ela também transmite sensações positivas que dificilmente seriam passadas apenas com informações textuais. "As cores e a motivação, né? Um campo, com frutas, remete a gente para um lugar que eu, por exemplo, adoro. Mato, campo, sol, ar livre, a embalagem te remete para isso" (CA21, 2013).

Os bichinhos e insetos característicos da Mãe Terra trazem um apelo positivo, porém infantil, segundo um dos consumidores, e é algo que a empresa faz questão de ter. "Acho que tem um apelo familiar pelo bichinho, corujinhas, que também é a jogada do marketing, para uma criança ir lá: 'Ah, mamãe, leva esse', e tal” (CA28, 2013).

A ilustração da fazenda circula por toda a embalagem, dando uma unidade visual. Ela também identifica a identidade visual da Mãe Terra, sendo a primeira informação a ser vista em todos os painéis, principalmente pela cor.

\section{Cores da embalagem}

Segundo o Designer1, para a escolha das cores das embalagens, o predomínio do branco na embalagem foi determinado usando como referência as embalagens da marca própria do Pão de Açúcar, Taeq, que tem em seu conceito a questão da saúde, usando o branco como um pano de fundo das ilustrações.

Como os desenhos eram muito coloridos, ajudou [sic] também a trazer um pouco de seriedade também para não cair no infantil, que era outro ponto que a gente também tinha que cuidar (DESIGNER1, 2012).

Porém, o excesso de cor e a pouca transparência foram considerados como algo negativo, por dificultar a visibilidade do produto. A única forma para ver o produto dentro da embalagem é através da área transparente da janela, conforme podemos ver na declaração e na figura a seguir: "Acho que tem muita cor, coloração, podia ser mais transparente, não só aqui, mais coisas transparentes na embalagem" (CA10, 2013). 


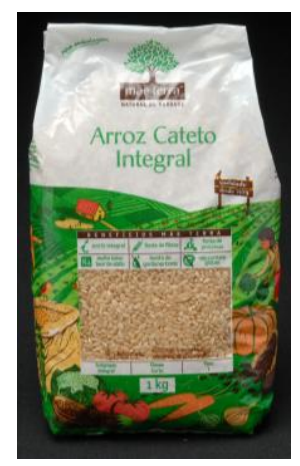

Figura 49 - Janela no painel frontal da embalagem da Mãe Terra

As cores da embalagem são as informações visuais que mais se destacam na embalagem. 0 predomínio do verde do campo na ilustração faz com que a embalagem seja vista à distância, identificando ser um produto Mãe Terra.

\section{Placa "qualidade desde 1979"}

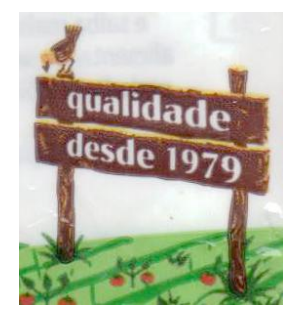

Figura 50 - Placa "qualidade desde 1979”

Segundo Designer1, a placa com a informação "qualidade desde 1979", criada na época do redesign da embalagem, reforça a imagem de tradição da empresa e qualidade de seus produtos. "Tinha a preocupação de mostrar que, mesmo renovando a embalagem, era uma empresa que já existia desde a década de 70" (DESIGNER1, 2012).

\section{Box de benefícios nutricionais}

Para a linha de ingredientes, a Mãe Terra teve a preocupação de ter um box bem claro dos benefícios do produto, apresentando de forma didática. Cada benefício é apresentado junto de um ícone simbolizando a informação apresentada de forma textual. Segundo Designer1, eles queriam destacar muitas informações e o box foi o caminho encontrado.

Tinha a questão de informar que era um produto integral, que ele não tinha, não era transgênico, que ele tinha benefícios como 'contém mais ferro, mais fósforo'. Então toda essa informação, ela ficava nesse box, que era bem central da embalagem. [...] Uma coisa que os produtos desse segmento não trabalhavam. (DESIGNER1, 2012)

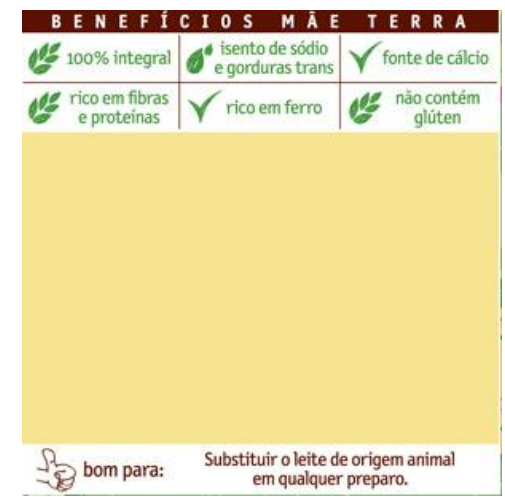

Figura 51- Box de benefícios da farinha de soja Mãe Terra 
Ao longo da pesquisa, foi observado que, na hora de separação dos produtos, os consumidores apenas olhavam a parte da frente da embalagem, poucos procuraram outras informações no resto da embalagem. Um consumidor declarou que o fato de as informações estarem acessíveis no painel frontal das embalagens, dentro do box de benefícios, era uma coisa positiva. "Ah! Também que tem informações [aponta o box], assim, acho que é legal" (CA09, 2013).

Não precisar procurar na embalagem as informações necessárias para saber se o produto era saudável ou não foi considerado positivo por um dos consumidores: "O importante são essas informações assim na frente da embalagem. 'Não contém glúten' e tal, bem fácil de você ver. Isso me chama a atenção. Não tem que ficar procurando" (CA10, 2013).

A janela transparente, dentro do box, permite a visualização do produto. Poder ver o produto foi considerado importante para separar como mais saudável. Isso foi observado por 7 das 28 vezes em que foi apresentado um produto de uma linha de ingredientes. 0 mesmo não acontece com os produtos de pronto consumo. "Eu acho que ver o produto é legal, principalmente no caso de farinha e açúcar, de grãos. É legal você poder ver, claro, eu acho que isso é positivo" (CA28, 2013).

\section{Tipografia}

Para a linha de ingredientes, segundo Designer1 (2012), foram usados basicamente dois tipos nas embalagens. Os textos informativos usam tipos manuscritos para parecer mais caseiro. O nome do produto, segundo ele, usa "uma tipografia um pouco mais séria, com serifa".
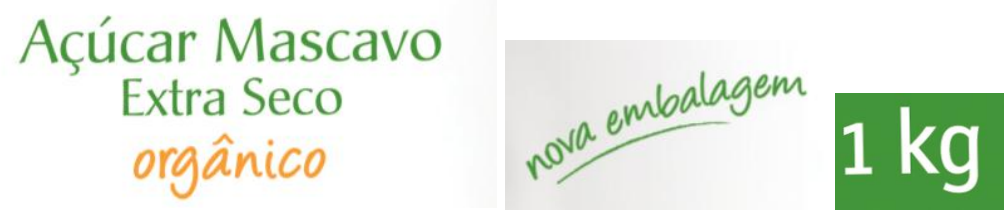

Figura 52 - Exemplo da tipografia usada nas embalagens da linha de ingredientes Mãe Terra

\section{Questões técnicas da linha de ingredientes da Mãe Terra}

A impressão em flexografia é de boa qualidade e não interfere na visualização das informações. Porém, por causa da forma de fechamento da embalagem, na emenda no painel traseiro, o texto fica desalinhado, com informações ocultas, contribuindo para a falta de legibilidade.
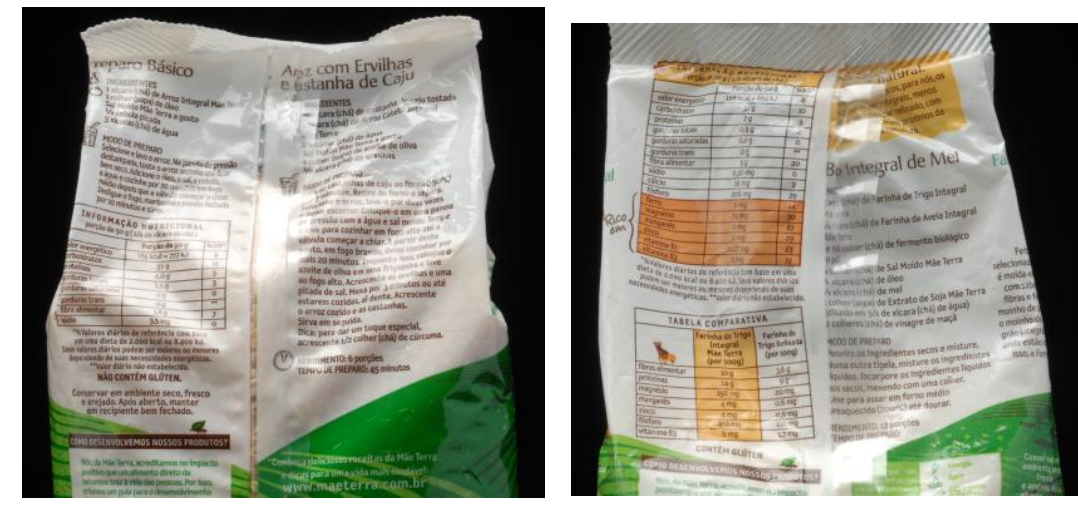

Figura 53 - Informações ocultas no painel traseiro das embalagens de arroz integral e farinha de trigo 
O material das embalagens de arroz integral da Mãe Terra é um compósito ${ }^{13}$ de plásticos, uma mistura de Polietileno de Baixa Densidade (PEBD) mais Polipropileno (PP).

\section{Aspectos ambientais da linha de ingredientes da Mãe Terra}

O material da embalagem, o plástico, produzido com um material não renovável, pode impactar mais no meio ambiente e isso também foi observado pelos consumidores entrevistados.

Então, o que eu vou falar agora é uma coisa que eu penso muito a respeito. Mas eu acho que não tem muita opção. Eu acho que a gente tinha que ter uma opção para o plástico. Mas todas as embalagens, não existe, né?, mesmo a que vem no papel vem com plástico junto, mas é uma coisa que me incomoda, o plástico. (CA21, 2013)

Por ser uma mistura de plásticos, a sua reciclagem é dificultada e tem pouco valor na cadeia de reciclagem. Caso seja reciclada, perderá algumas características técnicas, não podendo ser utilizada para a mesma função.

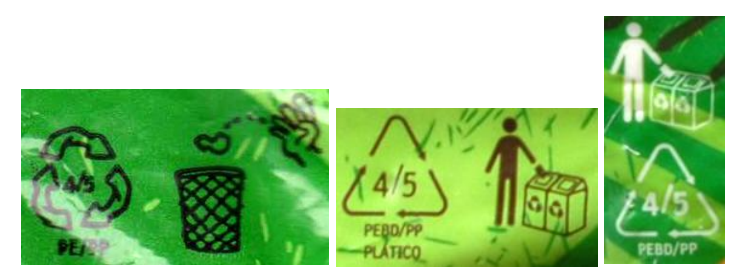

Figura 54- Identificação dos materiais na embalagem: orientação para o descarte nas embalagens do arroz integral, açúcar mascavo e farinha de trigo Mãe Terra

A informação de que material é a embalagem está bem identificada, porém a embalagem do arroz integral não segue o padrão ISO 14021 e, no texto, não especifica qual é o PE (apenas identificável pelo número). Nas embalagens da linha de ingredientes, são utilizados ícones que orientam o consumidor a não jogar a embalagem na rua e sim em uma lixeira, porém as embalagens do açúcar mascavo e da farinha de trigo integral usam o padrão ISO 14021, que ainda orienta que a embalagem deve ser descartada corretamente, separando o lixo reciclável do não reciclável. $O$ fato de não seguir um padrão dificulta a percepção do consumidor em relação ao material da embalagem e dificulta a sua futura reciclagem.

O fato de a embalagem não orientar melhor a forma de descarte foi observado por apenas um consumidor, que tem o costume de separar as embalagens por tipo de material, o único dos 29 entrevistados: "Essa questão de novo do reciclável, eu não sei em qual deles eu poderia jogar. Poderia talvez ter a 'corzinha', o 'hominho' com a 'corzinha' do lixo. Para eu saber em qual lixo mais específico para jogar" (CA12, 2013)

O gasto energético no transporte da embalagem é reduzido por sua característica flexível, que torna possível transportar uma boa quantidade de arroz por caixa de transporte. É uma embalagem leve, em comparação à de papel ou a vácuo, e por isso não pesa muito, reduzindo provavelmente o gasto de combustível.

Três das quatro embalagens apresentadas nesta pesquisa apresentam alguma informação do projeto Pensando Bem. Alguns consumidores observaram a informação na embalagem e consideraram uma informação positiva: "'Pensando Bem', que reduz energia. Mostra que é uma empresa preocupada com a sustentabilidade, com o meio ambiente, eu acho interessante" (C29, 2013).

${ }_{13}^{13}$ Plásticos diferentes combinados para a formação de blendas (misturas), com o objetivo de melhorar as propriedades mecânicas e de barreira. 


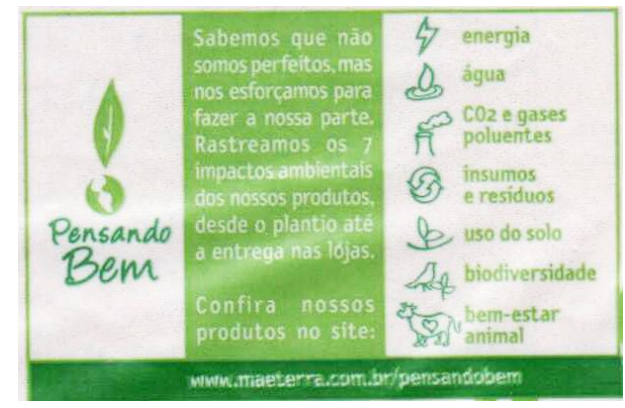

Figura 55 - Box Pensando Bem aplicado em quase todas as embalagens Mãe Terra

O box "Como desenvolvemos nossos produtos?" apresenta a carta de princípios da Mãe Terra, que inclui os princípios ambientais e de saúde da Mãe Terra. O texto muda um pouco quando a embalagem tem mais espaço e dá ênfase aos aspectos ambientais.

Aquilo que se chama cartilha de princípios, eu acho que é o cuidado na produção do alimento, você já tem uma visão, o fabricante já tem uma visão voltada para a preservação de meio ambiente e de saúde. (C05, 2013)
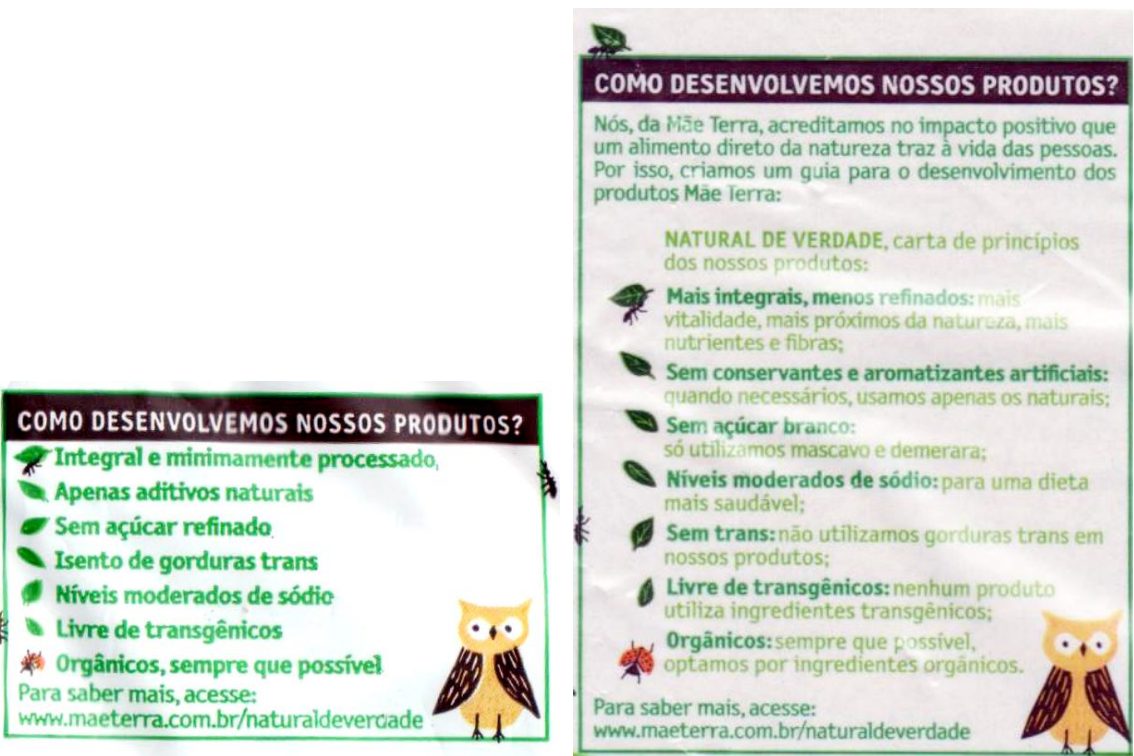

Figura 56 - Box com carta de princípios da Mãe Terra. Como é apresentada no Caseirito e nas embalagens com mais espaço.

A linha de ingredientes da Mãe Terra tem uma estrutura visual marcante que reforça a imagem da marca de produtos naturais e saudáveis. A unidade visual se dá principalmente pela ilustração e pelas cores com destaque para o verde e o fundo branco das embalagens. Nas entrevistas com os consumidores, ela foi facilmente reconhecida.

\subsubsection{Linha de pronto consumo Mãe Terra}

As embalagens dos produtos de pronto consumo foram desenvolvidas depois das embalagens de ingredientes. Segundo Indústria1, esses lançamentos fazem parte da estratégia de adequar a Mãe Terra para um público mais amplo, que

[...] quer praticidade e sabor acima de tudo. Ele quer um produto saudável sim, mas também quer praticidade, sabor e preço. Então, assim, esses produtos de pronto consumo, que estão sendo lançados mais recentemente, aí tem o Ritto, o Caseirito. (INDÚSTRIA1, 2012) 

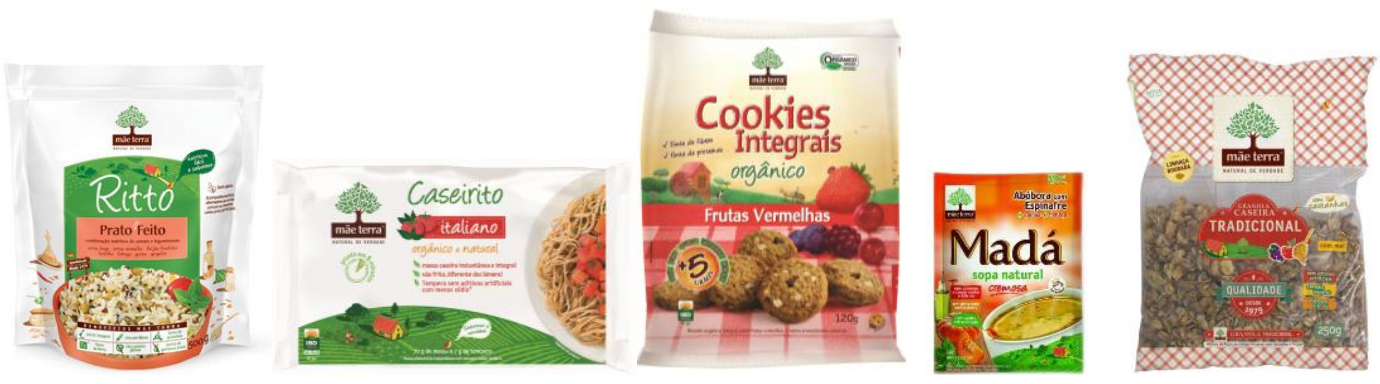

Figura 57 - Alguns produtos de pronto consumo da Mãe Terra (Ritto, Caseirito, cookies, sopa Madá, e granola)

Produtos de pronto consumo como o Ritto, o Caseirito, a sopa, os cookies e as granolas adquiriram identidades próprias remetendo a um produto mais caseiro. Nessas embalagens, eles contam com artifícios estéticos como "as texturas que imitam a aquarela", como nos cookies integrais. "[...] hoje ainda o que prevalece é a coisa do sabor e do prazer de comer. E a gente busca ter um produto que proporcione esse prazer, sabor mesmo e tal, e que a embalagem transmita isso" (INDÚSTRIA1, 2012).

As embalagens de pronto consumo, diferentemente do que acontece na linha de ingredientes, adaptam o design e provocando o appetite appeal ${ }^{14}$. As embalagens seguem o que Indústria1 (2012) declarou: que a Mãe Terra busca inovar e encantar o consumidor pela embalagem.

\subsubsection{Embalagens selecionadas para as entrevistas}

As embalagens da Mãe Terra que foram apresentadas para os consumidores para o experimento foram: arroz integral, açúcar mascavo, farinha integral, macarrão instantâneo Caseirito, barra de cereais, cookies integrais e granola. Elas foram escolhidas por terem produtos similares com a Monama e a Via Pax Bio.

\section{Linha de ingredientes}

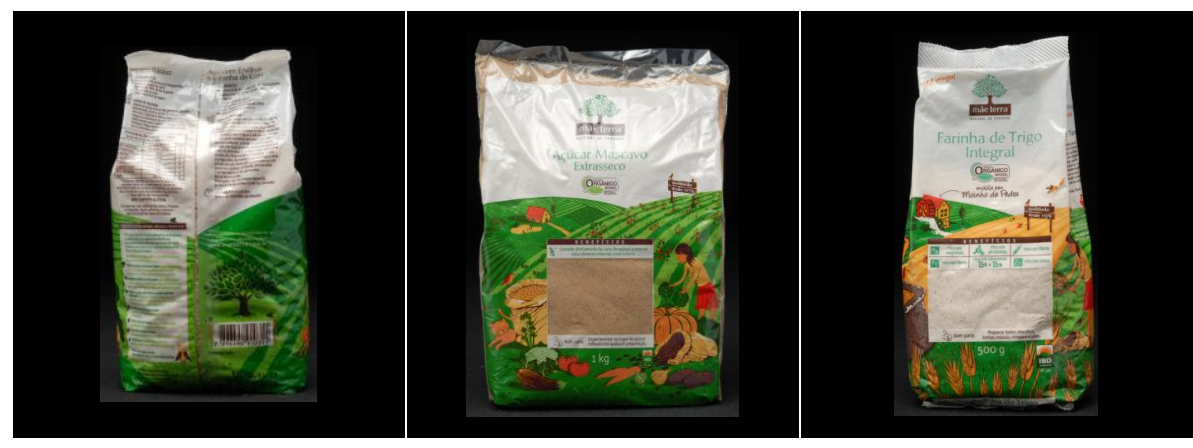

Figura 58-Arroz integral Figura 59- Açúcar mascavo Figura 60- Farinha de trigo Mãe Terra de $1 \mathrm{~kg} \quad$ Mãe Terra de $1 \mathrm{~kg} \quad$ integral Mãe Terra de $1 \mathrm{~kg}$

\footnotetext{
${ }^{14}$ Expressão usada no design de embalagens alimentos sobre o recurso visual utilizado para fazer o produto parecer mais gostoso.
} 


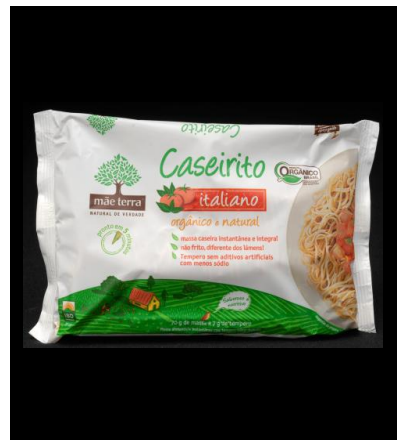

Figura 61- Caseirito Mãe Terra de $120 \mathrm{~g}$

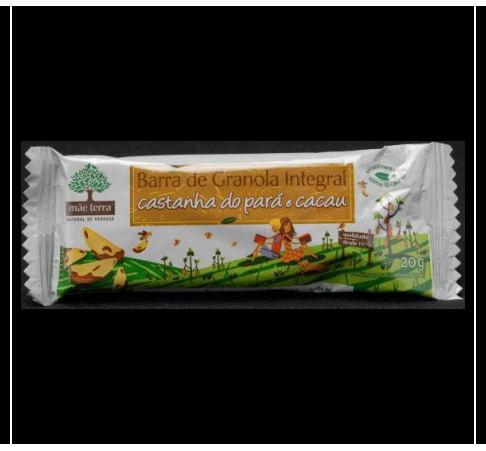

Figura 62- Barra de cereais Mãe Terra de $20 \mathrm{~g}$

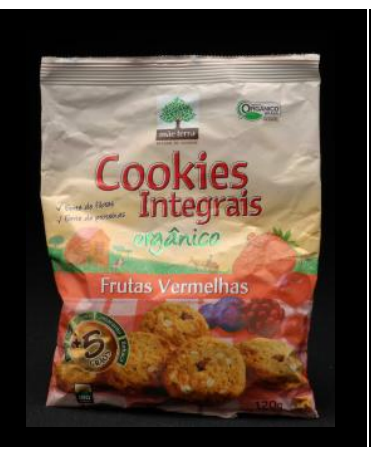

Figura 63- Cookies Mãe Terra de $120 \mathrm{~g}$

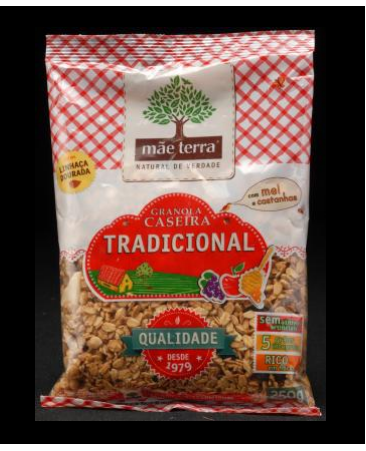

Figura 64 - Granola Mãe Terra de $500 \mathrm{~g}$

\subsubsection{Monama}

Indústria2 (2012) é a principal responsável pelo desenvolvimento das embalagens da empresa junto com a A10 Design. Para a escolha do escritório de design, inicialmente foi feita uma concorrência, em que foi escolhido o A10 Design. O critério de escolha foi a amizade existente entre as proprietárias das duas empresas, e por logo o escritório acreditar no projeto da nova empresa.

Primeiro nasceu toda essa imagem lúdica e o nome, que eu queria que a marca fosse, e depois a gente foi para os produtos que iam constar na linha, o que normalmente acontece o contrário, né? (INDÚSTRIA2, 2012)

No processo de desenvolvimento das embalagens, dificilmente outros fornecedores são chamados para pensar junto. Devido ao tamanho pequeno da empresa, ela prefere centralizar tudo nela.

Indústria2 (2012) considera importante o impacto visual que a embalagem pode causar e a sua usabilidade: "Não tem nada mais chato do que você tentar abrir uma embalagem, e ela quebra no meio do caminho [...] ou não abre" (INDÚSTRIA2, 2012).

Segundo ela, a embalagem é o principal meio para conquistar um cliente. "[...] a primeira impressão é sempre a que fica. A pessoa é assim, a embalagem e o produto é [sic] a mesma coisa. Não adianta de nada de você ter um produto incrível e a embalagem péssima (INDÚSTRIA2, 2012).

A A10 trabalha com a Monama desde 2009, quando a empresa ainda estava iniciando, e eles fizeram desde o trabalho do naming ${ }^{15}$ até o desenho da marca e embalagens. Segundo Designer3, responsável pelas embalagens da Monama, os três pontos importantes para o desenvolvimento das embalagens que caracterizam o design da A10 são:

- Identidade do cliente;

- Questões mercadológicas intrínsecas ao projeto de embalagem;

- Clareza de informação.

Segundo Designer3 (2012), a clareza das informações são importantes porque o momento de compra no varejo é rápido e é importante que a comunicação seja muito focada. "[...] tanto em relação à identidade do cliente quanto em relação ao que é o produto em si. Então eu acho que isso dá clareza, dá objetividade, é um ponto muito importante (DESIGNER3, 2012)

15Uma série de técnicas e estudos de redação, linguística e tendências de consumo e comportamento adotados para encontrar um nome adequado para a marca. 


\title{
Briefing
}

As informações para o desenvolvimento de embalagens são passadas com base nas reuniões e conversas com o cliente. A Monama não envia essas informações em um arquivo só, que seria o briefing. Segundo Indústria2 (2012), não existe um modelo padrão. Para organizar tudo, a A10 possui um sistema interno que organiza esse tipo de informação e produz um documento dos pedidos.

No site da empresa, além dos produtos de fabricação própria, a Monama revende produtos de outras marcas, como a farinha e óleo de coco do Fino Coco. Esses dois produtos, a partir do ano de 2013, começaram a ser vendidos em uma embalagem Monama. Indústria2 (2012) está sempre pesquisando novas referências de embalagem, para isso ela costuma fazer visitas ao bairro oriental da Liberdade, em São Paulo.

\section{Acompanhamento da produção}

O acompanhamento da produção da embalagem, na gráfica, muitas vezes é feito pela $A 10$, mas, segundo Designer3 (2012), depende do caso: "é uma questão de acerto da agência com o cliente". Após a embalagem entrar no mercado, eles costumam avaliá-la principalmente pelas informações dadas pelo cliente, e em geral pela equipe de atendimento.

\section{Comunicação nas embalagens}

A A10 Design costuma, em geral, sugerir inclusões ou exclusões de informações na embalagem, além das informações obrigatórias por legislação.

\begin{abstract}
A Monama tem algumas coisas que eles mandam e a gente sempre analisa e vê com base na nossa experiência mesmo o que já foi feito, se aquilo é pertinente, não é. Geralmente, esses textos diversos, de marketing, que contam a história do produto, ou a história da empresa, isso tudo é sugerido por nós também. Claro que com a aprovação deles, né? No final, eles batem o martelo, mas a gente sugere tudo. Não coisas muito legais como ingredientes e afins. (DESIGNER3, 2012)
\end{abstract}

Quanto às informações das embalagens, além das informações obrigatórias da legislação, eles consideram importante que as informações relacionadas ao produto estejam em um tom bem humorado. Esse estilo de texto foi iniciado a partir das embalagens da chia e do óleo de coco. A embalagem do óleo de coco foi a primeira que saiu um pouco da linha das granolas.

\section{Relacionamento com outros setores e escritórios de design}

Como a empresa ainda é muito nova, todas as decisões da Monama são centralizadas em Indústria2, dona da empresa.

[...] no meu caso, eu sou o DNA ainda da empresa, eu ainda consigo fazer isso, mas eu sei que daqui a 10, 20 anos eu não vou conseguir. [...] deixar a agência livre para criar. Nesse ponto eu ainda não deixei eles [sic] ainda muito livres. (INDÚSTRIA2, 2012)

A A10 participou de várias decisões estratégicas. Segundo Designer3, a Monama ouve bastante as sugestões do escritório.

[...] Para gente é uma sorte mesmo, porque ter um cliente pequeno que a gente tem a oportunidade de acompanhar desde o começo, e ainda com uma pessoa que super se preocupa com o design. Então várias coisas a gente já aceitava a sugestão dela logo de cara, porque era fácil. Ela traz muitas referências para a gente também, isso ajuda. (DESIGNER3, 2012)

Como a Monama é uma empresa pequena, eles enfrentaram vários desafios, como encontrar fornecedores parceiros. 
É uma empresa relativamente pequena, então enfrenta vários desafios de lançar um produto no mercado. Não só por ser orgânico, que já tem vários desafios [...] de ser competitivo, né? [...] De encontrar fornecedores parceiros, que consigam produzir em um valor adequado. Em uma quantidade pertinente para a empresa. (DESIGNER3, 2012)

\section{Consumidores da Monama}

Ao perguntar como eram os consumidores da Monama, Indústria2 (2012) respondeu que prefere não trabalhar por público alvo, classificar por classe social ou perfil de consumo.

Eu acho que o público da Monama é todo mundo. [...] eu não faria uma empresa para um público específico. Eu acho que toda vez que você segrega, você rotula, você corre o risco de sumir do mapa. Eu quero o Brasil inteiro. Eu quero todos os consumidores. (INDÚSTRIA2, 2012)

A Monama não faz pesquisas com o consumidor de maneira formal, mas está sempre atenta a como suas embalagens são recebidas, visitando o ponto de venda e perguntando o que foi comprado, no que o público se interessou e porquê. A posição da empresa é "dar o que o consumidor quer, mesmo não achando a melhor opção", mostrando que o mais importante é atender o mercado, não optar por uma solução melhor caso ela não agrade o cliente.

Essas pesquisas são colocadas no papel para direcionar as novas melhorias nos produtos. Desta forma, as decisões são tomadas de forma rápida e todos conseguem vê-las acontecendo, sendo esta uma das vantagens de ainda ser uma empresa pequena.

Nessas pesquisas, eles perceberam que o consumidor gosta de ver o produto na embalagem. Por isso, a Monama estava mudando a embalagem da granola de papel reciclado para plástico transparente. Essa opção de embalagem já havia sido oferecida, mas na época ela tinha sido contra por considerá-la agressiva ao meio ambiente, e por passar uma imagem de produto barato, mas tiveram de voltar atrás.

\section{Logística}

A distribuição dos produtos Monama depende muito de quem é o cliente, pode ser feita por empresas de logística ou por Sedex, quando o pedido é feito pela internet. Para alguns clientes, como o Pão de Açúcar, eles mandam um caminhão.

Os produtos da Monama podem ser encontrados em 1200 pontos de venda no Brasil, em dez capitais do país. Eles têm um posicionamento de não pagar, ou de não dar nada em troca, para entrar em uma grande rede de varejo.

\footnotetext{
Não sei se você sabe como funciona o mundo do varejo, mas ele é um pouco obscuro, então às vezes a gente pede para entrar em uma grande rede e 'tudo bem, quanto você vai me dar'. Desse jeito que funciona. [...] A gente não vai pagar para entrar em nenhum lugar. É preferível não entrar do que pagar alguma coisa. E foi assim, está sendo assim. Então de um jeito ou de outro a gente acaba entrando, só demora mais. (INDÚSTRIA2, 2012)
}

Para a entrega de todos os produtos Monama, é usada uma caixa de transporte, sem variações no seu tamanho. Os fornecedores das embalagens da Monama estão em sua maioria localizados em São Paulo, o mais próximo possível da fábrica.

A Monama já vendeu seus produtos para o Chile em 2011 e tem planos futuros de exportação. Atualmente, ela quer crescer no Brasil, para depois pensar em exportar para a América do Sul, Europa e Estados Unidos. 


\section{Impacto ambiental}

Os materiais das embalagens são definidos internamente pela Monama e depois são passados para o escritório de design. No início, para reduzir o impacto ambiental das embalagens, a Monama procurou no mercado de embalagens opções de materiais biodegradáveis.

Hoje já tem uns outros, mas quando a gente lançou era importado da China, se não me engano. A quantidade de emissão de gás carbônico até aquele negócio chegar no Brasil [...] não justifica. [...] É um setor que tem muita dificuldade em lidar ainda. Porque no Brasil você não tem muitas opções ainda de embalagem para você ser sustentável assim. Não tem. (INDÚSTRIA2, 2012)

Com o propósito de ser sustentável, a primeira embalagem lançada pela Monama foi a granola em papel reciclado. Como apenas o papel reciclado não dá proteção suficiente para o produto, a granola também utiliza um saco plástico que fica em contato direto com o alimento. Segundo Indústria2 (2012), o papel reciclado tem a vantagem de não ser importado, suas matérias-primas são dos resíduos do consumo de papéis brasileiros, e por isso um material melhor do que os de origem chinesa pesquisados por ela. "No Brasil, papel reciclado é sempre consumo interno assim, aquilo nem foi para o consumidor e voltou para ser reciclado" (INDÚSTRIA2, 2012).

A gestão da Monama nunca pensou em fazer um relatório de sustentabilidade com o rastreamento dos impactos produtos, mas "não está fechada a isso", parecendo não conhecer o que é um relatório de sustentabilidade e demonstrando despreparo para lidar com as questões ambientais centrais do processo produtivo.

\subsubsection{Estratégia de design da Monama}

\section{Marca Monama}

A marca Monama foi desenvolvida com base no principal produto da empresa: a granola. Pensando nisso, a A10 Design sugeriu o nome, de origem indígena, que significa mistura.

[...] todas as ideias surgiram dessa ideia de mistura e de ser orgânico. [...] desde a nossa apresentação de todo o universo visual, a gente já pensava em como isso poderia ser aplicado em uma embalagem de granola orgânica. (DESIGNER3, 2012)

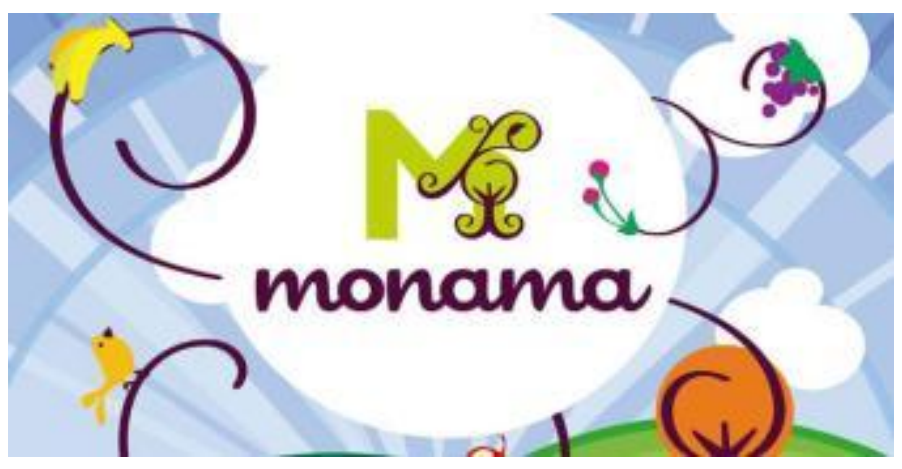

Figura 65 - Marca Monama

Para desenvolver a identidade visual da Monama, a A10 Design fez uma análise de mercado.

Na nossa análise de mercado, os produtos orgânicos, eles tinham que ter simplicidade, assim, em relação aos outros [...] eles tinham que ser simples para mostrar essa questão de não ter agrotóxico, então tem menos coisas agregadas, então a gente não usaria, por exemplo, ilustrações hiper-realistas, sabe? (DESIGNER3, 2012) 
A marca é sempre aplicada sobre o fundo branco de uma bola branca integrada à ilustração. A marca desconhecida foi percebida como algo negativo por um consumidor, incluindo o seu desenho.
O logotipo da empresa, se for esse aqui, eu acho que eles poderiam mudar um pouco, né? Monama? Não sei, pode ser alguma coisa para a pesquisa, mas não é uma coisa 'gravável'. Ninguém vai levar uma Monama. Não. Então alguma coisa que pudesse facilitar a compra. Olha, eu quero o cereal de quem? Então, não tem. Não tem uma coisa fácil de identificar de quem é ou que é barra de cereal. $(\mathrm{CC23}, 2013)$

Quando as embalagens foram apresentadas para os consumidores, apenas um dos 15 entrevistados a quem foi apresentada uma embalagem Monama já havia visto a marca, mas não comprou por não conhecer.

\section{Ilustração}

Seguindo o que foi observado na análise de mercado, a equipe da A10 Design desenvolveu uma ilustração simples para o primeiro produto da Monama, a granola, que serviu de base para outros produtos para a empresa.

[...] partindo um pouco dessa ideia elementar das coisas, a essência. Então por isso que a gente pensou em uns grafismos vetoriais, ilustrações bem simples e coloridas. Essa ideia de ser colorido, com desenhos superafáveis, isso veio muito da solicitação do cliente mesmo. (DESIGNER3, 2012)

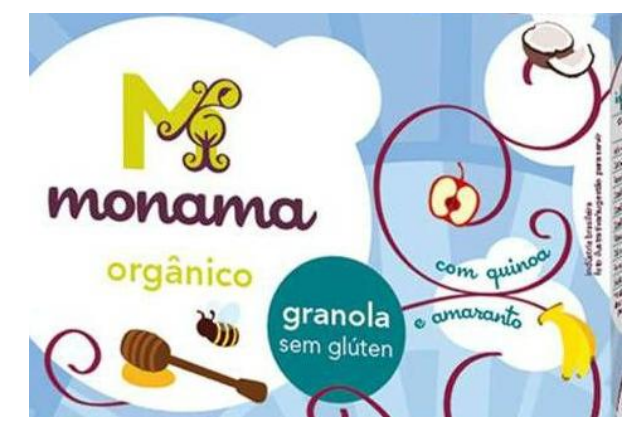

Figura 66 - Grafismos e ilustrações da embalagem de granola Monama. Fonte: Monama , 2012

Os grafismos das primeiras embalagens da Monama tinham o objetivo de passar a ideia de mistura do produto. "A gente usa esses grafismos para dar suporte e movimento para embalagem. Então, analisando os elementos, a gente usa essas bolas brancas, os grafismos" (DESIGNER3, 2012).

A composição do grafismo e da ilustração é a principal informação visual que identifica as embalagens Monama. "Como se fosse uma paisagem, que é um universo Monama. Um mundinho assim, um cenário para tudo acontecer" (DESIGNER3, 2012).

\section{Tipografia}

A tipografia escolhida para a marca Monama, segundo Designer3, é uma fonte bem desenhada e "com bastante personalidade", por isso as outras fontes usadas na embalagem têm objetivo de dar equilíbrio.

As tipografias escolhidas foram definidas logo no início do projeto para a identidade da marca e são usadas em todas as embalagens. Para os textos informativos e legais, foi escolhida a fonte Avenir, "por ser simples e informativa, combinando com a marca", que usa 
uma tipografia gestual, e a Cocktail Shaker, que é "mais desenhada e com personalidade", para dar destaque para algumas informações.

\section{Análise da marca Monama}

A marca Monama é composta por uma letra $M$, sem serifa, composta por um grafismo que remete a galhos de plantas e uma árvore. A árvore, conforme já visto na marca Mãe Terra, é um símbolo da vida e faz a conexão com a terra.

O nome, abaixo da letra $\mathrm{M}$, é escrito com tipo manuscrito, remetendo a algo feito manualmente.

A cor da marca, um verde azulado próximo à cor do pistache, pode variar conforme o suporte, puxando mais para o azul ou amarelo, podendo ser brilhante ou, dependendo do suporte, com um tom que parece sujo.

Os grafismos de galhos de plantas que compõem a marca mais os ícones de frutas e animais têm um estilo alegre, porém infantil. $O$ fundo azul simboliza o azul do céu e, segundo TiskiFranckowiak (2000), acalma e tranquiliza.

\subsubsection{Extensão da linha de produtos Monama}

Em 2012, a Monama lançou outros produtos além dos baseados na granola. Para diferenciar os produtos de linhas diferentes, o recurso utilizado é principalmente a cor do fundo, os círculos para a marca e informações do produto.

Quando a gente estendeu para o coco, esses produtos derivados de coco, a identidade, é que a gente começou a pensar em diversas questões de desdobramento da identidade dela mesmo. Mas nasceu muito conectado com a granola. (DESIGNER3, 2012)
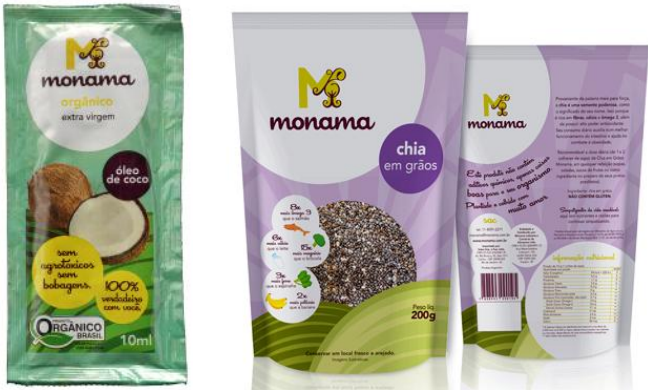

Figura 67 - Desdobramento da identidade visual nas embalagens de óleo de coco e chia. Fonte: Monama, 2012

Nas embalagens do óleo de coco e da chia, eles retiraram os grafismos da granola, mantendo ainda a imagem do morro estilizado do antigo horizonte das granolas. Segundo Designer3 (2012), no caso do coco e da chia, "as ilustrações não são tão pertinentes", pois não há a mistura de ingredientes; "[...] foram mantidos os morrinhos, a área de respiro branca para a marca e áreas reservadas para as informações se conectando ao universo Monama". 


\subsubsection{Embalagens selecionadas para as entrevistas}

As embalagens da Mãe Terra que foram apresentadas para os consumidores para o experimento foram: granola e barra de cereais. Elas foram escolhidas por terem produtos similares com a Mãe Terra.

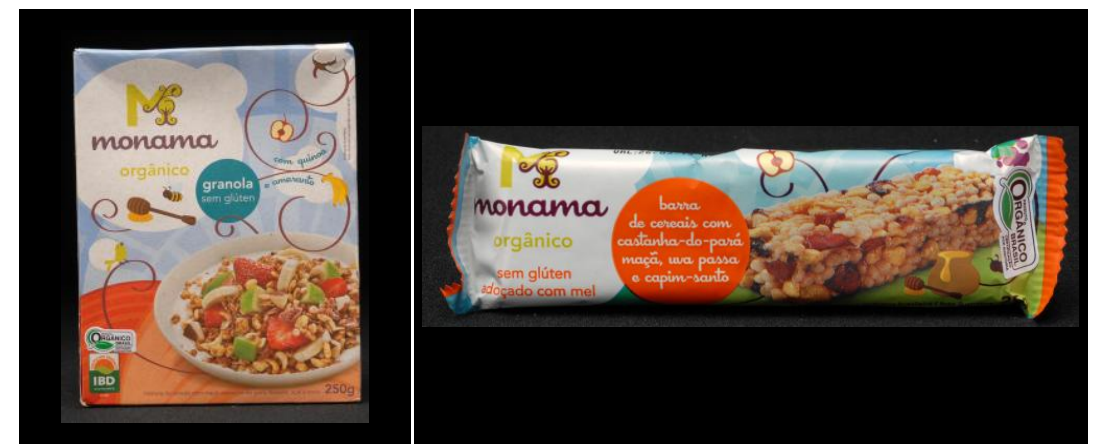

Figura 68 - Granola

Figura 69 - Barra de cereais Monama de 25g

Monama de $250 \mathrm{~g}$

\subsubsection{Via Pax Bio}

\section{Desenvolvimento de embalagens}

Para a Via Pax Vio, os três pontos mais importantes no desenvolvimento das embalagens são saúde, sustentabilidade ambiental e social, que fazem parte da visão da empresa.

Eu posso falar um pouquinho de visão de empresa. A Via Pax Bio está galgada em alguns preceitos: saúde, sustentabilidade ambiental e sustentabilidade social. Então a gente procura trazer esses três ingredientes. Nesses três chamarizes da visão de negócios, também na expressão de embalagem. Então eu partiria daí. (INDÚSTRIA3, 2012)

Todas as embalagens da Via Pax Bio foram desenvolvidas pela Sintonia Comunicação, que começou a trabalhar com eles quando ela se mudou para Joinville, em 2006, e continuavam até o dia da entrevista. A agência fez toda a comunicação da Via Pax a partir de então: desenvolvimento de website, parte de papelaria e de materiais promocionais.

Para o escritório de design Sintonia Comunicação, segundo Designer4 (2013), os três pontos mais importantes para o desenvolvimento das embalagens que caracterizam o seu design são:

- Entender a empresa;

- Entender o que o mercado está oferecendo de alternativas de materiais;

- Entender a produção do produto.

Segundo Designer4 (2013), além de entender a produção do produto, é preciso sempre acompanhar a evolução.

A empresa, durante o processo, ela também evolui, certo? Os maquinários, ela também... Então, nesse processo de criação, você tem que estar muito, você tem que imergir mesmo, uma imersão em todo o processo, principalmente com o cliente. (DESIGNER4, 2013)

A Via Pax Bio é uma empresa pequena e não é dividida em setores, por isso, para o desenvolvimento das embalagens, ela é a principal responsável pelo conceito e divulgação dos produtos junto com Indústria3 e outras empresas que participam com a consultoria.

\section{Briefing}

Indústria3 (2012) não se lembrava de haver alguma diferença no briefing para cada uma das embalagens desenvolvidas, mas até onde ele tinha conhecimento, não se diferenciavam, 
tanto que toda a linha é padronizada. As decisões foram tomadas em conjunto com a Sintonia Comunicação. Segundo Designer4 (2013), para o briefing, não foi feito um material formal, porém tudo o que foi escrito nesse período eles consideram mais do que um briefing. Esse material foi solicitado aos entrevistados, porém o que foi enviado foi apenas o texto da defesa do design da marca Via Pax Bio.

\section{Pesquisa com consumidor}

Eles não fazem nenhum tipo de pesquisa formal com o consumidor, mas, no ponto de venda, eles sempre verificam como o produto está sendo posicionado, se tem uma boa visibilidade e destaque em relação aos outros.

Designer4 (2013) declarou que sempre está sempre acompanhando o produto no ponto de venda e no cliente.

Na verdade, é um acompanhamento que vai muito além da entrega do layout [...] a equipe toda está de olho. Se está rasgando, se tem algum problema no lacre, se está sendo violado, tudo isso a gente não apenas aguarda o que o cliente nos passa como a gente também faz meio que um trabalho de campo. Até para sugerir melhorias e tal. (DESIGNER4, 2013)

\section{Produção da embalagem}

No caso da produção da embalagem na gráfica, a Sintonia Comunicação costuma não só acompanhar a produção como também verificar depois com o cliente como foi o resultado final na linha de produção e no ponto de venda. Eles perguntam para o cliente se está atendendo às expectativas e verificam se precisa de algum ajuste. A não ser que o acompanhamento na gráfica seja feito pelo cliente.

\section{Comunicação nas embalagens}

Quanto às informações das embalagens, além das informações obrigatórias da legislação, eles consideram importante constar em todas as embalagens as receitas e o selo da certificadora. Mesmo após declararem isso, todas as embalagens encontradas para esta pesquisa não possuíam o selo da certificadora. A Via Pax Bio pretende fazer revisão da linha:

A gente tem por objetivo, na hora que começar a revisão da linha, trabalhar com uma parte de simbologia que represente o que é o conceito da empresa, vinculado à parte de embalagem também, que faz parte de toda a temática, de todo o conceito. (INDÚSTRIA3, 2013)

As informações textuais são criadas baseadas no que a Agência Nacional de Vigilância Sanitária (Anvisa) exige, mas também pensando na parte promocional do produto. Eles pensam em textos que promovam o produto e informem o consumidor como pode ser usado. Sempre a primeira proposta é a agência que apresenta a partir do que o cliente pediu.

Além das informações obrigatórias pela legislação, Designer4 (2013) lembrou que costuma sugerir colocar informações de reciclagem, pois ela acha que isso pode ter um destaque um pouco maior. Como, por exemplo, a questão de como separar, o que é possível separar e o que não é possível separar para a reciclagem.

\section{Relacionamento com outros setores e escritórios de design}

A empresa sempre está atenta aos feedbacks fornecidos principalmente por seus clientes do varejo, em como o produto aparece dentro daquela loja e em que altura ou seção ele deve ser colocado. Indústria3 (2012) exemplifica com o caso dos néctares:

[...] por isso que nós tivemos, ao colocar a embalagem do néctar, tirar ele da sessão daquele corredor seco, onde estão os demais sucos, refrigerantes e afins, e colocar na seção de legumes e 
verduras, na mesma geladeira que está lá a alface. Tem também os néctares gelados. Comercialmente para a gente foi bem interessante, acho que aguçou a curiosidade do consumidor. (INDÚSTRIA3, 2013)

Para a escolha do escritório de design para desenvolver suas embalagens, eles buscaram:

Primeiro a afinidade com a causa. [...] que a gente já pregou, nesses três pilares. E uma empresa de design que também [...] nos atendam no prazo, em ideias sustentáveis também. E que tenha o mínimo de conhecimento de mercado ou então que procure se aprimorar nesse aspecto também para contribuir com a gente mais habilmente. (INDÚSTRIA3, 2012)

A troca entre a Sintonia Comunicação e o cliente é muito grande. Eles procuram ouvir o cliente, pesquisam para poder sugerir alguma coisa. Para as decisões estratégias fornecedores e o escritório de comunicação podem ser chamados.

\footnotetext{
Mas a decisão final sempre foi tomada aqui dentro da empresa. Claro que grande parte da contribuição, não sei medir percentualmente, foi feito em conjunto, então discutiram-se as ideias aqui, o que é que é o orgânico, o que é que é o mercado, como é que a gente tem que atuar como decisão estratégica da empresa. (INDÚSTRIA3, 2012)
}

A Sintonia Comunicação participou, em conjunto com o cliente, da redefinição da linha de produtos após a compra da Via Pax Bio; antes a linha era maior e precisou ser ajustada. Sobre o fundador da empresa, Designer4 (2013) afirma que ele "fazia muita questão dessa interação, que a gente fosse bastante proativo, que a gente sugerisse e participasse bastante com a opinião".

\section{Consumidores da Via Pax Bio}

Quando perguntado sobre o público alvo da Via Pax Bio, Indústria3 (2012) se lembrou de uma pesquisa que fala que o consumidor de orgânico é essencialmente mulher por volta dos 40 anos, com nível superior, público $A$ e $B$, concentrado nos grandes centros, com um a dois filhos em casa. Porém, eles entendem que o consumidor de seus produtos "é mais amplo que isso", apesar de não terem feito nenhuma pesquisa. Existe um perfil de consumidor bem interessado que está concentrado na região litorânea, próximo dos mercados hoteleiros. Outro mercado, um pouco menor, mas fiel, é daqueles que "entendem a causa e nos preceitos da empresa, não só do orgânico, mas também da causa sustentável e ecológica".

\section{Logística}

Quanto à logística de seus produtos, a Via Pax Bio compra a matéria-prima de todo o Brasil, e eventualmente importa. Sua venda é feita para todo o Brasil e se concentra nos estados do Sudeste, mas também chega aos estados do Rio Grande do Sul, Santa Catarina, Paraná, Bahia, Pernambuco, Sergipe, Ceará, Mato Grosso e Mato Grosso do Sul.

A empresa não tem foco na exportação. Eles compram a matéria-prima, embalam e processam na fábrica. $O$ transporte terrestre é feito em caminhão, por contratação diária de transportadora. Os fornecedores de embalagens em geral estão localizados perto da fábrica, nos estados de Santa Catarina e Paraná.

Quando se decidiu colocar o produto na embalagem secundária de papel cartão, foi também pensando na forma de transporte, pois ela protege o produto de duas formas: "contra impactos de perfilo cortantes e contra impactos de contato". 


\section{Pós-consumo}

A empresa não tem nenhum projeto de pós-consumo das embalagens, porém a escolha do vidro para as embalagens dos néctares e geleias foi feita pensando na possibilidade do reuso da embalagem, por ser um material inerte e durável.

A embalagem de vidro [...] no nosso entendimento, é uma das apresentações mais sustentáveis, e é o que cabe no processo de produção também de normas e segurança, e de qualidade. Nós recebemos as embalagens que são devolvidas por clientes nossos, mas nós não temos ações específicas de retorno e recolhimento dessas embalagens vazias. Nós não temos estrutura e nem capacidade para recebimento, mas a própria embalagem do néctar, ela pode ser reutilizada na casa do próprio consumidor, e colocar outros líquidos. (INDÚSTRIA3, 2012)

Nas embalagens de ingredientes, o fato de ter o papel separado do plástico é para possibilitar a reciclagem, pois eles são vendidos em um plástico, que, segundo a Sintonia, tem uma qualidade superior para reciclar, mas como não foi especificado qual é o plástico, isso não pode ser confirmado. Por ser uma embalagem fechada a vácuo, deve ser uma composição de mais de um tipo de plástico, dificultando a reciclagem.

\section{Reciclagem}

Para incentivar a reciclagem, eles colocam o símbolo de reciclagem em suas embalagens. Designer4 (2013) considera que as informações relacionadas à reciclagem devem ter mais destaque.

[...] A legislação não exige, até onde eu sei, mas acaba ocupando um espaço pequeno na embalagem. Eu acho que poderia ter um destaque um pouco maior, essa questão de como você separar, principalmente. O que é possível você separar e o que não é possível você separar. (DESIGNER4, 2013)

\section{Impacto ambiental}

A sustentabilidade ambiental faz parte da visão da empresa Via Pax Bio e o escritório de design também compartilha dessa mesma visão. Segundo Designer4 (2013), a equipe da Sintonia Comunicação tem essa consciência ecológica para todos os seus trabalhos. Eles sempre acabam sugerindo em seus trabalhos opções mais ecológicas:

[...] mesmo que a gente venha a ter um cliente que não tenha essa consciência ecológica, a gente vai fazer questão de usar essas informações com essa consciência que a gente tem, dentro da agência todos são bem conscientes e participativos. A gente percebe muito isso no nosso dia a dia. (DESIGNER4, 2013)

A Via Pax Bio não faz o rastreamento dos impactos ambientais de seus produtos, apenas o que é exigido pela certificação de orgânicos. São emitidas notas fiscais para todas as ações da empresa como a compra de matéria-prima, o carregamento para chegar até a fábrica, o processamento de todos os produtos que são colocados e vendidos no caminhão, e para tudo que compram é pedido o Certificado de Transação.

Nunca fizeram um relatório de impacto ambiental, mas praticam já várias ações para a redução de emissão de $\mathrm{CO}_{2}$ e uso de água. A fábrica está localizada no Sítio do Braço, que também tem certificação do IBD. O Sítio do Braço tem um projeto de revitalização do rio, que passa por ele, e de reflorestamento. Um terço da área é de preservação ambiental.

Para a construção da fábrica, a Via Pax Bio não aterrou a fábrica sobre pilotis ${ }^{16}$, usou tijolos de solo-cimento ${ }^{17}$, tinta atóxica, com aproveitamento de água e de luz natural. $O$ teto da

\footnotetext{
16 Sistema construtivo baseado na sustentação de uma edificação através de uma grelha de pilares (ou colunas) em seu pavimento térreo. ${ }_{17}$ Material obtido pela mistura de solo, cimento e água. 0 tijolo deste material é feito pela prensa, manual ou automatizada, dessa mistura. Após a prensa ele passa pela cura e secagem, não sendo necessária sua queima.
} 
fábrica permite a circulação do ar: o ar quente sobe e refresca o ambiente.

Telhas translúcidas permitem a passagem de luz natural. Quando necessário, usam lâmpadas frias. Isso pode ser comprovado na visita no dia da entrevista, conforme mostrado no registro fotográfico feita no dia 18 de setembro de 2012.

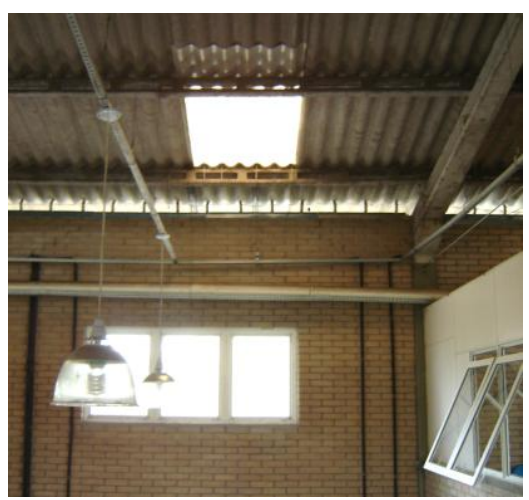

Figura 70 - Teto permite a circulação do ar e a passagem de luz natural
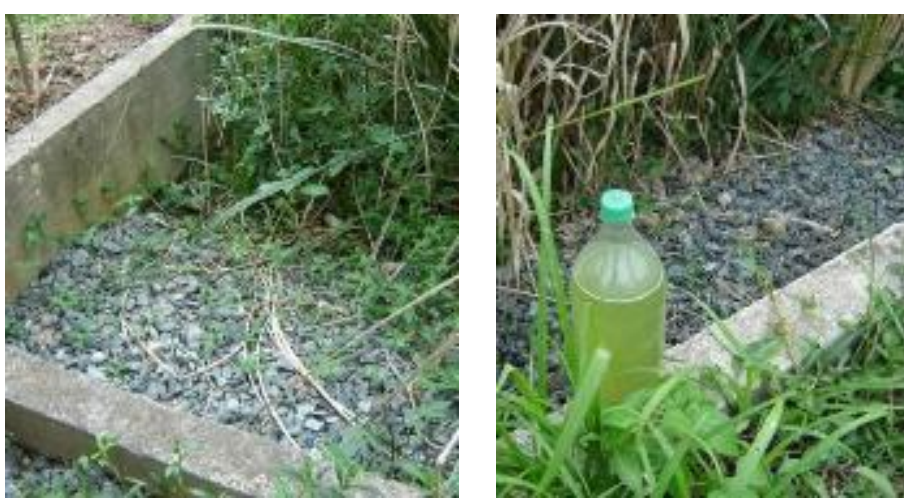

Figura 71 - Processo de filtragem do esgoto de todo o Sítio do Braço da Via Pax Bio. Garrafa com a água filtrada

A água usada vem de um poço artesiano. Após o seu uso, passa por uma estação de tratamento que usa camadas de terra, pedra, plantas e raízes para a filtragem. Depois, a água é despejada no lago do sítio. Esse sistema de filtragem não faz parte das obrigações para se obter a certificação de orgânicos, o regulamento apenas estabelece que os resíduos devem ser controlados.

\subsubsection{Estratégia de design da Via Pax Bio}

\section{Marca Via Pax Bio}

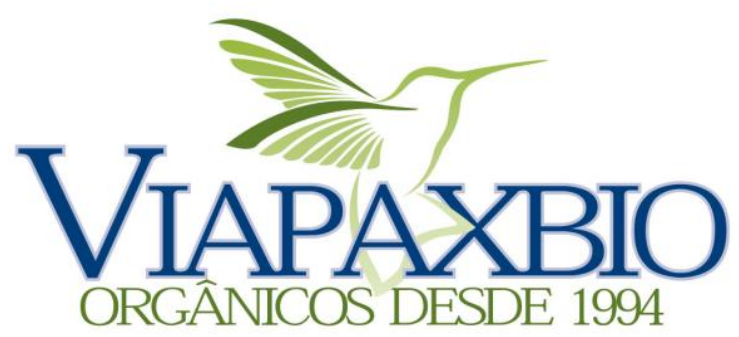

Figura 72 - Marca Via Pax Bio

O nome Via Pax Bio já existia antes da compra da empresa, porém a marca era diferente.

Era uma marca mais caseira, mais artesanal, digamos assim. Então, na época, o que ele usava era o homem integrado ao meio. Era uma logomarca [sic], assim, para ele funcionava, mas para uma empresa já com outra estrutura, maior e tal, precisava de uma nova identidade. Era como se uma nova empresa estava [sic] nascendo, então precisava de uma nova identidade. (DESIGNER4, 2013)

A marca foi criada pela Sintonia Comunicação. Para isso, fizeram um estudo para desenvolver um elemento que representasse a empresa. Foi feita uma pesquisa de mercado para conhecer as marcas de orgânicos da época, não só no Brasil, mas no exterior. Nessa pesquisa, perceberam alguns elementos que eram muito repetitivos, chegando à conclusão de que precisavam de uma identidade diferente.

Para isso, eles procuraram por elementos como o sol, a terra, o mar, o homem, a natureza, até chegar à imagem do beija-flor, que foi logo aceita. 
Porque o beija-flor, em primeiro lugar, não vive em gaiola, não tem beija-flor em gaiola. Então ele é a ave que quer a liberdade, que precisa do contato com a natureza e livre, da forma como ele veio ao mundo e como ele deve ficar. (DESIGNER4, 2013)

Para a criação do desenho do beija-flor, baseado no conceito de que ele se alimenta da natureza diretamente, eles o colocaram em uma posição ascendente para a direita, onde está se alimentando do néctar da flor.

As cores da marca também foram pensadas para viabilizar a produção, usando apenas duas cores. Depois da marca pronta, eles fizeram um estudo de aplicação de diversas maneiras, desde uma embalagem até uma serigrafia em um uniforme.

Foi sugerido pela Sintonia Comunicação colocar embaixo da marca a informação "orgânicos desde 1994", como diferencial. Em 1994, ninguém conhecia o que era orgânico. Segundo a Designer4 (2013), a Via Pax Bio foi pioneira no Brasil. Em 2006 e 2007, já havia uma disseminação bem maior do que era orgânico e, por isso, resolveram acrescentar essa informação, passando a credibilidade da marca.

\section{Análise da marca Via Pax Bio}

A marca é formada pelo nome Via Pax Bio, o ícone do beija-flor e a informação "orgânicos desde 1994". A frase passa a ideia de uma empresa tradicional e estabelecida no mercado, passando confiabilidade, porém as linhas finas perdem a legibilidade quando a marca é reduzida.

O ícone do beija-flor, em posição de voo, forma uma linha ascendente, transmitindo crescimento. Segundo o Dicionário de Símbolos de Jean Chevalier e Alain Gheerbrant (1998), os pássaros são conexões entre o Céu e a Terra.

O logotipo é formado por duas cores, verde e azul, em duas variações diferentes. A cor verde do beija-flor simbolicamente está ligada aos "campos e árvores", reforçando a ideia de um produto em equilíbrio com a natureza. A cor azul acalma e tranquiliza (TISKI-FRANCKOWIAK, 2000).

O contorno do nome em um azul mais claro diminui visualmente a espessura da letra, dificultando a legibilidade, principalmente quando aplicada em tamanho reduzido. Os tipos, todos juntos e sem espaço entre as palavras, atrapalha a leitura e pronúncia da marca. 0 significado do nome é mais forte quando as palavras são separadas, como é usado nos textos do site e material de divulgação da empresa.

As palavras da marca, de origem latina, significam: Via, caminho; Pax, paz; Bio, vida. Alguns consumidores declararam que não gostaram do nome da marca, talvez por não entenderem o seu significado ou mesmo pela forma da grafia com as palavras juntas. "É um nome muito difícil de a gente saber falar. Isso é uma coisa que dá uma certa... não é repulsa, mas é um fator negativo para a marca ter um nome tão estranho assim" (CA02, 2013). "Negativo, o nome da empresa, ele não é informativo" (CB31, 2013).

As embalagens da Via Pax Bio foram todas criadas em um mesmo momento, junto com a criação da identidade da marca.

A gente teve uma visão do todo logo de início. Isso foi bacana. Uma porque economiza tempo, e outra que você tem essa visão, você já cria a identidade da marca e utiliza como um cordão. Fica mais fácil para visualizar, fica mais fácil para definir com o cliente, fica mais fácil para o cliente visualizar como vai ser. (DESIGNER4, 2013)

Na época do desenvolvimento das embalagens, Indústria3 (2012) não participou diretamente, mas acompanhou uma parte do processo. 
A gente teve alguma participação e eu estou bem ciente do que foi a estratégia, dos preceitos para tomar as decisões, e hoje eu tenho participação 100\%, de qualquer levantamento que a gente faça, ou qualquer tomada de decisão daqui para frente, sim. (INDÚSTRIA3, 2012)

\subsubsection{Linha de ingredientes Via Pax Bio}

Todas as embalagens da linha de ingredientes foram projetadas na época da compra da empresa. Elas seguem a mesma estrutura visual e estratégia de design, se diferenciando pouco para cada produto.

As embalagens foram percebidas pelos consumidores de forma positiva, passando a impressão que a empresa teve cuidado na hora de desenvolvê-las.

Ela é uma embalagem fácil de utilizar, ela é bonita, é elegante, e tudo está bem informado aqui, e ela tem um destaque, ela não esconde o produto, está bem visível, não é daquelas embalagens que você tem que ficar olhando com cuidado, não, ela é bem bacana, está bem acessível, você identifica logo, mas eu não conheço essa marca. (CB32, 2013)

Primeiramente, foram analisados os seus elementos gráficos e textuais em comum para, posteriormente, analisar a embalagem por painel e por produto no item 4.4 deste capítulo.

A diferenciação dos produtos da linha Via Pax Bio é feita principalmente pelas cores e informações textuais específicas de cada produto. A localização e as fontes não mudam de um produto para o outro, a não ser para se adaptar às variações de altura da embalagem, que muda conforme o tipo de produto.

O design das embalagens da linha de ingredientes Via Pax Bio segue a mesma estrutura visual. Poucas informações mudam de um produto para o outro. Os textos são adaptados, mas mantêm a mesma localização.

A diferenciação dos produtos da linha Via Pax Bio é feita principalmente pelas cores e informações textuais do produto.

A análise das diferenças entre os produtos serão apresentados no item 4.4 desta dissertação. As embalagens em tamanho real estão no Anexo C.

\section{Análise do painel frontal da linha de ingredientes Via Pax Bio}

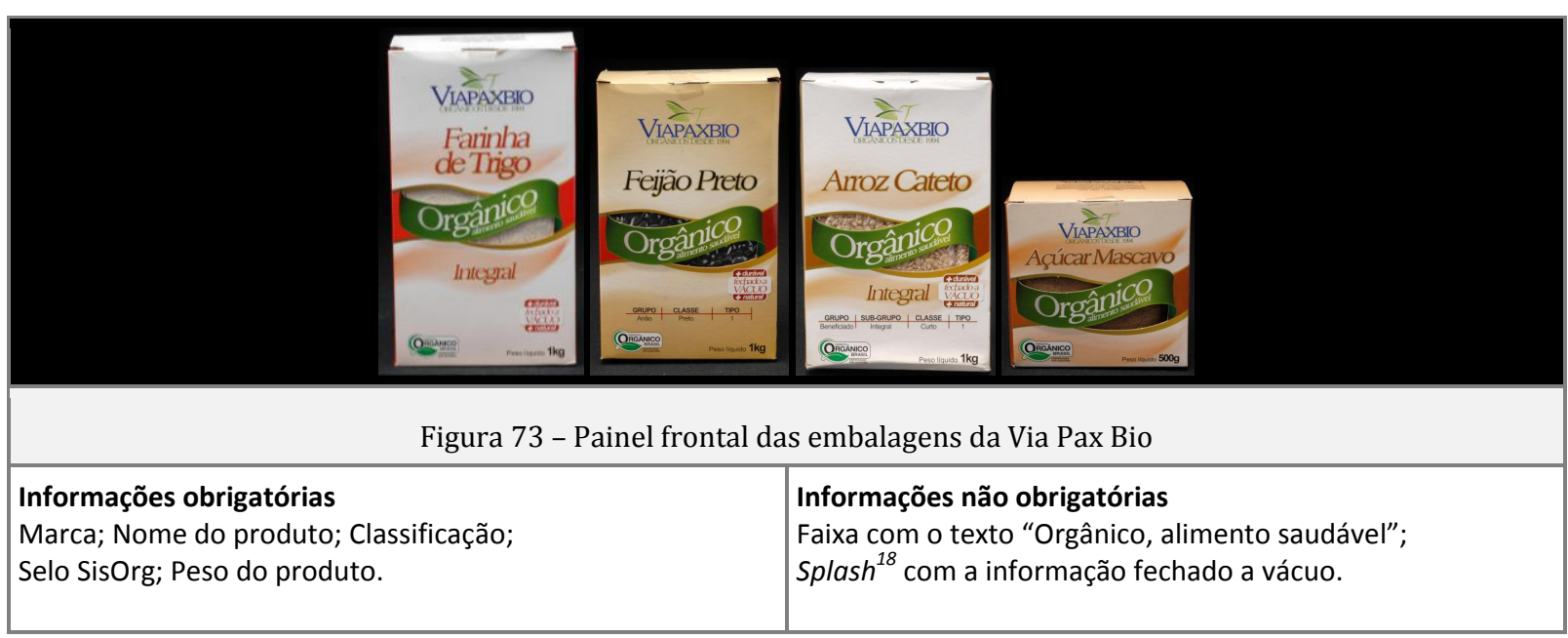

18 Termo originário das onomatopeias criadas pelas histórias em quadrinhos, nas embalagens é usado para destacar os atributos importantes do produto. 
Segundo o sentido de leitura, de cima para baixo, da esquerda para a direita, a primeira informação do painel frontal é a marca Via Pax Bio, porém a primeira informação a ser lida é a faixa verde com a palavra "Orgânico", por sua forma diferenciada e cor em contraste com o fundo branco.

A marca da Via Pax Bio é aplicada sobre um fundo claro, dando boa leitura em contraste com as cores da marca, que são o azul e o verde escuro.

A janela no centro do painel frontal permite visualizar apenas uma pequena parte do produto dentro da embalagem. Localizada no centro, ela é pequena em relação à área total do painel frontal. A área de visualização é igual para todos os produtos da linha.

A faixa verde divide ao meio a janela e tem a informação "Orgânico, alimento saudável". Essa faixa verde, por sua forma e cor, é o principal destaque desse painel, sendo mais visível que o nome do produto, mostrando visualmente, principalmente, a importância de ser um alimento orgânico e dando a identidade da linha de produtos, pois se repete em produtos de outras linhas da Via Pax Bio. Essa faixa verde fica sobre outra faixa de cor algumas vezes igual à das laterais, porém nem sempre segue uma regra específica.

A classificação do produto fica logo abaixo da faixa verde de orgânico. Sua forma de aplicação muda conforme o produto.

Abaixo da classificação do produto, do lado direito, é aplicado o splash com a informação "+ durável. Fechado a vácuo. + natural". A cor do texto é a mesma cor das laterais da embalagem. Abaixo do splash, é aplicada a informação do peso do produto, em fonte sem serifa e em cor preta.

O selo de certificação de orgânico, SisOrg, é aplicado em todas as embalagens no canto inferior esquerdo. Se considerarmos o sentido de leitura da embalagem, ele está localizado no canto de pior visualização. Porém, o olho favorece a zona inferior esquerda de qualquer campo visual, segundo o padrão de varredura. A faixa verde localizada no centro geométrico da embalagem faz com que o olho reaja a esse impulso perceptivo. A localização do selo facilita a sua leitura por estar em uma área de grande tensão visual.

O fundo em cor clara contrasta com as cores das informações gráficas e textuais, tendo uma boa legibilidade. As embalagens não usam nenhuma fotografia para ilustrar, apenas a imagem do próprio produto, que aparece pouco pela pequena janela composta com a imagem da faixa.

A tipografia escolhida também permite uma boa leitura, seja pelas cores em contraste com o fundo ou por seu tamanho.

Os elementos gráficos estão em equilíbrio, onde a faixa forma uma linha horizontal marcante e a composição centralizada, simétrica e regular, forma uma linha vertical imaginária no centro, harmonizando a sua composição. 


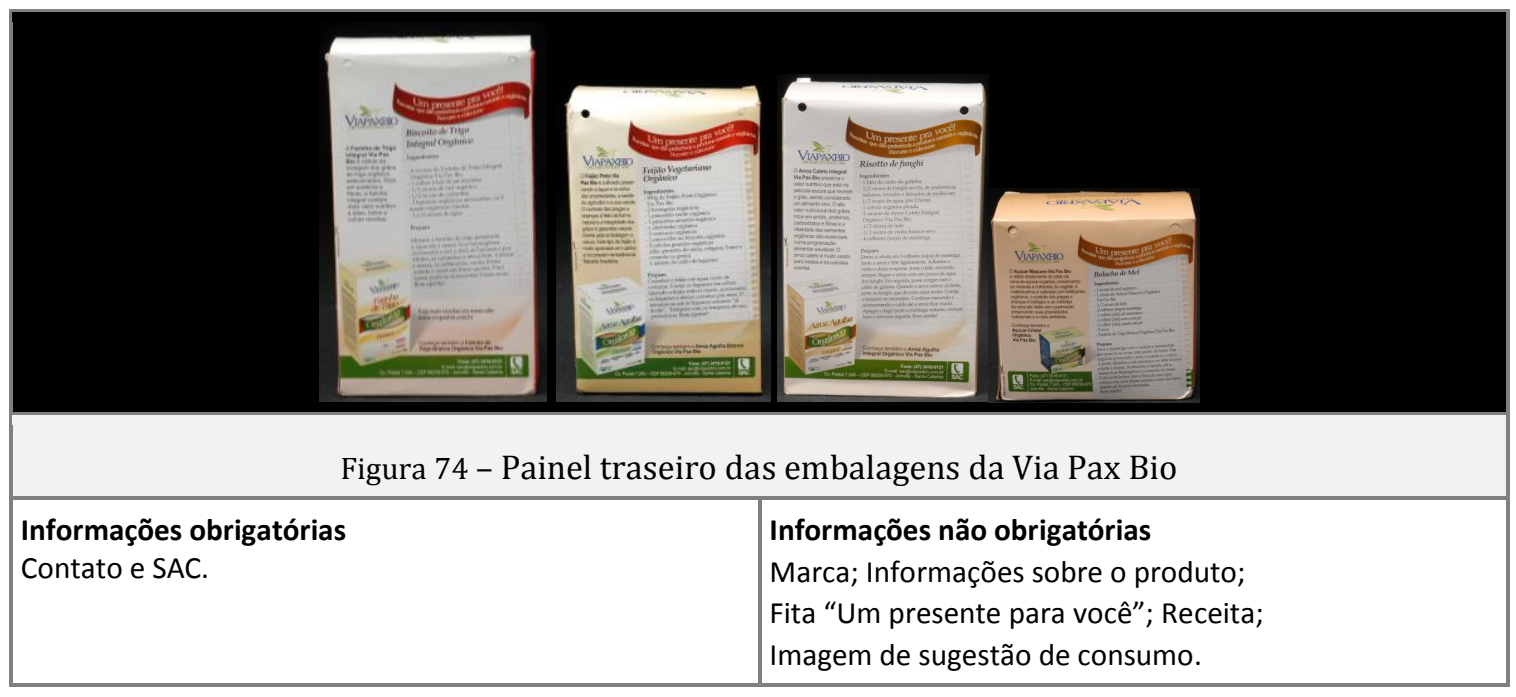

A primeira informação a ser lida neste painel é a faixa vermelha onde está escrito "Um presente para você". Ela se destaca por sua cor e forma em relação aos outros elementos visuais. Logo em seguida, vem a imagem da embalagem de sugestão de produto, por ser uma foto e se destacar visualmente em relação aos outros elementos visuais. A última informação a ser lida é o texto informativo sobre o produto, por estar localizado em uma área de menor tensão visual.

O painel traseiro das embalagens da Via Pax Bio é dividido visualmente em duas colunas, o que dá um equilíbrio visual de linhas verticais e horizontais. A coluna da esquerda, mas estreita, apresenta primeiramente o logotipo da Via Pax Bio, depois um texto com informações sobre o produto e, abaixo, apresenta outro produto da linha como sugestão de consumo. $O$ texto é bem legível, pois é aplicado sempre sobre um fundo de cor clara.

A coluna da direita começa com a faixa vermelha onde está escrito "Um presente para você", fazendo uma metáfora visual de que é um presente da empresa para o consumidor. Porém, como o texto está sobre uma curva, os tipos ficaram condensados, dificultando um pouco a leitura.

Logo abaixo, sobre uma ilustração de folha de caderno como fundo, é apresentada uma receita em um tipo com serifa e bem legível. A imagem de folha de caderno faz uma metáfora visual de receitas caseiras, que eram passadas apenas para familiares e amigos.

Abaixo da receita, aparece a informação textual da sugestão de consumo de outro produto da linha e, logo abaixo, dentro de uma caixa verde, as informações do Serviço de Atendimento ao Consumidor (SAC), que utiliza um ícone de telefone como símbolo de forma de contato.

No canto lateral esquerdo, aparece um ícone de tesoura com a informação "recorte e guarde" e, em cima, localizam-se dois orifícios, sugerindo que os consumidores guardem e colecionem as receitas.

Se considerarmos o sentido de leitura da embalagem da esquerda para a direita e de cima para baixo, o logotipo da Via Pax Bio é o primeiro a ser visualizado, finalizando a leitura com as informações do SAC.

Todas as informações têm uma boa legibilidade. O fundo de cor clara só muda na receita que é apresentada sobre uma imagem de folha de caderno. 


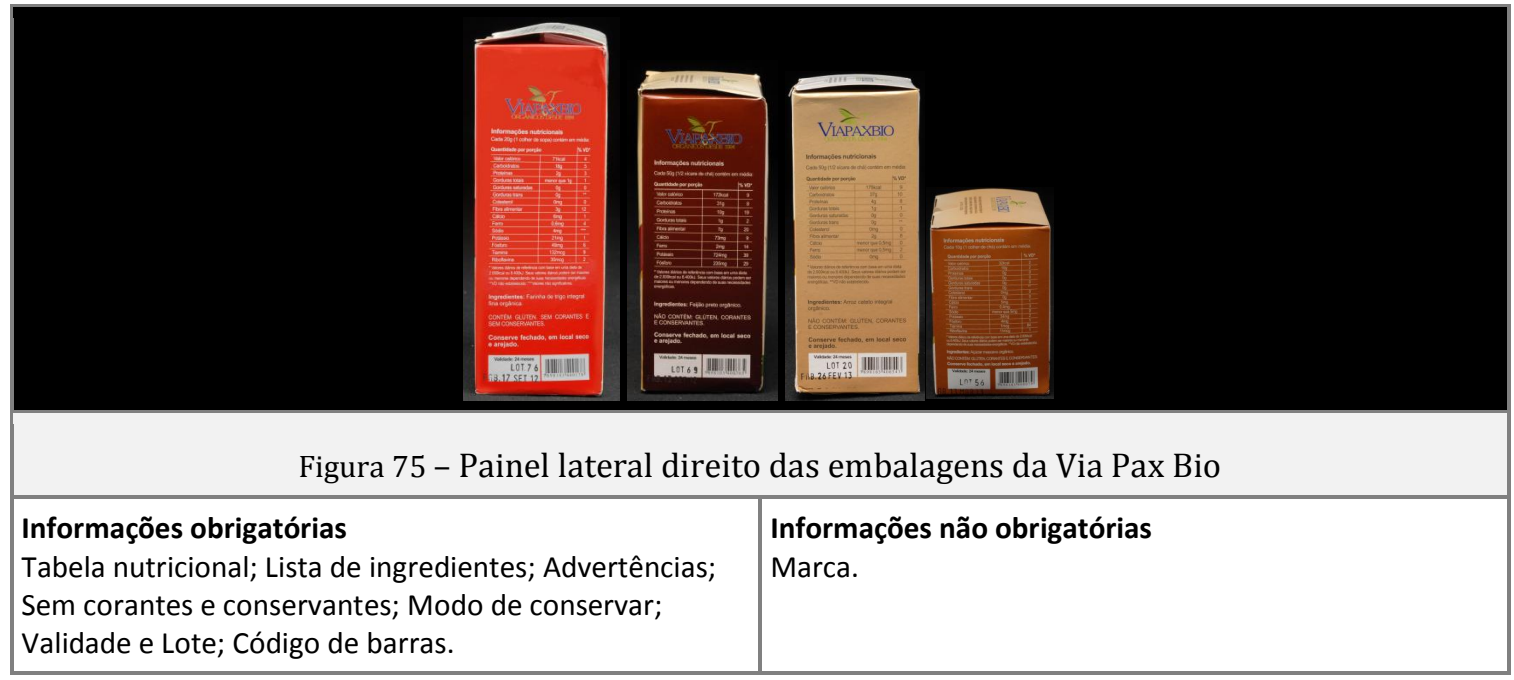

Segundo o sentido de leitura, de cima para baixo, a primeira informação do painel lateral direito a ser lida é a marca Via Pax Bio, seguida da tabela nutricional, ingredientes, advertências, forma de conservação, validade, lote e código de barras. Porém, o grande destaque aqui são as informações nutricionais do produto, com bom contraste com a cor do fundo e em um tamanho de boa leitura, mostrando uma preocupação em destacar esse tipo de informação.

A marca Via Pax Bio tem os mesmos problemas de aplicação na lateral esquerda, pois é aplicada no mesmo tamanho sobre a mesma cor. Os textos estão em cor branca, no caso das embalagens com cores escuras, e pretas, quando aplicada sobre cores mais claras.

Os ingredientes, advertências e modo de conservação são impressos com o mesmo tipo, variando apenas o negrito para dar mais destaque para alguma informação.

A validade, o lote e o código de barras são aplicados sobre caixas brancas, dando bom contraste. A área reservada para a validade é pequena. Em todas as embalagens coletadas, uma parte do carimbo acaba ficando para fora da área determinada para essa função.

\section{Análise do painel lateral esquerdo da linha de ingredientes Via Pax Bio}

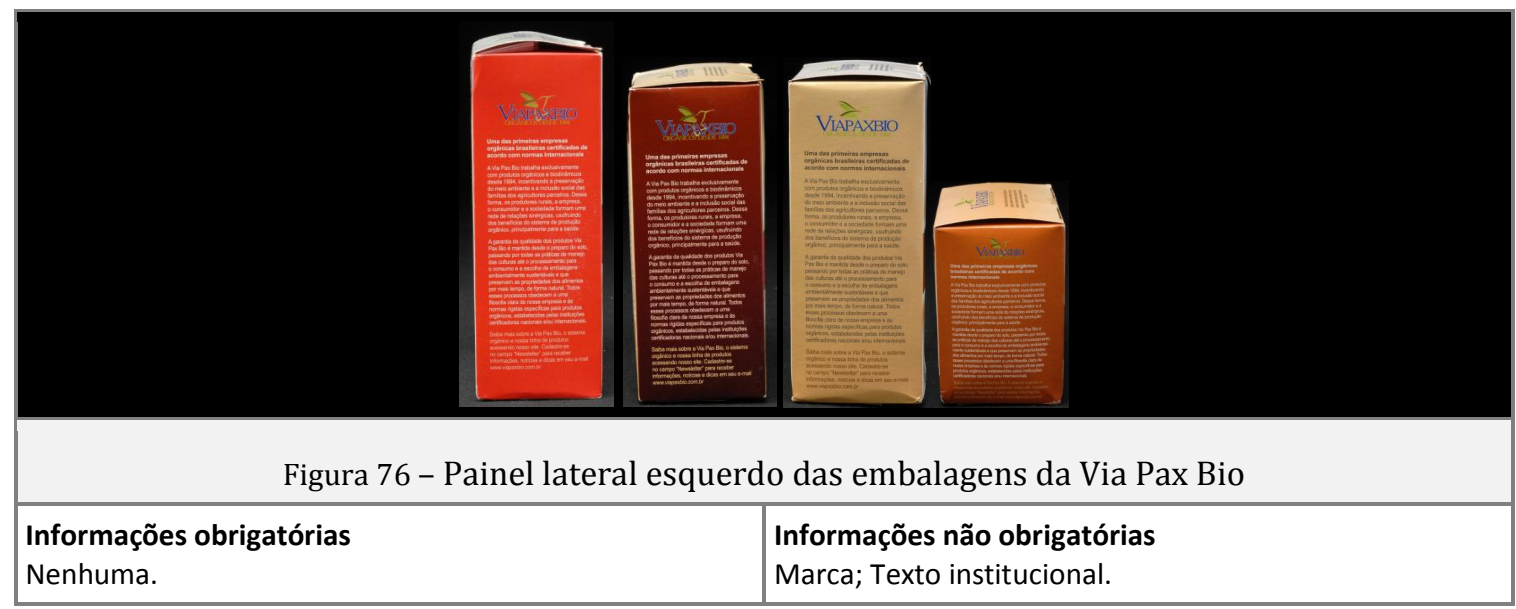

Segundo o sentido de leitura, de cima para baixo, a primeira informação do painel lateral esquerdo a ser lida é a marca Via Pax Bio, seguida de um texto com quatro parágrafos sobre a empresa. O primeiro parágrafo é o primeiro a ser lido, por estar em negrito e pelo contraste com a cor do fundo. 
O texto, que é o mesmo em todas as embalagens da linha, usa um tipo sem serifa, alinhado à esquerda. O primeiro parágrafo em negrito enfatiza a informação de que se trata de uma das primeiras empresas orgânicas brasileiras. O segundo e terceiro parágrafo, na mesma fonte, mas sem negrito, conta um pouco mais sobre a empresa e sua história. $O$ último parágrafo, também sem negrito, indica o site e forma de cadastro.

A cor do texto nos primeiros três parágrafos é branca, contrastando com o fundo colorido, e o último é impresso em uma cor em um tom mais claro, parecido com o fundo, se diferenciando dos outros parágrafos. A cor branca do texto só muda para preto nos casos em que é aplicada em fundos de cor mais clara, como no arroz integral.

A marca Via Pax Bio não fica tão legível sobre fundos de cor escura, mas ainda é possível ler. A informação "orgânicos desde 1994", por ter sido aplicada com um tipo com serifa e muito fino, não é vista com facilidade à distância.

Como a altura das embalagens muda conforme o produto, no caso das embalagens mais baixas, o texto é impresso em um tipo menor e mais condensado, dificultando a leitura, no caso do açúcar.

O texto, apesar de completo, é longo, formando um bloco visual que dificilmente será lido no supermercado antes da venda, por necessitar de mais tempo para a leitura.

O último parágrafo, por ter uma cor diferente, também acaba dificultando a leitura por diminuir o contraste com o fundo.

\section{Análise da tampa da linha de ingredientes Via Pax Bio}

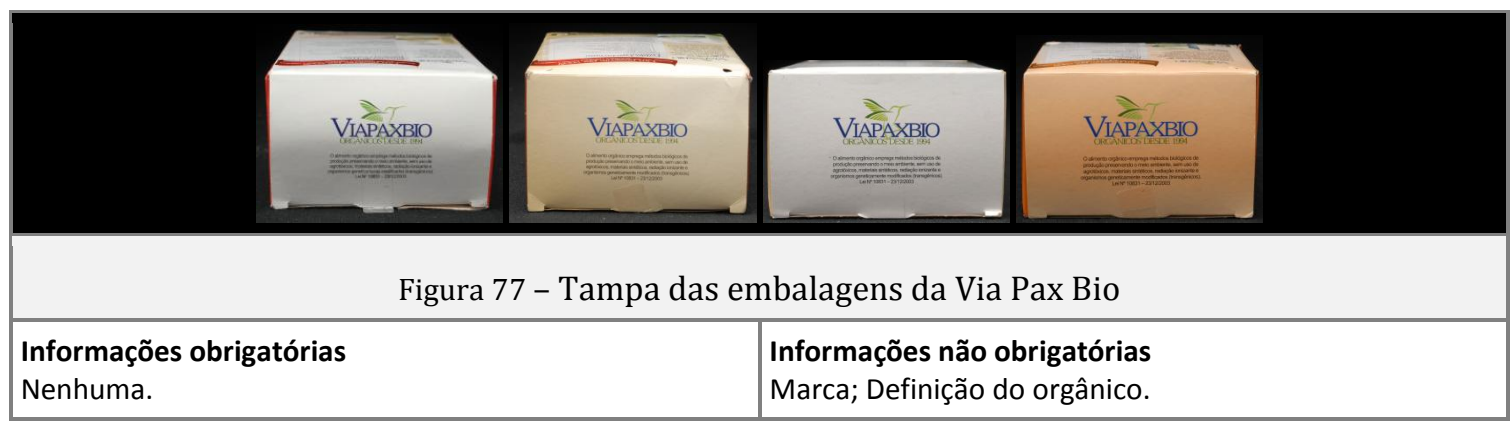

A tampa das embalagens da Via Pax Bio é composta pela marca e pelo texto da Lei no 10831 , que define o que é um alimento orgânico. Estas duas informações estão alinhadas ao centro da tampa.

O tamanho do tipo do texto da lei é bem pequeno, podendo ser lido apenas de perto. Tanto a marca quanto o texto contrastam bem sobre o fundo de cor clara, usado em toda a linha.

Na parte interna da tampa da farinha de trigo integral, é apresentada a informação de que a embalagem contém um filtro de algodão, que, conforme foi mostrado na visita à fábrica, é indispensável para o perfeito fechamento da embalagem. 


\begin{tabular}{ll|l|}
\hline Figura 78 - Base das embalagens da Via Pax Bio \\
\hline $\begin{array}{l}\text { Informações obrigatórias } \\
\text { Identificação de origem; CNPJ; SAC; Indústria Brasileira. }\end{array}$ & $\begin{array}{l}\text { Informações não obrigatórias } \\
\text { Ícones “Impresso com tintas sem metais pesados"; } \\
\text { "Embalagem 100\% reciclável"; e "Separe o plástico do } \\
\text { papel". }\end{array}$ \\
\hline
\end{tabular}

\section{Hierarquia de leitura}

Quanto à hierarquia de leitura, o painel frontal é o que contém as principais informações do produto. Os painéis laterais, por sua localização, são lidos em uma segunda etapa, mas a cor é que chama a atenção. A base é o último painel a ser lido, por estar escondido. Na gôndola do supermercado, o produto é exposto na vertical.

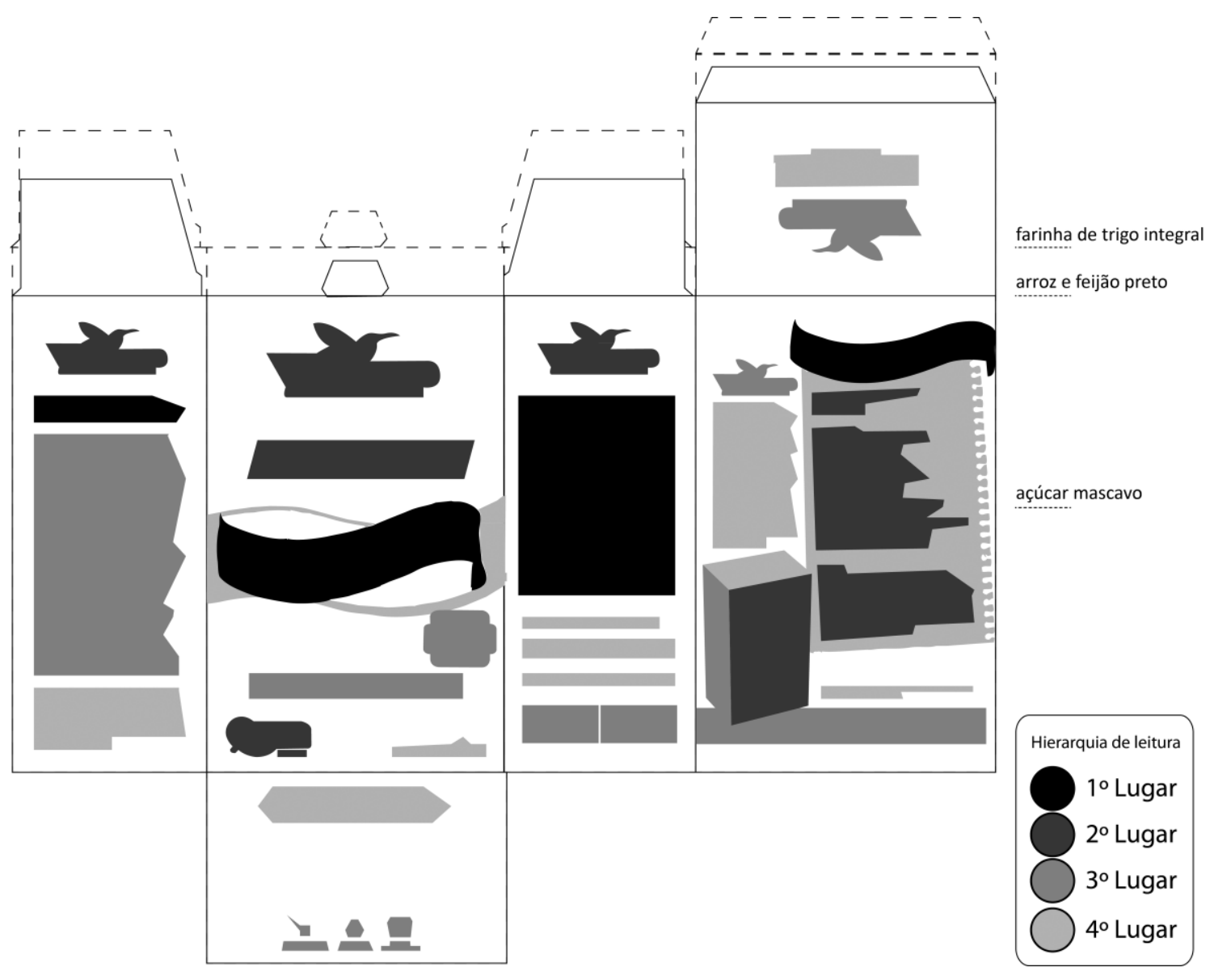

Figura 79 - Hierarquia de leitura das embalagens da linha de ingredientes da Via Pax Bio.

\section{Análise da base da linha de ingredientes Via Pax Bio}

A base das embalagens da Via Pax Bio é composta pelo endereço, CNPJ, registro no Ministério da Saúde, as informações de que foi impressa com tinta sem metais pesados e de que a embalagem é $100 \%$ reciclável, e a orientação "separe o plástico do papel".

Nos ícones de reciclagem, tinta da impressão e separação de lixo, foi utilizada a mesma cor das laterais da embalagem. 


\section{Apresentação dos dados das entrevistas}

Vários elementos visuais e textuais desenvolvidos para a linha de ingredientes são repetidos em todas as embalagens da Via Pax Bio. A seguir, alguns elementos que se destacam.

\section{Embalagem fechada a vácuo}

O fato de a embalagem ser a vácuo traz uma durabilidade maior ao produto, pois evita a proliferação de fungos, de carunchos ${ }^{19}$, insetos ou outros tipos de culturas, ampliando o seu shelf life. Tirando o oxigênio desse meio, o produto se preserva por mais tempo também. Segundo Indústria3 (2012):

A terceira característica é que quando você coloca assim, no vácuo, você pode adotar formas. Daí, entra aquela parte que o produto está sendo apresentado de pezinho. Do ponto de vista dos consumidores, isso é mais interessante. (INDÚSTRIA3, 2012):

O consumidor percebe como algo positivo, por considerar que esse tipo de embalagem preserva e protege mais o alimento: “É orgânico, fechado a vácuo, que dá uma sensação de que preserva mais os nutrientes, por ser a vácuo" (CA29, 2013).

Além disso, por preservar mais o alimento, alguns consideraram que isso passa a percepção de que a empresa tem mais cuidado com a sua produção.

\footnotetext{
Parece um produto que tem um cuidado com a embalagem. Privilegia a embalagem como processo para o produto final. [...] me chama bastante a atenção, visualmente muito bonito, e o cuidado de ser a vácuo. (CA02, 2013)
}

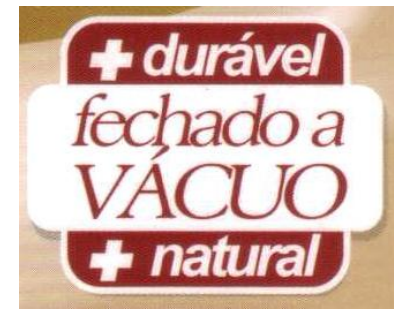

Figura 80 - Splash “fechado a vácuo”.

Apesar de chamar a atenção, e ter um splash destacando esse tipo de embalagem, alguns dos entrevistados tinham dúvida de quais seriam as vantagens. "Ele é a vácuo. Quando é a vácuo já é pronto? É isso?" (CB18, 2013); “Aqui está falando 'fechado a vácuo, mais natural', isso me chamou mais a atenção. É positivo, porque como ele é plástico, não é, mas esse 'mais natural' eu gostaria de entender" (CA31, 2013).

Segundo Designer4 (2013), a embalagem fechada a vácuo foi um grande desafio. Cada produto, por sua densidade e volume, tem alturas diferentes. O desafio foi usar o menor número de facas possível para o maior número de itens. Mesmo quando achavam que tinham conseguido, na produção dava diferença por causa da regulagem do envase.

Já que a gente estava usando a segunda embalagem, usar o menor número possível de facas para um maior número de itens possível. E nós conseguimos. Não temos nenhum problema depois da produção, deu tudo certo. (DESIGNER4, 2013)

\footnotetext{
${ }^{19}$ Besouros que atacam os produtos armazenados, como feijão, arroz, trigo, milho, farinhas, chás e outros produtos desidratados. A ação desses insetos, nos produtos armazenados, deprecia o produto qualitativamente e quantitativamente, causando perda de peso, depreciação do produto para consumo e perda do valor comercial. Possuem elevado potencial reprodutivo e alta capacidade adaptativa.
} 


\section{Embalagem em caixa de papel cartão}

Segundo Designer4 (2013), na época do desenvolvimento das embalagens da linha de ingredientes, a ideia inicial era evitar a segunda embalagem. Foram desenvolvidos projetos para disso, onde foi criada uma cinta adaptada à embalagem a vácuo. Na época, essa ideia acabou sendo inviabilizada na linha de produção. Outra possibilidade era o rótulo ser impresso na própria embalagem, o que Designer4 (2013) considera o ideal, porém nessa técnica é preciso uma quantidade muito grande por item para não ficar muito caro. Eles precisaram adotar a segunda embalagem, a caixa em papel cartão, escolhida por ser mais viável.

Para a impressão, eles pesquisaram bastante as gráficas da região de Joinville. Tudo deveria ser feito de forma sustentável, incluindo o papel, a cola e a tinta atóxica. Eles se preocuparam em colocar em todas as caixas a informação de que tinha sido impressa com tinta atóxica, pedindo para a gráfica um documento comprovando isso. Eles acompanharam a primeira impressão, feita em uma gráfica que não existe mais, a gráfica Meyer, que trabalhava exclusivamente com embalagens em Joinville.

O resultado com a caixa em papel cartão acabou sendo considerado como positivo pela indústria e pelo escritório de design.

A caixinha, ela protege de duas formas, né? Contra impactos de perfilo cortantes e contra impactos de contato. Ela tem uma melhor apresentação visualmente na gôndola, porque ela não é um produto que fica deitado, ela não é um produto que fica esparramado, ela fica em pé. (INDÚSTRIA3, 2012)

[...] destacou o produto em relação aos demais, a questão do vácuo eu acho fantástico. [...] Eu acho que, visualmente, quando eu vejo um produto a vácuo, dá a impressão que ele é mais limpo. Eu tenho essa impressão, como consumidora. E outra, a durabilidade do vácuo, não é? Então, para o orgânico, é fundamental, porque não tem nada que, nenhum aditivo que vá fazer o produto durar mais, como a farinha. (DESIGNER4, 2013).

O formato final, quadrado e em papel cartão, foi considerado uma vantagem pelos consumidores, pois é melhor para ler as informações e para guardar os produtos.

Para mim, que, quando eu vou comprar, é muito mais fácil entender que tipo de produto é esse e tal. Isso talvez tenha a ver com a caixa de papelão, tem mais espaço, não fica amarfanhado, né?, que nem no plástico. Tudo fica mais organizado. Não tenho dúvida que é mais gostoso [sic] uma embalagem de papel do que de plástico, até dá tatibilidade. (CA21, 2013)

É um produto fácil de empilhar, se arrumar no carrinho, no supermercado, é outra coisa, não é? Um saquinho na prateleira é terrível. (CC13, 2013)

Foi questionada em entrevista a necessidade do lacre na embalagem. Segundo Designer4 (2013), a caixa em papel cartão foi criada para não precisar de lacre, a lingueta tem um vinco justamente para impedir de ser aberta, mas tiveram de colocar pois foi percebido, no ponto de venda, que estavam comendo o produto, ou mesmo abriam a embalagem para ver o que tem dentro, mostrando um aspecto negativo: o de não ser transparente. Porém, Designer4 (2013) acrescentou: "Eu não incluiria". O lacre foi um dos aspectos negativos percebido por dois consumidores. "[...] aqui, é ruim para abrir. Dependendo do jeito, você vai rasgar a embalagem" (CA12, 2013); “Alguma coisa negativa? Esse 'durex' aqui em cima” (CA09, 2013).

O fato de estar em uma caixa lacrada e opaca, com uma janela pequena, foi citado com algo negativo da embalagem, pois dá pouca visibilidade ao produto.

Acho que expõe muito pouco o produto. Dá vontade de abrir a caixa e saber como é dentro. A janela é pequena e então você não pode abrir. E você vai destruir o produto, rasgar a caixa. $O$ cara vai olhar, abrir a caixa e colocar na prateleira e guardar rasgado. Só isso. (CA10, 2013) 
A visibilidade de produtos é uma informação importante no caso de produtos como as farinhas e os grãos. Isso foi pensando na hora de projetar a embalagem, também para evitar que o consumidor abra a caixa.

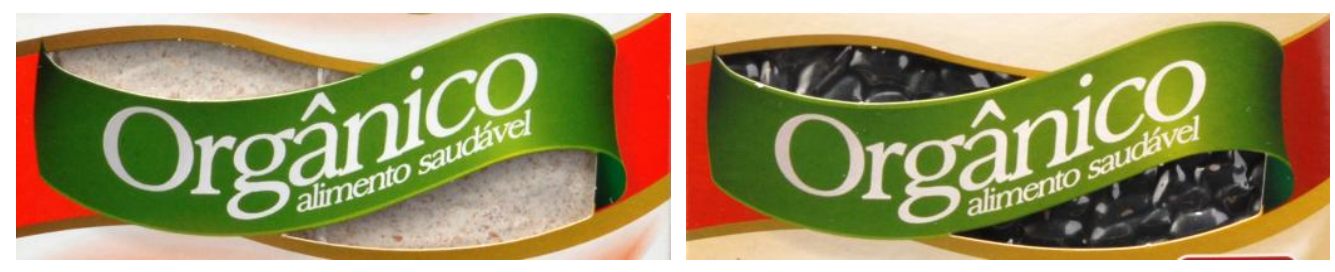

Figura 81 - Janela para visualizar o produto Via Pax Bio

\section{Cores da embalagem}

A cor é o principal elemento visual usado para diferenciar os produtos da linha de ingredientes da Via Pax Bio. Ela é usada em um tom mais forte nas laterais da caixa para uma melhor identificação do produto, e nas faixas, para dar destaque para alguma informação. Os tons mais claros similares às cores mais fortes são usados como cor de fundo para dar unidade visual à embalagem. Não há uma associação clara da cor da embalagem com a cor do produto. Designer4 (2013) exemplificou, com a embalagem da farinha integral, que é um tom um pouco mais escuro que a farinha branca.

\footnotetext{
A gente procurou diferenciar, para diferenciar produto e também, claro, tendo uma sinergia com o produto. Por exemplo, a farinha integral é um tom um pouco mais escuro, a farinha branca eu não sei se mais um azul, um mais claro. A lateral também muda, né? Tudo que é mais integral a gente procurou usar cores. (DESIGNER4, 2013)
}

Para a informação da classificação dos produtos, como no caso do feijão, a Sintonia Comunicação fez uma pesquisa para saber quais informações deveriam ser colocadas na embalagem, por grupo, classe e tipo.

Foi uma informação que nós tínhamos que pesquisar porque ainda não havia essa classificação no produto, então nós tínhamos que pesquisar, junto com o cliente, qual seria a classificação de cada item, de cada produto. (DESIGNER4, 2013)

\section{Sugestão de consumo}

Outro elemento gráfico que muda de um produto para o outro é a imagem de outra embalagem no painel traseiro da embalagem, usada como sugestão de consumo. Por não estar localizada no painel frontal da embalagem, ela não se diferencia visualmente com essa imagem, apenas pelas cores.

O produto escolhido para esta posição ou é uma variação do produto (integral ou não integral) ou é algum produto que pode ser consumido junto (arroz e feijão).

\section{Tipografia}

Para a escolha da tipografia usada na embalagem, Designer4 (2013) declarou que eles iam "sentindo o que se encaixava mais, criando uma unidade". Essa declaração mostra que a escolha da tipografia não foi técnica ou baseada em alguma teoria.

Para as informações com mais destaque e maiores, foi escolhido um tipo com serifa, bem legível, igual ao da marca. Para os demais textos, foi escolhido um tipo sem serifa, com boa legibilidade e em tamanho grande, se comparado com as outras embalagens apresentadas na pesquisa com os consumidores. As informações textuais foram consideradas legíveis em 4 
das 14 vezes em que foi apresentada uma embalagem Via Pax Bio. "Eu acho que uma coisa que sempre compromete muito a embalagem são as informações muito pequenas. Essa aqui tem letras razoáveis, e tem uma organização interessante" (CB27, 2013); "Está bem claro [sic] a tabela aqui. Está facinho [sic], letras grandes. Isso é muito legal. Às vezes você tem que ficar assim, né? [aproxima a cabeça da embalagem]" (CA28, 2013).

\section{Receita}

O fato de ter uma receita como sugestão de consumo é visto como positivo por 5 das 14 vezes em que foi apresentada uma embalagem Via Pax Bio. Ela foi sugerida pela Sintonia Comunicação. "Tem uma receitinha aqui básica, às vezes você quer fazer alguma coisa diferente e tem aqui" (CA12, 2013).

\section{Texto institucional}

O texto institucional é um texto padrão que se repete em todos os produtos da linha de ingredientes. Os consumidores que leram gostaram e acharam positivo ter esse tipo de informação, passando credibilidade.

Então, está tudo bem explicado. Eu acho. Eu acho que é uma empresa que passa credibilidade pela sua embalagem, entendeu? Porque diz aqui, está na cara, receba a newsletter, nosso telefone é tal, tem uma receitinha, informação nutricional, está claro, um pouquinho da história da empresa, contando que eles incentivam as famílias produtoras, né, os pequenos agricultores. Um alimento orgânico, biodinâmico. Bacana. (CA28, 2013)

Porém, poucos mencionaram esse texto, apenas 6 das 14 vezes em que foram feitas perguntas mais detalhadas sobre uma embalagem Via Pax Bio. Um dos consumidores observou que esse texto é muito longo e poderia ser menor.

Esse é um texto que praticamente ninguém lê, numa embalagem de mercado. Acho legal, tudo, mas acho muito grande. Acho que a comunicação do negócio poderia ser mais direta e, para quem quisesse, ter acesso à internet. (CA29, 2013)

\section{Tabela nutricional}

Um dos destaques observados pelos consumidores foi a forma de apresentação da tabela nutricional, que ocupa mais da metade do painel direito. "Outra questão positiva que eu achei interessante é a tabela nutricional estar bem visível e bem grande, fácil de acessar" (CA10, 2013).

\section{Ícones na base}

O ícone de impresso em tinta sem metais pesados utiliza a metáfora visual de uma retícula de impressão, dado técnico que nem todos os consumidores podem reconhecer. $O$ ícone de pincel acaba sumindo dentro da imagem de retícula.

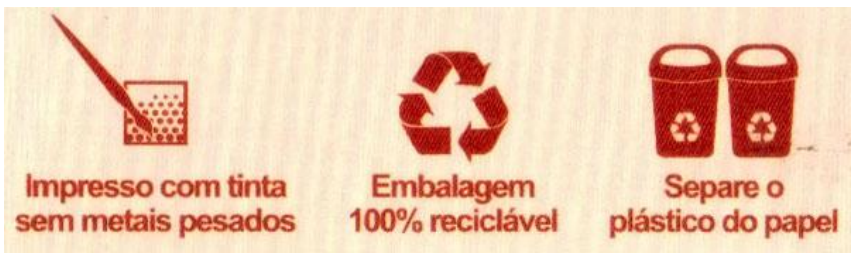

Figura 82 - Detalhe dos ícones na base da embalagem Via Pax Bio

O símbolo indicando "Embalagem 100\% reciclável" é o símbolo universal de reciclagem e, por isso, de fácil assimilação, por ser bem conhecido. 
O ícone de forma de descarte contendo a imagem de duas lixeiras sugere ao consumidor separar por tipos de materiais e não por reciclável e não reciclável, que é o recomendado no Brasil.

O conjunto das informações visuais e textuais das embalagens da linha de farinhas e grãos da Via Pax Bio está organizado de forma harmônica, principalmente pela embalagem ser uma caixa com seis faces com espaço para as informações. A distribuição está organizada de forma clara, sem muitos ruídos visuais, e de forma equilibrada, dando mais ênfase às informações textuais.

As embalagens da linha de ingredientes da Via Pax Bio passam seriedade, mas não é utilizada nenhuma foto ou ilustração que poderia transmitir algo que o consumidor se identificasse de forma não racional. Assim, destaca-se mais pelo material do que pelas informações visuais gráficas.

\section{Questões técnicas das embalagens de ingredientes Via Pax Bio}

A linha de ingredientes da Via Pax Bio usa duas embalagens de materiais diferentes.

A embalagem primária, de plástico, é envasada a vácuo, permitindo uma maior durabilidade do produto e manutenção dos nutrientes por um período mais longo do que a embalagem plástica envasada em outro sistema. Porém, não foi informado qual o plástico utilizado.

As embalagens secundárias são impressas em papel duplex, com uma face branca e outra parda, facilitando a impressão e leitura das informações textuais e visuais.

A impressão em offset na caixa permite uma boa qualidade de impressão e legibilidade das informações.

\section{Aspectos ambientais das embalagens de ingredientes Via Pax Bio}

Por serem duas embalagens e dois processos de produção, o gasto energético de matériasprimas é maior do que em outras embalagens com apenas uma.

A complexidade da logística aumenta, por haver fornecedores diferentes. A gráfica que imprimiu a embalagem, conforme indicado na sua base, é de outra cidade, Toledo no Paraná, a $671 \mathrm{~km}$ de Joinville, aumentando o gasto de combustível. Já os fornecedores dos produtos, como a farinha e feijão, vêm do leste do Paraná, próximo à fábrica.

As embalagens da linha de ingredientes da Via Pax Bio usam duas embalagens de materiais diferentes, que, após o uso, vão para duas cadeias de reciclagem diferentes. A embalagem poderia ser reduzida a apenas uma sem diminuir a proteção ao produto e diminuindo o desperdício, imprimindo todas as informações diretamente no plástico.

A embalagem primária, de plástico, é fechada a vácuo. A forma de envase a vácuo permite uma maior durabilidade. Porém, o material, provavelmente feito com um compósito de plásticos, praticamente inviabiliza a sua reciclagem, por ser difícil a separação dos materiais. Até o término desta pesquisa, não foi descoberto nenhum material plástico que pudesse ser usado sem ser uma mistura de plásticos. A embalagem secundária, em papel cartão, é reciclável e tem grande valor na cadeia de reciclagem.

O símbolo usado para indicar a frase "100\% reciclável" é o símbolo universal de reciclagem. Esse símbolo e a mensagem especificam quais são os materiais usados nas embalagens primária e secundária. 
Na base da embalagem, é possível encontrar informações sobre a tinta impressa e a forma de descarte - principalmente a informação da tinta impressa. Comparada às outras embalagens pesquisadas, é a única que apresenta essa informação.

Segundo Indústria3 (2012), faz parte da premissa de impressão das embalagens de papel não usar tintas com metais pesados. A ideia de usar esse tipo de tinta e de destacar na embalagem veio da Sintonia Comunicação, com o objetivo de a embalagem ser mais sustentável e dentro do que os fornecedores da região de Joinville poderiam oferecer.

Inclusive, a gente pediu para a gráfica nos mandar um documento para a gente ter a comprovação disso que a gente estava colocando. Até para a gente não fazer propaganda enganosa. Eles nos mandaram um documento para a Via Pax para a gente não correr nenhum risco nesse sentido. (DESIGNER4, 2013)

A iniciativa de imprimir a embalagem com tinta sem metais pesados, quando vista, foi elogiada: "E aqui eu encontrei algumas informações que eu não encontrei nas outras. Por exemplo, isso foi impresso com tinta sem metais pesados. Isso é uma informação que eu não vi em nenhuma outra" (CA21, 2013).

A informação "Separe o plástico do papel" foi percebida como insuficiente para um dos consumidores, que tem o costume de separar por tipo de material:

[...] e aqui também... separe o plástico do papel. Está. Mas e aí? E o plástico sujo? Depois que eu usei a farinha, eu não sei como é que vai ficar depois. Eu vou ter que lavar o plástico, não vou ter? Jogo no de plástico mesmo ou jogo no de... que esteja sujo. (CA12, 2013)

O texto no painel lateral direito informa que a empresa tem práticas e processos que obedecem às normas dos orgânicos, reduzindo o seu impacto no meio ambiente, desde a escolha das embalagens até inclusão social das famílias produtoras de orgânicos.

O texto institucional com as informações das ações socioambientais da empresa, quando lido, foi percebido como positivo.

Nossa, que legal! [...] Essas informações. Incentivando a preservação, a inclusão social das famílias dos agricultores. [...] isso aqui é uma coisa superimportante e é tão... [Faz sinal de pequeno] Eu não tinha lido ainda. Eu achei legal porque não é só o produto, tem benefício mais amplo, tem uma garantia da qualidade, uma embalagem sustentável. Ambientalmente sustentável. Legal isso. (CA31, 2013)

\subsubsection{Linha de néctares, geleias e polpas}

A Via Pax Bio começou como produtor de geleias e néctares. Um novo design de embalagens foi feito após a compra da empresa. O design das embalagens mantém o padrão visual das embalagens da linha de ingredientes. Apenas o design das embalagens de polpa de tomates foi criado em 2011.
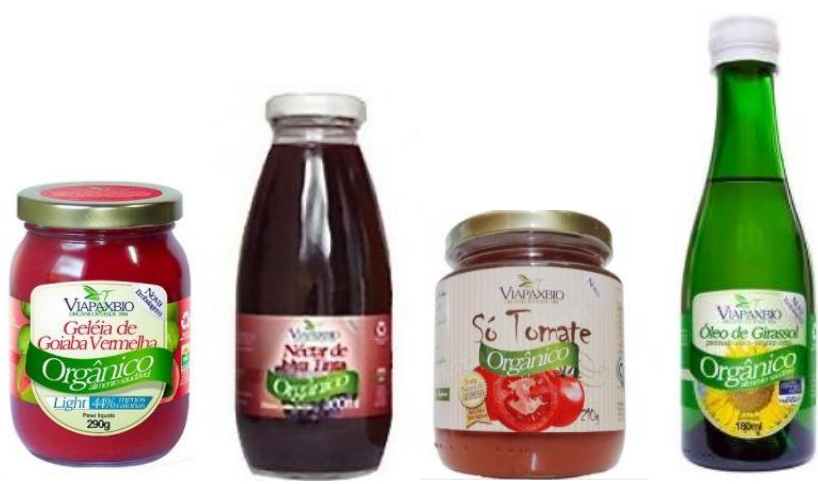

Figura 83 - Geleia, néctar, óleo e polpa da Via Pax Bio em emblagens de vidro. Fonte: Via Pax Bio, 2012 
As frutas usadas nas geleias e polpas são compradas in natura, inteiras, na forma de polpa ou concentradas. As frutas congeladas são mantidas em câmaras frias, conforme a foto abaixo, tirada no dia da visita à fábrica.

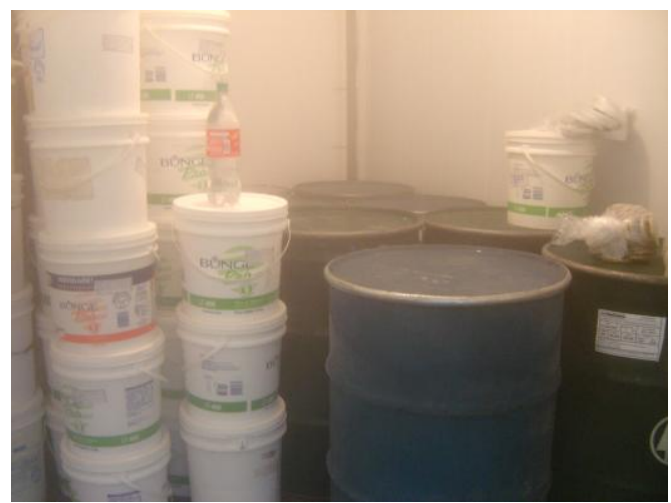

Figura 84 - Câmara refrigerada a $-14^{\circ} \mathrm{C}$, onde são estocadas as frutas.

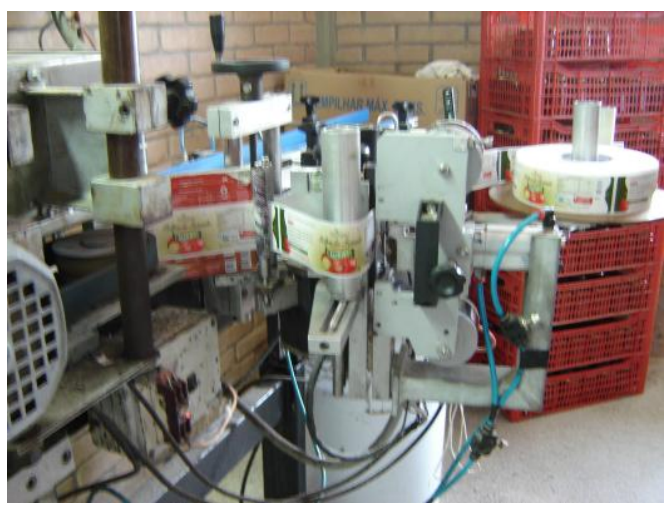

Figura 85 - Máquina rotuladeira da fábrica da Via Pax Bio

Os rótulos são aplicados nas embalagens de vidro em uma máquina rotuladeira. A compra dessa máquina foi um dos motivos de mudança no design das embalagens, que antes era previsto para impressão offset. Os rótulos para esta rotuladeira são impressos em serigrafia.

Na época, a Via Pax havia adquirido uma rotuladeira, então, na verdade, o processo vai mudando [...]. Nós recebemos no briefing que a Via Pax iria imprimir o rótulo em gráfica de offset. Nós criamos fundo, sombra, detalhes etc. Não houve uma preocupação tão grande com tamanho de fonte, porque a offset é tranquilo [sic] para produzir assim. E, ao longo do processo, foi que essa rotuladeira, enfim, eles iam imprimir e rotular por um novo processo, a serigrafia, e aí houve algumas perdas, se você tiver alguma embalagem original, algumas até sofreram avarias gravíssimas. (DESIGNER4, 2013)

Para as novas embalagens, o material das embalagens em vidro foi um consenso entre a indústria e o escritório de design. Para a escolha, foram levadas em conta as questões ambientais, principalmente quando comparado à embalagem cartonada tipo Tetra Pak, que foi outra opção considerada nesse período. Designer4 (2013) também reafirmou que o vidro foi escolhido pela possibilidade de reuso pelo consumidor e facilidade de separação dos materiais para a reciclagem.

O vidro é reutilizável. [...] a dona de casa dificilmente vai jogar o vidro fora, ela vai ou dar para uma vizinha que faz geleia ou vai entregar para alguma empresa que recicla. Acho muito difícil jogar o vidro no lixo, assim. Pelo menos já não é padrão, então você já pensa duas vezes, pensa na questão da reutilização. (DESIGNER4, 2013)

As embalagens são compradas de um distribuidor local, sendo as de vidro fabricadas em São Paulo.

\subsubsection{Embalagens selecionadas para as entrevistas}

As embalagens de néctares, geleias e polpas não foram incluídas nessa fase porque as outras empresas selecionadas não possuem produtos semelhantes e com o mesmo tipo de embalagem, impossibilitando a triangulação dos dados.

As embalagens da Via Pax Bio que foram apresentadas para os consumidores para o experimento foram: feijão preto, farinha de trigo integral, açúcar mascavo e arroz integral, conforme mostrado abaixo. Elas foram escolhidas por terem produtos similares ao da Mãe Terra. 


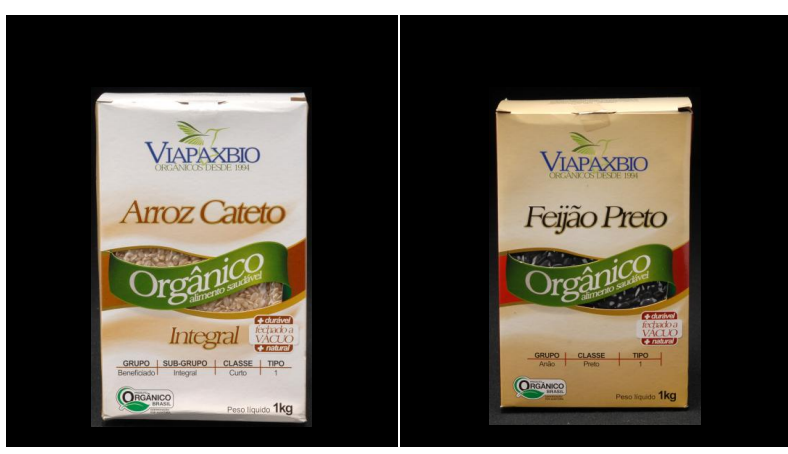

Figura 86 - Arroz integral Figura 87 - Feijão preto Via Via Pax Bio de $1 \mathrm{~kg}$
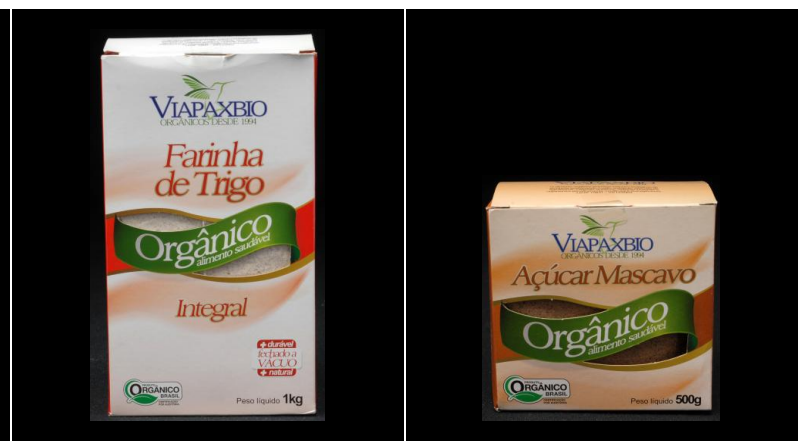

Figura 88 - Farinha de trigo Figura 89 - Açúcar mascavo integral Via Pax Bio de 1 kg Via Pax Bio de 500g

\subsection{PERFIL DOS CONSUMIDORES ENTREVISTADOS}

Foram entrevistados 32 consumidores de alimentos industrializados. Destes, três foram retirados da análise final: dois por terem sido apresentados grupos de produtos diferentes do padrão das outras entrevistas e o terceiro por falha no gravador e na câmera. Dos 29 contabilizados, cinco são do sexo masculino e 24, do feminino. Em relação à faixa etária, o gráfico seguinte mostra sua distribuição.

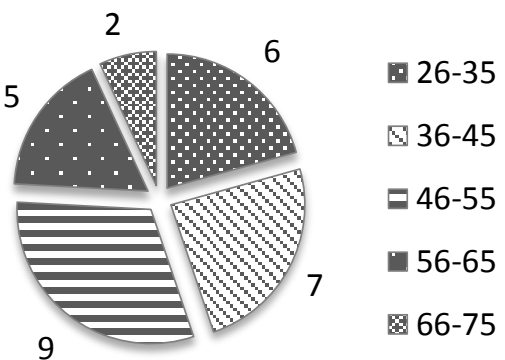

Gráfico 2 - Distribuição de consumidores por idade

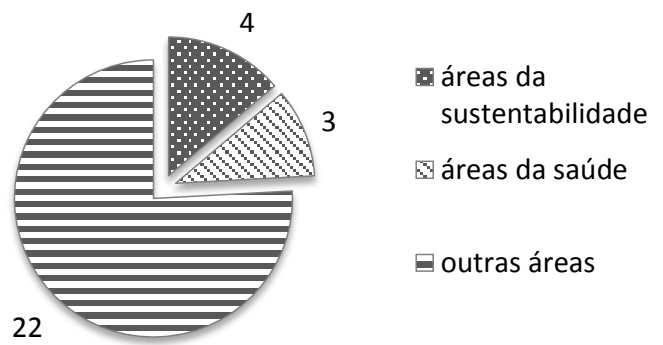

Gráfico 3 - Formação e ocupação

Quanto à formação e ocupação dos consumidores, quatro eram de áreas relacionadas à sustentabilidade, três da área da saúde e 22 de outras áreas. Foram excluídos profissionais das áreas de design, publicidade, pesquisa ou de outras áreas envolvidas no desenvolvimento de embalagens.

Foi questionada qual era a rotina de refeições dos entrevistados para poder entender qual era o grau de familiaridade com os produtos apresentados. Primeiro, foi perguntado, antes da entrevista, se o entrevistado era o responsável pela comida da casa, e 16 dos 29 entrevistados são os responsáveis pelas refeições. Para esses, foram escolhidos produtos que necessitassem de mais preparo e fossem menos processados.

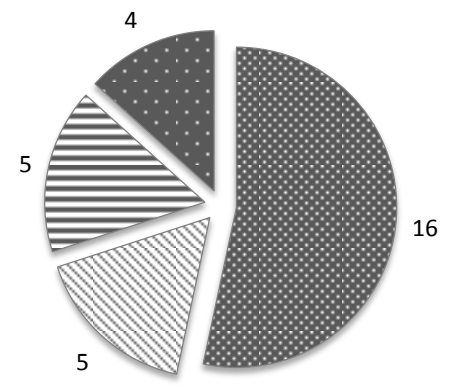

[0. Entrevistado

@ Empregada doméstica

ĐOutra pessoa da família

- Compra comida pronta

Gráfico 4 - Costume de preparar as refeições em casa

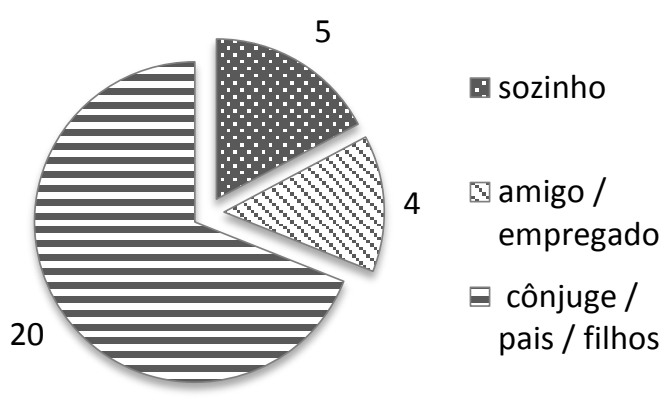

Gráfico 5 - Pessoas com quem mora 
Também foi questionado com quem o entrevistado morava. Para os entrevistados que moravam sozinhos e não cozinhavam, foi dada a preferência para mostrar alimentos de pronto consumo. Vinte dos entrevistados moram com algum familiar, cinco moram sozinhos e quatro dividem a casa com outra pessoa sem nenhum relacionamento familiar.

Quanto aos hábitos de compras dos entrevistados, foi pedido para que fossem citados os três estabelecimentos nos quais compram alimentos com mais frequência. Em primeiro lugar, apareceu o Pão de Açúcar, com 19 citações; em segundo, o Carrefour, com 12 citações; e em terceiro, com 10 citações, o Extra.

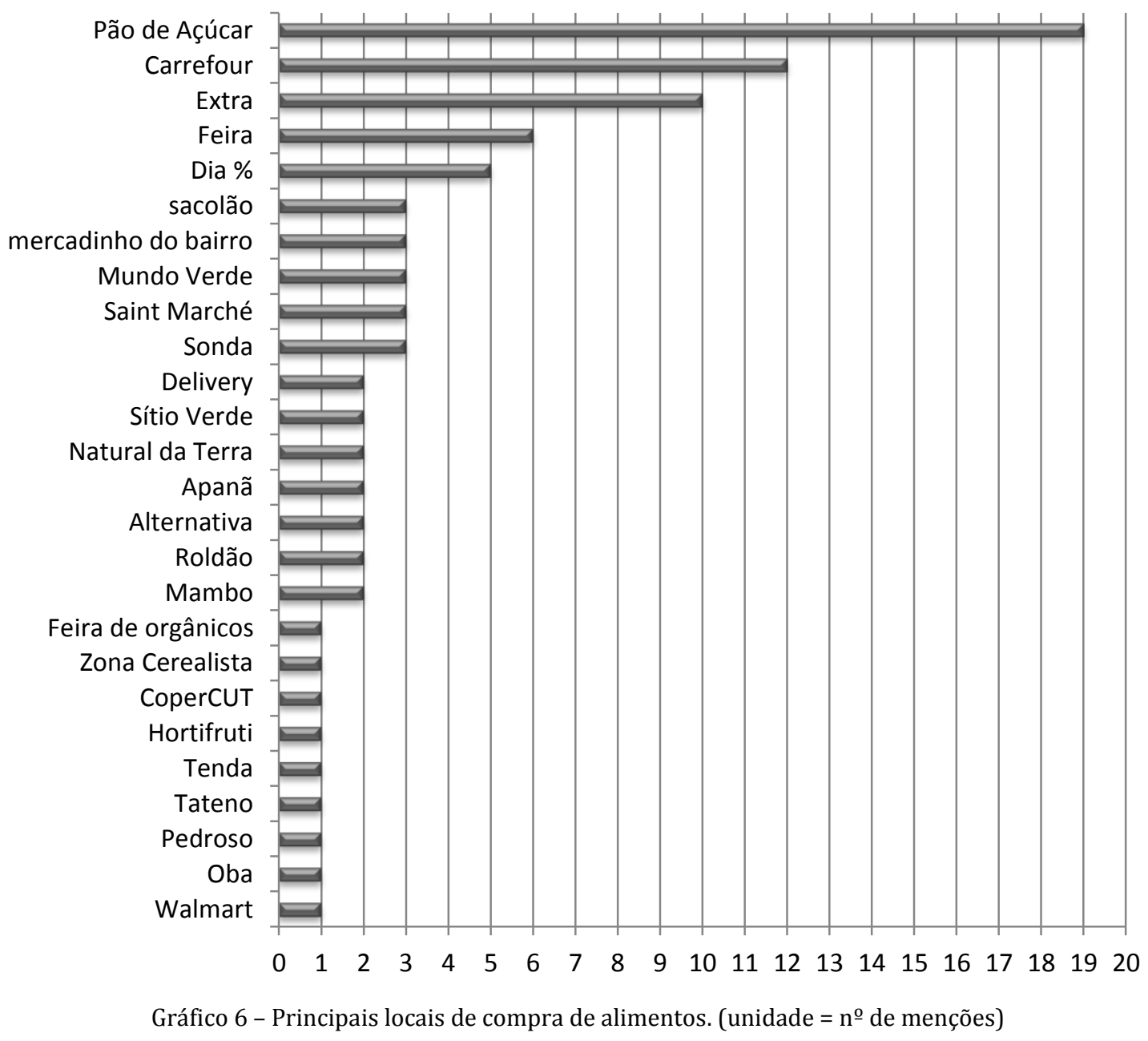

Sobre os hábitos de compras dos entrevistados, foi perguntado se eles faziam lista de compras ou algum tipo de planejamento antes de ir ao local de compra, para verificar o grau de influência de venda da embalagem na hora da compra. A maioria, 20 pessoas, falou que costuma fazer lista de produtos antes de sair de casa, sete declararam que planejam, mas não costumam fazer uma lista escrita, e apenas duas pessoas costumam comprar sem planejar.

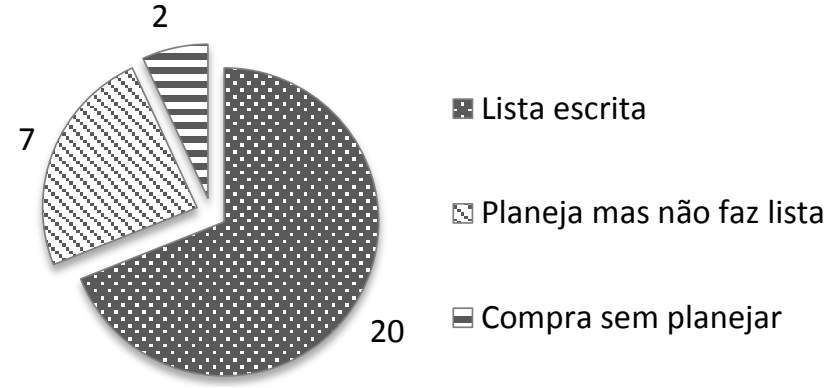

Gráfico 7 - Costume de fazer lista de compras, ou algum planejamento, antes de ir às compras 
Quanto aos motivos que as levaram a comprar algo fora do planejamento, 16 pessoas declararam que fazem isso para experimentar (seja por ser um produto novo ou desconhecido).

Em segundo lugar, por lembrar no supermercado algo de que precisava, mas de que haviam se esquecido de colocar na lista. Empatados em terceiro lugar, nove pessoas declararam que o preço acessível faz com que comprem fora do planejado e nove pessoas declararam que é a vontade de comer algo (guloseimas, doces etc.).

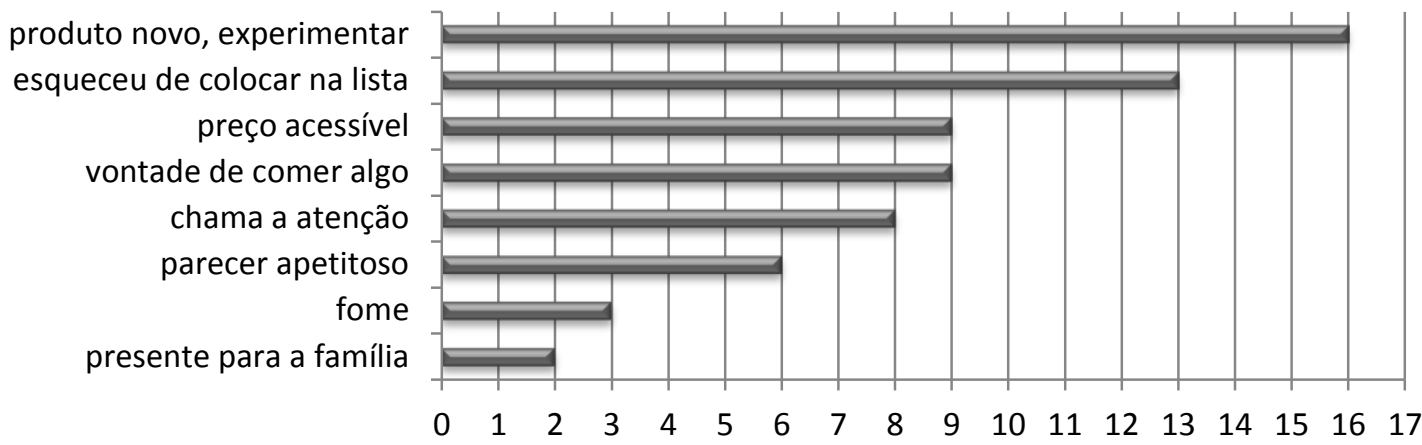

Gráfico 8 - Motivos para comprar algo fora do planejado (unidade = no de menções)

Foi perguntado também aos entrevistados o que eles olham na embalagem para decidir se levam ou não um produto. Em primeiro lugar, apareceram empatados a marca e o conteúdo do produto; em segundo, algum item das informações nutricionais e a validade do produto.

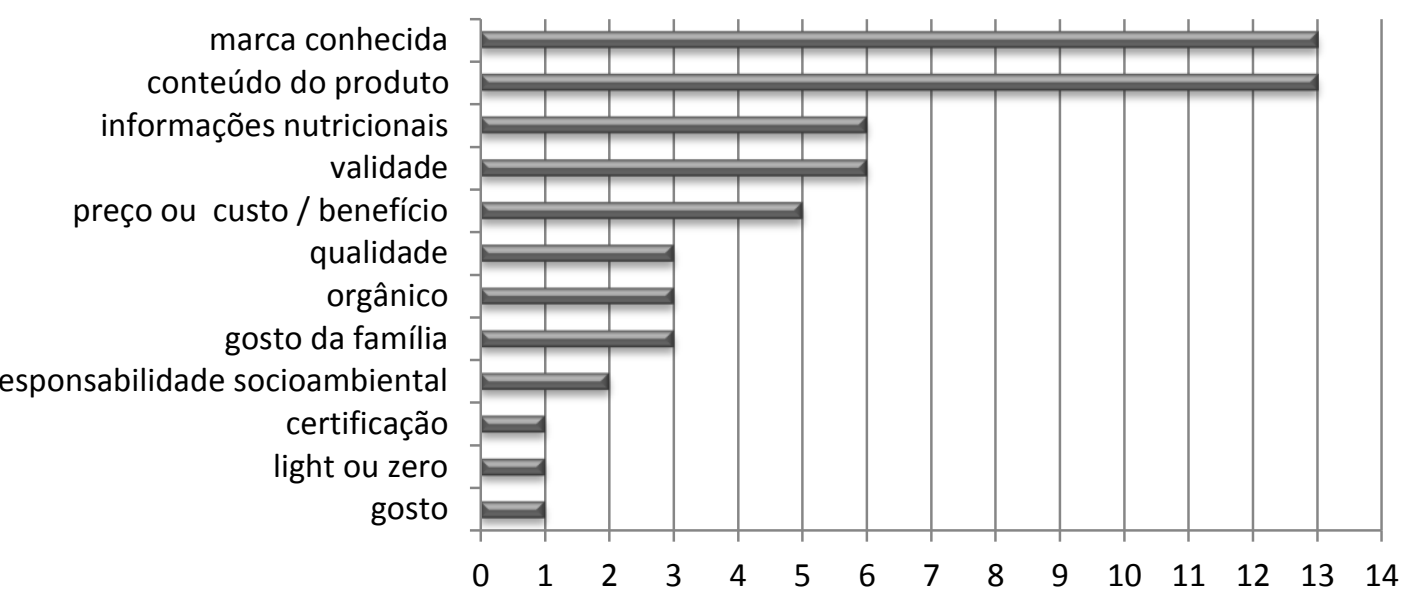

Gráfico 9 - Informações decisivas na embalagem para a compra de um produto (unidade = no de menções)

Quanto às respostas mais relacionadas à embalagem, foram declaradas quatro vezes que o cuidado visual com a embalagem é importante para a decisão de compra do produto, conforme mostrado no gráfico.

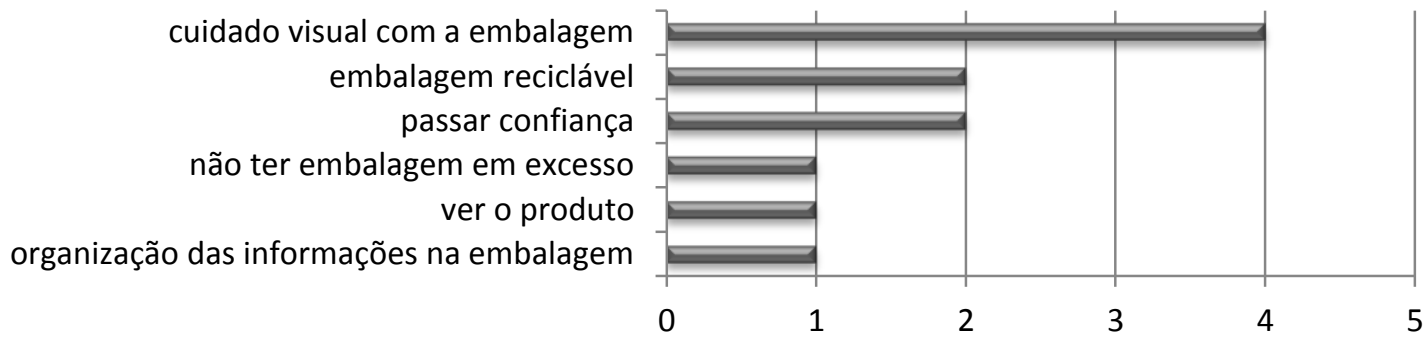

Gráfico 10 - Aspectos decisivos da embalagem para a compra de um produto (unidade $=$ no de menções) 


\subsubsection{Diferenças entre os perfis}

Para uma melhor análise dos dados das entrevistas, os consumidores entrevistados foram classificados por perfil de consumo de orgânicos. O objetivo foi verificar se havia diferença entre os consumidores regulares e os que têm pouco conhecimento ou não consomem produtos orgânicos, para que a pesquisa pudesse expressar a opinião dos consumidores em geral. Para cada grupo de produtos, buscou-se ter pelo menos um consumidor de cada perfil, havendo, assim, um maior equilíbrio nas respostas.

Para isso, foi avaliado o grau de conhecimento sobre alimentos orgânicos e a frequência de consumo. A avaliação do conhecimento sobre a definição do que é um alimento orgânico considerou correto quando o entrevistado respondia pelo menos um dos aspectos da produção orgânica. O gráfico abaixo mostra o grau de conhecimento dos consumidores.

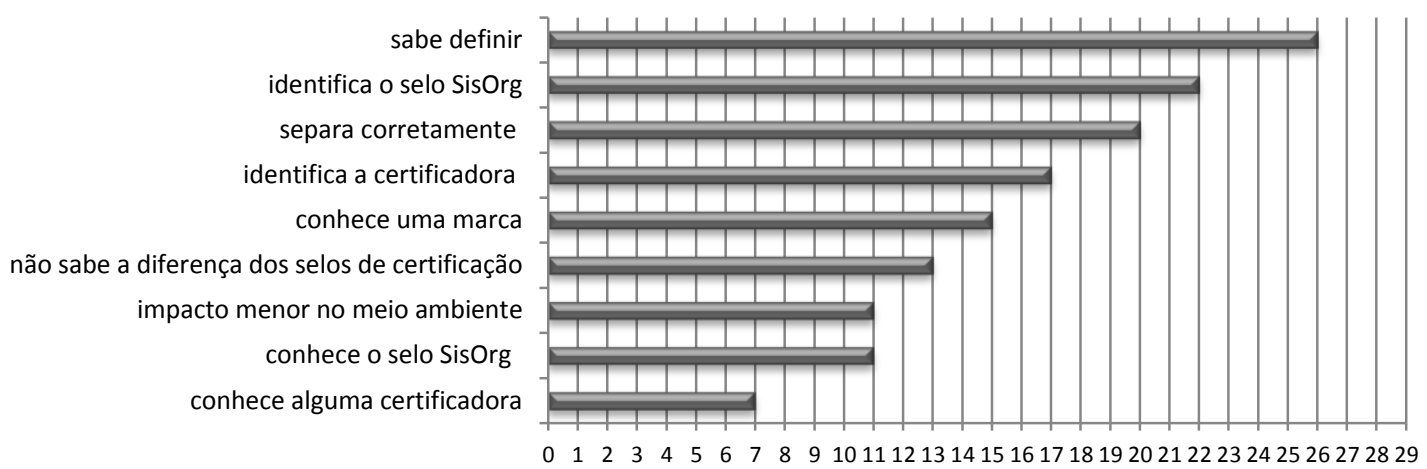

Gráfico 11 - Avaliação do conhecimento do que é um orgânico (unidade = no de consumidores)

O próximo gráfico mostra o perfil do consumidor por conhecimento do que é um alimento orgânico por frequência de consumo.

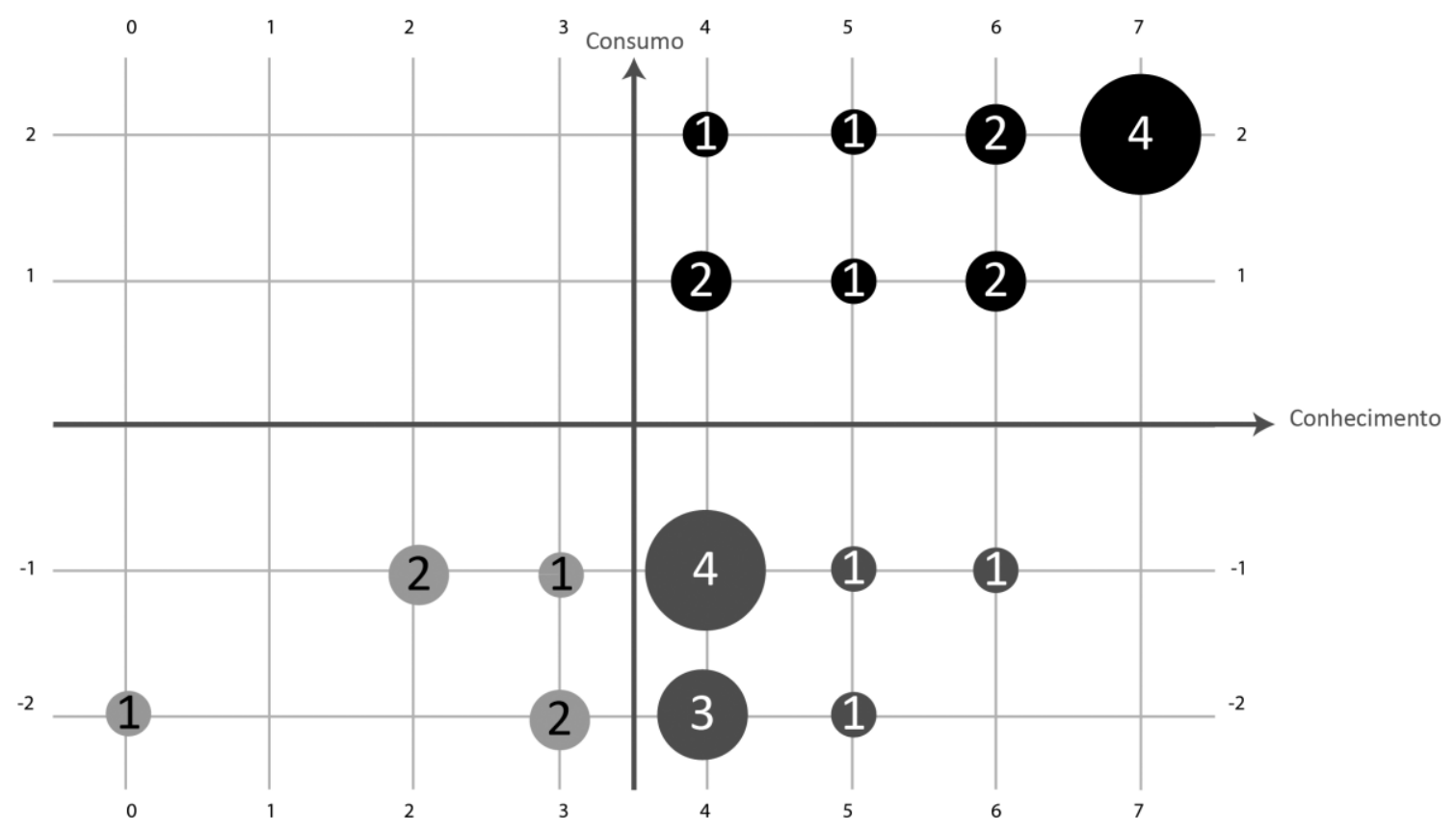




\begin{tabular}{|l|l|}
\hline \multicolumn{2}{|c|}{ Conhecimento do orgânico (um ponto para cada) } \\
\hline Sabe definir & $\begin{array}{l}\text { Impacto menor no meio } \\
\text { ambiente }\end{array}$ \\
\hline Separa corretamente & $\begin{array}{l}\text { Sabe a diferença dos selos } \\
\text { de certificação }\end{array}$ \\
\hline $\begin{array}{l}\text { Identifica ou conhece } \\
\text { o selo SisOrg }\end{array}$ & Conhece uma marca \\
\hline $\begin{array}{l}\text { Identifica ou conhece a } \\
\text { certificadora }\end{array}$ & \\
\hline
\end{tabular}

\begin{tabular}{|c|l|}
\hline \multicolumn{2}{|c|}{ Frequência } \\
\hline 2 & Sempre \\
\hline 1 & Regularmente \\
\hline-1 & Raramente \\
\hline-2 & Nunca \\
\hline
\end{tabular}

\begin{tabular}{|l|l|}
\hline & $\begin{array}{l}\text { Perfil de consumo } \\
\text { Conhece e } \\
\text { consome sempre }\end{array}$ \\
\hline & $\begin{array}{l}\text { Conhece e não consome } \\
\text { (ou consome raramente) }\end{array}$ \\
\hline $\begin{array}{l}\text { Não conhece e } \\
\text { não consome }\end{array}$ \\
\hline $\begin{array}{l}\text { O tamanho e o número dentro das } \\
\text { circunferências correspondem à } \\
\text { quantidade de consumidores. }\end{array}$ \\
\hline
\end{tabular}

Gráfico 12 - Perfil do consumidor por conhecimento do orgânico por frequência de consumo

Conforme é possível observar no gráfico anterior, quanto mais conhecimento a pessoa tem do que é um alimento orgânico, maior é a tendência em consumi-lo. Os que não consomem mostraram que têm pouco conhecimento sobre o assunto. Nesta pesquisa, não foi encontrado nenhum consumidor que não tenha conhecimento e consuma alimentos orgânicos.

Para um melhor entendimento dos dados apresentados nesta dissertação, foi utilizado um código alfanumérico para identificar o consumidor e o seu perfil de consumo. A letra ' $C$ ' identifica que é uma citação de um consumidor. As letras ' $A$ ', ' $B$ ', e ' $C$ ' identificam o perfil do consumidor e o número identifica um consumidor específico.

\begin{tabular}{|c|c|l|l|}
\hline \multicolumn{1}{l|}{} & Código & Significado & Total por perfil \\
\hline & CA & Consumidor conhece e consome alimentos orgânicos & 13 consumidores \\
\hline & CB & Consumidor conhece, mas não consome alimentos orgânicos & 10 consumidores \\
\hline & CC & Consumidor não conhece e não consome alimentos orgânicos & 6 consumidores \\
\hline
\end{tabular}

Tabela 14 - Codificação para identificar o perfil do consumidor e número total de consumidores por perfil

\subsection{RECONHECIMENTO E IDENTIFICAÇÃO DOS ALIMENTOS ORGÂNICOS}

Durante as entrevistas com os representantes das indústrias e escritórios de design, todos demonstraram acreditar nos diferenciais do alimento orgânico. A empresa que demonstrou maior envolvimento com o tema, e até mesmo por vender apenas alimentos orgânicos, foi a Via Pax Bio. O falecido fundador participava de várias ações para incentivar os alimentos orgânicos. Essa convicção ele passou para a família, e o negócio é agora administrado por sua filha. A produção orgânica e a sustentabilidade fazem parte dos princípios da empresa, que está localizada em uma área certificada, onde são produzidos alguns dos produtos comercializados.

Já Designer4 (2013), do escritório responsável pelo desenvolvimento das embalagens da Via Pax Bio, partilha as mesmas convicções e falou da importância de comunicar bem na embalagem o que é o alimento orgânico, pois, segundo ela, "Muita gente confunde até hoje orgânico com hidropônico. Até lojista, supermercadista. Existe essa confusão" (DESIGNER4, 2012).

A representante da Via Pax Bio também comentou que, nas embalagens, eles se preocuparam em destacar essa informação.

Você pode ver pelas embalagens que a gente tem ainda vigente o destaque para o orgânico. Quando essa linha foi elaborada em 2007, foi feita também toda uma reformatação da empresa e, tendo em vista as características do mercado na época, [...] entendeu-se que seria por bem ter esse destaque. (INDÚSTRIA3, 2012) 
No caso da Monama, Indústria2 (2012) também acredita que o alimento orgânico proporciona uma alimentação saudável, que é o foco da empresa, porém, apesar de nem todos os produtos serem certificados, no rodapé do site está escrito que são $100 \%$ orgânicos, mostrando uma informação incorreta. Essa informação permaneceu exibida no site desde o início até o fim desta pesquisa.

No caso da A10, escritório de design da Monama, eles já tinham conhecimento sobre alimentos orgânicos antes do início do projeto, mas, depois que começaram a desenvolvê-lo, pesquisaram mais aspectos que ainda não conheciam. Todas as informações foram usadas em benefício da personalidade da marca e da comunicação. Foi a primeira embalagem de alimento orgânico desenvolvida pela representante da $\mathrm{A} 10$ e responsável pelo design das embalagens da Monama. Ela comentou o desafio de comunicar o que é o orgânico, pois, segundo ela, "não é só hortaliça e pode ser industrializado", tendo os mesmos desafios relacionados às empresas pequenas.

Um dos desafios de se produzir alimentos orgânicos, segundo o representante da Mãe Terra, é que as pessoas ainda consideram o alimento orgânico uma coisa cara.

Eu acho que a alimentação natural tem que estar cada vez mais no dia a dia das pessoas, seja mais ricas ou mais pobres, e, à medida que esse consumo cresce, toda a cadeia produtiva ganha uma escala e os preços tendem a cair. Porque é a história do orgânico, a polêmica, 'pô, mas o orgânico é caro' e tal. É a questão da escala. (INDÚSTRIA1, 2012)

O aumento nas vendas e na escala de produção pode diminuir o preço dos orgânicos, conforme a declaração, porém isto depende muito do produto. Em geral, a produção de orgânico necessita de mais cuidado, porém já existem produtos certificados, em grande escala e orgânicos. Além disso, o orgânico é mais caro também pela dificuldade de distribuição, passando por vários atravessadores até chegar ao ponto de venda. Quando vendidos diretamente ao consumidor, nas feiras de orgânicos, podem até ser mais baratos.

Outro desafio de design comentado por Designer1 (2012) foi que as indústrias ainda precisam colocar muitas informações na embalagem para explicar o que é um alimento orgânico.

\footnotetext{
Uma coisa que incomoda muito a gente é que no Brasil ainda a percepção da embalagem precisa falar tudo. Então o excesso de informação que é colocado, e tudo tem que ter destaque e, no final, mesmo se você querendo [sic] fazer uma coisa um pouco mais limpa, você não consegue. E principalmente nessa categoria de produtos orgânicos, há a necessidade de se falar tudo na parte frontal [...] e muitas vezes isso cria uma malha, uma poluição visual que no final você não consegue destacar nada. Tudo tem que pular, tem que ter vermelho. $\mathrm{E}$, às vezes, por ser orgânico, já tem muitos benefícios que já estão atrelados a isso, então não precisa ter destaque. (DESIGNER1, 2012)
}

A Mãe Terra trabalha com alimentos orgânicos e não orgânicos, por isso foi questionado na entrevista se eles sentiam alguma diferença em desenvolver embalagens para alimentos orgânicos e não orgânicos. "O orgânico, ele não tem nenhum aspecto, para embalagem, diferente de um natural. O natural tem do convencional, pela falta de conservante. Agora, o orgânico, não" (INDÚSTRIA1, 2012).

A mesma pergunta foi feita para Indústria2, da Monama, que comentou sentir mais dificuldade por causa do processo de certificação e aprovação da embalagem.

Qualquer produto que você lance orgânico, ao contrário dos normais, dos convencionais, você tem que pedir primeiro a aprovação para o IBD, que ele certifica e dá aquele selinho de orgânico para a gente. [...] E ele tem que aprovar toda a receita primeiro, se certificar que cada ingrediente que está naquela receita é realmente orgânico, entendeu? Então, ele vai atrás de cada fornecedor, através do que a gente chama de CT, que é o certificado de transação, e aí sim você tem o aval deles para lançar o produto. (INDÚSTRIA2, 2012) 
Essa declaração, dizendo que não tem diferença e se preocupa apenas com o processo de certificação, demonstra que a empresa não tem uma abordagem adequada para com esse tipo de projeto, partindo do pressuposto de que a empresa que produz orgânicos poderia ter mais cuidados em relação aos materiais e outros processos.

Os profissionais do escritório de design que atende a Mãe Terra acrescentaram à entrevista que eles foram pesquisar mais sobre os alimentos orgânicos, além do que foi passado pelo cliente. Eles comentaram que foram para a Alemanha para conhecer o mercado de embalagens de alimentos orgânicos. Eles ficaram "impressionados em como o mercado lá é mais maduro", onde é possível encontrar um supermercado especializado em produtos orgânicos a cada esquina e as pessoas os consomem. Segundo eles, lá os produtos orgânicos não são muito mais caros.

\section{Definição de orgânico}

Na entrevista com os consumidores, foi pedido aos entrevistados que definissem o que é um alimento orgânico. Para avaliar estas definições, foi considerado correto quando as pessoas respondiam pelo menos um dos aspectos da produção orgânica. A grande maioria, com 24 declarações, disse que o alimento orgânico é aquele produzido sem agrotóxico.

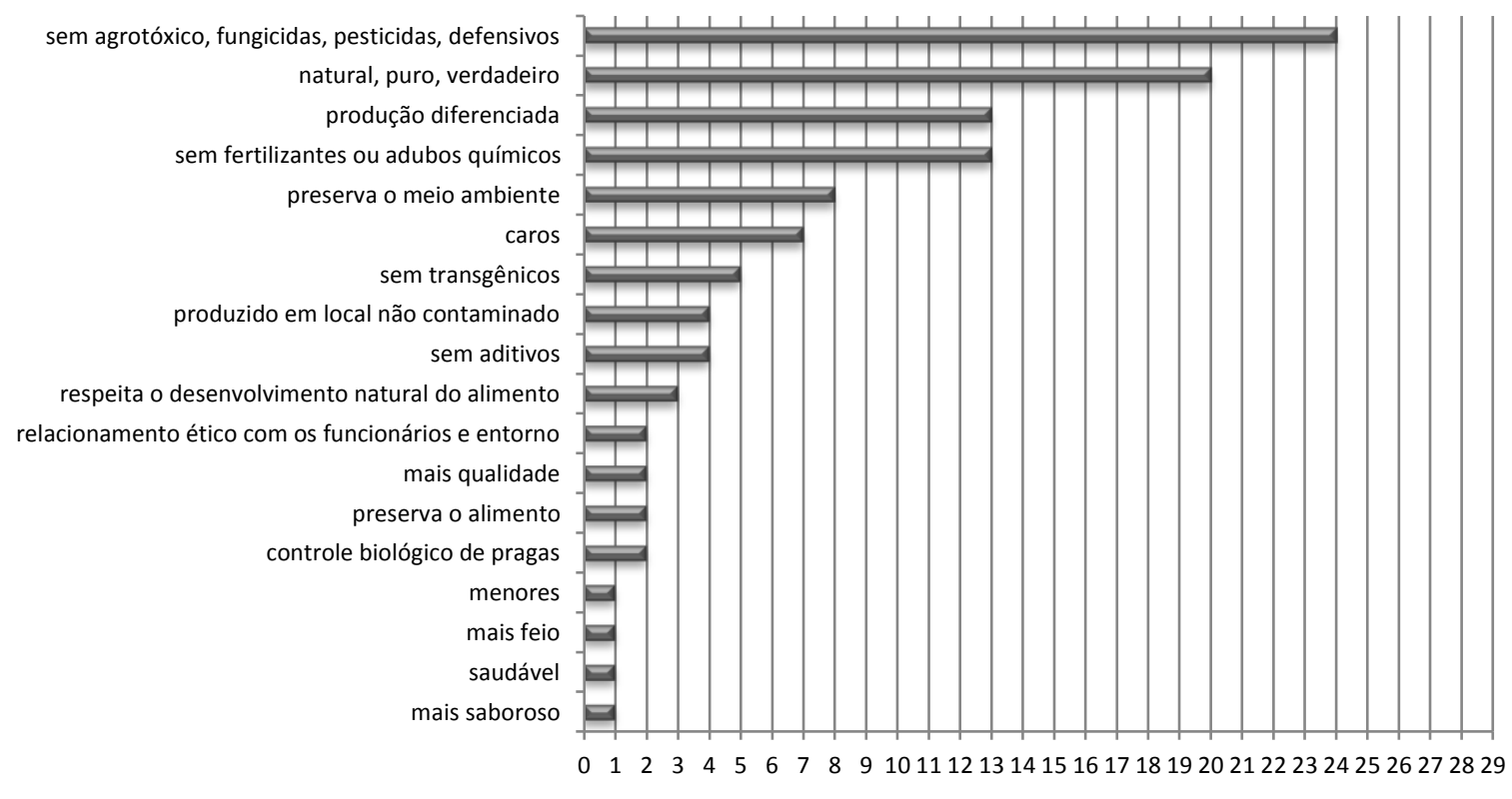

Gráfico 13 - Percepção do que é um alimento orgânico. (unidade = no de menções)

O conceito geral de definição do que é um alimento orgânico declarado pelos consumidores entrevistados é que o alimento orgânico é produzido sem o uso de agrotóxicos ou produtos químicos.

Alimento orgânico, pelo que eu entendo, é um alimento produzido sem o uso de agrotóxicos, não vou dizer naturais, porque é produzido como uma fruta natural, mas não é tratada com agrotóxicos. Eu acho que é o principal ponto: não ser tratado com produtos químicos. (CB01, 2013)

Eu acredito que é um alimento que passa minimamente pelo processo químico, com adição de química, de agrotóxico, enfim, químicas de um modo geral. Está muito mais próximo do in natura. (CB27, 2013)

Um dos consumidores acrescentou à definição a forma natural e biológica de controle de pragas. 
Um alimento orgânico é um alimento que não usa pesticidas e venenos no seu cultivo. Ele usa pulverizadores naturais como o fumo dissolvido no álcool de cereais, ou alguma outra planta que ajuda a combater os pulgões, que ficam ali perto daquela horta, então o orgânico é isso, ele trabalha com os próprios elementos da natureza para combater as mazelas, que viriam atacar aquela produção. Ou o uso menos possível, né? (CA28, 2013)

A associação a um produto mais natural também é percebida por outros consumidores nas suas definições do que é um alimento orgânico.

Eu acho que o alimento orgânico é aquele que é produzido com alguns cuidados especiais, quando você geralmente não usa o agrotóxico na produção, uma série de produtos químicos e conservantes e coisa assim. Ele é um produto que ele tende a ser um pouco mais como ele deveria ser na natureza. É esse o conceito que eu tenho de orgânico. (CB20, 2013)

Muitos incluíram a não adição de químicas ao alimento final, e de industrializados como os conservantes e aromatizantes artificiais.

O que eu entendo por orgânico, geralmente eu sempre penso que é feito com cuidado, sem conservantes, não é transgênico, não tem uso de agrotóxico. É o mais puro possível. É o que mais se aproxima de uma plantação que você teria em casa, por exemplo. Quase que a pessoa tenha feito isso, e usado a menor quantidade de conservante e agrotóxico possível. Embalado e botado no supermercado. (CA26, 2013)

Mesmo que não soubessem definir bem, ou lembrar a palavra agrotóxico, associavam a isso.

Sem aqueles produtos lá... agro... de intoxicação. Esqueci o nome daquilo. Que é natural, né, sem a utilização de agrotóxico. É assim que fala? Aqueles, para crescer e tal. Sem aquela... eu entendo, é isso, sem essas coisas artificiais, quando vai plantar um alimento. (CB17, 2013)

Foi observado que, mesmo declarando que sabia o que era um alimento orgânico, alguns ainda confundiam com outros tipos de produto, como os hidropônicos ou o alimento integral, conforme mostra o gráfico abaixo.

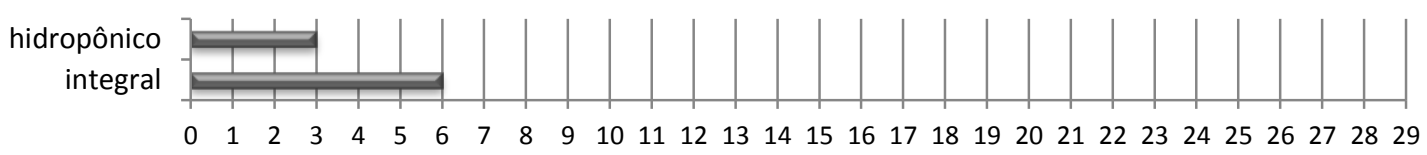

Gráfico 14 - Quantidade de pessoas que confundem orgânico com algo diferente. (unidade = no de consumidores)

Observou-se que esse tipo de confusão aconteceu mais quando o consumidor apresentou menos conhecimento do que é um alimento orgânico. Cinco dos seis consumidores com menos conhecimento confundiram o orgânico com um alimento integral e um confundiu com o hidropônico. Dos consumidores que têm mais conhecimento, mas que não consomem, três deles confundiram com os hidropônicos e um com o alimento integral. Apenas um consumidor com mais conhecimento ficou em dúvida, mas resolveu usar como critério principal a informação textual da embalagem. "Bom, eu acho que tudo é orgânico em si, né, mas eu vou pelo que a embalagem está me mostrando, apesar de achar que tudo é orgânico" (CA12, 2013).

A confusão provavelmente surge pela palavra ter mais de um significado, dependendo do contexto. Tanto pode significar: (A) um produto de origem que segue princípios agroecológicos; como, no contexto dos resíduos urbanos, (B) o lixo que não pode ser reciclado. Segundo o dicionário Aurélio (2009), a palavra "orgânico" é um adjetivo "relativo a órgãos, à organização, a seres organizados".

Em uma das declarações de um não consumidor de alimentos orgânicos, fica clara a confusão com o hidropônico, mesmo não acreditando que é a mesma coisa. 
[...] Nos supermercados, aquilo que é fornecido, o orgânico, o hidropônico, entendeu, embora eu acho que no hidropônico eles colocam alguma coisa, alguma solução para o crescimento das verduras, mas eu espero que tenha menos uso de pulverizações desnecessárias. (CC13, 2013)

Os consumidores que não souberam definir se confundiram com os alimentos mais naturais, não processados. Isso aconteceu com apenas um do grupo CB (não consumidor, mas com conhecimento) e dois do grupo CC (não consumidores e sem conhecimento).

\begin{abstract}
[...] que não sejam processados, que não sejam transformados, produto orgânico é exatamente isso, o produto que sai da produção, não é modificado em nada e vem para sua mesa e é você que dá o final para ele, certo? Os produtos não orgânicos são aqueles que são processados, então já tem uma modificação, seja ele triturando, seja passando por algum processo. E aí que está, eu diria que o arroz integral é mais orgânico que o arroz refinado, o açúcar refinado é menos orgânico que o açúcar cristal ou o açúcar mascavo, ou o açúcar orgânico que tem outro nome também, que meio termo entre o refinado e o mascavo, fica mais clarinho, mas não é tão orgânico como seria o mascavo. (CC13, 2013)
\end{abstract}

Em um dos casos, o consumidor acabou definindo o alimento integral, ou mais natural, como "semiorgânico", o que não é possível. Perguntado o motivo de separar assim, o entrevistado declarou: "Semiorgânico seriam os produtos integrais" (CC23, 2013).

Nos casos dos grupos de produtos compostos por mais de um ingrediente, como os cookies, as barras de cereais, as granolas e os macarrões instantâneos, a composição dos alimentos acabou interferindo na hora da separação em grupos de orgânicos e não orgânicos. Foi observado que essa confusão aconteceu com três consumidores dos seis com pouco conhecimento do que é um alimento orgânico. Quando perguntado sobre qual foi o critério escolhido para a separação, um entrevistado declarou: "Os ingredientes, não digo os ingredientes, mas, como eu te digo, o conteúdo mesmo, né? [...] porque o orgânico é o mais natural mesmo, né? (CC11, 2013).

\title{
Transgênicos
}

Um dos itens da matriz semântica (Apêndice $C$ ) apresentada aos consumidores era a palavra transgênico, mostrada para os consumidores 58 vezes. A maior parte dos entrevistados (31 vezes) preencheu na matriz semântica outras opções além do extremo mais próximo do "não modificado geneticamente". Segundo a legislação, para ser considerado orgânico, o alimento não pode usar nada transgênico.

A opção do meio, que indica que o consumidor não sabia responder, foi escolhida 14 vezes, por cinco consumidores frequentes, dois do grupo CB (não consumidores, mas com conhecimento) e um não consumidor. As opções intermediárias mais próximas do não modificado geneticamente foram escolhidas dez vezes e a mais próxima do transgênico foi escolhida quatro vezes. Dois consumidores frequentes marcaram a opção mais próxima da palavra transgênicos. Para esses dois casos, foi apresentado o arroz da Mãe Terra, não orgânico, e talvez tenha sido por isso a escolha por essa opção.

A variação das respostas indica que a informação de que o alimento orgânico é isento de transgênico não é muito divulgada e poderia estar nas embalagens apresentadas. A questão para definir o que é um alimento orgânico foi feita logo após o preenchimento da matriz de diferencial semântico que citava a ideia de transgênicos. Este fato pode ter influenciado os consumidores CA15 e CB24 a colocarem essa informação na definição. 
Orgânico é aquele que não utiliza grãos, ou, sei lá, produtos que tenham transformações genéticas, transgênicos, e também não usam coisas que contêm agrotóxicos, são, assim, bem mais naturais, não é?, procuram preservar as coisas naturais. (CA15, 2013)

É um produto cultivado sem agrotóxicos, sem nenhuma modificação, eu acredito, sem nenhuma modificação genética. O mais natural possível. Essa é a minha definição de orgânico. (CB24, 2013)

\section{Produção}

Apenas nove pessoas declararam que a produção do orgânico tem como preocupação a preservação do ambiente em que é produzido, sendo oito consumidores frequentes e apenas um consumidor do grupo CB (com conhecimento, mas que não consome) e um do grupo CC (não consumidor com pouco conhecimento). Possivelmente, indicar algum aspecto ambiental na embalagem poderia aumentar o consumo do alimento orgânico, pois, segundo a análise do perfil, quanto mais conhecimento maior a frequência de consumo. Uma dessas declarações falou da forma de produção diferenciada dos orgânicos, respeitando os ritmos da natureza.

É um alimento cultivado sem o uso de fertilizantes, adubos químicos, não sei se isso é do orgânico, mas é plantado na época em que deve ser plantado, colhido na época em que deve ser colhido, não altera aqui, respeita a natureza, é, que não força o crescimento dele, não é? Então é respeitada a qualidade dele. Acho que é isso, e é um alimento mais saboroso, geralmente, por conta disso, mais puro e mais verdadeiro. Ah! Que lindo... (CA09, 2013)

Relacionando também com a forma de tratamento da terra:

Alimento orgânico, ele é feito a partir de produtos que são cultivados em terra sem, além de não ter agrotóxicos, a terra já é adubada organicamente, então já vem todo o processo lá de trás, para depois, tudo é plantado dessa forma, cuidado dessa forma, a química, na base orgânica, para depois ir para o feitio do alimento, a indústria. Orgânico para mim é lá na terra, na raiz, no cuidado com a matéria-prima, com a planta. É o que eu conheço de orgânico, se tem mais eu não estou informada, e vem essa visão. (CC13, 2013)

O local de produção, a terra e a água, sem contaminação com produtos químicos, também foram lembrados.

O alimento orgânico é aquele que é cultivado sem nenhum tipo de agrotóxico e é um alimento que é cultivado em um ambiente, não é só a terra, é a água, é o lençol freático, é tudo que também está isento disso. Mesmo que essa terra em algum momento tenha recebido agrotóxico, tem um tempo para liberar, e a mesma coisa com a água, então o alimento orgânico ele só pode acontecer em um sistema em que está todo ele preservado. Eu acho que é isso. (CA21, 2013)

Um dos consumidores lembrou que o alimento orgânico também incentiva a agricultura familiar, facilitando a sua forma de certificação.

Ah, sabe o que eu descobri que eu achei legal e não sabia? É que esse selo IBD: é caro para ter uma certificação dessa, né? Agora tem um processo com o Ministério da Agricultura que é o PAC, que é o processo de certificação participativa, pela agricultura familiar. [...] Daí possibilita pequenos agricultores. (CA25, 2013)

\section{Preservação do meio ambiente}

Os orgânicos como um alimento com produção que preserva o meio ambiente foi lembrado por alguns consumidores. "Primeiro é produzido sem o uso de agrotóxicos, sem o uso de fertilizantes artificiais, e tomando cuidado com a terra, a água, enfim, todo o meio que mantém aquilo" (CA10, 2013); "Que tenha menos agrotóxicos, que agrida menos a natureza, que faz uma maior preservação da natureza do que os outros não orgânicos" (CA12, 2013). 
Alguns consumidores consideravam que tinham pouco conhecimento sobre o assunto e se sentiram inseguros em responder, porém responderam corretamente e de forma completa.

\begin{abstract}
No meu pouco conhecimento, apesar de eu buscar os alimentos orgânicos, são alimentos que não são preparados na base com agrotóxicos, têm uma preocupação aonde [sic] que é plantado, em áreas onde os lençóis freáticos são mais livres de contaminação [...] não têm os conservantes, são produzidos de uma forma mais natural também, não só à base de maquinário, pode até ser, mas tem um controle maior de quem está plantando. No sentido de plantio e colheita, não é? (CA31, 2013)
\end{abstract}

Em um desses casos, a embalagem também foi incluída, mesmo não fazendo parte da legislação, mostrando que o consumidor considera também importante pensar a embalagem junto com o produto final.

\begin{abstract}
Um alimento orgânico, como uma pessoa leiga e não especializada no assunto, é um alimento que tem uma procedência de processo produtivo que tem cuidado desde a preparação do solo, proveniente de propriedades rurais menores, não tem agricultura intensiva e o processo industrial não é muito grande. Não usa agrotóxico, usa fertilizantes naturais, procura preservar o desenvolvimento natural dos alimentos. Deveria também estender toda essa preocupação com a ética no seu relacionamento com os seus funcionários, com seu entorno, e se preocupa até com o produto final, com a embalagem, com a comunicação, com a segurança da embalagem e com o descarte. (CA02, 2013)
\end{abstract}

Também foi observado, em algumas entrevistas, que o fato de ter crianças pequenas na família influencia a escolha por alimentos orgânicos.

\begin{abstract}
Mas como a gente tem criança em casa, eu acho que muda. Porque eu andei lendo o quanto que eles são submetidos a pesticidas. Com dois anos de idade, eles já consumiram o que deveriam consumir em 20 ou 30 anos de idade, de aditivos químicos e de pesticidas e de agrotóxicos. Então a gente tenta aqui. (CA28, 2013)

O comprar mesmo a gente compra legume, porque tem criança na família, então milho verde a gente compra orgânico, porque toda semana a gente cozinha milho verde para as crianças. (CB32, 2013)
\end{abstract}

\title{
Motivos para não consumir
}

Mesmo conhecendo um pouco o que é um alimento orgânico, alguns consumidores ainda não consomem com muita frequência. Os principais motivos declarados para não consumir foi o preço e a falta de interesse, conforme podemos ver no gráfico:

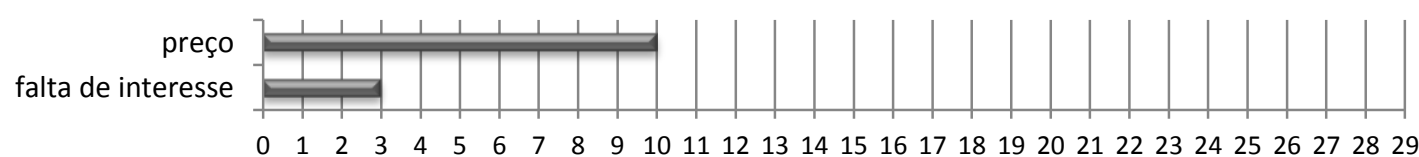

Gráfico 15 - Motivos para não ter comprado um alimento orgânico. (unidade = n⿳o de consumidores)

O principal motivo declarado é a percepção de que o alimento orgânico é um alimento mais caro, para poucos: oito dos 29 entrevistados mencionaram o preço do orgânico como algo negativo e três declararam que não consomem por falta de interesse.

[...] a maior dificuldade é o preço também, infelizmente os orgânicos são bem mais caros, nem sempre, às vezes você encontra coisas que são orgânicas e são mais baratas, ou o preço assim equivalente, mas, geralmente, eles são mais caros, e não deveria, para estimular o consumo. (CA15, 2013) 
No caso do grupo CB (não consumidores de alimentos orgânicos com conhecimento), três não compram pelo preço e dois por falta de interesse. Entre o grupo CC, apenas um falou do preço e outro, de falta de interesse.

Eu acho que eu nunca fui muito atrás dele. Eu nunca procurei, na verdade. É, eu nunca fui mesmo de falar, assim, vou comprar aquele alimento porque é orgânico. (CC11, 2013)

Porque eu não pensei em comprar, não é tão evidente que é orgânico. Eu sempre entro e saio correndo, né. E aí, quando você compra fruta, os orgânicos são mais caros. É tudo separado, e é caro também, dependendo é bem mais caro, então não dá. (CB17, 2013).

Eu não entrei ainda na parte de orgânico, eu tenho uma alimentação muito simples. Não me chamou ainda a atenção para o orgânico. Não compro. [...] Nunca comprei, não sei como é que é, só sei que o orgânico é bom (CB18, 2013).

Mesmo no caso dos consumidores mais frequentes, e com conhecimento, o preço foi citado como um dos fatores para não consumir apenas alimentos de origem orgânica, sendo esta informação declarada por cinco consumidores.

Eu só não compro orgânico quando está muito caro, na verdade o muito caro, porque eu não compro muita quantidade porque eu sou sozinha. (CA09, 2013)

As minhas opções, elas são para os produtos orgânicos. No mercado, na feira. Só quando o preço é muito alto, que aí eu não compro, mas normalmente, sim. (CA10, 2013)

Eu dou sempre preferência, se eu vejo que está lá, e se está acessível, porque às vezes é três vezes o preço, né? Então aí você vai com essa coisa de quanto você quer gastar, ou você está disposto a gastar, por ser um alimento orgânico. (CA28, 2013)

A questão de estranhar o sabor do alimento orgânico também foi apontada por um consumidor, o gosto mais pronunciado foi considerado por ele como um motivo para não consumir, apesar de que, neste caso, estava confundindo com os alimentos integrais, com mais fibras.

Vou dizer a você que a história do orgânico está entrando em minha vida de uma forma muito paulatina. Eu digo paulatina porque muitas coisas orgânicas ainda estão num preço que não é tão acessível e talvez também por falta de conhecimento meu, ou até a nível de sabor [sic], porque, em algumas coisas, o sabor é diferente daquilo que conhecemos. (CC13, 2013)

Muitos dos entrevistados declararam em suas entrevistas que o fato de não saber onde comprar ou de não encontrar uma grande variedade de produtos acaba impedindo, ou dificultando, de consumir os alimentos orgânicos. "Não é fácil de encontrar produto orgânico, eu compro algumas vezes quando eu encontro no mercado, mas não é tudo que eu encontro" (CA04, 2013).

Alguns dos entrevistados, por morarem em regiões com mais opções de lojas que vendem alimentos orgânicos ou perto de alguma feira, como a região perto do Parque da Água Branca $^{20}$, tendem a comprar mais e acabam consumindo com mais frequência.

[...] só que eu não comprei só especificamente os orgânicos. Eu gosto porque eu uso muito esta loja que tem aqui, Mundo Verde, eu gosto muito das coisas que tem lá, das barras de cereais, eu compro a chia, a quinua, são coisas que eu gosto. (CB05, 2013)

A localização das embalagens de alimentos orgânicos no supermercado também é importante. $O$ fato de estarem concentrados em um corredor só facilita para quem procura esse tipo de alimento, em uma compra planejada.

${ }^{20}$ A Feira do Produtor Orgânico, no Parque da Água Branca, acontece toda terça-feira, sábado e domingo, das 7h às $12 \mathrm{~h}$. 
Eu estou bem feliz, aqui no Pedroso tem um corredor só com produtos saudáveis. Então tem lá os dos diabéticos, que são sem açúcar, e aí começa [sic] as farinhas integrais, os alimentos orgânicos, os leites de soja, todos em um corredor. É legal, né? (CA28, 2013)

Quando eu compro orgânico eu já vou numa prateleira que tem produtos orgânicos. Não preciso ler com tantos detalhes porque são produtos que eu já conheço. (CB31, 2013)

\subsubsection{Relacionando o alimento orgânico com alimentos saudáveis}

Um dos questionamentos analisados na entrevista foi se o consumidor relaciona o alimento orgânico ao alimento mais saudável. Para isso, foi pedido para que ele separasse os produtos apresentados em saudáveis e menos saudáveis, antes de fazer qualquer menção ao alimento orgânico.

As marcas que os consumidores demonstraram mais dúvida, seja por demorar mais ou por comentarem durante a separação, foi a Jasmine (cinco vezes), a Gran Pure (quatro vezes) e a Mãe Terra (três vezes).

Foi mencionado 42 vezes que o critério para a separação foi ter encontrado a palavra "orgânico" na embalagem, em 58 vezes que foi pedido esse procedimento. O selo de certificação foi mencionado apenas quatro vezes, conforme podemos ver em algumas declarações abaixo:

A maneira que eu consegui separar, na verdade, é pelo fato de ser considerado orgânico ou não, porque todos eles falam em fibras, ferro, cálcio, nutrientes, se eu usar a classificação como eu estava usando antes, eu teria que considerar que todos são saudáveis, então eu parei, pensei, raciocinei e aí, opa! (CB05, 2013)

É por ser orgânico. [...] Não que não seja saudável. [...] Ele é menos saudável pelo processo produtivo deles, não pela cara da embalagem. A embalagem diz que é orgânico, então eu aponto para esse, principalmente pelo processo de plantio, sem agrotóxico e tal. (CA10, 2013)

Mesmo quando na primeira separação do primeiro grupo de produtos a pessoa usou outros critérios, no segundo grupo, muitos perceberam que a pesquisa era sobre alimentos orgânicos e acabaram usando esse critério para separá-los como saudáveis.

No fundo, para mim, é que é tudo saudável, que não é o arroz comum. Como você já me falou o negócio do orgânico, eu separei do orgânico. Nunca comprei, não sei como é que é, só sei que o orgânico é bom. (CB18, 2013)

A separação do alimento orgânico como mais saudável aconteceu principalmente nos produtos menos processados, como o feijão.

Eu não consegui distinguir aqui o que é saudável. Para mim, no caso, eu acho, pela pouca informação que eu tenho, é que o orgânico é mais saudável. Mas eu aqui não estou conhecendo o que é saudável e o que não é. Para mim, é tudo feijão. Só se diferencia é esse, que a gente sabe, por questões assim de publicidade, que o orgânico é uma coisa mais saudável. E nem sei se é verdade. (CB18, 2013)

No caso dos alimentos compostos por mais ingredientes e mais processados, a composição nutricional e de ingredientes influenciou mais do que o fato de ser orgânico ou não. Em todas as 30 vezes em que foi feito esse procedimento, foi mencionado 19 vezes que o motivo da escolha foi a composição dos ingredientes. "Levei muito em consideração os ingredientes. [...] Os mais saudáveis, eu levei em consideração também a mistura dos alimentos" (CC11, 2013); "[...] os ingredientes principais não me interessam, porque os ingredientes vêm na ordem da proporção que eles têm, não é?" (CC16, 2013). 
A opção das informações sobre a composição de ingredientes dos produtos foi a mais escolhida pelos consumidores com pouco conhecimento. Já os consumidores com conhecimento optaram pela informação textual, se era ou não um produto orgânico. Durante a separação, 15 consumidores buscaram alguma informação na parte de trás da embalagem, possivelmente informações sobre a composição de ingredientes e nutricional.

A marca também foi a informação mais mencionada como critério para a separação como saudável ou não saudável, aparecendo 19 vezes. A presença de uma marca conhecida fez com que algumas pessoas separassem sem nem mesmo olhar a sua composição, pois confiam nela.

Eu acho que uma das coisas que interfere no mais ou menos saudável é uma coisa que depende muito de você conhecer a marca, a proposta, de onde vem, e tudo mais, porque não adianta você dizer que é um produto orgânico. É um produto orgânico, mas que é pouco conhecido, pelo menos para mim. (CC13, 2013)

O fato de não conhecer a marca fez com que a pessoa não confiasse no produto. "Quando você não conhece a empresa, já fica um pouco mais pensativo. Como é a qualidade, como é feito, qual o tipo de manuseio, se tem muita gente pondo a mão ou não, se é operacional, então daí muda muito. Você tem que ver" (CC23, 2013); "Acho que para novas marcas é muito difícil, você entrar no mercado e ser aceita na primeira fornada, não é?" (CB32, 2013).

Ao mesmo tempo em que as grandes marcas são as mais divulgadas, e por isso mesmo mais conhecidas, alguns dos entrevistados declararam dar preferência para comprar produtos de marcas menores, por terem uma percepção de que as marcas grandes não têm tanto cuidado com o produto.

E aqui estou te falando por causa dos fabricantes, que, como são grandes compradores de cereais, eu acho que eles compram transgênicos, e eles não falam não que têm transgênico. (CB22, 2013)

Outro ponto que é bom é porque não é de uma empresa grande como a Nestlé, sabe, essas grandonas internacionais. Aparentemente, ela parece ser uma indústria pequena. Não sei. É de Itupeva, interior de São Paulo, é bom. Melhor que grupo grande, né? (CA25, 2013)

Das marcas pesquisadas, a Mãe Terra foi a mais lembrada como saudável, citada 41 vezes, seguida pela Jasmine, citada oito vezes. "[...] apenas por ser uma marca que a gente já identifica, a Mãe Terra, como uma marca de produtos mais saudáveis, mais naturais" (CA02, 2013); "Eu acho que Mãe Terra não faria uma coisa que não fosse saudável” (CC06, 2013); "[...] essa Mãe Terra, essa arvorezinha, está bem associada à natureza, os desenhos de produtos saudáveis que você pode consumir com tranquilidade" (CB32, 2013).

Ninguém citou a Monama para separar como mais saudável e a Via Pax Bio foi citada apenas três vezes. A marca Mãe Terra foi lembrada em todos os perfis de consumo, já a Via Pax Bio apenas por consumidores frequentes e com conhecimento.

A politica da empresa junto com a estratégia de comunicação da marca e distribuição dos produtos fazem com que os consumidores atribuam valores subjetivos aos produtos selecionados. Nenhuma das empresas pesquisadas faz propaganda nos grandes veículos de comunicação como a televisão, por isso a embalagem é de extrema importância para o reconhecimento de valores subjetivos buscados pelos consumidores.

Após a separação por saudável e menos saudável, foi pedido ao entrevistado que separasse por orgânicos e não orgânicos. Os entrevistados olharam primeiro para o grupo de saudáveis em 45 das 58 vezes em que foi pedido esse procedimento para poder encontrar os 
alimentos orgânicos e depois olhavam para o grupo dos não saudáveis para conferir se não tinham deixado nada no outro grupo. Isto demonstra que já haviam considerado na primeira separação como mais saudável o alimento orgânico.

\subsubsection{Relacionamento do orgânico com a marca}

Outra confusão feita na hora da separação foi relacionar a marca a um alimento orgânico. A estratégia de comunicação da marca e sua identidade visual podem levar o consumidor a considerar como orgânico mesmo quando não é. Essa confusão pode levá-lo a acreditar que a empresa não é confiável. Identificar e diferenciar o alimento orgânico é extremamente necessário para haver um consumo mais consciente.

A marca mais associada aos orgânicos foi a da Mãe Terra, citada por 15 consumidores. Em segundo lugar, aparecem empatadas a Jasmine e a Taeq, com três citações, e em terceiro lugar a Via Pax Bio, com duas citações. Dois consumidores frequentes e com conhecimento ficaram em dúvida por causa da marca Mãe Terra e só optaram separar como orgânico quando encontraram a informação na embalagem. "Essa daqui eu vou ficar na dúvida, porque não tem a informação. [...] Aí, olha! Mãe Terra eu sei que é orgânico, mas tem coisa que não é, né? [...] geralmente Mãe Terra é orgânico" (CA26, 2013).

Quando os consumidores conheciam um pouco sobre os alimentos orgânicos, mas não consumiam com frequência, em dois casos acabaram separando produtos da Mãe Terra como orgânicos, mesmo não sendo. Um consumidor com pouco conhecimento separou um produto Mãe Terra como orgânico, por conhecer a marca.

No final da entrevista, foi perguntado se o consumidor se lembrava de alguma marca de alimentos orgânicos. A marca mais citada, por 16 consumidores, foi a marca Mãe Terra, conforme podemos ver no gráfico abaixo:

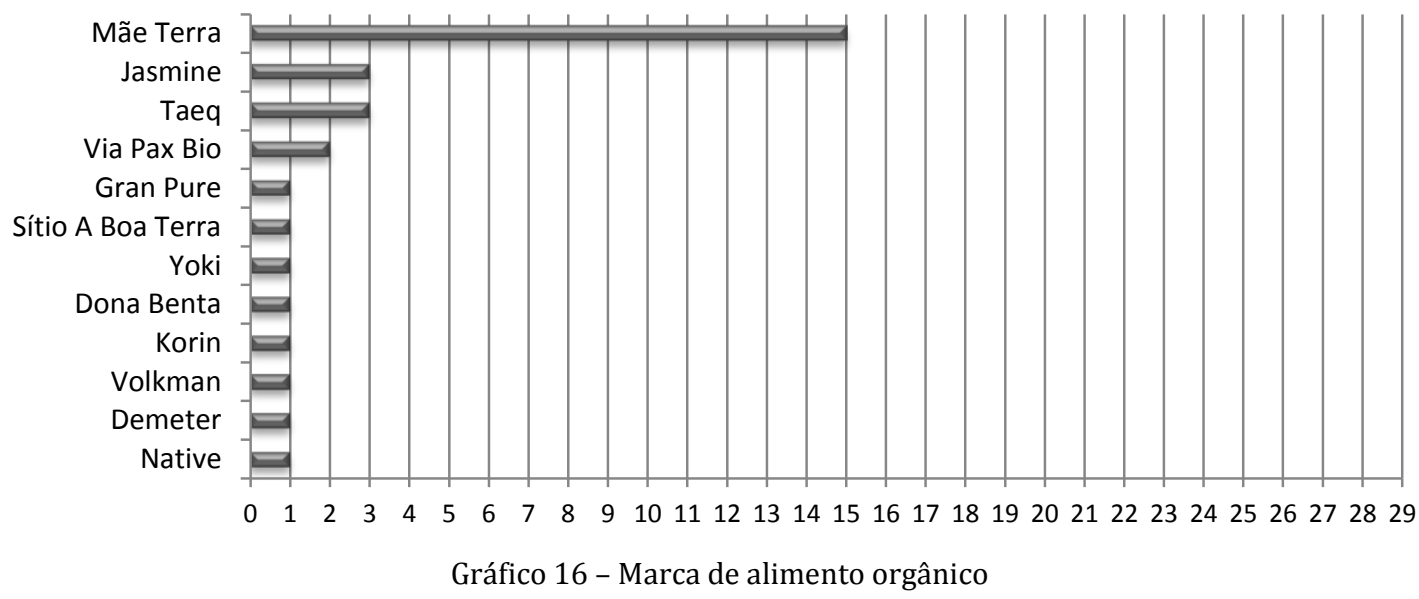

As marcas Mãe Terra e Jasmine, conforme observado no mapeamento das empresas no início das pesquisas, têm maior distribuição do que a Monama e a Via Pax Bio e talvez por isso elas tenham sido mais lembradas. Nenhuma das marcas pesquisadas faz propaganda em outros meios de comunicação além da internet ou da embalagem.

\subsubsection{Mãe Terra e orgânicos}

A relação da marca Mãe Terra com o alimento orgânico foi observada por oito dos 29 entrevistados. Alguns inclusive declararam que achavam que era uma empresa que só produzia alimentos orgânicos. Porém, na pesquisa, foram apresentados produtos da Mãe 
Terra orgânicos e não orgânicos. "A Mãe Terra eu sei que é orgânico. [...] Esse aqui eu conheço a marca, eu sempre comprei ela achando que era uma marca só de orgânicos" (CB22, 2013).

A percepção de que a Mãe Terra é uma fabricante de alimentos orgânicos acontece principalmente pela tradição da marca.

A Mãe Terra, que ela aposta na identidade visual dela como ela já sendo uma marca que trabalha com produtos orgânicos, ela não investe em informar muito que ela é orgânica além da marca dela. (CA02, 2013)

Por relacionar a marca com o alimento orgânico, muitos tiveram dificuldade para separar em grupo de orgânico e não orgânico. Um dos consumidores só acreditou que a Mãe Terra também produzia alimentos não orgânicos quando leu a frase 'orgânico sempre que possível'.

É uma marca que trabalha com orgânicos, Mãe Terra [...] e eu acredito que eles não iam sujar o nome deles se não fosse orgânico. Fala que é orgânico. [...] Fala aqui, quer ver? 'Orgânico sempre que...' Ah, orgânico sempre que possível. [...] talvez não seja orgânico, será? (C25, 2013)

\section{Identificação dos orgânicos nas embalagens Mãe Terra}

Na época que foi desenvolvida a linha de ingredientes da Mãe Terra, ainda não era obrigatório ter o selo SisOrg na embalagem. Por isso, para diferenciar os produtos orgânicos dos não orgânicos da linha de ingredientes, foi usada na palavra "orgânico" num tipo manuscrito e em cor laranja. No início, esta era a única diferenciação da empresa de um produto orgânico e não orgânico.

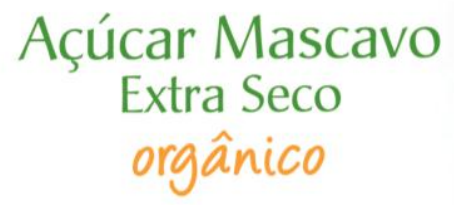

Figura 90 - A palavra 'orgânico', embaixo do nome do produto Identificação para diferenciar um produto orgânico do não orgânico

Depois da obrigação do uso do selo SisOrg, inicialmente a Mãe Terra começou a usar como um elemento a mais na embalagem, quase sempre próximo ao nome do produto. Nas novas embalagens, a Mãe Terra começou a substituir a palavra em laranja pelo selo, como no exemplo da farinha de trigo e açúcar mascavo.

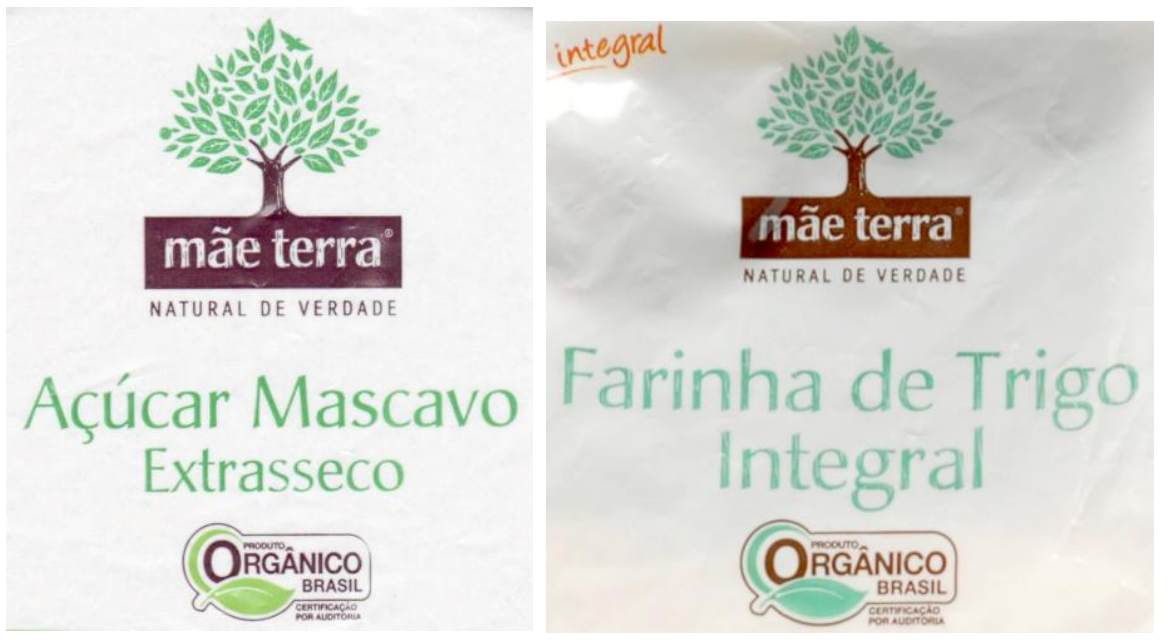

Figura 91 - Selo SisOrg substituindo a palavra "orgânico" nas novas embalagens da Mãe Terra

Isso foi comentado por Designer1, que, na época da entrevista, estava desenvolvendo novas embalagens para os cookies da Mãe Terra. 
Então essa linha nova de light e diet, o selo orgânico já vai informar que é produto orgânico, vai estar embaixo do nome. Porque, por exemplo, aqui existia a palavra 'orgânico' e tinha o selo orgânico. Então são duas informações que dizem a mesma coisa. [...] Agora o selo continua, mas ele está aqui embaixo, no lugar da palavra 'orgânico'. A gente tirou essa informação da palavra 'orgânico' e entrou, e ele também já certifica. (DESIGNER1, 2012)

Foi observado, porém, nas entrevistas, que, nessa localização nas embalagens, apesar de estar no centro ótico ou geométrico da embalagem, localização que teoricamente daria boa visibilidade, algumas vezes a indicação não foi vista em um primeiro momento, e o consumidor separou como produto não orgânico, como foi no caso da farinha de trigo integral. "Olha, que coisa. Tem orgânico aqui e eu não prestei atenção. Que legal, está tão pequenininho. [...] Eu não vi que era orgânico. Eu vi que era integral, eu acho que o integral está muito mais destacado" (CA19, 2013).

As embalagens da farinha de trigo integral e do açúcar mascavo apresentam muitas informações visuais e textuais, onde a informação que mais se destaca é a marca Mãe Terra, seguida pela área colorida com a ilustração. O selo SisOrg perde força do meio desses dois elementos. O nome do produto também não chama a atenção, o que ajudaria para destacar o selo.

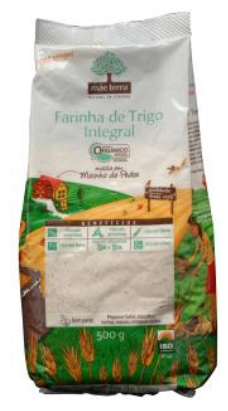

Figura 96 - Selo SisOrg aplicado na embalagem da farinha de trigo integral Mãe Terra

\title{
4.3.2.2. Monama e orgânicos
}

Indústria2 considera importante informar na embalagem os diferenciais de um produto orgânico de forma divertida, para um maior entendimento do consumidor.

\begin{abstract}
A gente antes falava alimentos orgânicos, mas aí a gente fez umas pesquisas de rua e a gente percebeu que, para o consumidor, o diet, light, natural e orgânico, para ele, era tudo a mesma coisa, então ele não entendia o que era orgânico. [...] Então a gente começou, em algumas embalagens, no nosso site, a fazer umas brincadeiras então assim: sem aditivo químico, sem besteira, sem bobagem, para a pessoa entender o que era orgânico. Porque ela não entendia nem o que era orgânico e nem o que era agrotóxico. (INDÚSTRIA2, 2012)
\end{abstract}

A equipe da A10 Design já conhecia o que era um alimento orgânico antes do início do projeto, mas depois que começaram a desenvolvê-lo, pesquisaram mais aspectos que ainda não conheciam. Todas as informações foram usadas em benefício da personalidade da marca e da comunicação. Foi a primeira embalagem de alimento orgânico desenvolvida por Designer3. Na época da entrevista, a A10 também tinha outro cliente no ramo de quinua orgânica além da Monama.

\section{Identificação dos orgânicos nas embalagens Monama}

$\mathrm{Na}$ época em que foi desenvolvida a linha de ingredientes da Monama, ainda não era obrigatório ter o selo SisOrg na embalagem. Por isso, para diferenciar os produtos orgânicos dos não orgânicos, foi usada a palavra "orgânico", com tipo sem serifa, na mesma cor do ' $M$ ' da marca, e embaixo dela, sempre sobre fundo branco. 


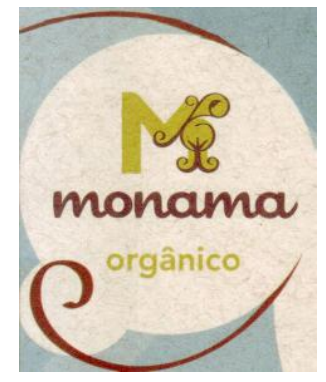

Figura 92 - A palavra "orgânico" embaixo da marca é usada para diferenciar o produto do não orgânico

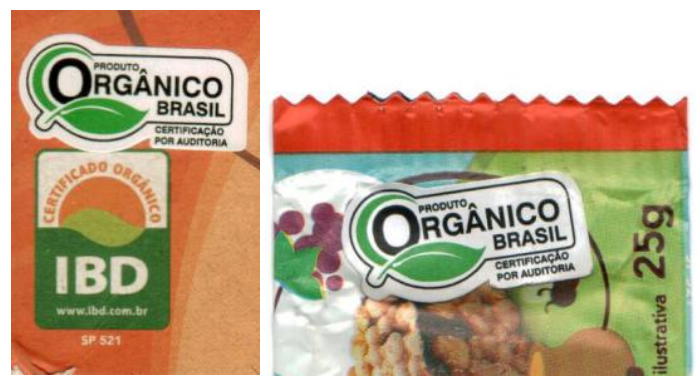

Figura 93 - Adesivo do selo SisOrg aplicado sobre a embalagem de granola e barra de cereais

Até o final do primeiro semestre de 2013, o selo SisOrg ainda era aplicado sobre a marca com um adesivo, não fazendo parte do design da embalagem.

Nenhum dos 15 consumidores entrevistados relacionou a marca Monama como saudável ou orgânica, por não a conhecerem. Apenas descobriram que era produtora de orgânicos após manusearem as embalagens e verem os escritos, para poder separar como sendo saudável. Isto mostra que a atribuição de conceitos subjetivos a uma marca está relacionado a um conhecimento prévio de seus produtos. No mapeamento, no início da pesquisa, os produtos da Monama foram encontrados nos supermercados Pão de Açúcar, na rede Mundo Verde e pela internet.

\subsubsection{Via Pax Bio e orgânicos}

Segundo Designer4 (2013), muitas pessoas confundem o alimento orgânico com outros tipos de produtos, por isso eles escolheram destacar essa informação nas embalagens da Via Pax Bio até mais que a marca, pois, na época, não existia o selo do SisOrg e foi observado que, nos produtos da concorrência, a informação de orgânico era muito discreta.

\footnotetext{
Muita gente confunde até hoje orgânico com hidropônico. Até lojista, supermercadista. Existe essa confusão, então a gente procurou assim, na medida do possível, colocar o máximo de informações, aqui na parte da planta, aqui em cima, além da legislação, o máximo de informação que a gente pode colocar, a gente colocou para o consumidor. (DESIGNER4, 2013)
}

Também foi uma forma de facilitar para o consumidor, pois o orgânico era mais procurado pelo consumidor do que a marca Via Pax Bio, ainda desconhecida. A frase "alimento saudável" foi uma sugestão da Via Pax Bio, logo abaixo, como um diferencial do produto.

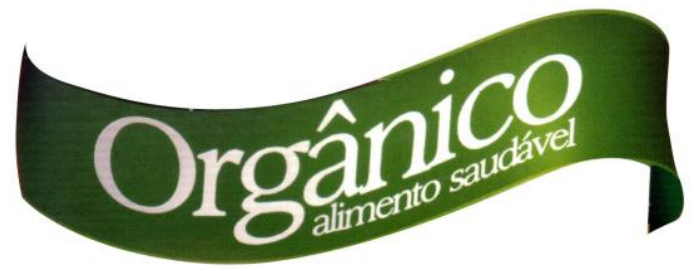

Figura 94 - Faixa que identifica a palavra "orgânico" em todas as embalagens Via Pax Bio

Três dos 14 consumidores entrevistados declararam que olharam o selo de certificação SisOrg. Mas a maioria, 13 consumidores, declarou que olhou a palavra "orgânico". Três consumidores especificaram a faixa verde com a palavra "orgânico" para separar o produto, mostrando a importância do reforço da informação. "Comunica muito bem na hora da decisão porque está bem grande, bem óbvio que se trata de um produto orgânico" (CA02, 2013); "O rótulo de orgânico, a faixa verde é que chama a atenção" (CA10, 2013).

Apenas um consumidor relacionou a marca como uma empresa que vende alimentos orgânicos no momento de fazer a separação entre orgânicos e não orgânicos. 


\subsection{EXPERIMENTO COM OS CONSUMIDORES}

\subsubsection{Grupos de produtos apresentados}

Para verificar se as embalagens de alimentos orgânicos passam a filosofia da empresa, se os consumidores percebem isso pela embalagem e se conseguiam identificar os produtos orgânicos pelas embalagens, os consumidores foram postos a manipular embalagens de diferentes produtos orgânicos e não orgânicos. Outro questionamento era se os consumidores associavam os orgânicos aos alimentos saudáveis.

A seguir serão apresentados os dados relacionados a esses grupos de produtos.

\section{Grupo 1 - Não processado}

O Grupo 1 se refere aos produtos que não foram processados, conservando os grãos inteiros. Apenas foram embalados para serem comercializado com a marca da empresa.
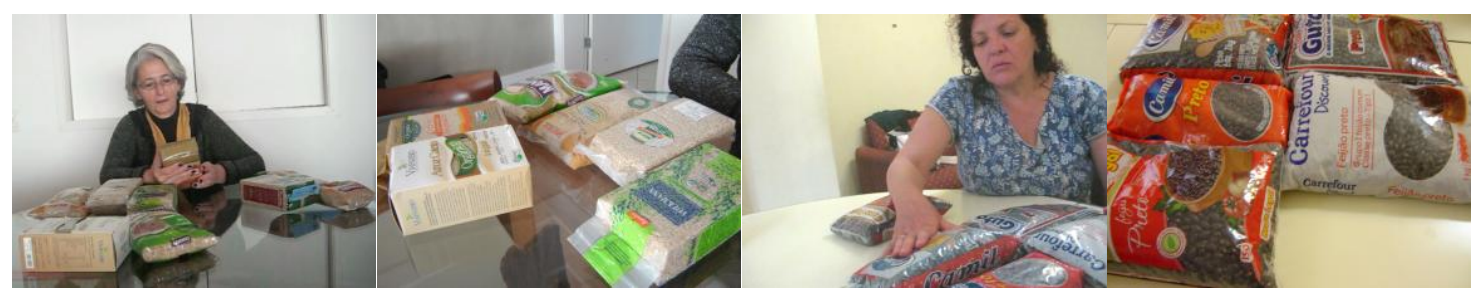

Figura 95 - Imagens das gravações das entrevistas do Grupo 1 (arroz integral e feijão preto). (CB01; CC30, 2013)

\section{Grupo 2 - Pouco processado}

O Grupo 2 se refere aos produtos pouco processados, transformando-os para serem vendidos como ingrediente, porém conservando boa parte de seus nutrientes.

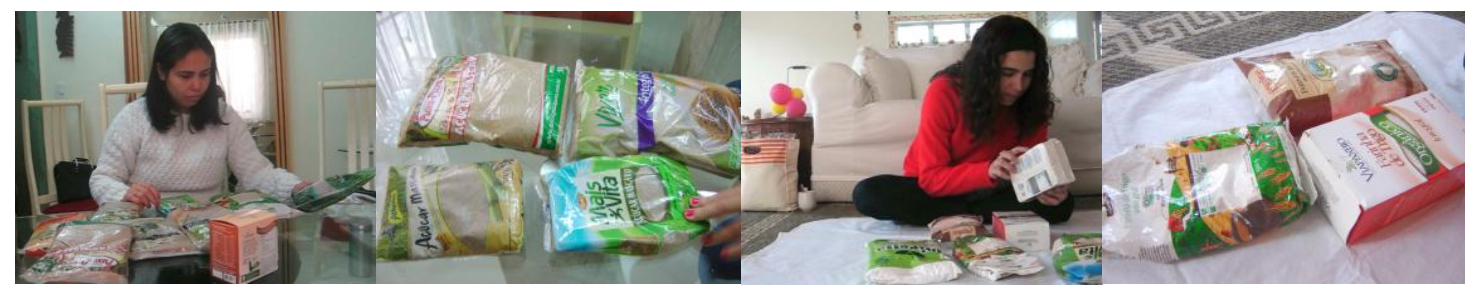

Figura 96 - Imagens das gravações das entrevistas do Grupo 2 (farinha de trigo integral e açúcar mascavo) (CB01; CC30, 2013)

\section{Grupo 3 - Pronto consumo}

O Grupo 3 se refere aos produtos que não precisam ser preparados, ou cozidos, para serem consumidos, basta abrir a embalagem. Usados também para lanches rápidos.
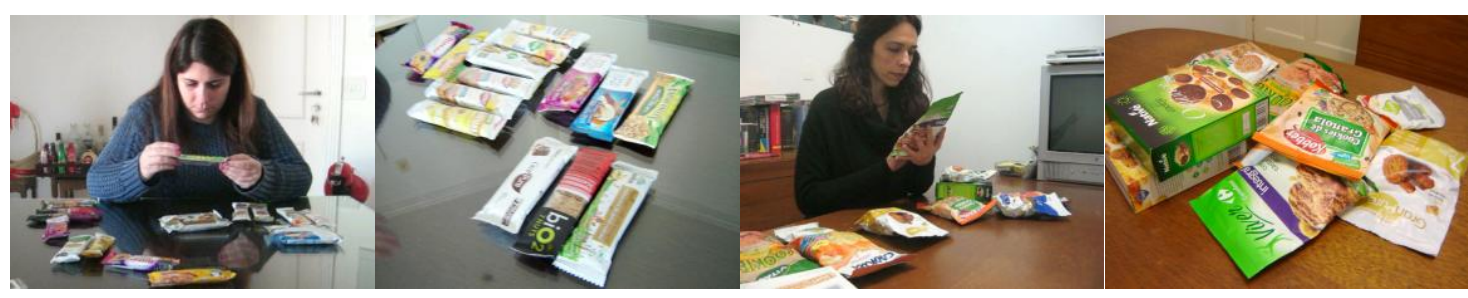

Figura 97 - Imagens das gravações das entrevistas do Grupo 3 (cookie e barra de cereais). (CB01; CC30, 2013) 


\section{Grupo 4 - Preparo rápido para o consumo}

O Grupo 4 se refere aos produtos que precisam ser preparados para serem consumidos, seja aquecendo a água para cozinhar, como no caso do macarrão instantâneo, ou adicionando algo, como no caso da granola.

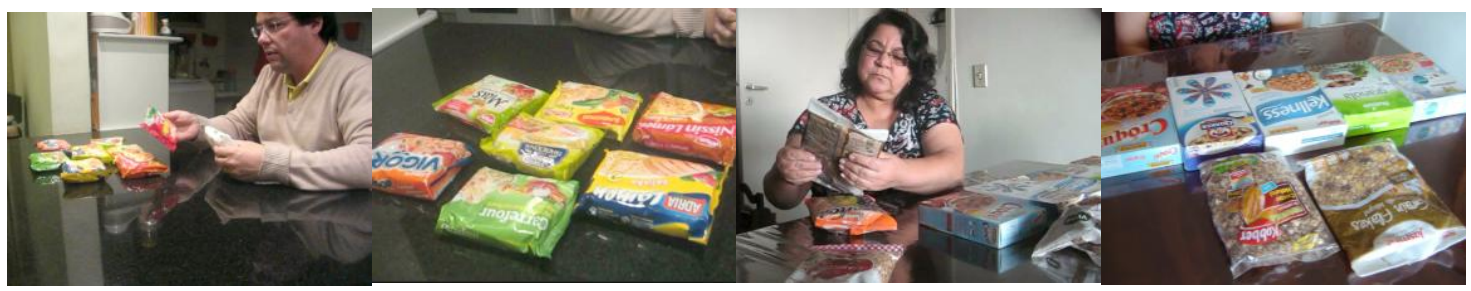

Figura 98 - Imagens das gravações das entrevistas do Grupo 4 (macarrão instantâneo e granola). (CB01; CC30, 2013)

A seguir, serão apresentados os resultados das entrevistas por grupos de produtos seguidos pela respectiva análise das embalagens selecionadas.

\subsubsection{Arroz integral do Grupo 1 de não processados}

As marcas mais separadas como saudáveis foram a Tio João e a Volkman, por seis consumidores. A Mãe Terra foi separada quatro vezes.

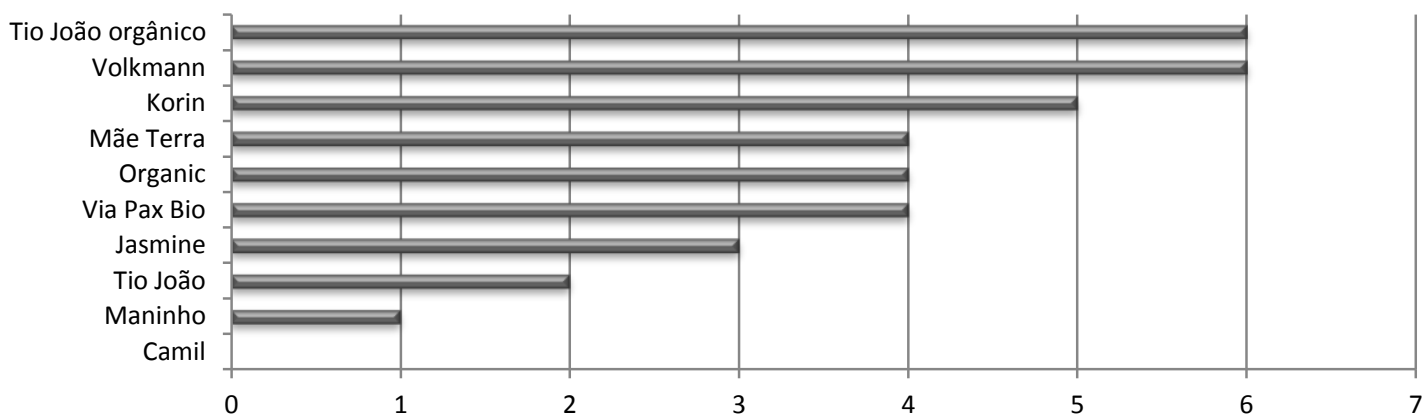

Gráfico 17 - Marcas de arroz integral separadas como mais saudáveis (unidade = no de consumidores)

Os principais critérios para a separação foram: a marca, por ser orgânico, e um deles por ser biodinâmico ${ }^{21}$, como podemos ver no gráfico a seguir:

${ }^{21}$ A agricultura biodinâmica usa preparados homeopáticos feitos de minerais, esterco bovino e plantas medicinais, promovendo, assim, a vitalidade nos alimentos. Os agricultores usam o Calendário Astronômico Agrícola como ferramenta de orientação para os melhores momentos de se trabalhar a terra (ABD, 2014). 


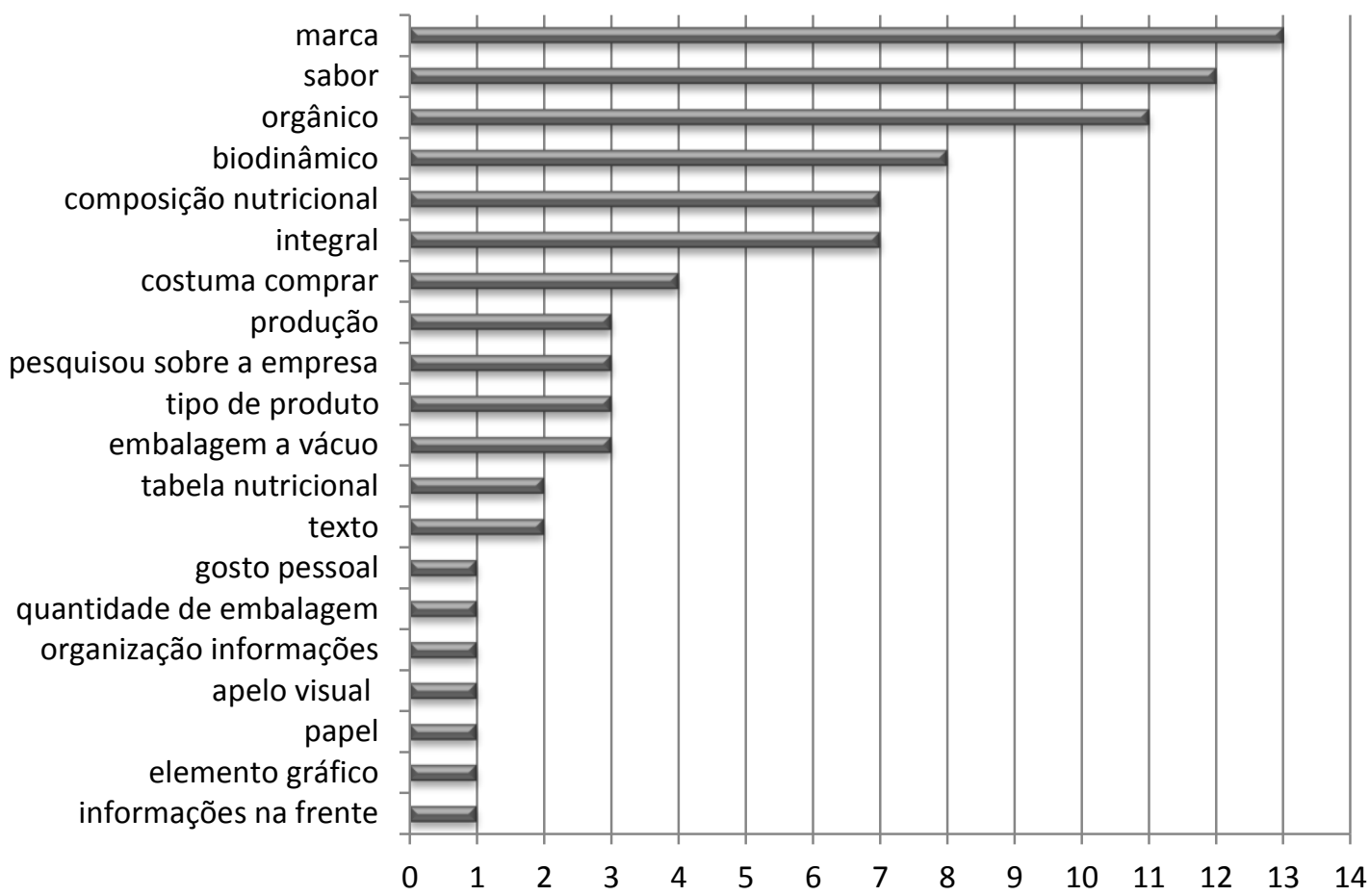

Gráfico 18 - Critérios para a separação de arroz como mais saudável. (unidade = № de menções)

O arroz Tio João foi mais separado, por ser orgânico e de uma marca conhecida, e a Volkmann se diferenciou por ser biodinâmico. Apenas um consumidor mencionou o sabor, isso acontece porque a análise de conteúdo privilegia a quantidade de termos citados e não o seu contexto. Outra distorção do gráfico é que apenas duas pessoas mencionaram algo da composição nutricional.

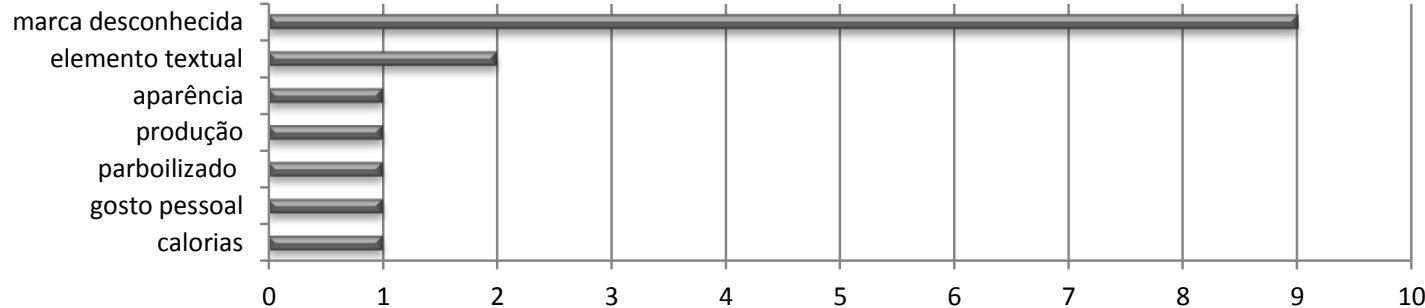

Gráfico 19 - Critérios para a separação das marcas de arroz como menos saudável (unidade = nº de menções)

A marca foi uma informação importante para fazer a separação como menos saudável: dois de sete consumidores relacionaram esse atributo a uma marca desconhecida.

As marcas de arroz integral separadas como orgânicas foram a Tio João Orgânico, Korin, Volkman, Organic e Via Pax Bio, por todos os consumidores.

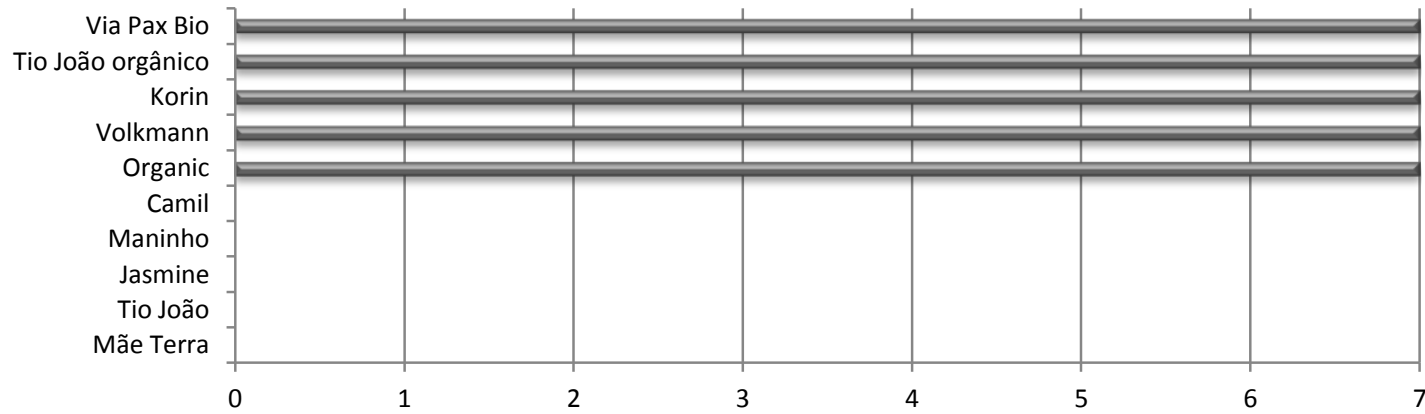

Gráfico 20 - Marcas de arroz separadas como orgânicas (unidade = nํำ de consumidores) 
O arroz integral da Mãe Terra não é um produto orgânico. Ele foi escolhido para verificar se mesmo assim os consumidores o separariam dessa forma. Dois consumidores demonstraram alguma dúvida para separar o arroz Mãe Terra como orgânico, porém ninguém o separou desta forma. Nessa categoria de produtos, a marca Mãe Terra pesou menos para identificar o produto como orgânico, comparado a outras categorias, como a granola e a barra de cereais. Isso pode ter acontecido por ser um produto composto por apenas um ingrediente, menos complexo, fazendo o consumidor acreditar na informação textual da embalagem.

Para separar em orgânico e não orgânico, a principal informação textual olhada foi a palavra "orgânico". O selo SisOrg apareceu em segundo lugar como critério de separação.

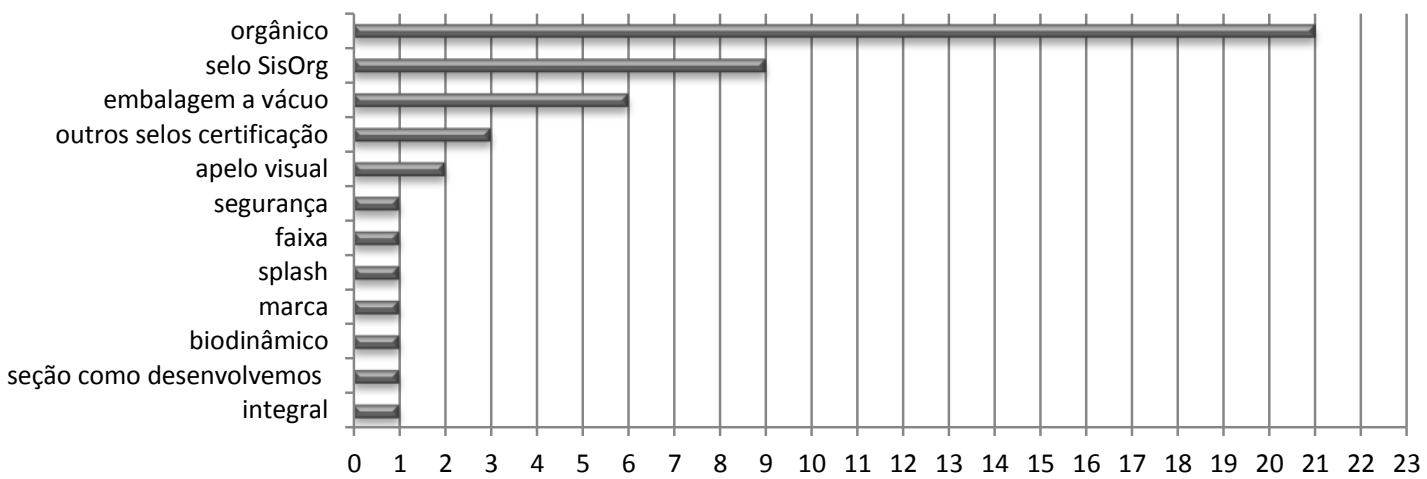

Gráfico 21 - Critérios para a separação do arroz como orgânico (unidade = no de menções)

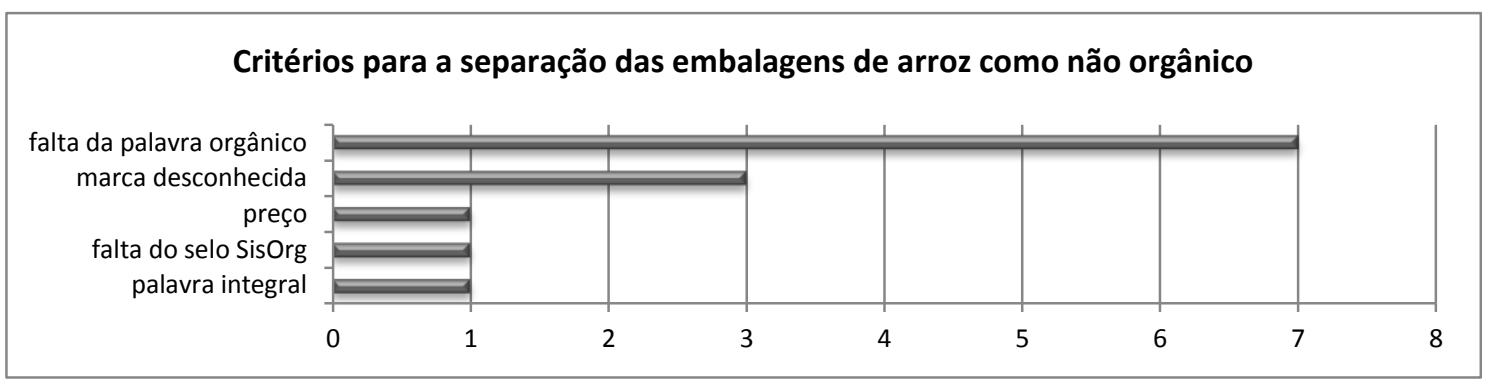

Gráfico 22 - Critérios para a separação do arroz como não orgânico (unidade = no de menções)

Com base nos dados apresentados, podemos considerar que a marca tem grande influência nessa categoria na percepção de que se trata de um alimento saudável. Por ser um alimento com um ingrediente só, a composição nutricional não foi o primeiro critério para separar como orgânico.

Para identificar como alimento orgânico, a informação textual e o selo SisOrg foram suficientes, havendo pouca dúvida.

\subsubsection{Arroz integral Mãe Terra}

O arroz integral Mãe Terra segue o mesmo padrão de design das embalagens da linha de ingredientes, por isso, a seguir, serão analisadas as diferenças específicas desse produto. A embalagem em tamanho real pode ser conferida no Anexo $A$. 


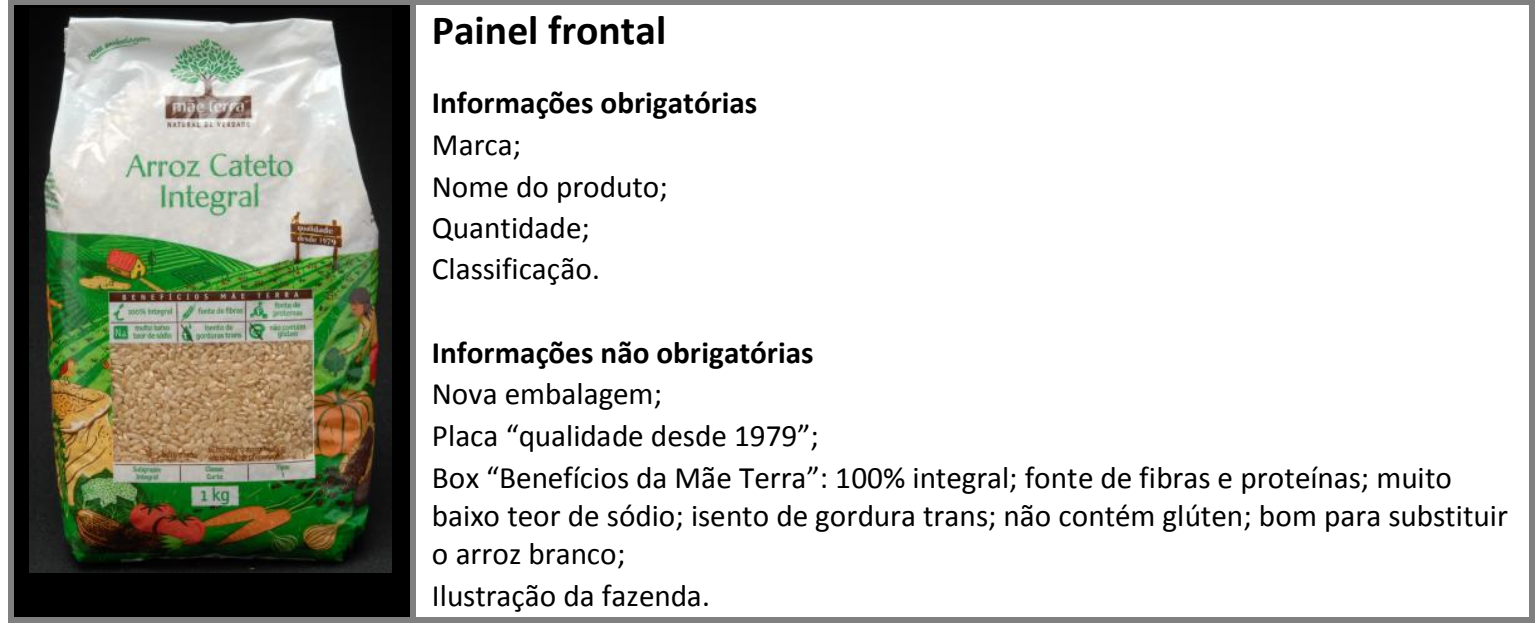

Figura 99 - Painel frontal da embalagem de arroz integral Mãe Terra

O nome do produto está em um tamanho maior que os outros produtos da linha de ingredientes analisados por esta pesquisa. Por não ser orgânico, não utiliza a área abaixo do nome para o selo SisOrg, sobrando mais espaço para aumentar o nome do produto.

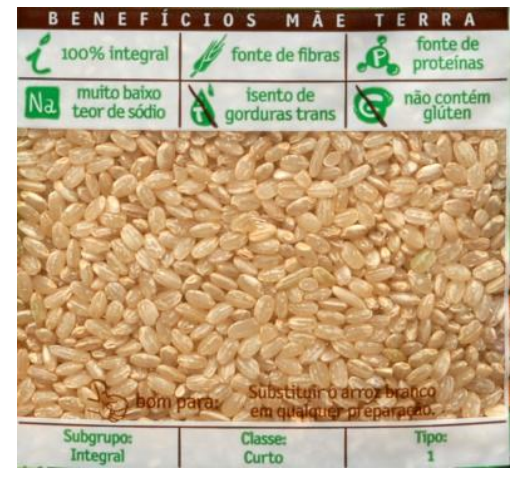

Figura 100 - Box da embalagem de arroz integral Mãe Terra

\section{Análise do box de benefícios do arroz Mãe Terra}

Apesar de apresentar muitas informações, desde a classificação do arroz a características nutricionais, elas estão bem legíveis. Os ícones utilizados não são muito conhecidos ou visíveis. Alguns só são compreensíveis se também ler a informação textual, como no caso do "não contém glúten".

A informação "bom para substituir o arroz branco" ficou pouco legível, por ter sido aplicada em um fundo transparente, não contrastando com a cor do arroz. A janela do box permite bem a visualização do produto.

\section{Análise das diferenças do painel traseiro do arroz integral Mãe Terra}

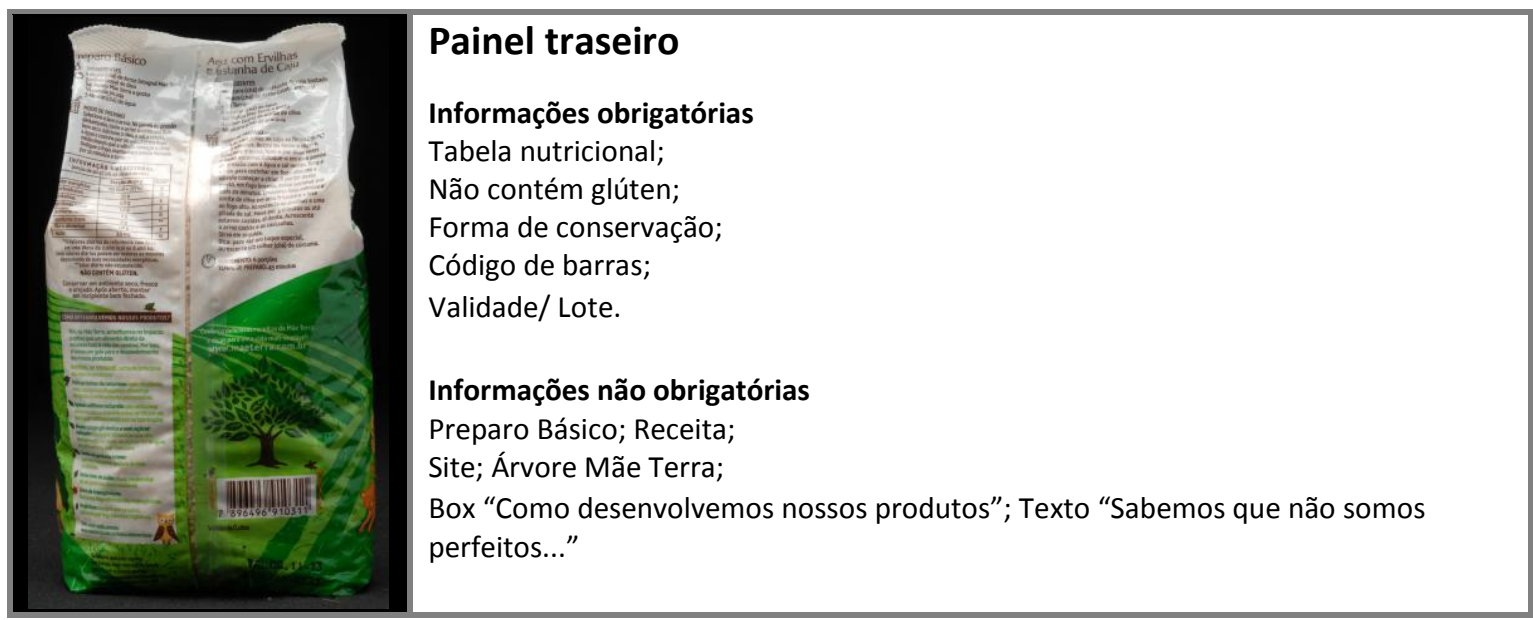

Figura 101 - Painel traseiro da embalagem de arroz integral Mãe Terra 
Segundo o sentido de leitura, de cima para baixo, da esquerda para a direita, a primeira informação do painel traseiro é o preparo básico do arroz, porém todas as informações textuais que estão sobre o fundo branco têm o mesmo peso visual, não destacando nada. $A$ primeira informação a ser vista é a ilustração, por causa das cores em contraste com o fundo branco. Os textos aplicados sobre a ilustração sem um fundo claro têm pouca legibilidade por seu tamanho reduzido e pouco contraste de cor.

As informações que mais se destacam são as que estão dentro do box "Como desenvolvemos nossos produtos". Dentro desse box, ainda tem uma ilustração da coruja, cujo significado pode ser interpretado como símbolo da sabedoria, inteligência e conhecimento. A árvore da marca da Mãe Terra é aplicada na ilustração, integrada à fazenda.

Os elementos gráficos e textuais estão divididos na embalagem e alinhados em duas colunas, estando em equilíbrio. Todos os textos são escritos na mesma tipografia do nome do produto.

Análise das diferenças dos painéis laterais do arroz integral Mãe Terra

$\begin{array}{ll}\text { Painel lateral direito } & \begin{array}{l}\text { Painel lateral esquerdo } \\ \text { Informações obrigatórias } \\ \text { legislação. }\end{array} \\ \begin{array}{l}\text { Informações não obrigatórias } \\ \text { Marca; } \\ \text { Nome do produto; } \\ \text { Texto institucional. }\end{array} & \begin{array}{l}\text { Informações obrigatórias } \\ \text { Nenhuma. Não há nada especificado na } \\ \text { legislação. }\end{array} \\ \text { Informações não obrigatórias } \\ \text { Marca; } \\ \text { Nome do produto; } \\ \text { Texto sobre o arroz. }\end{array}$

Figura 102 - Painéis laterais da embalagem de arroz integral Mãe Terra

Segundo o sentido de leitura, de cima para baixo, da esquerda para a direita, a primeira informação a ser lida nos dois painéis laterais é a marca Mãe Terra, seguida pelo nome do produto.

A marca é aplicada sobre o fundo banco, dando boa visibilidade e contraste de cor. O nome do produto é aplicado como no painel frontal, reduzido e com boa visibilidade.

A informação que vem abaixo do nome do produto no painel esquerdo é um ícone de panela e um pequeno texto centralizado, em cor verde, sobre o arroz integral. O tamanho do tipo e o contraste de cor com o fundo dá boa legibilidade.

A informação que vem abaixo do nome do produto no painel direito é um texto institucional da Mãe Terra em cor marrom. O tamanho do tipo e o contraste de cor com o fundo dá boa legibilidade.

Todas essas informações estão acima da ilustração que contorna toda a embalagem. No painel esquerdo, o destaque da ilustração é o espantalho e o gato; no painel direito, é a moça colhendo as hortaliças, transmitindo integração com a fauna e flora.

Os elementos gráficos estão em equilíbrio e centralizados em relação à marca Mãe Terra. 
Análise das diferenças da base do arroz integral Mãe Terra

\begin{tabular}{|l|l|l|}
\hline Base frente & $\begin{array}{l}\text { Base traseira } \\
\text { Informações obrigatórias } \\
\text { Nenhuma. Não há nada } \\
\text { especificado na legislação. } \\
\text { Informações não obrigatórias } \\
\text { Marca; } \\
\text { Nome do produto. }\end{array}$ & $\begin{array}{l}\text { Informações obrigatórias } \\
\text { Identificação de origem; CNPJ; SAC; } \\
\text { Indústria Brasileira. }\end{array}$ \\
$\begin{array}{l}\text { Informações não obrigatórias } \\
\text { Identificação do material da } \\
\text { embalagem; } \\
\text { Ícone "jogue o lixo no lixo" }\end{array}$
\end{tabular}

Figura 103 - Bases da embalagem de arroz integral Mãe Terra

Segundo o sentido de leitura, de cima para baixo, da esquerda para a direita, a primeira informação a ser lida na base da frente é a marca Mãe Terra, seguida pelo nome do produto. Na base traseira não há nenhuma informação de destaque.

$\mathrm{Na}$ base da frente, a marca e o nome do produto tem bom contraste de cor e estão bem legíveis. Já a base traseira, todas as informações não tem contraste de cor com o fundo verde, dificultando a leitura das informações.

Tanto na base da frente, quanto a base traseira, as informações não são legíveis quando a embalagem está de pé, mostrando claramente que é uma área reservada para informações consideradas menos importantes. O fato da identificação do material estar nessa área e sem contraste de cor com o fundo mostra que essa informação não é considerada importante para esse produto.

\section{Hierarquia de leitura}

A hierarquia de leitura da embalagem de arroz integral da Mãe Terra demonstrada abaixo faz com que informações mais relacionadas à marca tenham mais destaque do que as informações mais específicas do produto.

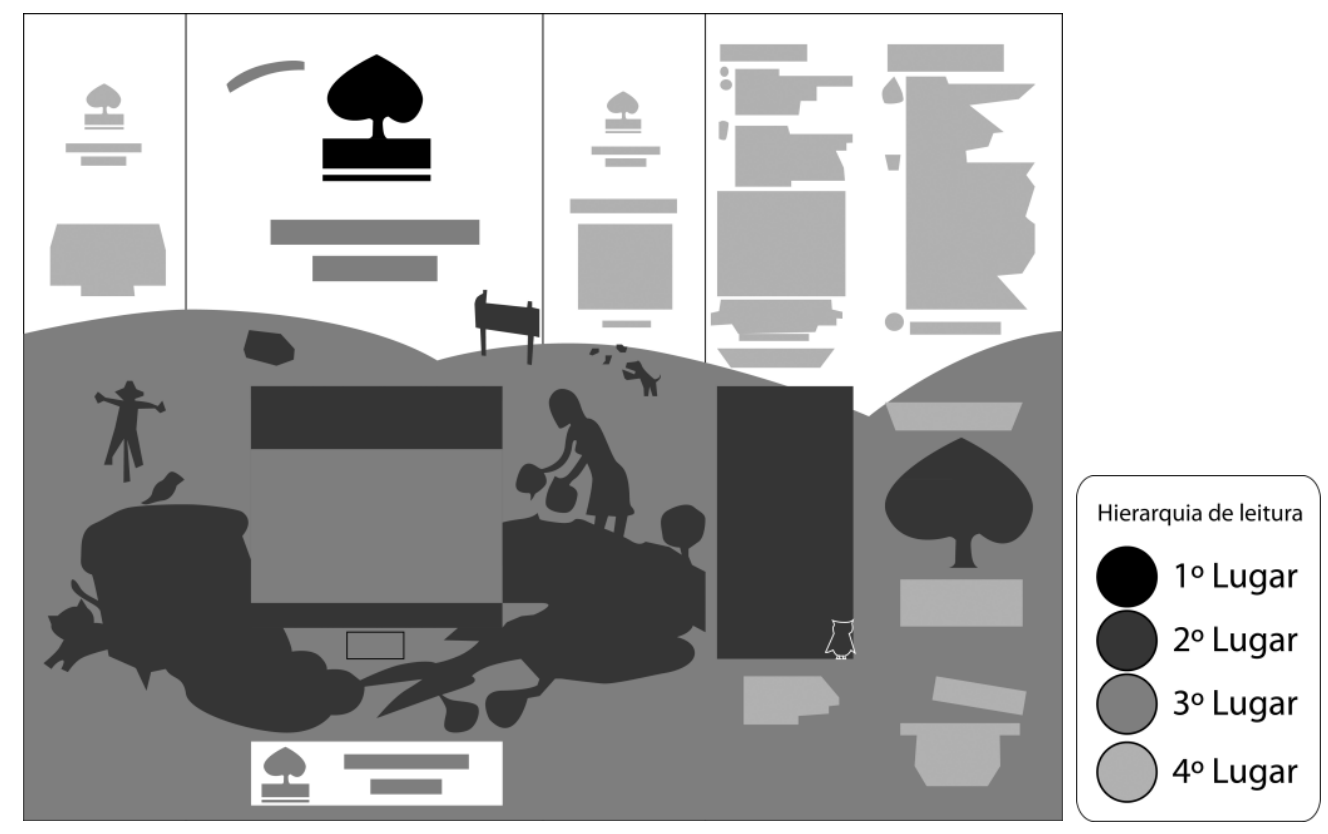

Figura 104 - Hierarquia de leitura do arroz integral Mãe Terra 


\section{Apresentação dos dados das entrevistas}

Quando perguntados se já tinham comprado o arroz integral ou algum outro produto da Mãe Terra dessa linha, quatro dos sete entrevistados declararam que sim e dois que já tinham visto, mas não compraram. Quando questionados o que influenciou a compra, quatro consumidores declararam que compraram por causa da marca.

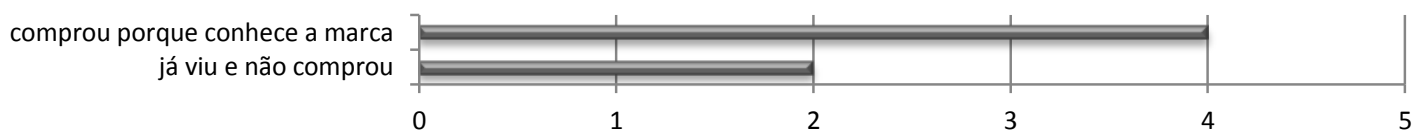

Gráfico 23 - Respostas à pergunta "Você já comprou o arroz integral Mãe Terra ou de outro sabor?" (unidade $=\mathrm{n}^{\mathrm{o}}$ de consumidores)

O principal motivo declarado para não comprar o arroz integral Mãe Terra foi por falta de costume em comer arroz integral.

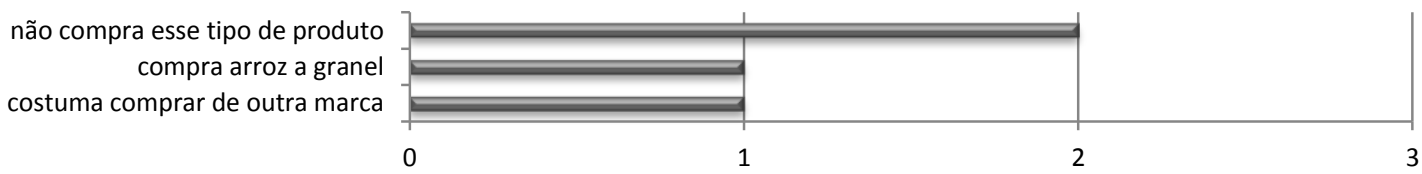

Gráfico 24 - Motivos para não ter comprado o arroz Mãe Terra. (unidade = n⿳o de consumidores)

As principais categorias positivas do arroz integral Mãe Terra, declaradas pelos consumidores, foram: a ilustração (seis consumidores), a embalagem passa "algo bom" (quatro consumidores) e as principais informações estão na frente da embalagem (três consumidores).

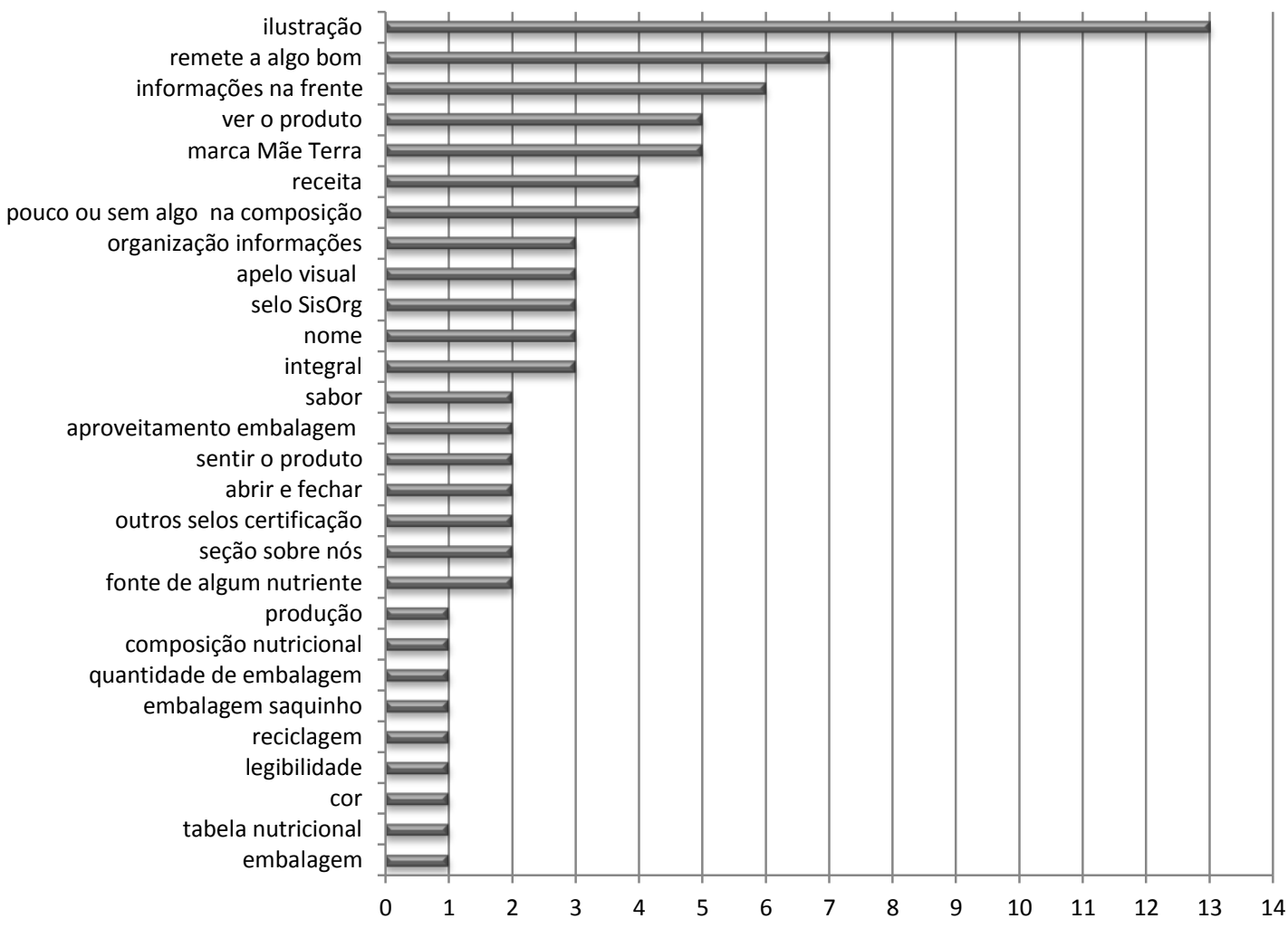

Gráfico 25 - Aspectos positivos do arroz integral Mãe Terra (unidade = n⿳0 de menções) 
As principais categorias negativas do arroz integral Mãe Terra, declaradas pelos consumidores, foram: a aparência do arroz (três consumidores), a demora em cozinhar (um consumidor) e a percepção de que é um produto mais caro (três consumidores). A forma de preparo, por considerar que demora para cozinhar, foi citada apenas por um consumidor, apesar do destaque no gráfico.

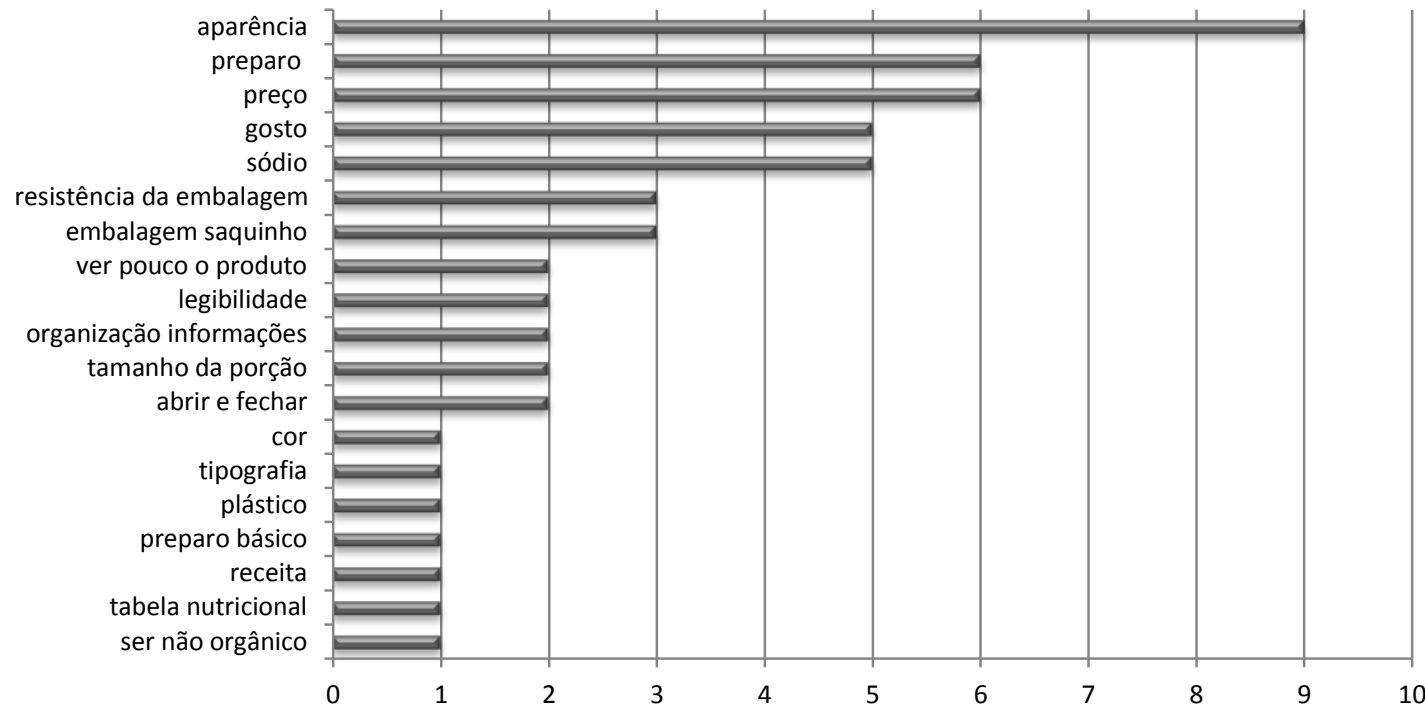

Gráfico 26 - Aspectos negativos do arroz integral Mãe Terra (unidade = no de menções)

Alguns itens em comum com outras embalagens de ingredientes já foram falados anteriormente, mas alguns aspectos mais específicos do arroz integral Mãe Terra se destacam.

\section{Produto}

O tipo de produto (arroz integral cateto) chamou a atenção de dois consumidores e é considerado um alimento saudável. "O que primeiro me chamou atenção é porque é o arroz cateto" (CB32, 2013).

Por não gostar do sabor do produto, por ser integral, um dos consumidores acabou associando o produto como algo negativo, mesmo considerando mais saudável.

Eu tenho um pouco de restrição ao arroz integral, acho que tem um sabor meio proeminente. Acho que demora muito para cozinhar, e não tem o mesmo efeito do arroz refinado, eu sei que não é tão saudável. Pelo menos, a questão do sabor para mim e a aparência é [sic] o que chama muito atenção, um arroz branco soltinho gostoso, o gosto do tempero, o costume do arroz refinado, o gosto que a gente tem dele é muito mais suave e não interfere nos outros alimentos que você vai colocar à mesa, eu acho que este aqui modifica o sabor. (CC13, 2013)

Apesar de declarar que não consome, um dos consumidores tem a percepção de que é um produto mais caro por causa da marca, pois tem o costume de consumir o mesmo tipo de arroz, porém compra a granel. Outra coisa negativa seria por não ser orgânico, principalmente por terem sido mostradas na entrevista outras opções orgânicas. "Eu acho que o preço seria uma coisa negativa. O fato dela não ser 100\% orgânico" (CB32, 2013).

Um dos consumidores, que já conhecia o produto, comentou que, comparado com outros produtos similares, o preço do arroz integral da Mãe Terra é acessível. "Acho assim bem razoável, o preço é intermediário, ele não é nem tão caro” (CA09, 2013). 


\section{Embalagem}

O tipo da embalagem, em saquinho e de plástico, foi percebido por alguns dos consumidores como algo negativo. Um dos motivos foi por considerar que preserva menos o produto em comparação com as embalagens fechadas a vácuo.

Hoje em dia, depois você vai me dizer se procede ou não, eu acho que na embalagem assim, em sacos plásticos, a criação dos carunchos é muito mais proliferada, nessa embalagem, então isso é um ponto negativo, dura pouco. [...] E não ser a vácuo. (CC13, 2013)

A quantidade de produto $(1 \mathrm{~kg})$ foi considerada como algo negativo por um dos entrevistados.

[...] como as embalagens são de um quilo, você tem que comprar um quilo, se você usa só um pouquinho não adianta, você tem que comprar um quilo e isso com o tempo vai criar o caruncho e eu não sei lidar com isso. [...] então eu acho que essas coisas deveriam ter a possibilidade de você comprar em menor tamanho isso, para as pessoas que moram sozinhas, é de fundamental importância. (CC13, 2013)

Porém, a embalagem em saquinho também foi considerada como algo positivo por um dos consumidores, por remeter às embalagens mais antigas, quando comparadas às embalagens fechadas a vácuo. "E também essa coisa de ser saquinho lembra um pouco embalagem antiga, é quase um arroz solto, mas ele está nessa embalagem assim, ele remete ao arroz solto" (CA09, 2013).

A forma de abrir a embalagem também foi considerada como algo positivo, por um consumidor, e negativo por outro. "E eu consigo abrir só uma parte aqui da embalagem. Abrir só a ponta para poder fazer assim e depois fica fechadinho, não precisa nem rasgar a embalagem" (CA10, 2013).

Existem no mercado de embalagens opções que facilitam a abertura da embalagem, como picotes, e o seu fechamento, como um zíper. Porém, esse tipo de solução teria um custo adicional na embalagem. Provavelmente por isso não é utilizado.

O que considerou como negativo reclamou de uma forma geral das embalagens em saquinho como a do arroz.

A negativa é que eu acho dessas coisas é a dificuldade que se tem aqui de abrir, mas não é dela em si, é esse processo aqui. [...] Eu não me dou muito bem com ele. Ou eu não tenho força, eu não sei. Eu não gosto desse processo. Não sei se os outros, as outras pessoas também acham desse processo assim de abrir. (CB18, 2013)

\section{Box de benefícios}

As características do produto, apresentadas no box de benefícios da Mãe Terra, foram algo que chamou a atenção dos entrevistados de forma positiva.

[...] diz as fontes, as características. Bom para substituir o arroz branco, e ele então é integral, com baixo teor de sódio, fibras, isento de gordura, fonte de proteína, sem glúten. Ele explica bem. E uma coisa que eu gosto muito de ler é essa parte aqui. Eu tomo muito cuidado na minha alimentação atual, é o sódio. (CB18, 2013)

\section{Painel traseiro}

Conforme já observado na análise da embalagem, o excesso de informações e a forma com que elas foram organizadas na embalagem acabaram dificultando a leitura por alguns consumidores. "Muita informação ao mesmo tempo, não consigo ler tudo. É informação solta assim, tem aqui, tem aqui, benefício, acho que isso poderia ser bem diagramado" (CA31, 2013). 
A embalagem, volto a dizer, eu, mesmo usando óculos, tenho uma grande dificuldade para lê-las. Então eu acho então que deveriam ser elegidas [sic] algumas coisas mais importantes, que se use mais a embalagem com menos desenhos e mais informações. (CC13, 2013)

As informações que deveriam melhorar a legibilidade, mencionadas pelos consumidores, são as informações nutricionais e as receitas.

[...] informação nutricional, por exemplo, está minúscula. 'Não contém glúten' eu acho que é importante e está bem visível, 'preparo básico' você precisa pegar óculos de aumento, e também tem aqui uma receita que também eu não enxergo, e então, você tem todo esse espaço e a receita fica aqui ou a informação nutricional, que é importante. (CC13, 2013)

A receita é uma informação que é percebida como algo positivo constar na embalagem, apesar da dificuldade de leitura. "[...] tem receita também. Eu posso não fazer, mas eu costumo ver. São as ideias e tudo. A gente, como uma pessoa só, já não faz muito, mas eu gosto" (CB18, 2013).

Como na entrevista é dado um tempo livre para olhar as informações, as observações provavelmente não seriam as mesmas em uma situação normal de consumo. "Aqui a gente está em um tempo largo, mas, no supermercado, você não tem tanto tempo, e é muito difícil. [...] a letra é muito pequena ou tem um jeito que é mais difícil de acessar a informação" (CA21, 2013).

\section{Matriz semântica arroz Mãe Terra}

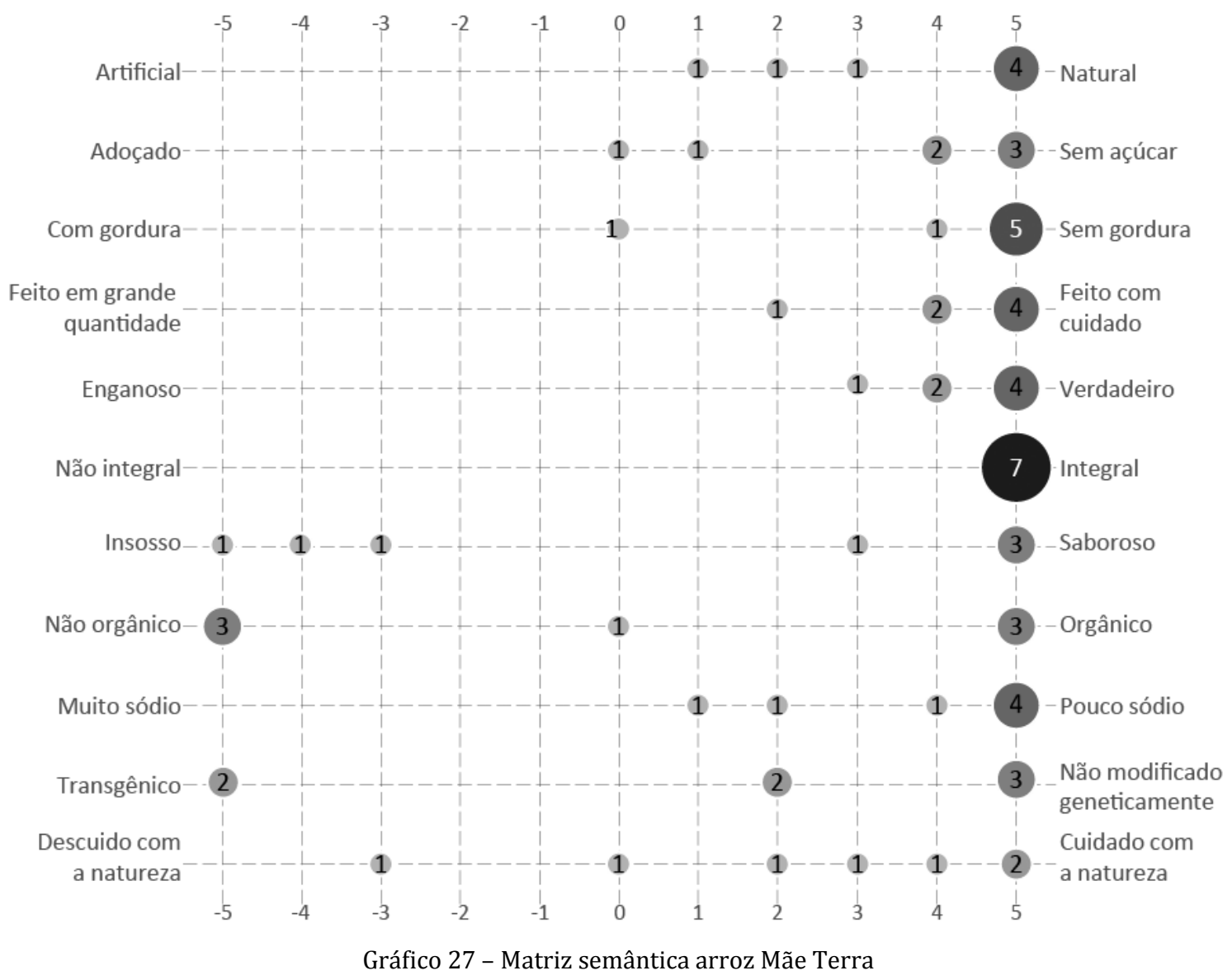

Observa-se, na matriz semântica, preenchida no final da entrevista, um predomínio de respostas mais positivas do produto. Todos colocaram no nível máximo que o produto é integral, talvez pelo fato de estar escrito na embalagem. 
O gosto por arroz integral é bem dividido, três consumidores classificaram como mais insosso, podendo esse ser um fato que influenciou nas respostas.

Apesar de o produto não ser orgânico, essa foi uma resposta bem dividida, três escolheram a opção mais próxima de não orgânico, um escolheu a opção do meio, provavelmente por ter ficado em dúvida, e três optaram por ser orgânico, talvez pelo fato da marca Mãe Terra estar relacionada com produtos orgânicos ou até mesmo pelo tipo de produto.

Apesar de a informação "livre de transgênicos" estar no box "Como desenvolvemos os nossos produtos", o espectro de respostas também ficou dividido.

A partir dos dados apresentados, observa-se que a embalagem de arroz integral Mãe Terra passa bem a informação de que é um alimento mais saudável, porém o excesso de informações da embalagem faz com que algumas delas não fiquem muito legíveis, principalmente as que estão no painel traseiro.

\subsubsection{Arroz integral Via Pax Bio}

O arroz integral Via Pax Bio segue o mesmo padrão de design das embalagens da linha de ingredientes, por isso a seguir serão analisadas as diferenças específicas desse produto. A embalagem em tamanho real pode ser conferida no Anexo $C$.

\section{Análise das diferenças do painel frontal do arroz integral Via Pax Bio}

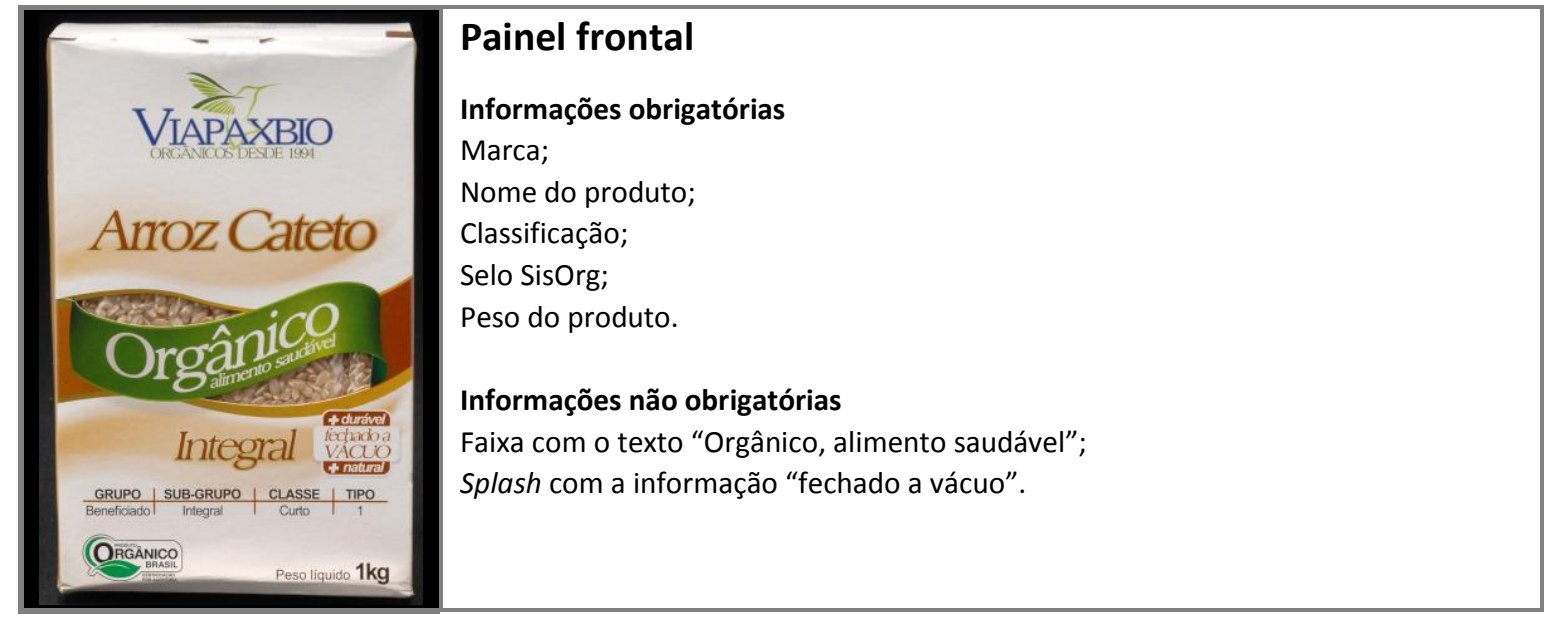

Figura 105 - Painel frontal da embalagem de arroz integral Via Pax Bio

A cor do fundo do painel frontal é um degradê do bege até o branco, não interferindo na leitura e se diferenciando dos outros produtos da linha.

A classificação do produto usa a mesma tipografia do peso do produto. A linha usada para dividir as informações é da mesma cor que as laterais da embalagem.

O splash fica em uma área menor e mais apertada se comparada com a embalagem da farinha de trigo, entre a faixa verde e a classificação do produto, do lado direito, não se relacionando visualmente com nenhum outro elemento. A cor branca do fundo em relação à cor do splash faz com que não haja contraste de cores, não se destacando. 


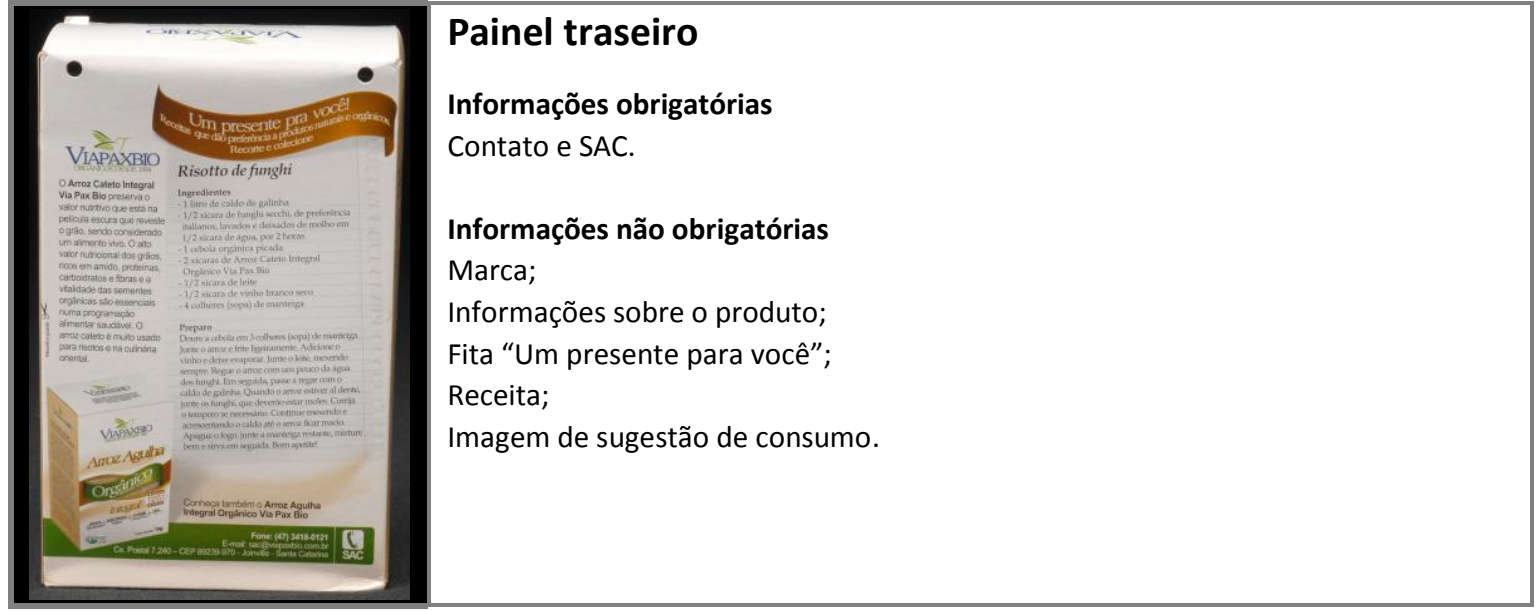

Figura 106 - Painel traseiro da embalagem de arroz integral Via Pax Bio

A cor do fundo usa as mesmas cores do painel frontal para o degradê. A imagem escolhida como sugestão de consumo foi uma variação do produto: o arroz tipo agulha. A receita escolhida foi um rizotto de funghi. A fita com a frase "Um presente para você" no arroz integral é em cor marrom claro, a mesma cor usada atrás da faixa verde no painel frontal. Talvez essa cor tenha sido escolhida para evitar o uso da cor magenta, reduzindo custos e uso de tinta.

\section{Análise das diferenças dos painéis laterais do arroz integral Via Pax Bio}

\begin{tabular}{|c|c|c|c|}
\hline & Painel lateral direito & & Painel lateral esquerdo \\
\hline VIAPAXBIO & Informações obrigatórias & VIAPAXBIO & Informações obrigatórias \\
\hline 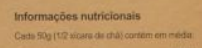 & ingredientes: Advertências. & 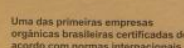 & iverimuma. \\
\hline$=$ & Sem corantes e conservantes; & & Informações não obrigatórias \\
\hline siste- & Modo de conservar; & & Marca; \\
\hline$=$ & Validade e lote; Código de barras. & & Texto institucional. \\
\hline - & Informações não obrigatórias & & \\
\hline 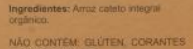 & Marca. & & \\
\hline 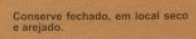 & & & \\
\hline 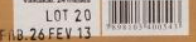 & & & \\
\hline
\end{tabular}

Figura 107 - Painéis laterais da embalagem de arroz integral Via Pax Bio

A cor do painel esquerdo e direito do arroz integral é bege claro, contrastando com o texto e dando boa legibilidade. A cor também tem relação com a cor do produto.

A marca da Via Pax Bio sobre o fundo colorido tem pouco contraste, principalmente com a cor verde. A frase "Orgânicos desde 1994" é pouco legível pela falta de contraste de cor.

A cor do painel direito é a mesma do painel esquerdo, criando uma relação entre os painéis. 


\section{Análise das diferenças da tampa e da base do arroz integral Via Pax Bio}

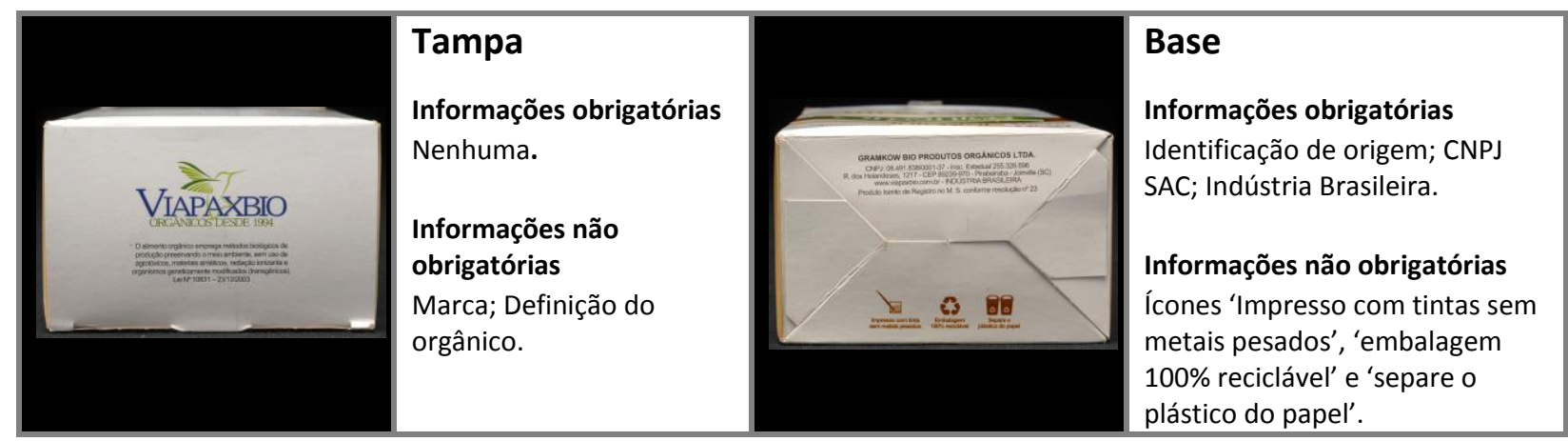

Figura 108 - Tampa e base do arroz integral Via Pax Bio

A cor do fundo da tampa e da base é o branco, que dá boa legibilidade para a marca e os textos. A cor dos ícones do arroz integral, em marrom, é a mesma usada na fita no painel posterior e atrás da faixa verde no painel frontal.

Como não foram feitas perguntas específicas sobre o arroz integral Via Pax Bio, a partir da análise da embalagem observa-se que a embalagem de arroz integral apresenta as informações do produto de forma clara e legível, seguindo a mesma estrutura visual dos outros produtos da linha de ingredientes.

Passa bem a informação de que é um alimento mais saudável, porém o excesso de informações da embalagem faz com que algumas informações não fiquem muito legíveis, principalmente as que estão no painel traseiro.

\subsubsection{Feijão preto do Grupo 1 de não processados}

Foram entrevistados sete consumidores para o feijão preto. A marca considerada mais saudável foi a da Via Pax Bio, por seis consumidores, seguida pela Camil exportação, por três consumidores.

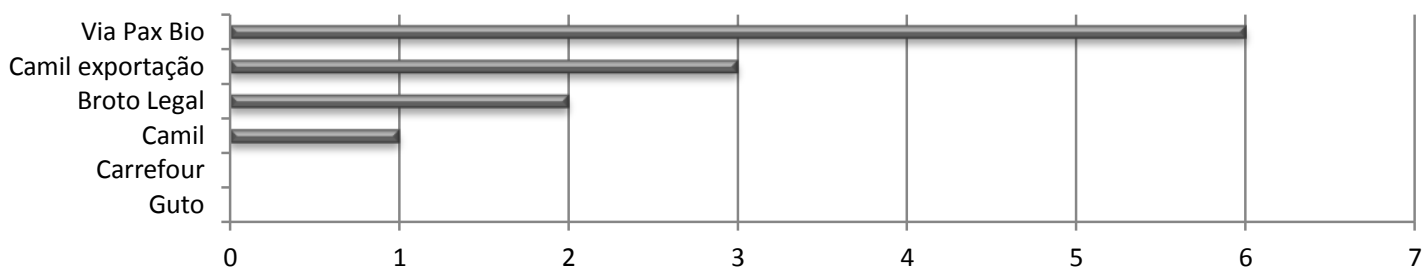

Gráfico 28 - Marcas de feijão preto separadas como mais saudáveis (unidade $=$ no de consumidores)

Os principais critérios para a separação foram: a palavra "orgânico" (cinco consumidores), a composição nutricional (um consumidor), o tamanho da porção (dois consumidores) e a forma de produção (dois consumidores), como podemos ver no gráfico a seguir: 


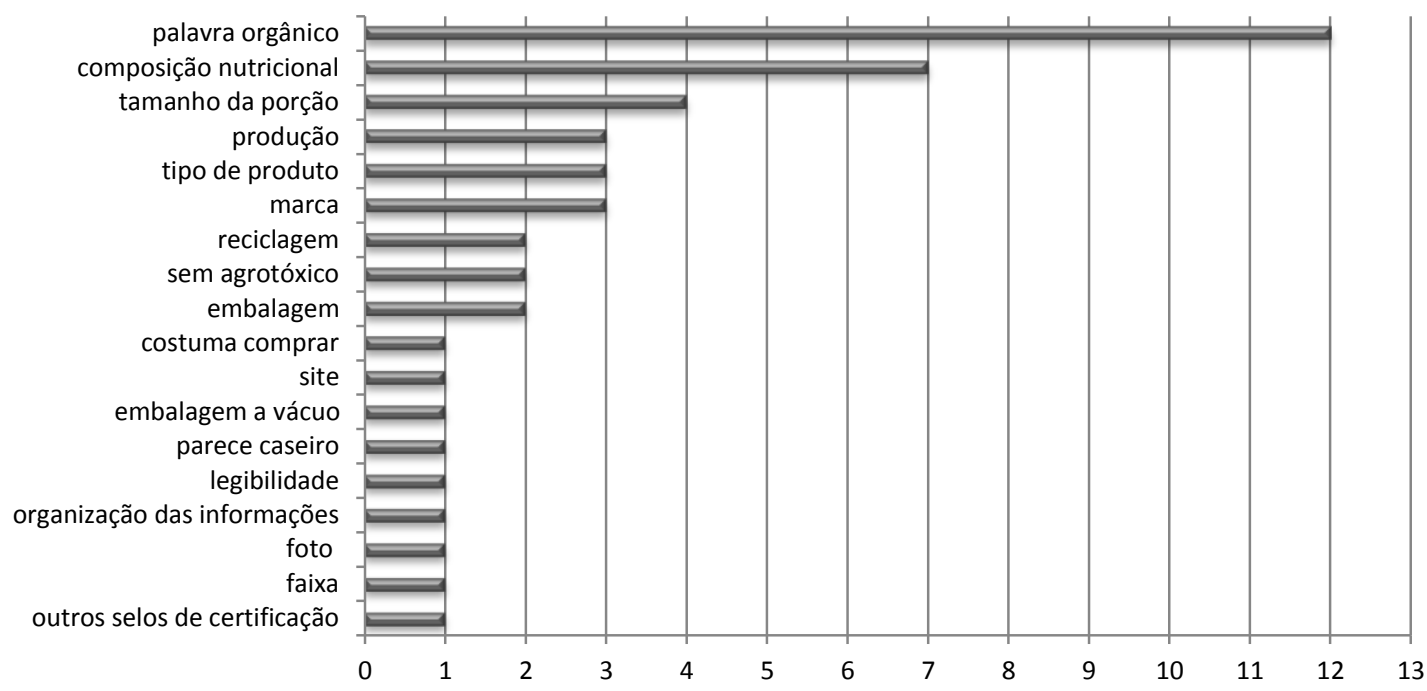

Gráfico 29 - Critérios para separação do feijão preto como mais saudável. (unidade = no de menções)

No gráfico anterior, apenas um dos consumidores olhou principalmente a composição nutricional e citou vários nutrientes da tabela, por isso a distorção do gráfico, levando essa menção a ficar em segundo lugar.

O preço foi a informação mais citada para separar como menos saudável, porém por apenas um consumidor, seguido pela marca (dois consumidores) e por não considerar a embalagem atrativa (um consumidor).

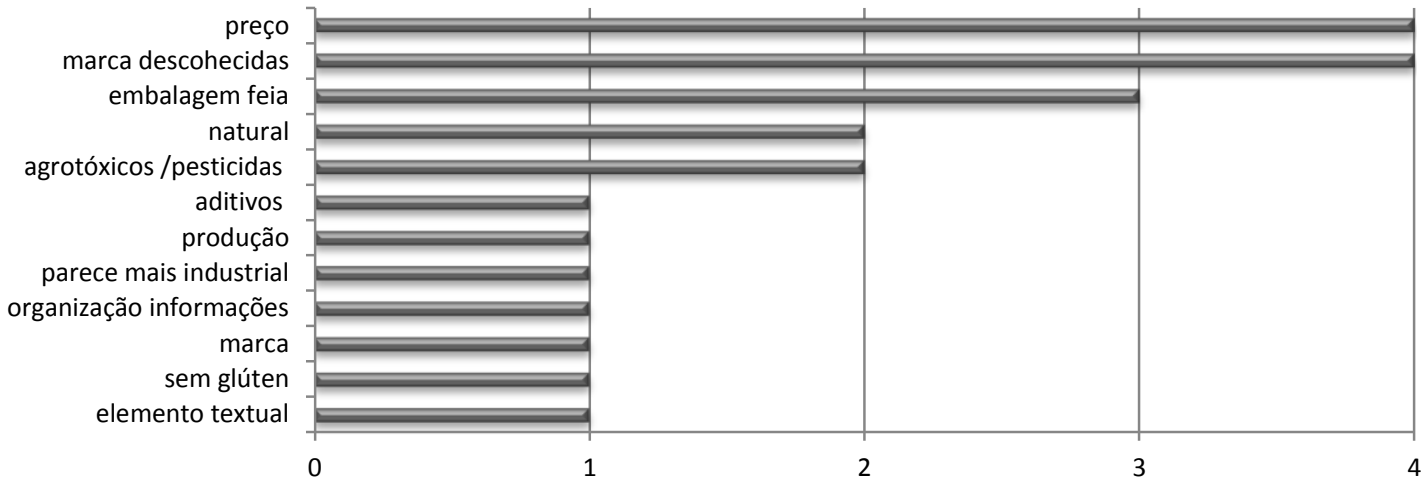

Gráfico 30 - Critérios para separação do feijão preto como menos saudável. (unidade = no de menções)

A marca de feijão preto mais separada como orgânica foi a Via Pax Bio, por todos os consumidores. Um consumidor separou todas as embalagens por considerar o feijão um alimento não processado e, segundo ele, orgânico.

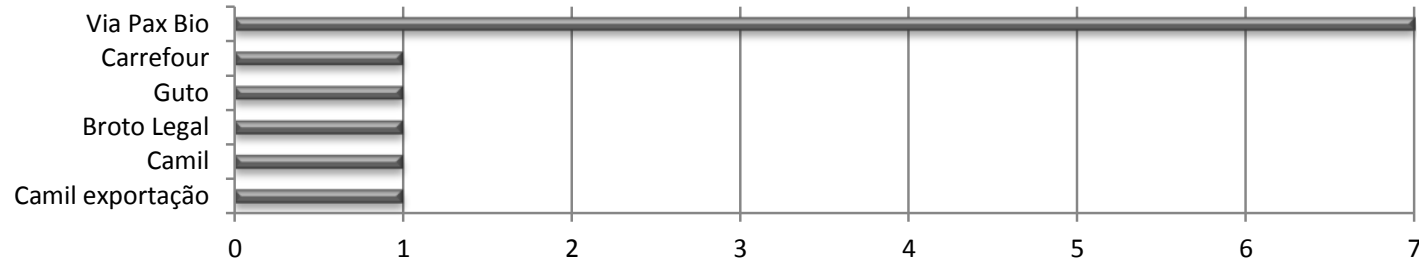

Gráfico 31 - Separação do feijão preto por orgânico (unidade = no de consumidores)

Para separar o feijão preto em orgânico e não orgânico, a principal informação textual olhada foi a palavra "orgânico" (seis consumidores), seguida pela embalagem ser fechada a vácuo (dois consumidores), o tipo e o selo SisOrg, por quatro consumidores. 


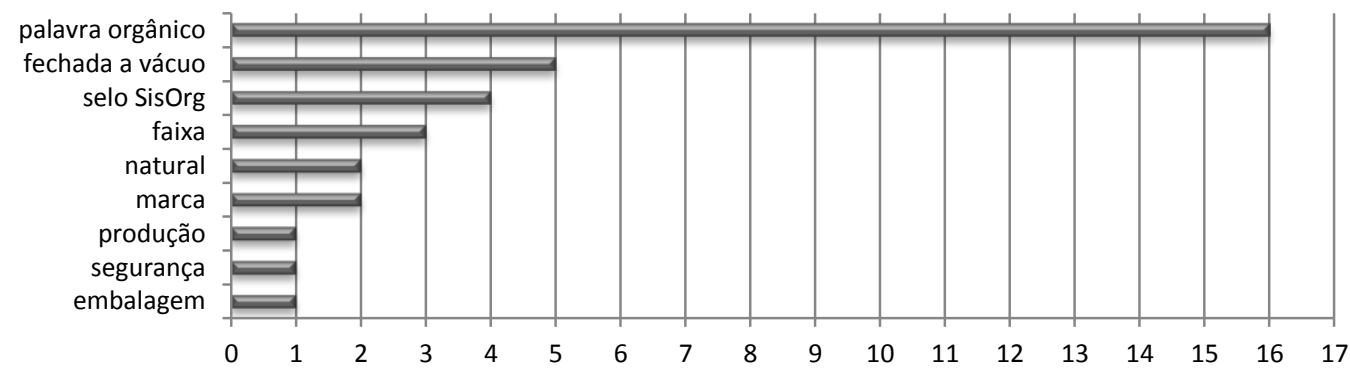

Gráfico 32 - Critérios para separação do feijão preto como orgânico (unidade = no de menções)

Para separar como não orgânico, além da falta da palavra "orgânico", também foram mencionados uma vez, por um consumidor a seção "sobre nós" e outros selos de certificação.

Com base nos dados apresentados, podemos considerar que o principal critério para separar o feijão preto como mais saudável foi por ser orgânico, principalmente por ser um alimento com um ingrediente só e sem variações na sua composição nutricional.

Para identificar como alimento orgânico, a informação textual e o selo SisOrg foram suficientes, havendo pouca dúvida.

\subsubsection{Feijão preto Via Pax Bio}

O feijão preto Via Pax Bio segue o mesmo padrão de design das embalagens da linha de ingredientes; por isso, a seguir, serão analisadas as diferenças específicas desse produto. A embalagem em tamanho real pode ser conferida no Anexo C.

\section{Análise das diferenças do painel frontal do feijão preto Via Pax Bio}

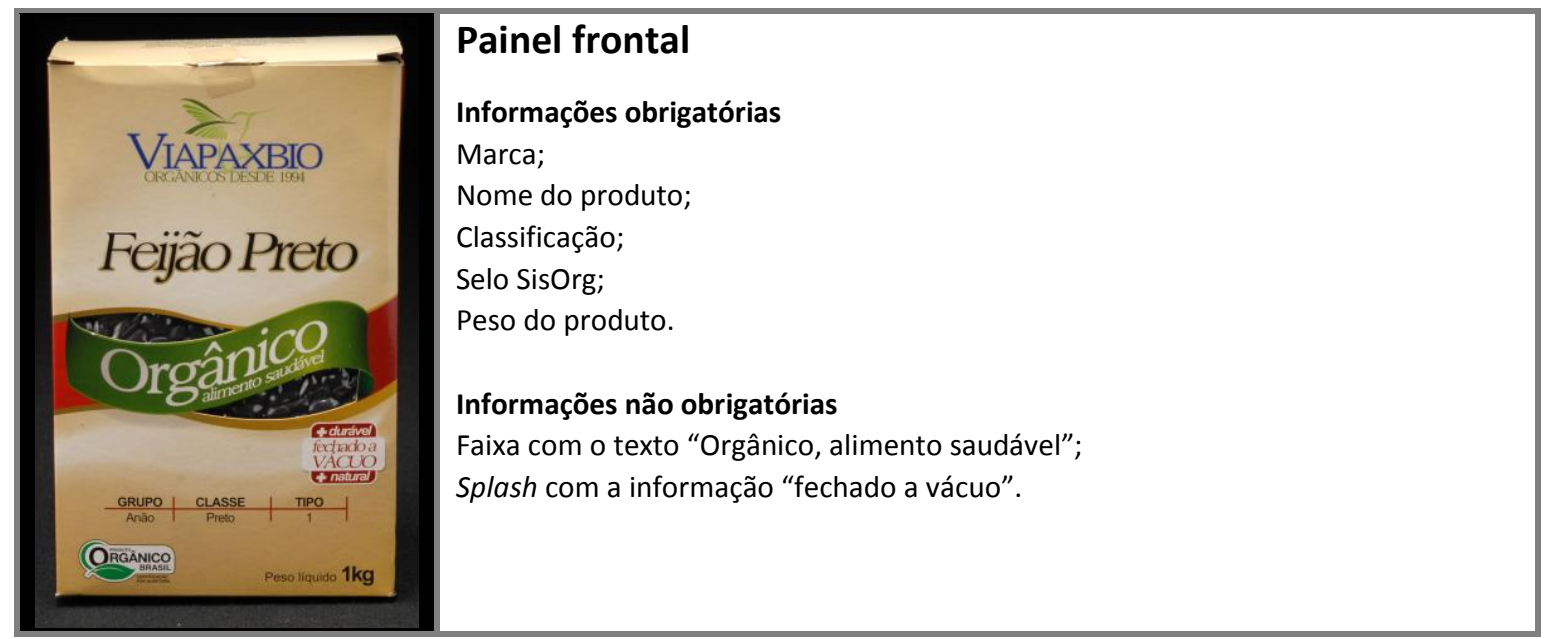

Figura 109 - Painel frontal da embalagem de feijão preto Via Pax Bio

No caso do feijão preto, a cor principal do painel frontal é o fundo em degradê do ocre até um creme quase branco. Um tom que compõe com as laterais marrons que fazem referência à cor do produto.

A classificação do produto usa a mesma tipografia do peso do produto. A linha usada para dividir as informações é da mesma cor que as laterais da embalagem. O texto está bem legível e não entra em conflito com outras informações do produto. 
O splash está localizado em uma área menor e mais apertada se comparado à farinha de trigo, entre a faixa e a classificação do produto, do lado direito, não se relacionando visualmente com nenhum outro elemento. Como a cor do fundo é mais escura, se comparado com o arroz e a farinha de trigo, tem bom contraste com as cores do splash, dando boa legibilidade.

\section{Análise das diferenças do painel traseiro do feijão preto Via Pax Bio}

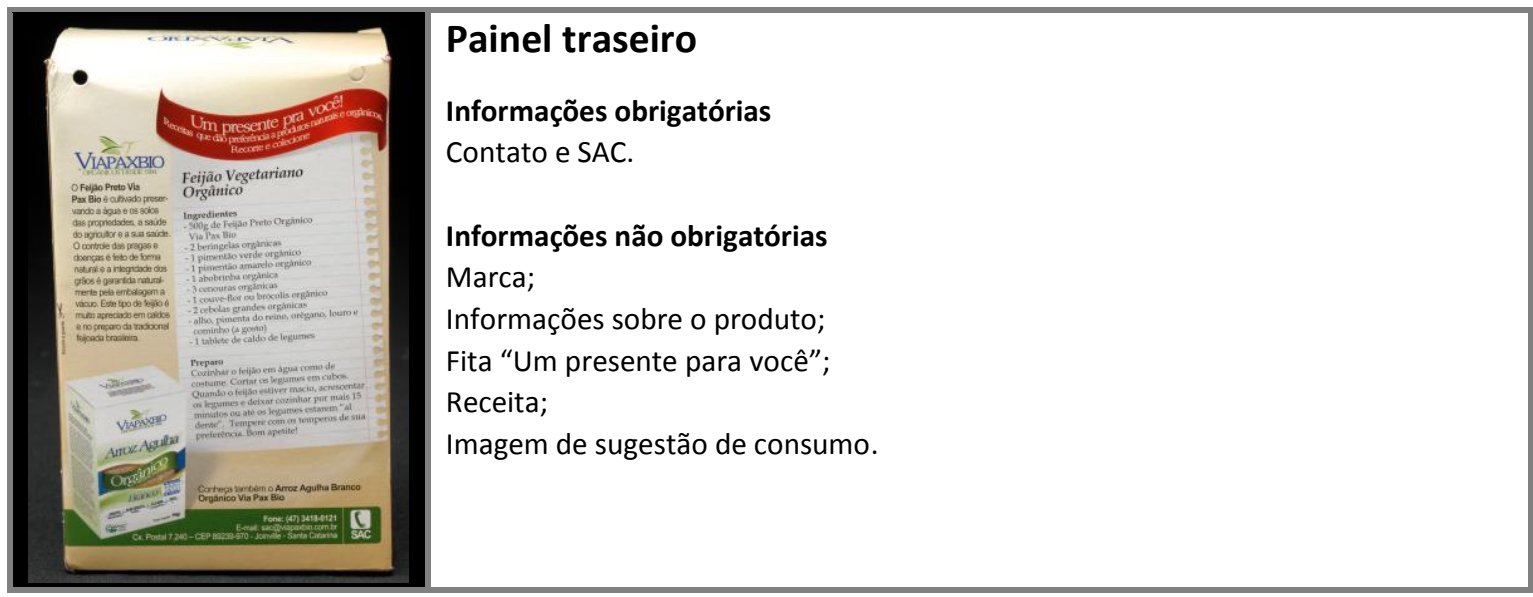

Figura 110 - Painel traseiro da embalagem de feijão preto Via Pax Bio

O fundo usa as mesmas cores do painel frontal para o degradê.

A imagem escolhida como sugestão de consumo foi o arroz agulha branco, pois, tradicionalmente, se come feijão com arroz. A receita escolhida para o feijão preto é a de feijão vegetariano orgânico.

\section{Análise das diferenças dos painéis laterais do feijão preto Via Pax Bio}

\begin{tabular}{|l|l|l|l|}
\hline & Painel lateral direito & Painel lateral esquerdo \\
Informações obrigatórias & $\begin{array}{l}\text { Nenhuma. } \\
\text { Informações obrigatórias }\end{array}$ \\
Informações não obrigatórias & $\begin{array}{l}\text { Marca; } \\
\text { Texto institucional. }\end{array}$ & $\begin{array}{l}\text { Tabela nutricional; Lista de } \\
\text { ingredientes; Advertências; } \\
\text { Sem corantes e conservantes; } \\
\text { Modo de conservar; } \\
\text { Validade e Lote; Código de barras. }\end{array}$ \\
\hline
\end{tabular}

Figura 111 - Painéis laterais da embalagem de feijão preto Via Pax Bio

A cor do painel esquerdo do feijão preto é marrom escuro, fazendo relação com a cor do produto, e é a mesma do painel esquerdo, criando uma relação entre os painéis.

O marrom escuro contrasta bem com o texto da empresa, permitindo uma boa leitura. $\mathrm{O}$ último parágrafo em ocre, apesar de diminuir o contraste, ainda permite uma boa leitura.

A marca da Via Pax Bio sobre o fundo escuro tem pouco contraste, onde só é possível ler por ter um contorno nas letras em azul claro. 
Análise das diferenças da tampa e da base do feijão preto Via Pax Bio

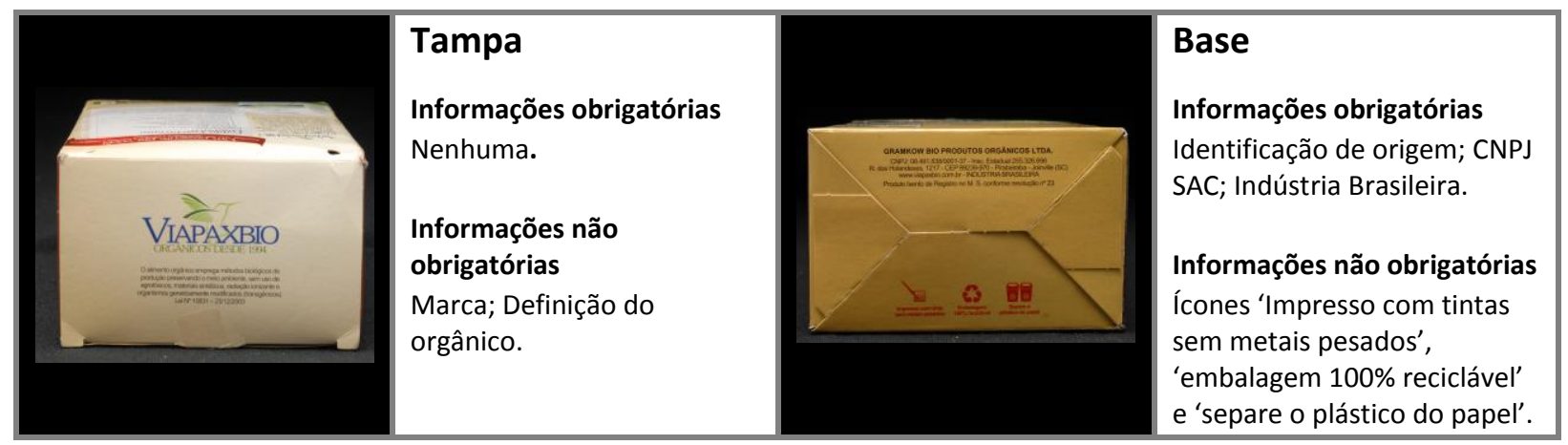

Figura 112 - Tampa e base da embalagem de feijão preto Via Pax Bio

A tampa do feijão preto usa a mesma cor do painel frontal e traseiro, um bege claro em degradê. A marca Via Pax Bio tem bom contraste com a cor do fundo.

A cor dos ícones na base é o mesmo vermelho da fita vermelha no painel traseiro. Tem bom contraste de cor com o fundo e está bem legível.

\section{Apresentação dos dados das entrevistas}

Os grãos do feijão preto foram comprados de fornecedores do leste do Paraná. Foram colhidos por diversos produtores, depois armazenados e ensacados na cooperativa, seguindo de caminhão para a Via Pax Bio. Tudo com controle, desde a origem até o ensaque. Segundo Indústria3 (2012), o feijão preto é:

[...] um de seus produtos mais desafiadores. Logo quando chegam os grãos, são selecionados manualmente, devendo ser embalados a vácuo o quanto antes para não criar caruncho, para depois ser armazenado em condições adequadas. (INDÚSTRIA3, 2012)

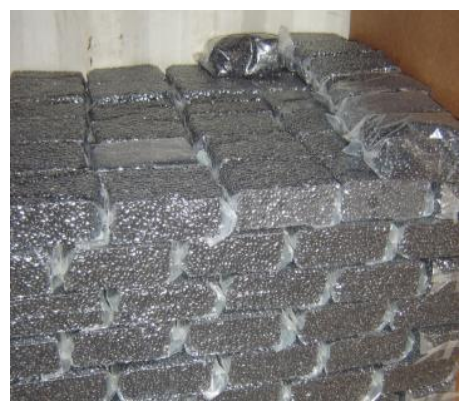

Figura 118 - Feijões são estocados já embalados a vácuo para evitar os carunchos

No local onde são estocados os grãos, por serem orgânicos, não é permitido usar nenhum tipo de produto químico para matar as diversas culturas que podem ser formadas, usando para isso um produto à base de Neem ${ }^{22}$ orgânico.

Quando perguntados se já tinham comprado o feijão preto ou algum outro produto da Via Pax Bio dessa linha, dois consumidores disseram já ter comprado e um disse já ter visto, mas não comprou por achar caro e por considerar um alimento comum. "Acho que eu achei que era muito luxo, assim: 'mas feijão preto, precisa disso também?' Porque esta marca é bem, é bem mais cara" (CA09, 2013).

\footnotetext{
220 Neem (Azadirachta indica) é utilizado na agricultura, no combate a lagartas e pragas como nematóides, fungos e bactérias.
} 
As principais categorias positivas do feijão preto Via Pax Bio, declaradas pelos consumidores, foram: a organização das informações (cinco consumidores), a legibilidade (três consumidores) e a palavra "orgânico" (quatro consumidores).

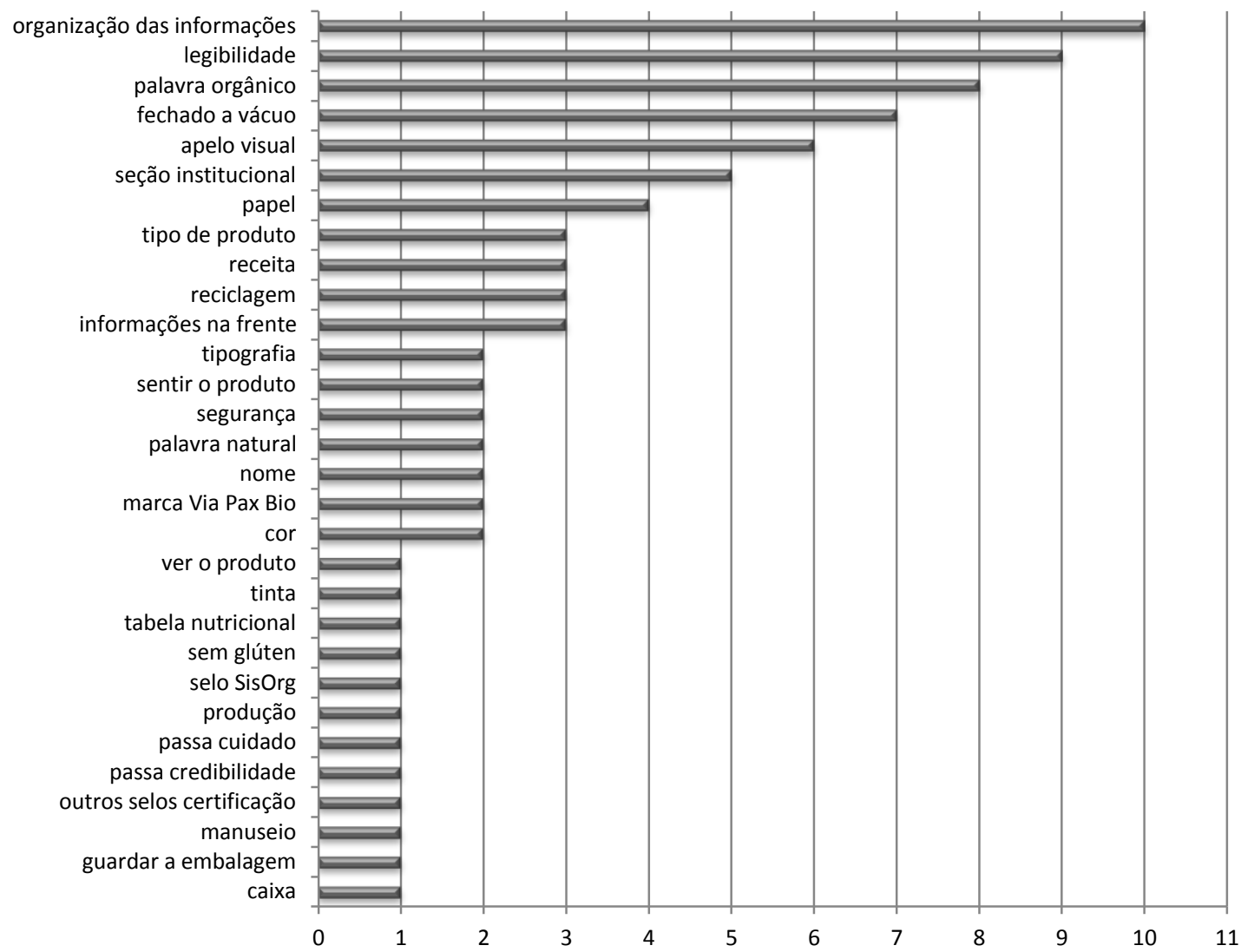

Gráfico 33 - Aspectos positivos do feijão preto Via Pax Bio (unidade = no de menções)

Um dos consumidores achou positiva a informação da classificação do feijão. "Quando fala grupo anão, eu acho legal porque é um tipo diferenciado de feijão. Mostra que existe um tipo e esse é anão, não é comum a todos" (CA31, 2013).

As principais categorias negativas do feijão preto Via Pax Bio, declaradas pelos consumidores, foram: o lacre (quatro consumidores), o preço (dois consumidores) e o excesso de embalagem (dois consumidores).

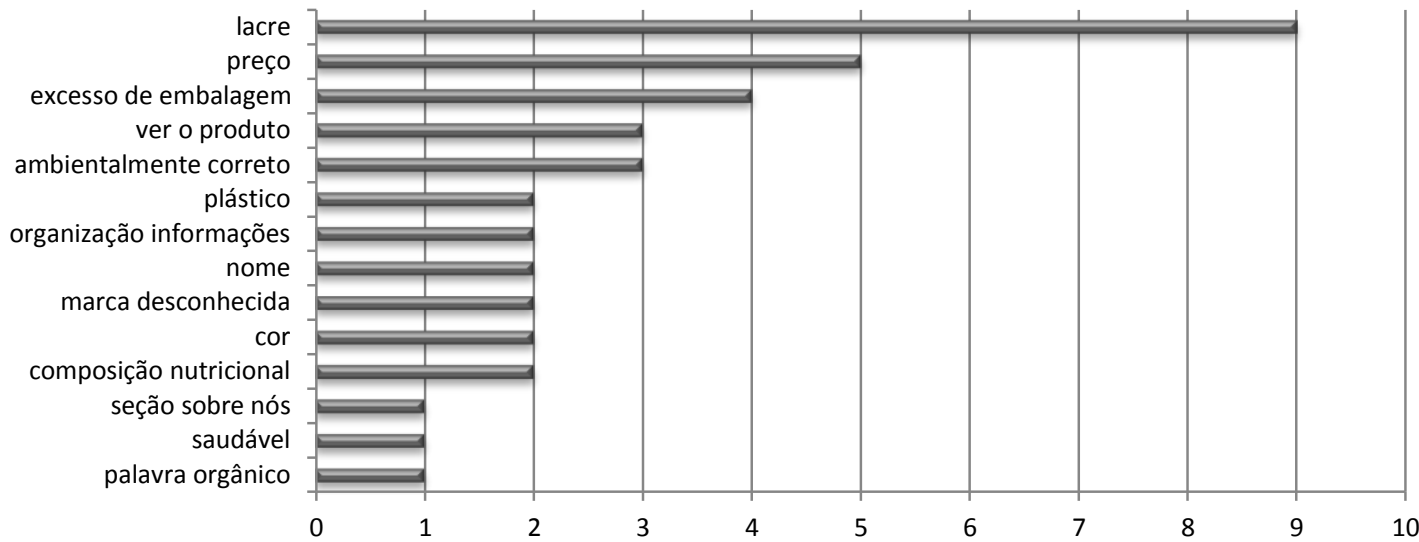

Gráfico 34 - Aspectos negativos do feijão preto Via Pax Bio (unidade = nº de menções) 
A cor da embalagem também foi considerada algo negativo por um dos consumidores.

Talvez as cores dela não sejam tão... mas isso eu não sei se é uma coisa negativa. Eu confesso para você que eu não sei. Está próximo do feijão preto, da terra, mas não são cores que me entusiasmam. (CA21, 2013)

\section{Diferencial semântico do feijão}

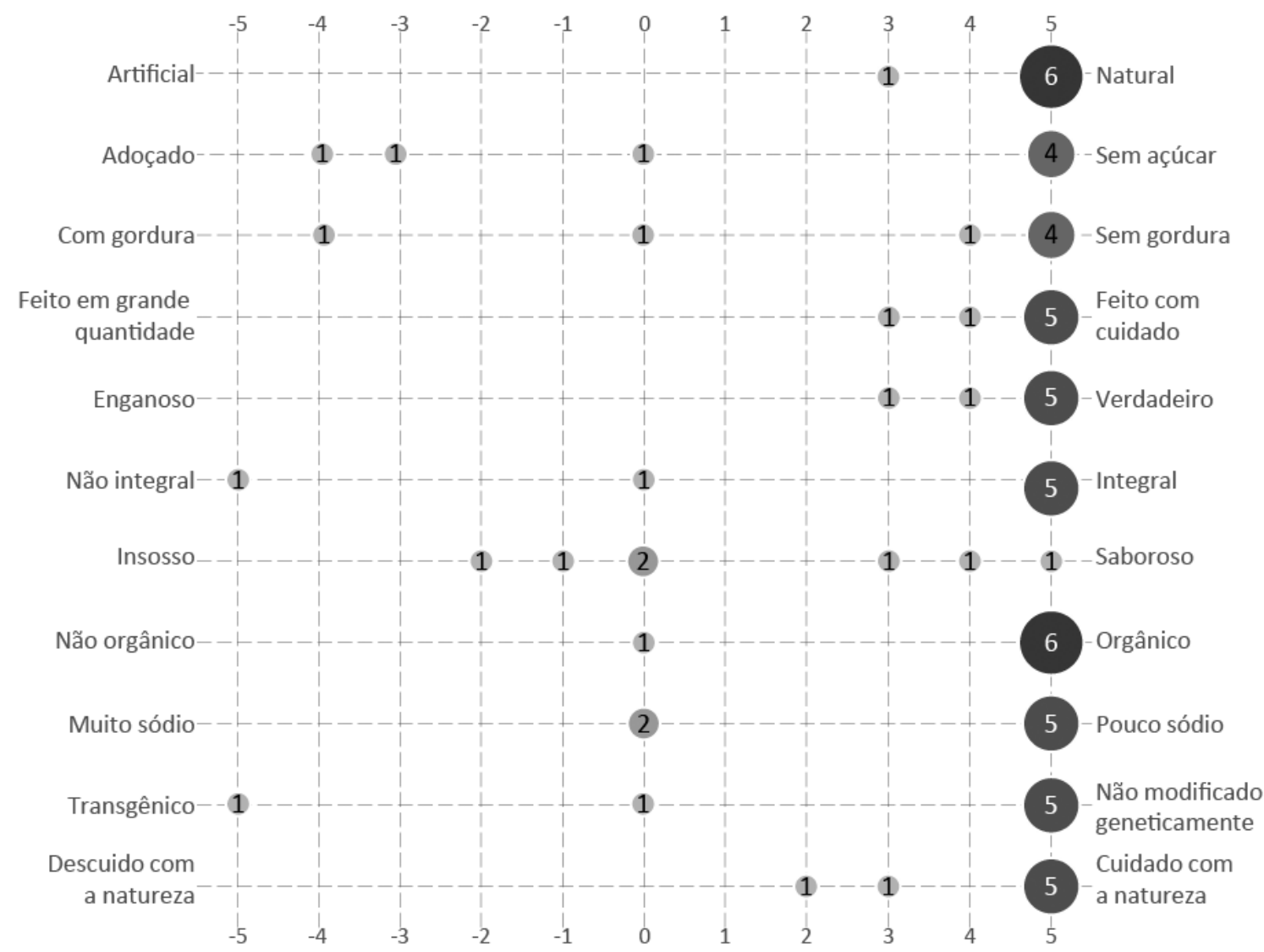

Gráfico 35 - Diferencial semântico do feijão preto Via Pax Bio

Como podemos ver no gráfico acima, há um predomínio dos aspectos mais positivos do produto. Podemos observar que nem todos sabem que o alimento orgânico é livre de transgênicos.

A partir dos dados apresentados, observa-se que a embalagem de feijão preto Via Pax Bio apresenta as informações do produto de forma clara e legível, seguindo a mesma estrutura visual dos outros produtos da linha de ingredientes. Mas por sempre manter as mesmas informações, o texto institucional foi prejudicado em sua legibilidade, mostrando que o ideal é adaptar as informações para cada produto para uma melhor eficiência da comunicação.

\subsubsection{Açúcar mascavo do Grupo 2 de pouco processado}

As marcas mais separadas como mais saudáveis foram a Mãe Terra e a Jasmine, por todos os consumidores. 


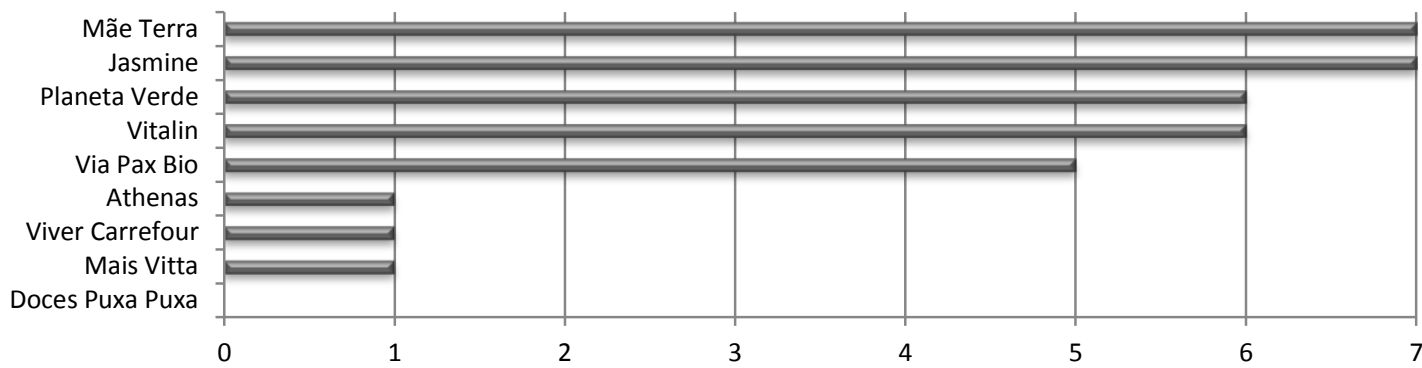

Gráfico 36 - Marcas de açúcar mascavo separadas como mais saudáveis (unidade = no de consumidores)

Os principais critérios para a separação como mais saudável foram: a palavra "orgânico" (cinco consumidores), a aparência do produto (quatro consumidores) e a marca Mãe Terra (três consumidores). A composição nutricional, destacada no gráfico abaixo, foi citada por apenas um consumidor, como podemos ver no gráfico abaixo:

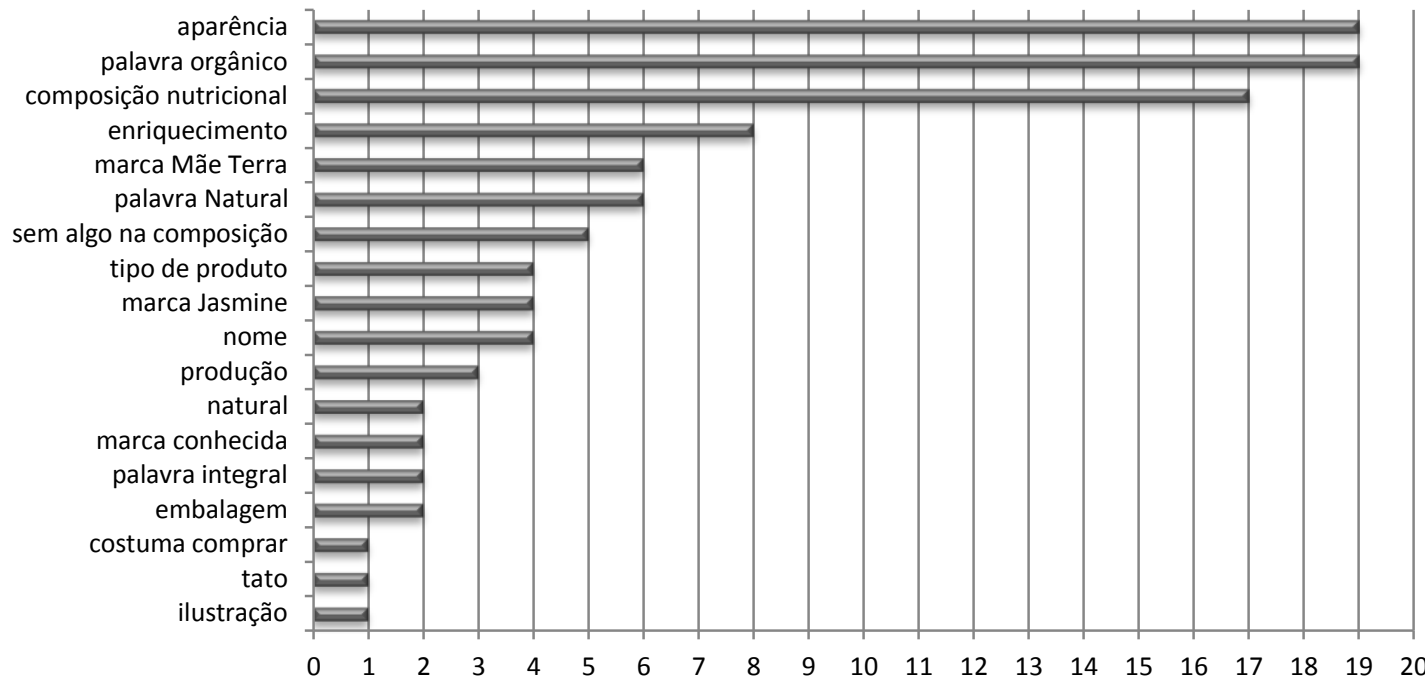

Gráfico 37 - Critérios para separação do açúcar mascavo como mais saudável (unidade = no de menções)

Os principais critérios para a separação como menos saudável foram: por não ter a palavra "orgânico" (quatro consumidores), a aparência do açúcar (três consumidores) e a marca desconhecida (dois consumidores), como podemos ver no gráfico abaixo:

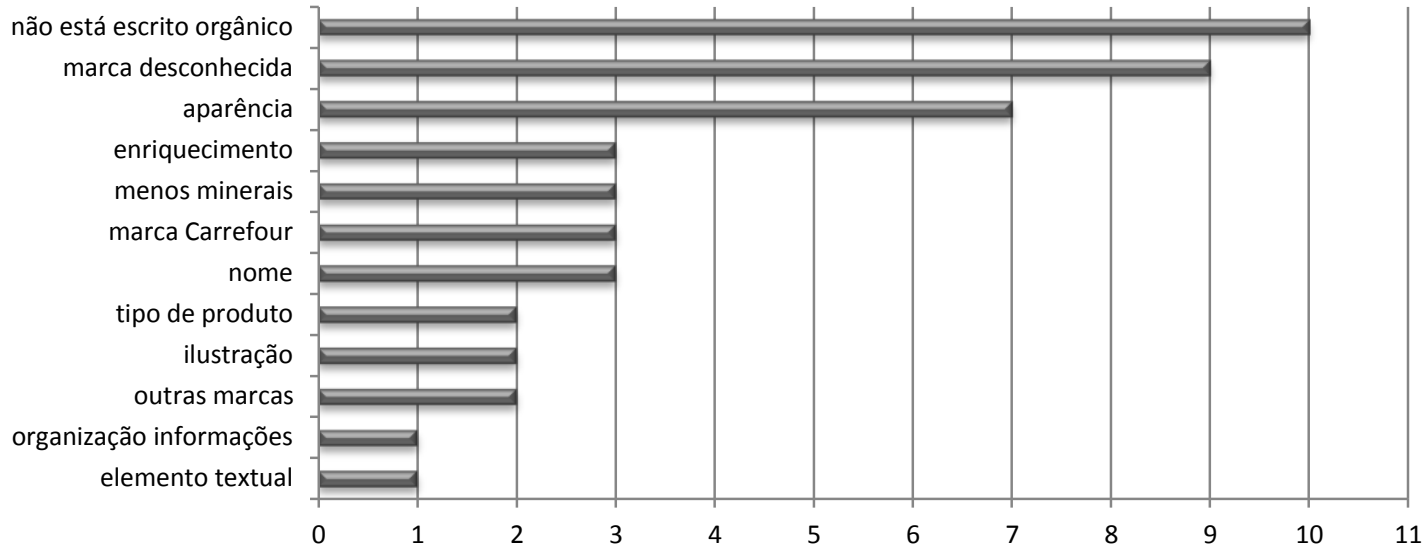

Gráfico 38 - Critérios para separação do açúcar mascavo como menos saudável (unidade = no de menções) 
O conceito de saudável pela aparência do açúcar muda de consumidor para consumidor. Alguns preferem o açúcar mais solto e seco como o da Mãe Terra. Isso foi comentado por dois consumidores.

Não sei o que é o açúcar mascavo extrasseco. Eu imagino que todo o açúcar mascavo seja mais sequinho, né? Apesar que esse [Athenas] está mais molhado do que esse [Mãe Terra]. [...] Isso não que denigra, mas para mim me parece muito pastoso, meio macienta. (CA12, 2013)

Para outro consumidor, quanto menos solto melhor, por considerar que assim está menos refinado.

A textura dele. Quando ele forma pedra. Quando ele é muito assim como esse aqui [Planeta Verde], está vendo, ele é bem pozinho, ele já está mais refinado. Quando ele está mais integrado, ele está mais perto da cana. (CA28, 2013)

As marcas de açúcar mascavo separadas como orgânicas foram a Planeta Verde, Vitalin, Jasmine, Via Pax Bio e Mãe Terra, por todos os consumidores.

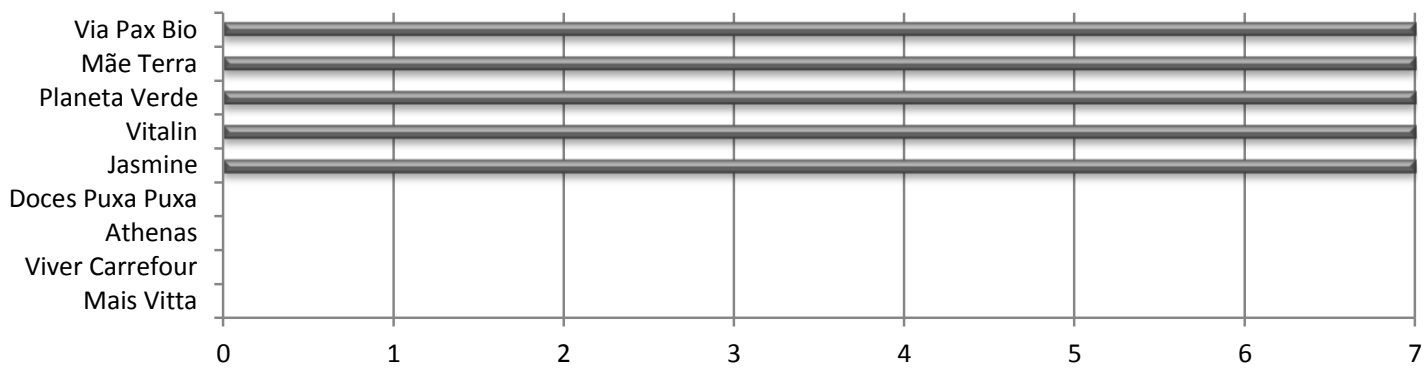

Gráfico 39 - Marcas de açúcar mascavo separadas como orgânicas (unidade = no de consumidores)

Para separar em orgânico e não orgânico, a principal informação textual olhada foi a palavra "orgânico" (seis consumidores). O selo SisOrg apareceu em segundo lugar, para quatro consumidores, como critério de separação.

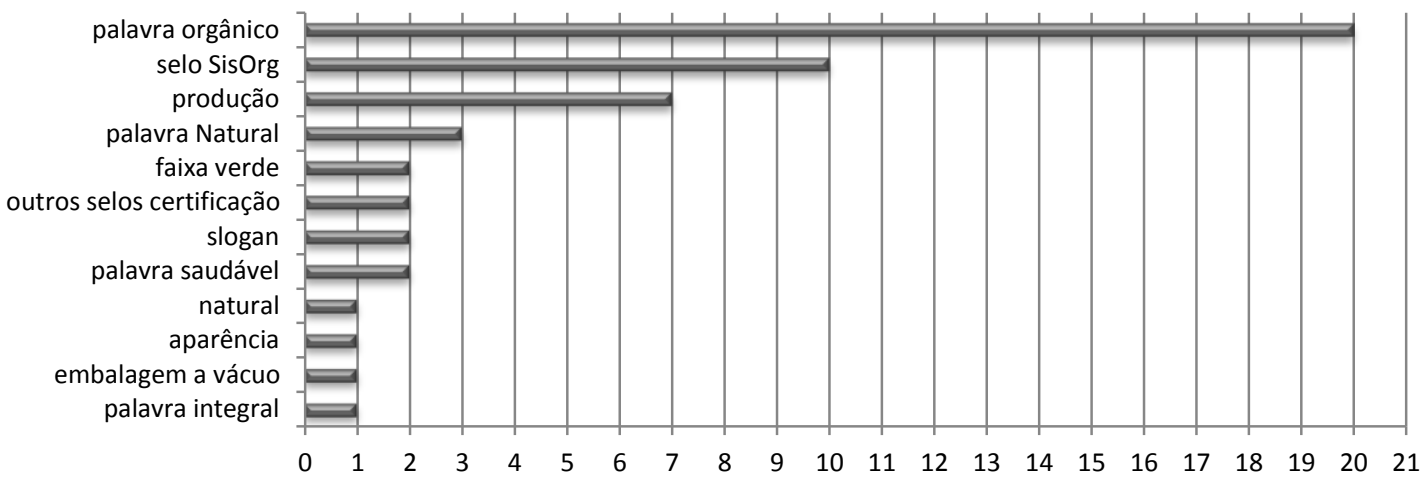

Gráfico 40 - Critérios para a separação do açúcar mascavo como orgânico (unidade = no de menções)

Para separar em orgânico e não orgânico, a principal informação textual procurada, e não encontrada, foi a palavra "orgânico", por três consumidores. 


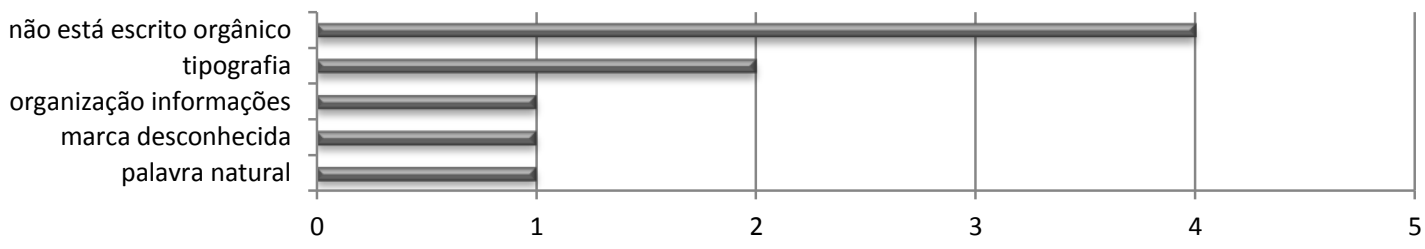

Gráfico 41 - Critérios para a separação do açúcar mascavo como não orgânico (unidade = nº de menções)

Com base nos dados apresentados, podemos considerar que a aparência do produto é muito importante para o consumidor. Há, portanto, uma maior necessidade de que a embalagem tenha mais áreas transparentes e que possibilitem o consumidor a visualizar o produto sem ter de abrir a embalagem.

Para identificar como alimento orgânico, a informação textual e o selo SisOrg foram suficientes, havendo pouca dúvida.

\subsubsection{Açúcar mascavo Mãe Terra}

O açúcar mascavo Mãe Terra segue o mesmo padrão de design das embalagens da linha de ingredientes, por isso, a seguir, serão analisadas as diferenças específicas desse produto. $\mathrm{A}$ embalagem em tamanho real pode ser conferida no Anexo $A$.

\section{Análise do painel frontal do açúcar mascavo Mãe Terra}

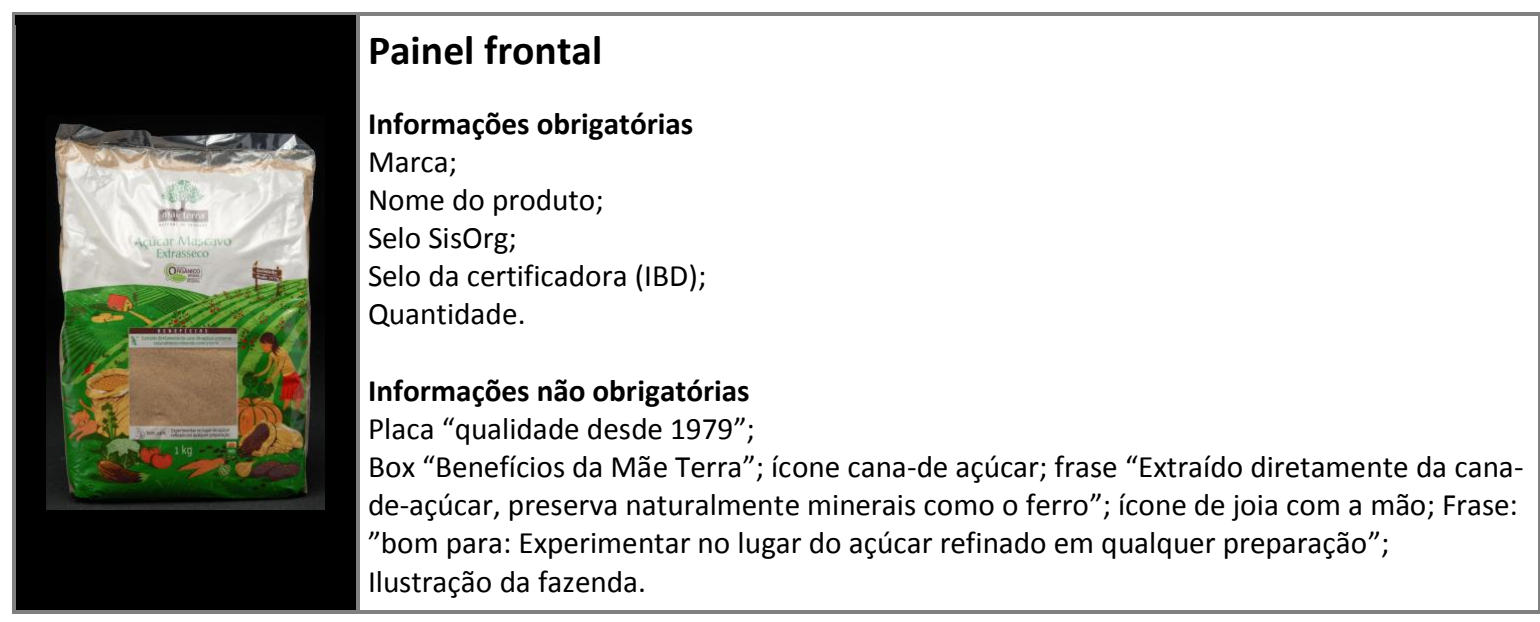

Figura 113 - Painel frontal da embalagem de açúcar mascavo Mãe Terra

O painel frontal da embalagem do açúcar mascavo segue a mesma estrutura visual das outras embalagens da linha de ingredientes da Mãe Terra. As únicas diferenças são os selos de certificação (SisOrg e IBD) e as informações no box de benefícios.

O selo SisOrg, abaixo do nome do produto, tem o mesmo peso visual que ele e, por isso, sem destaque, mesmo estando no centro ótico da embalagem. 


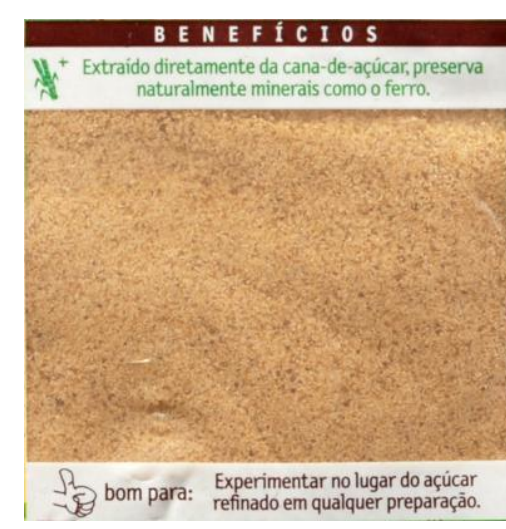

Figura 114 - Box de benefícios da embalagem de açúcar mascavo Mãe Terra

\section{Análise do box de benefícios do açúcar mascavo}

Diferentemente do box do arroz integral, o do açúcar mascavo apresenta menos informações e mudou o título "Benefícios Mãe Terra" para apenas "Benefícios". Os textos estão bem legíveis e todos foram aplicados sobre um fundo de cor branca, dando bom contraste. Os ícones utilizados para falar da cana-de-açúcar são pouco visíveis, podendo ser reconhecidos apenas olhando a embalagem com mais atenção.

A informação "Bom para: Experimentar no lugar do açúcar refinado", diferentemente do arroz, foi aplicada sobre o branco e ficou legível. O ícone de joia com as mãos é bem visível e representa bem que é algo positivo. A janela do box permite bem a visualização do produto.

\section{Análise do painel traseiro do açúcar mascavo Mãe Terra}

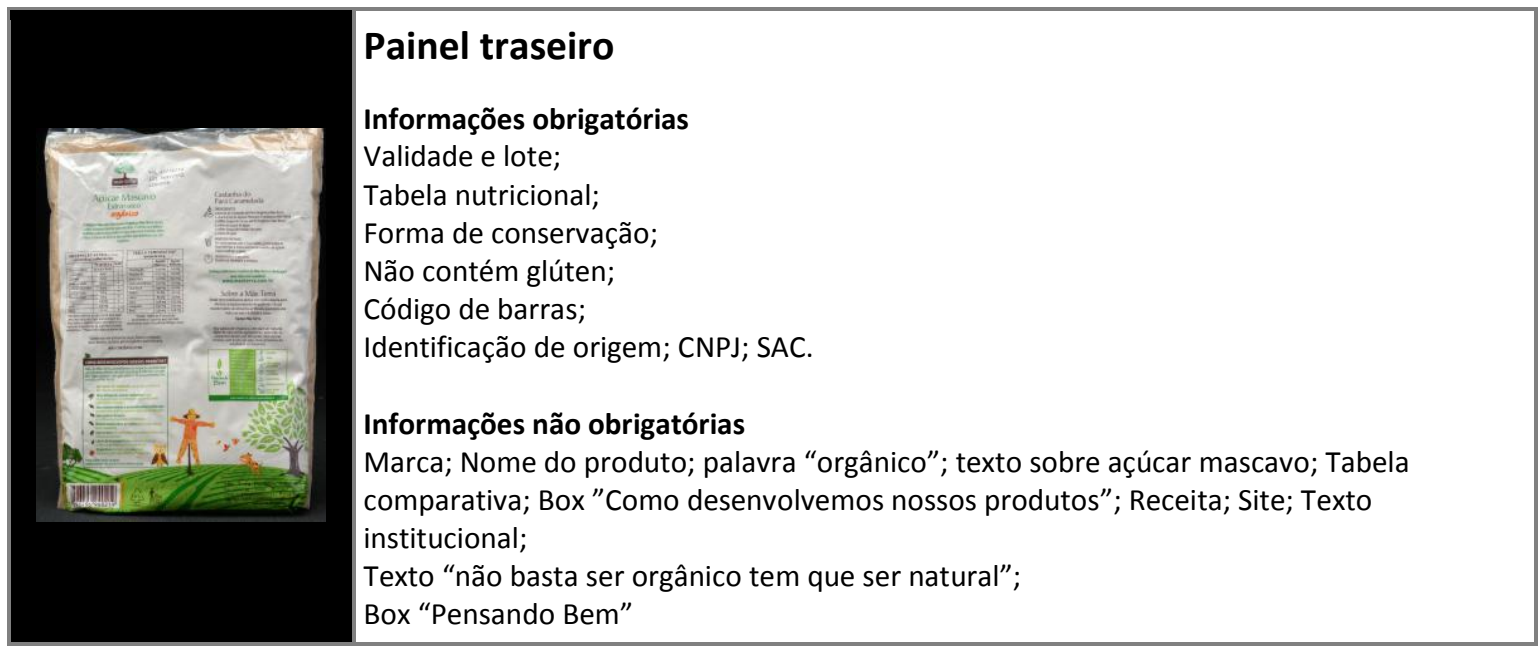

Figura 115 - Painel traseiro da embalagem de açúcar mascavo Mãe Terra

Segundo o sentido de leitura, de cima para baixo, da esquerda para a direita, a primeira informação do painel traseiro é a marca Mãe Terra e, em seguida, o box "Pensando Bem", com as informações que eles rastreiam os impactos ambientais, demonstrando a importância que eles dão de divulgar os princípios ambientais da empresa.

As informações textuais que estão sobre o fundo branco, fora de algum box, têm o mesmo peso visual, não destacando nada.

A primeira informação a ser vista é a ilustração, por causa das cores em contraste com o fundo branco. $O$ texto do endereço e forma de contato aplicado sobre a ilustração sem um fundo claro tem pouca legibilidade, por seu tamanho reduzido e pouco contraste de cor.

O box "como desenvolvemos nossos produtos" é igual ao do arroz e usa a mesma ilustração da coruja. Os elementos gráficos e textuais estão divididos na embalagem e alinhados em duas colunas, estando em equilíbrio. Todos os textos são escritos na mesma tipografia do nome do produto. 
Análise da base do açúcar mascavo Mãe Terra

\begin{tabular}{|l|l|l|}
\hline & \multicolumn{2}{c|}{ Base } \\
\hline & $\begin{array}{l}\text { Informações obrigatórias } \\
\text { Nenhuma. Não há nada especificado Mascavo } \\
\text { na legislação. }\end{array}$ & $\begin{array}{l}\text { Marca; Nome do produto; } \\
\text { Quantidade; palavra "orgânico". }\end{array}$ \\
\hline
\end{tabular}

Figura 116 - Base da embalagem de açúcar mascavo Mãe Terra

Segundo o sentido de leitura, de cima para baixo, da esquerda para a direita, a primeira informação da base é a marca da Mãe Terra, seguida pelo nome do produto e a palavra "orgânico". A marca é aplicada sobre o fundo branco e tem boa legibilidade e contraste de cor. O nome do produto usa a mesma tipografia do nome do painel frontal e tem boa legibilidade.

\section{Hierarquia de leitura}

A hierarquia de leitura da embalagem de açúcar mascavo da Mãe Terra demostrada abaixo faz com que informações mais relacionadas à marca tenham mais destaque do que as informações mais específicas do produto.

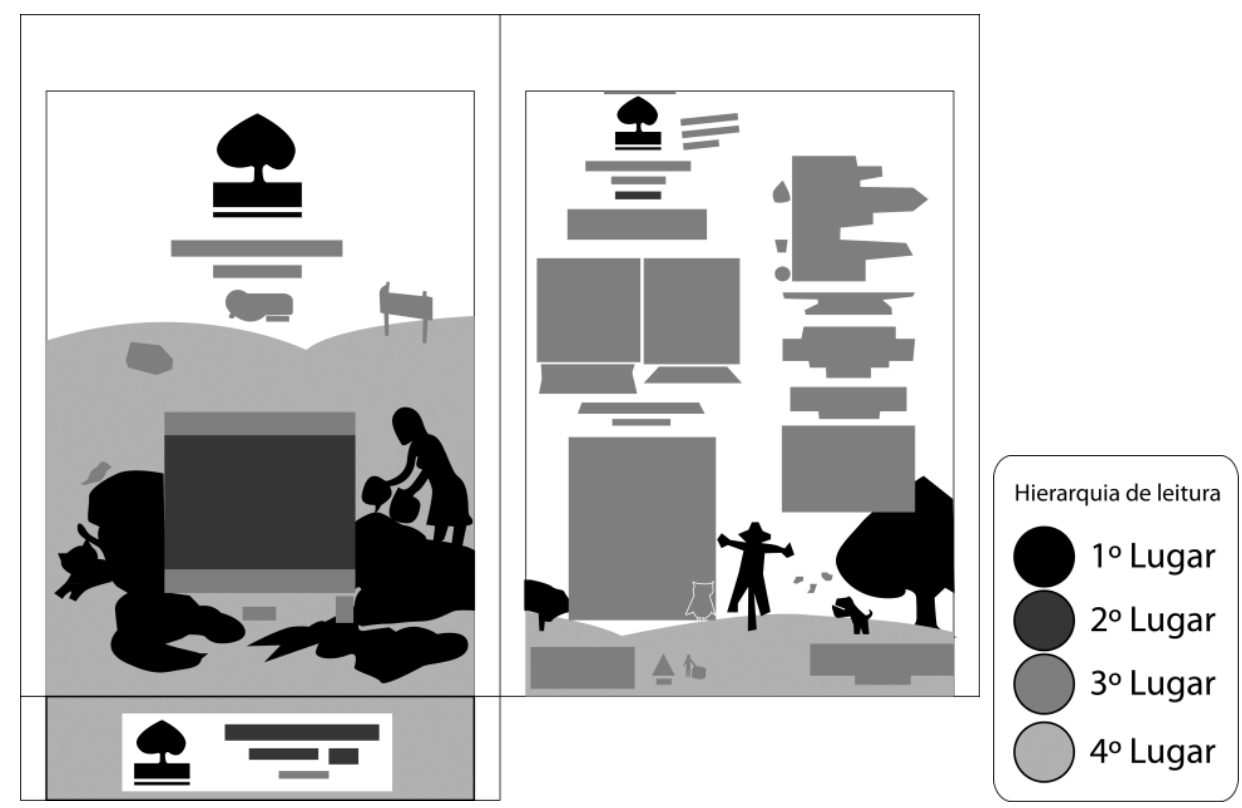

Figura 117 - Hierarquia de leitura do açúcar mascavo Mãe Terra

\section{Apresentação dos dados das entrevistas}

Quando perguntados se já tinham comprado o açúcar mascavo, ou algum outro produto da Mãe Terra dessa linha, três dos sete entrevistados declararam que sim. Quando questionados o que influenciou a compra, três consumidores declararam que compraram por causa da marca e um, por ter o preço mais acessível. 


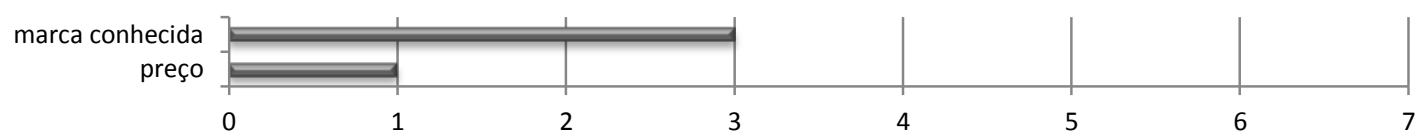

Gráfico 42 - Motivos da compra do açúcar mascavo Mãe Terra (unidade = nํ de consumidores)

O motivo principal de não terem comprado o açúcar mascavo, declarado por dois consumidores, foi por não ter o costume de comprar açúcar mascavo. Apenas um declarou que nunca viu e outro alegou falta de interesse.

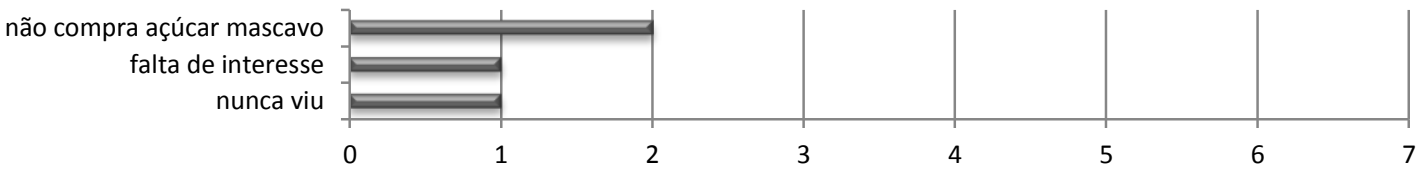

Gráfico 43 - Motivos por não ter comprado o açúcar mascavo Mãe Terra (unidade = no de consumidores)

As principais categorias positivas do açúcar mascavo Mãe Terra, declaradas pelos consumidores, foram: a marca (três consumidores), a embalagem, que remete a "algo bom" (três consumidores), e ver o produto (três consumidores).

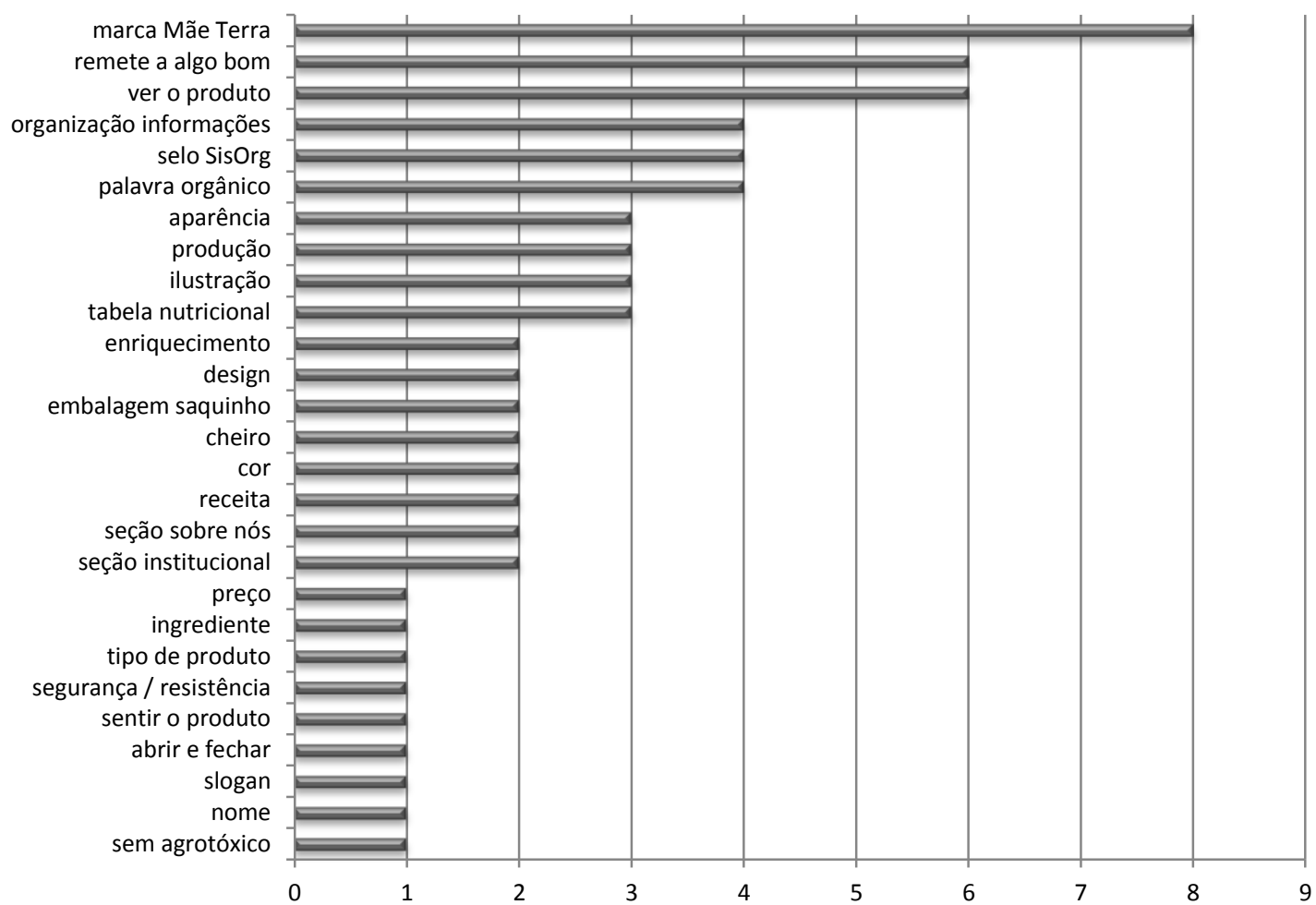

Gráfico 44 - Aspectos positivos do açúcar mascavo Mãe Terra (unidade = no de menções)

As principais categorias negativas do açúcar mascavo Mãe Terra, declaradas pelos consumidores, foram: a organização das informações (quatro consumidores), a embalagem tipo saquinho (quatro consumidores) e a segurança da embalagem (dois consumidores). 


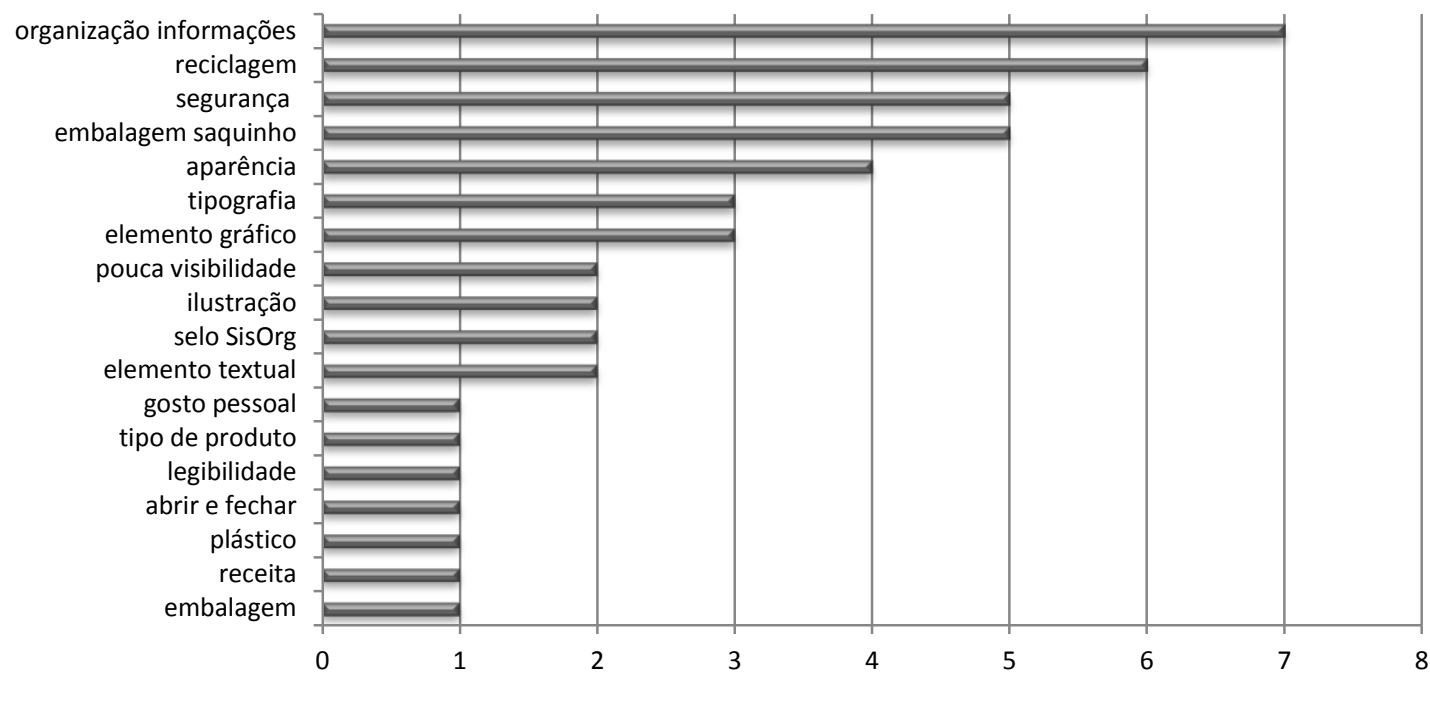

Gráfico 45 - Aspectos negativos do açúcar mascavo Mãe Terra (unidade = nº de menções)

O tipo da embalagem, em plástico, foi apontado como algo negativo quando comparado com a embalagem fechada a vácuo mostrada em outros produtos. "Pode ser um mito, para mim existe, mas se fosse embalado a vácuo, acho que seria melhor que o fato de a embalagem ser assim" (CA19, 2013).

Um dos consumidores, porém, mesmo considerando o tipo da embalagem negativo, reconheceu que isso torna o produto mais acessível.

Eu não gosto muito da embalagem no plástico, essa coisa assim simples, mas não que seja negativo, eu acho que isso deixa o produto mais acessível. Então, enquanto embalagem não é legal, mas, como consumidora, eu prefiro comprar um negócio que tem menos embalagem, apesar dela poder estourar no carro, no caso de uma farinha. No caso de um açúcar, você pode colocar um negócio em cima e estourar, né? Mas é um plástico bem resistente. (CA28, 2013)

\section{Box de benefícios}

As características do produto, apresentadas no box de benefícios da Mãe Terra, foram algo que também chamou a atenção no açúcar mascavo de forma positiva, principalmente pela janela que possibilita ver o produto. "Eu achei bacana a forma que eles estão colocando aqui o açúcar mascavo, aqui no meio, eu achei que está legal” (CA19, 2013).

Conforme já demonstrado anteriormente, a visibilidade do produto é importante para os consumidores e a janela dentro do box proporciona bem isso, porém alguns consumidores consideraram a área pequena. "Tem uma visibilidade maior que a outra, mas não muito [sic] também" (CB27, 2013).

$O$ tato também é importante para um dos consumidores. $O$ fato de a embalagem não ser a vácuo, e por sentir se o açúcar era mais solto ou não, foi considerado também como algo positivo. "Dá para sentir um pouco mais a textura do produto. A embalagem é mais folgadinha, coloridinha e simples de manusear" (CB27, 2013). 


\section{Palavra "orgânico"}

A informação no açúcar mascavo de que se trata de um alimento orgânico não foi facilmente encontrada por alguns consumidores. Os que encontraram acharam que estava muito pequena. Isso acontece pelo excesso de informações, já falado anteriormente, e o pouco destaque para a informação. “Eu achei que o 'orgânico' está pequeno. Eu acho que poderia ter um maior destaque para o 'orgânico'” (CA19, 2013).

Um dos consumidores não viu o selo SisOrg para saber se o açúcar era orgânico ou não, ele viu apenas a informação textual apresentada na base da embalagem e no painel traseiro.

Olha onde isso [Mãe Terra] diz que é orgânico [aponta para a parte de baixo da embalagem]. Eu tenho que virar toda a embalagem para achar se isso aqui é orgânico ou não. Olha aqui atrás. Olha, também tem um 'orgânico' pequenininho aqui. (CA12, 2013)

\section{Legibilidade}

Um consumidor comentou que sentiu dificuldade para ler algumas informações do painel traseiro e considera a quantidade de informações excessiva. "Aqui é um pouco poluído. Você vê, tem uma receita, sobre a Mãe Terra... é um pouco poluído, mas é interessante, que eles colocam várias informações aqui" (CA29, 2013).

As letras foram consideradas pequenas e as informações, com pouco destaque. "Aqui, a parte gráfica, é tudo muito pequeno. Muito sem destaque, inclusive o fabricante" (CB27, 2013).

Além da tabela nutricional, obrigatória por lei, a embalagem também apresenta uma tabela comparativa com o açúcar refinado, demonstrando a importância que a empresa dá em mostrar as vantagens nutricionais do açúcar mascavo.

\begin{tabular}{|c|c|c|}
\hline \multicolumn{3}{|c|}{$\begin{array}{c}\text { INFORMAÇÃO NUTRICIONAL } \\
\text { porção de } 5 \mathrm{~g}(1 \text { collher de chá) }\end{array}$} \\
\hline & Porção de $5 \mathrm{~g}$ & $\%$ VD* \\
\hline valor energético & $20 \mathrm{kcal}=84 \mathrm{~kJ}$ & 1 \\
\hline carboidratos & 4.99 & 2 \\
\hline proteinas & $0,0 \mathrm{~g}$ & 0 \\
\hline gorduras totais & $0,0 \mathrm{~g}$ & 0 \\
\hline gorduras saturadas & $0,0 \mathrm{~g}$ & 0 \\
\hline gorduras trans & $0,0 \mathrm{~g}$ & $*$ \\
\hline fibra alimentar & $0,0 \mathrm{~g}$ & 0 \\
\hline sótio & $2,0 \mathrm{mg}$ & 0 \\
\hline ferro & $0,10 \mathrm{mg}$ & 1 \\
\hline cálcio & $4.3 \mathrm{mg}$ & 0 \\
\hline $\begin{array}{l}\text { "\%Valores diários } \\
\text { em uma dieta de } 2 \text {. } \\
\text { Seus valores diários } \\
\text { menores dependend } \\
\text { energéticas. " "Valor }\end{array}$ & $\begin{array}{l}\text { e referència com } \\
\text { ooo kcal ou } 8.40 \\
\text { podem ser maior } \\
\text { o de suas necessi } \\
\text { tiário nảo estabe }\end{array}$ & $\begin{array}{l}\text { base } \\
\text { o kJ. } \\
\text { res ou } \\
\text { idades } \\
\text { elecido. }\end{array}$ \\
\hline
\end{tabular}

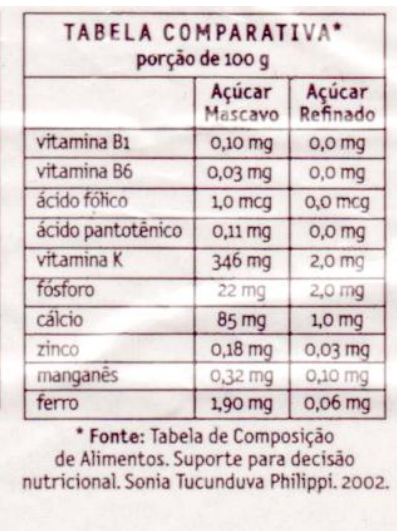

Figura 118 - Tabela nutricional e tabela comparativa

E os conteúdos que a embalagem traz, né? Isso também eu acho que é positivo. Como aqui atrás, tem a informação nutricional direitinho, tabela comparativa com os alimentos que foram enriquecidos, como eu te falei, o cálcio, o zinco, o manganês. (CA28, 2013) 


\section{Matriz semântica açúcar mascavo Mãe Terra}

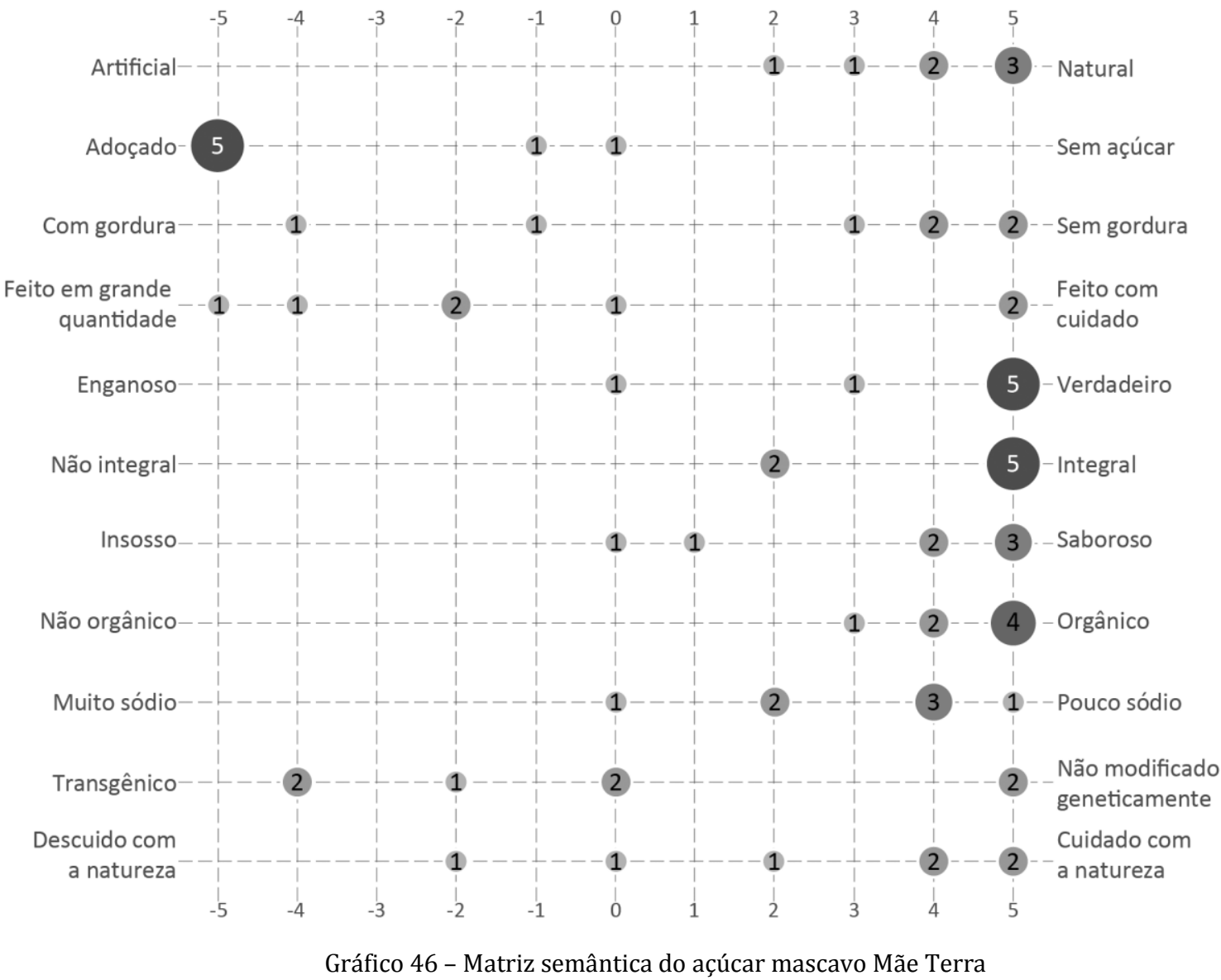

Observa-se, na matriz semântica, preenchida no final da entrevista, um predomínio de respostas mais positivas do produto.

Por ser açúcar, esperava-se que todos colocassem a opção mais próxima do adoçado, porém dois consumidores resolveram optar pelas opções mais centrais, demonstrando suas dúvidas.

As informações "feito com cuidado" e "feito em grande quantidade", que tinham o objetivo de entender como os consumidores percebiam a produção do produto, dividiram opiniões, mas a maior parte associou a um produto industrializado feito em grande quantidade.

Apesar de a informação "livre de transgênicos" estar no box "Como desenvolvemos os nossos produtos", o resultado também ficou bem dividido.

A partir dos dados apresentados, observa-se que a embalagem de açúcar mascavo Mãe Terra se destacou positivamente por ter sido identificada como um produto Mãe Terra. Porém, a organização das informações do painel traseiro e a dificuldade em ver o produto foram apontadas como algo negativo. Essa categoria de produto, segundo o que foi declarado pelos consumidores, necessita de mais transparência na embalagem.

\subsubsection{Açúcar Mascavo Via Pax Bio}

O açúcar mascavo Via Pax Bio segue o mesmo padrão de design das embalagens da linha de ingredientes, por isso, a seguir, serão analisadas as diferenças específicas desse produto. $A$ embalagem em tamanho real pode ser conferida no Anexo C. 
Análise das diferenças do painel frontal do açúcar mascavo Via Pax Bio

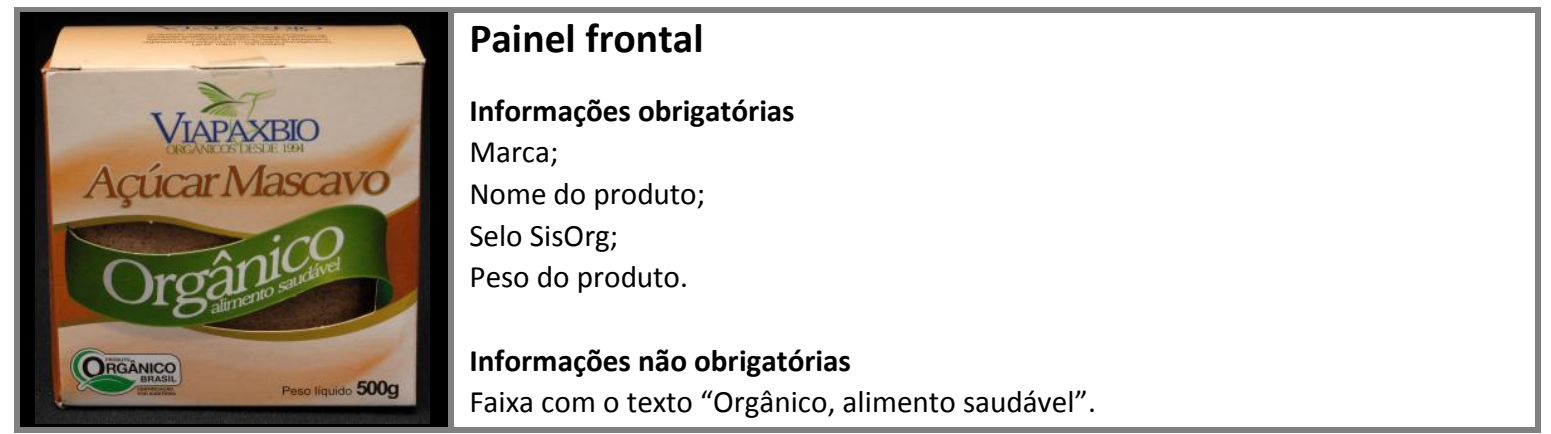

Figura 119 - Painel frontal da embalagem de açúcar mascavo Via Pax Bio

A cor do fundo do painel frontal é um degradê do marrom claro até o creme, não interferindo na leitura e se diferenciando dos outros produtos da linha.

O açúcar mascavo não apresenta o splash de "fechado a vácuo" como os outros produtos da linha. Talvez por ter menos espaço e por ser uma embalagem mais baixa.

Análise das diferenças do painel traseiro do açúcar mascavo Via Pax Bio

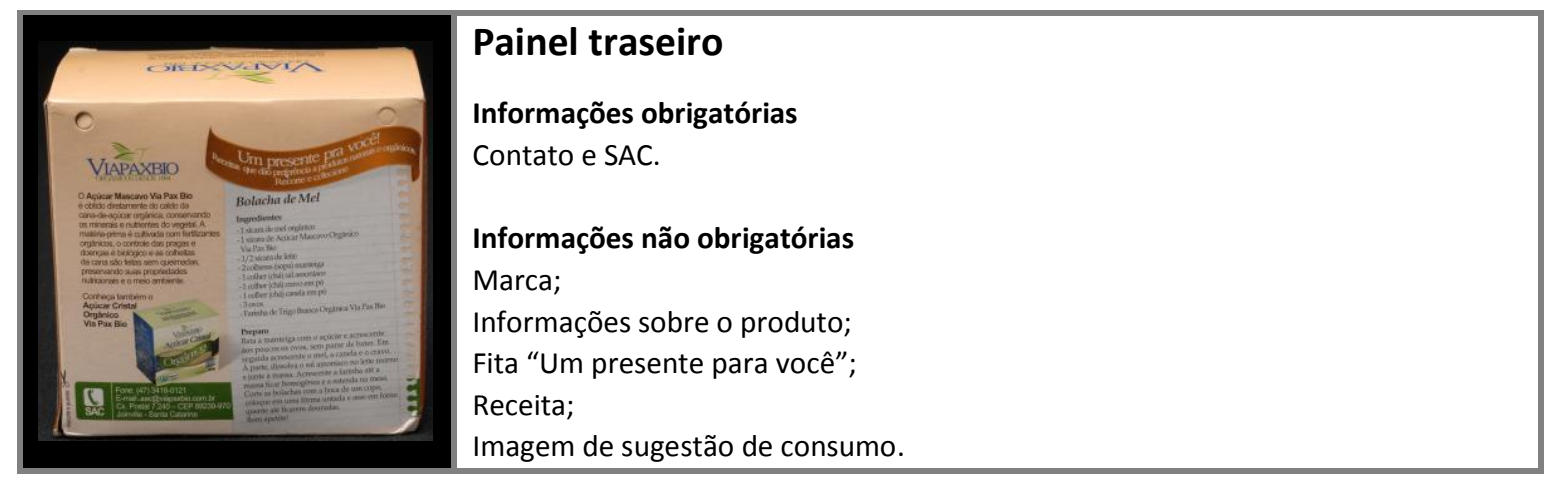

Figura 120 - Painel traseiro da embalagem de açúcar mascavo Via Pax Bio

O fundo usa as mesmas cores do painel frontal para o degradê. A imagem escolhida como sugestão de consumo foi uma variação do produto: o açúcar cristal. A receita escolhida foi a de bolacha com mel. A fita com a frase "Um presente para você" no açúcar mascavo é em cor marrom claro, a mesma cor usada nos painéis laterais.

\section{Análise das diferenças dos painéis laterais do açúcar mascavo Via Pax Bio}

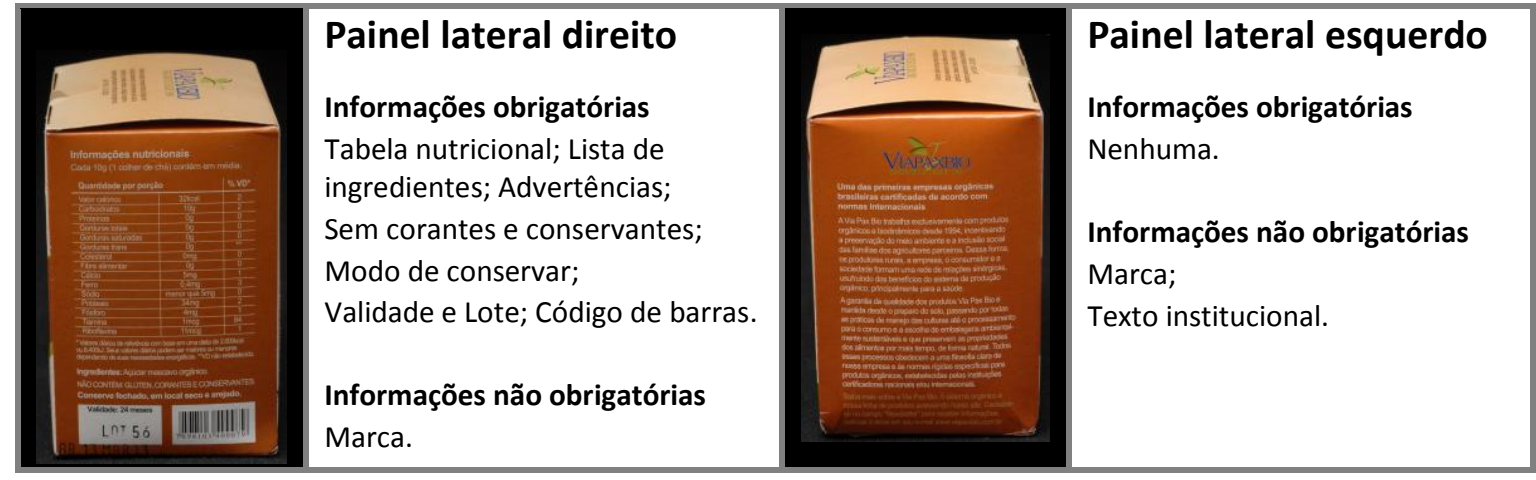

Figura 121 - Painéis laterais da embalagem de açúcar mascavo Via Pax Bio 
A cor dos painéis esquerdo e direito do açúcar mascavo é o marrom claro, que tem relação com a cor do produto. $O$ contraste de cores dá boa legibilidade, porém, no texto institucional do painel esquerdo, por ser igual em todas as embalagens, no caso do açúcar mascavo, perdeu um pouco da sua legibilidade por estar em uma área menor. Percebe-se que a letra do texto foi reduzida e condensada para poder caber.

A marca da Via Pax Bio sobre o fundo colorido tem pouco contraste, tanto a cor verde quanto o azul. A frase "Orgânicos desde 1994" é pouco legível pela falta de contraste com a cor. A cor do painel direito é a mesma do painel esquerdo, criando uma relação entre os painéis.

\section{Análise das diferenças da tampa e da base do açúcar mascavo Via Pax Bio}

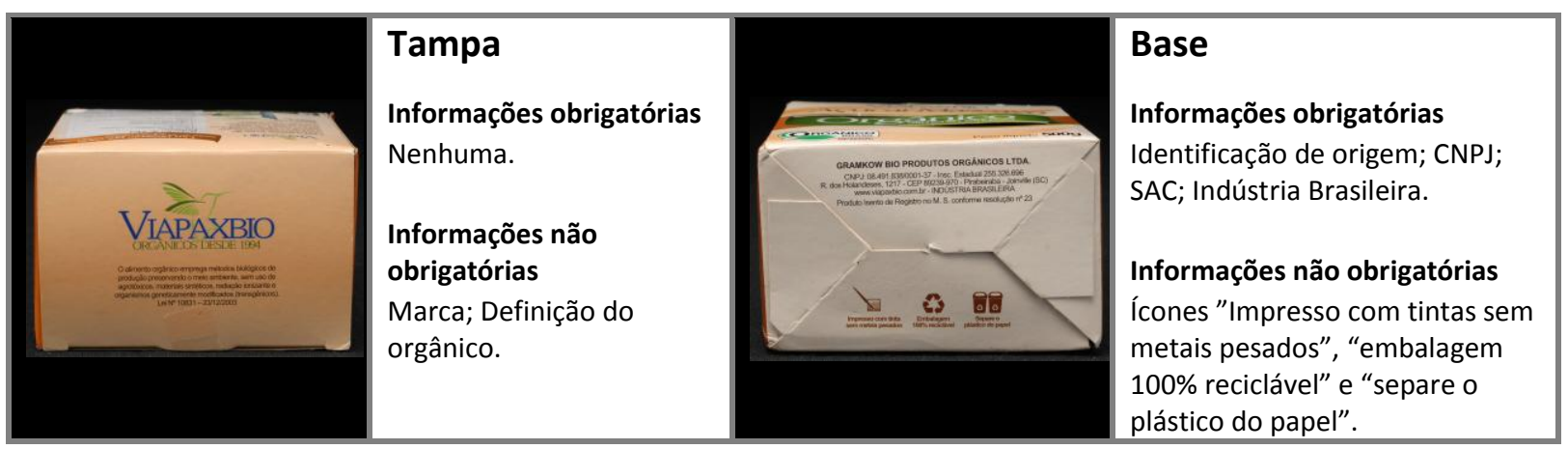

Figura 122 - Tampa e base da embalagem de açúcar mascavo Via Pax Bio

A cor do fundo da tampa é um creme e da base é o branco, dando boa legibilidade para a marca e os textos. A cor dos ícones do açúcar mascavo em marrom escuro dá boa legilidade, mas não é igual a nenhuma outra cor usada na embalagem.

Como não foram feitas perguntas específicas sobre o açúcar mascavo Via Pax Bio, a partir da análise da embalagem, observa-se que a embalagem de açúcar mascavo apresenta as informações do produto de forma clara e legível, seguindo a mesma estrutura visual dos outros produtos da linha de ingredientes.

\subsubsection{Farinha de trigo integral do Grupo 2 de pouco processado}

A marca de farinha de trigo integral separada como mais saudável foi a da Via Pax Bio, por seis de sete consumidores.

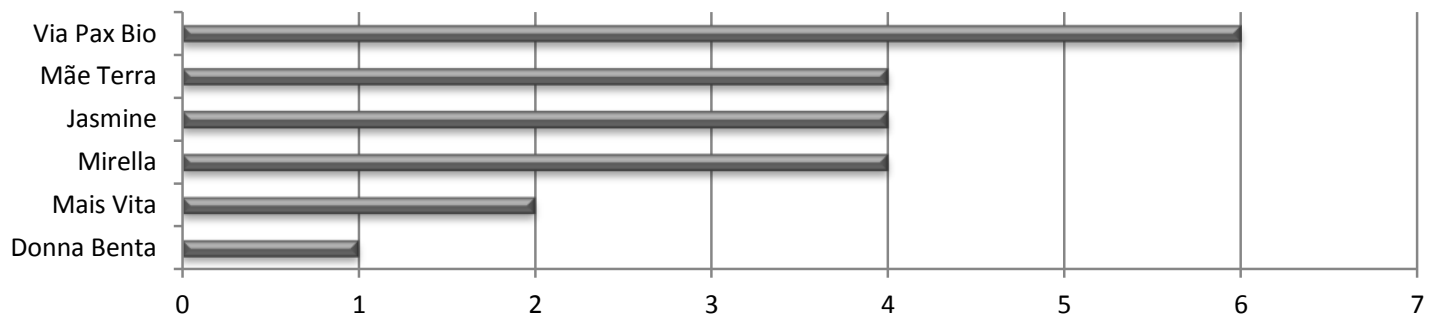

Gráfico 47 - Marcas de farinha de trigo separadas como mais saudáveis (unidade $=$ no de consumidores)

Os principais critérios para a separação foram: ter a palavra "orgânico" (cinco consumidores), a composição nutricional (três consumidores) e a marca (dois consumidores), como podemos ver no gráfico abaixo: 


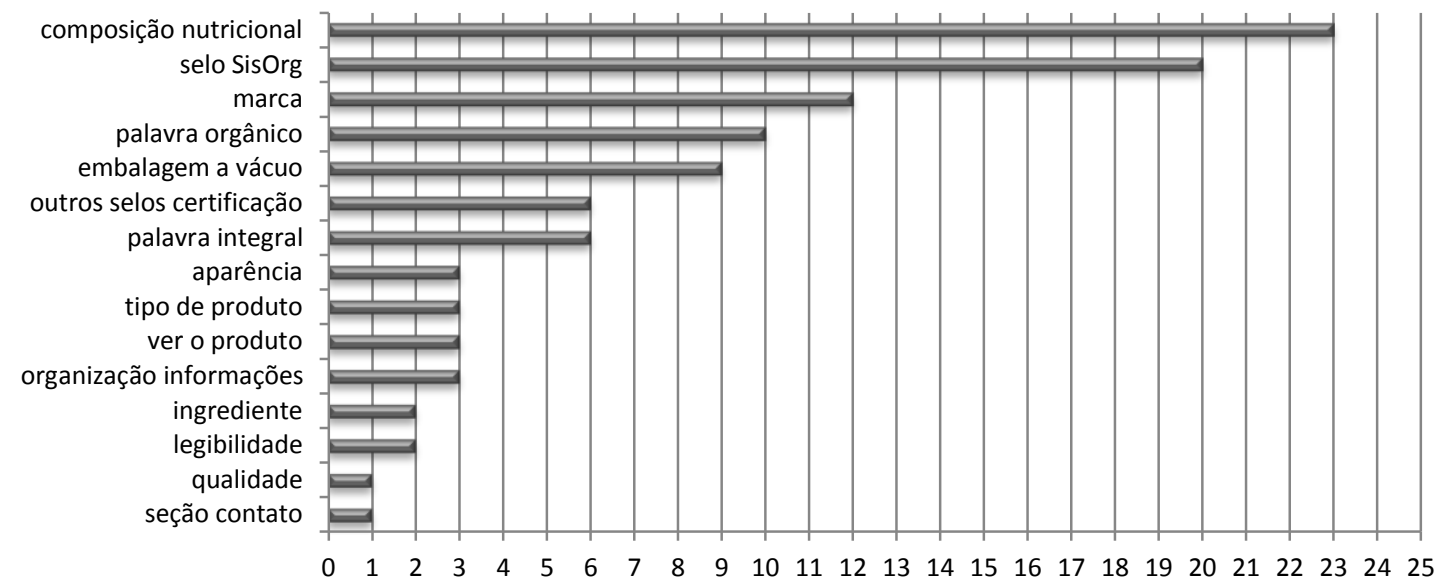

Gráfico 48 - Critérios para separação da farinha de trigo integral como mais saudável. (unidade = no de menções)

Um dos consumidores olhou principalmente a composição nutricional e citou vários nutrientes da tabela, por isso a distorção do gráfico, uma vez que a análise de conteúdo privilegia a quantidade de termos citados e não o seu contexto.

Mais saudáveis seriam essas que têm enriquecimento de ferro, de manganês, de cálcio. E essas não estão enriquecidas. Independente da embalagem. Mas essa daqui [Via Pax Bio] chama a atenção, né? (CA28, 2013)

A aparência da farinha foi a informação mais olhada para separar como menos saudável (dois consumidores), seguida por algum item da composição nutricional (dois consumidores) e por não ser fechada a vácuo (dois consumidores).

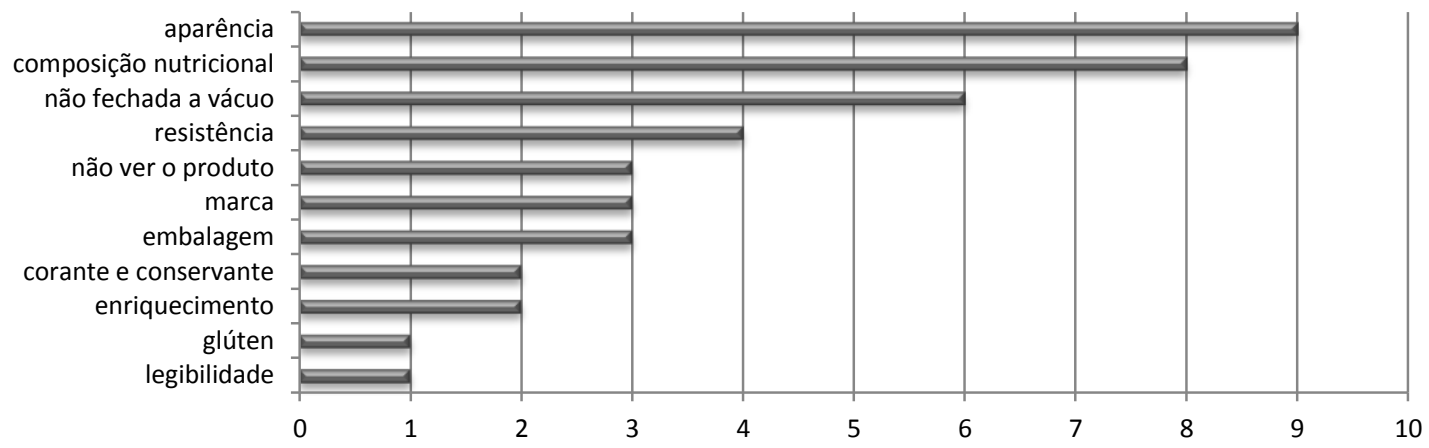

Gráfico 49 - Critérios para a separação da farinha de trigo integral por menos saudável (unidade $=\mathrm{n}$ o de menções)

As marcas de farinha de trigo integral separadas como orgânicas foram a Via Pax Bio e a Mirella. A Mãe Terra, mesmo sendo orgânica, não foi separada por um consumidor por ele não encontrar a palavra "orgânico".

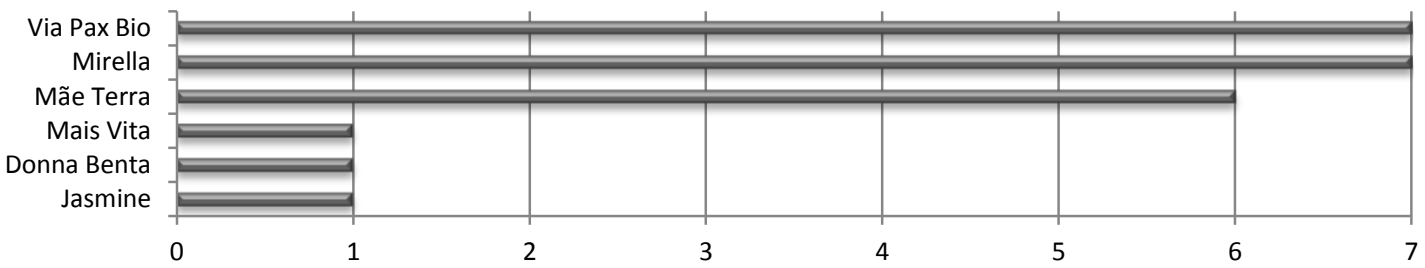

Gráfico 50 - Marcas de farinha de trigo integral separadas como orgânicas (unidade = no de consumidores)

Para separar em orgânico e não orgânico, a principal informação textual olhada foi a palavra "orgânico", por todos os sete consumidores. O selo SisOrg apareceu em segundo lugar (três consumidores) como critério de separação. 


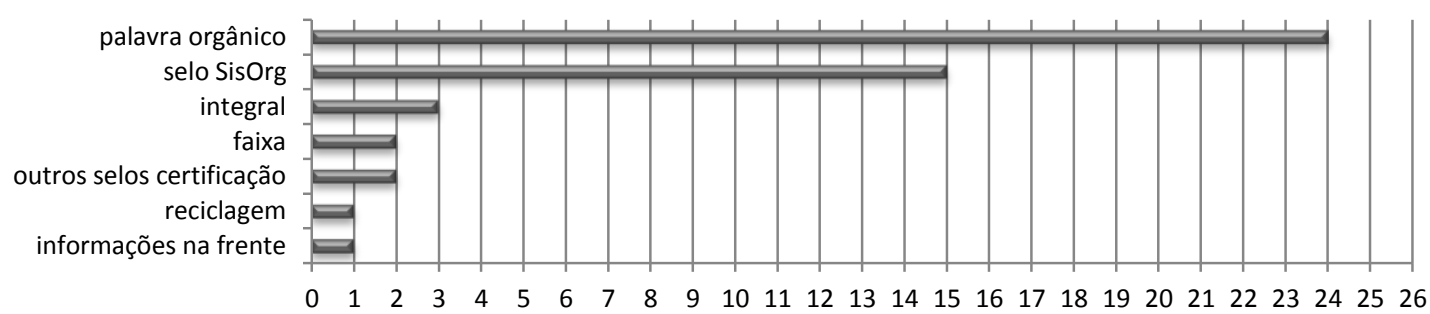

Gráfico 51 - Critérios para separação de farinha de trigo integral como orgânica. (unidade = no de menções)

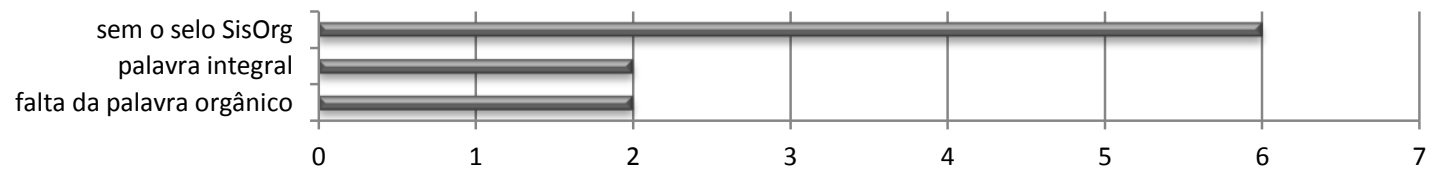

Gráfico 52 - Critérios para separação de farinha de trigo integral como não orgânica. (unidade = no de menções)

Com base nos dados apresentados, podemos considerar que a aparência do produto tem grande influência na percepção de que se trata de um alimento saudável, havendo uma maior necessidade de transparência da embalagem. Embalagens sem transparência foram até separadas como menos saudável por esse motivo.

Para identificar como alimento orgânico, a informação textual e o selo SisOrg foram suficientes, havendo pouca dúvida.

\subsubsection{Farinha de trigo integral Via Pax Bio}

A farinha de trigo integral Via Pax Bio segue o mesmo padrão de design das embalagens da linha de ingredientes, por isso, a seguir, serão analisadas as diferenças específicas desse produto. A embalagem em tamanho real pode ser conferida no Anexo C.

\section{Análise das diferenças do painel frontal da farinha de trigo Via Pax Bio}

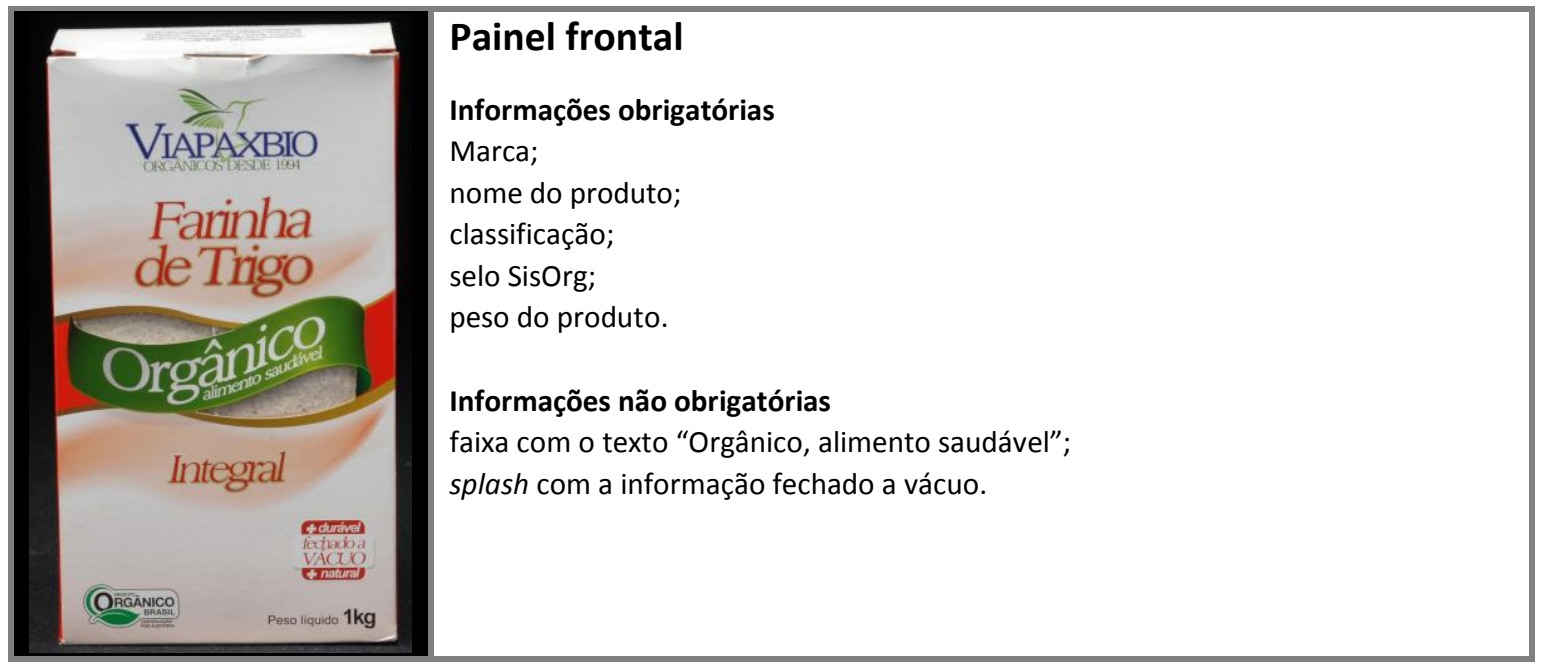

Figura 123 - Painel frontal da embalagem da farinha de trigo Via Pax Bio

A cor do fundo faz um degradê do rosa até o branco e não tem relação com a cor do produto. A cor da farinha é quase branca e não destacaria a embalagem, mas a escolha do vermelho parece aleatória. 
A classificação do produto é feita apenas pela palavra "integral", escrita em um tipo com serifa com as mesmas cores do nome do produto, porém em um tamanho menor.

A cor do splash, com a informação de "Fechado a vácuo", muda conforme o produto e usa a mesma cor das laterais. No caso da farinha de trigo, não há nenhuma informação visual do lado esquerdo, causando um desequilíbrio visual, pelo fato também de ser uma embalagem com mais área, por ser mais alta que as outras embalagens Via Pax Bio.

\section{Análise das diferenças do painel traseiro do arroz integral Via Pax Bio}

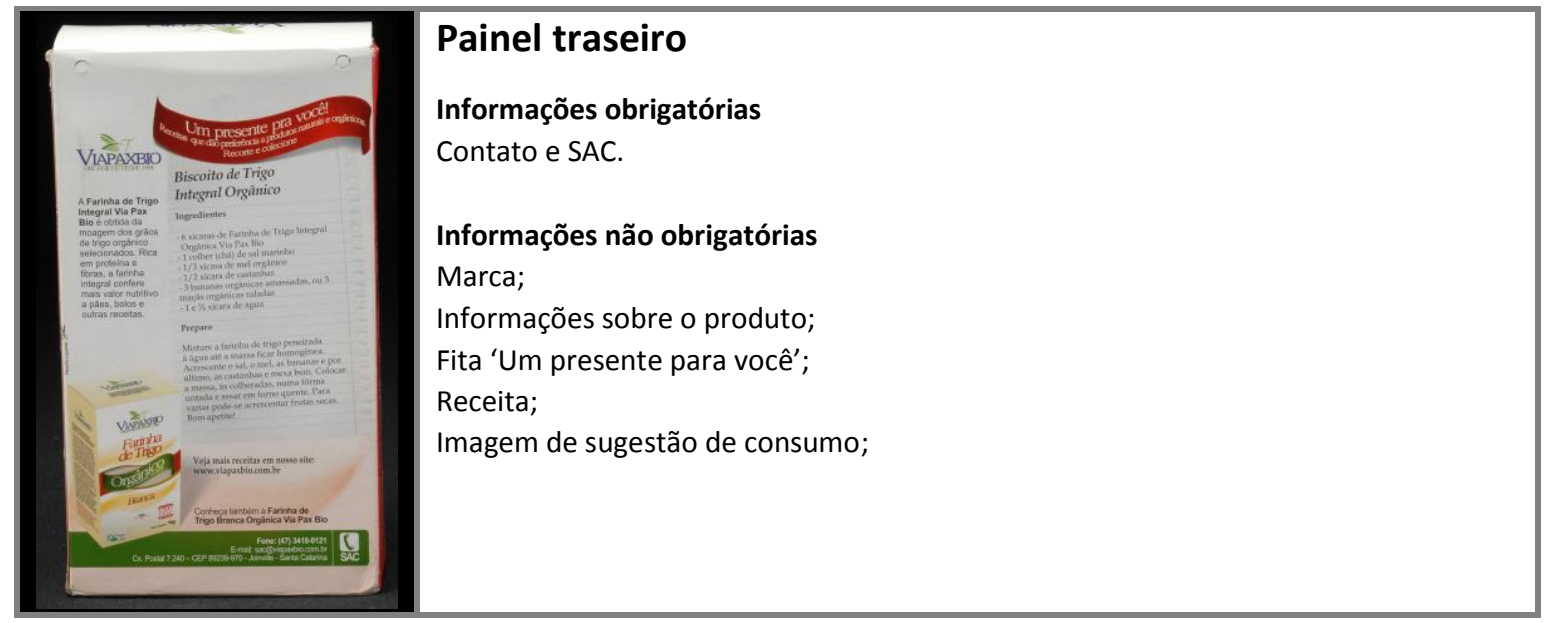

Figura 124 - Painel traseiro da embalagem da farinha de trigo Via Pax Bio

O fundo usa as mesmas cores do painel frontal para o degradê. A imagem escolhida como sugestão de consumo é de uma variação do produto, no caso, a farinha de trigo branca. A receita apresentada é de biscoito de trigo integral orgânico.

\section{Análise das diferenças dos painéis laterais do arroz integral Via Pax Bio}

\begin{tabular}{|c|c|c|c|}
\hline 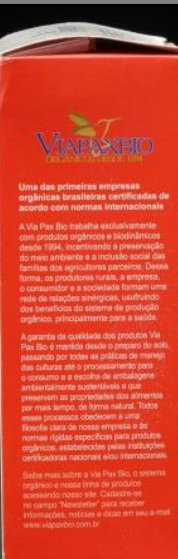 & $\begin{array}{l}\text { Painel lateral direito } \\
\text { Informações obrigatórias } \\
\text { Nenhuma. } \\
\text { Informações não obrigatórias } \\
\text { Marca; } \\
\text { Texto institucional. }\end{array}$ & 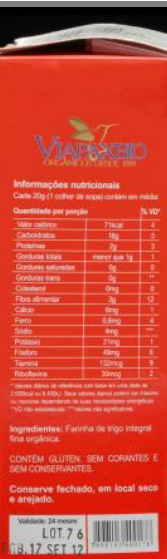 & $\begin{array}{l}\text { Painel lateral esquerdo } \\
\text { Informações obrigatórias } \\
\text { Tabela nutricional; Lista de } \\
\text { ingredientes; Advertências; } \\
\text { Sem corantes e conservantes; Modo } \\
\text { de conservar; } \\
\text { Validade e Lote; Código de barras. } \\
\text { Informações não obrigatórias } \\
\text { Marca. }\end{array}$ \\
\hline
\end{tabular}

Figura 125 - Painéis laterais da embalagem da farinha de trigo Via Pax Bio

A cor do painel esquerdo da farinha de trigo integral em vermelho não tem nenhuma relação com o produto, mas chama a atenção. É a mesma do painel esquerdo, criando uma relação entre os painéis. $O$ vermelho contrasta bem com o texto da empresa, permitindo uma boa leitura. O último parágrafo em rosa claro, apesar de diminuir o contraste, ainda permite uma boa leitura. A marca da Via Pax Bio sobre o fundo vermelho tem pouco contraste, onde só é possível ler por ter um contorno nas letras em azul claro. 
Análise das diferenças da tampa e da base do arroz integral Via Pax Bio

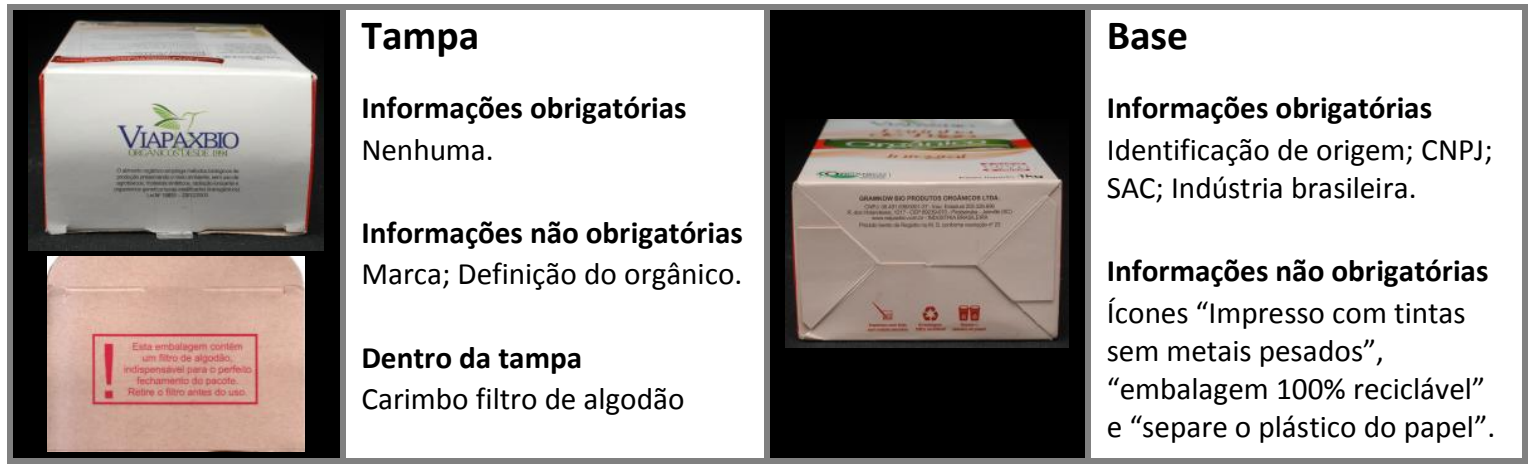

Figura 126 - Tampa e base da embalagem da farinha de trigo Via Pax Bio

A cor da tampa da farinha de trigo integral é branca, dando boa legibilidade para as informações. A cor dos ícones na base da embalagem da farinha é o vermelho, dando boa visibilidade.

Dentro da tampa, diferentemente dos outros produtos Via Pax Bio analisados, tem um carimbo avisando que a embalagem vem com um filtro de algodão para o seu fechamento. Essa mensagem só pode ser vista após a abertura da embalagem, mostrando que não é uma informação importante para a venda, e, por isso mesmo, tem pouco destaque, podendo algum consumidor mais desatento adicionar o algodão na receita.

\section{Apresentação dos dados das entrevistas}

A farinha integral é comprada no leste do Paraná. Para ser estocada, ela é guardada em uma câmara refrigerada em sacas até ser embalada a vácuo, fazendo com que aumente a sua durabilidade.

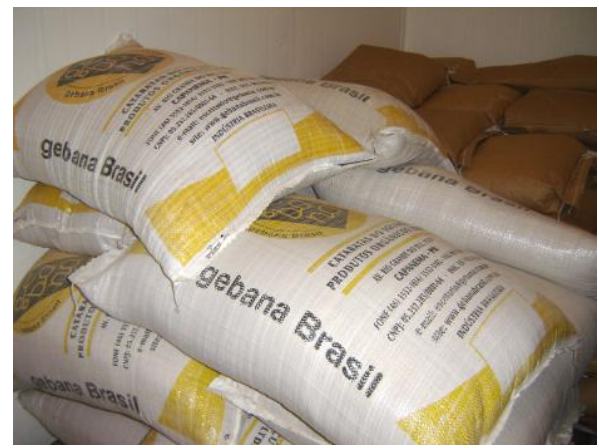

Figura 127 - Câmara refrigerada onde é estocada a farinha de trigo Via Pax Bio

Quando perguntados se já haviam comprado a farinha de trigo integral ou algum outro produto da Via Pax Bio dessa linha, apenas um consumidor disse já ter visto, porém não comprou, por não ter no supermercado que costuma frequentar. 


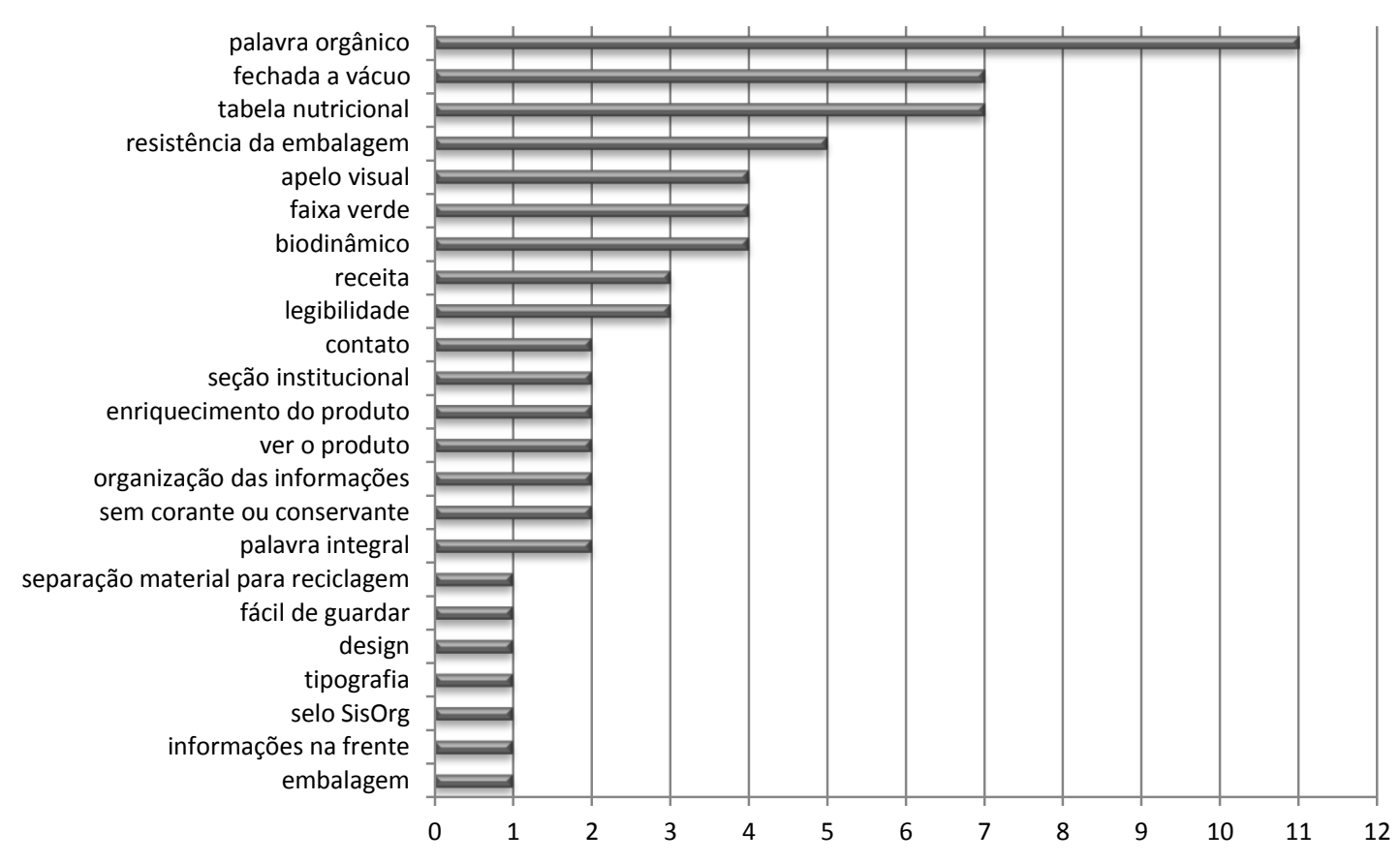

Gráfico 53 - Aspectos positivos da farinha de trigo integral Via Pax Bio

O fato da procedência do produto ser de Joinville foi considerado positivo por um consumidor. "Deve ser boa esta farinha, vem do Sul, vem de Joinville, eles têm produtos muito bons orgânicos lá" (CC06, 2013).

O fato de o nome estar bem destacado foi percebido como positivo por um consumidor.

Achei que o título aqui, 'Farinha de trigo integral', está bem vistoso, está bem chamativo, e gostei desta parte da embalagem de papelão porque eu acho que protege bem a embalagem de plástico a vácuo. (CC06, 2013)

Um dos consumidores se lembrou de um dado da farinha considerado importante. "A farinha, eles colocam uns algodões para manter a mesma temperatura, temperatura não... umidade, uma coisa assim. Então um cuidado, não é?" (CA09, 2013)

Esses algodões são usados para o perfeito fechamento da embalagem. Essa solução foi encontrada para minimizar os problemas de fechamento da embalagem a vácuo, que acontecem muito com os produtos em pó.

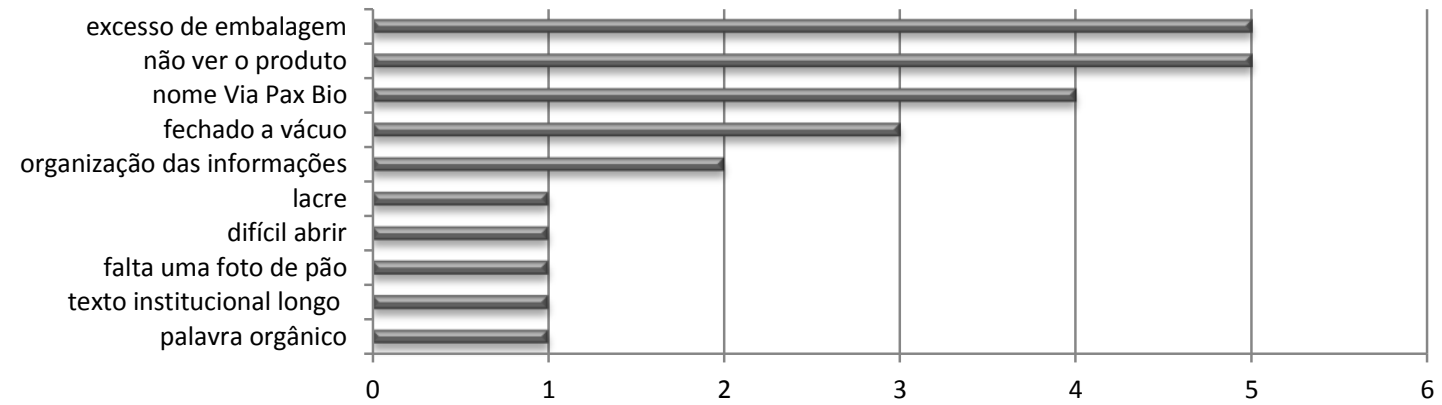

Gráfico 54 - Aspectos negativos da farinha de trigo integral Via Pax Bio

Um dos entrevistados costuma fazer pães caseiros para vender, e sentiu falta de ter uma fotografia que relacionasse com o principal produto produzido por ele. "[...] talvez alguma coisa que chamasse mais atenção para o lado do pão" (CC06, 2013). 
A embalagem fechada a vácuo também foi considerada negativa por um consumidor, por não poder sentir o produto. "Primeiro de uma farinha de trigo ser empacotada a vácuo. Para mim, eu sempre compro a normal, a branca. Eu realmente nunca vi. Nem vi na prateleira" (CB27, 2013).

A cor, da embalagem e da farinha, foi considerada algo positivo por um consumidor. "A cor, eu acho que a cor chama a atenção. Você sabe que o vermelho chama a atenção nas laterais. Você consegue ver, pouco, você consegue ver a cor do produto dentro" (CA12, 2013).

\section{Diferencial semântico da farinha}

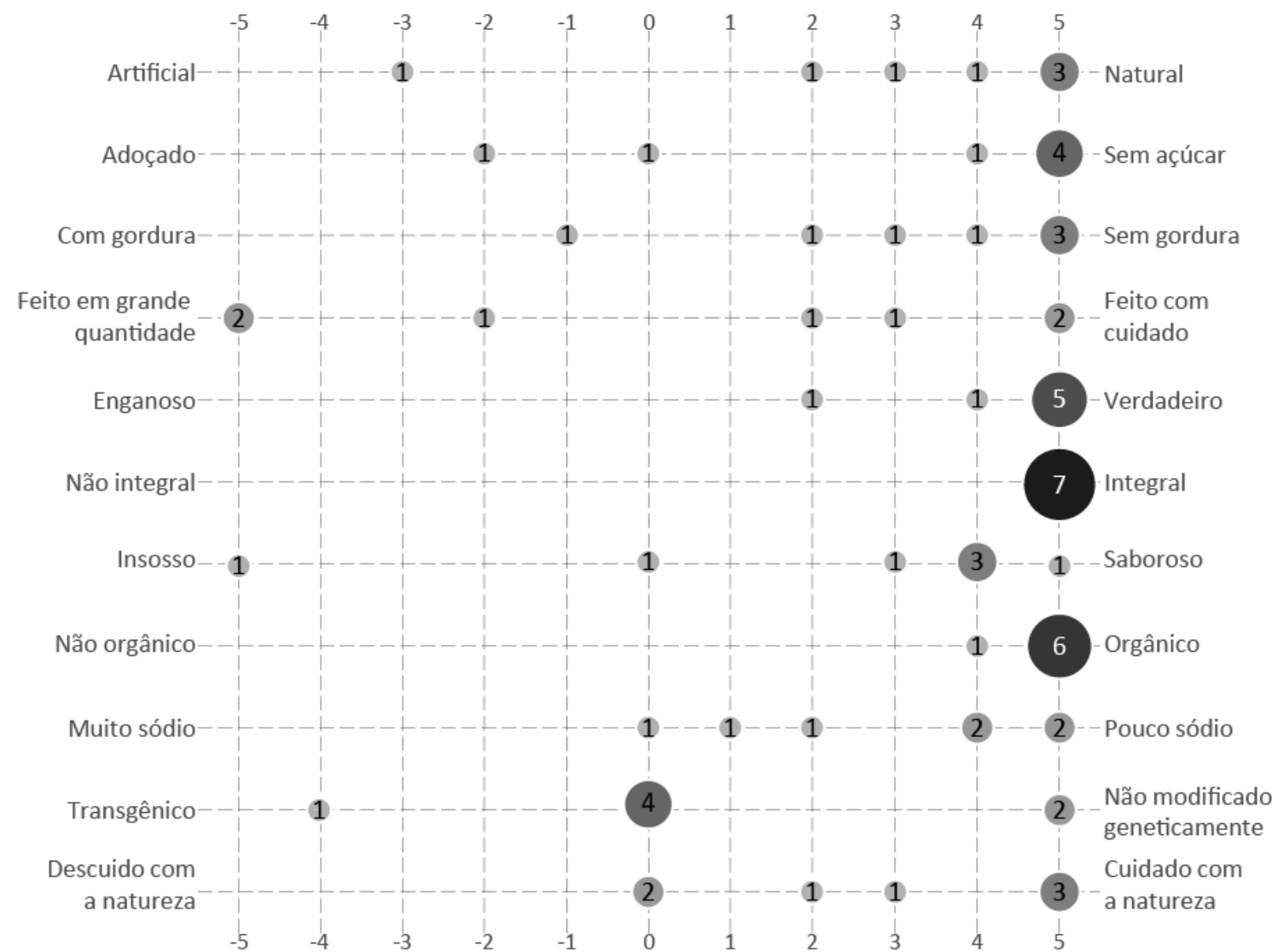

Gráfico 55 - Diferencial semântico da farinha de trigo integral Via Pax Bio

Como podemos ver no gráfico acima, há predomínio de uma percepção mais positiva do produto. Podemos observar que nem todos sabem que o alimento orgânico é livre de transgênicos. Esse desconhecimento do que é um alimento orgânico ainda aparece quando a pessoa não sabe se há cuidado ou não com a natureza.

A partir dos dados apresentados, observa-se que a embalagem de farinha de trigo integral Via Pax Bio foi percebida como positiva por ser orgânica e por estar em uma embalagem fechada a vácuo. Porém, mesmo gostando da embalagem, percebe-se que o consumidor considera a segunda embalagem um desperdício de material e ainda atrapalha a visibilidade do produto, considerada importante para essa categoria.

\subsubsection{Farinha de trigo Integral Mãe Terra}

A farinha de trigo integral Mãe Terra segue o mesmo padrão de design das embalagens da linha de ingredientes, por isso, a seguir, serão analisadas as diferenças específicas desse produto. A embalagem em tamanho real pode ser conferida no Anexo A. 


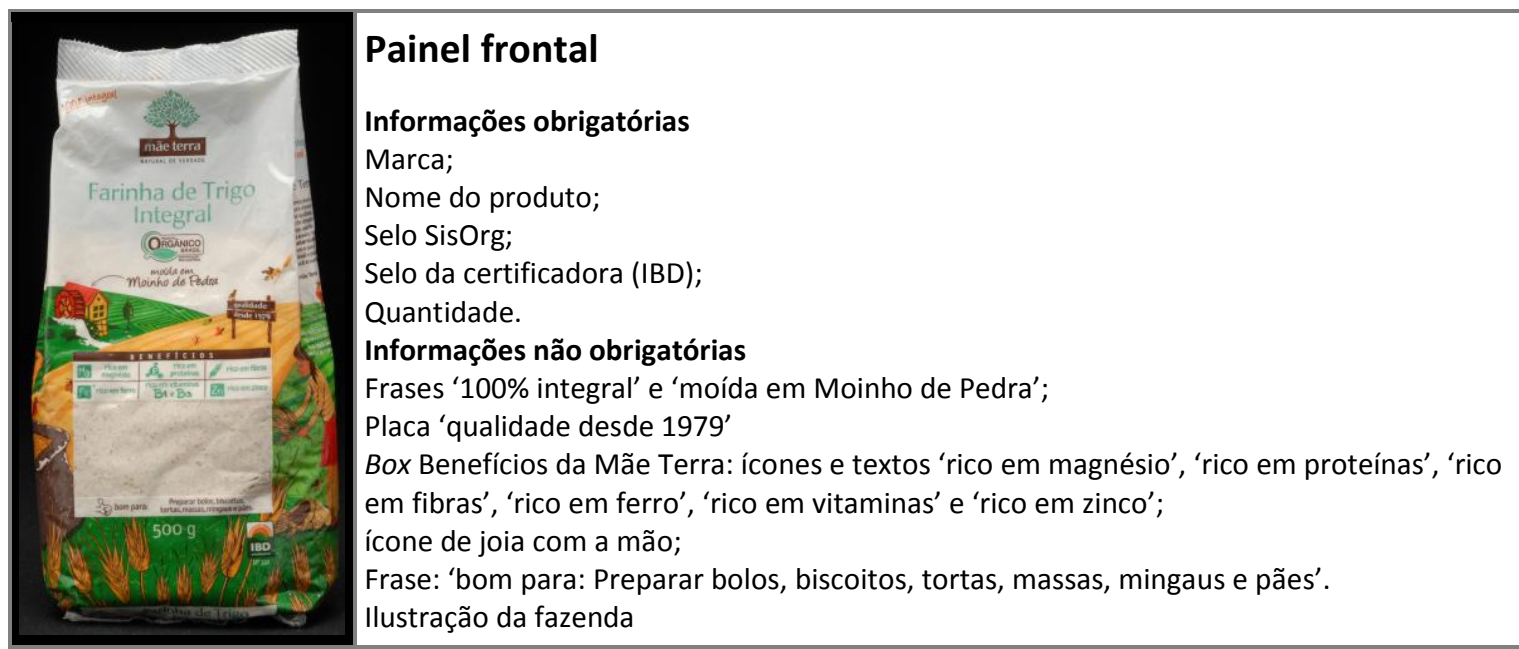

Figura 128 - Painel frontal da embalagem da farinha de trigo integral Mãe Terra

O painel frontal da embalagem da farinha de trigo segue a mesma estrutura visual das outras embalagens da linha de ingredientes da Mãe Terra, porém, neste caso, a ilustração da fazenda foi adaptada ao produto.

A casa mudou para um moinho de pedra, parte do campo mudou de cor, do verde para o amarelo (cor do trigo), e, na parte de baixo, por toda a embalagem, estão ramos de trigo, que também podem ser vistos na mão da moça. Essa mudança mostra o destaque que a empresa quer dar para o trigo por ele ser moído em moinho de pedra pela Mãe Terra. A embalagem também apresenta mais bichinhos se comparada com as outras embalagens da linha de ingredientes.

O selo SisOrg está localizado abaixo do nome do produto. Como na embalagem de açúcar, ele tem o mesmo problema e não se destaca. Na embalagem de farinha de trigo, o selo ainda fica mais escondido, por ter outra informação abaixo com o mesmo peso e cor.

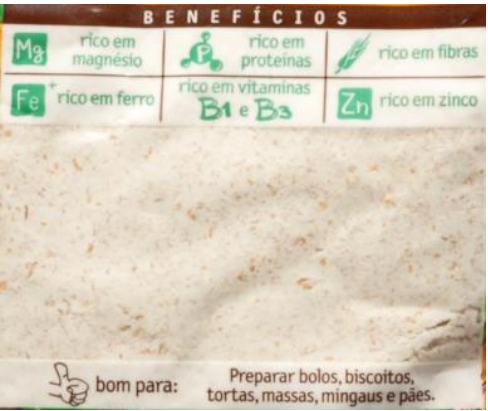

Figura 129 - Box de benefícios da embalagem da farinha de trigo integral Mãe Terra
Análise do box de benefícios da farinha de trigo integral Mãe Terra

Apesar de apresentar muitas informações nutricionais, elas estão bem legíveis. Os ícones utilizados não são muito conhecidos, mas apenas o de trigo que é mais ilegível.

A informação "Preparar bolos, biscoitos, tortas, massas, mingaus e pães" foi aplicada sobre um fundo branco e está bem legível. A janela do box permite bem a visualização do produto. 


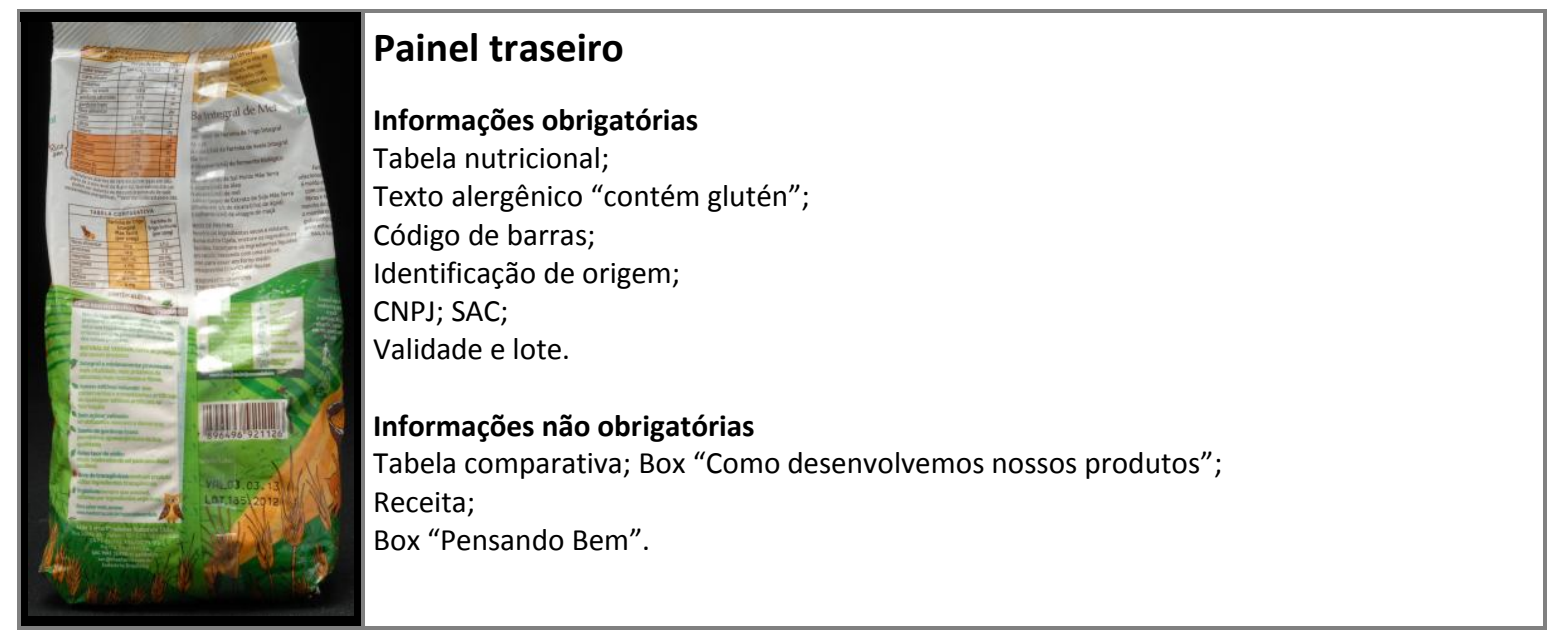

Figura 130 - Painel traseiro da embalagem da farinha de trigo integral Mãe Terra

Segundo o sentido de leitura, de cima para baixo, da esquerda para a direita, a primeira informação do painel traseiro é a tabela nutricional.

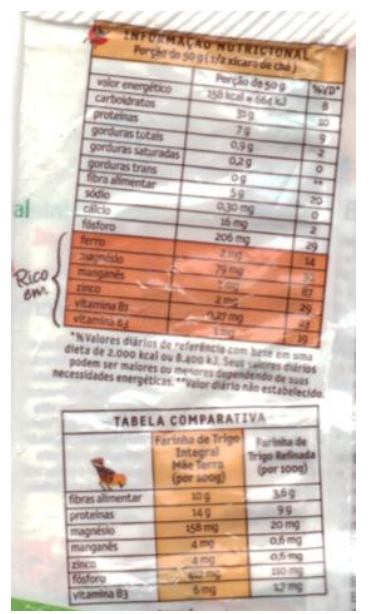

Figura 131 - Tabela nutricional da embalagem da farinha de trigo integral Mãe Terra

\section{Análise tabela nutricional e comparativa da farinha de trigo integral Mãe Terra}

A tabela nutricional da farinha de trigo tem uma estratégia de design diferente das outras embalagens da linha de ingredientes, que usam um formato padrão.

Ela destaca alguns nutrientes com o fundo colorido e a informação "Rico em". A tabela comparativa usa uma cor laranja para destacar as diferenças do produto junto com a imagem de um passarinho.

Essa mudança de estratégia de design em relação às outras embalagens da linha de ingredientes mostra o valor que a empresa quis passar para o consumidor: os diferenciais nutricionais da farinha moída dentro da empresa.

Após as tabelas, a segunda informação a ser vista é a cor da ilustração e o box "como desenvolvemos os nossos produtos". O box "Pensando Bem" ficou com pouco destaque por estar localizado abaixo da emenda da embalagem e sobre o fundo verde, de mesma cor das informações dentro do box.

O texto do endereço e forma de contato aplicado sobre a ilustração, com letras brancas, melhorou em relação ao arroz, mas ainda tem pouca legibilidade.

Os elementos gráficos e textuais estão divididos na embalagem e alinhados em duas colunas, estando em equilíbrio. Algumas informações têm uma leve inclinação, que dá um pouco de movimento à embalagem. 


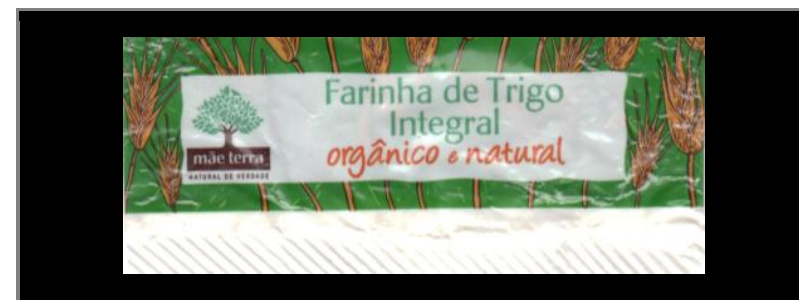

\section{Base}

Informações obrigatórias

Nenhuma. Não há nada especificado na legislação.

Informações não obrigatórias

Marca; Nome do produto;

frase "orgânico e natural".

Figura 132 - Base da embalagem da farinha de trigo integral Mãe Terra

Segundo o sentido de leitura, de cima para baixo, da esquerda para a direita, a primeira informação da base é a marca da Mãe Terra, seguida pelo nome do produto e a frase "orgânico e natural".

A marca é aplicada sobre o fundo branco e tem boa legibilidade e contraste de cor. O nome do produto usa a mesma tipografia do nome do painel frontal e tem boa legibilidade.

\section{Hierarquia de leitura}

A hierarquia de leitura da embalagem da farinha de trigo integral da Mãe Terra demostrada abaixo faz com que informações mais relacionadas à marca tenham mais destaque do que as informações mais específicas do produto.

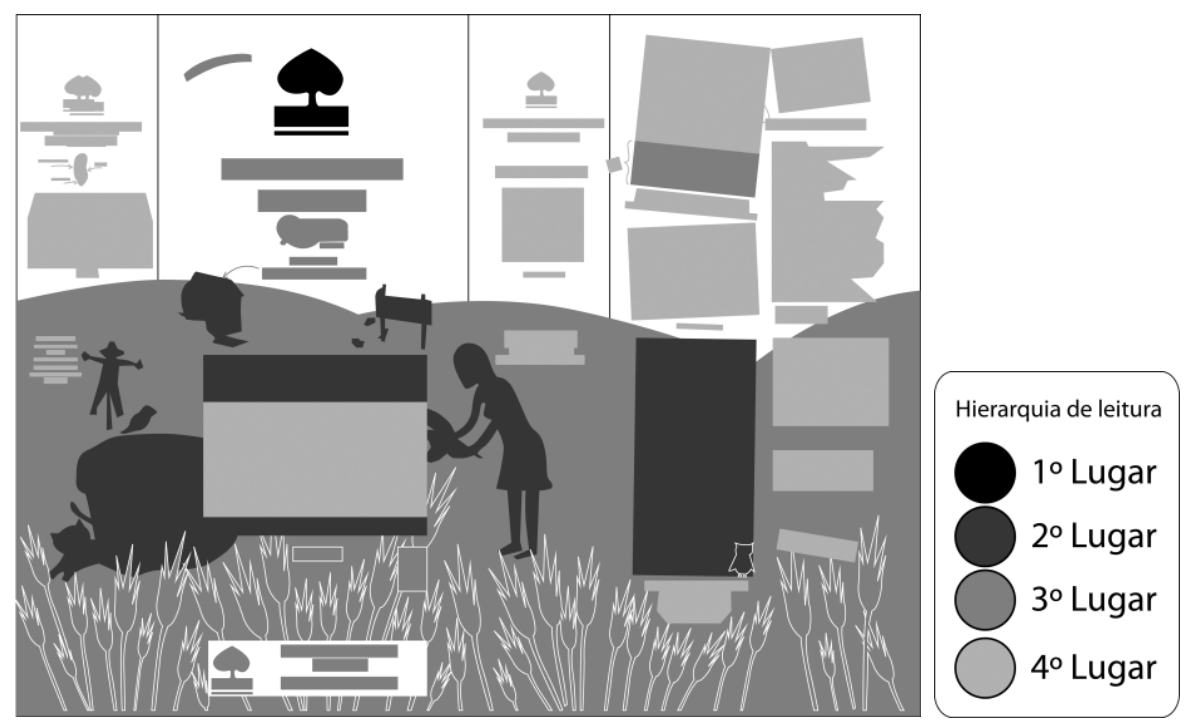

Figura 133 - Hierarquia de leitura da farinha de trigo integral Mãe Terra

\section{Apresentação dos dados das entrevistas}

A farinha de trigo integral da Mãe Terra se diferencia por ser moída dentro da fábrica da Mãe Terra. Segundo Indústria1 (2012):

O moinho de pedra é um moinho mais rústico, é como se moía antigamente. São duas pedras que moem o grão. Ele machuca, ele mói menos o grão do que uma farinha branca refinada. [...] A moagem dela, é bem alto, porque ele vai descendo em etapas, até chegar naquela farinha branca bem fina.

Ainda segundo Indústria1 (2012), ela também se diferencia por não ser reconstituída, que, segundo ele, "[...] seria uma farinha branca adicionada com fibra. Então a gente comprou esse moinho e faz a farinha aqui. Faz o produto aqui" (INDÚSTRIA1, 2012). 
As informações nutricionais em destaque chamaram a atenção de dois de sete entrevistados. "Essa daqui [Mãe Terra] também está enriquecida, olha. Tem ferro, manganês, zinco" (CA28, 2013).

Porém, mesmo a informação nutricional tendo chamado a atenção, um dos consumidores ficou em dúvida por causa da aparência do produto.

Bom, aqui, [Mãe Terra] diz que rico em... mas não sei, isso aqui não está parecendo tão integral não. Se comparar esse aqui [Mãe Terra], está mais branco do que essa daqui [Mais Vitta]. Mais branco que essa [Jasmine], isso se você for pela cor, né. Esse aqui [Mirella], eu não consigo ver a cor. Não sei. Está esquisito esse treco [Mãe Terra]. (CA12, 2013)

Um dos consumidores também comentou que demorou a encontrar a informação de que a farinha integral Mãe Terra era orgânica. "Esse aqui [Mãe Terra], está muito pequeno o 'orgânico'. Eu não vi que era orgânico. Eu vi que era integral, eu acho que o integral está muito mais destacado" (CA19, 2013).

Isso provavelmente aconteceu não apenas pelo tamanho do selo, mas por não se destacar em relação às outras informações conforme visto na análise da embalagem.

Como não foram feitas perguntas específicas sobre a farinha de trigo integral Mãe Terra, as informações dos consumidores foram fornecidas de forma espontânea durante a separação do produto em grupos.

A partir dos dados apresentados, observa-se que a estratégia de design da embalagem de farinha de trigo integral escolheu destacar mais os aspectos nutricionais do produto. Porém, o excesso de informações da embalagem faz com que algumas informações não fiquem muito legíveis, como o selo SisOrg e as informações do painel traseiro. Além disso, pelo mau acabamento, algumas informações do produto ficaram escondidas na emenda da embalagem.

\subsubsection{Cookies do Grupo 3 de pronto consumo}

As marcas mais separadas de cookies como sendo saudáveis foram a Mãe Terra e a Jasmine, por todos os oito consumidores.

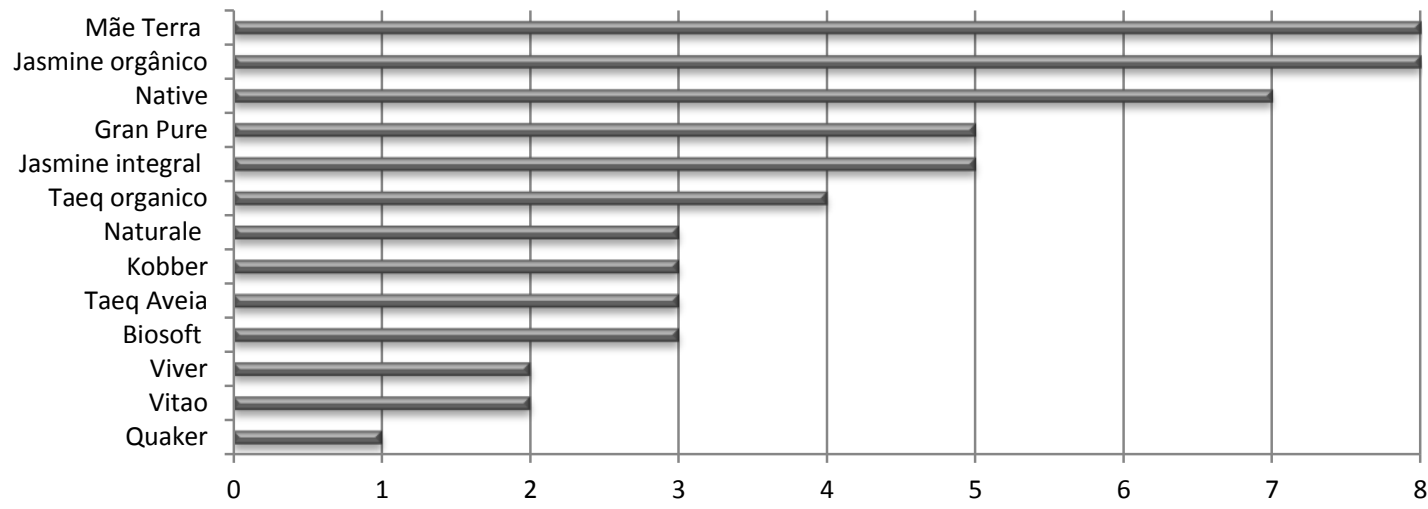

Gráfico 56 - Marcas de cookie separadas como mais saudáveis (unidade = nํㅡㄹ de consumidores)

Os principais critérios para separar como mais saudável foram a palavra "orgânico", por todos os oito consumidores, a palavra "integral" (sete consumidores) e a composição nutricional (quatro consumidores). Três de sete entrevistados relacionaram a marca Mãe Terra como um produto saudável. 


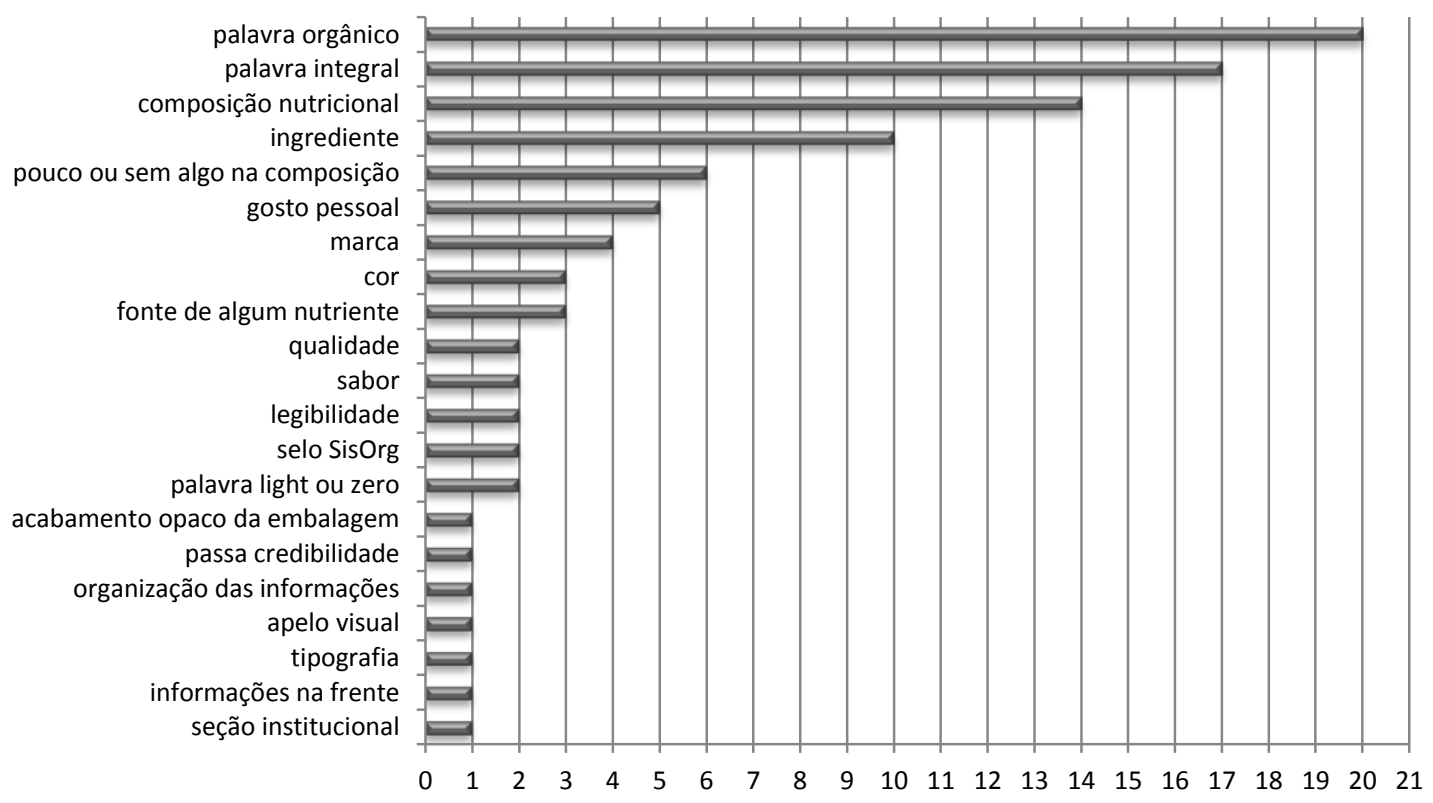

Gráfico 57 - Critérios para separação de cookie como mais saudável. (unidade $=$ n⿳o de menções)

Os principais critérios para separar o cookie como menos saudável foram: composição dos ingredientes (seis consumidores), composição nutricional (quatro consumidores) e as palavras "orgânico" (quatro consumidores) e "light" ou "zero" (três consumidores).

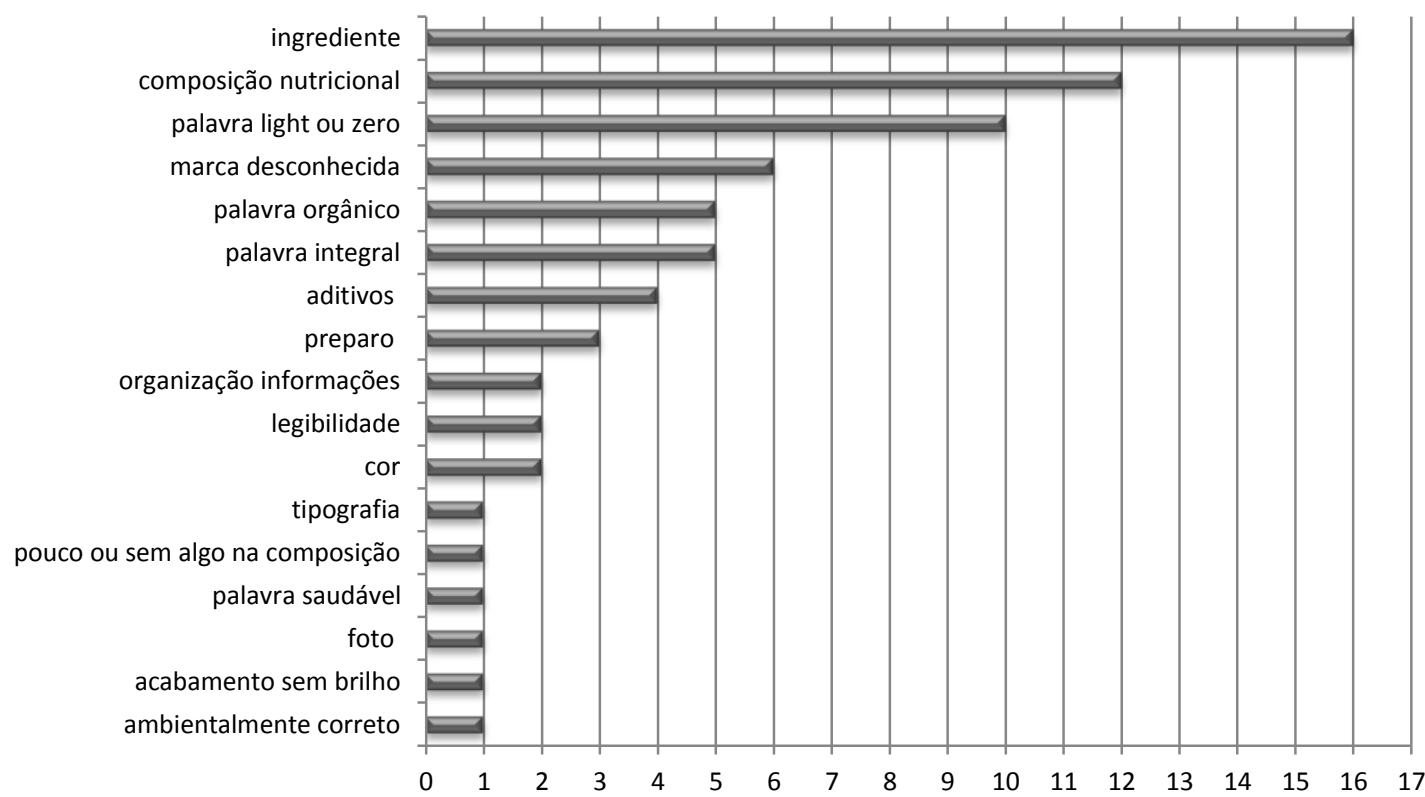

Gráfico 58 - Critérios para separação de cookie como menos saudável. (unidade = no de menções)

As marcas de cookies separadas como orgânicas foram a Mãe Terra e a Native, por todos os oito entrevistados, e a Taeq e Jasmine, por sete consumidores. 


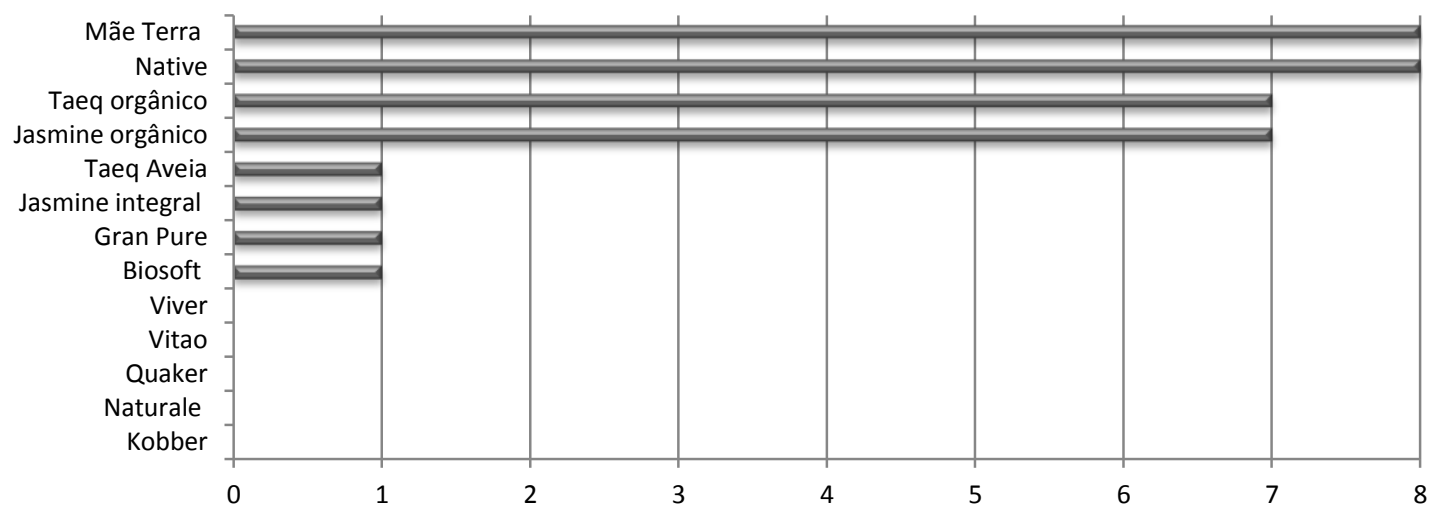

Gráfico 59 - Marcas de cookie separadas como orgânicas (unidade = no de consumidores)

Para separar em orgânico e não orgânico, a principal informação textual olhada foi a palavra "orgânico" (sete consumidores). O selo SisOrg apareceu em segundo lugar (seis consumidores), seguido pela marca Mãe Terra (três consumidores).

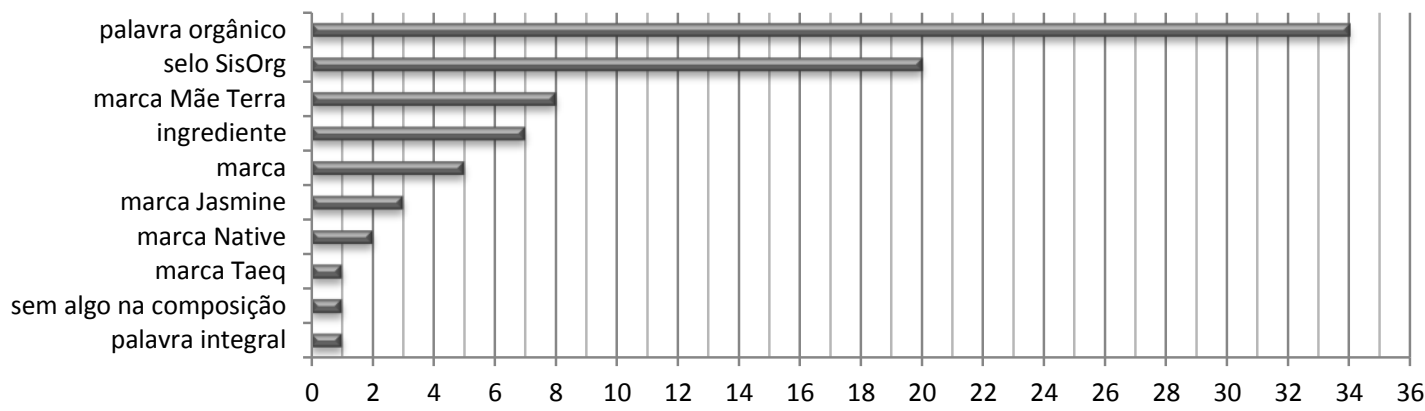

Gráfico 60 - Critérios para a separação dos cookies como orgânicos. (unidade $=\mathrm{n}^{\circ}$ de menções)

O principal critério para a separação como não orgânico foi a falta da palavra "orgânico", citado por seis consumidores.

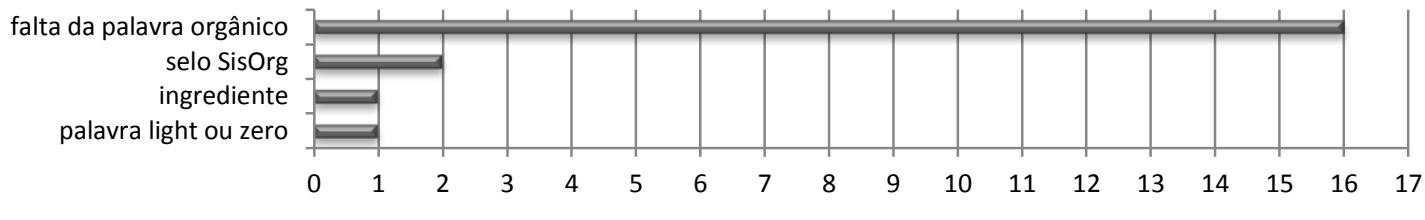

Gráfico 61 - Critérios para a separação de cookie como não orgânico. (unidade = no de menções)

Com base nos dados apresentados, podemos considerar que a marca e a composição do produto têm grande influência nessa categoria para a percepção de que se trata de um alimento saudável. Diferentemente de outros produtos, os consumidores buscaram mais informações na lista de ingredientes e composição nutricional para separá-los como mais saudáveis.

Para identificar como alimento orgânico, a informação textual e o selo SisOrg foram suficientes, porém alguns consumidores, por terem dúvidas sobre o que é um alimento orgânico, acabaram confundindo com a composição de ingredientes. 


\subsubsection{Cookies integrais Mãe Terra}

A embalagem dos cookies integrais da Mãe Terra segue outro padrão de design das demais embalagens da empresa. A seguir, serão analisadas as características específicas desse produto. A embalagem em tamanho real pode ser conferida no Anexo $A$.

\section{Análise do painel frontal dos cookies integrais Mãe Terra}

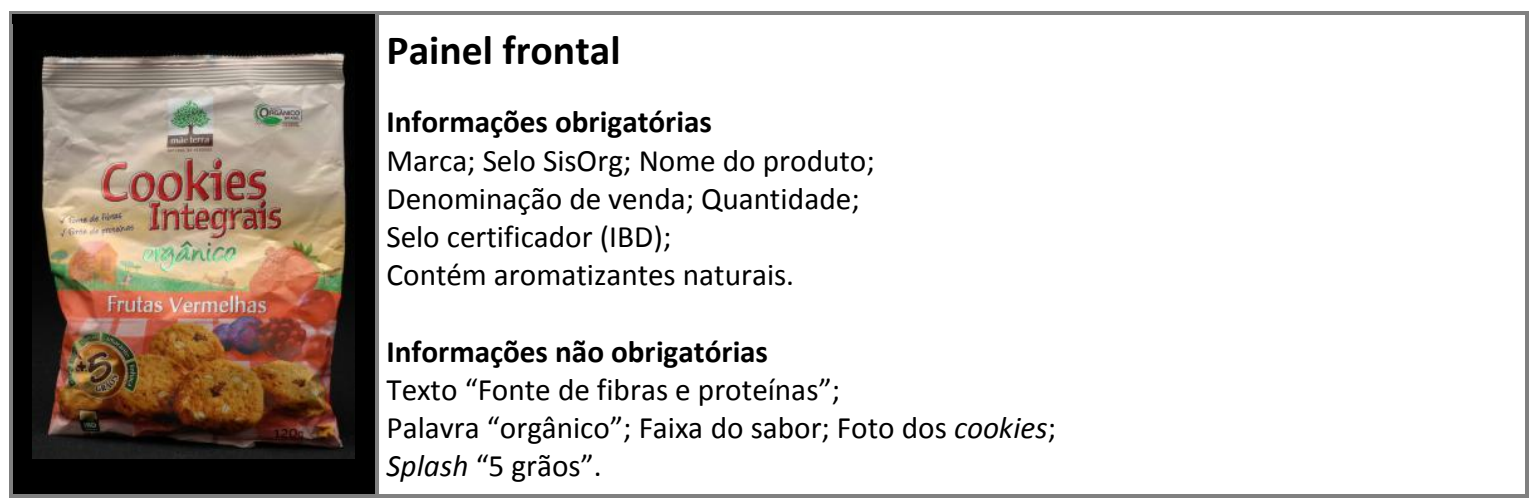

Figura 134 - Painel frontal da embalagem dos cookies integrais Mãe Terra

Segundo o sentido de leitura, de cima para baixo, da esquerda para a direita, a primeira informação do painel frontal é a marca Mãe Terra, seguida pelo nome do produto, porém, pela característica do tipo escolhido para o nome, e por sua cor, o nome do produto é o que chama primeiro a atenção.

A marca é aplicada sobre um fundo claro, na cor creme, dando boa legibilidade, mas com menos contraste em relação às outras embalagens brancas. Porém, como a área de respiro branca atrás da árvore foi mantida, não prejudica a visibilidade.

O nome do produto tem um grande destaque na embalagem, localizado no centro óptico da embalagem, em um tipo sem serifa, mas com linhas irregulares.

O horizonte da fazenda na embalagem dos cookies integrais ficou em segundo plano, perdendo importância. Essa mudança no design perdeu um pouco da identidade da marca, mas atingiu o objetivo de "encantar e inovar", declarado pelo responsável da Mãe Terra e fazendo o produto parecer mais apetitoso.

Em primeiro plano, aparecem os cookies com as frutas do sabor. A cor vermelha da toalha de piquenique se destaca e está relacionada ao sabor de frutas vermelhas.

O splash " 5 grãos" tem um bom destaque na embalagem, por ser a única informação que manteve o brilho do material. Porém, como foi aplicado sobre a imagem dos cookies, que possui uma cor parecida, acaba sumindo em relação às outras informações.

O Selo SisOrg tem pouco destaque na embalagem, apesar de ter sido aplicado sobre o fundo claro. A informação de que se trata de um produto orgânico é mais bem vista pela palavra, em cor verde, abaixo do nome.

Os elementos gráficos foram aplicados de forma centralizada em relação à embalagem e estão em equilíbrio, porém com muita informação visual. 


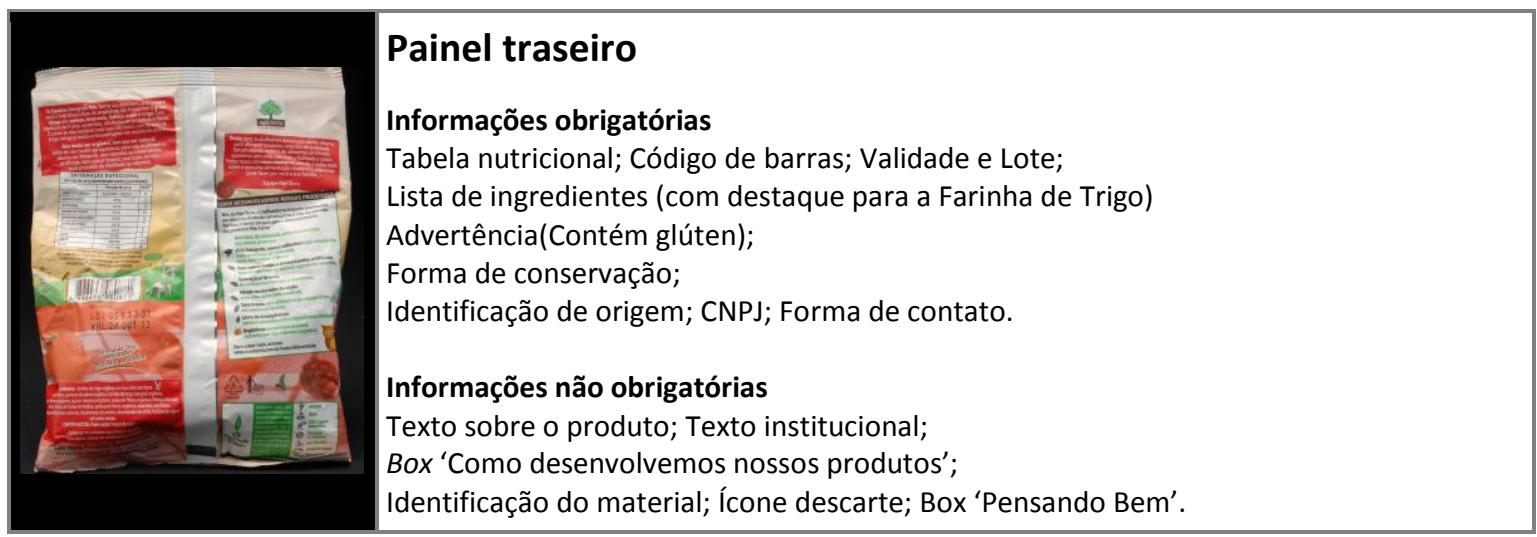

Figura 135 - Painel traseiro da embalagem dos cookies integrais Mãe Terra

Segundo o sentido de leitura, de cima para baixo, da esquerda para a direita, a primeira informação do painel traseiro é o texto do produto, seguido pelo box "Como desenvolvemos nossos produtos" e o box "Pensando Bem", que se destacam pela cor em relação ao fundo da ilustração.

A marca é aplicada sobre um fundo claro, na cor creme, dando boa visibilidade.

Na lista de ingredientes, é destacada a informação da farinha de trigo integral produzida em moinho de pedra, mas não explica o porquê dessa informação ser relevante.

A identificação dos materiais e o ícone de orientação para a reciclagem estão aplicados sobre o fundo com a imagem da toalha, com pouco destaque.

Há muitos elementos visuais no painel traseiro da embalagem, dificultando a leitura. Os elementos gráficos, divididos em duas colunas com a emenda da embalagem no meio em cor branca, estão em desequilíbrio, com as informações à direita com mais destaque e peso.

\section{Hierarquia de leitura}

A hierarquia de leitura da embalagem de cookies integrais da Mãe Terra, demostrada abaixo, faz com que o nome do produto tenha mais destaque, porém o termo "cookies integrais" se sobressai mais do que o "orgânico".

A marca Mãe Terra ainda se destaca, principalmente por sua localização. 0 splash de " 5 grãos" se destaca por ter sido aplicado sobre o fundo brilhante do material da embalagem, mostrando a importância de informar o conteúdo do produto. 


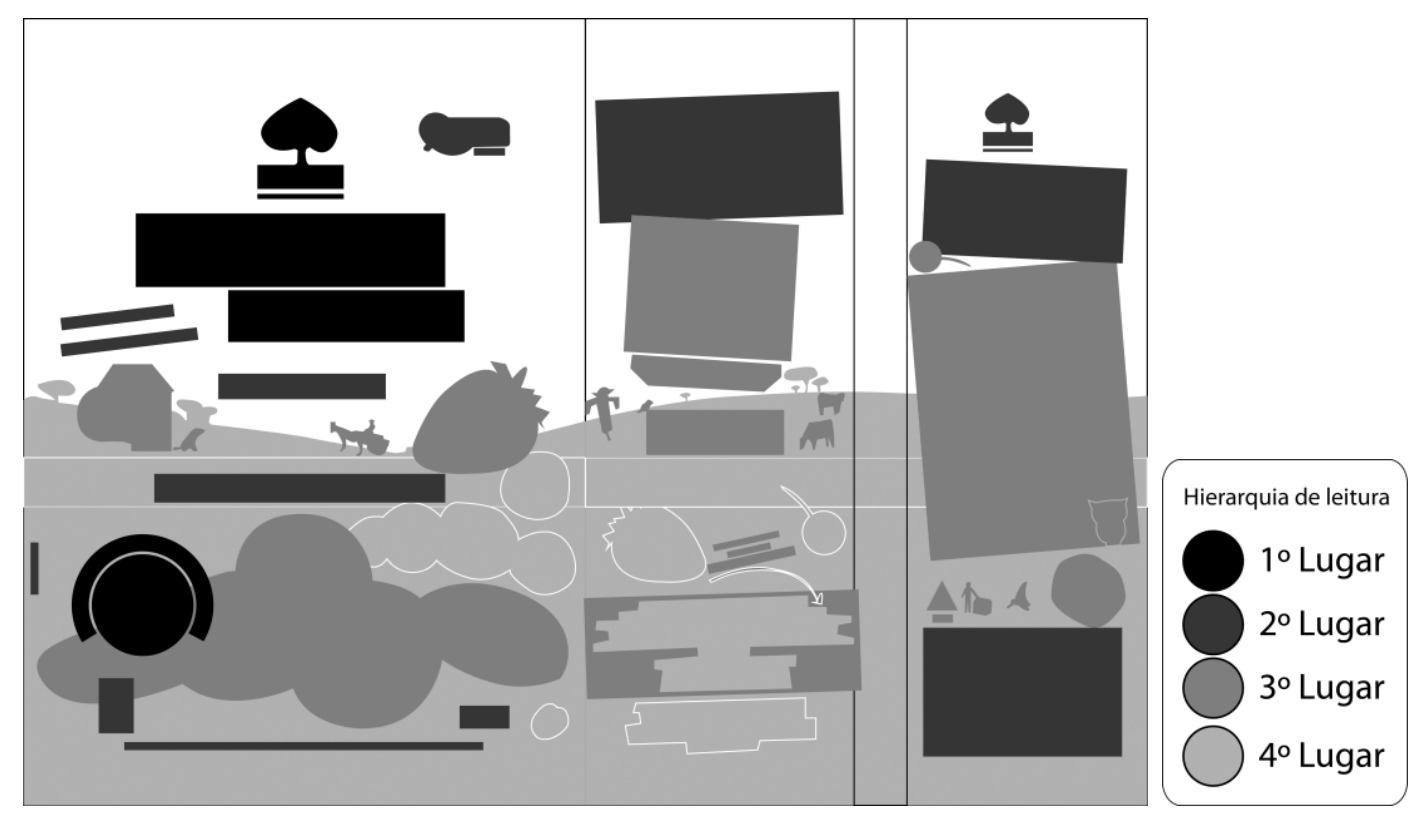

Figura 136 - Hierarquia de leitura dos cookies integrais Mãe Terra

\section{Questões técnicas dos cookies Mãe Terra}

Quanto ao material, segundo Indústria1 (2012), o cookie precisa de uma barreira maior para o oxigênio e para ter um shelf life estendido. Sem ela, o produto "murcha, a gordura oxida e deixa um gosto de rançoso".

O plástico da embalagem é o Polipropileno Biorientado (BOPP) metalizado, identificado na embalagem pelo número sete, que garante a barreira necessária para o produto. Esse material foi percebido por um consumidor como algo negativo e que protege pouco o produto, por ser mole. "É uma embalagem meio mole, sem proteção. Porque ele está esfarelado embaixo, olha. Uma embalagem que poderia ter um pouquinho mais de proteção nela, para não esfarelar" (CC11, 2013).

Durante a produção da embalagem, houve um problema técnico de reprodução do degradê, pois não dava para ir direto para o branco. A impressão em flexografia é limitada para o degradê de cores até $0 \%$ da cor; o mínimo é $5 \%$. A proposta da cor creme ajudou o processo de impressão.

\section{Aspectos ambientais dos cookies Mãe Terra}

Os cookies são produzidos na fábrica da Mãe Terra, diminuindo o gasto de energia e transporte, em comparação ao caso de que fossem produzidos em um de seus fornecedores. Já a fornecedora de embalagem, a Qualy Print, de Diadema, na grande São Paulo, está localizada perto da fábrica.

A reciclagem do BOPP mais a camada metalizada é dificultada, porém é necessária para preservar o produto. Todas as embalagens multicamadas têm problemas para reciclar, pois têm pouco valor na cadeia de reciclagem no Brasil, pela dificuldade de separação dos materiais.

As informações sobre o material e a orientação para o descarte foram aplicadas de acordo com o padrão ISO 14021, estando de acordo com o que é recomendável para facilitar a reciclagem do material. 


\section{Apresentação dos dados das entrevistas}

O cookie foi um dos projetos que a Petersen \& Avila iniciou para reformular e fazer uma proposta nova para a Mãe Terra, sendo sua terceira versão da embalagem. A primeira, branca, veio de um fenômeno que eles observaram fora do Brasil, com embalagens muito limpas, minimalistas, com poucos elementos e muita área de branco.

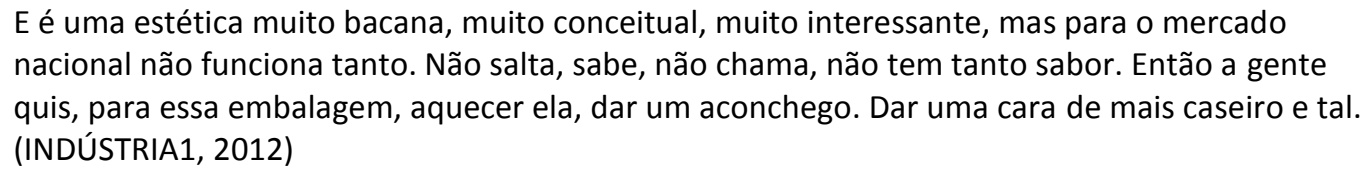

Ela tinha uma imagem de um cookie grande, vendido apenas em uma embalagem menor, de $35 \mathrm{~g}$, e a ideia era que a ilustração mostrasse as formigas trazendo o cookie para o consumo, tendo um cookie na frente.
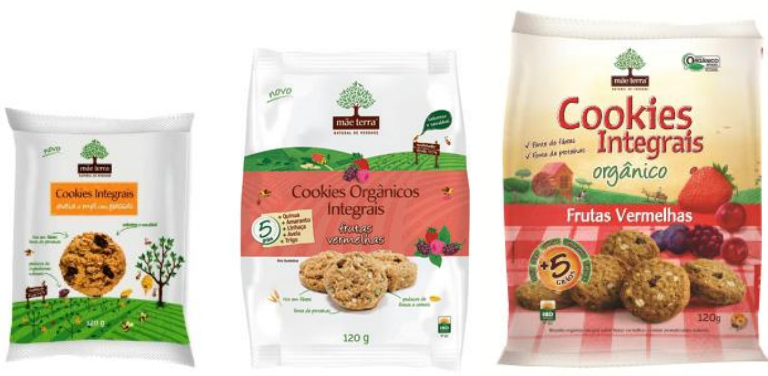

Figura 144 - Primeira, segunda e terceira fase da embalagem de cookies integrais da Mãe Terra. Fonte: Mãe Terra, 2012

Depois, quando eles desenvolveram a embalagem maior, houve a necessidade de mostrar que, na nova embalagem, havia mais produto. Para isso, foi desenvolvida uma nova embalagem da qual a formiga saiu, colocando os cookies soltos no horizonte, mudando a cor do sabor, na forma de uma tarja atrás, colorindo parte do horizonte. "[...]essa segunda fase do cookie foi o auge da crise na Dezign com Z. Eles não estavam acertando isso. Então o cookie foi um dos projetos que a gente entrou para reformular a embalagem e fazer uma proposta nova (DESIGNER1, 2012).

Na última versão, analisada nesta pesquisa, a estratégia de design foi optar por um estilo de ilustração diferente, aquarelada, onde a fazenda fica em segundo plano e uma cena de piquenique fica em primeiro.

Houve também uma mudança de enfoque. A ênfase na embalagem anterior era em "cookies orgânicos integrais" e, na nova embalagem, ficou "cookies integrais orgânicos", enfatizando mais o integral do que o orgânico. A linha de cookies foi estendida em 2013, porém não foi avaliada por esta pesquisa.

$\mathrm{Na}$ entrevista com os consumidores, quatro dos sete entrevistados já haviam comprado o cookie da Mãe Terra e um já havia visto, mas não comprou.

Eu já comprei o cookie da Mãe Terra, não me lembro se era de frutas vermelhas. [...] É uma marca que eu conheço, eu já falei que eu comprei outros produtos desta marca, é um produto orgânico, e acho que tem pouco sódio. (CA04, 2013)

Os principais motivos que influenciaram a compra dos cookies integrais Mãe Terra foram: parecer apetitoso e marca conhecida. 


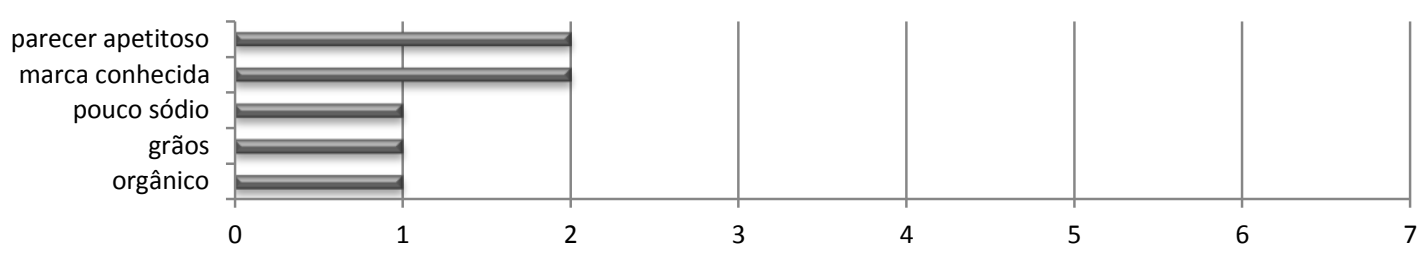

Gráfico 62 - Motivos da compra dos cookies integrais da Mãe Terra (unidade $=\mathrm{n} \times$ de consumidores)

Os principais aspectos positivos dos cookies da Mãe Terra declarados pelos consumidores foram: ser orgânico (sete consumidores), composição dos ingredientes (seis consumidores) e ter pouco sódio (dois consumidores). A marca, mencionada por oito consumidores, e o sabor, mencionado por quatro consumidores, aparecem logo em seguida.

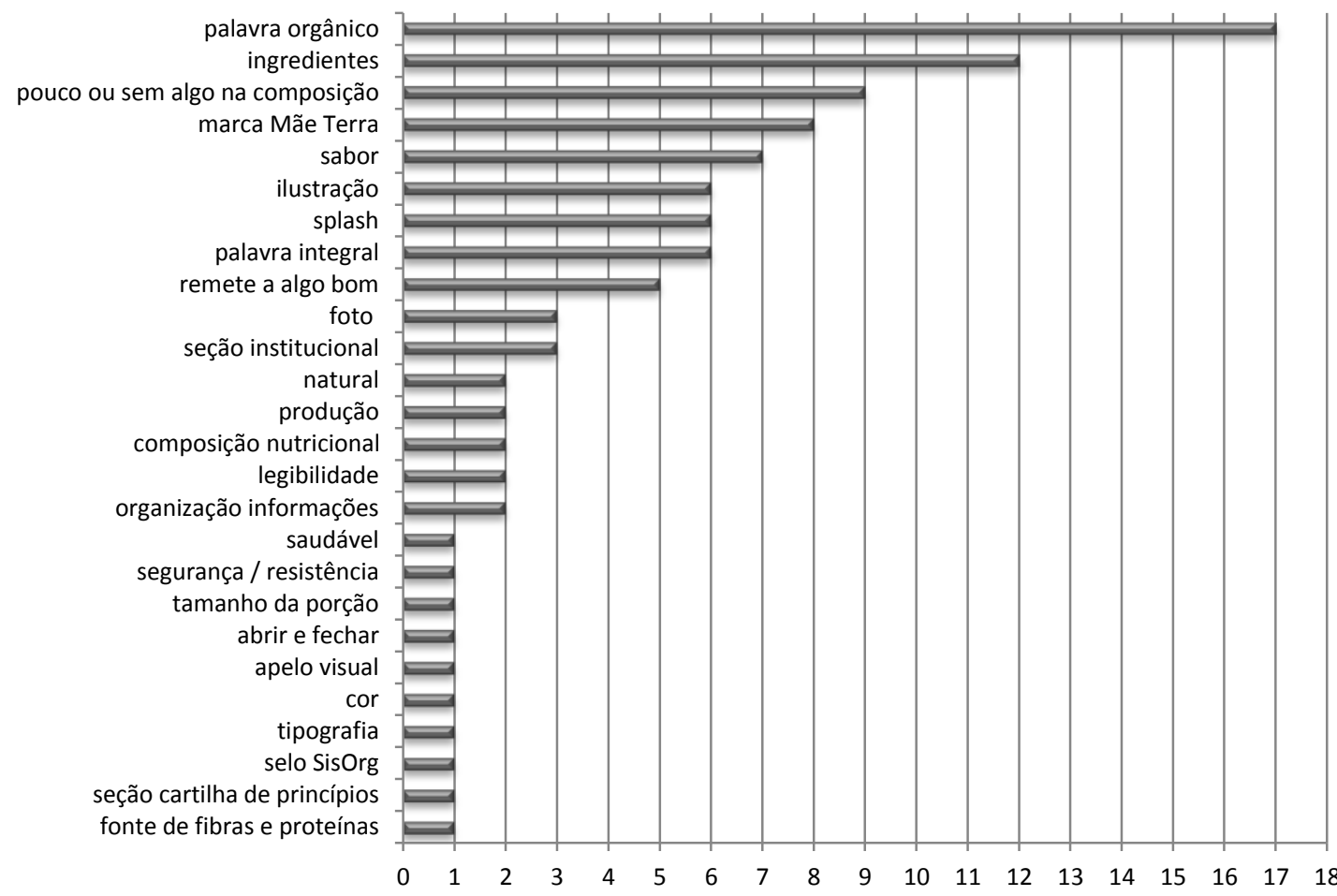

Gráfico 63 - Aspectos positivos dos cookies integrais Mãe Terra (unidade = no de menções)

As principais observações negativas dos cookies da Mãe Terra declaradas pelos consumidores foram: a organização das informações (três consumidores), o sabor de frutas vermelhas (dois consumidores) e a quantidade de cookies que vem na embalagem (dois consumidores), sendo que um consumidor achou muito para oferecer para a filha e outro achou pouco para ele e a esposa: "Uma embalagem que vem muito cookie, é preciso dividir, ou guardar, se minha filha tivesse que levar na escola, eu não daria uma embalagem dessa para ela levar na escola. Teria que fracionar" (CA04, 2013); "Para um consumo pequeno e rápido, ele é bom. Às vezes, para um consumo maior, o custo não daria certo. [...] Para mim, é uma quantidade boa, para mim, só para mim. Consumiria isso aqui em um minuto" (CC23, 2013).

A embalagem foi percebida por alguns consumidores como algo positivo.

A embalagem está tão bonita, está bem apresentada, está bem especificado que o produto é orgânico, aqui mostra os grãos que contém o biscoito, eu acho que essa embalagem está muito boa, bem explicativa, eu não tenho nada contra. (CB14, 2013)

Primeiro de tudo, porque é uma coisa importante que eu acho que a embalagem tem que ter. Ela te dá vontade de comprar. Eu acho que ela é uma embalagem que ela me faria olhar com algum cuidado. (CB20, 2013) 
Porém, alguns consumidores declaram que a embalagem não chama muito a atenção. "Eu não gostei da embalagem não. [...] Posso até ter visto no supermercado e ter passado batido. Não chama a atenção" (CA26, 2013); "A apresentação, não é aquela apresentação que te obriga tecnicamente a comprar, ela não é aquela coisa que te chama, mas ela te impressiona" (CC23, 2013).

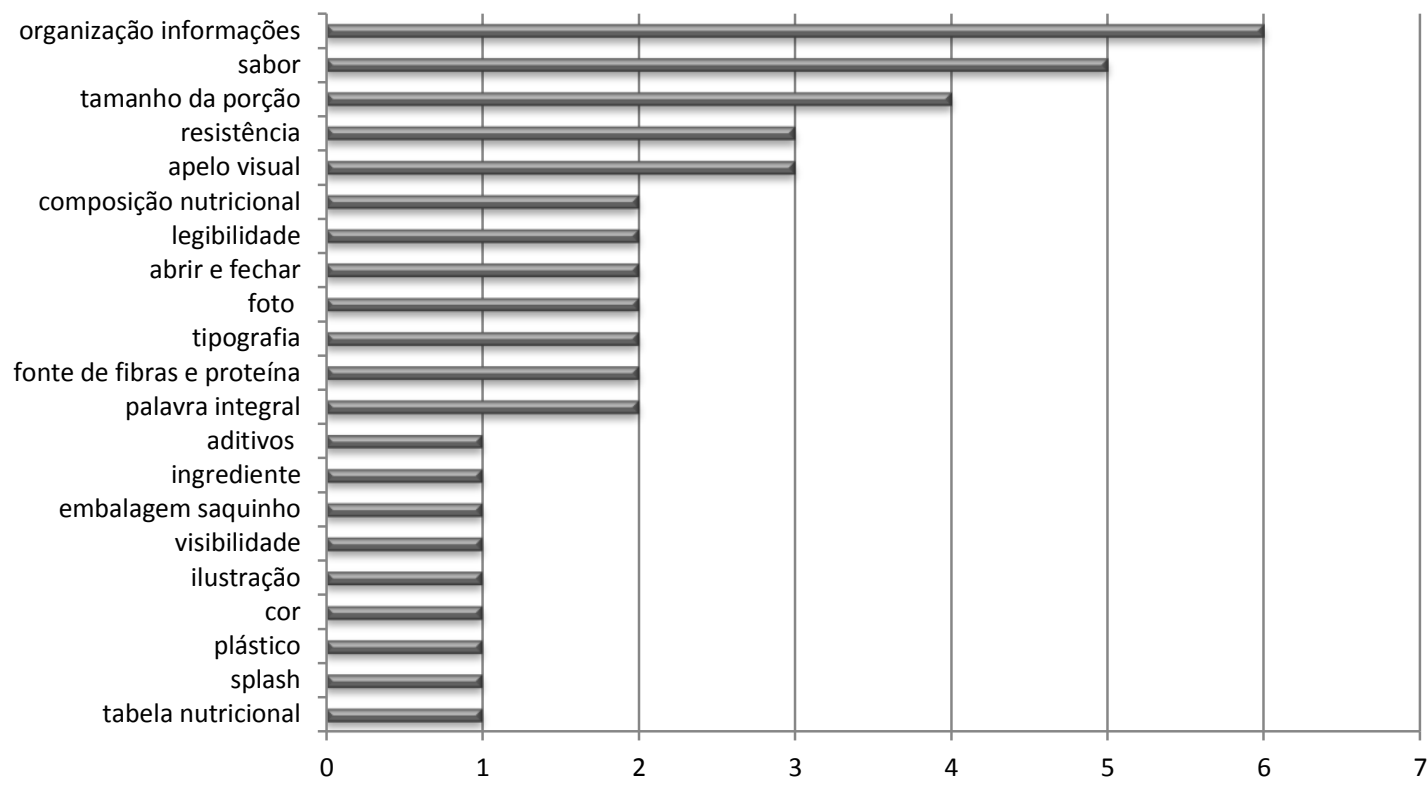

Gráfico 64 - Aspectos negativos dos cookies integrais Mãe Terra (unidade = n⿳o de menções)

O sabor de frutas vermelhas foi considerado como algo negativo por dois consumidores, influenciando na percepção do produto como algo saudável.

Isso para mim, que não aprecio muito, os cookies de frutas vermelhas, eu gosto mais de castanhas, aveia, quinua, sabe? Não é que seja alguma coisa negativa, mas eu acho que as frutas vermelhas, eu não compraria, talvez da mesma marca, mas que tivesse castanha. (CB14, 2013)

Frutas vermelhas. Eu acho que frutas vermelhas sempre me dá [sic] a impressão de que vai ter alguma coisa artificial. (CB24, 2013)

\section{Ilustração}

A ilustração foi desenvolvida pelo mesmo ilustrador que fez a linha infantil da Mãe Terra. 0 estilo de ilustração das primeiras embalagens foi quebrado, trazendo a opção aquarelada, mas mantendo a identidade da Mãe Terra com o horizonte da fazenda.

A gente gosta de trabalhar com essas texturas que imitam a aquarela e um produto mais caseiro. Obviamente, esse produto é industrializado, mas ele não deixa de ter uma característica de caseiro, porque ele é feito sem aditivos artificiais etc. Então a gente tenta trazer isso com esses artifícios mais estéticos. [...] A gente sempre gosta de contar uma história na embalagem. [...] Então a gente também achou interessante trazer, para cá, um pouco de lúdico. (INDÚSTRIA1, 2012)

A ilustração foi percebida pelos consumidores de forma positiva.

Aqui te dá uma simplicidade, né, você vê que é uma coisa da terra mesmo. Onde tem fazenda, onde tem o pessoal que trabalha... quem planta e quem colhe é quem produz. E o repasse é isso, né. Ele faz de toda a cadeia, né. Ele produz e vende. E a exposição está boa. (CC23, 2013)

A casa, característica da antiga ilustração da linha de ingredientes, na embalagem do cookie se transformou na imagem de um moinho de pedra, por sugestão da Mãe Terra. Essa mudança aconteceu para os produtos produzidos por eles com farinha de trigo integral em um moinho de pedra. 
Designer1 acrescentou que, após o lançamento dos cookies, a Mãe Terra recebeu reclamações da imagem da carroça na ilustração, que será modificada nas próximas embalagens.

[...] era uma ideia lúdica de que o grão estava chegando para o moinho, através de um carroceiro, com seu cavalo. Nessa segunda embalagem que a gente está fazendo agora, a gente teve que tirar a figura da carroça porque eles receberam muitos e-mails dos consumidores sobre a exploração do trabalho animal. (DESIGNER1, 2012)

Essa declaração mostra a importância de se conhecer a cultura dos consumidores para poder melhor desenvolver imagens com significados positivos. Para um perfil de consumidor consciente, é preciso uma postura atenta no projeto por parte dos profissionais envolvidos.

\section{Cor}

Durante a produção da embalagem, Designer1 contou que foram feitos muitos testes de cor, durando dois meses. No projeto inicial, a cor do céu era azul mais claro, com algumas nuvens brancas, para passar a ideia do externo e do piquenique. Após pesquisas feitas internamente, eles perceberam que o azul remetia ao produto light e ficava mais "frio". Então definiram, junto com a empresa, usar a cor creme no fundo, mais quente, com a luz branca da marca.

A diferenciação de sabor por cor, que era bastante forte na versão da embalagem anterior, foi resgatada no xadrez da toalha. "A gente tinha a necessidade de ter diferenciação de cor bastante forte nas embalagens. A gente trouxe o xadrezinho da toalha como um elemento que trouxesse a cor de diferenciação" (DESIGNER1, 2012).

As cores, em tons pastéis, foram percebidas também pelos consumidores como algo positivo. "As cores, essa cor pastel, ela parece menos artificial do que uma cor talvez muito mais brilhante" (CB24, 2013).

\section{Tipografia}

A tipografia usada na embalagem também foi mudada em relação às embalagens de ingredientes. Segundo Designer1 (2012), o nome do produto ficou mais "gordinho" e "craqueladinho", trazendo a crocância do cookie na própria fonte, o que ajudou a chamar a atenção dos consumidores. "Essa palavra 'orgânico' já chama a atenção, integrais também" (C14, 2013).

Eu acho que poderia dar mais ênfase para os grãos do que para o integral, por exemplo. [...] 0 cookie eu acho que poderia ter mais ênfase que é cookie. Porque olhando rapidamente, olhando no supermercado, com um monte de embalagem, talvez eu nem visse que era cookie. (CA26, 2013)

\section{Splash “5 grãos”}

O splash " 5 grãos", com as informações do que contém, foi percebido pelos consumidores como algo positivo e algo a ser destacado. "Eu acho interessante o que eles fazem ao descrever os grãos. Por exemplo, que tem aqui, eles deixam bem claro que é aveia, trigo, quinua, amaranto e linhaça. Então isso é bacana como informação já bem na frente da embalagem" (CB24, 2013); “Aqui está bem detalhado o que está tendo, destacado também, porque ele sai da parte fosca e entra na parte mais brilhante, então destaca o que realmente tem" (CC23, 2013). 


\section{Fotografia}

Para definir a quantidade de cookies na embalagem e a forma de arranjo, foram feitos vários testes fotográficos, produzidos pela Petersen \& Avila, incluindo o tratamento digital, onde foram acrescentados alguns ingredientes nos cookies. Esse tratamento foi necessário para destacar esses ingredientes, principalmente por ser um produto integral. Depois que é feita a massa do cookie, eles ficam misturados e somem.

A manipulação é uma prática comum no design de embalagens, porém deve ser a mínima possível e não deve maquiar o produto a ponto de ficar irreconhecível após abrir a embalagem. Para destacar os ingredientes do produto, existem outros recursos gráficos, como colocar a informação fora da imagem, sem manipular a imagem do produto. Um dos consumidores declarou que a imagem poderia ser um pouco maior. "Talvez o cookie ser um pouco maior, para a gente ver como é que vem, os ingredientes, se aumentasse a foto do cookie" (CA04, 2013).

\section{Organização das informações}

Um consumidor declarou que a embalagem tem muita informação: "Talvez uma poluição visual. Embora eu tenha gostado do desenho e tudo, eu acho que ficou um pouco demais. Tem muitos desenhos e o cookie mesmo, ele está lá meio que em segundo plano" (CB24, 2013).

As informações institucionais sobre a Mãe Terra foram percebidas de forma positiva pelos consumidores. "Esse tipo de apresentação é boa, como eles desenvolvem os produtos" (CC23, 2013).

Um dos consumidores, ao comparar as informações do produto que apareciam no painel frontal da embalagem com as informações da tabela nutricional, no painel traseiro, mudou a sua opinião em relação ao produto ser saudável.

A informação quanto às fibras que tem, sobre a quinua, amaranto, a linhaça, o trigo, que mais? 0 valor energético que é assustador, sério, três unidades e meia são 155 calorias.

[...] porque normalmente você não vê nessas marcas que não são utilizados nem aromatizantes, conservantes, açúcar branco, o nível de sódio. (CB05, 2013)

Se eu tivesse lido aqui atrás, talvez eu não tivesse optado. Muita gordura, principalmente a saturada. (CA26, 2013)

A tabela nutricional também foi considerada pequena, mas legível. "Eu acho que a informação nutricional, ela está pequena, mas está bem visível. Ela não é aquela que você fica procurando para achar onde é que está" (CC23, 2013).

Porém, um consumidor sentiu dificuldade em ler as informações do painel traseiro. "Algumas letrinhas poderiam ser maiores, um pouquinho. [...] Aqui, como desenvolvemos o produto. Como foi desenvolvido o produto. Acho que todas, viu, todas da parte informativa para o consumidor" (CC11, 2013). 


\section{Matriz semântica dos cookies integrais Mãe Terra}

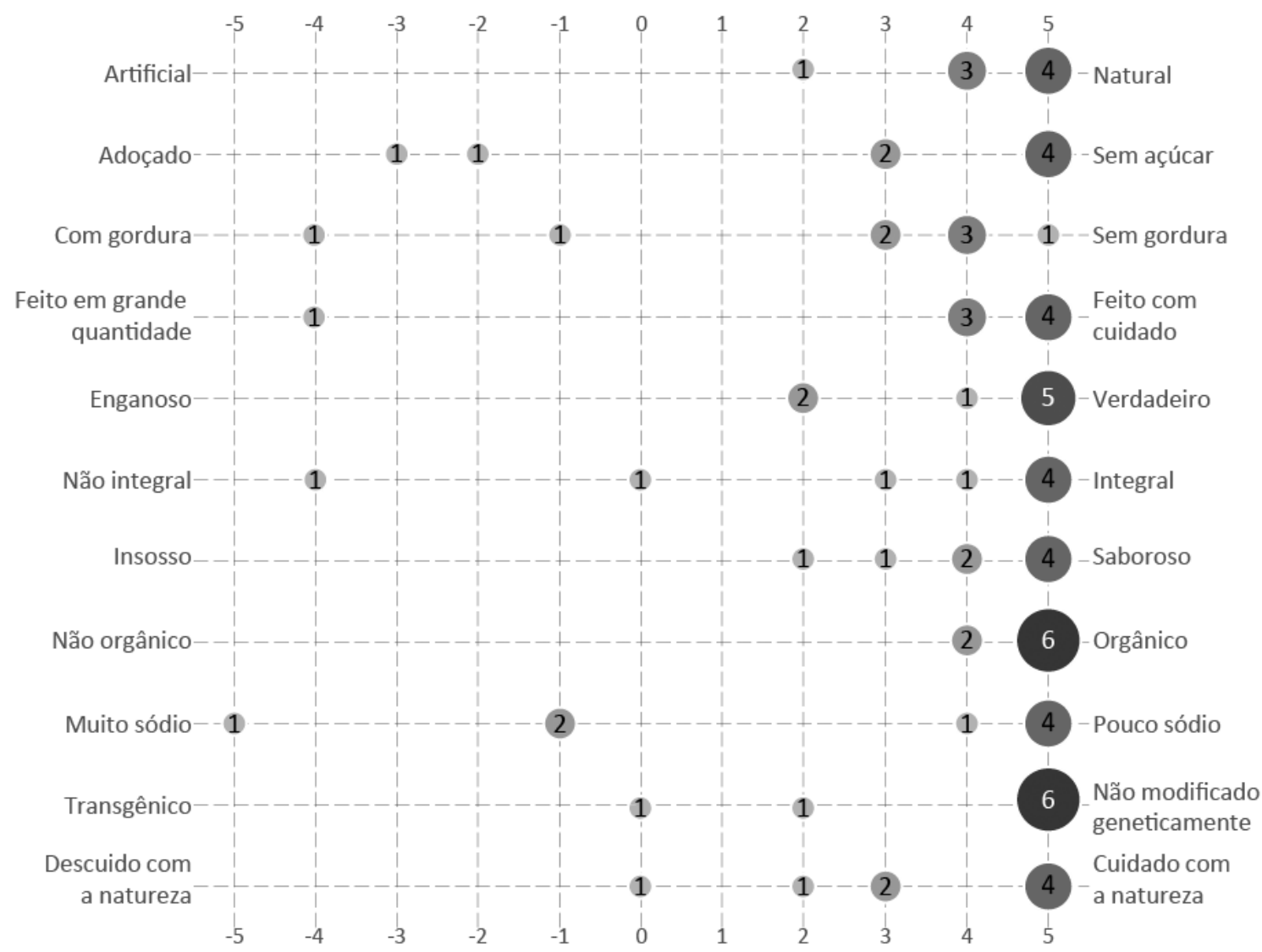

Gráfico 65 - Matriz semântica dos cookies Mãe Terra

Observa-se na matriz semântica, preenchida no final da entrevista, um predomínio de respostas mais positivas do produto.

Mesmo com a informação em destaque de integral, no painel frontal, alguns consumidores não consideraram que o produto era integral, talvez pelo fato de a farinha de trigo aparecer em segundo lugar na lista de ingredientes. ${ }^{23}$

Os espectros de informações "feito com cuidado" e "feito em grande quantidade", como no caso do Caseirito, estão mais próximos do positivo.

As respostas da informação dos transgênicos aqui também tenderam para o não modificado geneticamente, talvez por haver esta informação no box "Como desenvolvemos nossos produtos".

A partir dos dados apresentados, observa-se que a embalagem de cookies integrais Mãe Terra passa a informação de que é um alimento mais saudável, principalmente baseado na composição de ingredientes do produto e informações em destaque, como no splash " 5 grãos". Porém, o excesso de informações da embalagem faz com que o fato de o produto ser orgânico fique em segundo plano.

${ }^{23} \mathrm{~A}$ ordem de ingredientes na embalagem segue a ordem de quantidade presente do produto, de a cordo com a Resolução ANVISA RDC no 259 de 2002. 


\subsubsection{Barra de cereais do Grupo 3 de pronto consumo}

No caso da barra de cereais, a marca mais separada como saudável foi a Native, por todos os oito consumidores, seguida pela Mãe Terra e Bio2, por sete consumidores.

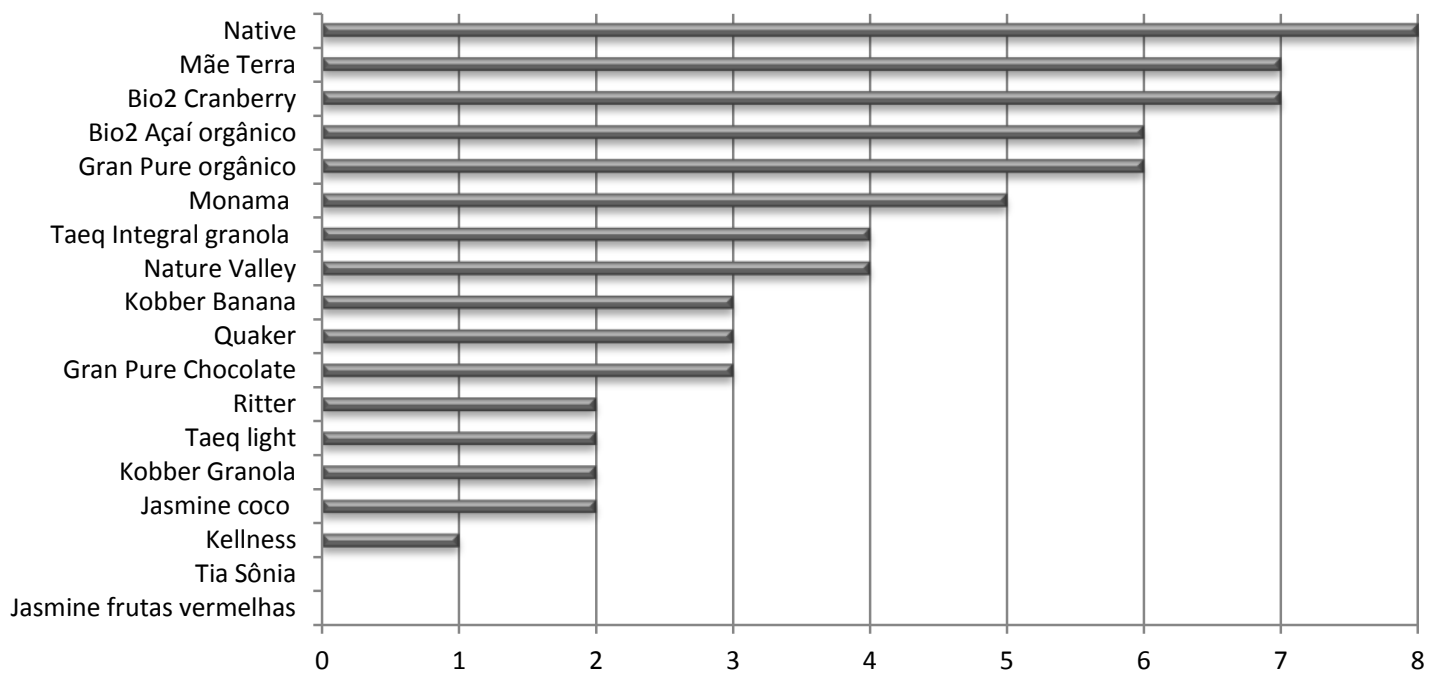

Gráfico 66 - Marcas de barra de cereais separadas como mais saudável (unidade = no de consumidores)

Os principais critérios para a separação foram: a marca (cinco consumidores); a composição dos ingredientes (seis consumidores); e ser orgânico (seis consumidores). A marca de barra de cereais mais relacionada com algo saudável foi a Mãe Terra, por quatro consumidores.

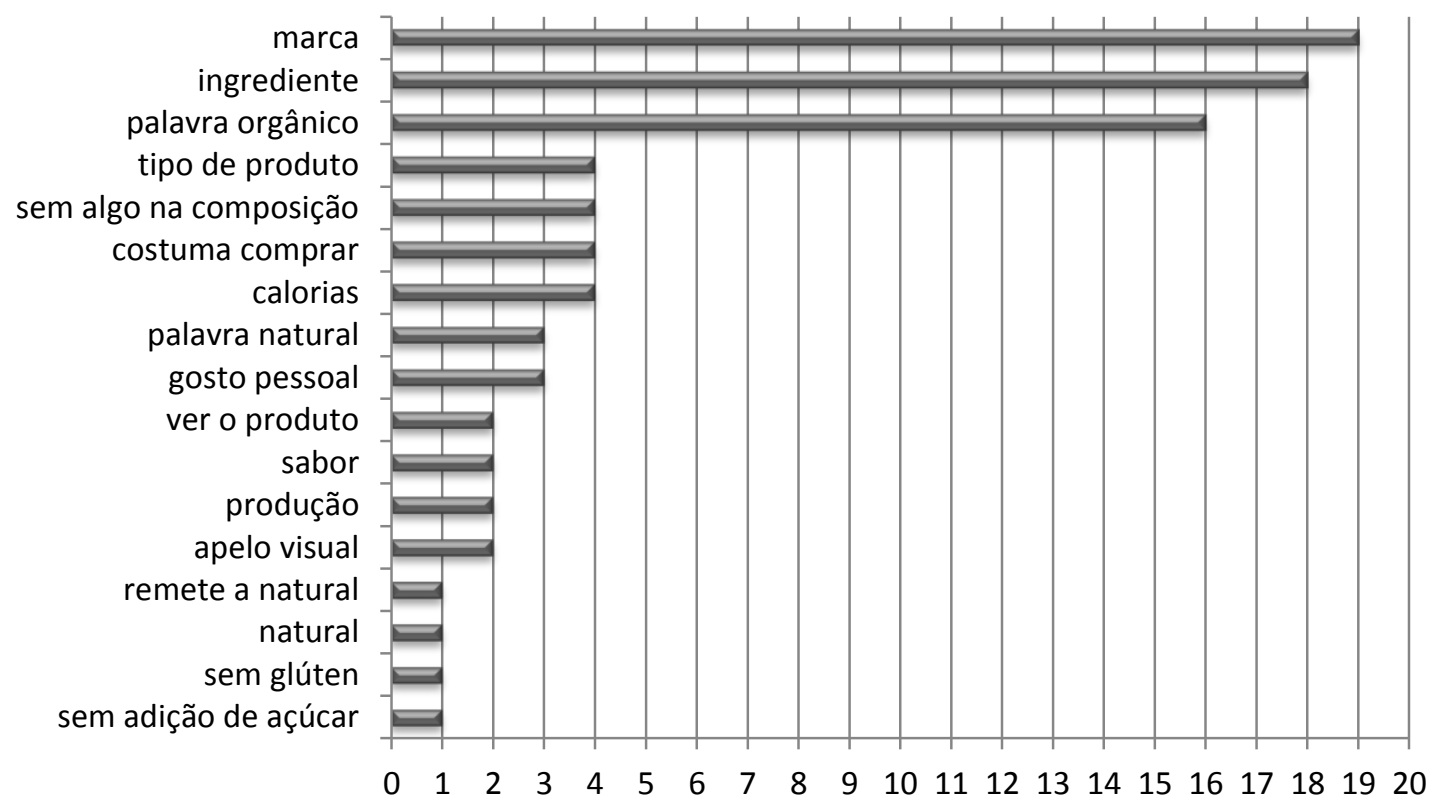

Gráfico 67 - Critérios para a separação de barra de cereais como mais saudável. (unidade = no de menções)

O principal critério para separar como menos saudável foi a composição do produto pelos ingredientes, por sete consumidores. A marca desconhecida foi mencionada por quatro consumidores e os aditivos químicos foram mencionados por três consumidores. 


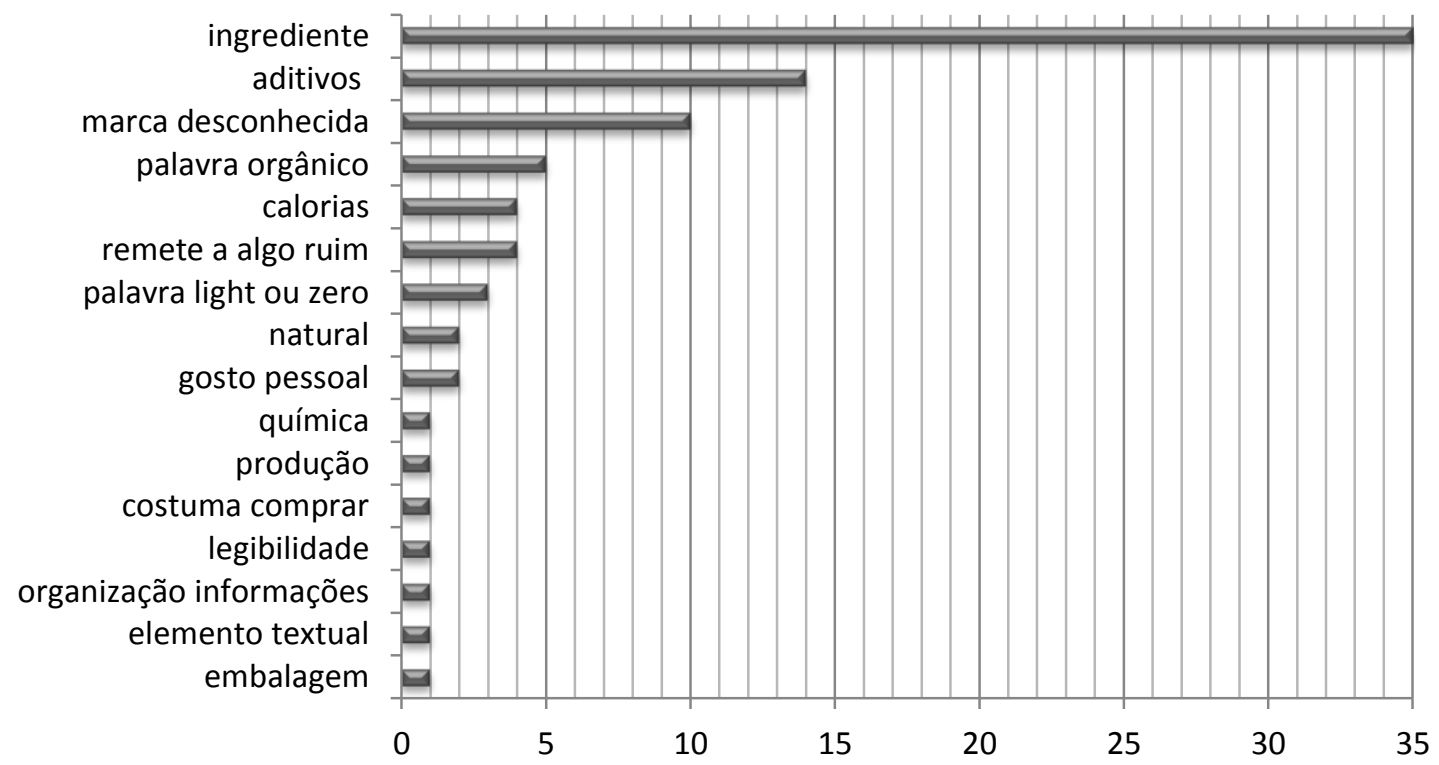

Gráfico 68 - Critérios para a separação de barra de cereais como menos saudável (unidade = nº de menções)

A composição da barra de cereais foi o principal critério para separar, porém um dos consumidores declarou que normalmente não olha a embalagem com tanta atenção para essa informação.

Nossa, eu nunca tinha pensado nisso, eu como muita barrinha de cereal no trabalho e aí você pega a primeira que aparece no supermercado [...] e você acha que está comendo alguma coisa saudável ao invés de estar comendo um biscoito, um pacote de qualquer tranqueira, e não é bem assim. (CB05, 2013)

O principal critério para separar as barras de cereais como saudáveis foi a marca, principalmente quando já era conhecida. "Separei estas porque são marcas que eu conheço, que eu compro, eu acho que são barrinhas saborosas, e acho que são saudáveis" (CA04, 2013).

As marcas de barra de cereais separadas por todos os oito consumidores como orgânicas foram a Monama, Gran Pure e Native.

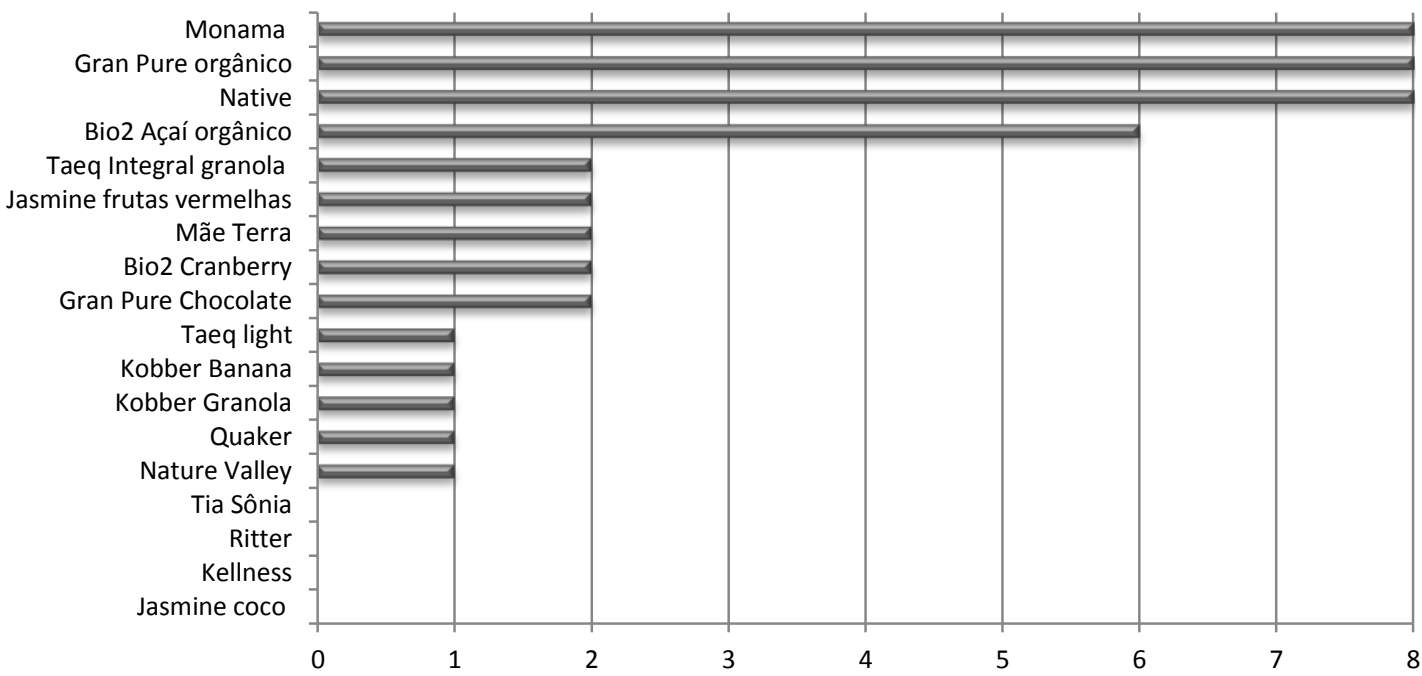

Gráfico 69 - Marcas de barra de cereais separadas como orgânicas (unidade $=\mathrm{n}^{0}$ de consumidores)

Para separar como orgânico, a principal informação textual olhada foi a palavra "orgânico", por todos os oito consumidores. A marca e a composição de ingredientes foram o principal critério para dois consumidores. 


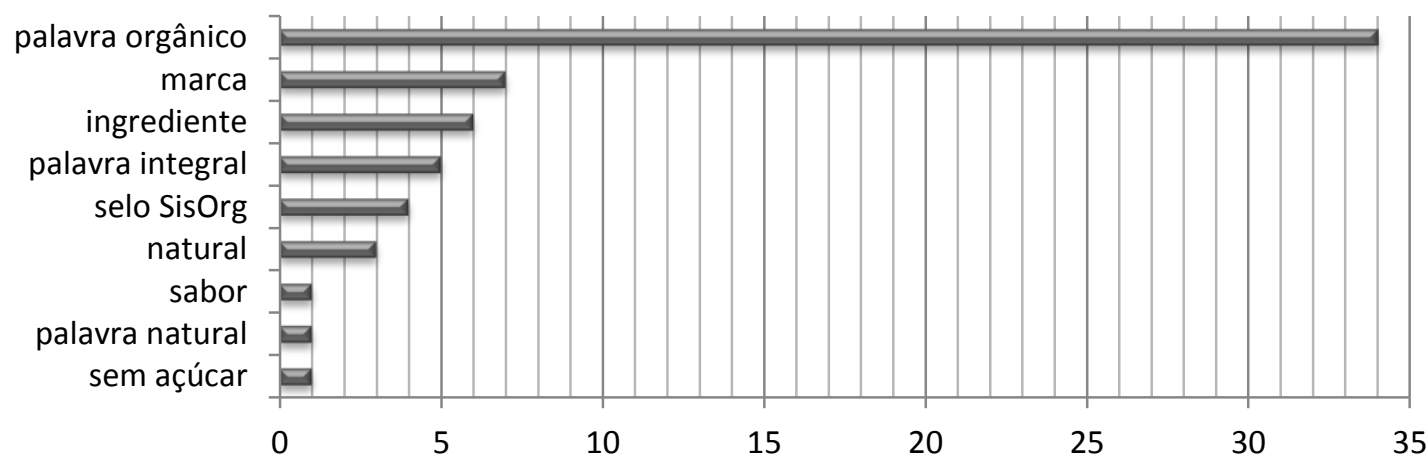

Gráfico 70 - Critérios para separação de barra de cereais como orgânicas (unidade = no de menções)

O principal critério para separar a barra de cereal como não orgânica foi a falta de alguma informação textual que a identificasse como orgânica, para cinco consumidores. Em seguida, o segundo critério foi a composição dos ingredientes do produto, para quatro consumidores.

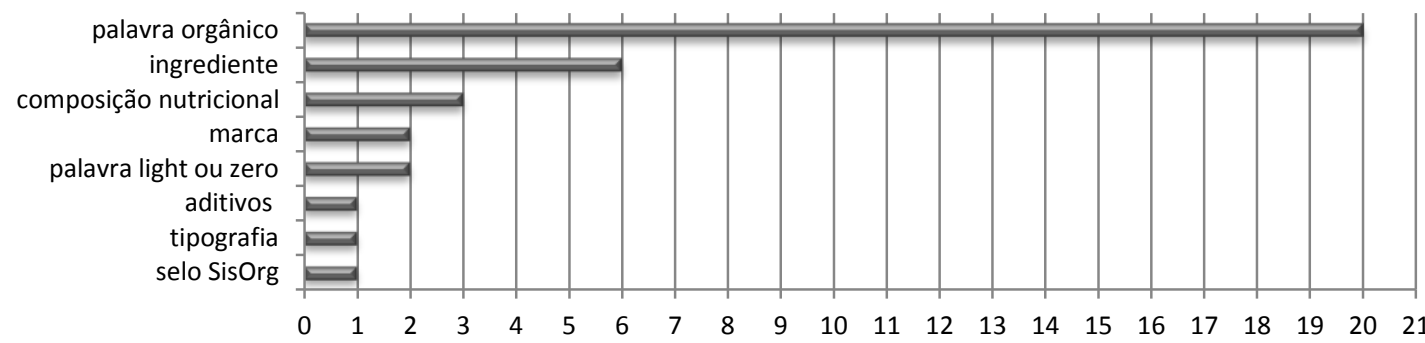

Figura 137 - Critérios para separação de barra de cereais como não orgânica. (unidade = no de menções)

Com base nos dados apresentados, a marca e a composição de ingredientes têm grande influência, nessa categoria, na percepção de que se trata de um alimento saudável.

Para identificar como alimento orgânico, a informação textual e o selo SisOrg foram suficientes, porém alguns ainda fazem confusão, dependendo da composição de ingredientes.

\title{
4.4.7.1. Barra de cereais Monama
}

A barra de cereais Monama é um desdobramento do design da embalagem da granola. A seguir, serão analisadas as características específicas desse produto e diferenças. A embalagem em tamanho real pode ser conferida no Anexo B.

\section{Análise do painel frontal da barra de cereais Monama}

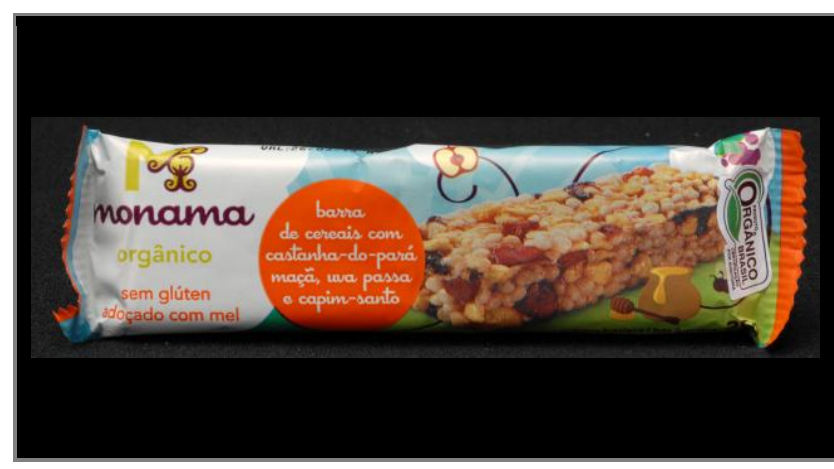

\author{
Painel frontal \\ Informações obrigatórias \\ Marca; Palavra "orgânico"; Denominação de venda; \\ Selo SisOrg; Quantidade. \\ Informações não obrigatórias \\ Frases "sem glúten" e "adoçado com mel"; \\ llustração de maçã, uva e pote de mel; \\ Fundo com grafismos na cor azul e verde; \\ Imagem da granola.
}

Figura 138 - Painel frontal da embalagem de barra de cereais Monama 
Segundo o sentido de leitura, de cima para baixo, da esquerda para a direita, a primeira informação do painel frontal é a marca Monama, seguida pelo círculo laranja com a informação do sabor da barrinha.

A marca é aplicada sobre o fundo branco, dando um bom contraste de cor e sendo fácil de visualizar. Logo abaixo, a palavra "orgânico" em verde da cor de pistache tem pouco contraste com o fundo branco. As informações em laranja "sem glúten" e "adoçado com mel" têm mais destaque que a informação de "orgânico".

O selo SisOrg foi aplicado sobre a embalagem com uma etiqueta adesiva no lado direito da embalagem, sobre a imagem da granola e com pouco contraste de cor com o fundo.

A foto da barra de cereais tem pouco de definição e, por isso, não parece muito apetitosa. A ilustração, com os grafismos iguais aos da granola, fica em segundo plano nessa embalagem e indica os ingredientes usados na barra de cereais, continuando infantil.

A tipografia usada é a mesma da granola, cujos tipos manuscritos são usados para as informações em destaque.

Os elementos gráficos estão em equilíbrio. O grande centro focal é o círculo laranja com os ingredientes, um pouco mais à esquerda, e o equilíbrio visual é reestabelecido com a imagem da barra de granola.

\section{Análise do painel traseiro da barra de cereais Monama}

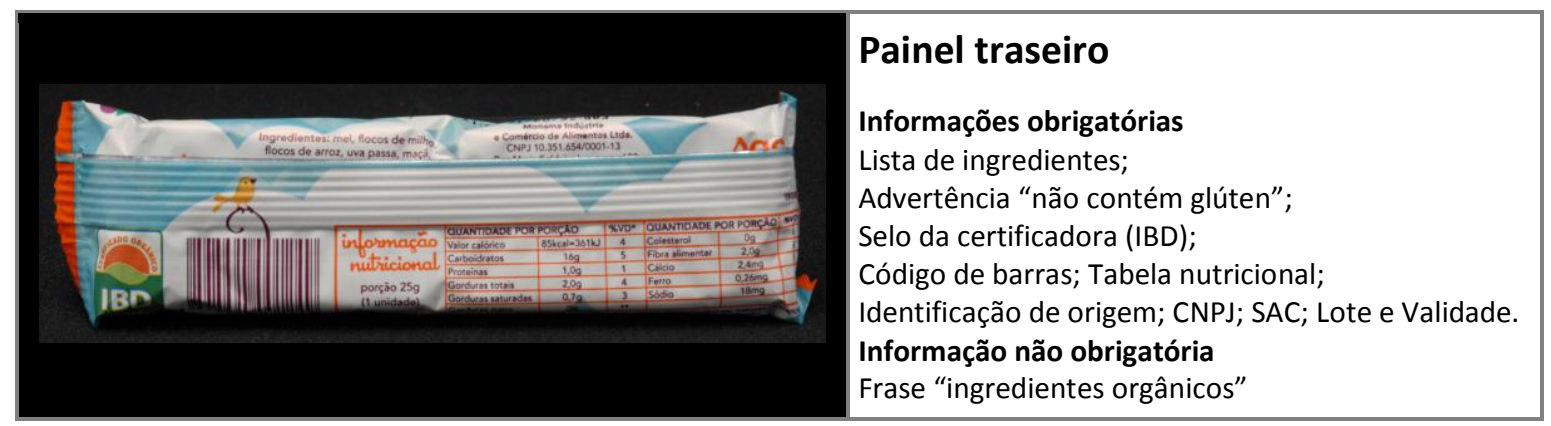

Figura 139 - Painel traseiro da embalagem de barra de cereais Monama

Segundo o sentido de leitura, de cima para baixo, da esquerda para a direita, a primeira informação do painel traseiro é o passarinho acima do código de barras, apenas ilustrativo, seguido pela tabela nutricional.

O selo de certificação IBD está localizado no canto inferior esquerdo de maior tensão visual da embalagem.

Muitas informações estão cobertas pela emenda da embalagem, na área de selagem, dificultando a leitura. Abaixo dela, estão a lista de ingredientes e as formas de contato da empresa, mostrando que deram mais ênfase à tabela nutricional.

\section{Hierarquia de leitura}

A hierarquia de leitura da embalagem de barra de cereais da Monama, demonstrada abaixo, mostra que o círculo laranja, com a descrição do produto, é a primeira informação a ser lida, por causa da cor. A marca Monama, por sua localização e por estar aplicada sobre o fundo branco, é a segunda informação a ser lida, porém suas cores não contrastam com o fundo branco. 
A palavra "orgânico", abaixo da marca, tem pouco contraste de cor, e o selo SisOrg, aplicado sobre a foto e ilustração, também não se destaca.

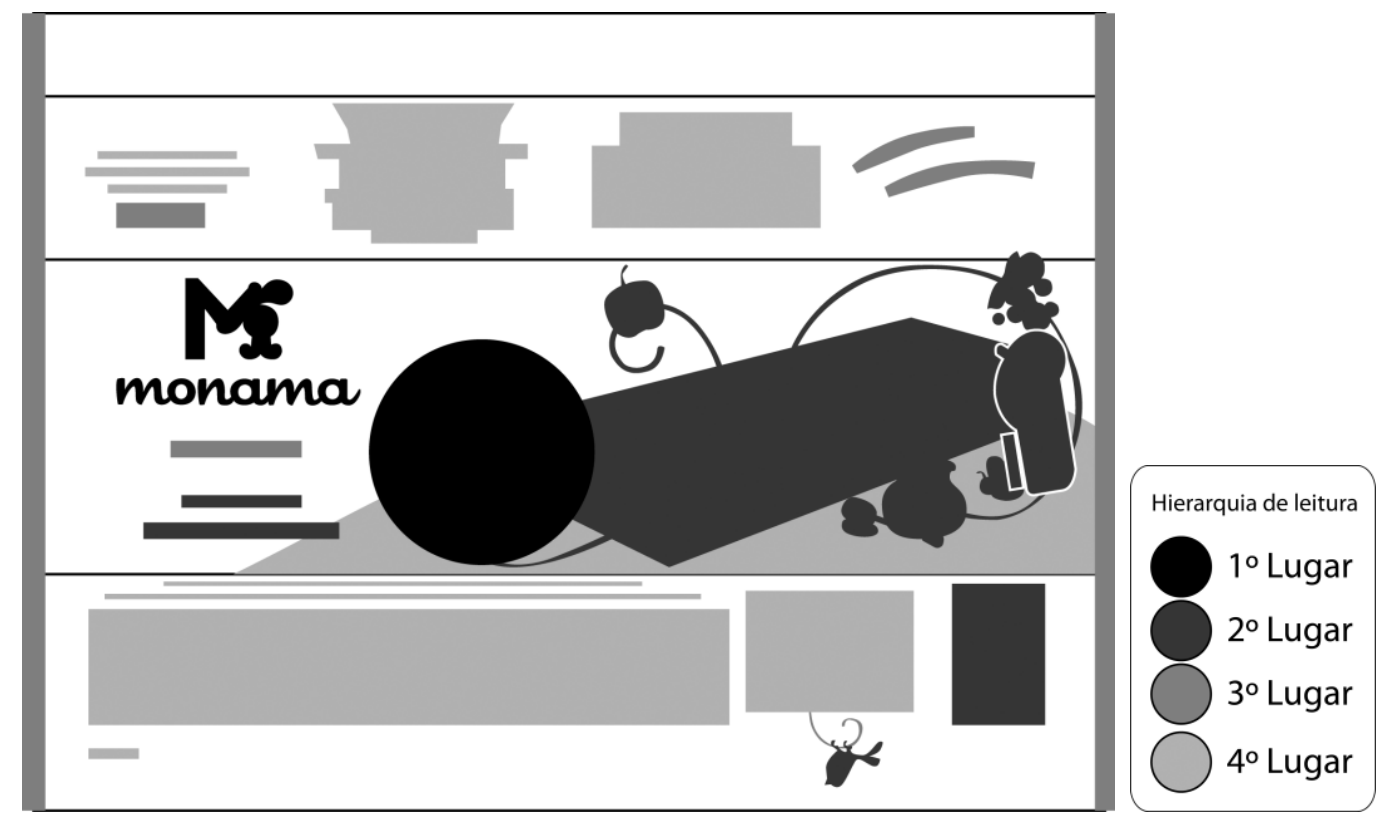

Figura 146 - Hierarquia de leitura da barra de cereais Monama

\section{Questões técnicas da barra de cereais Monama}

A embalagem da barra de cereais foi produzida pela Cordel Embalagens, conforme informação impressa na embalagem. Localizada em Jundiaí, produz embalagens laminadas e entrega na indústria em bobinas para o seu envase. O plástico da embalagem é o Polipropileno Biorientado (BOPP) laminado com alumínio, que garante a barreira necessária para o produto.

A impressão em flexografia tem boa qualidade para as informações em cores chapadas e perde na fotografia da barra de cereal.

Por causa da forma de fechamento da embalagem, na emenda no painel traseiro, o texto fica desalinhado, com informações ocultas, contribuindo para a falta de legibilidade.

\section{Aspectos ambientais da barra de cereais Monama}

A embalagem é produzida com um material de reciclagem complexo e de pouco valor na cadeia de reciclagem do Brasil, por ser um compósito de materiais (BOPP + metal). Em nenhum lugar na embalagem, é identificado qual é o material, o que dificulta ainda mais a sua reciclagem e reaproveitamento.

\section{Apresentação dos dados das entrevistas}

A informação de que as barrinhas não contêm glúten e são adoçadas com mel receberam destaque, por sugestão da A10.

Foi uma informação que a gente achou bacana trazer aqui para esse espaço, que teoricamente era um espaço limpo e reservado para marca, a gente achou bacana colocar em todas, porque é um produto que você leva para comer e é para comer em uma ocasião mais rápida do que a granola. [...] esse tipo de informação, de uma maneira mais rápida, é importante para o consumidor saber. [...] E também porque a gente acredita que é um diferencial das outras do mercado. Você não encontra toda hora um lanchinho rápido, sem glúten, e que não tenha açúcar. (DESIGNER3, 2012) 
Segundo Designer3 (2012), da granola para as barrinhas já há uma diferença de cor: o tom de azul mudou, ficando mais azulado e tirando um pouco do magenta, ficando "mais chamativo, mais cor de céu". Essa mudança ocorreu para ter uma diferenciação entre um produto e outro, mas mantendo a mesma identidade. Os círculos com os ingredientes "ganharam cores diferentes para a diferenciação de sabor".

A barrinha é vendida por unidade, em embalagens com três barrinhas e em uma caixa display com doze barrinhas. As caixas display foram projetadas para serem colocadas no balcão de estabelecimentos tipo drogarias, academias e padarias. Já as caixas de três unidades são vendidas nos supermercados.

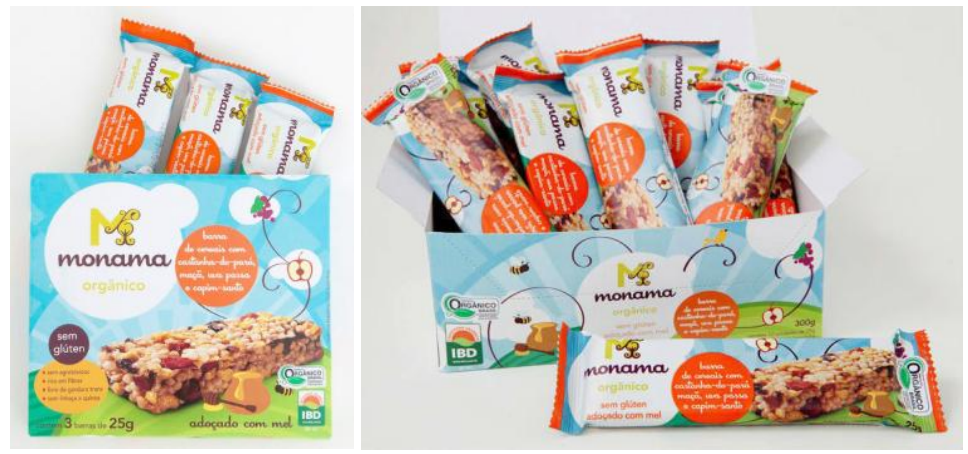

Figura 140 - Embalagens para comercialização com três barrinhas e caixa display com doze barrinhas. Fonte: Monama, 2012

Apenas um dos sete entrevistados já havia visto a barra de cereais da Monama no supermercado, mas não comprou por não conhecer a marca.

A principal categoria positiva da barra de cereais Monama, declarada pelos consumidores, foi a composição dos ingredientes (sete consumidores). Em seguida, por ser orgânica (cinco consumidores).

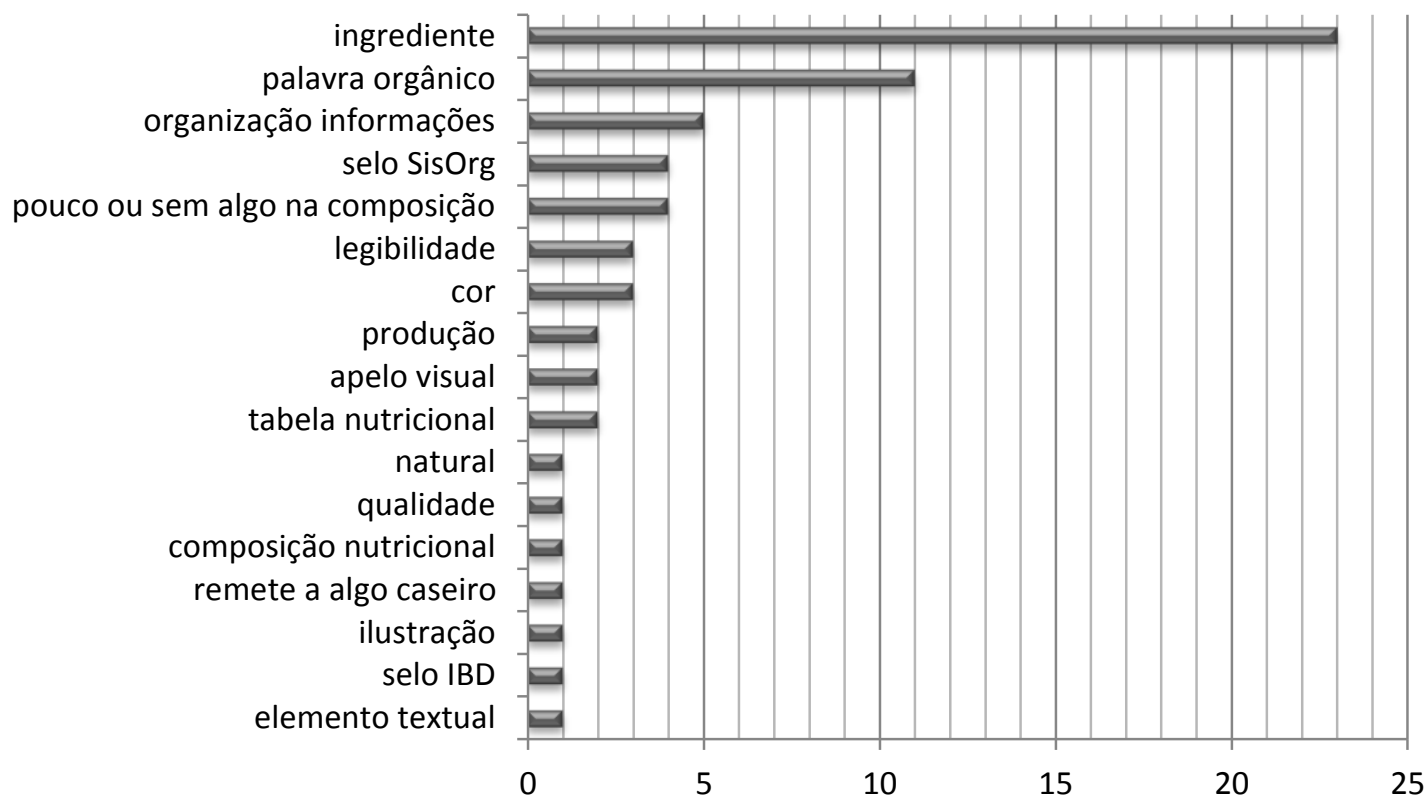

Gráfico 71 - Aspectos positivos da barra de cereais Monama (unidade = no de menções)

Os principais aspectos negativos da barra de cereais Monama foram a composição de ingredientes (dois consumidores), a marca desconhecida (cinco consumidores) e porque não remete a algo saudável (quatro consumidores). 


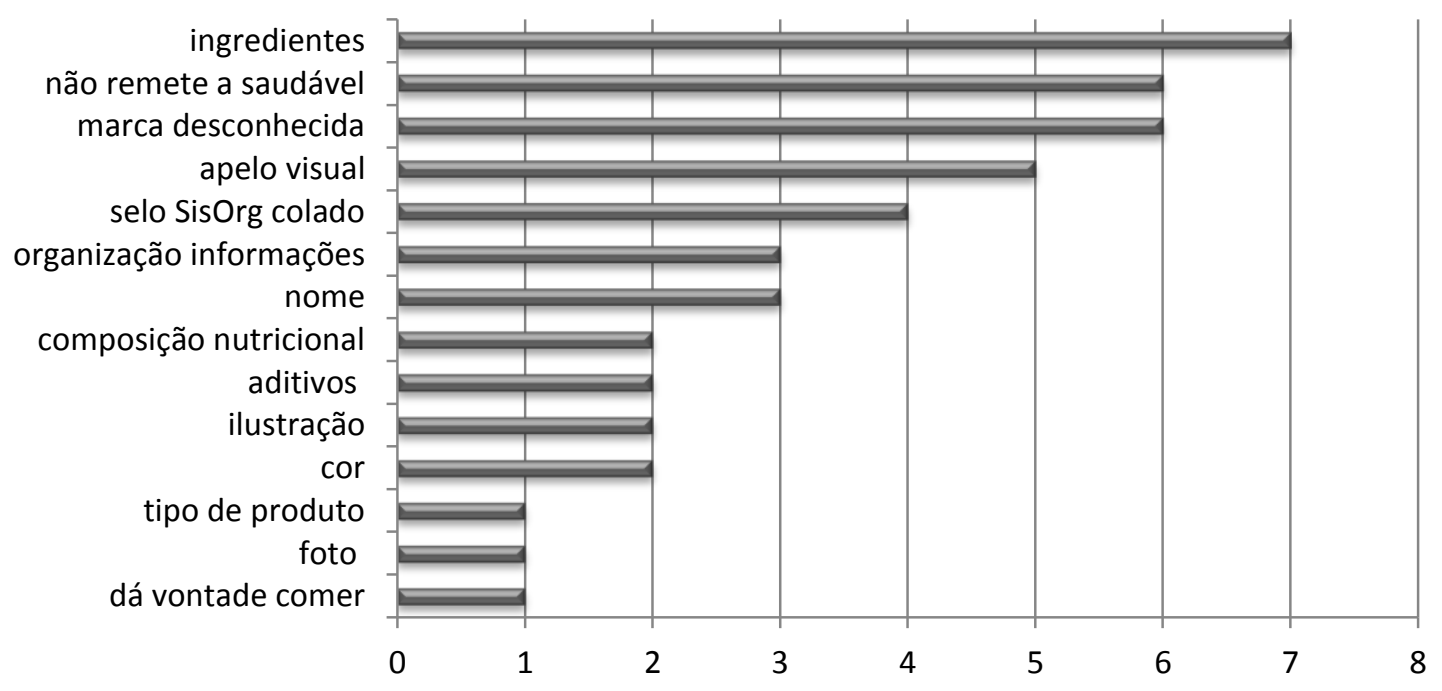

Gráfico 72 - Aspectos negativos da barra de cereais Monama (unidade = no de menções)

A composição da barra de cereal com capim-santo e o fato de ser adoçada com mel chamaram a atenção dos consumidores de forma positiva.

Bom, é uma embalagem de um produto que é orgânico, os ingredientes são normais, mas tem capim santo, eu nunca vi uma barrinha com esse ingrediente. Não tem glúten e é adoçado com mel, mas sempre que eu vejo a embalagem eu vou ver se não tem mais açúcar, às vezes é adoçado com mel, mas às vezes tem mel e tem outra coisa, e eu sempre dou uma olhada. Este aqui acho que só tem mel, parece que não tem açúcar, acho que é saudável. (CA04, 2013)

Porém, em alguns casos, alguns ingredientes já eram percebidos como algo negativo, pelo gosto pessoal. "Bom, uva passa, eu não gosto, seria uma barrinha que eu não comeria" (CA04, 2013); "Ele é adoçado com mel, para mim ele me traz uma ideia de essência de mel, não mel de verdade" (CB24, 2013).

A organização das informações foi percebida pelos consumidores como algo positivo.

Primeiro, porque eu achei a embalagem bem bonita, assim, não muito colorida, mas deu a atenção para coisas que eu gosto. Eu gosto de castanha-do-pará, uva e tal, mas principalmente o adoçado com mel. (CA26, 2013)

A ilustração da embalagem foi percebida por um consumidor como de um produto caseiro. "Bom, primeiro essa embalagem, o desenho dela, me remete alguma coisa bem caseira, esses desenhos aqui" (CB24, 2013). Alguns consumidores, porém, consideraram a embalagem não atrativa: "A embalagem não está muito atraente, aquela coisa que chama a sua atenção como uma barrinha boa de comer. Não. Acho que ela não está chamando muito a atenção" (CC11, 2013).

O selo SisOrg colado por cima da embalagem foi considerado negativo, passando a impressão de que a informação não era verdadeira e diminuindo a credibilidade do produto. Isso mostra a importância de mudar logo a embalagem quando muda a legislação.

Você está me maquiando aqui. Essa embalagem, por ter o adesivo de orgânico, isso aqui é um adesivo, não é o original. Ou você me colocou ou você está querendo me enganar. Se eu pegasse uma embalagem assim eu descartaria totalmente. [...] Por causa do adesivo. Nem olharia. Por isso que eu comecei a passar o dedinho aqui e vi que a coisa estava errada. Deu uma descoladinha aqui. Esse aqui eu não compraria. (CC23, 2013)

A legibilidade foi considerada boa por alguns consumidores. "Ele aparentemente tem as informações nutricionais bem visíveis, com uma letra que é possível de ler. Porque geralmente barrinha tem uma letra bem pequenininha porque a embalagem é menor" 
(CC14, 2013). Algumas informações, porém, ficam ocultas na emenda da embalagem, dificultando o acesso às informações. "Os negativos: eu acho que ele tem um pouco de informação oculta que é um pouco por causa da embalagem e isso acaba ficando mesmo, tem informação aqui que acaba ficando mais difícil de acessar" (CB20, 2013).

\section{Matriz semântica barra de cereais Monama}

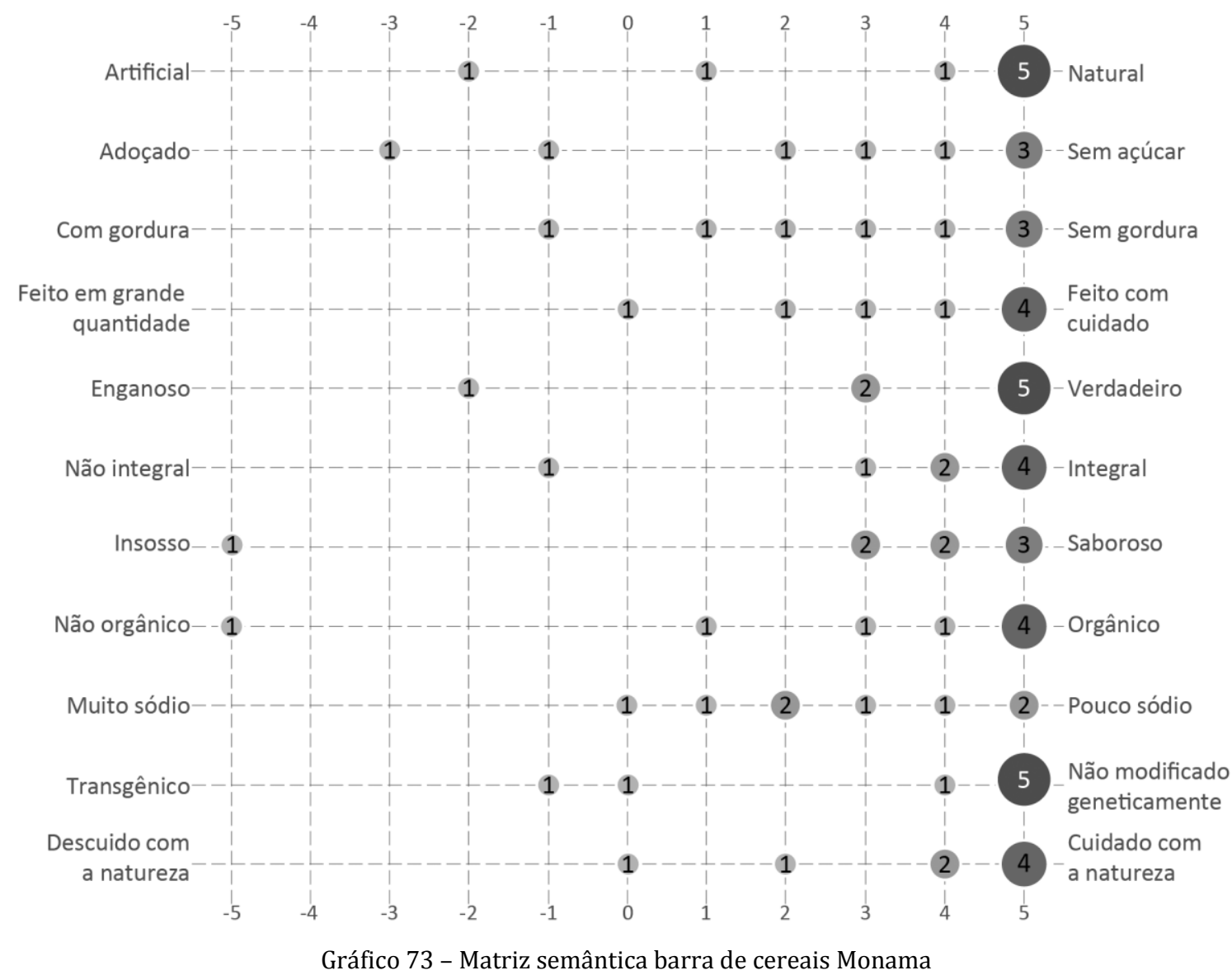

Observa-se na matriz semântica, preenchida no final da entrevista, o predomínio de respostas mais positivas. A informação "adoçado com mel" acabou dividindo o espectro de respostas, porém mais próximo do adoçado. A questão se o produto era saboroso tendeu mais para o positivo, porém três escolheram a opção do meio, talvez por não conhecerem o produto.

As respostas da informação dos transgênicos aqui tenderam para o "não modificado geneticamente", apesar de não ter nada escrito na embalagem sobre isso, porém dois consumidores escolheram as opções mais centrais, por não encontrarem essa informação na embalagem.

A partir dos dados apresentados, observa-se que a embalagem de barra de cereais Monama se destacou principalmente pela composição de ingredientes, diferentemente das outras barras de cereais, como o capim-santo, ser adoçado com mel e por não ter glúten.

Porém, a aparência da embalagem não foi considerada positiva ou atrativa, talvez pela falta de definição da imagem ou por não se identificar com a ilustração infantil. 


\subsubsection{Barra de cereais Mãe Terra}

A barra de cereais Mãe Terra é um desdobramento do design da embalagem da linha de ingredientes, porém com modificações na ilustração. A seguir, serão analisadas as características específicas desse produto e diferenças. A embalagem em tamanho real pode ser conferida no Anexo A.

\section{Análise do painel frontal da barra de cereais Mãe Terra}

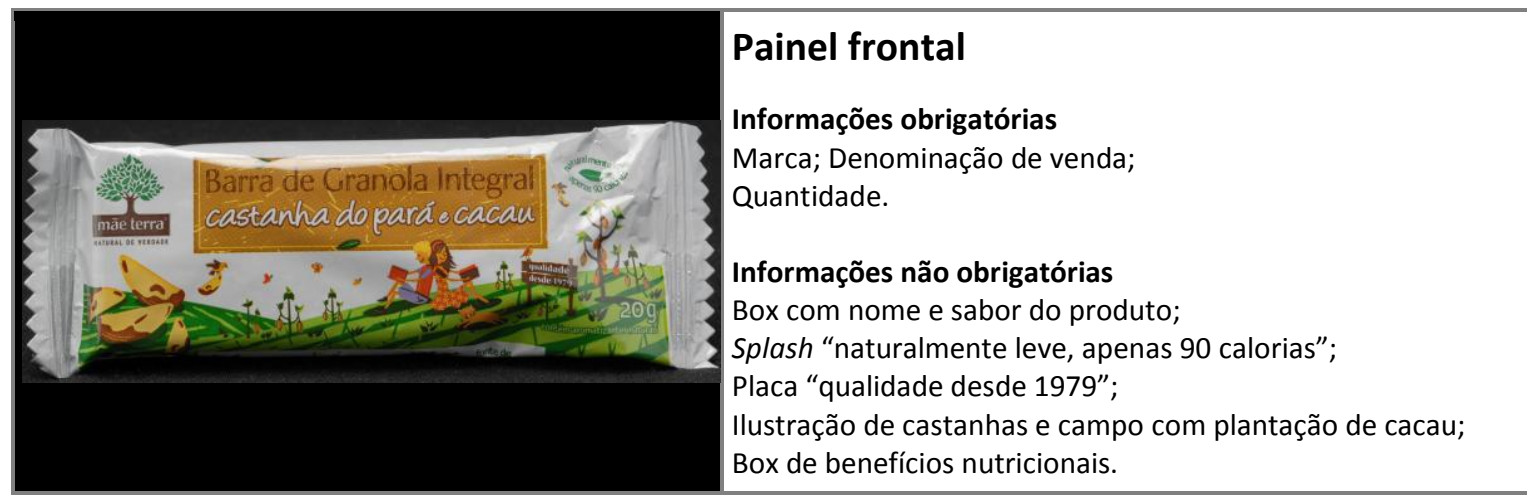

Figura 141 - Painel frontal da embalagem de barra cereal Mãe Terra

Segundo o sentido de leitura, de cima para baixo, da esquerda para a direita, a primeira informação do painel frontal é a marca Mãe Terra, seguida pelo box marrom claro com o nome do produto e a informação do sabor da barra de cereais.

A marca Mãe Terra é aplicada sobre o fundo branco, dando um bom contraste de cor e sendo fácil de visualizar. O nome do produto em marrom escuro sobre o box em marrom claro tem pouco contrate de cor, aparecendo mais os ingredientes principais do produto castanha do pará e cacau - com tipografia manuscrita em cor branca e contorno marrom, dando boa legibilidade.

O splash "naturalmente leve, apenas 90 calorias" tem pouca visibilidade por ser pequeno e estar localizado no canto superior direito, sendo o último a ser lido.

A ilustração usa cores parecidas com as da linha de ingredientes. O campo apresenta uma plantação de cacau que só pode ser entendida se vista muito de perto, e dá destaque para as castanhas-do-pará no canto inferior esquerdo da embalagem, de grande tensão visual. A ilustração também apresenta um casal sentado no gramado, com um gato, lendo livros, situação que não aconteceria em uma plantação de cacau, talvez sugerindo que o produto pode ser levado como lanche para qualquer lugar.

O box de benefícios fica escondido na dobra da embalagem, na parte inferior do painel frontal da embalagem. A tipografia usada é a mesma da embalagem de ingredientes, usando a fonte manuscrita para os destaques como a palavra "orgânico" e o sabor.

Os elementos gráficos estão centralizados e em equilíbrio por causa das duas grandes áreas de cor: a do box de sabor e a do campo verde. 


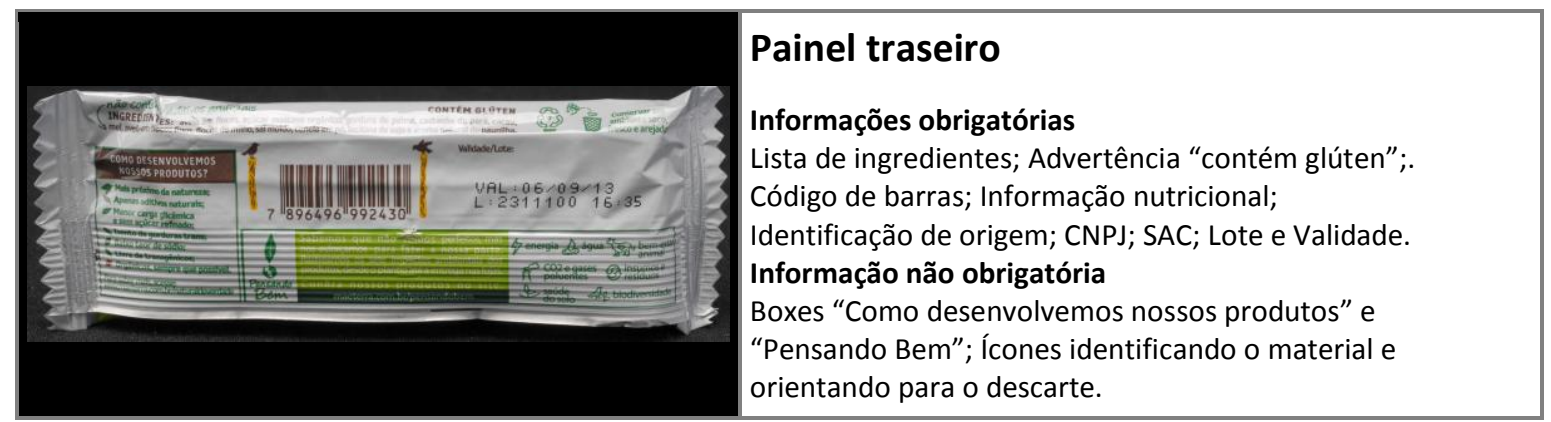

Figura 142 - Painel traseiro da embalagem de barra cereal Mãe Terra

Segundo o sentido de leitura, de cima para baixo, da esquerda para a direita, a primeira informação do painel traseiro é a lista de ingredientes, com destaque para a frase "não contém aditivos artificiais", demonstrando o destaque que quer dar à sua composição. Já a composição nutricional tem pouco destaque, ela não está em forma de tabela e fica localizada abaixo da dobra da emenda da embalagem.

Os textos abaixo da emenda e sobre a imagem do campo verde estão escondidos e ilegíveis, pela falta de contraste de cor com o fundo.

As informações que mais chamam a atenção no painel traseiro são os boxes "Como desenvolvemos nossos produtos" e o do projeto "Pensando Bem", apesar que a leitura é prejudicada por estarem localizados na área de selagem, que tem uma ondulação no material. Isso mostra que, nesse produto, a empresa se preocupou mais em mostrar as suas ações do que as informações sobre o produto.

\section{Hierarquia de leitura}

A hierarquia de leitura da embalagem de barra de cereais da Mãe Terra, demonstrada abaixo, mostra que o box do sabor, em marrom claro, é a primeira informação a ser lida, por causa da cor. As cores da ilustração são vistas em segundo lugar.

A marca Mãe Terra, por sua localização e por estar aplicada sobre o fundo branco, é a terceira informação a ser lida. 


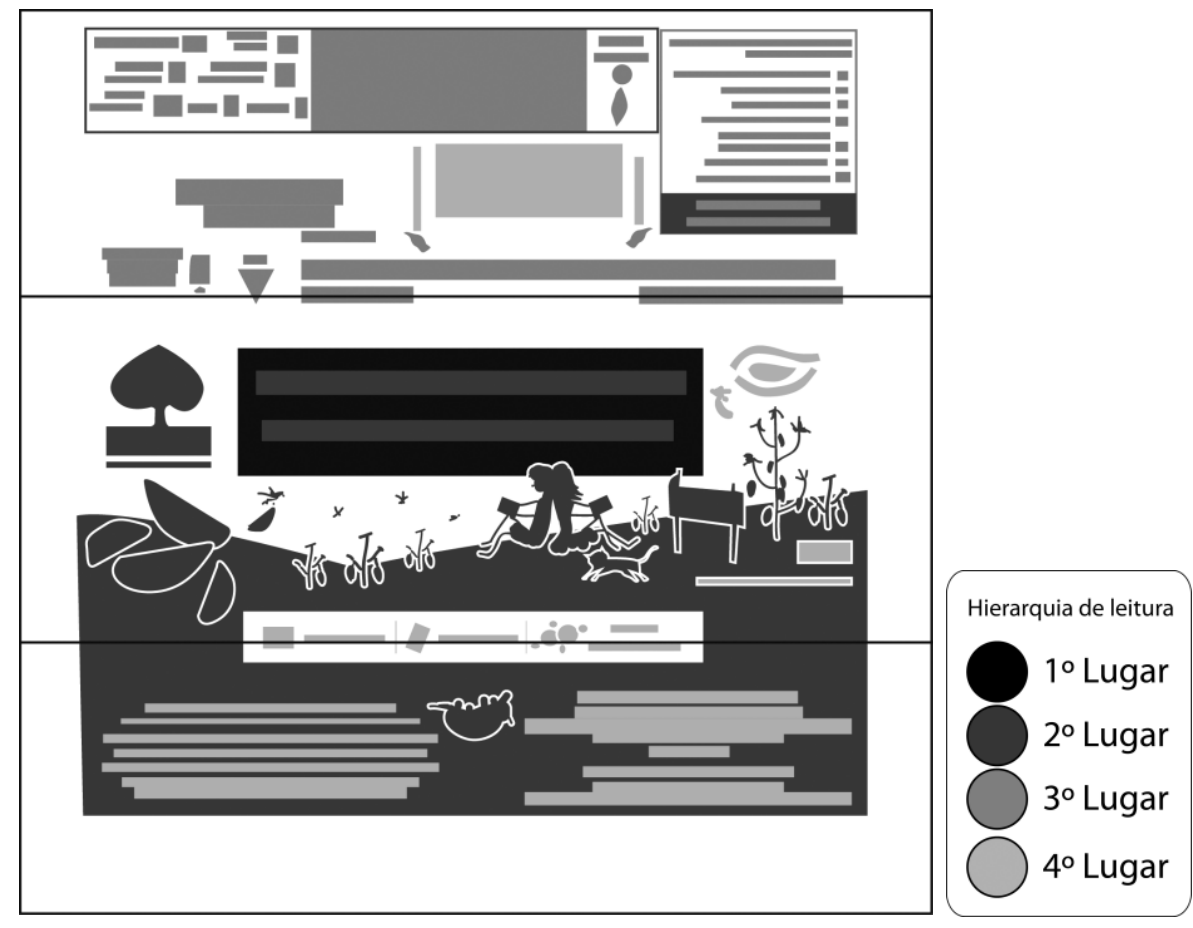

Figura 150 - Hierarquia de leitura da barra de cereais Mãe Terra

\section{Questões técnicas da barra de cereais Mãe Terra}

O plástico da embalagem é o Polipropileno Biorientado (BOPP) metalizado, que garante a barreira necessária para o produto. A impressão em flexografia tem boa qualidade.

Por causa da forma de fechamento da embalagem, na emenda no painel traseiro, algumas informações ficam ocultas, contribuindo para a falta de legibilidade.

\section{Aspectos ambientais da barra de cereais Mãe Terra}

A embalagem é produzida com um material de reciclagem complexa e de pouco valor na cadeia de reciclagem do Brasil, por ser um compósito de materiais (BOPP + metal). 0 material é identificado na embalagem, mas não usa o padrão ISO para tanto.

\section{Apresentação dos dados das entrevistas}

A marca, conhecida por produzir alimentos saudáveis, foi usada como critério para separar a barra de cereais como mais saudável. "Bom, num primeiro momento foi a marca. A marca Jasmine, a marca Mãe Terra” (CB24, 2013).

Outro consumidor separou a embalagem como saudável por gostar da marca e por já consumir, mesmo considerando menos saudável se comparada com as outras. "Aqui [Mãe Terra] eu sei que tem açúcar. Mas você vai fazer pergunta, né. Mas é porque eu gosto dessa marca [Mãe Terra] mesmo" (CA26, 2013).

Um consumidor com pouco conhecimento sobre o que é um alimento orgânico chegou a classificar a barra de cereais Mãe Terra como "meio orgânico", por conhecer a marca, considerá-la saudável e por não ter encontrado a informação de orgânico. "Bom, pra mim a Mãe Terra, como sendo um produto bem mais selecionado, eu considero ela 'meio orgânico' [sic]" (CC23, 2013).

Consumidores com mais conhecimento, que conheciam a marca, mas que não costumam consumir o produto, ficaram em dúvida se separavam ou não o produto como orgânico. 
“Essa [Mãe Terra] não fala se é orgânico. [...] Olha, eu não estou vendo nada orgânico, eu vou colocar pra cá. À primeira vista, porque eu não vou levar esse tempo todo olhando quando eu for comprar" (CB24, 2013).

Como não foram feitas perguntas específicas sobre a barra de cereais Mãe Terra, as informações dos consumidores foram fornecidas de forma espontânea durante a separação do produto em grupos.

A partir dos dados apresentados, observa-se que a estratégia de design da embalagem de barra de cereais escolheu destacar mais a marca, utilizando as mesmas cores da linha de ingredientes e demonstrando que tem o mesmo conceito dos outros produtos na sua fabricação. Talvez por isso alguns consumidores a tenham identificado como orgânica, apesar de não ser.

\subsubsection{Granola do Grupo 4 de preparo rápido para o consumo}

As marcas de granola mais separadas como saudáveis foram a Monama, Mãe Terra, Trio e Kobber, por cinco de sete consumidores entrevistados.

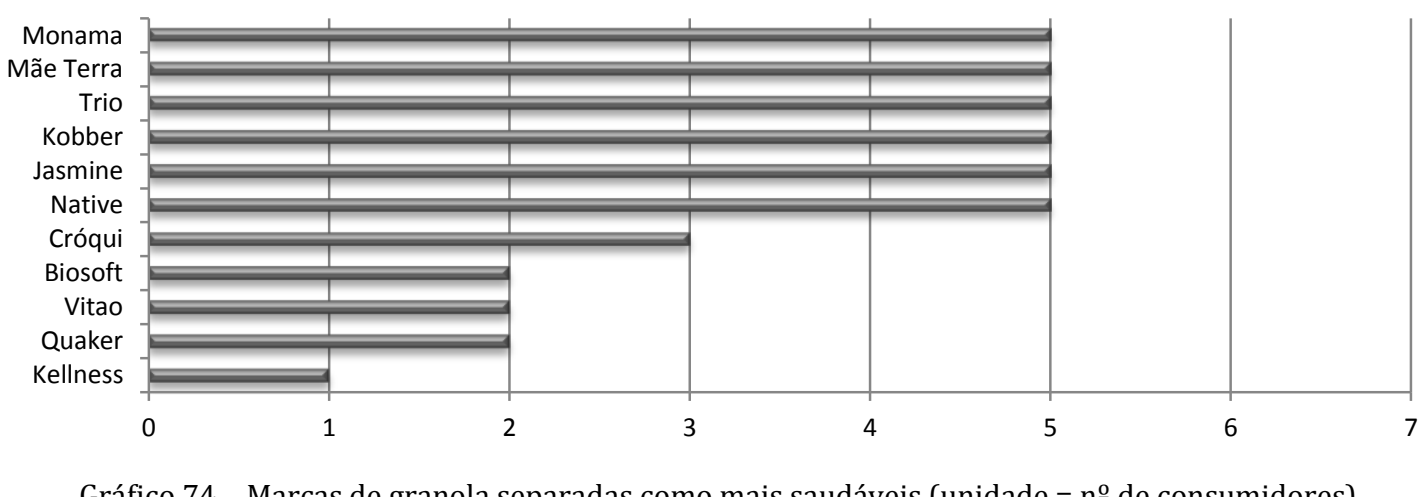

Gráfico 74 - Marcas de granola separadas como mais saudáveis (unidade = nํ de consumidores)

Os principais critérios para a separação foram: a composição dos ingredientes (cinco consumidores), ter pouco ou nada de algo na composição como o glúten ou o açúcar (cinco consumidores) identificar-se como orgânico (seis consumidores) e a marca (cinco consumidores). A marca mais relacionada a algo saudável foi a Mãe Terra, por quatro consumidores. 


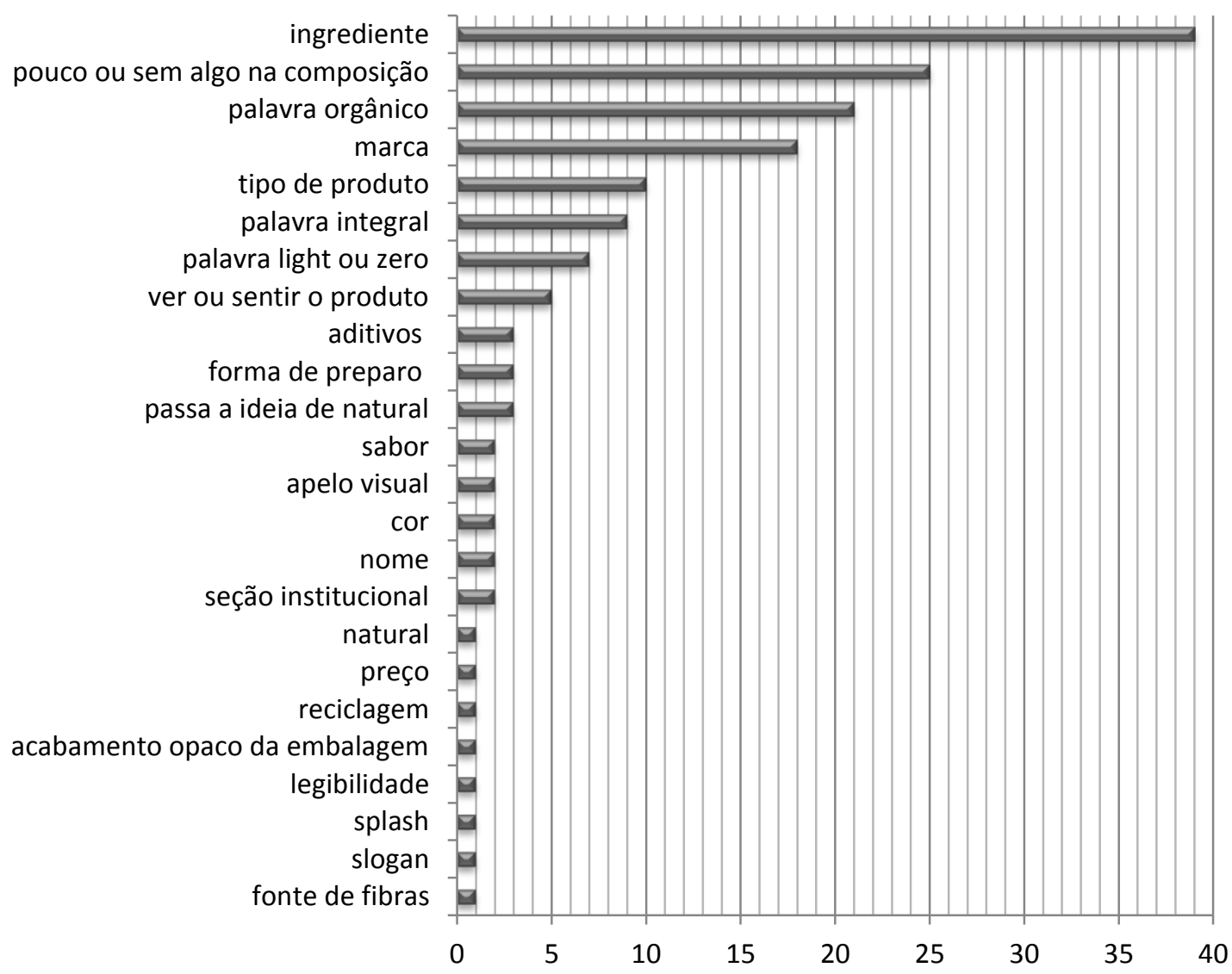

Gráfico 75 - Critérios para separação de granola como mais saudável (unidade = no de menções)

Para separar como saudável, os consumidores procuraram informações relacionadas à composição do produto. Ingredientes como os grãos e sementes foram considerados como saudáveis. "Eu gosto de sementes, eu rejeitei os que tinham muitos flocos e eu gosto de sementes" (CC16, 2013).

As palavras "light" ou "zero" também foram relacionadas, por um dos entrevistados, como uma informação de um produto mais saudável.

No meu conceito de saudável, por eu ser gordinho, eu abdico o que não for 'light' ou 'zero', então eu já diminuo minha caloria nesse ponto. Mas, pela embalagem, sem ler ou sem conhecer o produto, é difícil. (CB01, 2013)

A granola também foi considerada por alguns consumidores como saudável pelo próprio conceito do produto. "Em geral, as granolas, no meu ponto de vista, são saudáveis" (C30, 2013). Por isso, um consumidor declarou que sentiu mais dificuldade para separar a granola, comparando com a separação do macarrão instantâneo, com conceito negativo. "A granola, no geral, eu acho bem saudável. Vai ser difícil" (CA25, 2013).

Os principais critérios para a separação como menos saudável foram: a composição dos ingredientes (três consumidores); os aditivos como corantes, aromatizantes e adoçantes (três consumidores); e a marca, por serem desconhecidas (três consumidores) ou de grandes produtores (dois consumidores). 


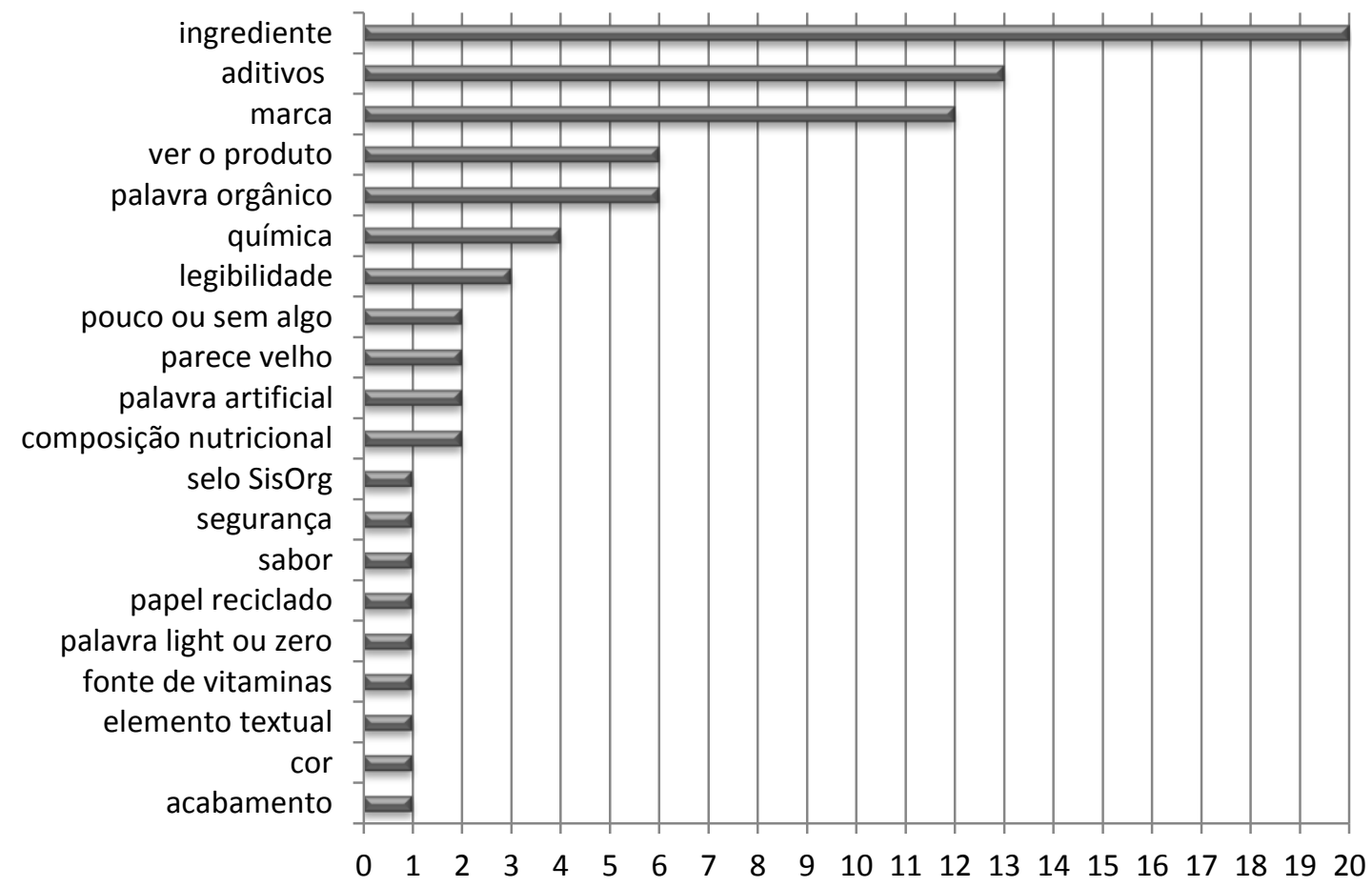

Gráfico 76 - Critérios para separação de granola como menos saudável (unidade = $\mathrm{n}^{\mathrm{o}}$ de menções)

O fato de a granola ser de uma marca conhecida, de uma empresa grande, foi considerado negativo por dois consumidores.

É, eu acho que os menos saudáveis são esses. E aqui estou te falando por causa dos fabricantes, que, como são grandes compradores de cereais, eu acho que eles compram transgênicos. E eles não falam não que têm transgênico. (CB22, 2013)

A marca de granola mais separada como orgânica foi a Monama, por todos os consumidores, e em segundo lugar a Native, por seis consumidores.

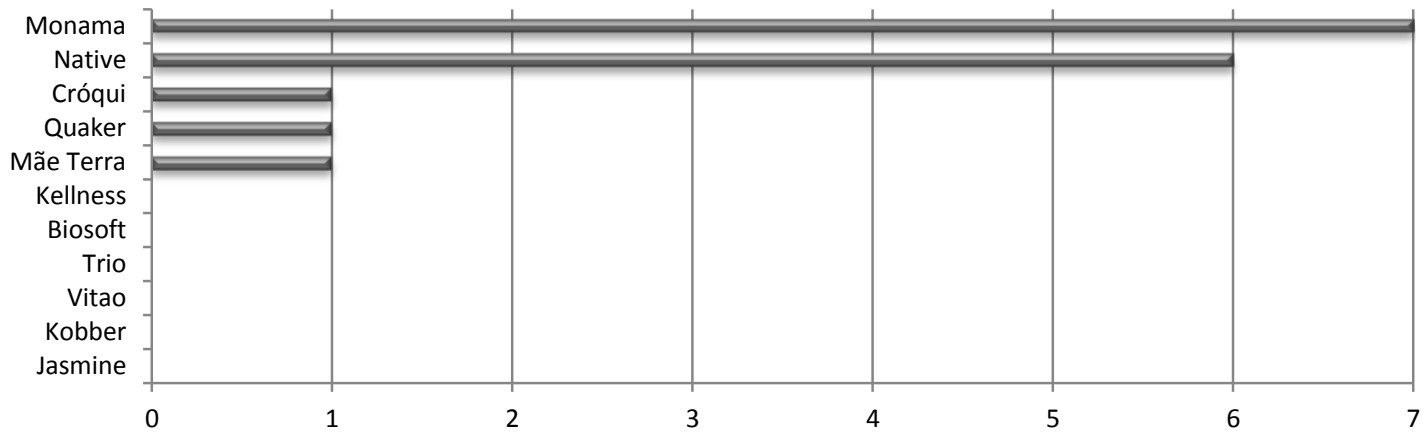

Gráfico 77 - Marcas de granola separadas como orgânicas (unidade = no de consumidores)

Para separar em orgânico e não orgânico, a principal informação textual olhada foi a palavra orgânico, por todos os consumidores. O selo SisOrg aparece em segundo lugar (dois consumidores), seguido pela marca Mãe Terra (dois consumidores), conforme podemos ver abaixo: 


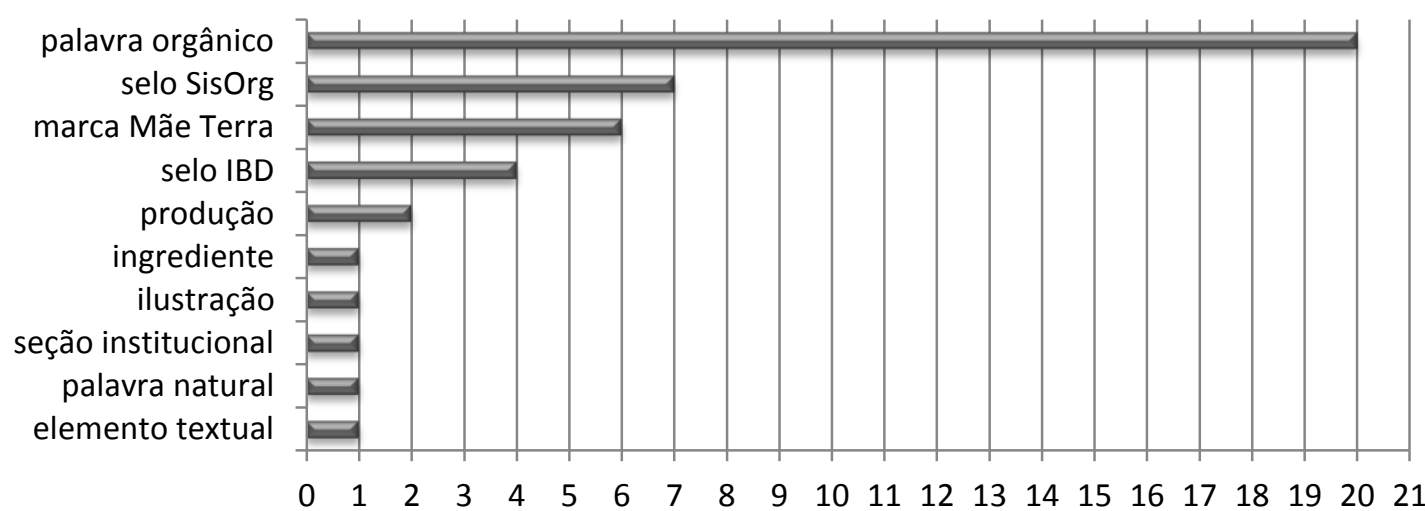

Gráfico 78 - Critérios para a separação da granola como orgânica (unidade = no de menções)

O principal critério para separar os produtos como não orgânicos foi a falta da informação, por seis consumidores.

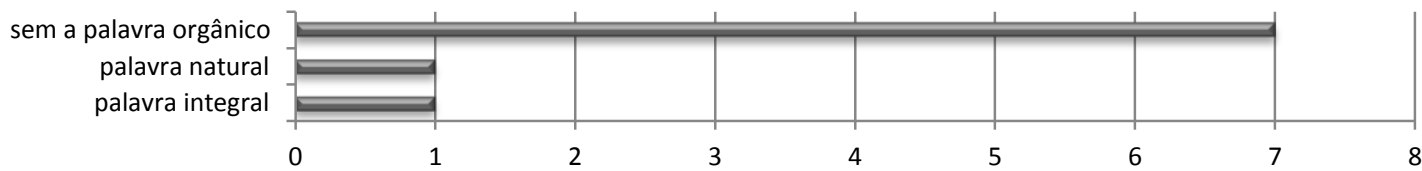

Gráfico 79 - Critérios para a separação da granola como não orgânica. (unidade = no de menções)

Com base nos dados apresentados, podemos considerar que a composição do produto é o principal fator para determinar se o produto é saudável ou não. Informações como "sem açúcar", "sem glúten" ou sem algum outro componente considerado não saudável chamaram a atenção. Observa-se também que os consumidores valorizam embalagens transparentes que possibilitem ver os produtos dentro da embalagem.

A marca não teve muita influência nessa categoria, mas também foi mencionada na percepção de que se trata de um alimento saudável.

Para identificar como alimento orgânico, a informação textual e o selo SisOrg foram suficientes, porém a marca do produto acabou confundindo os consumidores.

\subsubsection{Granola Monama}

A embalagem da granola é usada como base para o desdobramento da identidade em outros produtos da empresa. A seguir, serão analisadas as características específicas desse produto. A embalagem em tamanho real pode ser conferida no Anexo B.

\section{Análise do painel frontal da granola Monama}

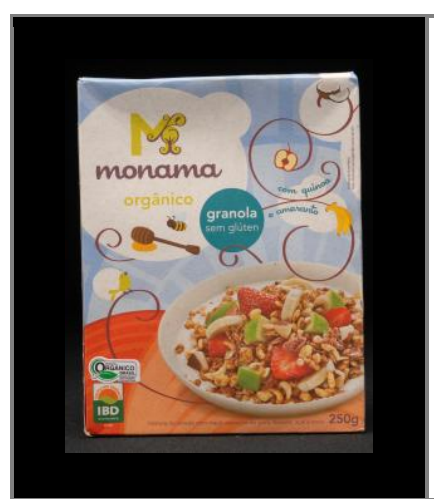

\section{Painel frontal}

Informações obrigatórias

Marca; Palavra "orgânico"; Selo SisOrg;

Denominação de venda; Quantidade; Selo certificador (IBD).

Informações não obrigatórias

Splash "granola sem glúten";

Lista de ingredientes;

llustração dos ingredientes (mel, maçã, banana e coco);

llustração de horizonte no fundo;

Fotografia do prato com granola e frutas.

Figura 143 - Painel frontal da embalagem de granola Monama 
Segundo o sentido de leitura, de cima para baixo, da esquerda para a direita, a primeira informação do painel frontal é a marca Monama, seguida pelo splash azul com a informação "granola sem glúten" e o prato de granola em uma diagonal descendente.

No canto inferior esquerdo, de grande tensão visual, estão localizados os selos de certificação do SisOrg e do IBD, sobre o fundo de cor avermelhado.

A marca é aplicada sobre o círculo branco, dando um bom contraste de cor, fácil de visualizar e grande em relação aos outros elementos da embalagem.

A foto do prato de granola perde um pouco de definição por ter sido impressa em papel reciclado. As cores perderam definição, não parecendo apetitoso.

A ilustração, com os grafismos que lembram galhos de plantas, integra visualmente os elementos da embalagem. Os ícones de frutas e do mel têm um estilo alegre, porém um pouco infantil.

Os elementos gráficos estão em equilíbrio, tendo as informações com maior peso visual, a marca e o prato, um em cada canto da embalagem.

Os textos usam dois tipos diferentes, um manuscrito, para as informações com destaque, e outro uma fonte sem serifa, para as informações com menos destaque. $O$ texto "com quinua e amaranto" segue a curva do galho, integrando-se às informações visuais dos ícones de frutas.

O painel principal passa as informações adequadamente, dentro da estratégia de destacar que se trata de uma granola sem glúten, mas não destaca nenhum aspecto ambiental ou mesmo de se tratar de um produto orgânico.

\section{Análise do painel traseiro da granola Monama}

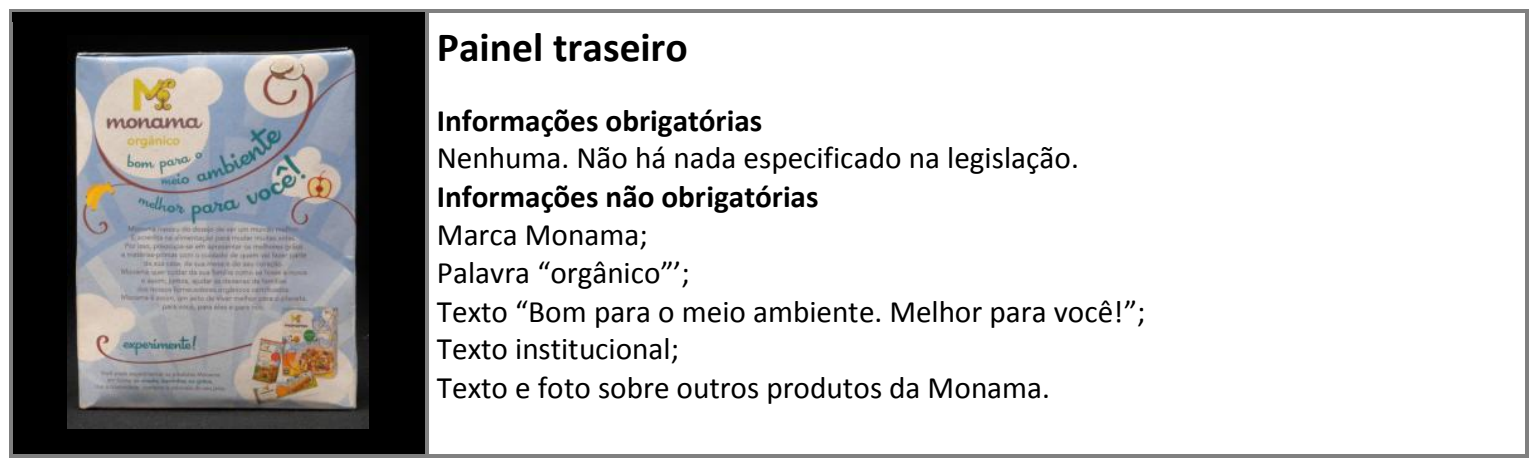

Figura 144 - Painel traseiro da embalagem de granola Monama

Segundo o sentido de leitura, de cima para baixo, da esquerda para a direita, a primeira informação do painel traseiro é a marca Monama, seguida pelas fotos da sugestão do consumo de outros produtos da Monama.

O painel traseiro apresenta poucas informações, com destaque para o texto "bom para o meio ambiente, melhor para você!".

No centro do painel traseiro, há um texto institucional da Monama, pouco legível, apesar do tipo estar em um tamanho grande, mas com pouco contraste de cor em relação ao azul do fundo.

As fotos com as embalagens de outros produtos da Monama estão bem visíveis, por terem sido aplicadas sobre círculos brancos. 
Análise dos painéis laterais da granola Monama

\begin{tabular}{|l|l|l|} 
Painel lateral esquerdo & Painel lateral direito \\
Informações obrigatórias \\
Forma de contato (SAC); \\
Código de barras; \\
Identificação de origem; CNPJ. \\
Informações não obrigatórias \\
Marca; \\
Palavra "orgânico"; \\
Texto composição da granola.
\end{tabular}

Figura 145 - Painéis laterais da embalagem de granola Monama

Segundo o sentido de leitura, de cima para baixo, da esquerda para a direita, a primeira informação do painel lateral esquerdo é a marca Monama, com a palavra "orgânico" logo abaixo. Ela é aplicada sobre um círculo branco, o que dá boa legibilidade por causa do contraste de cor com o fundo. Todas as informações que necessitam de legibilidade foram aplicadas sobre as esferas brancas, que, sobre o fundo azul, simbolizam as nuvens da metáfora visual do universo Monama.

Abaixo, no centro do painel e dentro de outra esfera branca, estão características do produto em destaque, escritas em tipos manuscritos. A forma do contato (SAC) está bem destacada e tem boa legibilidade.

O código de barras integra-se ao resto da embalagem, pois uma de suas barras foi aumentada no mesmo estilo dos outros grafismos, onde um passarinho está pousado, representando um galho de planta.

No painel lateral direito, segundo o sentido de leitura, de cima para baixo, da esquerda para a direita, a primeira informação do painel superior é a tabela nutricional, seguida pela lista de ingredientes, o ícone do papel reciclado e a área para o lote e validade.

A tabela nutricional, apesar de pequena, é bem legível e foi aplicada sobre o fundo branco, cor do papel reciclado. A lista de ingredientes destaca a informação de que é composto por ingredientes orgânicos.

O ícone criado para falar do papel reciclado lembra o ícone padrão da ISO 14021, porém é menos legível. Ele segue o mesmo estilo dos grafismos da ilustração, e isso é uma desvantagem, pois pode confundir o consumidor na hora de separar o material para a reciclagem. 


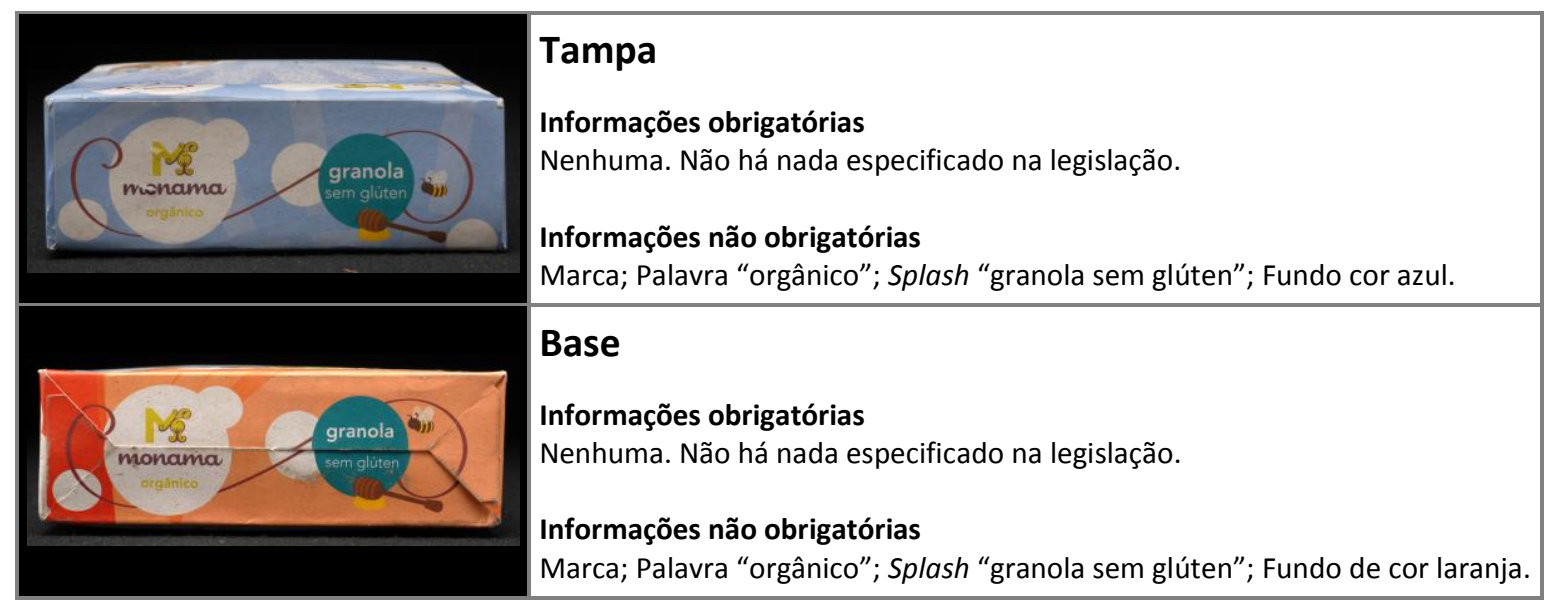

Figura 146 - Tampa e base da embalagem de granola Monama

Segundo o sentido de leitura, de cima para baixo, da esquerda para a direita, a primeira informação da tampa e da base é a marca Monama, com a palavra "orgânico", logo abaixo.

Ao lado, o círculo com a informação "granola sem glúten" está integrado pelo grafismo com a ilustração da abelha e do mel.

Visualmente, o que diferencia a tampa da base é a cor do fundo, que segue a cor da ilustração dos outros painéis.

A base, com fundo automático ${ }^{24}$, faz com que as imagens tenham um pequeno desalinhamento, mas não dificulta a legibilidade.

\section{Hierarquia de leitura}

A hierarquia de leitura da embalagem de granola da Monama demostrada abaixo faz com que informações mais relacionadas à marca tenham destaque, principalmente por estarem aplicadas sobre o fundo branco e por sua localização na embalagem.

O splash "granola sem glúten" é a primeira informação a ser lida, por sua cor em contraste com o fundo e também pela posição, que parece ser o centro ótico da embalagem. Está bem no meio de duas diagonais, que levam o olho para este elemento, que também apresenta mais destaque por utilizar leitura em negativo, ou seja, fundo escuro e letras claras com contraste adequado de luminosidade.

\footnotetext{
${ }^{24}$ Sistema que permite o envase e fechamento de cartuchos por máquina encartuchadeira.
} 


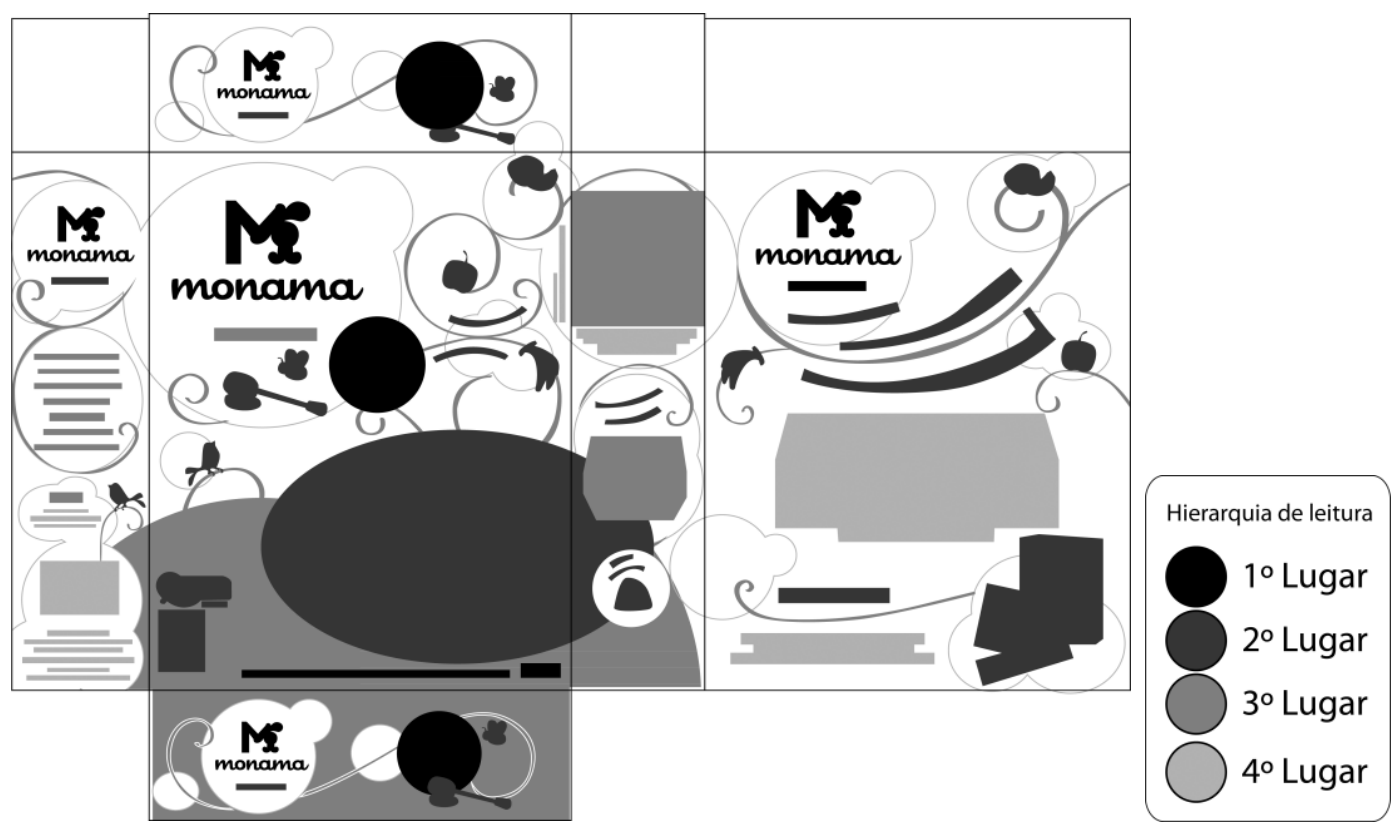

Figura 147 - Hierarquia de leitura da granola Monama

\section{Questões técnicas da granola Monama}

A granola Monama vem em um saquinho plástico dentro de uma caixa de papel reciclado. A receita do produto foi desenvolvida pela primeira vez junto com o pessoal do Instituto de Tecnologia de Alimentos (ITAL) ${ }^{25}$, quando já foi especificado o material próprio para a vedação que era necessário para a embalagem.

A impressão da embalagem foi feita em uma impressora offset. Foi usada uma grande quantidade de cola para fechar a tampa. Segundo Designer3 (2012), sobre isso, "a A10 não teve muito controle", mas vão rever isso na próxima produção. Essa declaração mostra que não influenciaram no processo de produção, mas que vão tentar na próxima vez. O excesso de cola não foi comentado na indústria.

\section{Aspectos ambientais da granola Monama}

Por haver duas embalagens, uma externa e outra interna, e dois processos de produção, a soma dos gastos energéticos é maior do que de outras formas de embalagem. Ela poderia ser reduzida a apenas uma, plástica, sem diminuir a proteção e a barreira ao oxigênio, diminuindo o desperdício.

A empresa utiliza saco plástico mais papel com objetivo de aumentar a barreira ao oxigênio sem utilizar materiais multicamadas.

A complexidade da logística também aumenta com a embalagem dupla, vinda de fornecedores diferentes, porém Indústria2 (2012) não quis especificar quais são seus fornecedores e onde estão localizados:

[...] isso de verdade é uma das poucas coisas que eu não posso te passar, eu sei de onde vem cada um, mas quando você cria uma empresa de orgânicos, o maior troféu que você tem na mão são os fornecedores. E tem pessoas entrando nesse mercado que pagam assim milhares para ter... a gente tem trackeado o mapa do Brasil de quem produz o quê, isso é uma coisa que eu não divulgo e não falo para ninguém.

${ }^{25}$ Atua na área de pesquisa, desenvolvimento, inovação, assistência tecnológica e difusão do conhecimento nas áreas de embalagem e de transformação, conservação e segurança de alimentos e bebidas. 
O papel reciclado e sem acabamento facilita a reciclagem, além de aproveitar uma matériaprima, que iria para um aterro sanitário, incentivar a coleta seletiva e reduzir o corte de árvores para a produção do papel.

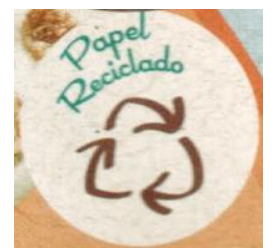

Figura 148 - Ícone que identifica o papel reciclado na embalagem da granola

Nenhum dos materiais utilizados foi identificado na embalagem. O símbolo estilizado de reciclagem não está dentro dos padrões ISO 14021.

\section{Apresentação dos dados das entrevistas}

O design das embalagens das granolas Monama nasceu junto com o nome. Desde a apresentação do universo visual, já se pensava em como poderia ser aplicado em uma embalagem de granola orgânica. A maior parte dos grãos é produzida no Brasil, desde o Rio Grande do Sul até o Nordeste.

$\mathrm{Na}$ entrevista com os consumidores, nenhum dos sete entrevistados conhecia a granola Monama e, por isso, nunca a comprou. As principais categorias positivas da granola Monama declaradas pelos consumidores foram: ter pouco ou nada de algum nutriente como o glúten ou aditivos (quatro consumidores); o papel reciclado da embalagem (cinco consumidores); ser orgânica (cinco consumidores); e composição de ingredientes (três consumidores).

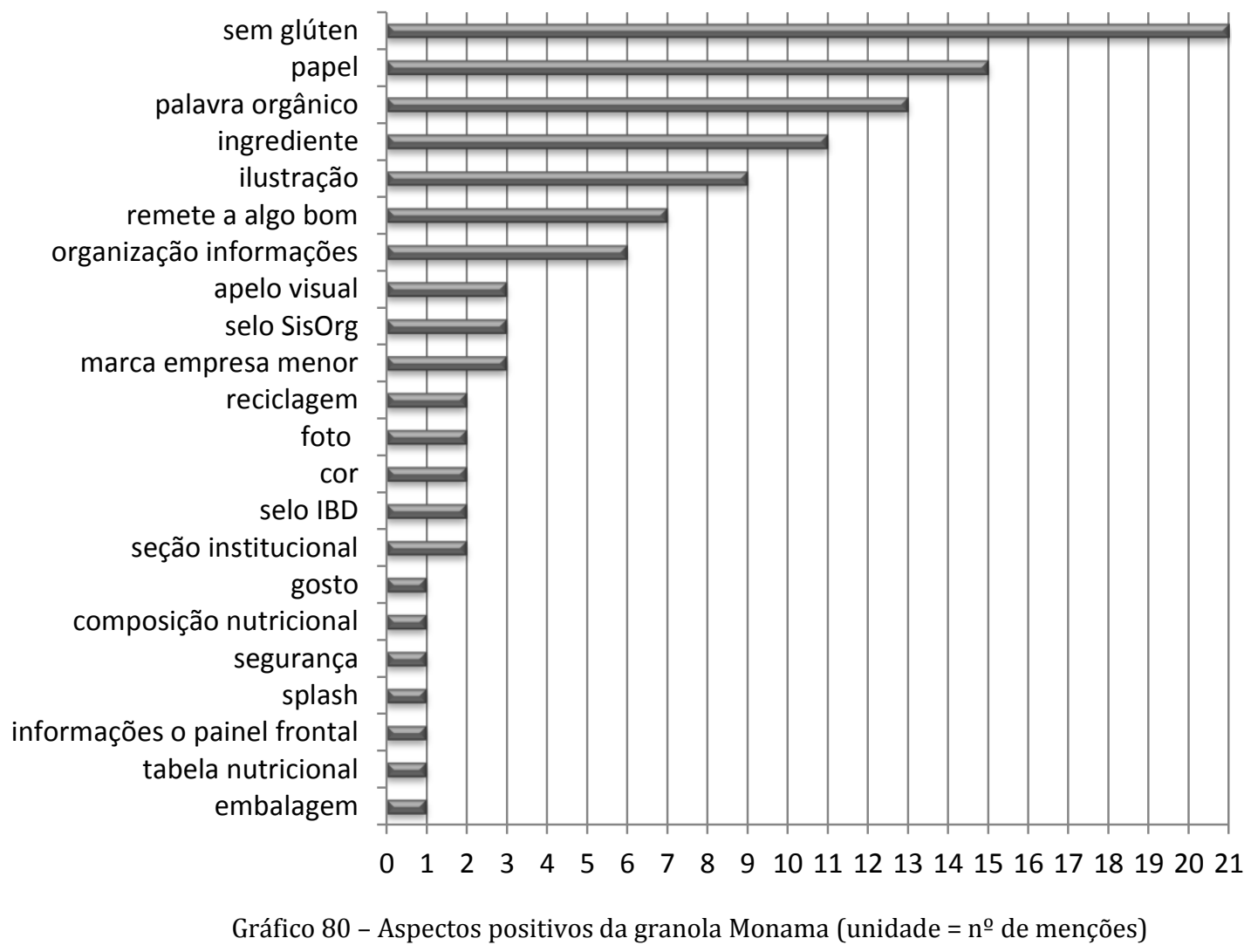

Os principais aspectos negativos da granola Monama declarados pelos consumidores foram: embalagem frágil (quatro consumidores); parecer infantil (dois consumidores); e o material da embalagem (três consumidores). 


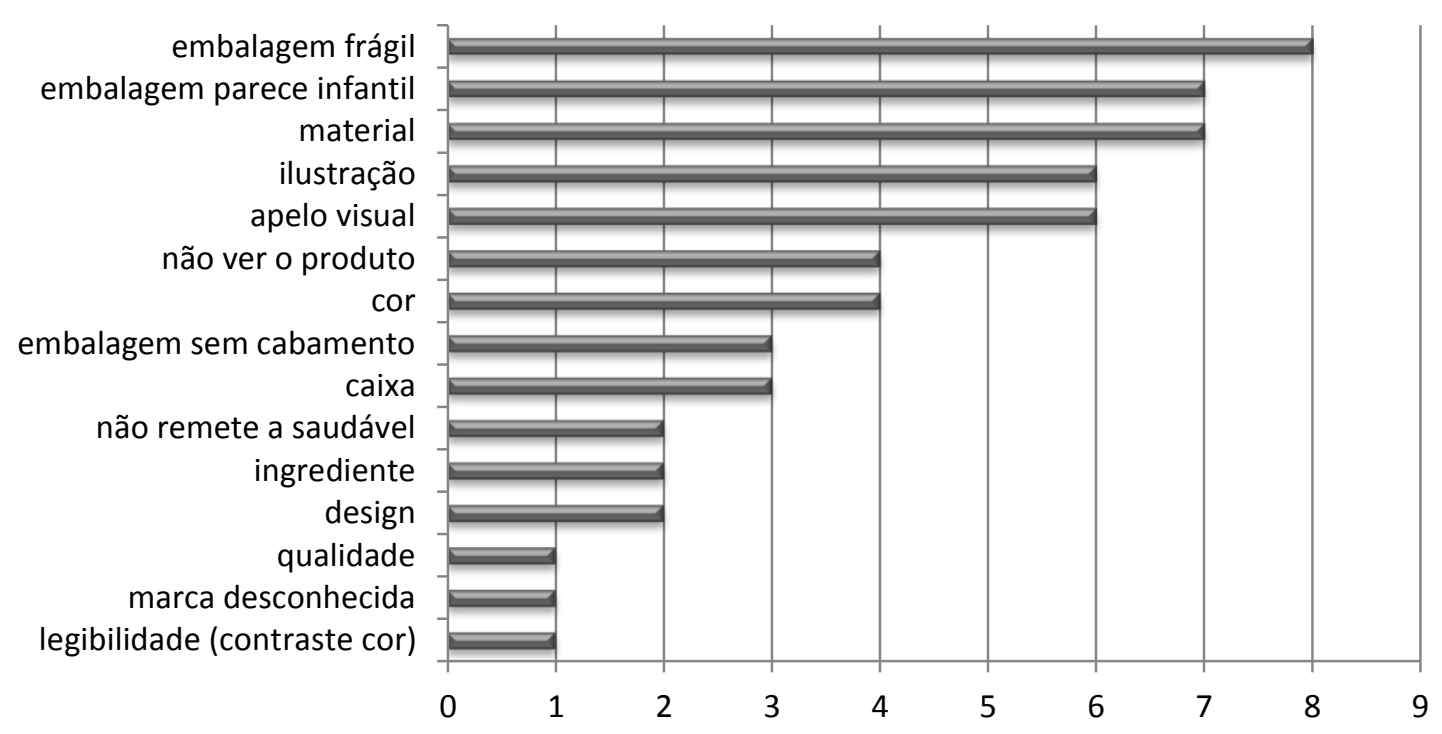

Gráfico 81 - Aspectos negativos da granola Monama (unidade = no de menções)

A composição da granola Monama, por ser orgânica, foi vista como algo positivo. "Este aqui, apesar de ser de uma marca que eu não conhecia, me surpreendeu quando eu vi. E é orgânico, tem quinua, tem amaranto, tem castanha-do-pará, que é legal, banana, que eu gosto" (CC16, 2013).

O fato de ser uma granola sem glúten também surpreendeu outro entrevistado.

[...] porque é difícil achar alimento sem, então eu prefiro sem, porque para mim eu acho que eu me sinto melhor. Então por que que eu compraria por isso [aponta a palavra 'glúten'] e por isso [aponta a palavra 'orgânico']? Porque é orgânico. (CC16, 2013)

Outro entrevistado, porém, considera que o destaque para a informação "sem glúten" não é importante. "A coisa do 'sem glúten' para mim é um mistério, tem uma parte que eu acho que é uma frescura" (CA15, 2013).

A organização das informações na embalagem da granola Monama foi percebida como positiva por alguns consumidores. "Eu leio o perfil, já leio o que tem e o que não tem" (CB17, 2013). "Eu adorei, eu adorei. Achei a mais legal. [...] De longe é a melhor embalagem de todas. Tem tudo o que a gente está procurando. Está tudo aqui, especificado e separado. (CB22, 2013).

A embalagem apresenta uma fotografia de um prato com granola. Segundo Designer3 (2012), essa imagem tem como objetivo passar o appetite appeal do produto.

O desenho das frutas da ilustração na embalagem corresponde aos ingredientes da granola. Um consumidor percebeu isso, porém só após manusear melhor a embalagem.

Eu não prestei atenção tanto no desenho, porque tem a banana, tem a maçã, tem o coco, tem o mel. Eu li, primeiro me chamou esse desenho e eu li o escrito, sem glúten e o amaranto, e orgânico, não é? Agora que eu comecei a prestar mais atenção nestes desenhinhos [sic]. [...] Quando a gente está no supermercado, a gente não tem tempo de ficar olhando tanto detalhe. (CC16, 2013)

Esse tempo disponível e a possibilidade de se ater aos detalhes para o experimento aproximam o consumidor mais da situação de uso e consumo do produto. Na situação de compra, o que importa mais é a informação de maior destaque na hierarquia de leitura.

Dois entrevistados consideraram a ilustração infantil, não se identificando com o produto. "[...] se eu estivesse com as crianças eu pegaria, porque eu a vi com meus olhos de criança. 
[...] Para mim, sinceramente, eu não compraria, eu passaria batido. [...] eu não tenho mais criança em casa, acho que é para um público diferente" (CA15, 2013)

Segundo Designer3, cores diferentes foram usadas na base da embalagem para a diferenciação do sabor. $O$ fato de parecer infantil também está relacionado à escolha das cores da embalagem, segundo um dos consumidores, que julga que poderia ter cores mais relacionadas à saudável.

Sei lá, eu acho que poderia ser mais verdinha, alguma coisa ressaltando que é mais saudável Aqui está muito criança. Vamos conversar. Poderia ser uma embalagem mais relacionando a verde, a saudável. (CA25, 2013)

A embalagem em caixa de papel reciclado, e fechada, foi percebida como algo negativo por um consumidor, por não relacionar esse tipo de embalagem à granola e por não poder ver o produto.

Negativo é que você demora para ver que é granola, parece bolo, sei lá. Por causa dessas caixinhas que vende. [...] E, não sei, não dá para ver direito. Poderia ter um buraquinho, eu gosto de ver. Então eu preferia que tivesse um buraco aqui na caixa. (CC16, 2013)

O papel reciclado foi percebido como algo positivo por alguns consumidores.

Acho que ser papel é um ponto bom. [...] Eu acho legal ser de papel reciclável, melhor do que plástico, gostei de ser uma embalagem de papel, embora tipo amasse, não tem nenhum problema, gostei de ser papel. (CA25, 2013)

Porém, mesmo considerando o papel reciclado como algo positivo, muitos declararam não gostar da aparência desse material e perceberam como mais frágil.

Negativo [sic] é a aparência dela. Não acho uma aparência tão bonita como embalagem. Por ser de papel reciclado, ela se torna mais frágil, se torna mais flexível, e poderá ficar mais amassada com o tempo; esse eu disse que não era tão bonito, então quer dizer que o design dela eu não achei tão legal. (CB01, 2013)

O material fez com que um dos consumidores nem quisesse olhar com mais atenção para a embalagem.

Virgem. Essa não deu nem vontade de olhar, sabia? Acho que eu não vou olhar [...] Me deu uma impressão de coisa velha ... Tanto falei da coisa zenzinha [sic], coisa velha, acho que é o tipo de papel, embora eu tenha visto assim, orgânico, sem glúten, que bacana, mas você pega e amassa. (CA15, 2013)

O fato de a embalagem não ser plastificada, por não ter nenhum tipo de acabamento, também foi percebido como algo negativo.

\footnotetext{
Eu acho ruim pela embalagem ser de um cartão, sem acabamento. Sem aquele plastificado, me dá uma ideia de uma coisa mais artesanal, uma marca menor, mas não que eu não confie na marca, não é isso. É exatamente o contrário, ele me deu ideia de uma coisa mais natural. Mas eu acho que ele precisava melhorar a embalagem. (CC16, 2013)
}

Isso mostra que o consumidor não tem a informação de que, se fosse plastificada, a embalagem não seria reciclável e considera apenas os atributos estéticos, desconsiderando os aspectos ambientais. 


\section{Matriz semântica granola Monama}

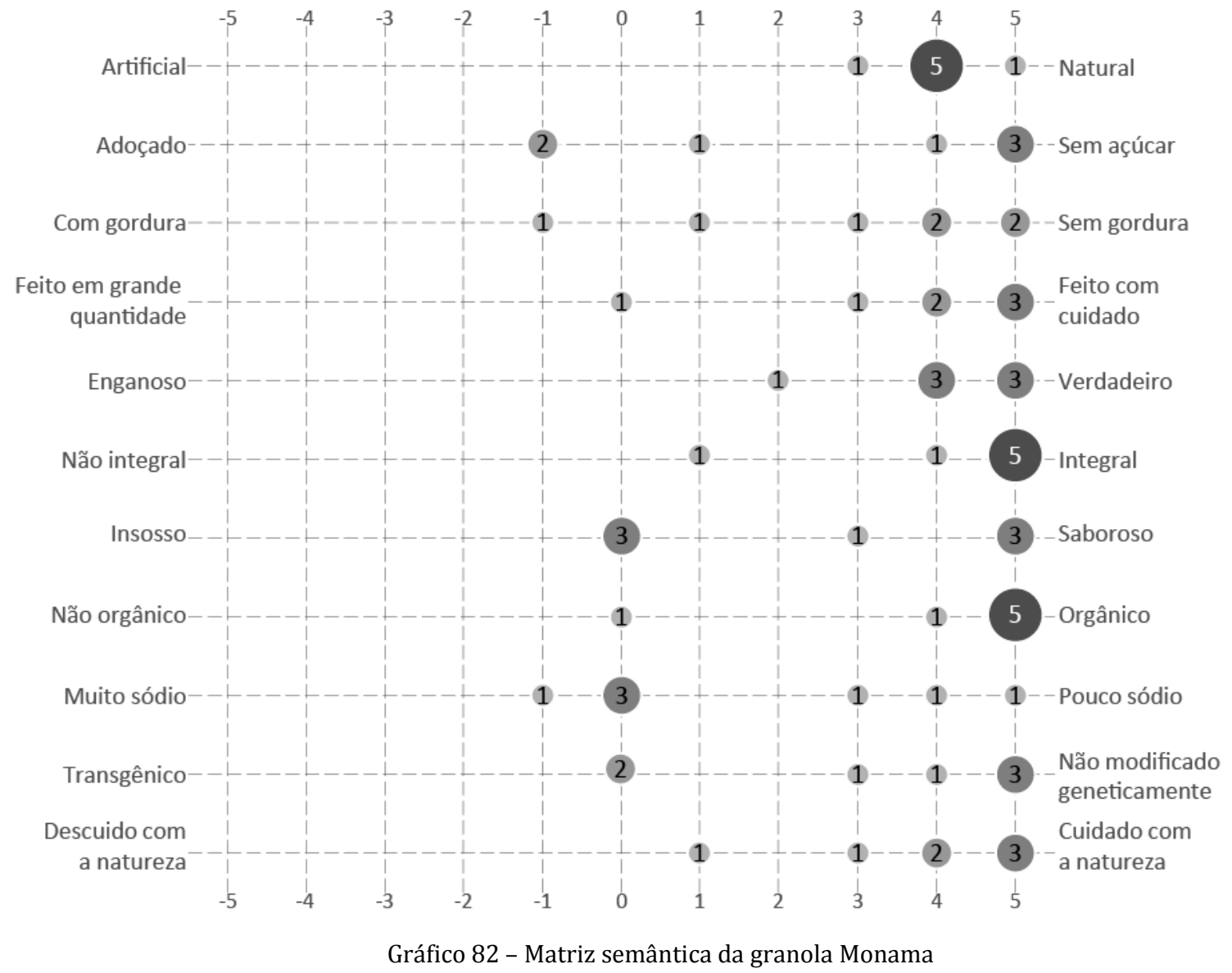

Observa-se na matriz semântica, preenchida no final da entrevista, o predomínio de respostas mais positivas.

A informação "adoçado com mel" acabou espalhando o espectro de respostas. Dois consumidores responderam mais próximo do adoçado. A informação se o produto era saboroso tendeu mais para o positivo, porém três escolheram a opção do meio, talvez por não conhecerem o produto.

As respostas da informação dos transgênicos aqui tenderam para o não modificado geneticamente, apesar de não ter nada escrito na embalagem sobre isso.

A partir dos dados apresentados, observa-se que a embalagem da granola Monama chama a atenção de forma positiva pela composição dos seus ingredientes sem glúten e por usar o papel reciclado na embalagem. Porém, mesmo percebendo o papel reciclado como algo positivo para o meio ambiente, a aparência final resultante do material foi considerada como algo negativo e mais frágil, havendo uma incoerência entre os aspectos estéticos e ambientais. Outro aspecto estético considerado negativo foi a ilustração parecer infantil, fazendo com que alguns consumidores não se identificassem com o produto.

\subsubsection{Granola Mãe Terra}

A granola Mãe Terra segue outra estratégia de design quando comparada aos demais produtos da marca. Essa estratégia faz parte de uma nova linha de comunicação usada nas novas embalagens Mãe Terra. A seguir, serão analisadas as características específicas desse produto. A embalagem em tamanho real pode ser conferida no Anexo A. 
Análise do painel frontal da barra de cereais Mãe Terra

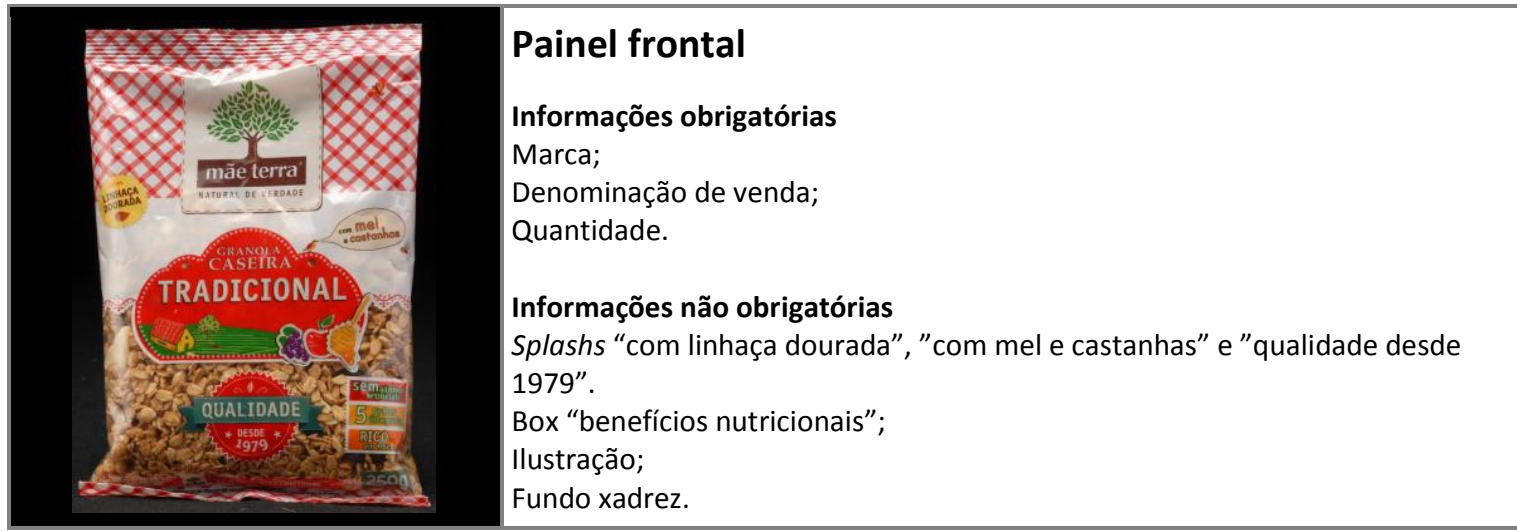

Figura 149 - Painel frontal da embalagens de granola Mãe Terra

Segundo o sentido de leitura, de cima para baixo, da esquerda para a direita, a primeira informação do painel frontal é a marca Mãe Terra, seguida pelo nome do produto dentro de uma ilustração que lembra uma placa de fazenda e junto à ilustração do campo.

A terceira informação mais vista é o splash "qualidade desde 1979". Essa informação ganhou mais destaque se comparada às outras embalagens da Mãe Terra analisadas nessa pesquisa, mostrando que a ênfase na comunicação da embalagem é mostrar que se trata de um produto tradicional, sendo esse o nome do produto, granola caseira tradicional.

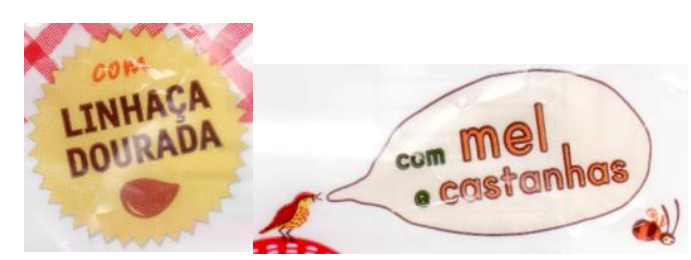

Figura 151 - Splash destacando alguns ingredientes

Quanto à composição nutricional, alguns itens foram destacados em um box colorido no canto inferior direito. Apesar das cores, ele tem menos destaque se comparado com o box de benefícios das embalagens da linha de ingredientes.

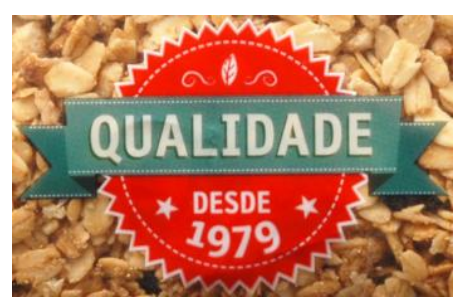

Figura 150 - Splash “qualidade desde 1979"

\begin{abstract}
A granola destaca alguns ingredientes do produto usando recursos visuais como as ilustrações das frutas, o splash "com linhaça dourada" e o balão saindo da boca do passarinho avisando "com mel e castanhas", mostrando a valorização da sua composição.
\end{abstract}

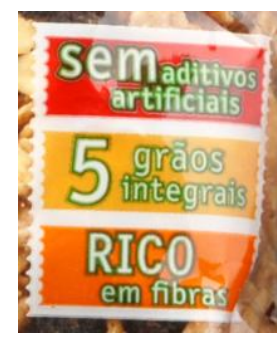

Figura 152 - Box de benefícios nutricionais

A marca foi aplicada sobre um fundo de cor creme que lembra uma etiqueta de tecido costurada, remetendo a algo caseiro. 
A ilustração da fazenda na embalagem da granola é um detalhe da embalagem, perdendo a identidade em relação aos outros produtos da linha. Se não fosse a marca aplicada em tamanho grande, poderia até parecer um produto de outra empresa.

A tipografia usada é diferente das outras embalagens Mãe Terra. São usados tipos sem serifa. E, para dar destaque, são também usados recursos de cor e de mudança de tamanho.

A cor é o que diferencia os sabores da granola: ela muda no fundo que imita uma toalha de piquenique e também no fundo atrás do nome do produto.

Os elementos gráficos estão em equilíbrio com seus elementos visuais principais alinhados ao centro.

\section{Análise do painel traseiro da barra de cereais Mãe Terra}

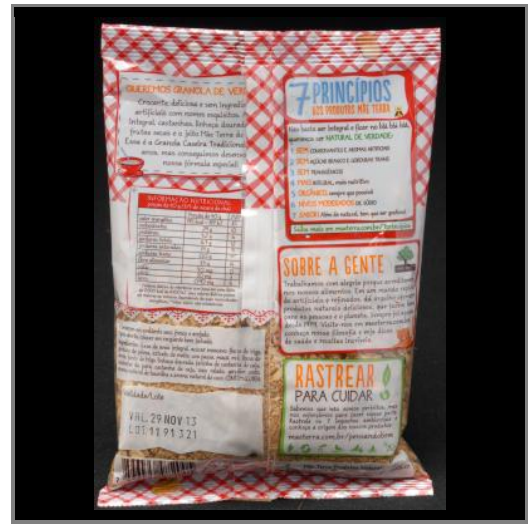

\section{Painel traseiro}

Informações obrigatórias

Lista de ingredientes; Advertência "contém glúten";

Código de barras; Tabela nutricional;

Identificação de origem; CNPJ; SAC;

Lote e Validade.

\section{Informação não obrigatória}

Texto sobre o produto; texto institucional;

Boxes "7 princípios dos produtos Mãe Terra" e "Rastrear para cuidar",

Simbologia técnica de identificação de matérias e orientação para o descarte.

Figura 153 - Painel traseiro da embalagens de granola Mãe Terra

Segundo o sentido de leitura, de cima para baixo, da esquerda para a direita, a primeira informação do painel traseiro é o box com o texto sobre o produto, seguida pelos outros boxes "7 princípios dos produtos Mãe Terra" e "Rastrear para cuidar".

$\mathrm{Na}$ embalagem da granola, mudou a forma de apresentar as mesmas informações que sempre aparecem em todas as embalagens. O box "Como desenvolvemos nossos produtos" mudou para "7 princípios dos produtos Mãe Terra" e o box do projeto "Pensando bem" mudou para "Rastrear para cuidar", como é possível ver abaixo:
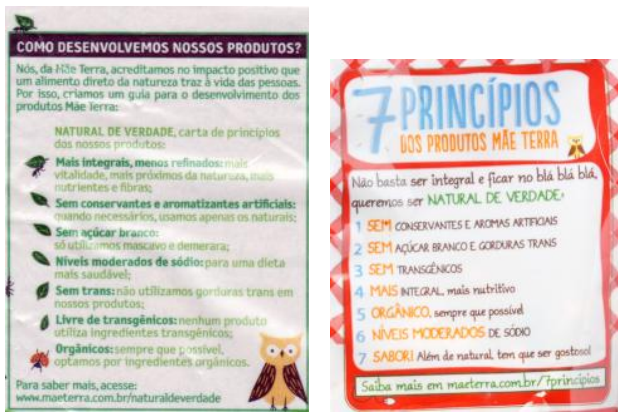

Figura 154 - Box como a Mãe Terra desenvolve seus produtos, antes e depois
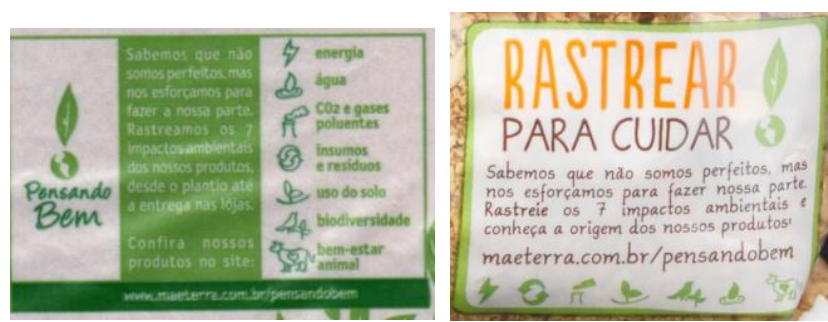

Figura 155 - Box do projeto "Pensando Bem", antes e depois

Percebe-se, por isso, uma mudança na forma de comunicação, que se distanci a mais da linha de ingredientes que está há mais tempo no mercado.

Ao contrário das primeiras embalagens da linha de ingredientes, como a do arroz, em que nada se destacava, aqui tudo parece ter ganhado muito destaque, fazendo com que 
nenhuma informação específica tenha um destaque mais especial, causando uma sensação de excesso de informação da mesma forma.

A legibilidade dos textos é boa, mesmo na linha de ingredientes, escritos em uma fonte manuscrita, que poderia atrapalhar a leitura, mas que, por seu tamanho e contraste com o fundo, é bem legível. Algumas informações, porém, ficaram ocultas por baixo da emenda da embalagem.

O código de barras manteve a ilustração do passarinho apoiado em uma haste, mas, por estar fora do fundo branco, não se relaciona visualmente. Ao lado do código de barras, está localizada a identificação do material e o ícone orientando a forma de descarte, conforme o padrão ISO 14021.

Os elementos gráficos estão em desequilíbrio, pois as informações do lado direito se destacam mais pelas cores do que as informações do lado direito.

\section{Hierarquia de leitura}

A hierarquia de leitura da embalagem de granola Mãe Terra, demonstrada abaixo, mostra que o nome do produto sobre o fundo vermelho é a primeira informação a ser lida, por causa da cor. A marca Mãe Terra, por sua localização e por estar em tamanho grande, é a segunda informação a ser lida.
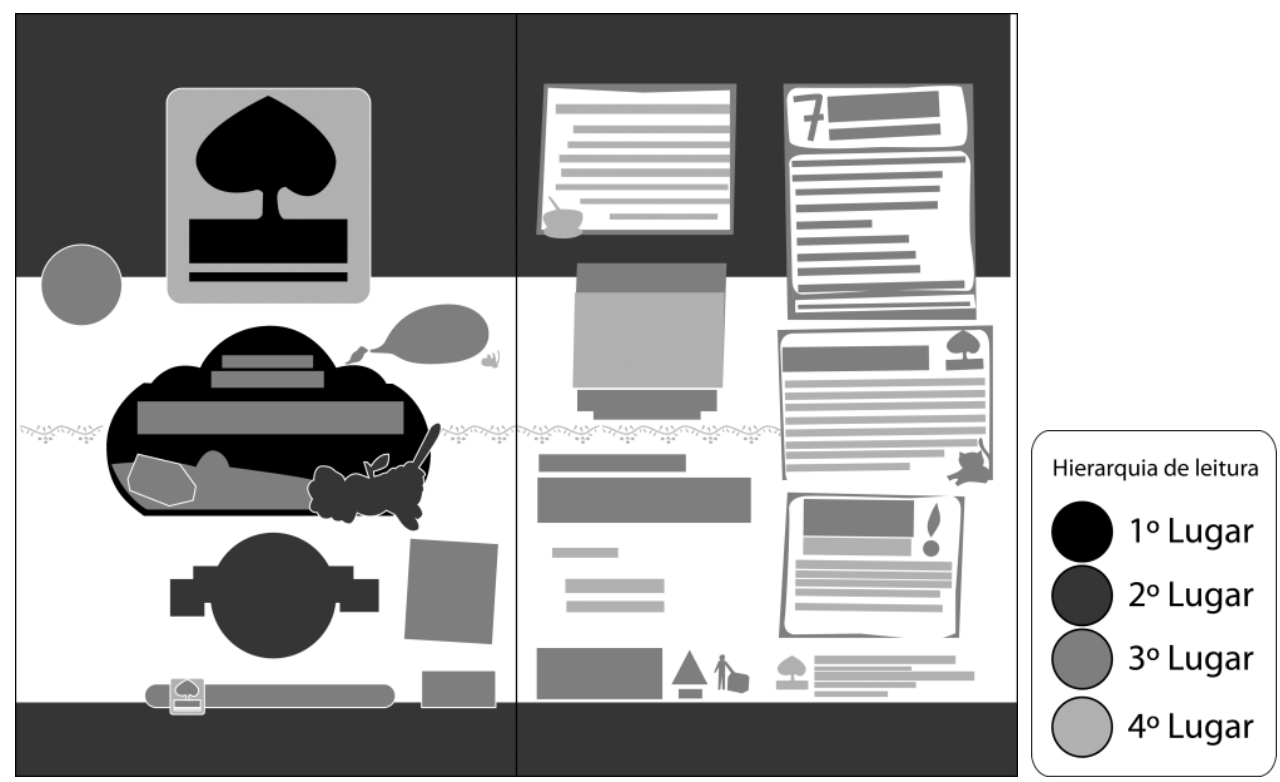

Figura 156 - Hierarquia de leitura da granola Mãe Terra

\section{Questões técnicas da granola Mãe Terra}

O plástico da embalagem é um composto de matérias de PET mais PP, que garante a barreira necessária para o produto. A impressão em flexografia tem boa qualidade.

Por causa da forma de fechamento da embalagem, na emenda no painel traseiro, parte das informações está oculta, contribuindo para a falta de legibilidade e demonstrando uma deficiência no acabamento.

\section{Aspectos ambientais da granola Mãe Terra}

A embalagem é produzida com um material de reciclagem complexa e de pouco valor na cadeia de reciclagem do Brasil, por ser um compósito de materiais (PET + PP), porém necessário para a preservação do produto. 


\title{
Apresentação dos dados das entrevistas
}

A marca Mãe Terra foi um dos principais critérios para separar a granola como mais saudável, sendo citada por quatro dos oito consumidores. Alguns também relacionaram a marca como um produto orgânico, mesmo não sendo, tendo essa informação citada por dois consumidores. "[...] e esse aqui eu conheço a marca, eu sempre comprei ela achando que era uma marca só de orgânicos" (CA22, 2013).

A composição dos ingredientes foi considerada como um dos critérios para separar como mais saudável.

\begin{abstract}
Ah, linhaça dourada. Mãe Terra, natural de verdade. Ah, tem mel, está vendo, não deve ter açúcar. Sem aditivos artificiais, cinco grãos integrais, rico em fibras. Sem conservantes, sem açúcar branco, sem gordura, sem transgênicos, mais integral, mais natural. Ah, esse é bom. (CA25, 2013)
\end{abstract}

Um dos consumidores (CA16, 2013) destacou uma informação do painel traseiro do texto que fala da composição do produto: "Você viu aqui: 'Sem ingredientes artificiais com nomes esquisitos. Aveia, castanha, linhaça, mel, frutas secas'”. E depois se lembrou desse texto enquanto olhava outro da granola Kellness. "[...] este aqui tem os nomes esquisitos que falou lá, porque tem o ácido ascórbico, o ascorpato, niacina amida, acho que era isso que eles estavam falando. Mas foi o único que eu encontrei nomes esquisitos".

A embalagem plástica e com brilho foi considerada por um consumidor como algo negativo, por imaginar que um produto mais saudável costuma ter um acabamento mais fosco.

Hum, engraçado. Tem alguma coisa de toque pra mim, isso aqui [Trio] seria mais natural do que esse aqui [Mãe Terra], e quando eu vi eu disse: 'Nossa, que coisa horrível', e quando eu vi 'Mãe Terra', não bate, minha cabeça não bateu, entendeu? [...] É a imagem da coisa natural ser mais de tons mais pastel [sic], mais zen. Muito ruim essa. (CA15, 2013)

Como não foram feitas perguntas específicas sobre a granola Mãe Terra, as informações dos consumidores foram fornecidas de forma espontânea durante a separação do produto em grupos.

A partir dos dados apresentados, observa-se que a estratégia de design da embalagem de granola mudou em relação aos outros produtos da empresa, deixando a embalagem menos séria e mais lúdica. Porém, essa mudança fez com que perdesse a sua identidade visual, o que não foi tão percebido como positivo pelos outros consumidores. Todas as informações querem se destacar fazendo com que nada em especial apareça.

\subsubsection{Macarrão instantâneo do Grupo 4 de preparo rápido para o consumo}

No caso do macarrão instantâneo, a marca mais separada como saudável foi a Mãe Terra, por todos os sete consumidores.

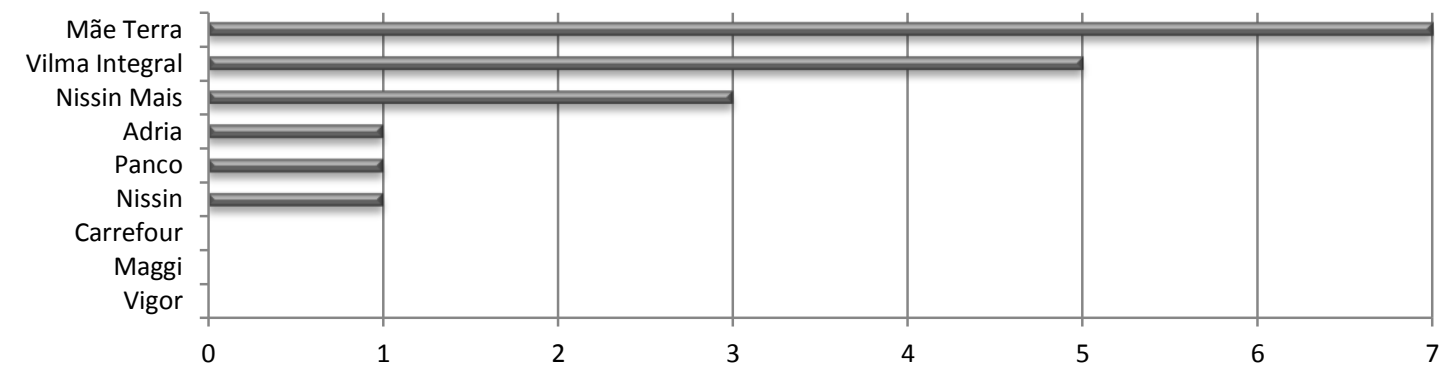

Gráfico 83 - Marcas de macarrão instantâneo separadas como mais saudáveis (unidade = ํㅡㅁ de consumidores) 
Os principais critérios para a separação foram: a forma de preparo não frita (cinco consumidores), a informação de que se trata de um macarrão integral (cinco consumidores) e que tem menos sódio ou aditivos (três consumidores), conforme o gráfico abaixo:

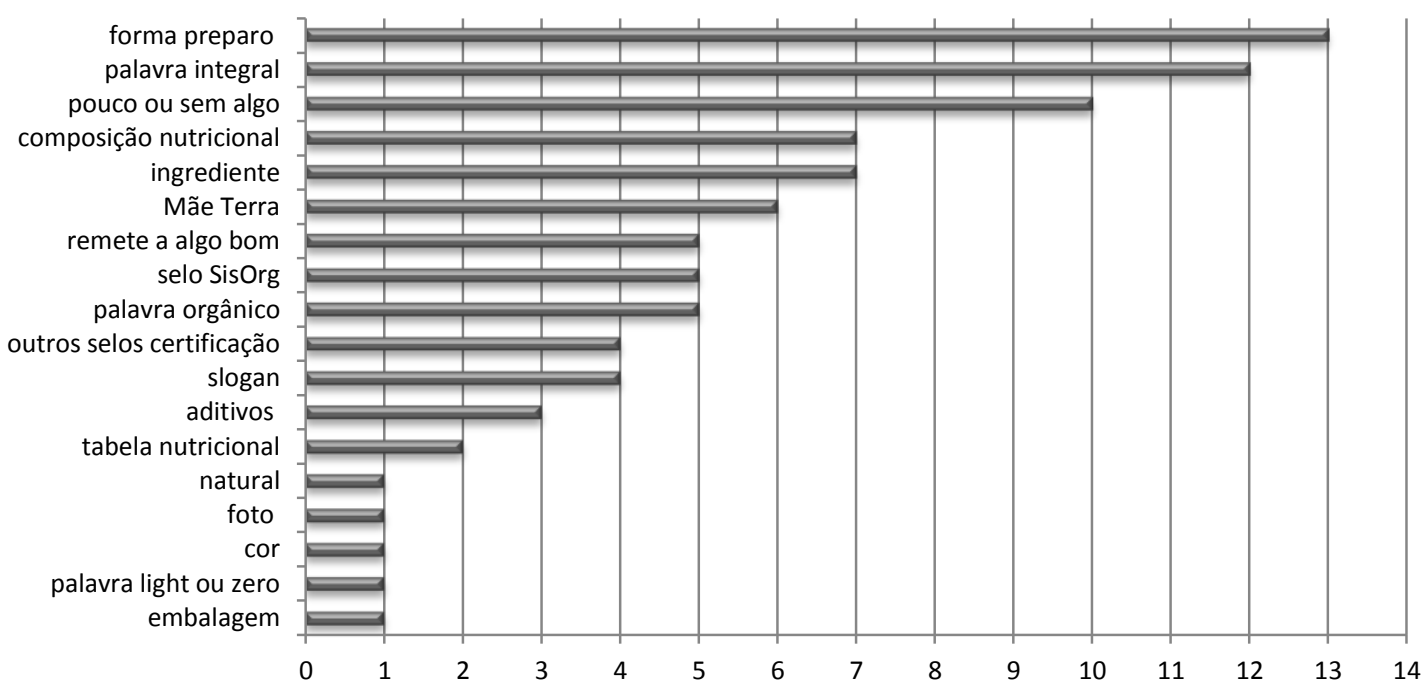

Gráfico 84 - Critérios para separação de macarrão instantâneo como mais saudável (unidade = nº de menções)

O Caseirito era o único macarrão instantâneo apresentado para os consumidores, e encontrado no mercado, cuja massa não é frita. O macarrão tipo lámen, para cozinhar rápido, usa bastante gordura na sua composição; já o Caseirito cozinha mais rápido pela massa ser mais fina. Muitos dos consumidores entrevistados não tinham essa informação antes da entrevista e a consideraram positiva, sendo uma das mais mencionadas. Na maioria das vezes, o critério para a separação em saudável e não saudável foi a composição do produto, por informar que tem menos sódio e não tem aditivos artificiais.

Nos dois, eu levei em consideração o que a gente sempre fala e leva em consideração, que é a adição de sódio. Então esse aqui está informando que é light em sódio, 37\% menos, então acredito que este aqui é mais saudável. E esse aqui também [Caseirito], além de menos sódio, está escrito que não é frito. (CB01, 2013)

Um dos consumidores comentou que só descobriu que esse tipo de macarrão tem tanto sódio durante a entrevista, e acabou sendo este o seu critério de seleção.

O critério foi em primeiro lugar o sódio, o que mais me chocou em porcentagem de necessidades diárias, esse grupo que eu não gostei, $76 \%$ das necessidades de sódio por dia, achei muito. E essa outra categoria aqui, a categoria que eu mais gostei, $37 \%$, tem uma que é até menos, $26,22 \%$ das necessidades diárias de sódio. Foi o que mais me chamou a atenção. (CC16, 2013)

Os principais critérios para separar o macarrão como menos saudável foram a composição nutricional (cinco consumidores), ser um macarrão instantâneo comum (sete consumidores) e a composição dos ingredientes (quatro consumidores). 


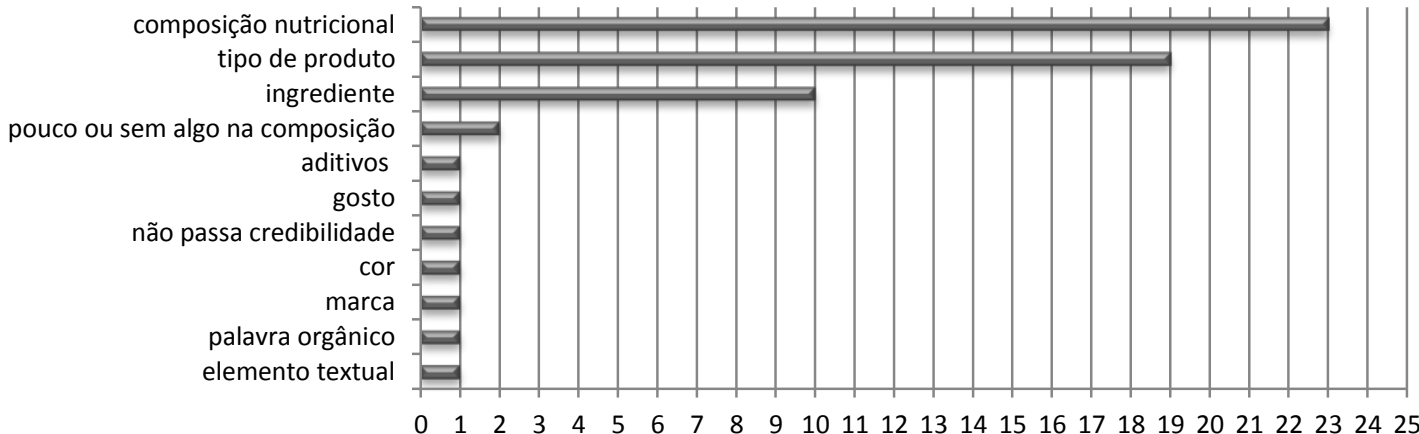

Gráfico 85 - Critérios para separação de macarrão instantâneo como menos saudável (unidade = no de menções)

O tempero oferecido em pó na embalagem é considerado como algo negativo, artificial e não saudável.

[...] o 'pozinho' que vem junto, o 'temperinho', eu sempre acreditei que é muito artificial, com muitos condimentos, uma coisa muito forte. Eu não acredito. Me dá até uma sensação que vai causar um buraco no estômago. (CA15, 2013)

Todos os consumidores entrevistados consideram que o macarrão tipo lámen é um produto não saudável, mesmo quando admitiram consumir. "[...] eu já tenho uma coisa de acreditar que Miojo é aquela coisa de última hora, que não tem nada de saudável, não tem conteúdo nenhum" (CA15, 2013).

As marcas de macarrão instantâneo separadas como orgânicas foram a Mãe Terra em primeiro lugar, indicada por todos os sete entrevistados, e, em segundo lugar, empatadas, a Maggi, Nissim Mais e Vilma Integral, por apenas um consumidor.

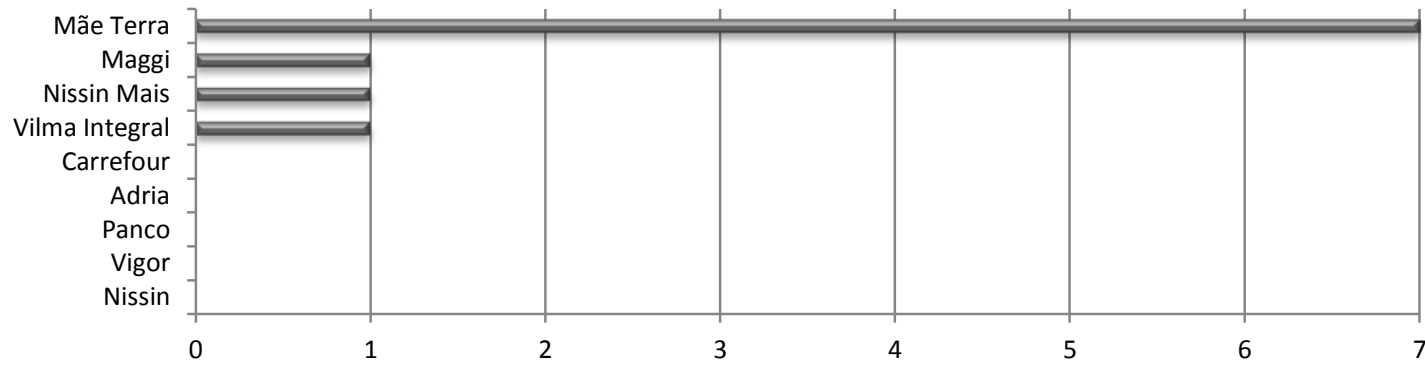

Gráfico 86 - Marcas de macarrão instantâneo separadas como orgânicas (unidade = ํㅜㅁ de consumidores)

Para separar em orgânico e não orgânico, a principal informação textual olhada foi a palavra "orgânico" (cinco consumidores), o slogan (três consumidores) e o selo SisOrg (dois consumidores). Abaixo, vêm os ingredientes (um consumidor) e ser frito (um consumidor).

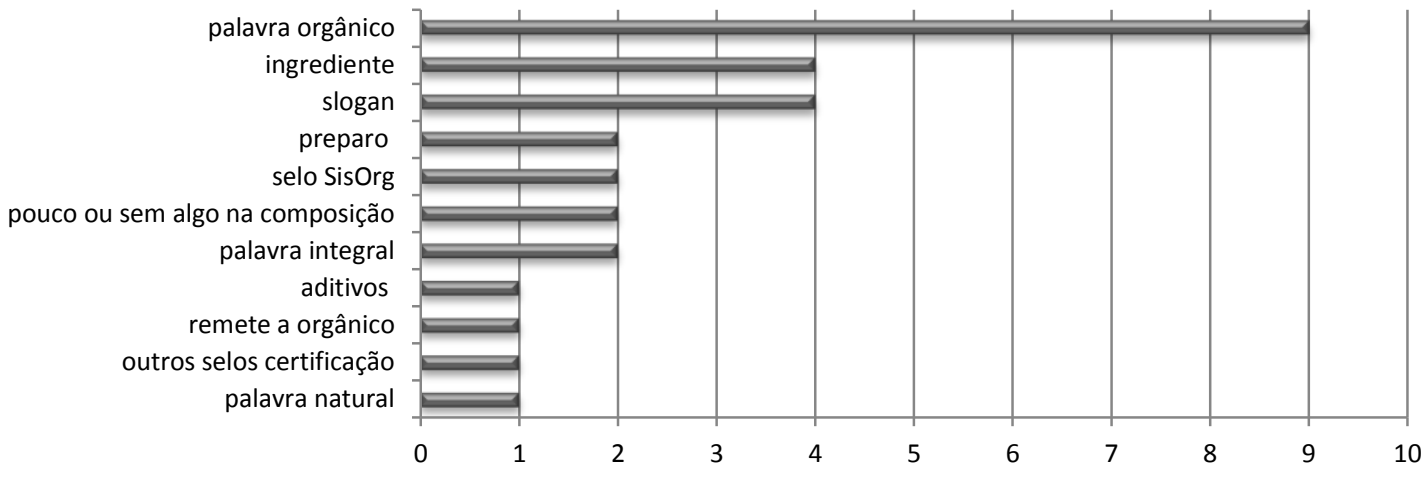

Gráfico 87 - Critérios para separação de macarrão instantâneo como orgânico (unidade = no de menções) 
O principal critério declarado para separar como não orgânico foi os aditivos químicos, por dois consumidores. Os outros consumidores já haviam declarado que já haviam separado os orgânicos e que os demais produtos não tinham essa informação.

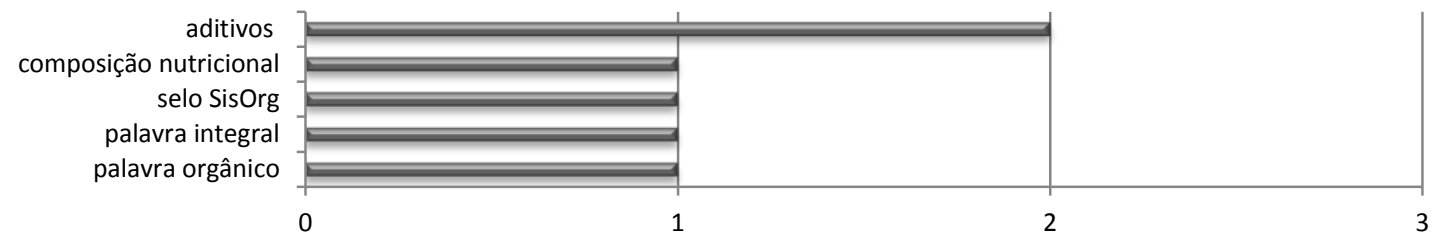

Gráfico 88 - Critérios para a separação de macarrão instantâneo como não orgânico. (unidade = no de menções)

Todos os consumidores consideraram o tipo de produto, macarrão instantâneo, como um produto não saudável, porém, com base nos dados apresentados, podemos considerar que a forma de preparo da massa do macarrão, no caso da Mãe Terra, não frita, e a palavra "integral" foram os principais critérios para separar o produto como mais saudável. Para identificar como alimento orgânico, a informação textual e o selo SisOrg foram suficientes havendo pouca dúvida, apenas um consumidor usou como critério o sabor do macarrão.

\subsubsection{Caseirito Mãe Terra}

O Caseirito Mãe Terra segue outro padrão de design das embalagens. A seguir, serão analisadas as características específicas desse produto. A embalagem em tamanho real pode ser conferida no Anexo A.

\section{Análise do painel frontal do macarrão instantâneo Caseirito Mãe Terra}

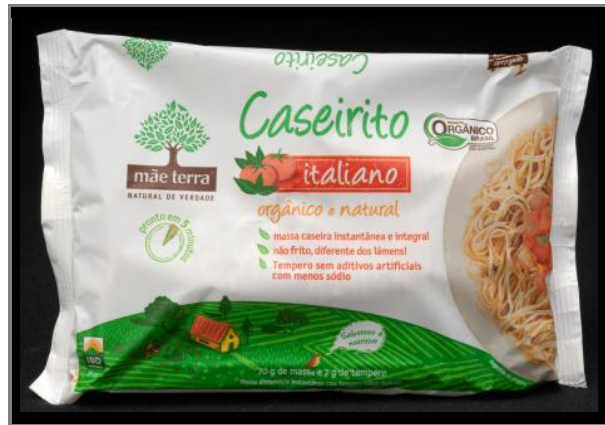

Painel frontal

Informações obrigatórias

Marca; Nome do produto; Selo SisOrg; Quantidade;

Selo certificador (IBD)

Informações não obrigatórias

Sabor; Tópicos com características do produto;

Splash "pronto em 5 minutos"; llustração da fazenda;

Fotografia do prato de macarrão pronto.

Figura 157 - Painel frontal da embalagem do macarrão instantâneo Caserito Mãe Terra

Segundo o sentido de leitura, de cima para baixo, da esquerda para a direita, a primeira informação do painel frontal é a marca Mãe Terra, seguida pelo box vermelho com a informação do sabor do macarrão.

A marca é aplicada sobre o fundo branco, dando um bom contraste de cor e sendo fácil de visualizar. $\mathrm{O}$ nome do produto em verde com um tipo manuscrito remete a algo mais caseiro, aplicado sobre o fundo branco é bem visível.

O selo SisOrg tem pouco destaque na embalagem, sendo aplicado entre várias informações visuais e acima do prato. A palavra "orgânico", em cor laranja, abaixo do sabor, tem pouco contraste com o fundo, mas é legível. 
O splash "Pronto em 5 minutos" tem pouca visibilidade e é uma das últimas informações vistas, por ter pouco contraste com o fundo, pela hierarquia das demais informações mais destacadas e pela sua localização na embalagem.

A foto do prato do macarrão tem pouca definição por causa do processo de impressão e não se destaca. As cores da foto parecem acinzentadas e o prato não aparenta ser apetitoso.

O box do sabor, que diferencia a embalagem dos outros sabores, chama a atenção por sua cor vermelha, mas a ilustração do tomate não contrasta com a cor do fundo.,

A ilustração da fazenda na embalagem do Caseirito é bem menor e com menos importância se comparada com as embalagens de ingredientes, mas ainda chama a atenção pelo predomínio da cor verde.

Os elementos gráficos estão em desequilíbrio com elementos mais do lado direito do que do esquerdo, porém o box do sabor na cor vermelha, no centro da embalagem, acaba compensando.

A tipografia usada é a mesma da embalagem de ingredientes, usando a fonte manuscrita para os destaques, como a palavra "orgânico" e o sabor.

\section{Análise do painel traseiro do macarrão instantâneo Caseirito Mãe Terra}

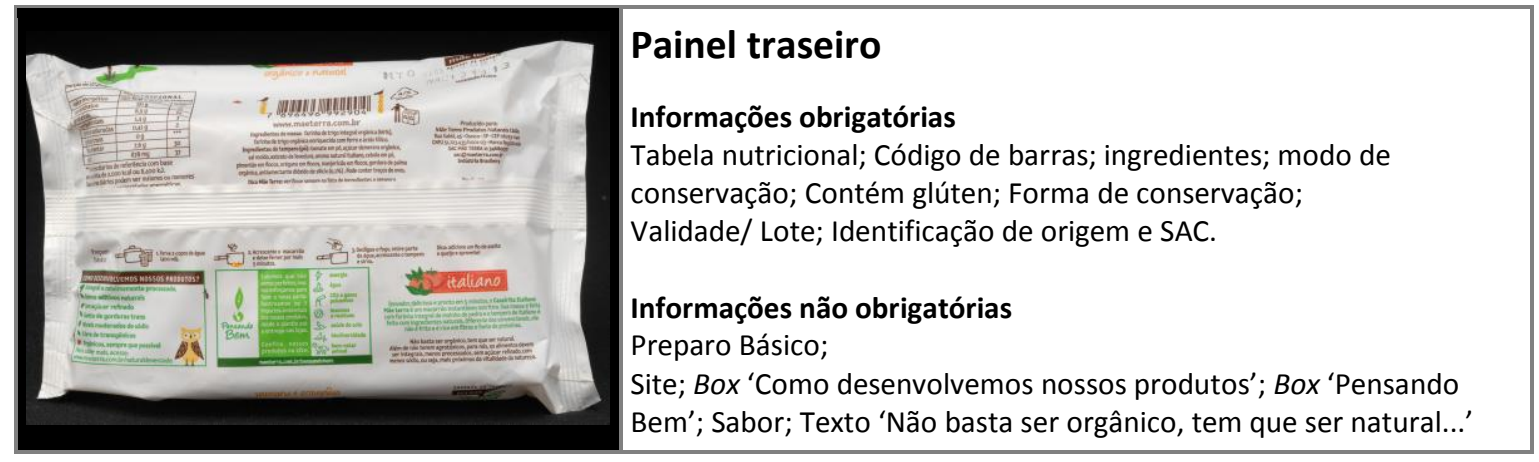

Figura 158 - Painel traseiro da embalagem do macarrão instantâneo Caserito Mãe Terra

Segundo o sentido de leitura, de cima para baixo, da esquerda para a direita, a primeira informação do painel traseiro é a tabela nutricional, seguida pelo box "Pensando Bem" e o box do sabor do macarrão.

O painel traseiro apresenta muitas informações com peso parecido, onde nenhuma se destaca. Os tipos dos textos estão em um tamanho pequeno, dificultando um pouco a leitura de textos como o dos ingredientes. Porém, em um texto com o tipo manuscrito e em verde, é destacada a informação "não contém glutamato monossódico", valorizando essa informação.

O código de barras é apresentado junto da ilustração de dois passarinhos apoiados e hastes que parecem de madeira, como uma cerca da fazenda.

Ao lado do código de barras, está localizada a identificação do material e o ícone orientando a forma de descarte conforme o padrão ISO 14021, facilitando a identificação dos materiais para a reciclagem. 
No modo de preparo, são utilizadas ilustrações de panelas, que agregam informação ao texto com o tipo pequeno e pouco legível. O box "Como desenvolvemos nossos produtos" está localizado em uma área de grande tensão visual, ganhando destaque.

Os elementos gráficos estão em desequilíbrio, pois as informações que mais se destacam estão localizadas na parte de baixo do painel traseiro.

\section{Análise dos painéis superior e inferior do Caseirito Mãe Terra}

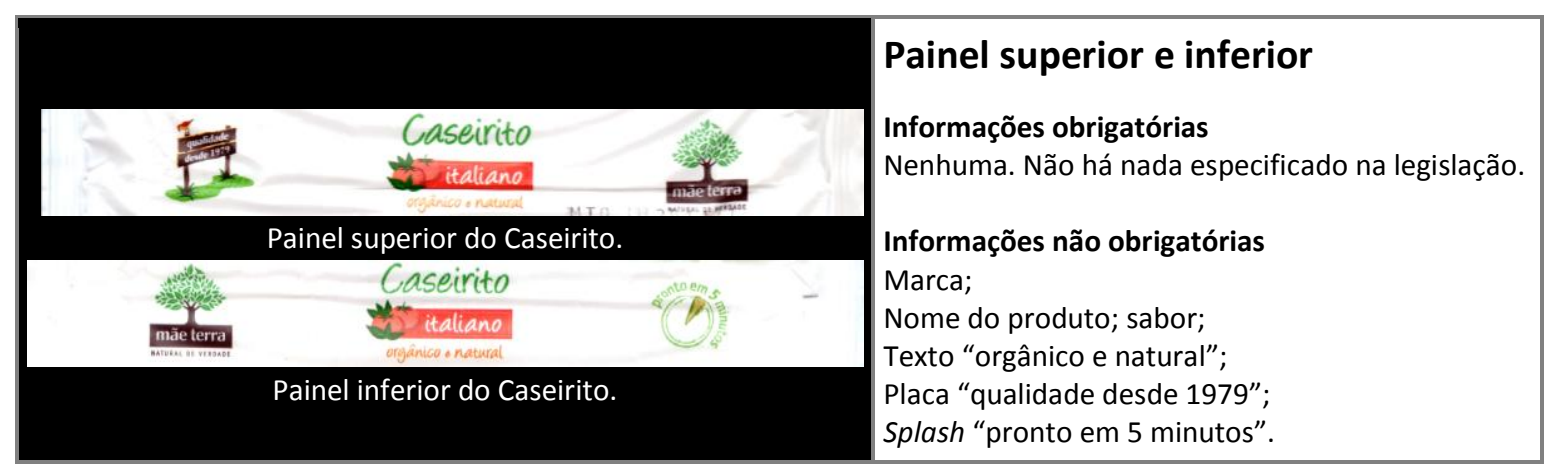

Figura 159 - Painel superior e inferior da embalagem do macarrão instantâneo Caserito Mãe Terra

Segundo o sentido de leitura, de cima para baixo, da esquerda para a direita, a primeira informação do painel superior é a plaquinha "Qualidade desde 1979".

No painel inferior, é a marca Mãe Terra, seguida do nome do produto e do sabor. No painel superior, a última informação, localizada à esquerda, é a marca Mãe Terra e, no inferior, o splash "Pronto em 5 minutos".

O que chama mais a atenção aqui, pela cor em contraste com o fundo, é o box de sabor do macarrão.Os tipos usados são os mesmos das embalagens de ingredientes, e as informações em destaque estão em fonte manuscrita.

\section{Hierarquia de leitura}

A hierarquia de leitura da embalagem do Caseirito da Mãe Terra demostrada abaixo faz com que informações mais relacionadas à marca também tenham destaque, porém, no caso do Caseirito, o sabor do macarrão se destaca, tendo um peso visual igual ao da marca Mãe Terra. 


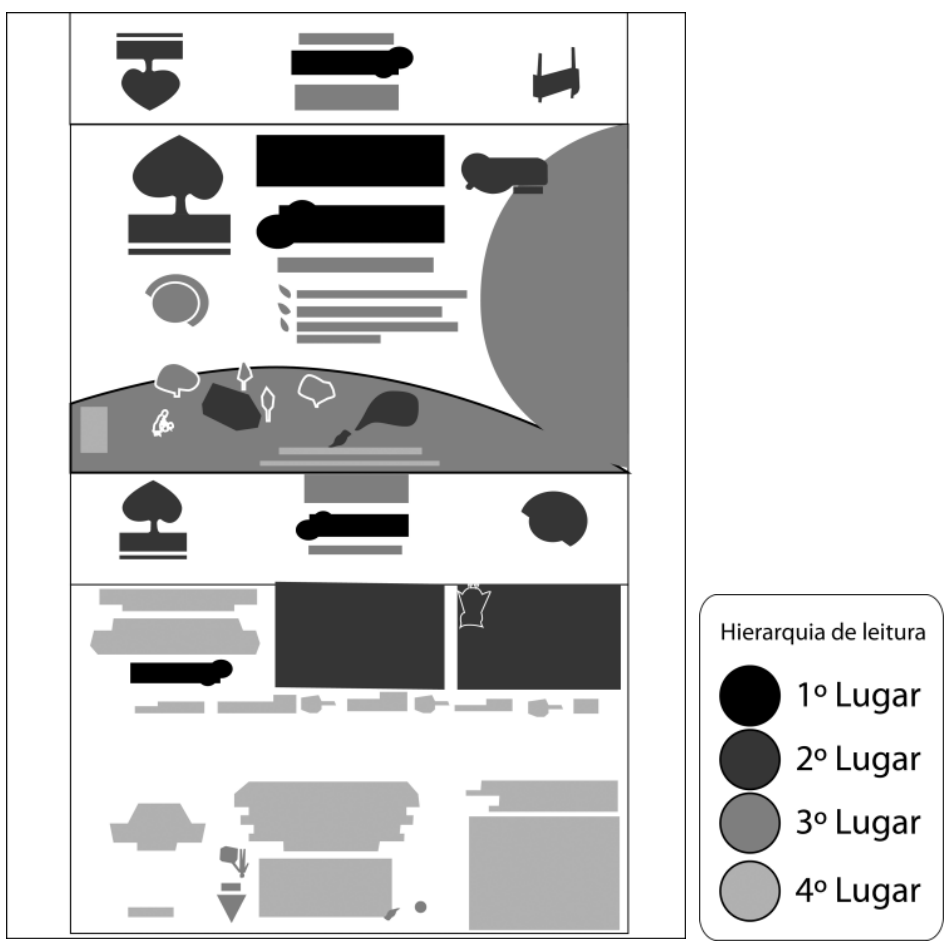

Figura 160 - Hierarquia de leitura do Caseirito Mãe Terra

\section{Questões técnicas do macarrão instantâneo Caseirito}

Foi questionado para Indústria1 se havia alguma característica no Caseirito que necessite de alguma barreira especial na embalagem. Segundo ele:

O Caseirito, ele não me parece que tenha uma necessidade muito específica de barreira. Ele é seco e processado. Ele é uma massa, não é um arroz que é só um grão. Mas ele precisa de barreira contra umidade. Mas uma resposta específica, mais técnica, eu não tenho condições de dar. (INDÚSTRIA1, 2012)

O plástico da embalagem é um compósito de materiais (PEBD+PP), identificado na embalagem, com o lado fosco para fora.

A embalagem possui um berço plástico para proteger o macarrão. Segundo Indústria1, a massa do Caseirito é muito mais frágil e diferente do macarrão tipo lámen convencional, que é uma massa pré-frita, com uma estrutura rígida. Para poder cozinhar em cinco minutos, e não sendo pré-frita, tem de ser uma massa mais fina.

Eles pensam em outras opções de materiais para a embalagem, como o papel, mas, por limitação do fornecedor, ainda não fizeram a mudança.

O problema da embalagem inteira cartonada, que seria muito legal [...] precisaria de uma encartuchadeira, você precisa de uma máquina. [...] Para contextualizar, esses produtos, eles são terceirizados, eles não são feitos aqui. A gente não tem máquina para fazer isso aqui. [...] No caso do Caseirito, o nosso fornecedor não tem essa máquina. É uma produção extremamente específica. A gente, na verdade, é uma parte muito pequena de uma linha gigante de massas, e eles não têm. (INDÚSTRIA1, 2012)

A possibilidade de a embalagem ser em papel também foi pensada por um consumidor.

Será que teria jeito de fazer a embalagem de "Miojo" de papel? Porque daí não é plástico, né? [...] Plástico é um ponto negativo sim. Se fosse de papel, sei lá, algum tipo de papel, que dizem que plástico solta resíduo. (CA25, 2013) 
A bandeja plástica foi percebida por alguns consumidores como algo positivo. "Tem até uma caixinha lá dentro. Isso é mais uma coisa positiva. É importante ter isso lá dentro para não quebrar" (CC16, 2013).

Porém, mesmo percebendo que era para proteger o produto, chamou a atenção de outro consumidor de forma negativa.

Ele tem uma bandeja plástica dentro da embalagem, isso aqui é um item que você descarta no ciclo do lixo. Se tem este plástico aqui, quer dizer que esse produto é mais frágil, talvez se quebre com facilidade, então a chance de você ter um macarrão inteiro é menor. (CB01, 2013)

A massa mais fina também foi percebida como algo positivo. "Bom, o macarrão é fino, e Miojo geralmente é grosso. Então o fato de ser fino parece ser uma coisa melhor, de qualidade superior" (CB17, 2013).

A bandeja plástica acaba aumentando a embalagem em comparação aos outros macarrões. Essa percepção passou como algo negativo, dando a sensação de que a embalagem estava vazia, com pouco produto. "E eu achei ele muito contrário aos outros, ele é muito vazio, tem muito ar dentro, a embalagem é pouco aproveitada, um espaço maior nela, e isso tem uma perda também e eu acho que isto é negativo" (CB01, 2013).

A qualidade da fotografia do prato tem pouca qualidade, aparentemente por limitação do processo de impressão e, por isso, não parece apetitoso.

\section{Aspectos ambientais do macarrão instantâneo Caseirito}

Os fornecedores de embalagem estão localizados perto da fábrica, não havendo muito gasto energético para o transporte.

Por ser um compósito de materiais (PEBD + PP), a reciclagem é dificultada, tendo pouco valor na cadeia de reciclagem. Além do material extra do berço da embalagem, sem identificação do tipo de material.

O ícone de forma de descarte e a informação do material são apresentados dentro do padrão ISO 14021, porém não é identificado qual foi o material utilizado na bandeja.

\section{Apresentação dos dados das entrevistas}

Apenas um dos sete entrevistados já havia comprado o Caseirito. O motivo da compra foi a marca Mãe Terra e por ser orgânico. Dois consumidores já haviam visto, mas não compraram porque não costumam comprar esse tipo de produto ou acham caro. Três consumidores nunca tinham visto o produto.

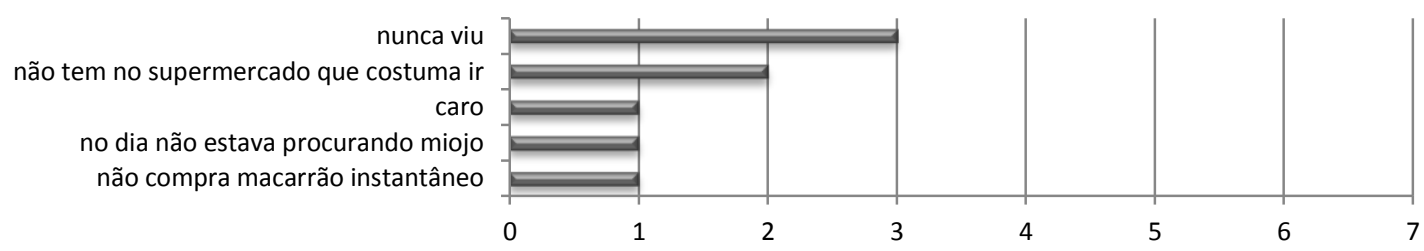

Gráfico 89 - Motivos para não ter comprado o macarrão instantâneo Caseirito (unidade = no de consumidores)

As principais características positivas do Caseirito da Mãe Terra declaradas pelos consumidores foram: a forma de apresentação e organização das informações (três consumidores), ter as informações de "menos sódio" e "sem aditivos artificiais" (quatro consumidores) e ser orgânico (cinco consumidores). 
organização informações palavra orgânico preparo
remete a algo bom natural cor palavra integral marca Mãe Terra porção ilustração

elemento textual aparência do macarrão sabor ingrediente resistência acabamento sentir produto apelo visual outros selos certificação nome qualidade do produto gosto pessoal composição nutricional design legibilidade plástico selo SisOrg informações na frente slogan modo preparo palavra natural

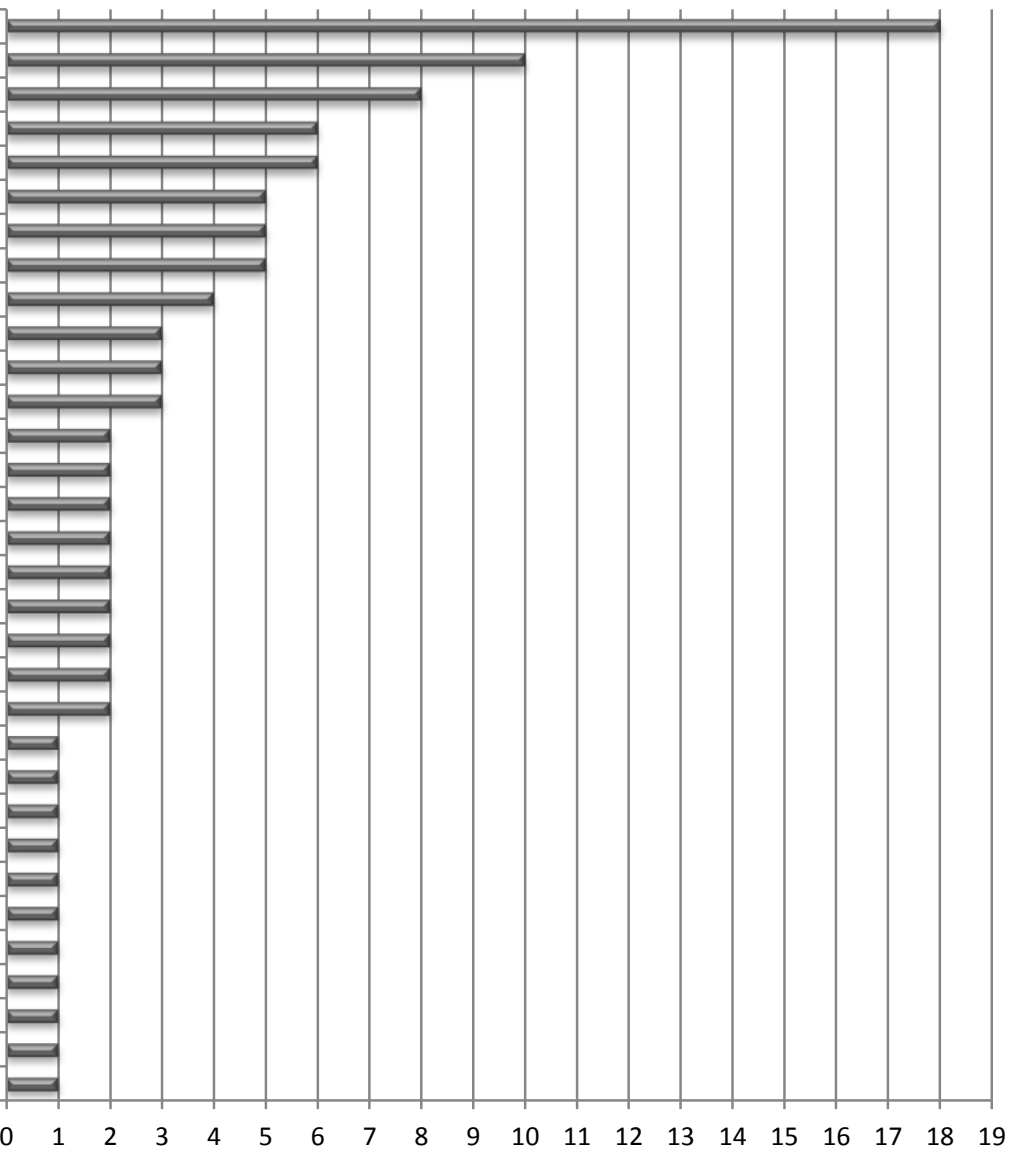

Gráfico 90 - Aspectos positivos do macarrão instantâneo Caseirito Mãe Terra (unidade = nํo de menções)

As principais características negativas do Caseirito declaradas pelos consumidores foram: remete a algo ruim como não passar credibilidade, por não parecer apetitoso (dois consumidores) e a composição de ingredientes (dois consumidores). "Não sei, eu acho que parece natural, mas não parece muito apetitoso. Me parece [sic] ser bem insosso já na embalagem" (CB22, 2013).

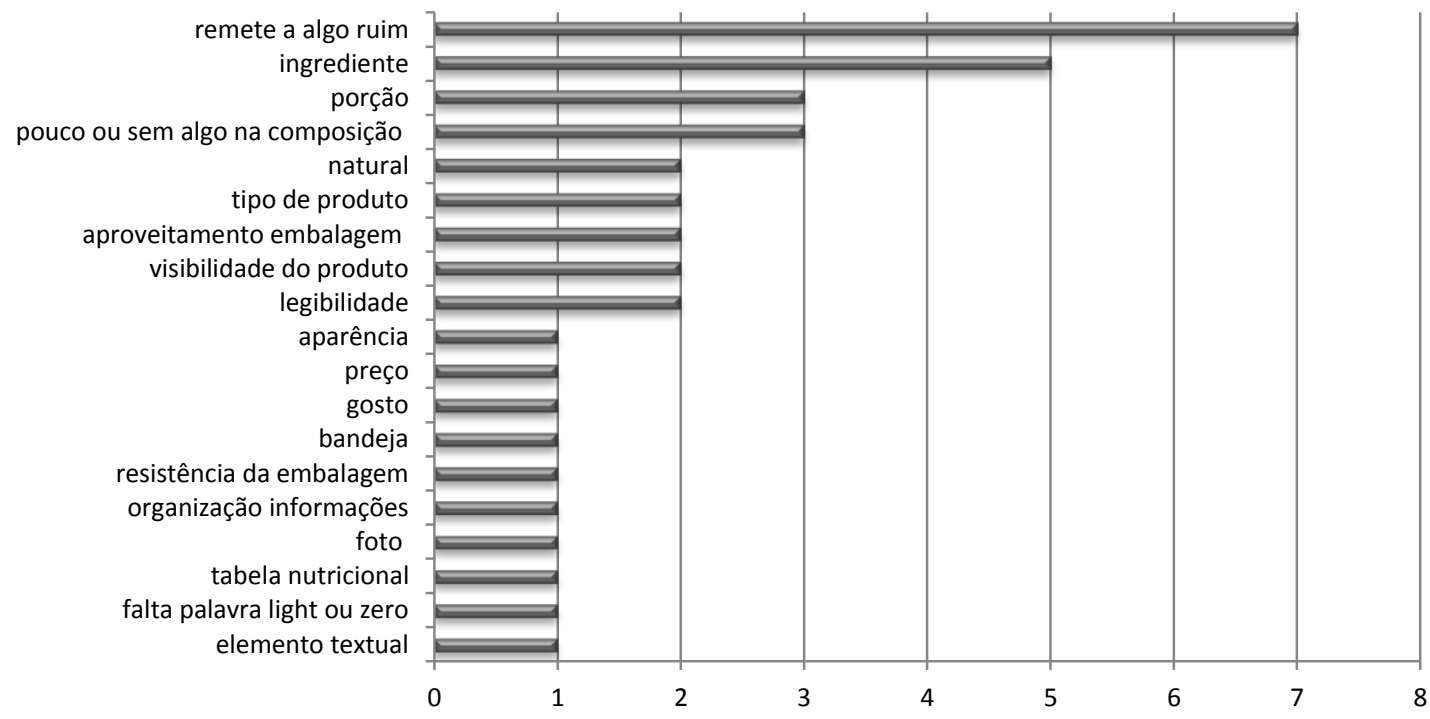

Gráfico 91 - Aspectos negativos do macarrão instantâneo Caseirito Mãe Terra (unidade = n⿳o de menções)

Mesmo sendo o macarrão da Mãe Terra um dos que tinham menos sódio, um outro apresentava uma quantidade um pouco menor. Por isso, então, foi considerado que a Mãe Terra não estava informando corretamente. 
Eles fazem propaganda enganosa: 'temperos com aditivos artificiais com menos sódio'. Mas olha que eu olhei o sódio de todos os "Miojos" e tem alguns que nem falam que têm menos e têm $36 \%$, e esse tem $37 \%$. Então um ponto meganegativo. Tem muito sódio. Tem a mesma coisa do que o Nissim. Essas marcas de "Miojo" que têm 36\%, inclusive, um por cento a menos. Então, né? Fez propaganda enganosa aqui. (CA25, 2013)

O fato de falar que é integral e depois mostrar que é apenas parte do produto também foi considerado negativo.

\begin{abstract}
Sabe o que eu acho engraçado? Mas é quase todos os produtos que falam que são integrais, mesmo assim, têm a farinha de trigo normal. Eles misturam a integral com a normal. Será que eles não poderiam fazer tudo com a integral? Esse aqui tem $66 \%$ da farinha de trigo integral. Tem uns que colocam $10 \%$ de integral e o resto é tudo trigo branco, e fala [sic] que é integral. Então eu acho que já que faz toda essa propaganda, destaca tudo isso, poderia fazer tudo de farinha de trigo integral. Embora seja $66 \%$, por que não $100 \%$ ? $(C A 25,2013)$
\end{abstract}

Dois dos sete consumidores entrevistados comentaram que não encontram com facilidade o produto. "Para falar a verdade, eu não vi esse produto no Carrefour. Estou sempre comprando no Carrefour, a Mãe Terra tem lá, mas não de macarrão instantâneo. Não observei" (CB01, 2013).

\title{
Embalagem
}

A embalagem da Mãe Terra, segundo os consumidores, destaca-se em relação aos outros macarrões instantâneos apresentados. "A embalagem é diferenciada em relação aos outros produtos. As embalagens dos outros [...] têm as embalagens muito parecidas" (CC16, 2013).

\section{Organização das informações}

Segundo Designer1, no Caseirito eles precisavam ter, na parte frontal, uma área grande para falar dos benefícios do produto, principalmente por ser o primeiro macarrão instantâneo natural.

A forma da organização das informações foi considerada como algo positivo pelos consumidores. "Porque ele é bem objetivo, ele coloca tudo aqui, o que a gente quer saber" (CB17, 2013).

\section{Slogan}

Na embalagem do Caseirito, além da palavra "orgânico", foi adicionada a palavra "natural", cuja forma acabou parecendo um slogan do produto. Essa informação ajudou um consumidor a separar a embalagem como mais saudável. "Diferentemente dos que aqui estão apontados, então, e é o único que vem escrito saudável na marca" (CB01, 2013).

Já um consumidor relacionou o slogan da marca "Natural de verdade" com o macarrão, o qual que não considera um produto natural. "Ele fala 'natural de verdade'. Macarrão nunca é natural. Eu não sei, assim totalmente, entendeu?” (CB17, 2013).

\section{Ilustração}

A ilustração foi aproveitada da primeira fase de redesenho de embalagens. Como elas eram vetoriais, eles tinham mobilidade de mudar os elementos e construir outras a partir dessa ilustração inicial. Ele também desenhou os ingredientes para a diferenciação de sabores de cada embalagem. 
A ideia do horizonte, mais arredondado, veio da embalagem do arroz Ritto. Os ícones dos sabores, os cogumelos, os tomatinhos e as ervas, também foram desenvolvidos pelo mesmo ilustrador.

E que espertinhos, desenharam uma casinha, um agricultor aqui, é verdinho, Mãe Terra, arvorezinha... Sabe aquela coisa que a granola tinha que ter? Porque a pessoa já associa, né? Porque ninguém vai perder tempo observando a embalagem. (CA25, 2013)

Acho bonitinho, olha, isso aqui eu adoro, esse tipo de casinha na... é, essas coisas, é isso que me chamou a atenção, e a embalagem também é diferente. (CC30, 2013)

\section{Cor}

As cores da embalagem foram determinadas na primeira fase de redesenho da Mãe Terra, baseada nas cores da ilustração. No caso do Caseirito, as cores também são utilizadas para diferenciar os sabores.

[...] uma coisa que durou um pouco mais tempo foi a questão das cores na diferenciação de sabor, onde teve a necessidade de entrar esse box de cor, no centro que era o que pontuava o sabor que acompanhava a ilustração. Porque, antes, a ilustração do sabor, ela vinha na cena, embaixo na fazenda que tinha uma mulher, que ela colhia as coisas. Ela estava colhendo os ingredientes da sopa, só que isso não foi suficiente, a gente teve a necessidade de vir com esse box de cor forte, com os ingredientezinhos [sic] do lado. E tirou a mulher. Ficou mais distante a fazenda. (DESIGNER1, 2012)

A cor branca do fundo da embalagem e o plástico não transparente chamou a atenção de um dos consumidores. "O plástico esbranquiçado deu ideia de ser uma coisa diferenciada, ser um pouco melhor" (CC16, 2013).

\section{Fotografia}

Designer1 relatou que o Caseirito foi feito baseado nas mudanças que já haviam sido feitas no Ritto, colocando uma fotografia para visualizar o produto em um bow/ ${ }^{26}$.

No início do projeto, que eu lembro, tinha a questão da visualização do produto pronto que se iniciou com o produto no bowl e depois chegou no prato, justamente por uma questão de área da embalagem, e o bowl ocupava muito espaço, então o prato, mais de frente, você mostrava a metade dele que já era suficiente. (DESIGNER1, 2012)

\section{Tipografia}

Quanto à tipografia, segundo Designer1, nas embalagens da Mãe Terra, são usados dois tipos: um mais informativo e outro mais cursivo, para parecer mais caseiro. O nome do produto usa uma tipografia um pouco mais séria, com serifa, e, na palavra "orgânico", é usado um tipo mais manuscrito, para parecer "mais humano e saudável". 


\section{Matriz semântica Caseirito Mãe Terra}

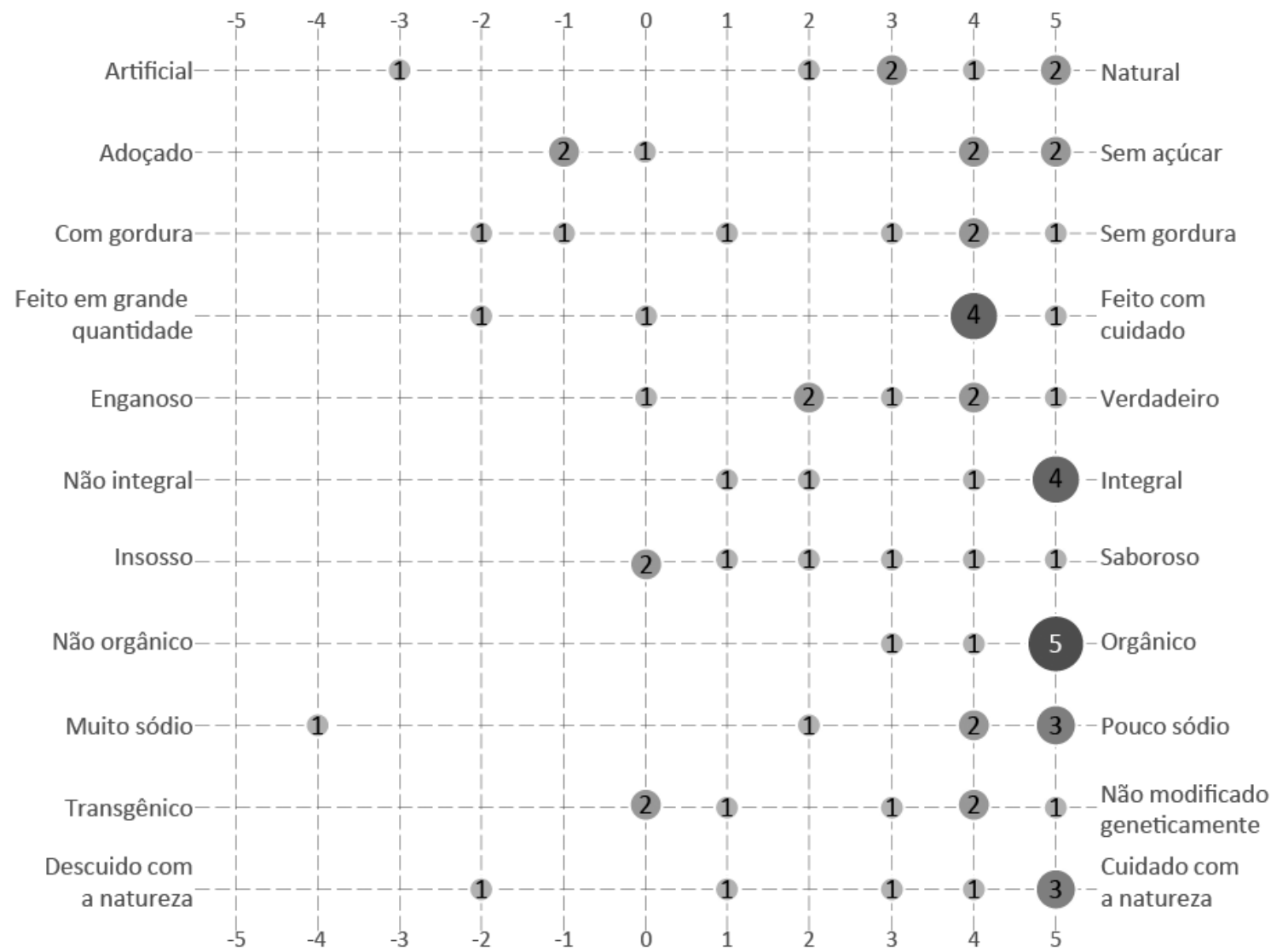

Gráfico 92 - Matriz semântica macarrão instantâneo Caseirito Mãe Terra

Observa-se na matriz semântica, preenchida no final da entrevista, um predomínio de respostas mais positivas do produto, porém mais distribuídas que nas embalagens anteriores.

Mesmo com a informação de não frito, as repostas de gordura estão mais distribuídas, porém tendendo mais para sem gordura.

As informações "feito com cuidado" e "feito em grande quantidade", no caso do Caseirito, tende mais para o positivo, diferente das outras embalagens.

As respostas da informação dos transgênicos, aqui, tenderam para o não modificado geneticamente.

A partir dos dados apresentados, observa-se que a embalagem do macarrão Caseirito da Mãe Terra passa bem a informação de que é um macarrão mais saudável se comparado com os outros macarrões instantâneos, pela forma de preparação não frita. Porém, mesmo percebendo que é um alimento mais saudável se comparado aos outros, a imagem do macarrão instantâneo é de um produto não saudável, para ser consumido apenas pela praticidade. 


\subsection{PÓS-CONSUMO, SIMBOLOGIA DE RECICLAGEM E CERTIFICAÇÃO}

Foi perguntado para os consumidores o que faziam com as embalegens após o seu consumo, para perceber se costumam separar as embalagens para a reciclagem ou se sentiam alguma dificuldade.

A maioria ( 25 consumidores) separa as embalagens para a reciclagem; 21 consumidores declararam que separam o lixo seco do úmido e sete declararam que separam as embalagens por material. Dois consumidores, um casal, declarou que separava, mas não separa mais, por não terem coleta seletiva na rua e por dependerem de levar para um catador conhecido. O material ficava acumulando na casa e acabaram desistindo do hábito.

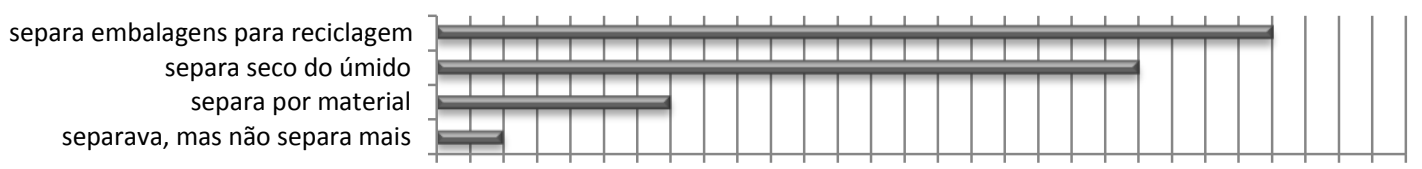

$\begin{array}{llllllllllll}0 & 1 & 2 & 3 & 4 & 5 & 6 & 7 & 8 & 9 & 1011 & 121314151617181920212223242526272829\end{array}$

Gráfico 93 - Forma de descarte das embalagens após o uso (unidade = ํㅡ de consumidores)

Questionados se sentiam alguma dificuldade para separar as embalagens para a reciclagem, 13 consumidores declararam que sentem algum tipo de dificuldade.

Quando os consumidores têm alguma dúvida de como separar a embalagem para a reciclagem, foi perguntado então o que eles fazem. Quatorze declararam que jogam no lixo reciclável; apenas dois consumidores declararam que procuram alguma informação na embalagem, revelando o desconhecimento pela maioria dos consumidores da Simbologia técnica de identificação de materiais, que poderia ajudar nessa hora.

\section{Quando fica em dúvida como separar a embalagem para a reciclagem o que faz?}

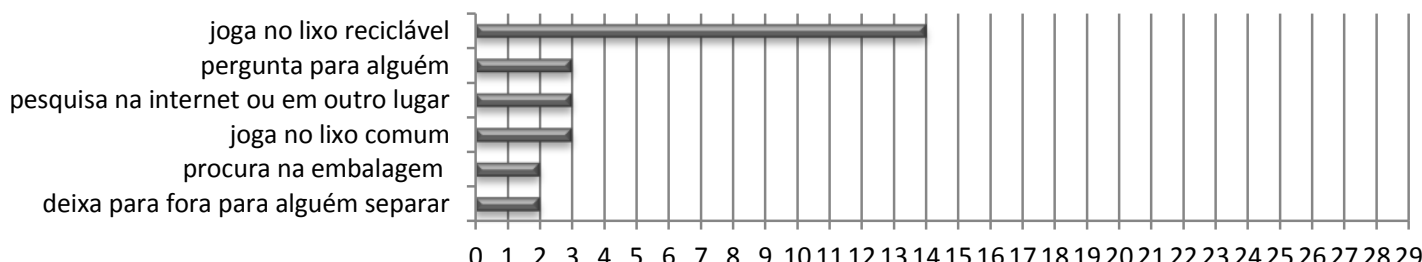

Gráfico 94 - Quando fica em dúvida de como separar para a reciclagem, o que faz? (unidade = no de consumidores)

Uma das questões da pesquisa era saber se as indústrias conheciam e aplicavam corretamente a Simbologia técnica de identificação de materiais, conforme estabelecido pelo ISO 14021, conforme orientação da Associação Brasileira de Embalagem (ABRE) para a melhoria do sistema de encaminhamento de materiais para a reciclagem.

Foi questionado, em entrevista, se os responsáveis pelas indústrias conheciam os símbolos da norma ISO 14021, e se os aplicavam. A Mãe Terra foi a única indústria que conhecia a simbologia e já a usava. Porém, em algumas embalagens selecionadas, como a do arroz integral, ainda usam outro padrão gráfico de identificação. 


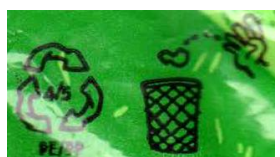

Figura 161 - Simbologia de identificação de materiais e reciclagem da 1ํㅡ fase das embalagens Mãe Terra

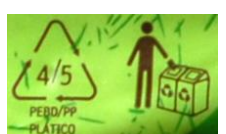

Figura 162 - Simbologia de identificação de materiais e reciclagem da $2^{\underline{a}}$ fase das embalagens Mãe Terra

Essa diferença nos símbolos foi justificada na entrevista da indústria: "A gente tinha uma linguagem própria, mas, por conselho de um parceiro nosso, que se chama Instituto de Embalagens $^{27}$, a gente passou a adotar o símbolo universal, que todos entendem" (INDÚSTRIA1, 2012).

Designer1, do escritório de design da Mãe Terra, também se lembra dessa mudança: ele conheceu a simbologia na mesma época que a Mãe Terra, em 2009. As embalagens depois alteraram a simbologia para o padrão ISO.

No começo, a proposta era toda a comunicação ter um pouco do lúdico e eles quiseram também trazer isso para essa parte de reciclagem. E aí depois, internamente, de casualidade na época, a gente participou daquele curso que a gente fez junto com você ${ }^{28}$. Na época, a gente recebeu aquela cartilha e toda uma orientação, e, automaticamente, eles, na mesma época, eles tiveram essa informação e aí foi uma mudança que foi feita. (DESIGNER1, 2012)

Para manter o lúdico do início do projeto, as novas embalagens que estavam ainda em desenvolvimento durante a entrevista, usarão de artifícios gráficos junto dos símbolos.

Hoje a gente está fazendo a linha de light/diet dos cookies. A gente manteve códigos e a gente colocou algo, setinhas com textinhos, por exemplo, 'reciclar faz bem', em volta, para chamar a atenção. Trouxe um pouco com a informação de pegar um pouco mais bem humorada, mas ainda respeitou os códigos de reciclagem. (DESIGNER1, 2012)

Indústria2 (2012), principal responsável pelas decisões da Monama, demonstrou, durante e após a entrevista, desconhecer a simbologia da ISO 14021. Declarando ser contra divulgar qualquer informação na embalagem que incentive a reciclagem, mostrou que orientar o consumidor para o descarte ambientalmente adequado não é prioridade para a empresa. "Eu sei reciclar, mas eu não vou passar para o meu consumidor como reciclar porque, se ele tentar reciclar, o governo vai misturar a embalagem de plástico com o lixo orgânico. Que é como funciona o Brasil" (INDÚSTRIA2, 2012).

Mesmo assim, na embalagem de granola (e apenas nela), há um símbolo estilizado parecido com o de reciclagem para identificar que a embalagem é de papel reciclado.

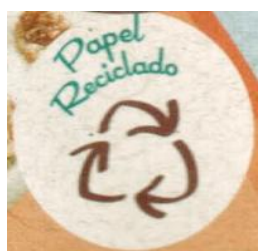

Figura 163 - Simbologia de reciclagem da Monama

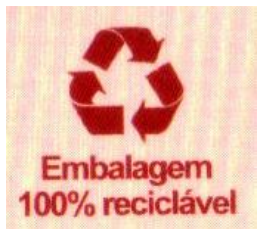

Figura 164 - Simbologia de reciclagem da Via Pax Bio

\footnotetext{
${ }^{27}$ Empresa que trabalha o ensino e pesquisa sobre as embalagens e sua qualidade técnica.

${ }^{28}$ Curso de Design de Embalagens Sustentáveis, realizado no Instituto de Design para o Desenvolvimento Sustentável (IDDS), em 2009, com os facilitadores Mateus Mendonça e Elisa Quartim Barbosa.
} 
Já Indústria3 (2012), da Via Pax Bio, não conhecia o padrão ISO, mas é a favor de passar a usar, pedindo mais informações a respeito após a entrevista. Mesmo desconhecendo a simbologia padrão, usa o símbolo de reciclagem nas embalagens como incentivo.

Para os dados relacionados ao conhecimento sobre os selos de certificação e simbologia para a reciclagem, foram mostrados alguns símbolos aos 29 consumidores entrevistados. Apesar de estarem em várias embalagens, apresentadas anteriormente, 18 consumidores não sabiam o significado dos símbolos apresentados. Em seguida, a tabela mostra amostragem de acertos em relação a cada símbolo.

\begin{tabular}{|c|c|c|}
\hline $\begin{array}{l}\text { Símbolo e } \\
\text { significado }\end{array}$ & $\begin{array}{c}\text { № de } \\
\text { consumidores }\end{array}$ & $\begin{array}{l}\text { Conhece este símbolo? } \\
\text { Qual o seu significado? }\end{array}$ \\
\hline \multirow{3}{*}{ Jogue o lixo no lixo } & 21 & diz que conhece \\
\hline & 20 & conhece e fala corretamente o significado \\
\hline & 03 & não conhece mas interpreta corretamente o significado \\
\hline \multirow{3}{*}{$\underbrace{}_{\substack{\text { Outros } \\
\text { Plástico Outros }}}$} & 20 & diz que conhece \\
\hline & 03 & conhece e fala corretamente o significado \\
\hline & 00 & não conhece mas interpreta corretamente o significado \\
\hline \multirow{3}{*}{ Descarte seletivo } & 20 & diz que conhece \\
\hline & 16 & conhece e fala corretamente o significado \\
\hline & 09 & não conhece mas interpreta corretamente o significado \\
\hline \multirow{3}{*}{ Reciclagem } & 19 & diz que conhece \\
\hline & 16 & conhece e fala corretamente o significado \\
\hline & 04 & não conhece mas interpreta corretamente o significado \\
\hline
\end{tabular}

Tabela 15 - Símbolos de identificação de materiais apresentados nas entrevistas e resultados da entrevista com os consumidores.

Apenas dois consumidores comentaram espontaneamente sobre um símbolo de reciclagem. Um deles, na hora de separar os produtos, e outro, na hora das perguntas mais específicas do produto, após manusear a embalagem. Esse fato mostra que a maior parte dos consumidores entrevistados não se preocupa com esse tipo de informação na embalagem.

\subsubsection{Selos de certificação}

No final da entrevista com os consumidores, foram mostrados alguns selos de certificação, muitos deles que apareciam nas embalagens mostradas anteriormente. Dentre os selos de certificação, doze dos entrevistados não sabiam a diferença entre eles. Foi tomado o cuidado em deixar o selo SisOrg por último, para não caracterizar os outros como selos de certificação. Abaixo, a amostragem de acertos em relação a cada selo de certificação: 


\begin{tabular}{|c|c|c|}
\hline $\begin{array}{l}\text { Símbolo e } \\
\text { significado }\end{array}$ & $\begin{array}{c}\text { № de } \\
\text { consumidores }\end{array}$ & $\begin{array}{l}\text { Conhece este símbolo? } \\
\text { Qual o seu significado? }\end{array}$ \\
\hline & 10 & diz que conhece \\
\hline & 06 & conhece e fala corretamente o significado \\
\hline FSC & 00 & não conhece mas interpreta corretamente do significado \\
\hline & 12 & diz que conhece \\
\hline & 10 & conhece e fala corretamente o significado \\
\hline IBD & 10 & não conhece mas interpreta corretamente do significado \\
\hline & 05 & diz que conhece \\
\hline & 04 & conhece e fala corretamente o significado \\
\hline Ecocert & 00 & não conhece mas interpreta corretamente do significado \\
\hline \multirow{3}{*}{ 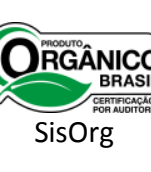 } & 21 & diz que conhece \\
\hline & 17 & conhece e fala corretamente o significado \\
\hline & 05 & não conhece mas interpreta corretamente do significado \\
\hline
\end{tabular}

Tabela 16 - Selos de certificação apresentados nas entrevistas e resultados da entrevista com os consumidores.

\subsubsection{Selo SisOrg}

Criado pelo Ministério da Agricultura, Pecuária e Abastecimento (MAPA) e escolhido por meio de consulta pública, segue a Instrução Normativa $n^{\circ} 50$, de 15 de novembro de 2009, conforme o decreto no 6.323, de 27 de dezembro de 2007.

O Manual de aplicação do selo oficial para produtos orgânicos (MAPA, 2009) define as normas de aplicação e exemplifica alguns exemplos de usos corretos e incorretos do selo. Ele define a proporção dos elementos que constituem o selo, determinada pelo seu módulo de referência conforme a figura abaixo:

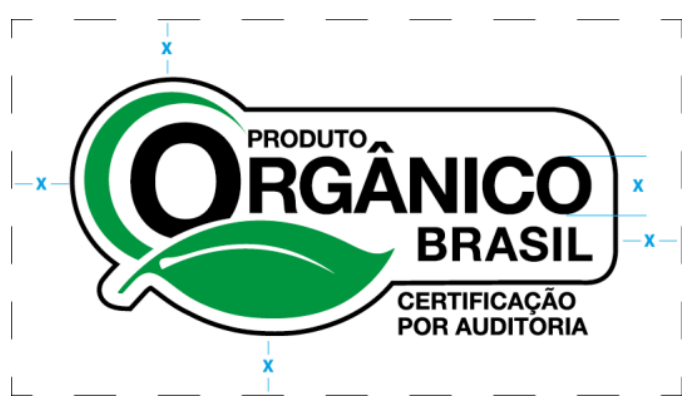

Figura 165 - Módulo de referência do selo SisOrg (MAPA, 2009)

Para garantir a integridade da marca na área delimitada em volta do selo (área de respiro), não podem ser aplicados quaisquer desenhos, fotos ou textos. Segundo o manual (MAPA, 2009), "as proporções e a área de respiro são definidas pelo módulo X. O fundo da área de respiro deve ser transparente, permitindo que a cor do rótulo prevaleça. A identificação do tipo de certificação, por auditoria ou sistema participativo, é aplicada na área de respiro".

A tipografia usada na construção do selo é a Helvetica Neue Bold. As letras podem ser utilizadas nas cores preta, quando o fundo é de cor clara, ou branca, quando o fundo é de cor escura, de forma a permitir melhor visualização. Para que ocorra a preservação da sua legibilidade, não é permitido reduzir o selo a medidas inferiores a $2,5 \mathrm{~cm}$. 
A versão colorida utiliza a cor preta $(100 \% \mathrm{~K})$ e verde $(100 \% \mathrm{C}+100 \% \mathrm{Y})$. Além da aplicação colorida, possui uma opção em apenas uma cor, o preto (100\%) nas letras e contorno e cinza (preto $30 \%$ ) substituindo o verde.

Quanto à localização do selo na embalagem, ele sempre deverá ser aplicado próximo ao nome do produto, em destaque, no painel principal.

O manual também fala do simbolismo de seus elementos gráficos:

[...] a folha verde como elemento principal remete à pureza do produto, por ser a parte mais delicada da planta. Aproveitamos a letra ' $O$ ' da palavra 'orgânico' para sugerir o sol por trás do horizonte, principal fonte de energia para o plantio. Um fio de contorno preto delimita irregularmente a figura, acompanhando seu desenho. $O$ fundo que preenche o interior do fio de contorno deve ser branco. (MAPA, 2009, p. 5)

\section{Análise do selo SisOrg}

O selo de certificação, como signo, comunica significados e expressa missões e posturas diante do mercado consumidor (SANTAELLA, 2012). No caso do produto orgânico, seria a promoção da qualidade de vida com proteção ao meio ambiente. A análise observa a tricotomia, formas e cores do selo.

\section{Tricotomia}

A tricotomia é uma rede de classificações sempre que pertence a uma tríade dos tipos possíveis de signo. Dentre todas essas tricotomias, as que ficaram mais conhecidas são: (1ㅇ) tomando-se a relação do signo consigo mesmo; $\left(2^{\circ}\right)$ a relação do signo com seu objeto dinâmico; (3ㅇ) e a relação do signo com seu interpretante. (SANTAELLA, 2005)

No caso do selo SisOrg, foi analisada a tricotomia da relação do signo com seu objeto dinâmico, em que é um ícone, quando remete ao produto, pois é a qualidade na sua relação com seu objeto (produto); é um índice, porque indica o universo do qual faz parte, apresentando uma conexão de fato com o todo do conjunto de que é parte; é um símbolo, pois extrai seu poder de representação, determinando que aquele signo represente um produto orgânico e é reconhecido pelos interpretantes como um produto que vem diretamente da natureza.

\section{Formas}

Quanto à sua forma, o selo SisOrg é formado por tipografia e desenho gráfico, possui formas geométricas arredondadas que transmitem neutralidade. A folha, abaixo da palavra "orgânico", contorna a primeira letra "O" e denota algo que vem da natureza. A fonte usada na construção do selo é da família da Helvética (Helvetica Neue Bold). Sem serifa, facilita a legibilidade, neutra, não transmite significado específico através de sua forma, porém, segundo Bringhurst (2005), a Helvética "evoca uma imagem de força bruta e persistência" devido à linha pesada e sem modulação e à pouca abertura, ou seja, pouco espaço interno entre as hastes.

\section{Cores}

Dondis (2007) nos indica que a percepção da cor é o mais emocional dos elementos específicos do processo visual, tem grande força e pode ser usada com muito proveito para expressar e intensificar a informação visual. 
No caso do selo SisOrg, o verde da folha simbolicamente está ligado aos "campos e árvores que fornecem proteção e abrigo" (TISKI-FRANCKOWIAK, 2000), sendo também associado ao bem-estar, qualidades estas divulgadas pelos produtores de alimentos orgânicos. A cor preta, no caso do selo, quando combinada com o verde, fica neutra, destacando os significados da folha e do verde.

\section{Opinião dos escritórios de design em relação ao selo}

Observou-se nas embalagens selecionadas no início da pesquisa, em 2011, que o selo de certificação era aplicado por cima da embalagem com um adesivo. Procedimento aprovado pela lei, que evitou um custo não programado para as empresas que são em sua maioria pequenas ou médias. Até o final da pesquisa de campo, no primeiro semestre de 2013, quase todas as embalagens já haviam resolvido esse problema e modificado suas embalagens, menos a Monama.

Esse período de mudança foi citado por Designer3 (2012), do escritório de design da Monama, que sentiu dificuldade em adaptar o projeto antigo para aplicar o selo de certificação.

\footnotetext{
Eu acho difícil de aplicar, ele tem uma redução superdifícil [...] não é um selo que tem personalidade para a gente conseguir aplicar em uma cor, por exemplo. [...] Claro que para o nosso cliente é legal ter isso aqui, é uma coisa que eles batalham para ter, mas ele chega aqui e a gente fica 'ai, estragou o nosso layout', sabe, mas não importa que estragou o layout, é uma informação que é bacana e tem que ter. [...] é muita informação [...] tinha que ser muito sintético. (DESIGNER3, 2012)
}

Já Designer2 (2013), do escritório de design da Mãe Terra, considerou que o design do selo SisOrg melhorou bastante em relação ao que era aplicado anteriormente, o do IBD. "É, por exemplo, esse selinho era bem feio e agora está bonitinho. Que antes tinha o da certificadora. [...] é bonitinho, acho que ele melhorou bastante" (DESIGNER2, 2012).

\subsection{CONSIDERAÇÕES FINAIS SOBRE OS DADOS}

Os dados da pesquisa apresentados mostram a complexidade do tema e as várias possibilidades de análise. $O$ foco da pesquisa são os aspectos ambientais e a percepção do consumidor, porém outros dados poderiam ser retirados e analisados para outros objetivos que valorizassem o projeto e a fabricação de novas embalagens de alimentos, sejam orgânicos ou não.

Uma vez que a análise de conteúdo privilegia a quantidade de termos citados e não o seu contexto, houve algumas distorções nos gráficos apresentados, que foram resolvidas com a triangulação com a análise do discurso das entrevistas e análise das embalagens.

As considerações finais em relação aos dados serão apresentadas no próximo capítulo. 


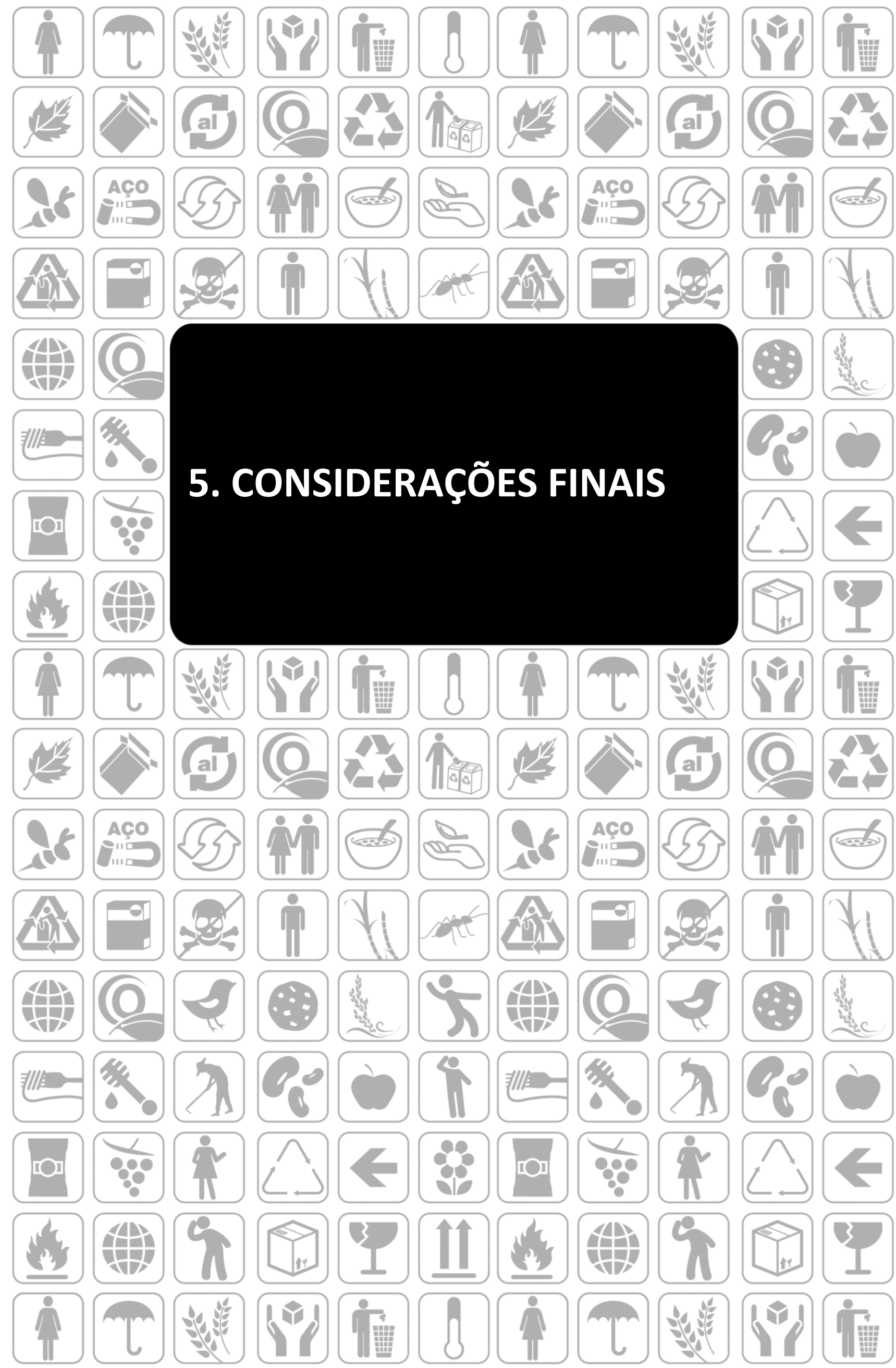




\section{CONSIDERAÇÕES FINAIS}

Nesta pesquisa, a proposta foi a de questionar se são considerados os princípios ambientais no design das embalagens de alimentos orgânicos industrializados por empresas selecionadas, representativas no mercado paulistano, e se estes princípios são percebidos pelos consumidores, assim como as especificidades inerentes aos alimentos orgânicos.

Diante dos resultados obtidos, pode-se afirmar que, dos questionamentos preliminarmente estabelecidos para a condução dos trabalhos de investigação desta dissertação, resultaram respostas que poderão orientar futuros projetos de embalagens de alimentos orgânicos.

As empresas Mãe Terra, Via Pax Bio e Monama demonstraram atender parte dos princípios ambientais para o desenvolvimento de seus produtos, porém a embalagem na maioria das vezes não foi incluída nesse processo.

As três empresas pesquisadas demonstraram adotar políticas internas para minimizar o impacto de suas embalagens, com ações como a escolha de materiais reciclados ou recicláveis para a embalagem, informações nas embalagens de ações já feitas pela empresa e rastreamento do impacto ambiental dos produtos. Entretanto, algumas vezes, o discurso de sustentabilidade da empresa não é condizente com o que foi observado, tanto na análise das embalagens, quanto no discurso dos profissionais envolvidos no desenvolvimento dos projetos e os profissionais responsáveis pelas próprias empresas. Isso mostra uma incoerência entre o que a empresa fala e a realidade observada na pesquisa.

As indústrias pesquisadas, por serem pequenas ou médias, dependem da disponibilidade de fornecedores e distribuidores, e consomem embalagens standard ${ }^{29}$ devido à falta de escala na produção de seus produtos. Por isso, entende-se que uma forma de minimizar seus impactos ambientais seria melhorar a comunicação nas embalagens de forma clara e rápida, para que o consumidor possa ser integrado ao processo de minimização dos impactos ambientais desses produtos. Poucas embalagens avaliadas refletiram no design de suas embalagens as ações ecológicas de suas empresas e não orientam o consumidor o que devem fazer.

Além disso, os consumidores demonstraram, pelas entrevistas realizadas, não conseguir perceber as ações de minimização do impacto ambiental de seus produtos ou das embalagens, como também não conseguiram identificar corretamente os produtos orgânicos ou perceber seu diferencial pelas embalagens dos mesmos.

Com base nos dados apresentados, pode-se observar que principalmente os consumidores de orgânicos, com mais conhecimento sobre a sua produção, foram capazes de comentar alguma informação da embalagem mais relacionada aos aspectos ambientais, dando indícios de que quanto mais consciente é o consumidor, mais ele pesquisa e mais ele procura outras informações na embalagem, além daquelas relacionadas ao produto.

Como as empresas, porém, declararam nas entrevistas que querem vender seus produtos para todos os consumidores, cabe a elas intensificar a divulgação das vantagens de se um alimento orgânico. O recurso ideal seria utilizar os meios de comunicação em massa, como a televisão, porém o custo é muito alto para uma pequena e média empresa. Por isso, um

${ }^{29}$ Embalagens padrão que não tem um design personalizado. 
trabalho mais intensivo em outros meios, como a internet, seria uma opção mais viável para estas empresas.

Em um caso, com o objetivo de passar a imagem de uma embalagem ecologicamente correta de empresa produtora de orgânico, a política de divulgação da marca nas embalagens conseguiu comunicar valores ecológicos. Muitas vezes, estes valores se sobressaíram ao que o produto ou a marca são, na realidade; por exemplo, ao fazer o consumidor considerar que todos os produtos de uma empresa são de origem orgânica, mesmo quando nem todos eles apresentam o selo de certificação.

Observa-se, portanto, que a identidade visual da marca e o branding da empresa têm grande influência na atribuição de valores a um produto e, por isso, marcas mais conhecidas são consideradas como mais positivas do que marcas desconhecidas.

Partindo-se das questões postuladas no capítulo introdutório desta dissertação, discutem-se a seguir as principais considerações obtidas a partir dos trabalhos de investigação.

Para um melhor entendimento das considerações finais desta dissertação, cada aspecto avaliado será apresentado em forma de tabela, onde os ícones simbolizam a avaliação final, conforme podemos ver abaixo:

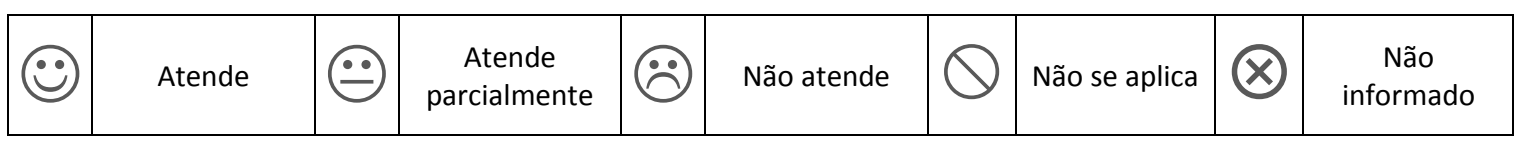

Figura 166- Forma de apresentação das respostas aos questionamentos desta pesquisa.

Para cada consideração, será apresentada primeiramente a avaliação baseada no discurso da empresa, para depois avaliar como isso se refletiu no design das suas embalagens e, finalmente, comprovar se o consumidor percebeu ou não os aspectos ambientais das empresas e as especificidades dos alimentos orgânicos pelas embalagens.

A avaliação dos aspectos ambientais foi baseada nos indicadores preconizados pelos órgãos reguladores e os aspectos relacionados às especificidades dos alimentos orgânicos foram baseados na legislação vigente, ambos apresentados no segundo capítulo desta dissertação.

\subsection{CONSIDERAÇÕES SOBRE O USO DE RECURSOS NATURAIS}

No que diz respeito ao uso de recursos naturais, observa-se que o discurso e as ações declaradas pelas empresas não se refletem nas embalagens. Não foi possível responder a alguns desses indicadores nesta pesquisa, seja por falta de conhecimento dos entrevistados ou por optarem por não fornecer a informação. Os indicadores que tiveram dados insuficientes para esta pesquisa foram:

- Consumo de recursos naturais;

- Uso de água;

- Demanda acumulada de energia;

- Uso de terra. 


\begin{tabular}{|c|c|c|c|c|}
\hline Uso de recursos naturais & Mãe Terra & Monama & Via Pax Bio & $\begin{array}{l}\text { Avaliação baseada nas declarações } \\
\text { das empresas }\end{array}$ \\
\hline $\begin{array}{l}\text { Evita o consumo de recursos não } \\
\text { renováveis }\end{array}$ & & & & $\begin{array}{l}\text { Foi avaliado se faz alguma ação na empresa } \\
\text { priorizando o uso de materiais renováveis } \\
\text { nas embalagens }\end{array}$ \\
\hline $\begin{array}{l}\text { Evita o uso de materiais virgens nas } \\
\text { embalagens }\end{array}$ & & & & $\begin{array}{l}\text { Foi avaliado se faz alguma ação na empresa } \\
\text { para evitar o uso de materiais virgens nas } \\
\text { embalagens }\end{array}$ \\
\hline $\begin{array}{l}\text { Preferência a materiais reciclados } \\
\text { em suas embalagens }\end{array}$ & & & & $\begin{array}{l}\text { Foi avaliado se a indústria dá preferência a } \\
\text { materiais reciclados em suas embalagens }\end{array}$ \\
\hline $\begin{array}{l}\text { Não usa substâncias perigosas ao } \\
\text { meio ambiente na produção de } \\
\text { embalagens }\end{array}$ & & & & $\begin{array}{l}\text { Foi avaliado se faz alguma ação na empresa } \\
\text { para avaliar o uso de substâncias perigosas } \\
\text { ao meio ambiente }\end{array}$ \\
\hline $\begin{array}{l}\text { Faz avaliação do ciclo de vida para a } \\
\text { minimização do uso de recursos } \\
\text { naturais como água, energia, } \\
\text { insumos e uso do solo }\end{array}$ & & & & $\begin{array}{l}\text { Foi avaliado se faz alguma ação na empresa } \\
\text { para avaliar e minimizar o uso de recursos } \\
\text { naturais }\end{array}$ \\
\hline
\end{tabular}

Tabela 17 - Avaliação do uso de recursos naturais baseada nas declarações das empresas.

Apenas uma das indústrias declarou que, no início da empresa, buscou materiais alternativos, de fontes renováveis para as suas embalagens, encontrando apenas fornecedores de outros países, aumentando o seu custo ambiental. Opções de materiais de fontes renováveis e que deem proteção suficiente para os produtos alimentícios ainda são poucas; assim, podemos considerar que pequenas e médias indústrias têm pouca margem no orçamento para inovar e buscar outras soluções de materiais de embalagens.

Nenhuma das empresas demonstrou evitar o uso de materiais virgens para suas embalagens. Além disso, apenas uma utilizou papel reciclado em uma embalagem, mantendo a embalagem primária em plástico, necessária para proteger o produto e também para que o material reciclado não entre em contato direto com o alimento.

Por outro lado, mesmo utilizando o papel reciclado na embalagem, foi declarado na entrevista que pretende-se trocá-lo por plástico transparente, por perceberem que os consumidores preferem comprar produtos com embalagens que permitam que eles vejam o conteúdo. Essa percepção e mudança de embalagem foram baseadas em visitas às lojas, onde esse questionamento foi feito de maneira informal, não baseado em metodologia científica, mostrando o despreparo da empresa em optar por uma grande mudança em sua embalagem sem conhecer profundamente o seu consumidor.

Essa mudança também mostra que o discurso da empresa não é coerente, uma vez que a mudança não é feita considerando os preceitos ambientais e sim questões de marketing. A empresa poderia optar em colocar uma janela na embalagem, sem desistir do uso do papel reciclado e do seu posicionamento de buscar materiais com menor impacto ambiental.

O não uso de substâncias perigosas na embalagem foi pensado apenas por uma indústria na hora da escolha de gráficas que imprimam as embalagens com tintas sem metais pesados. $A$ busca por fornecedores de embalagens que não utilizem materiais com substâncias perigosas, ou com certificação ambiental, é uma atitude que poderia ser considerada por todas as empresas.

Todas utilizam papel, material de fonte renovável, em algumas de suas embalagens secundárias. Foi constatado, nos casos analisados, que a embalagem de papel tem a função de servir de base para a exposição das informações necessárias para a venda. O uso de duas 
embalagens gasta mais material e não é necessário para manter a integridade do produto, mostrando que privilegiaram as questões de marketing. A embalagem ideal para os casos estudados seria uma com todas as informações impressas na embalagem primária. Nos casos das embalagens fechadas a vácuo, o custo da impressão direto na embalagem é inviável para pequenas e médias indústrias, como as estudadas, mostrando uma realidade e limitação do mercado onde a embalagem tem impacto ambiental, mas não tem outra solução possível identificada.

A Via Pax Bio tem ações de minimização do uso de recursos naturais, como a filtragem da água utilizada e a própria construção da fábrica, porém não fez o rastreamento dos impactos ambientais formalmente, e também não comunica a respeito na embalagem. Essas ações podem apenas ser conhecidas no site ou na visita à fábrica. Apenas uma empresa, a Mãe Terra, fez o rastreamento dos impactos ambientais para a minimização do uso de recursos naturais.

Baseado no que foi declarado pelas empresas, foi observado que as indústrias pesquisadas priorizam os aspectos mercadológicos das embalagens, deixando os aspectos ambientais em segundo plano, mostrando um distanciamento em relação ao discurso e à ação no que compete ao desenvolvimento de embalagens.

\begin{tabular}{|c|c|c|c|c|}
\hline Uso de recursos naturais & Mãe Terra & Monama & Via Pax Bio & $\begin{array}{l}\text { Avaliação baseada nas análises } \\
\text { das embalagens selecionadas }\end{array}$ \\
\hline Usa materiais de fontes renováveis & & & & $\begin{array}{l}\text { Foi avaliado se usa algum material de } \\
\text { fonte renovável em alguma embalagem } \\
\text { da empresa }\end{array}$ \\
\hline $\begin{array}{l}\text { Não usa materiais virgens ou usa } \\
\text { muito pouco }\end{array}$ & & & & $\begin{array}{l}\text { Foi avaliado se a embalagem usa mais } \\
\text { material reciclado do que virgem }\end{array}$ \\
\hline $\begin{array}{l}\text { Usa materiais reciclados } \\
\text { (pós ou pré-consumo) }\end{array}$ & & & & $\begin{array}{l}\text { Foi avaliado se usa algum material reciclado } \\
\text { em alguma embalagem da empresa }\end{array}$ \\
\hline $\begin{array}{l}\text { Não usa substâncias perigosas ao } \\
\text { meio ambiente }\end{array}$ & & & & $\begin{array}{l}\text { Foi avaliado se identificou na embalagem } \\
\text { que não usa alguma substância perigosa ao } \\
\text { meio ambiente }\end{array}$ \\
\hline $\begin{array}{l}\text { Texto sobre minimização do uso de } \\
\text { recursos naturais na embalagem }\end{array}$ & & & & $\begin{array}{l}\text { Foi avaliado se houve alguma declaração } \\
\text { sobre o texto de ações da empresa para } \\
\text { minimizar o uso de recursos naturais na } \\
\text { embalagem }\end{array}$ \\
\hline
\end{tabular}

Tabela 18 - Avaliação do uso de recursos naturais baseada nas análises das embalagens selecionadas.

A análise do uso de recursos naturais nas embalagens foi feita com base nos materiais utilizados nas embalagens, sem considerar todo o processo, pois as informações das outras etapas não foram fornecidas, quando existiam, ou foram avaliadas pelas empresas. As três empresas usam materiais em suas embalagens de fontes não renováveis, como o plástico. Observa-se que o plástico ou o composto de plástico com outro material torna-se necessário por fornecer a proteção necessária aos produtos, desde a produção até chegar ao consumidor.

Apenas uma embalagem de todas as avaliadas usa material reciclado. Esse fato reflete uma limitação técnica e legal brasileira. Segundo a Resolução RDC no 91, de 11 de maio de 2001 da Anvisa, todos os materiais utilizados em embalagens que entrem em contato com alimentos devem constar das listas positivas de componentes utilizados na fabricação de embalagens e equipamentos. Para a utilização de um material reciclado em embalagens de alimentos, este deve ser incluído nas listas comprovando que não representa risco significativo à saúde e que "seja justificada a necessidade tecnológica para sua utilização" (ANVISA, 2001). 
Para o papel reciclado, deve-se evitar a utilização de fibras secundárias provenientes da coleta indiscriminada de rejeitos que possam comprometer a inocuidade ou afetar a qualidade dos alimentos. As fibras recicladas devem ser obtidas através de processos adequados de fabricação que assegurem qualidade compatível com sua utilização em contato com alimentos (ANVISA, 2002). O plástico, para entrar em contato com o alimento, deve estar dentro do limite de quantidade máxima residual permitida de substâncias indicadas na lista positiva de polímeros autorizados para a elaboração de embalagens e equipamentos plásticos em contato com alimentos (ANVISA, 2012). Portanto, o uso de materiais reciclados que entrem em contato direto com alimentos está submetido à legislação e ao limite técnico do material que pode contaminar-lo.

Apenas a Via Pax Bio e a Mãe Terra colocaram em suas embalagens alguma informação sobre as suas ações de minimização do uso de recursos naturais, porém ou está muito sintetizada dentro de um box, como é no caso da Mãe Terra, ou misturada em um longo texto que dificilmente será lido antes da compra, nas embalagens da Via Pax Bio.

\begin{tabular}{|c|c|c|c|c|}
\hline Uso de recursos naturais & Mãe Terra & Monama & Via Pax Bio & $\begin{array}{l}\text { Avaliação baseada na percepção } \\
\text { dos consumidores }\end{array}$ \\
\hline $\begin{array}{l}\text { Percebe se usa materiais de fontes } \\
\text { renováveis }\end{array}$ & & & & $\begin{array}{l}\text { No caso das embalagens de papel, foi } \\
\text { avaliado se perceberam isso como positivo }\end{array}$ \\
\hline Percebe se usa materiais virgens & & & & $\begin{array}{l}\text { Foi avaliado se houve alguma declaração } \\
\text { sobre o material da embalagem ser virgem }\end{array}$ \\
\hline $\begin{array}{l}\text { Percebe se usa materiais reciclados } \\
\text { (pós ou pré-consumo) }\end{array}$ & & & & $\begin{array}{l}\text { Foi avaliado se houve alguma declaração } \\
\text { sobre o material reciclado }\end{array}$ \\
\hline $\begin{array}{l}\text { Percebe que não usa substâncias } \\
\text { perigosas ao meio ambiente }\end{array}$ & & & & $\begin{array}{l}\text { Foi avaliado se houve alguma declaração } \\
\text { sobre o texto na embalagem que indica que } \\
\text { não usou substâncias perigosas ao meio } \\
\text { ambiente, como a tinta }\end{array}$ \\
\hline $\begin{array}{l}\text { Percebe o texto sobre minimização } \\
\text { do uso de recursos naturais na } \\
\text { embalagem }\end{array}$ & & & & $\begin{array}{l}\text { Foi avaliado se houve alguma declaração } \\
\text { sobre o texto de ações da empresa para } \\
\text { minimizar o uso de recursos naturais na } \\
\text { embalagem }\end{array}$ \\
\hline
\end{tabular}

Tabela 19 - Avaliação do uso de recursos naturais baseada na percepção dos consumidores.

Os consumidores perceberam de forma positiva as embalagens que usam papel em vez do plástico. Isto mostra que o plástico tem uma imagem negativa em relação ao seu impacto ambiental, ainda que poucos entendam o porquê. Nenhum consumidor relacionou como negativo o uso de materiais virgens na embalagem, o que dificilmente uma pessoa leiga conseguiria detectar.

Alguns consideraram como positivo uma das embalagens ser em papel reciclado, porém outros perceberam a aparência da embalagem como algo negativo, não passando credibilidade da qualidade do produto, mostrando que, para os consumidores, prevalecem os atributos estéticos em detrimento dos aspectos ambientais. Há uma incoerência: o consumidor dá preferência a uma embalagem com acabamento plastificado, que a torna menos reciclável, ao invés de elogiar e perceber o material reciclável como algo benéfico para o meio ambiente.

O ícone com a indicação do não uso de tinta com metais pesados nas embalagens da Via Pax Bio foi percebido por apenas um consumidor. Isso pode indicar que o consumidor ainda não busca esse tipo de informação na embalagem, por ser rara e não obrigatória por lei, mas que 
ajudaria no pós-consumo para viabilizar a reciclagem e a minimização de contaminação dos aterros sanitários com materiais tóxicos provenientes da indústria gráfica.

Poucos consumidores perceberam a informação nas embalagens da Via Pax Bio, também devido à sua localização na embalagem e à falta de destaque. As outras empresas não falaram ou demonstraram preocupação nesse sentido.

\subsection{Considerações sobre a produção}

Não foi possível responder a alguns desses indicadores nesta pesquisa, seja por falta de conhecimento dos entrevistados ou por optarem não fornecer a informação. $O$ indicador que não teve dados suficientes para esta pesquisa foi: eficiência na produção para o não desperdício.

\begin{tabular}{|l|l|l|l|l|}
\hline Produção & Mãe Terra & Monama & Via Pax Bio & $\begin{array}{l}\text { Avaliação baseada nas declarações } \\
\text { das empresas }\end{array}$ \\
\hline $\begin{array}{l}\text { Avaliação do ciclo de vida do } \\
\text { produto }\end{array}$ & $\begin{array}{l}\text { Foi avaliado se avalia o ciclo de vida de seus } \\
\text { produtos, incluindo as embalagens }\end{array}$ \\
\hline $\begin{array}{l}\text { Controle da geração e destinação de } \\
\text { resíduos sólidos da produção }\end{array}$ & - & $\begin{array}{l}\text { Foi avaliado se controla a geração e } \\
\text { destinação de resíduos sólidos da produção }\end{array}$ \\
\hline
\end{tabular}

Tabela 20 - Avaliação da produção baseada na percepção dos consumidores.

Apenas a Mãe Terra fez a Avaliação do Ciclo de Vida (ACV) em alguns de seus produtos, porém esses dados não são atualizados desde 2011. Os dados que estão disponíveis no site na internet avaliam poucos produtos e não está informado qual foi o método utilizado, mostrando que a continuidade de uma ACV demanda muitos recursos nem sempre disponíveis em uma empresa pequena ou média. Segundo a Mãe Terra, o projeto está parado por falta de pessoas envolvidas só com isso.

Apenas a Monama não declarou que faz o controle da geração e destinação de resíduos. As outras fazem de forma pontual, sendo que a Mãe Terra declarou que faz apenas na fábrica e, no escritório, já teve iniciativas para isso, mas ainda não faz.

\begin{tabular}{|l|c|c|c|l|}
\cline { 2 - 5 } \multicolumn{1}{l|}{ Produção } & Mãe Terra & Monama & Via Pax Bio & $\begin{array}{l}\text { Avaliação baseada nas análises } \\
\text { das embalagens selecionadas }\end{array}$ \\
\hline $\begin{array}{l}\text { Avaliação do ciclo de vida do } \\
\text { produto }\end{array}$ & - & 0 & $\begin{array}{l}\text { Foi verificado se avalia o ciclo de vida de } \\
\text { seus produtos, incluindo as embalagens }\end{array}$ \\
\hline $\begin{array}{l}\text { Controle da geração e destinação de } \\
\text { resíduos sólidos da produção }\end{array}$ & - & $\begin{array}{l}\text { Foi avaliado se informa na embalagem o } \\
\text { controle da geração e destinação de } \\
\text { resíduos sólidos da produção }\end{array}$ \\
\hline
\end{tabular}

Tabela 21 - Avaliação da produção baseada nas análises das embalagens selecionadas

A ACV e o controle da geração e destinação de resíduos sólidos da produção são comunicados nas embalagens da Mãe Terra apenas dentro do box do projeto, de forma genérica, e em todas as embalagens, mesmo nos produtos que não fizeram parte do projeto, passando uma informação que pode ser interpretada como mentirosa.

As embalagens da Via Pax Bio não comunicam as ações que promovem na fábrica para o controle da geração e destinação de resíduos sólidos da produção, perdendo uma oportunidade para se diferenciar no mercado de alimentos industrializados. 


\begin{tabular}{|l|l|l|l|l|}
\hline Produção & Mãe Terra & Monama & Via Pax Bio & $\begin{array}{l}\text { Avaliação baseada na percepção } \\
\text { dos consumidores }\end{array}$ \\
\hline $\begin{array}{l}\text { Avaliação do ciclo de vida do } \\
\text { produto }\end{array}$ & $\begin{array}{l}\text { Foi avaliado se o consumidor falou alguma } \\
\text { coisa percebendo a informação sobre a } \\
\text { avaliação do ciclo de vida de seus produtos } \\
\text { incluindo as embalagens }\end{array}$ \\
\hline $\begin{array}{l}\text { Controle da geração e destinação de } \\
\text { resíduos sólidos da produção }\end{array}$ & & $\begin{array}{l}\text { Foi avaliado se o consumidor falou alguma } \\
\text { coisa percebendo a informação na } \\
\text { embalagem sobre o controle da geração e } \\
\text { destinação de resíduos sólidos da produção }\end{array}$ \\
\hline
\end{tabular}

Tabela 22 - Avaliação da produção baseada na percepção dos consumidores

O box com informações relacionadas ao ciclo de vida do produto nas embalagens da empresa Mãe Terra chamou a atenção de poucos dos consumidores entrevistados, e todos eles, consumidores frequentes de orgânicos, mostrando que esse tipo de informação ainda interessa pouco aos consumidores, mas é valorizada pelos principais clientes do setor, e deve ser destacada.

\subsection{Considerações sobre a logística}

Não foi possível responder a alguns desses indicadores nesta pesquisa, seja por falta de conhecimento dos entrevistados ou por optarem por não fornecer a informação. Os indicadores que tiveram dados insuficientes para esta pesquisa foram:

- fácil identificação;

- otimização no carregamento;

- energia utilizada no transporte;

- estoque eficiente;

- recuperação de embalagens secundárias e terciárias;

- proporção embalagem por produto.

\begin{tabular}{|c|c|c|c|c|}
\hline Logística & Mãe Terra & Monama & Via Pax Bio & $\begin{array}{l}\text { Avaliação baseada nas declarações } \\
\text { das empresas }\end{array}$ \\
\hline Meios de transporte & & & & $\begin{array}{l}\text { Foi avaliada a distância da fábrica em } \\
\text { relação aos seus fornecedores, baseada no } \\
\text { uso de caminhão }\end{array}$ \\
\hline Proteção do produto & & & & $\begin{array}{l}\text { Foi avaliado se usam como estratégia de } \\
\text { design de embalagem a proteção do } \\
\text { produto }\end{array}$ \\
\hline Proporção embalagem por produto & & & & $\begin{array}{l}\text { Foi avaliado se usam como estratégia de } \\
\text { design uma boa proporção de embalagem } \\
\text { por produto }\end{array}$ \\
\hline Recuperação de embalagens & & & & $\begin{array}{l}\text { Foi avaliado se há algum projeto de } \\
\text { recuperação das embalagens após o seu uso }\end{array}$ \\
\hline
\end{tabular}

Tabela 23 - Avaliação da logística baseada nas declarações das empresas

Todas as empresas declararam que transportam seus produtos por caminhão. Isso é uma característica brasileira de se depender do sistema rodoviário para a distribuição de seus produtos, havendo um gasto grande de combustível e energia. Por isso, quanto mais próximo da fábrica forem os seus fornecedores, menor é o seu custo ambiental, por demandar menos combustível e emitir menos gases do efeito estufa. 
Todas as empresas declararam que proteger o produto é um dos principais pontos no desenvolvimento de embalagens e nenhuma empresa declarou abertamente ser importante a proporção de embalagem por produto.

Foi comentado pela Via Pax Bio que a segunda embalagem em papel mostrou-se uma vantagem em relação a outras embalagens, por proteger a embalagem primária por mais tempo e evitar furos e rasgos.

Nenhuma das empresas pesquisadas tem um projeto de recuperação de embalagens após o seu uso ou de logística reversa. Apenas a Mãe Terra declarou que iria conversar com uma empresa de logística reversa para poder analisar a viabilidade de um projeto desse tipo.

\begin{tabular}{|c|c|c|c|c|}
\hline Logística & Mãe Terra & Monama & Via Pax Bio & $\begin{array}{l}\text { Avaliação baseada nas análises } \\
\text { das embalagens selecionadas }\end{array}$ \\
\hline Meios de transporte & & & & $\begin{array}{l}\text { Foi avaliada se há na embalagem alguma } \\
\text { informação a respeito da escolha de } \\
\text { fornecedores perto da fábrica para a } \\
\text { redução de uso de recursos. }\end{array}$ \\
\hline Proteção do produto & & & & $\begin{array}{l}\text { Foi avaliado se a embalagem primária e, } \\
\text { quando for o caso, a secundária são } \\
\text { suficientes para a proteção do produto no } \\
\text { transporte, estocagem e até chegar à casa } \\
\text { do consumidor. }\end{array}$ \\
\hline Proporção embalagem $\times$ produto & & & & $\begin{array}{l}\text { Não se aplica por não haverem dados } \\
\text { suficientes fornecidos pela empresa para } \\
\text { essa avaliação }\end{array}$ \\
\hline Recuperação de embalagens & & & & $\begin{array}{l}\text { Foi avaliado se há alguma informação na } \\
\text { embalagem incentivando o seu reuso ou } \\
\text { devolução para a indústria. }\end{array}$ \\
\hline
\end{tabular}

Tabela 24 - Avaliação da logística baseada nas análises das embalagens selecionadas

Alguns produtos, durante a pesquisa, se danificaram no transporte e armazenamento. Os cookies da Mãe Terra no final estavam quebrados, e isso foi percebido por um consumidor. A embalagem da farinha da Mãe Terra apresentava desde o início um furo de onde saía o produto. A granola da Monama, desde o início, foi guardada dentro de um plástico até a entrevista, para a proteção, porém, mesmo com esse cuidado, amassava e isso foi percebido pelos consumidores. Deve-se considerar que o armazenamento e transporte dos produtos durante as entrevistas não foram os ideais, mas mostra o que pode acontecer em condições fora do padrão e suas fragilidades.

Em nenhuma das embalagens havia alguma informação incentivando o seu reuso, porém deve-se observar que nenhuma delas era produzida em material durável, como o vidro, o dificultando o seu reuso. 


\begin{tabular}{|c|c|c|c|c|}
\hline Logística & Mãe Terra & Monama & Via Pax Bio & $\begin{array}{l}\text { Avaliação baseada na percepção } \\
\text { dos consumidores }\end{array}$ \\
\hline Meios de transporte & & & & $\begin{array}{l}\text { Foi avaliado se o consumidor considerou } \\
\text { como a embalagem foi transportada e a } \\
\text { distância da fábrica em relação aos seus } \\
\text { fornecedores baseado no uso de caminhão }\end{array}$ \\
\hline Proteção do produto & & & & $\begin{array}{l}\text { Foi avaliado se o consumidor percebe se a } \\
\text { embalagem protege bem o produto }\end{array}$ \\
\hline Proporção embalagem x produto & & & & $\begin{array}{l}\text { Foi avaliado se o consumidor considera } \\
\text { que a quantidade de embalagem é } \\
\text { suficiente por produto sem excessos }\end{array}$ \\
\hline Recuperação de embalagens & & & & $\begin{array}{l}\text { Não se aplica porque não há nenhuma } \\
\text { informação a respeito na embalagem }\end{array}$ \\
\hline
\end{tabular}

Tabela 25 - Avaliação da logística baseada na percepção dos consumidores

Poucos consumidores comentaram a respeito do transporte da loja até as suas casas, porém um considerou a embalagem fechada a vácuo melhor do que a embalagem plástica flexível, pois, segundo ele, é mais resistente e corre menos o risco de estourar no porta malas. Foi também comentado por mais de um consumidor que este tipo de embalagem conserva por mais tempo o produto em casa.

Foi comentado também, por outro consumidor, logo na segunda entrevista, que algumas embalagens de farinha de trigo integral estavam soltando um pouco da farinha. Elas já estavam assim desde a compra para a pesquisa e não foi encontrada nenhuma sem esse problema. Esses comentários mostram que a proteção do produto pela embalagem deve ser considerada até a hora do seu uso e não apenas até chegar ao ponto de venda.

\subsection{Considerações sobre o pós-consumo}

Não foi possível responder a alguns desses indicadores nesta pesquisa, seja por falta de conhecimento dos entrevistados ou por optarem não fornecer a informação. $O$ indicador que teve dados insuficientes para esta pesquisa foi o envio para aterros.

\begin{tabular}{|c|c|c|c|c|}
\hline Pós-consumo & Mãe Terra & Monama & Via Pax Bio & $\begin{array}{l}\text { Avaliação baseada nas declarações } \\
\text { das empresas }\end{array}$ \\
\hline Reciclabilidade & & & & $\begin{array}{l}\text { Foi avaliado se a indústria buscou } \\
\text { embalagens compatíveis para a reciclagem }\end{array}$ \\
\hline $\begin{array}{l}\text { Simbologia Técnica de Identificação } \\
\text { de Materiais }\end{array}$ & & & & $\begin{array}{l}\text { Foi avaliado se a indústria conhece a } \\
\text { Simbologia Técnica de Identificação de } \\
\text { Materiais, da ISO } 14021\end{array}$ \\
\hline $\begin{array}{l}\text { Separação dos componentes da } \\
\text { embalagem no pós-consumo }\end{array}$ & & & & $\begin{array}{l}\text { Foi avaliado se os componentes da } \\
\text { embalagem possibilitam a separação de } \\
\text { seus materiais }\end{array}$ \\
\hline Reutilização da embalagem & & & & $\begin{array}{l}\text { Foi avaliado se a escolha do material das } \\
\text { embalagens foi pensada na sua reutilização }\end{array}$ \\
\hline
\end{tabular}

Tabela 26 - Avaliação do pós-consumo baseada nas declarações das empresas

Todas as empresas declararam que pensaram na reciclagem de suas embalagens na hora do seu desenvolvimento, porém boa parte delas não é monomaterial, dificultando a sua separação para a reciclagem. Apenas a Mãe Terra utiliza o padrão recomendado para identificar os seus materiais. A não identificação dos materiais pode praticamente inviabilizar a reciclagem das embalagens. O processo de separação para a reciclagem é muito dinâmico e essa identificação deve ser rápida, pois, na dúvida, a embalagem não é separada 
e não é reciclada, porém infelizmente isso ainda não é obrigatório por lei, mas deveria ser incluído.

Foi comentado por uma das empresas que o fato dela não identificar na embalagem os materiais, além de por não conhecer a simbologia correta, também por considerar o sistema brasileiro de reciclagem deficiente e considerar que, por isso, seria propaganda enganosa. Essa declaração mostra uma incoerência entre o discurso e prática, já que, exatamente por termos muitos problemas, cada empresa, cada setor da sociedade deve fazer a sua parte.

Apenas a Via Pax Bio declarou que suas embalagens, divididas em primárias e secundárias, se deve ao fato também de facilitar a separação dos materiais para a reciclagem. Porém, como o plástico usado para as embalagens a vácuo não foi identificado, esse material provavelmente não será reciclado, pois não se sabe qual é a sua composição.

Quanto à taxa de reutilização das embalagens, nenhuma das indústrias entrevistadas possui um projeto de logística reversa. As embalagens também não foram projetadas para retornarem para as empresas. Apenas no caso das embalagens de vidro da Via Pax Bio, foi declarado que o material foi pensado na possibilidade de reuso.

\begin{tabular}{|c|c|c|c|c|}
\hline Pós-consumo & Mãe Terra & Monama & Via Pax Bio & $\begin{array}{l}\text { Avaliação baseada nas análises } \\
\text { das embalagens selecionadas }\end{array}$ \\
\hline Reciclabilidade & & & & $\begin{array}{l}\text { Foi avaliado se os materiais das embalagens } \\
\text { selecionadas são compatíveis para serem } \\
\text { reciclados e se estão identificados }\end{array}$ \\
\hline $\begin{array}{l}\text { Simbologia Técnica de Identificação } \\
\text { de Materiais }\end{array}$ & & & & $\begin{array}{l}\text { Foi avaliado se as embalagens usam a } \\
\text { Simbologia Técnica de Identificação de } \\
\text { Materiais da ISO } 14021\end{array}$ \\
\hline $\begin{array}{l}\text { Separação dos componentes da } \\
\text { embalagem no pós-consumo }\end{array}$ & & & & $\begin{array}{l}\text { Foi avaliado se os componentes das } \\
\text { embalagens são compatíveis de serem } \\
\text { separados para a reciclagem }\end{array}$ \\
\hline Taxa de reutilização da embalagem & & & & $\begin{array}{l}\text { Foi avaliado se as embalagens indicam } \\
\text { alguma informação de quepoderiam ser } \\
\text { reutilizadas pelo tipo de material e pela } \\
\text { forma }\end{array}$ \\
\hline
\end{tabular}

Tabela 27 - Avaliação do pós-consumo baseada nas análises das embalagens selecionadas

Todos os materiais das embalagens analisadas, tecnicamente, têm a possibilidade de que seus materiais sejam transformados em novos produtos ou novas embalagens, porém, no caso das embalagens plásticas produzidas por um compósito de materiais, essa reciclagem é praticamente inviabilizada, pela dificuldade de separação dos materiais e por não ter uma cadeia de reciclagem estruturada para esse tipo de material no Brasil.

Apenas a Mãe Terra utiliza a Simbologia Técnica de Identificação de Materiais. A Via Pax Bio não identifica o material, mas orienta o consumidor para separar os materiais para o descarte. Nenhuma embalagem tem alguma identificação ou sugestão de reuso da embalagem, ela poderia apresentar algum ícone com a sugestão e um endereço na internet com mais sugestões. 


\begin{tabular}{|c|c|c|c|c|}
\hline Pós-consumo & Mãe Terra & Monama & Via Pax Bio & $\begin{array}{l}\text { Avaliação baseada na percepção } \\
\text { dos consumidores }\end{array}$ \\
\hline Reciclabilidade & & & & $\begin{array}{l}\text { Foi avaliado se os consumidores identificam } \\
\text { os materiais e se sabem se são recicláveis } \\
\text { ou não }\end{array}$ \\
\hline $\begin{array}{l}\text { Simbologia Técnica de Identificação } \\
\text { de Materiais }\end{array}$ & & & & $\begin{array}{l}\text { Foi avaliado se os consumidores identificam } \\
\text { a Simbologia Técnica de Identificação de } \\
\text { Materiais da ISO } 14021\end{array}$ \\
\hline $\begin{array}{l}\text { Separação dos componentes da } \\
\text { embalagem no pós-consumo }\end{array}$ & & & & $\begin{array}{l}\text { Foi avaliado se o consumidor percebe se a } \\
\text { embalagem é constituída por mais de um } \\
\text { material e que isso pode dificultar a } \\
\text { reciclagem }\end{array}$ \\
\hline Taxa de reutilização da embalagem & & & & $\begin{array}{l}\text { Não se aplica porque nenhuma empresa } \\
\text { tem um programa de reutilização das } \\
\text { embalagens }\end{array}$ \\
\hline
\end{tabular}

Tabela 28 - Avaliação do pós-consumo baseada na percepção dos consumidores

Nenhum consumidor pareceu identificar qual embalagem é mais reciclável ou não, os poucos que comentaram falaram que têm esse tipo de dúvida. Poucos conheciam a Simbologia Técnica de Identificação de Materiais, que poderia ajudar nessa identificação. Isso ocorre devido à característica deficiente do sistema de coleta no Brasil, onde o lixo no máximo é separado por seco (reciclável) e úmido (não reciclável). Porém, mesmo não tendo sido tão percebida essa informação pelo consumidor, ela é importante para as etapas de pós-consumo. Os dados mostraram que mesmo os consumidores frequentes de orgânicos, mais conscientes e com mais conhecimento, tiveram dúvidas para identificar os símbolos e não valorizam esse tipo de informação.

Além de não conhecerem, os símbolos criados são parecidos e a maior parte confundiu o símbolo de identificação dos plásticos com o símbolo de reciclável, mostrando uma deficiência de design do padrão recomendado pela ISO 14021.

Nenhum consumidor comentou a dificuldade para reciclar quando a embalagem é constituída por mais de um material e a reutilização da embalagem não foi comentada, por não haver nenhuma informação nas embalagens.

Deve-se observar que os indicadores ambientais são termos ainda muito técnicos e de difícil entendimento para o consumidor. A forma de divulgação deles nas embalagens deve ser sintética, como feita em algumas embalagens, porém deve ter a indicação onde o consumidor pode buscar mais informações, e essas informações devem sempre ser atualizadas. Não se deve subestimar a capacidade de entendimento do consumidor e se limitar a informações genéricas baseadas apenas no marketing dos produtos. As ações em prol do meio ambiente devem ser divulgadas nas embalagens, porém de forma específica para não serem mal interpretadas.

\subsection{Considerações sobre os alimentos orgânicos industrializados}

As considerações sobre os alimentos orgânicos se basearam na legislação brasileira para a certificação de orgânicos. Foi avaliada qual foi a política estabelecida para divulgação dos diferenciais dos orgânicos no design das embalagens de seus produtos, se essa política se reflete nas embalagens e se são percebidas pelos consumidores. 


\begin{tabular}{|l|l|l|l|l|}
\hline $\begin{array}{l}\text { Alimentos orgânicos } \\
\text { industrializados }\end{array}$ & Mãe Terra & Monama & Via Pax Bio & $\begin{array}{l}\text { Avaliação baseada nas declarações } \\
\text { das empresas }\end{array}$ \\
\hline $\begin{array}{l}\text { Identificação na embalagem do } \\
\text { orgânico }\end{array}$ & - & $\begin{array}{l}\text { Foi avaliado se a indústria escolheu como } \\
\text { estratégia de comunicação destacar o } \\
\text { orgânico em seus produtos }\end{array}$ \\
\hline $\begin{array}{l}\text { Identificação na embalagem do selo } \\
\text { SisOrg }\end{array}$ & - & - & $\begin{array}{l}\text { Foi avaliado se a indústria declarou algo } \\
\text { sobre o selo SisOrg }\end{array}$ \\
\hline $\begin{array}{l}\text { Relaciona o alimento orgânico como } \\
\text { um alimento mais saudável }\end{array}$ & - & $\begin{array}{l}\text { Foi avaliado se a indústria declarou que } \\
\text { considera o alimento orgânico mais } \\
\text { saudável }\end{array}$ \\
\hline Uso de transgênicos & - & $\begin{array}{l}\text { Foi avaliado se a empresa não usa grãos } \\
\text { transgênicos mesmo quando o produto não } \\
\text { é orgânico }\end{array}$ \\
\hline
\end{tabular}

Tabela 29 - Avaliação do pós-consumo baseada nas declarações das empresas

Baseado nas declarações das indústrias, apenas a Via Pax Bio usa como estratégia de divulgação o fato do alimento ser orgânico, sendo essa a informação com mais destaque em suas embalagens. As outras empresas se limitaram em colocar os selos de certificação, obrigados pela legislação, no tamanho mínimo permitido e em áreas muitas vezes com pouco destaque, mostrando que priorizam outras informações nas embalagens.

Todas as empresas declararam que escolheram produzir alimentos orgânicos por considerarem mais saudáveis e usam isso como estratégia de comunicação, porém nenhuma comentou espontaneamente a vantagem de não usar grãos transgênicos nos alimentos orgânicos.

\begin{tabular}{|c|c|c|c|c|}
\hline $\begin{array}{l}\text { Alimentos orgânicos } \\
\text { industrializados }\end{array}$ & Mãe Terra & Monama & Via Pax Bio & $\begin{array}{l}\text { Avaliação baseada nas análises } \\
\text { das embalagens selecionadas }\end{array}$ \\
\hline $\begin{array}{l}\text { Identificação na embalagem do } \\
\text { orgânico }\end{array}$ & & & & $\begin{array}{l}\text { Foi avaliado se a embalagem destaca o fato } \\
\text { de se tratar de um alimento orgânico, além } \\
\text { do selo de certificação }\end{array}$ \\
\hline $\begin{array}{l}\text { Identificação na embalagem do selo } \\
\text { SisOrg }\end{array}$ & & & & $\begin{array}{l}\text { Foi avaliado se o selo está localizado em } \\
\text { uma área como boa visualização e com } \\
\text { contraste de cor com o fundo }\end{array}$ \\
\hline $\begin{array}{l}\text { Relaciona o alimento orgânico como } \\
\text { um alimento mais saudável }\end{array}$ & & & & $\begin{array}{l}\text { Foi avaliado se a embalagem relaciona o } \\
\text { produto orgânico como um produto mais } \\
\text { saudável na embalagem, seja de forma } \\
\text { textual ou visual }\end{array}$ \\
\hline Uso de transgênicos & & & & $\begin{array}{l}\text { Foi avaliado se há alguma informação sobre } \\
\text { o não uso de transgênicos na embalagem }\end{array}$ \\
\hline
\end{tabular}

Tabela 30 - Avaliação do pós-consumo baseada nas análises das embalagens selecionadas

Apenas a Via Pax Bio destaca mais a palavra "orgânico" em suas embalagens, utilizando recursos visuais. As outras ou se limitaram apenas à informação do selo de certificação ou escolheram uma tipografia com pouco destaque e em cores que não contrastam com o fundo.

Todas as indústrias, para venderem orgânicos, são obrigadas a utilizar o selo SisOrg, porém o local onde ele é aplicado na embalagem pode facilitar ou dificultar a sua identificação pela hierarquia de leitura. $\mathrm{Na}$ análise das embalagens, foi observado que, quando há muitas informações no painel frontal, o selo perde destaque e visibilidade.

Os alimentos orgânicos são isentos de grãos transgênicos, e foi avaliado nas empresas que produzem alimentos orgânicos ou não se isso fica claro na embalagem. A única que comunicou na embalagem foi a Mãe Terra, dentro do box Como desenvolvemos nossos produtos. 


\begin{tabular}{|c|c|c|c|c|}
\hline $\begin{array}{l}\text { Alimentos orgânicos } \\
\text { industrializados }\end{array}$ & Mãe Terra & Monama & Via Pax Bio & $\begin{array}{l}\text { Avaliação baseada na percepção } \\
\text { dos consumidores }\end{array}$ \\
\hline $\begin{array}{l}\text { Identificação na embalagem do } \\
\text { orgânico }\end{array}$ & & & & $\begin{array}{l}\text { Foi avaliado se identificou rapidamente o } \\
\text { produto como orgânico }\end{array}$ \\
\hline $\begin{array}{l}\text { Identificação na embalagem do selo } \\
\text { SisOrg }\end{array}$ & & & & $\begin{array}{l}\text { Foi avaliado se a principal informação para } \\
\text { identificar o produto como um alimento } \\
\text { orgânico foi o selo SisOrg }\end{array}$ \\
\hline $\begin{array}{l}\text { Relaciona o alimento orgânico como } \\
\text { um alimento mais saudável }\end{array}$ & & & & $\begin{array}{l}\text { Foi avaliado se o consumidor relacionou os } \\
\text { produtos selecionados como mais saudáveis } \\
\text { por serem orgânicos }\end{array}$ \\
\hline Uso de transgênicos & & & & $\begin{array}{l}\text { Foi avaliado se percebeu que os alimentos } \\
\text { são isentos de transgênicos }\end{array}$ \\
\hline
\end{tabular}

Tabela 31 - Avaliação do pós-consumo baseada na percepção dos consumidores

As embalagens da Mãe Terra foram as que mais confundiram os consumidores para identificar se era ou não um alimento orgânico. Alguns consumidores separaram todas as embalagens Mãe Terra como orgânicas por considerarem que é uma empresa que só produz alimentos orgânicos, mostrando que a política de comunicação da marca pode ser tão forte que leva o consumidor a interpretar uma mesma informação para todos os seus produtos, mesmo quando têm características diferentes, como o fato de não serem todos orgânicos.

Além de confundirem com a marca, a informação de que o produto é orgânico, ou não, é muito discreta e sem destaque, dificultando a sua visualização, principalmente quando o consumidor não está procurando especificamente por essa informação, não facilitando a comunicação com consumidores não frequentes.

No que diz respeito à percepção das especificidades inerentes aos alimentos orgânicos pelos consumidores, podemos observar que a maioria dos consumidores os identificou principalmente pela palavra "orgânico" na embalagem, mesmo quando não tinha muito conhecimento dos seus diferenciais. Nos casos em que o consumidor conhecia melhor o que é um alimento orgânico, além de perceber logo a palavra, buscou outras informações relacionadas à produção dos produtos, mostrando que o consumidor mais frequente de orgânicos valoriza outros aspectos do produto além dos nutricionais e da identificação com a marca.

O selo SisOrg, mesmo não o conhecendo, foi identificado pelos consumidores como uma informação que diferencia o produto como orgânico, mostrando que o desenho gráfico criado é eficiente na sua função de comunicar e identificar. Sua identificação só foi dificultada nos casos em que estavam localizado em áreas menos visíveis pela hierarquia de leitura.

A informação de que o orgânico é isento de transgênicos não é explorada por nenhum caso estudado nesta pesquisa, é apenas um tópico do box "Como desenvolvemos nossos produtos", das embalagens Mãe Terra. Assim, os consumidores, para preencherem a matriz semântica, tiveram dificuldade, por não saberem que os alimentos orgânicos são proibidos de usar grãos transgênicos. Devido às incertezas sobre a segurança à saúde desse tipo de alimento, é uma informação que poderia ser mais explorada na embalagem, pois mesmo os consumidores com mais conhecimento, e que consomem orgânicos, sentiram essa dúvida.

Considerando o que já foi exposto, conclui-se que a forma de comunicar as especificidades dos alimentos orgânicos, que incluem os aspectos ambientais, ainda pode ser mais explorada nas embalagens, e cabe ao profissional de design orientar a empresa de forma adequada, mesmo quando isso não é estabelecido no briefing inicial. Todos os designers entrevistados demonstraram não fazer muito além do que a empresa requisita, não 
investindo em pesquisas para conhecer melhor os consumidores ou para conhecer o mercado de orgânicos no Brasil.

O designer deve investir na parceria com as indústrias e se posicionar como consultor no que diz respeito ao design de embalagens com menor impacto ambiental, mesmo quando o produto não tem essa característica, sendo um integrador das diversas áreas de desenvolvimento de embalagens.

\subsection{SUGESTÕES PARA AS PRÓXIMAS PESQUISAS}

No que diz respeito aos resultados da pesquisa, foram abertas novas possibilidades de pesquisas e caminhos no sentido de orientar futuros trabalhos de design de embalagens. Percebeu-se que há muitas oportunidades para outras pesquisas a partir das questões levantadas por este trabalho.

Deve-se considerar que o experimento usado para avaliar a percepção dos consumidores se aproxima mais da situação de uso e consumo do produto, pelo tempo e possibilidade de se ater aos detalhes. Por isso, uma sugestão para a pesquisa seria avaliar a percepção do consumidor no ponto de venda em uma situação real de compra e como cada uma estabeleceu a estratégia de design para hierarquizar as informações e o alinhamento disso com os princípios ambientais e de respeito ao consumidor.

A segunda sugestão é a possibilidade de se fazer pesquisa quantitativa com amostragens estatísticas, como no caso da percepção dos símbolos utilizados para a identificação dos materiais e dos alimentos orgânicos. Isso permitiria que os resultados fossem generalizados, o que traria representatividade a eles.

Por fim, os aspectos sociais da embalagem, tais como as pessoas envolvidas no processo de fabricação, acabaram não sendo incluídos e poderiam ser mais bem explorados em outra pesquisa.

Esta pesquisa envolveu uma grande complexidade de conceitos e fontes de dados. No entanto, espera-se que possa contribuir para novas abordagens do design de embalagens de alimentos, orgânicos ou não orgânicos, com o objetivo de atingir o que de melhor se espera de um bom design: possibilitar uma melhor comunicação das especificidades dos alimentos orgânicos com os consumidores, minimizando os impactos nocivos que possam causar à natureza. 


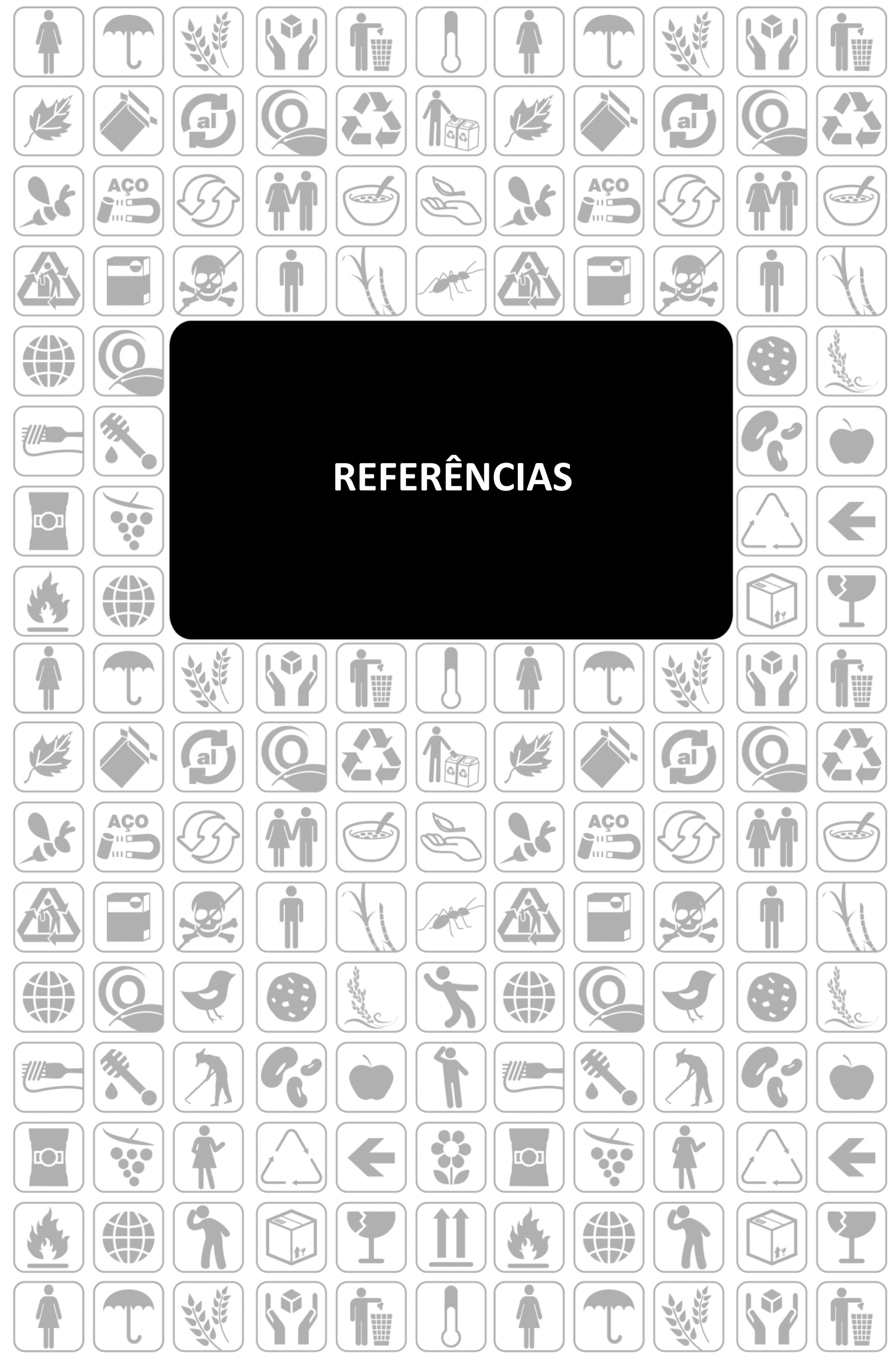




\section{REFERÊNCIAS}

A10 DESIGN. Escritório de design. Disponível em: <http://www.a10.com.br/>. Acesso em: 31 out. 2012.

ABCV - ASSOCIAÇÃO BRASILEIRA DO CICLO DE VIDA. Sociedade civil que tem por finalidade viabilizar a Gestão do Ciclo de Vida. São Paulo, 2011-2012. Disponível em: <http://www.abcvbrasil.org.br/>. Acesso em: 31 ago. 2012.

ABRAS - ASSOCIAÇÃO BRASILEIRA DE SUPERMERCADOS. Cinquenta anos de supermercados no Brasil. São Paulo: Informe Comunicação, 2002.

SuperHiper panorama 2011. São Paulo, 2011.

ABNT - ASSOCIAÇÃO BRASILEIRA DE NORMAS TÉCNICAS. ISO/TR 14062: gestão ambiental: integração de aspectos ambientais no projeto e desenvolvimento do produto. Rio de Janeiro, 2004.

NBR 13230: embalagens e acondicionamentos plásticos recicláveis: identificação e simbologia. Rio de Janeiro, 2008.

NBR ISO 14020: rótulos e declarações ambientais: princípios gerais. Rio de Janeiro, 2002.

NBR ISO 14021. Rótulos e declarações ambientais: autodeclarações ambientais: rotulagem do tipo II. Rio de Janeiro, 2004.

NBR ISO 14024. Rótulos e declarações ambientais: rotulagem ambiental do tipo I: princípios e procedimentos. Rio de Janeiro, 2004.

NBR ISO 14040. Gestão ambiental: avaliação do ciclo de vida: princípios e estrutura. Rio de Janeiro, 2009..

NBR ISO 26000. Diretrizes sobre responsabilidade social. Rio de Janeiro, 2010..

Rótulo ambiental. Disponível em: <http://www.abntonline.com.br/rotulo/>. Acesso em: 31 out. 2012.

ABRE - ASSOCIAÇÃO BRASILEIRA DE EMBALAGEM. Associação que tem o propósito de fomentar o desenvolvimento do mercado e atividades dos associados. São Paulo, 2010-2011. Disponível em: <http://www.abre.org.br>. Acesso em: 31 jul. 2013.

Abrenews 91. São Paulo, mar/abr 2011. Disponível em: <http://www.abre.org.br/jornal/index.htm>. Acesso em: 31 jul. 2012.

Abrenews 92. São Paulo, maio/jun 2011. Disponível em: <http://www.abre.org.br/jornal/index.htm>. Acesso em: 10 out. 2012.

Aplicação de simbologia. São Paulo, 2010-2011. Disponível em: <http://www.abre.org.br/ comitesdetrabalho/ meio-ambiente-e-sustentabilidade/reciclagem/aplicacao-de-simbologia/>. Acesso em: 31 jul. 2013.

Diretrizes de rotulagem ambiental para embalagens: autodeclarações ambientais: rotulagem do tipo II. 2. ed. São Paulo, 2012. Disponível em: <http://www.abre.org.br/comitesdetrabalho/meioambiente-e-sustentabilidade/cartilhas/>. Acesso em: 29 set. 2012.

Diretrizes de sustentabilidade para a cadeia produtiva de embalagem e bens de consumo. 3. ed. São Paulo, 2012. Disponível em: <http://www.abre.org.br/ downloads/ cartilha_diretrizes.pdf >. Acesso em: 13 de maio de 2012.

Estudo macroeconômico da embalagem ABRE/FGV referente a 2011. São Paulo, 2011. Disponível em: <http://www.abre.org.br/centro_dados.php>. Acesso em: 31 jul. 2012.

Integração de aspectos ambientais no projeto e desenvolvimento da embalagem: adequação da ABNT ISO/TR 14.062:2004 para as embalagens. São Paulo: 2006. Disponível em:

<http://www.abre.org.br/downloads/Cartilha_Iso_14062.zip>. Acesso em: 13 mai. 2012.

Protocolo global sobre sustentabilidade de embalagens 2.0. São Paulo, 2010-2011. Disponível em: <http://www.abre.org.br/comitesdetrabalho/meio-ambiente-e-sustentabilidade/documentos/>. Acesso em: 23 nov. 2013.

ABRELPE - ASSOCIAÇÃO BRASILEIRA DE EMPRESAS DE LIMPEZA PÚBLICA E RESÍDUOS ESPECIAIS. Panorama dos resíduos sólidos no brasil. São Paulo, 2011. Disponível em: <http://www.abrelpe.org.br/ panorama_apresentacao.cfm>. Acesso em: 10 out. 2012.

ABTG; CETESB. Guia técnico ambiental da indústria gráfica. São Paulo, 2003. Disponível em: <http://www.ciesp.com.br/ciesp/conteudo/guia_ambiental_setorgrafico.pdf>. Acesso em: 3 nov. 2012.

ACKOFF, R. L. Pensando em sistemas que pensam. System Dynamics Review, 1994. v. 10. p. 175-188.

AKATU. Caderno temático: a nutrição e o consumo consciente. São Paulo: Akatu, 2004. Consumo consciente. Disponível em: <http://www.akatu.org.br/>. Acesso em: 5 ago. 2012.

ANYADIKE, N. Embalagens flexíveis. São Paulo: Edgard Blücher, 2009.

ANVISA. Programa de análise de resíduos de agrotóxicos em alimentos (PARA). 2011. Disponível em: <http://portal.anvisa.gov.br/>. Acesso em: 29 ago. 2013. 
. Resolução RDC no 20, de 26 de março de 2008. 2008. Disponível em: <http://portal.anvisa.gov.br/ wps/wcm/connect/ beed818047459 7599feddf3fbc4c 6735/ RDC_20.pdf?MOD=AJPERES>. Acesso em: 18 fev. 2014.

. Resolução RDC no 56, de 16 de novembro de 2012. 2012. Disponível em: <http://portal.anvisa.gov.br/ wps/wcm/connect/ 9ed8b1804d8b6c3 daa51ebc116238c3b/ ALIMENTOS+ RESOLU\%C3\%87\%C3\%830 $+R D C+n .+56 \% 2 C+D E+16+D E+N O V E M B R O+D E+2012 . p d f ? M O D=A J P E R E S>$. Acesso em: 18 fev. 2014.

. Resolução RDC no 91, de 11 de maio de 2001. 2001. Disponível em: <http://portal.anvisa.gov.br/ wps/wcm/connect/ a97001004d8b6861aa00ebc116238c3b/

ALIMENTOS+RESOLU\%C3\%87\%C3\%830+-+RDC+ N\%C2 \%BA+91,+DE+11+DE+MAIO+DE+2001+-

+Crit\%C3\%A9rios+Gerais.pdf?MOD=AJPERES>. Acesso em: 18 fev. 2014.

. Resolução RDC n.o 129, de 10 de maio de 2002. 2002. Disponível em:

<http://portal.anvisa.gov.br/wps/wcm/connect/3b8b74004d8b6d50aa63ebc116238c3b/ALIMENTOS+ RESOLU\%C3\%87\%C3\%830+RDC+N.\%C2\%BA+129\%2C+DE+10+DE+MAIO+DE+2002.pdf?MOD=AJPERES

>. Acesso em: 18 fev. 2014.

ASHBY, M.; JONHSON, K. Materiais e design: arte e ciência da seleção de materiais no design de produto. Rio de Janeiro: Elsevier, 2011.

BAUER, M. W.; GASKELL, G. Pesquisa qualitativa com texto, imagem e som: um manual prático. Petrópolis: Vozes, 2002.

BAXTER, M. 1998. Projeto de produto: guia prático para o desenvolvimento de novos produtos. São Paulo: Edgard Blücher, 1998.

BERTALANFFY, L. V. Teoria geral dos sistemas. Petrópolis: Vozes, 1977.

BOUABCI, L. Reflexões sobre selos verdes e seus desafios. Revista Ideia Sustentável, São Paulo, v. 20, p. 55-60, jun./jul./ago. 2010. Dossiê 7. Disponível em: <http://www.ideiasustentavel.com.br/ 2010/06/dossierotulos-selos-e-certificacoes-verdes-uma-ferramenta-para-o-consumo-consciente/>. Acesso em: 15 jun. 2011.

BOURN, D.; PRESCOTT,J. A comparison of the nutritional value, sensory qualities and food safety of organically and conventionally produced foods. University of Otago: New Zealand. Crit. Rev. Food Science Nutrition, 2002.

BRACELPA - ASSOCIAÇÃO BRASILEIRA DE CELULOSE E PAPEL. Relatório de sustentabilidade 2010. Disponível em: <http://www.bracelpa.org.br/bra2/?q=node/451>. Acesso em: 3 nov. 2012.

BRASIL. Decreto no 6.323, de 27 de dezembro de 2007. Regulamenta a Lei Federal 10.831/03. Disponível em: <http://www.planalto.gov.br/ccivil_03/_ato2007-2010/2007/Decreto/D6323.htm>. 31 jul. 2012. Decreto-Lei no 986, de 21 de outubro de 1969. Institui normas básicas sobre alimentos. Disponível em: <https://www.planalto.gov.br/ ccivil_03/decreto-lei/Del0986.htm>.

. Lei no 8.078 , de 11 de setembro de 1990 . Dispõe sobre a proteção do consumidor e dá outras providências. Disponível em: <http://www.planalto.gov.br/ccivil_03/leis//8078compilado.htm>. Acesso em: 6 out. 2012.

. Lei no 10.831, de 23 de dezembro de 2003. Dispõe sobre a certificação e o controle de qualidade orgânica. Disponível em: <http://www.planalto.gov.br/ccivil_03/Leis/2003/L10.831.htm>. Acesso em: 15 jun. 2011.

. Lei no 12.305, de 2 de agosto de 2010. Institui a Política Nacional de Resíduos Sólidos. Disponível em <http://www.planalto.gov.br/ccivil_03/_ato2007-2010/2010/lei//12305.htm>. Acesso em: 14 out. 2012.

. Ministério da Agricultura, Pecuária e Abastecimento (MAPA). Instrução Normativa no 19/2009, de 29 de maio de 2009. Aprova os mecanismos de controle e informação da qualidade orgânica e os formulários para o Cadastro Nacional de Produtores Orgânicos. Disponível em:

<http://extranet.agricultura.gov.br/sislegis/action/detalhaAto.do?method=recuperarTextoAtoTematic aPortal\&codigoTematica=1501057>. Acesso em: 15 jun. 2011.

. Ministério da Agricultura, Pecuária e Abastecimento (MAPA). Instrução Normativa no 50/2009, de 29 de maio de 2009. Institui o selo único oficial do Sistema Brasileiro de Avaliação da Conformidade Orgânica. Disponível em: <http://extranet.agricultura.gov.br/sislegis/ action/detalhaAto.do?method=recuperarTextoAtoTematicaPortal\&codigoTematica=1501059>. Acesso em: 15 jun. 2011.

. Ministério da Justiça. Decreto no 4.680, de 24 de abril de 2003. Dispõe sobre o selo de transgênicos. Diário Oficial da República Federativa do Brasil, Brasília, DF, 27 dez. 2011. Disponível em: <http://www.jusbrasil.com.br/diarios/navegue/2011/Dezembro/27/DOU>. Acesso em: 15 jun. 2011. . Ministério da Saúde. Glossário temático: alimentação e nutrição. Brasília, DF: Editora do Ministério da Saúde, 2008. 
. Ministério da Saúde. Intoxicação por agrotóxicos. Brasília, DF. Disponível em:

<http://www.saude.pr.gov.br/arquivos/File/zoonoses_intoxicacoes/Intoxicacao_por_Agrotoxicos.pdf> . Acesso em: 29 ago. 2013.

Ministério do Meio Ambiente. Sustentabilidade aqui e agora: brasileiros de 11 capitais falam sobre meio ambiente, hábitos de consumo e reciclagem. Brasília, DF, 2010. Disponível em:

<http://www.mma.gov.br/estruturas/182/_arquivos/sustentabilidade_aqui_agora_182.pdf>. Acesso em: 16 nov. 2011.

Ministério do Meio Ambiente. Impacto das embalagens no meio ambiente. Brasília: 2010. Disponível em: <http://www.mma.gov.br/component/k2/item/7586-impacto-das-embalagens-no-meioambiente>. Acesso em: 14 out. 2012.

Ministério do Meio Ambiente.. Comitê gestor nacional de produção e consumo sustentável portaria no 44, de 13 de fevereiro de 2008. Plano de ação para produção e consumo sustentáveis - PPCS.

Disponível em <http://www.mma.gov.br/responsabilidade-socioambiental/producao-e-consumosustentavel/plano-nacional>. Acesso em: 16 nov. 2011.

Ministério do Meio Ambiente; IDEC; MEC; CONSUMERS INTERNATIONAL. Consumo sustentável: manual de educação. Brasília: 2005. Disponível em: <http://www.mma.gov.br/port/sds/guia.htm>. Acesso em: 16 nov. 2011.

BRAGA, M. C. (org.). O papel social do design gráfico: história, conceitos \& atuação profissional. São Paulo: Senac, 2011.

BRAUNGART, M.; MCDONOUGH, W. Cradle to cradle: re-making the way we make things. London: Vintage Books, 2008.

Cradle to cradle certified program. Disponível em: <http://www.mbdc.com/ images/MBDC\%20C2C\%20Certified.pdf>. Acesso em: 8 ago. 2012.

BREZET, V.; HEMEL, C. Ecodesign: a promising approach to sustainable production and consuption. Paris: United Nations Publication, 1997.

BRINGHURST, R. Elementos do estilo tipográfico. São Paulo: Cosac Naify, 2005.

BÜRDEK, B. E. História, teoria e prática do design de produtos. São Paulo: Edgard Blücher, 2006.

CA02. Entrevista com Consumidor 02. [jul. 2013]. Entrevistador: Elisa Jorge Quartim Barbosa. São Paulo, 2013. 1 arquivo . mp3 (38 min.). A entrevista na íntegra encontra-se transcrita no DVD anexo desta monografia.

CA04. Entrevista com Consumidor 04. [jul. 2013]. Entrevistador: Elisa Jorge Quartim Barbosa. São Paulo, 2013. 1 arquivo .mp3 (27 min.). A entrevista na íntegra encontra-se transcrita no DVD anexo desta monografia.

CA12. Entrevista com Consumidor 12. [jul. 2013]. Entrevistador: Elisa Jorge Quartim Barbosa. São Paulo, 2013. 1 arquivo .mp3 (28 min.). A entrevista na íntegra encontra-se transcrita no DVD anexo desta monografia.

CA15. Entrevista com Consumidor 15. [jul. 2013]. Entrevistador: Elisa Jorge Quartim Barbosa. São Paulo, 2013. 1 arquivo .mp3 (43 min.). A entrevista na íntegra encontra-se transcrita no DVD anexo desta monografia.

CA19. Entrevista com Consumidor 19. [ago. 2013]. Entrevistador: Elisa Jorge Quartim Barbosa. São Paulo, 2013. 1 arquivo .mp3 (31 min.). A entrevista na íntegra encontra-se transcrita no DVD anexo desta monografia.

CA21. Entrevista com Consumidor 21. [ago. 2013]. Entrevistador: Elisa Jorge Quartim Barbosa. São Paulo, 2013. 1 arquivo .mp3 (32 min.). A entrevista na íntegra encontra-se transcrita no DVD anexo desta monografia.

CA25. Entrevista com Consumidor 25. [ago. 2013]. Entrevistador: Elisa Jorge Quartim Barbosa. São Paulo, 2013. 1 arquivo .mp3 (1h01min.). A entrevista na íntegra encontra-se transcrita no DVD anexo desta monografia.

CA26. Entrevista com Consumidor 26. [ago. 2013]. Entrevistador: Elisa Jorge Quartim Barbosa. São Paulo, 2013. 1 arquivo .mp3 (31 min.). A entrevista na íntegra encontra-se transcrita no DVD anexo desta monografia.

CA28. Entrevista com Consumidor 28. [ago. 2013]. Entrevistador: Elisa Jorge Quartim Barbosa. São Paulo, 2013. 1 arquivo .mp3 (39 min.). A entrevista na íntegra encontra-se transcrita no DVD anexo desta monografia.

CA29. Entrevista com Consumidor 29. [ago. 2013]. Entrevistador: Elisa Jorge Quartim Barbosa. São Paulo, 2013. 1 arquivo .mp3 (22 min.). A entrevista na íntegra encontra-se transcrita no DVD anexo desta monografia. 
CA31. Entrevista com Consumidor 31. [ago. 2013]. Entrevistador: Elisa Jorge Quartim Barbosa. São Paulo, 2013. 1 arquivo .mp3 (49 min.). A entrevista na íntegra encontra-se transcrita no DVD anexo desta monografia.

CARBON TRUST. Organização mundial de suporte à sustentabilidade. Disponível em: <http://www.carbontrust.com/>. Acesso em: 15 out. 2012.

CARRANO, S. H. S. Estudo sobre rotulagem do alimento orgânico. Rio de Janeiro: Sociedade Nacional de Agricultura, 2008.

CARSON, R. L. Primavera silenciosa. São Paulo: Melhoramentos, 1964.

CAVALCANTI, P.; CHAGAS, C. História da embalagem no Brasil. São Paulo: Grifo Projetos Históricos e Editoriais, 2006.

CB01. Entrevista com Consumidor 01. [jul. 2013]. Entrevistador: Elisa Jorge Quartim Barbosa. São Paulo, 2013. 1 arquivo .mp3 (37 min.). A entrevista na íntegra encontra-se transcrita no DVD anexo desta monografia.

CB05. Entrevista com Consumidor 05. [jul. 2013]. Entrevistador: Elisa Jorge Quartim Barbosa. São Paulo, 2013. 1 arquivo .mp3 (40 min.). A entrevista na íntegra encontra-se transcrita no DVD anexo desta monografia.

CB09. Entrevista com Consumidor 09. [jul. 2013]. Entrevistador: Elisa Jorge Quartim Barbosa. São Paulo, 2013. 1 arquivo .mp3 (29 min.). A entrevista na íntegra encontra-se transcrita no DVD anexo desta monografia.

CB10. Entrevista com Consumidor 10. [jul. 2013]. Entrevistador: Elisa Jorge Quartim Barbosa. São Paulo, 2013. 1 arquivo .mp3 (28 min.). A entrevista na íntegra encontra-se transcrita no DVD anexo desta monografia.

CB14. Entrevista com Consumidor 14. [jul. 2013]. Entrevistador: Elisa Jorge Quartim Barbosa. São Paulo, 2013. 1 arquivo .mp3 (54 min.). A entrevista na íntegra encontra-se transcrita no DVD anexo desta monografia.

CB17. Entrevista com Consumidor 17. [ago. 2013]. Entrevistador: Elisa Jorge Quartim Barbosa. São Paulo, 2013. 1 arquivo .mp3 (33 min.). A entrevista na íntegra encontra-se transcrita no DVD anexo desta monografia.

CB18. Entrevista com Consumidor 18. [ago. 2013]. Entrevistador: Elisa Jorge Quartim Barbosa. São Paulo, 2013. 1 arquivo .mp3 (22 min.). A entrevista na íntegra encontra-se transcrita no DVD anexo desta monografia.

CB20. Entrevista com Consumidor 20. [ago. 2013]. Entrevistador: Elisa Jorge Quartim Barbosa. São Paulo, 2013. 1 arquivo .mp3 (37 min.). A entrevista na íntegra encontra-se transcrita no DVD anexo desta monografia.

CB22. Entrevista com Consumidor 22. [ago. 2013]. Entrevistador: Elisa Jorge Quartim Barbosa. São Paulo, 2013. 1 arquivo .mp3 (29 min.). A entrevista na íntegra encontra-se transcrita no DVD anexo desta monografia.

CB24. Entrevista com Consumidor 24. [ago. 2013]. Entrevistador: Elisa Jorge Quartim Barbosa. São Paulo, 2013. 1 arquivo .mp3 (35 min.). A entrevista na íntegra encontra-se transcrita no DVD anexo desta monografia.

CB27. Entrevista com Consumidor 27. [ago. 2013]. Entrevistador: Elisa Jorge Quartim Barbosa. São Paulo, 2013. 1 arquivo .mp3 (25 min.). A entrevista na íntegra encontra-se transcrita no DVD anexo desta monografia.

CB32. Entrevista com Consumidor 32. [set. 2013]. Entrevistador: Elisa Jorge Quartim Barbosa. São Paulo, 2013. 1 arquivo .mp3 (57 min.). A entrevista na íntegra encontra-se transcrita no DVD anexo desta monografia.

CC06. Entrevista com Consumidor 06. [jul. 2013]. Entrevistador: Elisa Jorge Quartim Barbosa. São Paulo, 2013. 1 arquivo .mp3 (29 min.). A entrevista na íntegra encontra-se transcrita no DVD anexo desta monografia.

CC11. Entrevista com Consumidor 11. [jul. 2013]. Entrevistador: Elisa Jorge Quartim Barbosa. São Paulo, 2013. 1 arquivo .mp3 (37 min.). A entrevista na íntegra encontra-se transcrita no DVD anexo desta monografia.

CC13. Entrevista com Consumidor 13. [jul. 2013]. Entrevistador: Elisa Jorge Quartim Barbosa. São Paulo, 2013. 1 arquivo .mp3 (39 min.). A entrevista na íntegra encontra-se transcrita no DVD anexo desta monografia.

CC16. Entrevista com Consumidor 16. [jul. 2013]. Entrevistador: Elisa Jorge Quartim Barbosa. São Paulo, 2013. 1 arquivo .mp3 (53 min.). A entrevista na íntegra encontra-se transcrita no DVD anexo desta monografia. 
CC23. Entrevista com Consumidor 23. [ago. 2013]. Entrevistador: Elisa Jorge Quartim Barbosa. São Paulo, 2013. 1 arquivo .mp3 (38 min.). A entrevista na íntegra encontra-se transcrita no DVD anexo desta monografia.

CC30. Entrevista com Consumidor 30. [ago. 2013]. Entrevistador: Elisa Jorge Quartim Barbosa. São Paulo, 2013. 1 arquivo .mp3 (37 min.). A entrevista na íntegra encontra-se transcrita no DVD anexo desta monografia.

CEMPRE - COMPROMISSO EMPRESARIAL PARA RECICLAGEM. Política Nacional de Resíduos Sólidos: agora é lei. São Paulo, 2011.

CHEVALIER, J.; GHEERBRANT, A. Dicionário de símbolos: mitos, sonhos, costumes, gestos, formas, figuras, cores, números. 12. ed. Rio de Janeiro: José Olympio, 1998.

CMMAD - COMISSÃO MUNCIAL SOBRE MEIO AMBIENTE E DESENVOLVIMENTO. Nosso futuro comum. 2. ed. Rio de Janeiro: Fundação Getúlio Vargas, 1991.

COLTRO, L. Avaliação do Ciclo de Vida como instrumento de gestão. Campinas: CETEA/ITAL, 2007.

COLTRO, L.; GASPARINO, B. F.; QUEIROZ, G. C. Reciclagem de materiais plásticos: a importância da identificação correta. In: Polímeros: ciência e tecnologia. São Carlos, v. 18, n. 2, p. 119-125, 2008.

CORDEL EMBALAGENS. Empresa de embalagens. Disponível em: <http://www.cordel.ind.br/>. Acesso em: 13 jan. 2013.

CRUL, M. R. M.; DIEHL, J. C. Design for sustainability: a step-by-step approach. United Nations Environment Programme (UNEP) e Delft University of Technology, 2009. Disponível em: <http://www.unep.fr/scp/publications/details.asp?id=DTI/0826/PA>. Acesso em: 10 jul. 2012.

DAROLT, M. R. Comparação entre a qualidade do alimento orgânico e convencional. In: STRIGHETA, P. C.; MUNIZ, J. N. Alimentos orgânicos: produção, tecnologia e certificação. Viçosa: Universidade Federal de Viçosa (UFV), 2003, p.289-312. Disponível em: <http://www.iapar.br/arquivos/File/zip_pdf/OrgConvenc.pdf>. Acesso em: 10 ago. 2013.

DER BLAUE ENGEL. Der Blaue Engel Umweltzeichen. Disponível em: <http://www.blauer-engel.de/>. Acesso em: 3 nov. 2012.

DESIGN BY NATURE. The australian resource forum for environmentally graphic design. Disponível em: <http://www.designbynature.org>. Acesso em: 3 nov. 2012.

DESIGNER1. Entrevista com Designers 1 e 2. [jun. 2012]. Entrevistador: Elisa Jorge Quartim Barbosa. São Paulo, 2012. 1 arquivo .mp3 (1h10min.). A entrevista na íntegra encontra-se transcrita no DVD anexo desta monografia.

DESIGNER2. Entrevista com Designers 1 e 2. [jun. 2012]. Entrevistador: Elisa Jorge Quartim Barbosa. São Paulo, 2012. 1 arquivo .mp3 (1h10min.). A entrevista na íntegra encontra-se transcrita no DVD anexo desta monografia.

DESIGNER3. Entrevista com Designer3. [set. 2012]. Entrevistador: Elisa Jorge Quartim Barbosa. São Paulo, 2012. 1 arquivo .mp3 (57 min.). A entrevista na íntegra encontra-se transcrita no DVD anexo desta monografia.

DESIGNER4. Entrevista com Designer4. [mai. 2013]. Entrevistador: Elisa Jorge Quartim Barbosa. Via programa eletrônico de chamada de voz Skype 2013. 1 arquivo .mp3 (1h06min.). A entrevista na íntegra encontra-se transcrita no DVD anexo desta monografia.

DEZIGN COM Z. Escritório de design. Disponível em: <http://www.dezigncomz.com.br/>. Acesso em: 3 nov. 2012.

Portifolio da Design com Z. São Paulo, 2009.

DONAIRE, D. Gestão ambiental na empresa. 2.ed. São Paulo: Atlas, 1999.

DONDIS, D. A. Sintaxe da linguagem visual. 2. ed. São Paulo: Martins Fontes, 1997.

DOUGHERTY, B. Design gráfico sustentável. São Paulo: Edições Rosari, 2011.

ECO MARK PROGRAM. Associação ambiental japonesa. Disponível em: <http://www.ecomark.jp/english/>. Acesso em: 3 nov. 2012.

ECOLABEL. The EU Ecolabel. Disponível em: <ec.europa.eu/environment/ecolabel/>. Acesso em: 3 nov. 2012.

ECOLOGO PROGRAM. Disponível em: <http://www.ecologo.org/en/>. Acesso em: 3 nov. 2012.

ECOURBIS. Press-kit 2 EcoUrbis Ambiental. São Paulo: 2011.

ELETROBRAS. Procel. Disponível em: <http://www.eletrobras.com/procel>. Acesso em: 5 out. 2012.

ELKINGTON, J. Canibais com garfo e faca. São Paulo: Makron Books, 2001.

EMBRAPA. Princípios norteadores da produção orgânica de hortaliças. Brasília, 2008.

EMPREENDEDOR RURAL. A embalagem correta. Ano 5, n. 7, abr. 2005. p. 59 a 61. Disponível em: <http://issuu.com/revistaempreendedor/docs/empreendedor_rural_07>. Acesso em: 13 nov. 2012

EUROPEN. Green paper: packaging and sustainability: an open dialogue between stakeholders. Brussels: 2011. Disponível em: <http://www.europen.be/ index.php? action= onderdeel\& onderdeel= 6\&titel= EUROPEN + Publications \&page=0>. Acesso em: 14 mai. 2012. 
. Packaging in the sustainability agenda: a guide for corporate decision makers. Brussels: 2009.

Disponível em: <http://www.europen.be/ index.php?action= onderdeel\& onderdeel=6\&

titel=EUROPEN+Publications \&page=0>. Acesso em: 14 mai. 2012.

EXAME. Empresa aposta em produtos naturais e fatura $\mathbf{R} \mathbf{4 , 2} \mathrm{mi}$. Disponível em:

$<$ http://exame.abril.com.br/pme/cases-de-sucesso/noticias/empresa-aposta-em-produtos-naturais-efatura-r-4-2-mi-2>. Acesso em: 23 nov. 2013.

FAIRTRADE INTERNATIONAL. The international Fairtrade system. Disponível em: <http://www.fairtrade.net/>. Acesso em: 14 out. 2012.

FERRARA, L. d’A. Leitura sem palavras. 3. ed. São Paulo: Ática, 1993.

FERREIRA, A. B. de H.; FERREIRA, M. B.; ANJOS, M. dos. Novo dicionário Aurélio da língua portuguesa. Curitiba: Positivo, 2009.

FIBL; IFOAM. -The World of Organic Agriculture. Alemanha, 2010.

FIESP; ITAL. Brasil food trends 2020. São Paulo, 2010.

FIESP; CIESP. Prêmio Ecodesign 2001/2002. Disponível em: <http:// www.fiesp.com.br/ download/publicacoes_meio_ambiente/catalogo_ecodesign.pdf>. Acesso em: 5 ago. 2012.

FIKSEL, J. Design for environment: creating eco-efficient products and processes. New York: McGraw-Hill, 1995.

FISCHER, T.; SHIPTON, J. Designing for re-use: the life of conumer packaging. London: Earthscan, 2010.

FLICK, U. Introdução à pesquisa qualitativa. 3. ed. Porto Alegre: Artmed, 2009.

FRY, T. Contra uma teoria essencialista de necessidade: algumas considerações para a teoria do design. In: Design em Foco, Salvador, v.2, n.1, p. 63-77, jan/jun 2005.

. Reconstruções: ecologia, design, filosofia. São Paulo: Editora da Universidade de São Paulo, 2009.

FSC - FOREST STEWARDSHIP COUNCIL. Certificação FSC. Disponível em: <http://br.fsc.org>. Acesso em: 13 out. 2012.

GIACOMINI FILHO, G. Meio ambiente \& consumismo. São Paulo: Editora Senac, 2008.

GIOVANNETTI, M. D. V. El mundo del envase: manual para el deseño y producción de envase y embalajes. 3. ed. Barcelona: Gustavo Gili, 2000.

GOLEMAN, D. Inteligência ecológica. São Paulo: Editora Elsevier, 2011.

GOMES FILHO, J. Gestalt do objeto: sistema de leitura visual da forma. 5. ed. São Paulo: Escrituras Editora, 2003.

GONÇALVES, A. A.; PASSOS, M. G.; BIEDRZYCKI, A. Percepção do consumidor com relação à embalagem de alimentos: tendências. In: Estudos Tecnológicos. v. 4, n. 3, p. 271-283, set/dez. 2008.

GREEN SEAL. Disponível em: <http://www.greenseal.org/>. Acesso em: 31 out. 2012.

GUADALUPE; E. A. S. Influência da embalagem no processo de decisão de compra de produtos alimentícios: estudo de caso: biscoitos "cookies". 1999. 125f. Dissertação (Mestrado em Administração) - Escola de Administração, Universidade Federal do Rio Grande do Sul, Porto Alegre, 1999. Disponível em: <http://www.scribd.com/doc/3566385/embalagens-marketing>. Acesso em: 31 jul. 2012.

GURGEL, F. A. Administração da embalagem. São Paulo: Thomson Learning, 2007.

GUSTAVO PERES. Portfolio online de Gustavo Peres. Disponível em: <http://www.gustavoperes.com/mae_terra/>. Acesso em: 31 out. 2012.

HAWKEN, P.; LOVINS, A.; LOVINS, L. H. Capitalismo natural. São Paulo: Cultrix, 2007.

HÉRNANDEZ, J. C. Patrimônio e globalização: o caso das culturas alimentares. In: CANESQUI, A. M.; HOFFMAN; D. D. Inteligência visual: como criamos o que vemos. São Paulo: Campus, 2001.

IBGE - INSTITUTO BRASILEIRO DE GEOGRAFIA E ESTATíSTICA. Censo Agropecuário 2006. Rio de Janeiro, 2006. Disponível em:

<http://www.ibge.gov.br/home/estatistica/economia/agropecuaria/censoagro/default.shtm>. Acesso em: 30 ago. 2013.

IDEC. Transgênicos: feche a boca e abra os olhos. São Paulo: Idec, 2010. Disponível em: <http://www.idec.org.br/uploads/publicacoes/publicacoes/cartilha-transgenico.pdf>. Acesso em: 29 ago. 2013.

INDÚSTRIA1. Entrevista com Indústria1. [mai. 2012]. Entrevistador: Elisa Jorge Quartim Barbosa. Osasco, 2012. 1 arquivo .mp3 (1h21min). A entrevista na íntegra encontra-se transcrita no DVD anexo desta monografia.

INDÚSTRIA2. Entrevista com Indústria2. [jul. 2012]. Entrevistador: Elisa Jorge Quartim Barbosa. Itupeva, 2012. 1 arquivo .mp3 (31 min.). A entrevista na íntegra encontra-se transcrita no DVD anexo desta monografia.

INDÚSTRIA3. Entrevista com Indústria3. [set. 2012]. Entrevistador: Elisa Jorge Quartim Barbosa. Joinville, 2012. 1 arquivo .mp3 (53 min.). A entrevista na íntegra encontra-se transcrita no DVD anexo desta monografia. 
INMETRO. Selo Cerflor. Disponível em: <http://www.inmetro.gov.br/qualidade/cerflor.asp>. Acesso em: 13 out. 2012.

INSTITUTO DE EMBALAGENS; CAMILO, A. N. (Coord.). Embalagens: design, materiais, processos, máquinas e sustentabilidade. Barueri: Instituto de Embalagens, 2011.

IPCC - INTERGOVERNMENTAL PANEL ON CLIMATE CHANGE. Climate change 2007: Synthesis Report. Valencia, 2007.

IPD - INSTITUTO DE PROMOÇÃO DO DESENVOLVIMENTO. O mercado brasileiro de produtos orgânicos. Curitiba: IPD, 2011.

JACOBI, P.; BESEN, G. Gestão de resíduos sólidos em São Paulo: desafios da sustentabilidade. In: Estudos avançados, São Paulo, v. 25, n. 71, abr. 2011. Disponível em: <http://www.scielo.br/ scielo.php? script=sci_pdf\&pid=S0103-40142011000100010 \&lng =em\& nrm =iso\&tlng=pt>. Acesso em: 13 out. 2012.

JEDLIČKA, W. Packaging sustainability: tools, systems and strategies for innovative package design. Hoboken: John Wiley and Sons, 2009.

KARSAKLIAN, E. Comportamento do consumidor. São Paulo: Atlas, 2000.

KAZAZIAN, T. (org). Haverá a idade das coisas leves: design e desenvolvimento sustentável. 2. ed. São Paulo: SENAC, 2005.

LAKATOS, E. M.; MARCONI, M. D. A. M. Fundamentos de metodologia científica. São Paulo: Atlas, 1996.

LAUTENSCHLÄGER, B. I. Avaliação de embalagem de consumo com base nos requisitos ergonômicos informacionais. 2001. 109 f. Dissertação (Mestrado em Engenharia de Produção). Universidade Federal de Santa Catarina, Florianópolis, 2001.

LEWIS, H.; GERTSAKIS J.; et al. Design + environment: a global guide to designing greener goods. Reino Unido: Greenleaf Publishing Limited, 2001.

LUMA INSTITUTE. Stakeholder Map. Disponível em: <http://www.luma-institute.com/>. Acesso em: 13 out. 2012.

MÄDER, P.; FLIEBACH, A.; DUBOIS, D.; GUNST, L.; FRIED, P.; NIGGLI, U. Soil fertility and biodiversity in organic farming science. 31 maio 2002. v. 296. p. 1694-1697.

MÃE TERRA. Empresa alimentícia. Disponível em: <http://www.maeterra.com.br/>. Acesso em: 31 out. 2012.

MAPA - MINISTÉRIO DA AGRICULTURA, PECUÁRIA E ABASTECIMENTO. Site prefira orgânicos. Disponível em: <http://www.prefiraorganicos.com.br/oquesao.aspx>. Acesso em: 31 jul. 2012.

Orgânicos. Disponível em: <http://www.agricultura.gov.br/desenvolvimento-sustentavel/organicos>. Acesso em: 31 jul. 2012.

Manual de aplicação do selo oficial para produtos orgânicos. Secretaria de Desenvolvimento Agropecuário e Cooperativismo. Brasília: Mapa/ACS, 2009.

MANZINI, E. A matéria da invenção. Lisboa: Centro Português de Design, 1993.

Context-based wellbeing and the concept of regenerative solution: a conceptual framework for scenario building and sustainable solutions development. The Journal of Sustainable product Design 2: 141-148. Kluwer Academic publishers. Holanda: 2002.

MANZINI, E., VEZZOLI, C. O desenvolvimento de produtos sustentáveis: os requisitos ambientais dos produtos industriais. São Paulo: EDUSP, 2002.

MEADOWS, D. L., MEADOWS, D. H., RANDERS, J.; BEHRENS, W. W. Limites do crescimento: um relatório para o projeto do Clube de Roma sobre o dilema da humanidade. São Paulo: Perspectiva, 1972.

MESTRINER, F. Gestão estratégica de embalagem: uma ferramenta de competitividade para sua empresa. São Paulo: Pearson Prentice Hall, 2007.

A função social da embalagem. Design Brasil, 2007. Disponível em:

<http://www.designbrasil.org.br/artigo/funcao-social-da-embalagem>. Acesso em: 8 out. 2012

Design de embalagem: curso avançado. São Paulo: Makron B, 2002.

Design de embalagem: curso básico. São Paulo: Makron B, 2001.

MMA - MINISTÉRIO DO MEIO AMBIENTE. Impacto doas embalagens no meio ambiente. Disponível em: <http://www.mma.gov.br/component/k2/item/7586-impacto-das-embalagens-no-meio-ambiente>. Acesso em: 31 jul. 2012.

Agenda 21. Disponível em: <http://www.mma.gov.br/responsabilidade-socioambiental/agenda-21>. Acesso em: 31 jul. 2012.

MONAMA. Empresa alimentícia. Disponível em: <http://www.monama.com.br/>. Acesso em: 8 out. 2012.

MONTGOMERY, D. C. Design and analysis of experiments. New York: J. Wiley, 2001.

MUNTER, J. S. L. e col. Whole grain, bran and germ intake and risk of type $\mathbf{2}$ diabetes: a prospective cohort study and systematic review. Plos Med, v. 4, n.8, p. 1385-1395, 2007.

NATIONAL GEOGRAPHIC; GLOBESCAN. Greendex 2012: consumer choice and the environment: a worldwide tracking survey. Jul, 2012.

NEGRÃO, C.; CAMARGO, E. Design de embalagem: do marketing à produção. São Paulo: Novatec Editora, 2008. NIEMEYER; L. Elementos de semiótica aplicados ao design. Rio de Janeiro: 2AB, 2003. 
OLIVEIRA, V. R.; MALTA, M. C. M.; LIMA FILHO, D. O. Conceito de alimento natural e alimento industrializado: uma abordagem sócio-comportamental. In: XXVII ENCONTRO NACIONAL DE ENGENHARIA DE PRODUÇÃO (ENEGEP). Foz do Iguaçu, 2007.

ORGANIC MONITOR. Research and business consulting company specializing in organic products. Disponível em: <http://www.organicmonitor.com>. Acesso em: 15 jun. 2011.

ORGANIC SERVICES; VITALFOOD. Pesquisa sobre o comportamento e a percepção do consumidor de alimentos orgânicos no Brasil 2010. Jundiaí: 2010.

ORGANICS BRASIL -Brazilian Organic and Sustainable Producers. Disponível em: <http://www.organicsbrasil.org/>. Acesso em: 15 jun. 2011.

ORMOND, J. G. P.; PAULA, S. R. L. DE; FAVERET FILHO, P.; ROCHA, L. T. M. da. Agricultura orgânica: quando o passado é futuro. Rio de Janeiro: BNDES Setorial, 2002.

OSGOOD, C. E.; SUCI, G. J.; TANNENBAUM, P. The measurement of meaning. 9. ed. Illinois: University of Illinois Press, 1967.

PAPANEK, V. Arquitetura e design: ecologia e ética. Lisboa: Edições 70, 1995. . Design for the real world: human ecology and social change. London: Thames \& Hudson, 1985.

PELTIER, F.; SAPORTA, H. Design sustentável: caminhos virtuosos. São Paulo: SENAC, 2009.

PETERSEN \& AVILA. Escritório de design. Disponível em: <http://www.petersenavila.com/>. Acesso em: 5 out. 2012.

PLANETA ORGÂNICO. História da agricultura orgânica: algumas considerações. Disponível em: <http://www.planetaorganico.com.br/histaorg1.htm>. Acesso em: 5 dez. 2011.

PLASTIVIDA. Desempenho e perspectiva da reciclagem dos plásticos no Brasil. Disponível em <http://www.plastivida.org.br>. Acesso em 9 dez. 2008.

POPAI. The global association for marketing at retail. Disponível em: <http://www.popai.com/engage/?p=52>. Acesso em: 8 jul. 2013.

REVISTA PACK. A história da embalagem no Brasil: evolução e sucesso. Revista Pack, São Paulo, out. 2003, edição especial, ano 6, n. 74.

ROHS. RoHS compliance guide. Disponível em: <http://www.rohsguide.com/>. Acesso em: 5 out. 2012.

ROSA, M. V. de F. P. do C.; ARNOLDI, M. A. G. C. A entrevista na pesquisa qualitativa: mecanismos para validação dos resultados. Belo Horizonte: Autêntica, 2006.

ROZIN, P.; SPRANCA, M.; KRIEGUER, Z.; NEUHAUS, R.; SURILLO, D.; SWERDLIN, A.; WOOD, K. Preference for natural: instrumental an ideational/moral motivations, and the contrast between foods and medicines. Appetite, v. 43, 2004, p. 147-54,

SACHS, I. Ecodesenvolvimento: crescer sem destruir. São Paulo: Vértice, 1986. . Caminhos para o desenvolvimento sustentável. 3. ed. Rio de Janeiro: Editora Garamond, 2008.

SAMPAIO, C. P. Diretrizes baseadas em sistemas produto-serviço para o design de embalagens em papelão ondulado movimentadas entre empresas. 2007. Dissertação (Mestrado em Design). Universidade Federal do Paraná, Curitiba, 2007.

SANTAELLA, L. Semiótica aplicada. São Paulo: Pioneira Thomson Learning, 2005. . O que é semiótica. 32. ed. São Paulo: Brasiliense, 2012.

SANTOS, M. C. L. Consumo, descarte, catação e reciclagem: notas sobre design e multiculturalismo. Estudo Avançado em Design, v. 1, São Paulo, 2008.

SÃO PAULO. Secretaria Municipal de Serviços. Departamento de Limpeza Urbana. Gestão de resíduos sólidos da cidade de São Paulo. São Paulo: 2009.

Departamento de Limpeza Urbana (Limpurb). Concessão. Disponível em:

<http://www.prefeitura.sp.gov.br/cidade/secretarias/servicos/limpurb/concessao/index.php?p=4630 >. Acesso em: 10 fev. 2011.

SCHUMACHER, E. F. O negócio é ser pequeno: um estudo de economia que leva em conta as pessoas. Rio de Janeiro: Zahar, 1977.

SILVEIRA NETO, W. D. Avaliação visual de rótulos de embalagens. 2001. 111 f. Dissertação (Mestrado em Engenharia de Produção). Universidade Federal de Santa Catarina, Florianópolis, 2001.

SINTONIA COMUNICAÇÃO. Empresa de comunicação. Disponível em: <http://www.sintonia.ppg.br/>. Acesso em: 10 out. 2012.

SPC - SUSTAINABLE PACKAGING COALITION. Definition of sustainable packaging. Charlottesville: 2011. Disponível em: <https://www.sustainablepackaging.org/resources/default.aspx>. Acesso em: 14 mai. 2012.

Sustainable packaging indicators and metrics framework. Charlottesville: 2009. Disponível em: <https://www.sustainablepackaging.org/resources/default.aspx>. Acesso em: 14 de mai. 2012.

STERNBERG, R. J. Psicologia cognitiva. Porto Alegre: Artmed. 2000.

STEWART, Bill. Estratégias de design para embalagens. São Paulo: Blucher, 2009. 
TERRACHOICE; MARKET ANALYSIS. Greenwashing no Brasil: um estudo sobre os apelos ambientais nos rótulos dos produtos. Florianópolis, 2010.

TISKI-FRANCKOWIAK, I. T. Homem, comunicação e cor. 4. ed. São Paulo: Ícone, 2000.

TRIVIÑOS, A. N. S. Introdução à pesquisa em ciências sociais: a pesquisa qualitativa em educação. São Paulo: Atlas, 1987.

TWEDE, D.; GODDARD, R. Materiais para embalagens. 2. ed. São Paulo: Blucher, 2009.

UFRGS. Laboratório de Design e Seleção de Materiais. CD-ROM Ecodesign. Porto Alegre, 2004.

UNEP - UNITED NATIONS ENVIRONMENT PROGRAMME. Life cycle management: a business guide to sustainability. Paris: 2007.

VEIGA, J. E. da. Rio+20: um passo adiante e dois para trás. In: Política externa. <http://www.politicaexterna.com.br/index.asp>. jul. 2012.

VIA PAX BIO. Empresa alimentícia. Disponível em: <http://www.viapaxbio.com.br/>. Acesso em: 15 out. 2012.

VOLTOLINI, R. Tendências para o Consumo Consciente. In: Revista Ideia Sustentável, São Paulo, v. 19, p. 47-54, mar./abr./maio 2010. Dossiê 6. Disponível em: <http:// www.ideiasustentavel.com.br/ pdf/IS19\%20\%20Dossie\%20v1.pdf>. Acesso em: 15 jun. 2011.

. Rótulos, selos e certificações verdes: uma ferramenta para o consumo consciente. In: Revista Ideia Sustentável, São Paulo, v. 20, p. 47-54, jun./jul./ago. 2010. Dossiê 7. Disponível em: <http://www.ideiasustentavel.com.br/2010/06/dossie-rotulos-selos-e-certificacoes-verdes-umaferramenta-para-o-consumo-consciente/>. Acesso em: 15 jun. 2011.

WBCSD - WORLD BUSINESS COUNCIL FOR SUSTAINABLE DEVELOPMENT. Eco-efficiency: creating more value with less impact. Reino Unido: WBCSD, 2000. Disponível em: <http://www.wbcsd.org>. Acesso em: 12 out. 2011.

. Eco-Efficiency: Overview. Disponível em: <http://www.wbcsd.org>. Acesso em: 12 out. 2011.

WILLER, H.; KILCHER, L. The world of organic agriculture: statistics and emerging trends 2012. Switzerland: FiBL, IFOAM, 2012.

WILLIAMS, C. M. Nutritional quality of organic food: shades of grey or shades of green? Proceedings of the Nutrition Society. n. 61, 2002, p. 19-24.

WWF - WORLD WIDE FUND FOR NATURE. Living planet report 2012: biodiversity, biocapacity and better choices. Switzerland: 2012. Disponível em: <http://wwf.panda.org/ about_our_earth/ all_publications/living_planet_report/2012_lpr/>. Acesso em: 28 jan. 2014.

YIN, R. K. Estudo de caso: planejamento e métodos. 3. ed. Porto Alegre: Bookman, 2005. 


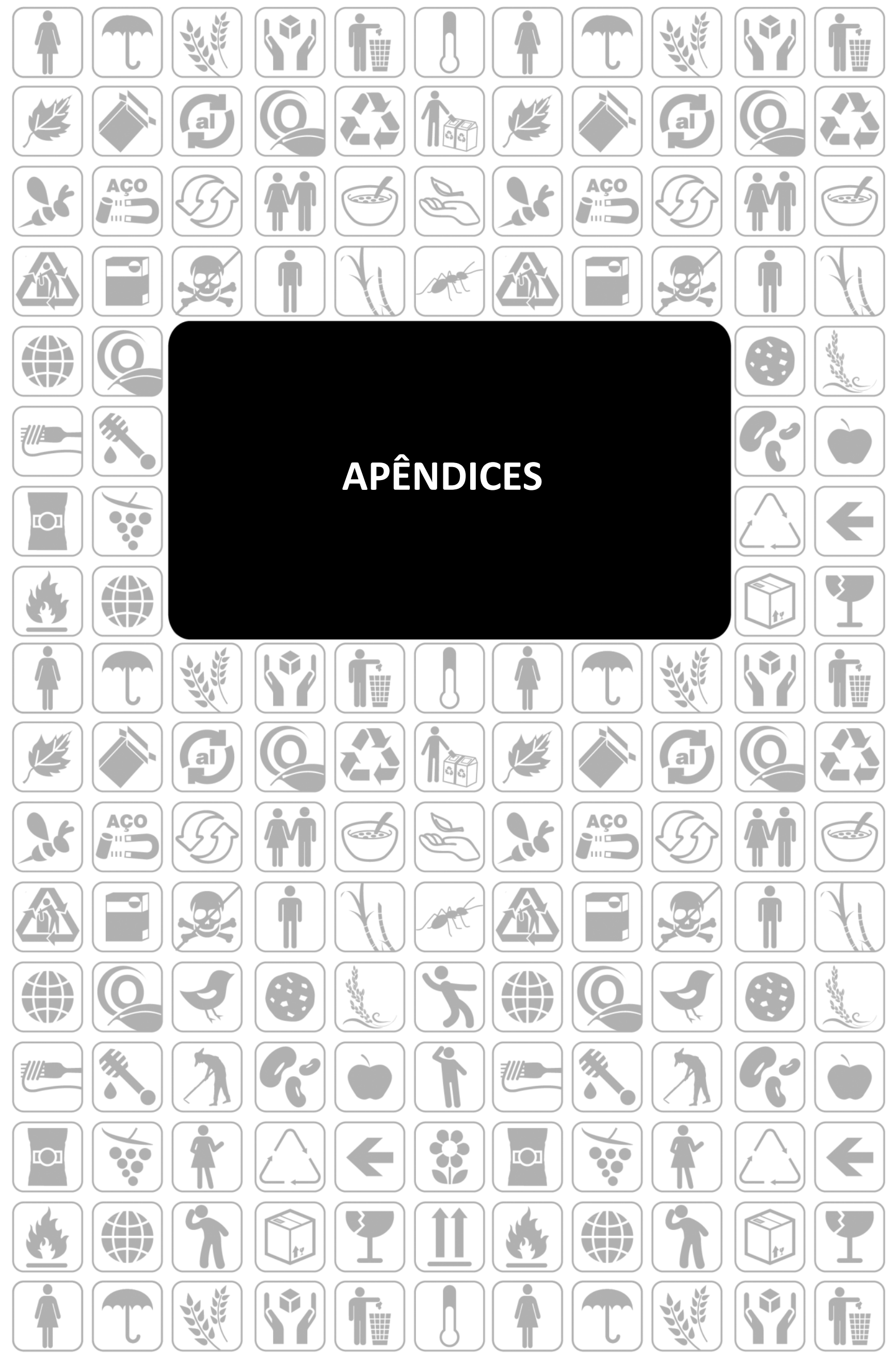




\section{APÊNDICES}

\section{A. ROTEIRO DA ENTREVISTA DAS INDÚSTRIAS}

Data, mês e ano.

Meu nome é Elisa e esta entrevista é para uma pesquisa do Programa de Pós Graduação da FAU USP sobre design de embalagens de alimentos orgânicos.

O objetivo desta entrevista é fazer um mapeamento do desenvolvimento de embalagens de alimentos orgânicos por todo o seu ciclo de vida. Desde a sua fabricação até o consumidor.

\section{GOSTARIA DE CONHECÊ-LO MELHOR.}

Qual o seu nome completo?

Qual é a sua formação?

Qual é o cargo que ocupa na sua empresa?

Quanto tempo trabalha na sua empresa? Sempre trabalhou na mesma área?

Você é um dos responsáveis pelo desenvolvimento das embalagens da sua empresa?

Qual a sua participação?

\section{ESTRATÉGIAS DO DESENVOLVIMENTO DE EMBALAGENS.}

Nas decisões estratégicas do desenvolvimento das embalagens, quais setores são envolvidos?

Fornecedores são chamados nessa etapa?

Cite 3 pontos mais importantes no desenvolvimento das embalagens da sua empresa Em qual departamento são definidos os materiais utilizados nas embalagens?

Pessoa responsável. Contato.

Existe alguma diferença na hora de escolher embalagens para alimentos orgânicos e não orgânicos?

Além das informações obrigatórias da legislação, quais outras informações considera importante constar em todas as embalagens?

Existe um padrão de linguagem, como ícones e cores, que sejam utilizados na comunicação de todas as linhas de embalagens da empresa?

Alguns exemplos

Usa os aspectos indicados nas normas ISO / ABNT no desenvolvimento das embalagens?

\section{RELACIONAMENTO DA EMPRESA COM OS ESCRITÓRIOS DE DESIGN.}

O que norteia a sua empresa na hora da escolha de um escritório de design?

Vocês têm um modelo de briefing para o desenvolvimento de embalagens?

Poderia ser cedido para esta pesquisa? Pode ser divulgado?

Vocês fazem pesquisa para avaliar as embalagens no mercado?

O escritório de design participa?

\section{PÓS-CONSUMO DAS EMBALAGENS.}

Existe alguma ação ou projeto da sua empresa em relação ao pós consumo de embalagens? Como incentivam a reciclagem das embalagens?

\section{DISTRIBUIÇÃO DOS PRODUTOS DA EMPRESA}

Como é a distribuição dos produtos da sua empresa?

Onde estão os centros de distribuição?

Quais são os meios de transporte utilizados? 
Em que estados são vendidos os produtos da sua empresa no Brasil?

Já exportam para outros países? Quais?

Em que cidades estão os seus fornecedores de embalagens?

\section{CONSUMIDOR DOS PRODUTOS}

Vocês fazem pesquisas com o consumidor sobre os seus produtos?

Como essas informações revertem em melhorias nas embalagens e nas decisões futuras?

Como você poderia descrever o principal público alvo da Monama?

\section{RASTREAMENTO DOS IMPACTOS AMBIENTAIS E SOCIAIS}

Vocês fazem relatórios anuais de sustentabilidade?

Poderia ser cedido para esta pesquisa? Pode ser divulgado?

As embalagens estão incluídas nesse relatório?

Gostaria de saber um pouco como é feito o rastreamento dos impactos ambientais.

\section{PRODUTOS}

Quais são os produtos mais vendidos da sua empresa?

Perguntas específicas por produto

Qual foi o escritório de design escolhido para desenvolver esta linha de produto?

Nome do responsável. Contato.

Poderia me ceder o briefing para o desenvolvimento da embalagem?

Quais foram os critérios de escolha dos materiais da embalagem?

Cite algumas características do produto que influenciaram nessa escolha?

Por exemplo, o produto por ter o ingrediente $X$ precisava de barreira de (oxigênio, umidade, gordura, etc).

Como é a logística desse produto?

Onde é produzido? Onde é embalado?

Qual o fornecedor de embalagem? Contato

Em que cidades ele é vendido?

Existe algum projeto de logística reversa?

Como é a embalagem para o transporte? Poderia ceder uma? 


\section{B. ROTEIRO DA ENTREVISTA DOS ESCRITÓRIOS DE DESIGN}

Data. Mês. Ano.

Meu nome é Elisa e esta entrevista é para uma pesquisa do Programa de Pós Graduação da FAU USP sobre design de embalagens de alimentos orgânicos.

O objetivo desta entrevista é fazer um mapeamento do desenvolvimento de embalagens de alimentos orgânicos por todo o seu ciclo de vida. Desde a sua fabricação até o consumidor.

\section{GOSTARIA DE CONHECÊ-LO MELHOR.}

Qual o seu nome completo?

Qual é a sua formação?

Qual é o cargo que ocupa na sua empresa?

Quanto tempo trabalha na sua empresa?

Sempre trabalhou na mesma área?

\section{ESTRATÉGIAS DO DESENVOLVIMENTO DE EMBALAGENS.}

Hoje, vocês diriam que o design de embalagens ocupa a maior parte do tempo de trabalho da sua empresa?

Cite os 3 pontos mais importantes no desenvolvimento das embalagens que caracterizam o design na sua empresa.

Vocês costumam sugerir a inclusão ou exclusão de informações nas embalagens?

Além das informações obrigatórias pela legislação, quais outras informações considera importante constar em todas as embalagens?

Vocês acompanham a produção da embalagem na gráfica?

Vocês fazem algum tipo de avaliação da embalagem após-esta entrar no mercado?

\section{RELACIONAMENTO COM A INDÚSTRIA.}

Faz quanto tempo que trabalha com a indústria?

Vocês participam das decisões estratégicas do desenvolvimento das embalagens?

Qual foi a sua participação?

Vocês participam das decisões da escolha dos materiais das embalagens?.

Qual foi a sua participação?

Vocês costumam receber um briefing para o design das embalagens?

Como vocês classificariam o briefing recebido: completo, regular ou muito incompleto?

\section{Perguntas específicas por produto}

Vocês foram os responsáveis pelo design da embalagem?

Quais informações tinham no briefing inicial?

A embalagem e seus materiais vieram definidos pelo cliente ou tiveram alguma participação na escolha?

O que já veio definido pelo cliente e o que foi sugestão de vocês?

Gostaria de saber um pouco o porquê das cores utilizadas? Qual era informação que

esperavam transmitir?

E das ilustrações?

E da tipografia escolhida?

Quem foi o ilustrador? Nome e contato.

Quem foi o fotógrafo? Nome e contato.

Gostariam de acrescentar mais alguma coisa? 


\section{ROTEIRO DA ENTREVISTA DOS CONSUMIDORES}

Data. Mês. Ano.

Meu nome é Elisa Quartim, sou designer e estou cursando o mestrado na FAU USP. Esta entrevista faz parte de uma pesquisa que estou desenvolvendo em meu mestrado sobre embalagens de alimentos industrializados. Você poderia responder a algumas questões. Leva cerca de 30 minutos.

Informações sobre o entrevistado.

Qual o seu nome completo?

Qual é a sua formação / ocupação?

Quantas pessoas moram com você?

Você costuma comprar alimentos para a sua casa?

( ) Sim ( ) Não

Você costuma fazer as refeições na sua casa?

( ) Sim ( ) Não. Com que frequência?

Você é o principal responsável pelas compras de sua casa?

( ) $\operatorname{sim}($ ) Não

\section{Separação de embalagens}

Escolher dois grupos de produtos por entrevistado. Se a pessoa cozinhar, dar preferência para os ingredientes, se não dar preferência para os produtos de pronto consumo.

(Perguntar antes do dia da entrevista para levar apenas os produtos selecionados.)

Separe os produtos que parecem ser mais saudáveis.

O que chamou a sua atenção no grupo dos saudáveis?

O que chamou a sua atenção no grupo dos não tão saudáveis?

Separe os produtos orgânicos.

O que te levou a concluir que esses produtos são orgânicos?

O que te levou a concluir que esses produtos não são orgânicos?

\section{Detalhamento da percepção do produto orgânico selecionado}

(Escolher algum produto do grupo de orgânicos selecionado das empresas pesquisadas) Já comprou este produto?

Se sim, cite algumas características do produto que influenciaram nessa escolha.

Se não, fale por quê?

O que chama a sua atenção nesta embalagem?

Cite três coisas positivas

Cite três coisas negativas 
Indique na tabela a abaixo as características que você acha que mais identificam o produto.

\begin{tabular}{|c|c|c|c|c|c|c|c|c|c|c|c|c|}
\hline & -5 & -4 & -3 & -2 & -1 & 0 & +1 & +2 & +3 & +4 & +5 & \\
\hline Artificial & & & & & & & & & & & & Natural \\
\hline Adoçado & & & & & & & & & & & & Sem açúcar \\
\hline Com gordura & & & & & & & & & & & & Sem gordura \\
\hline Feito em grande quantidade & & & & & & & & & & & & Feito com cuidado \\
\hline Enganoso & & & & & & & & & & & & Verdadeiro \\
\hline Não integral & & & & & & & & & & & & Integral \\
\hline Insosso & & & & & & & & & & & & Saboroso \\
\hline Inorgânico & & & & & & & & & & & & Orgânico \\
\hline Salgado & & & & & & & & & & & & Pouco sódio \\
\hline Transgênico & & & & & & & & & & & & $\begin{array}{l}\text { Não modificado } \\
\text { geneticamente }\end{array}$ \\
\hline Descuido com a natureza & & & & & & & & & & & & Cuidado com a natureza \\
\hline
\end{tabular}

\section{Produtos orgânicos}

Você poderia tentar definir o que é um alimento orgânico?

Você já comprou ou costuma comprar algum alimento orgânico industrializado?

( ) $\operatorname{sim}($ ) Não

Se sim, com que frequência isso acontece?

Se nunca comprou, explique o motivo?

Lembra-se de alguma marca de alimento orgânico?

\section{Hábitos de compras}

Costuma olhar as embalagens com atenção antes de comprar um produto?

O que procura nelas?

Você costuma fazer lista de produtos antes de fazer compras?

( ) $\operatorname{Sim}($ ) Não

Já comprou algum produto fora da lista?

( ) $\operatorname{Sim}($ ) Não

Cite três principais motivos que levaram você a comprar um produto fora da lista de compras.

Onde costuma fazer compras?

Cite três lugares em ordem de frequência: o primeiro aonde você vai mais, o terceiro aonde vai menos.

\section{Selos de certificação}

(foram selecionados selos de certificadoras usados nas embalagens selecionadas na pesquisa). Observação: o selo de certificação do MAPA fica por último para não influenciar nas respostas. 


\begin{tabular}{|l|l|l|}
\hline Selo & Você conhece este selo? & A que se refere este selo? \\
\hline \\
\hline
\end{tabular}

Simbologia técnica de materiais e descarte.

(foram selecionados selos de certificadoras usados nas embalagens selecionadas na pesquisa). Observação: O símbolo de reciclagem fica por último para não influenciar nas respostas.

\begin{tabular}{|l|l|l|}
\hline Símbolo & Você conhece este símbolo? & O que significa? \\
\hline & ( ) Conheço ( )Não conheço & \\
\hline
\end{tabular}

\section{Pós-consumo das embalagens.}

Você costuma separar embalagens para a reciclagem? ( ) Sim ( ) Não Se não, por quê?

Sente alguma dificuldade para saber o que é reciclável ou não? ( ) Sim （） Não O que faz quando fica em dúvida com separar uma embalagem para a reciclagem? 


\section{EMBALAGENS SELECIONADAS NA PESQUISA DE CAMPO}

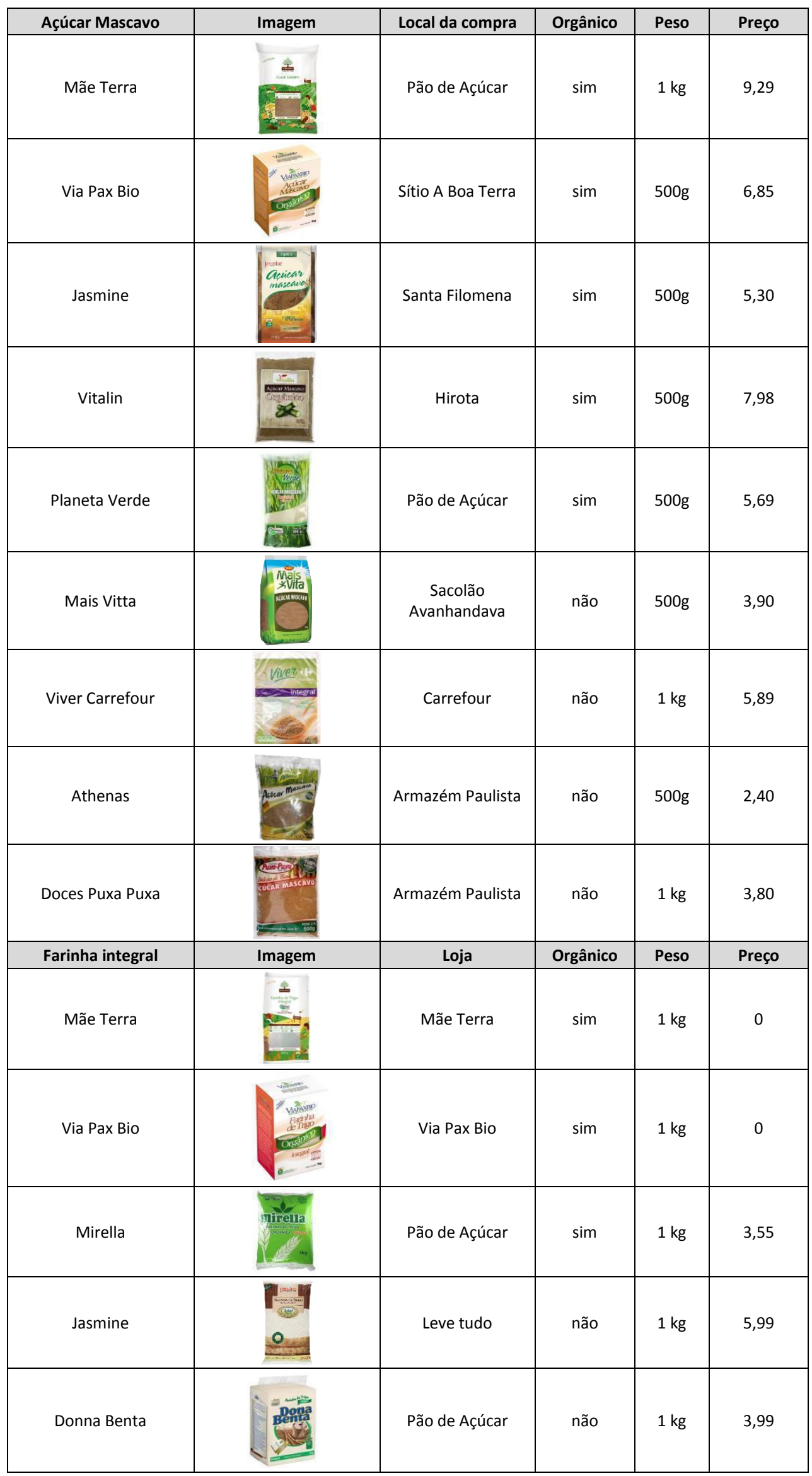




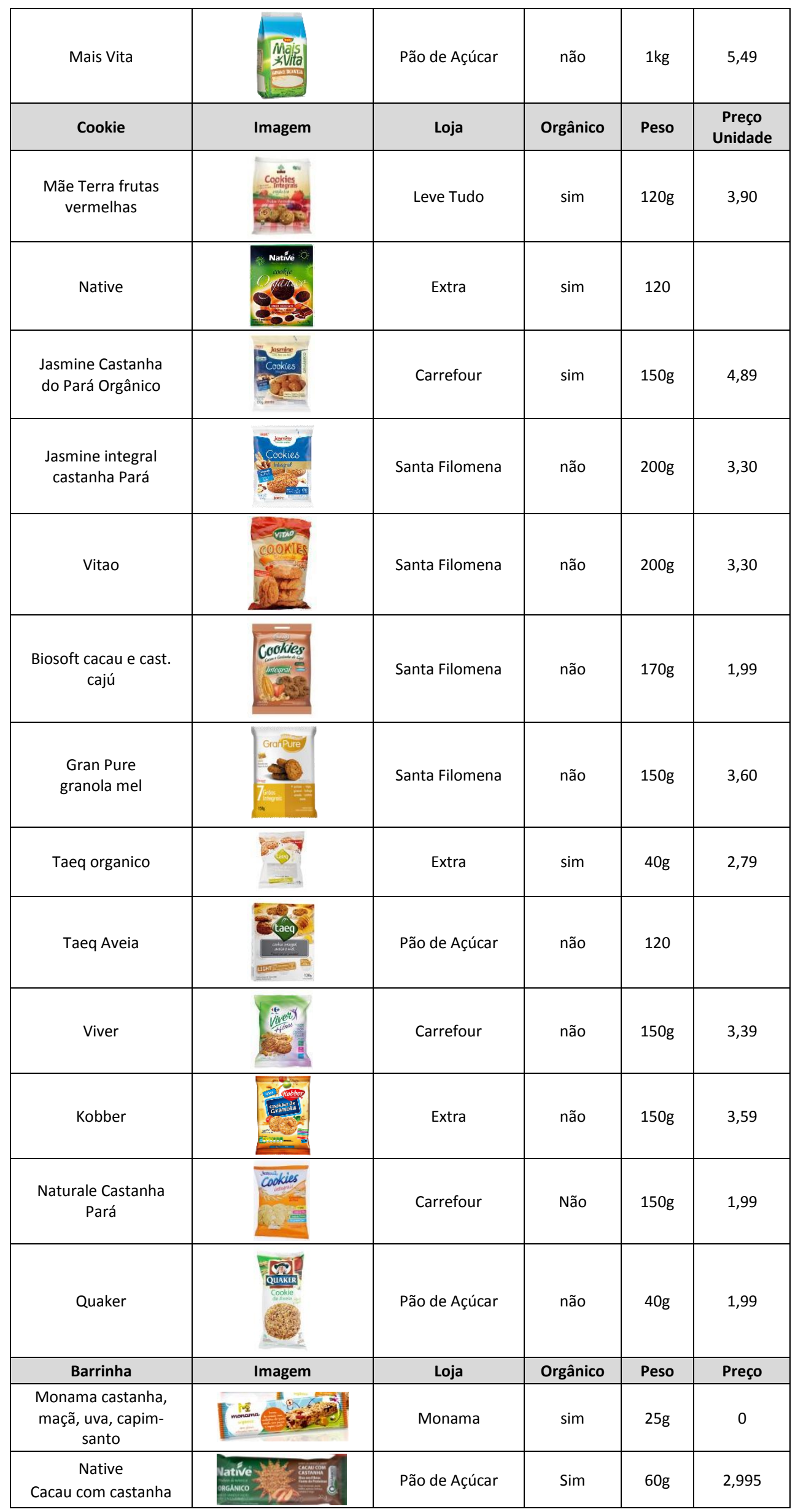




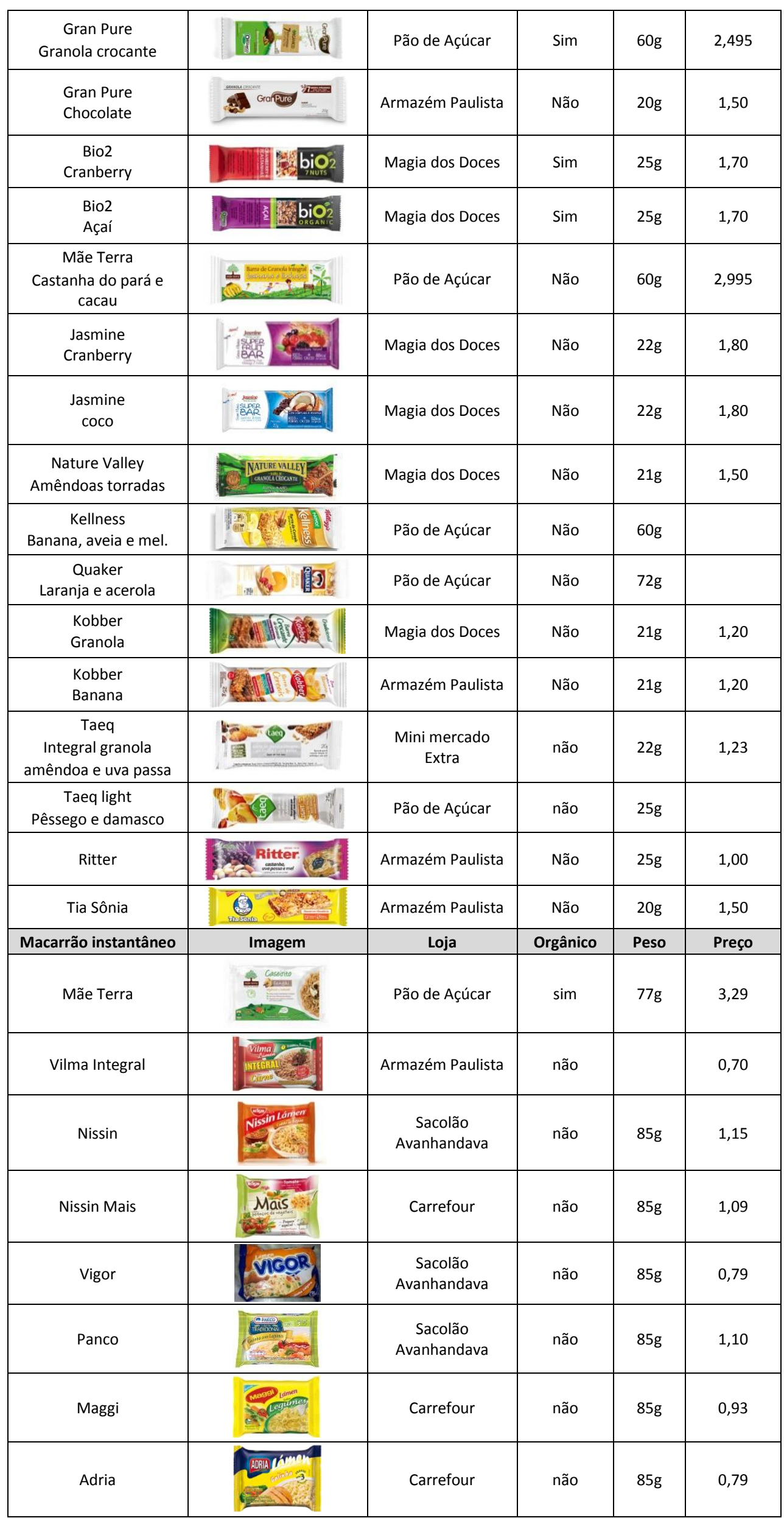




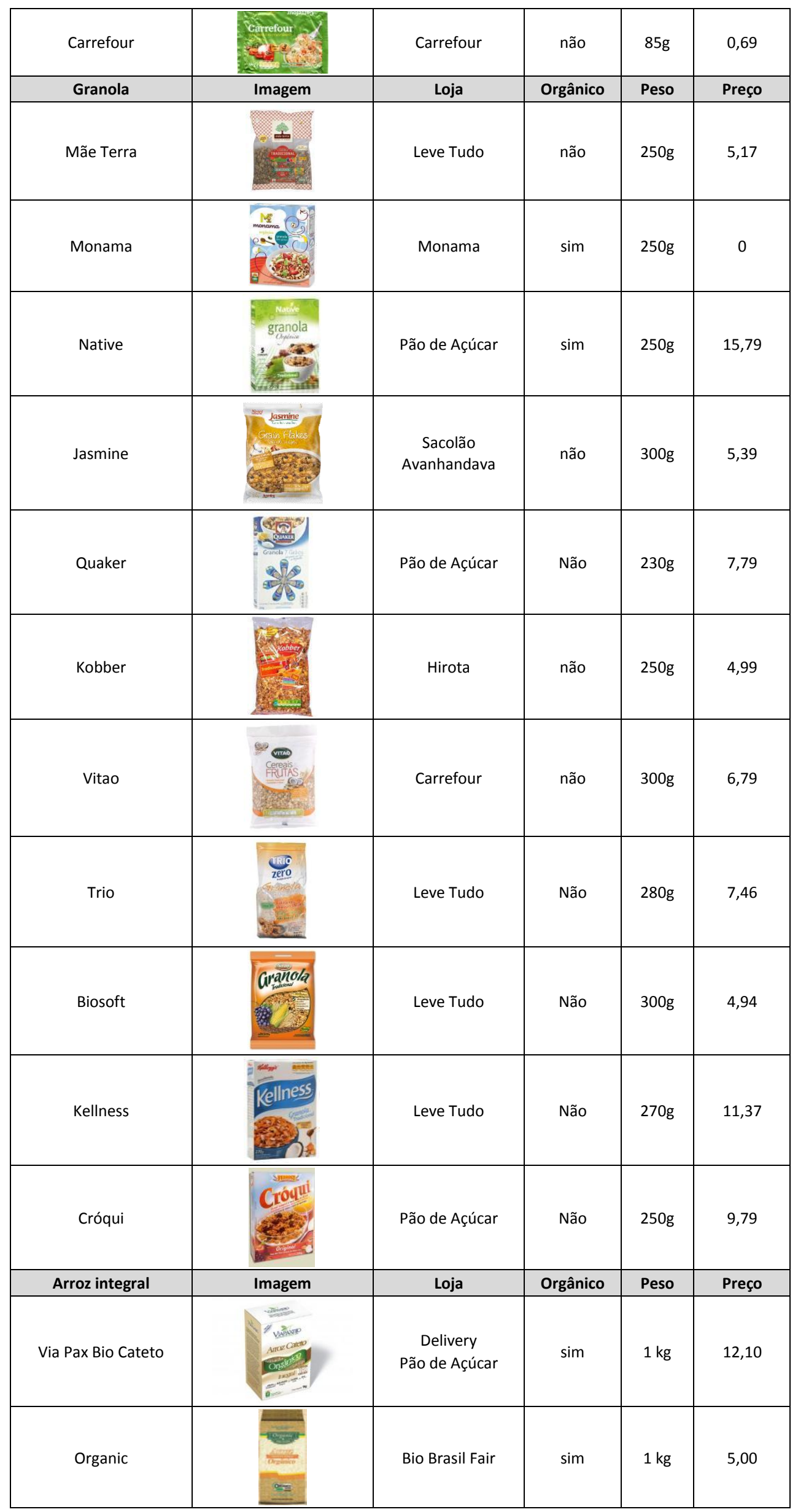




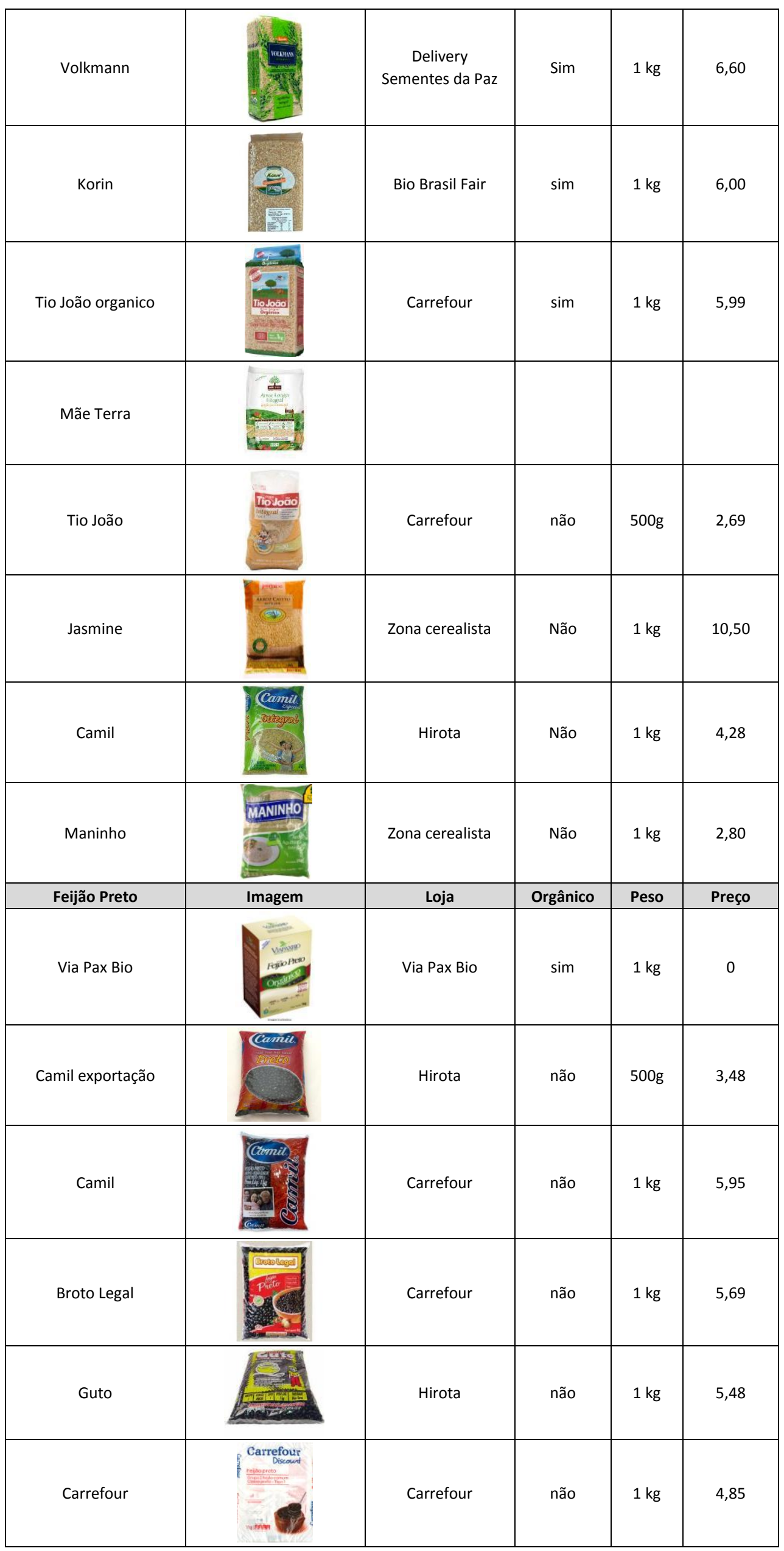




\section{E. SEPARAÇÃO DAS EMBALAGENS DO GRUPO 1}

\begin{tabular}{|l|l|}
\hline Grupo 1 - Não processados \\
\hline Arroz integral & Feijão preto \\
\hline $\begin{array}{l}\text { Via Pax Bio, Organic, Volkmann, Korin, Tio João Orgânico, } \\
\text { Mãe Terra, Tio João, Jasmine, Camil, Maninho }\end{array}$ & $\begin{array}{l}\text { Via Pax Bio, Camil exportação, Camil, Broto Legal, Guto, } \\
\text { Carrefour }\end{array}$ \\
\hline
\end{tabular}

\section{PRODUTOS SEPARADOS POR CA09}

\section{Arroz Integral}

\begin{tabular}{|c|c|c|c|}
\hline Saudável & Menos saudável & Orgânico & Não orgânico \\
\hline $\begin{array}{c}\text { Via Pax Bio, Organic, Mãe } \\
\text { Terra, Korin, Volkmann, Tio } \\
\text { João orgânico }\end{array}$ & Maninho, Jasmine & $\begin{array}{c}\text { Organic, Volkmann, Korin, } \\
\text { Tio João orgânico, Via Pax } \\
\text { Bio }\end{array}$ & $\begin{array}{c}\text { Mãe Terra, Jasmine, } \\
\text { Maninho. }\end{array}$ \\
\hline
\end{tabular}

\section{Feijão Preto}

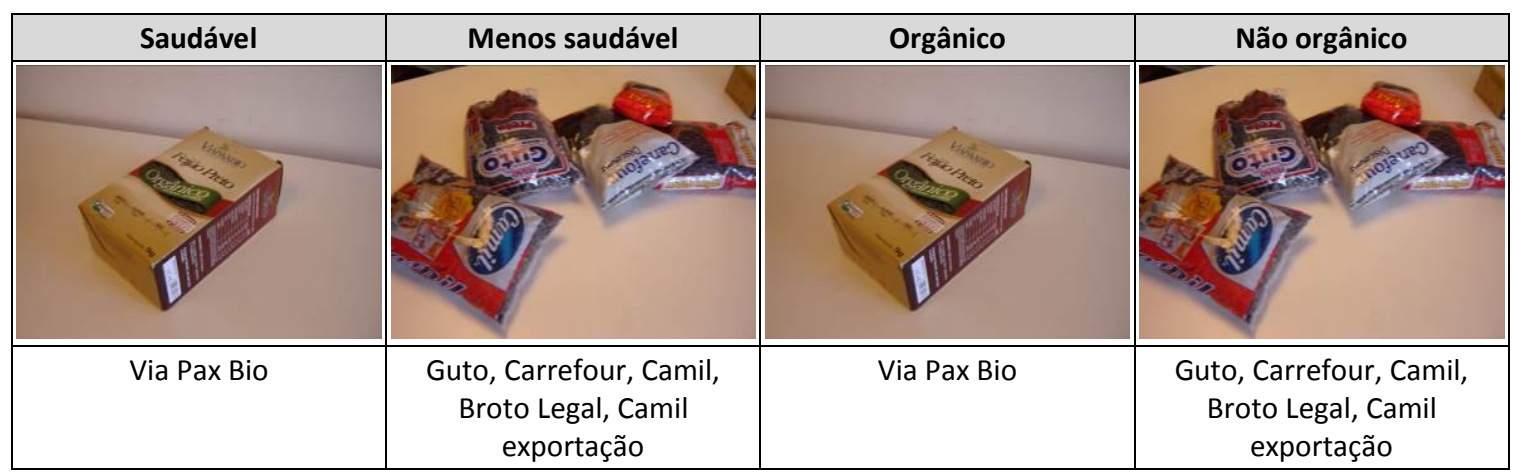

\section{PRODUTOS SEPARADOS POR CA10}

\section{Arroz Integral}

\begin{tabular}{|c|c|c|c|}
\hline Saudável & Menos saudável & Orgânico & Não orgânico \\
\hline & & & \\
\hline Korin, Volkmann & $\begin{array}{l}\text { Via Pax Bio, Organic, Tio } \\
\text { João orgânico, Mãe Terra, } \\
\text { Jasmine, Maninho }\end{array}$ & $\begin{array}{c}\text { Korin, Volkmann, Via Pax } \\
\text { Bio, Organic, Tio João } \\
\text { orgânico. }\end{array}$ & $\begin{array}{c}\text { Mãe Terra, Jasmine, } \\
\text { Maninho }\end{array}$ \\
\hline
\end{tabular}




\section{Feijão Preto}

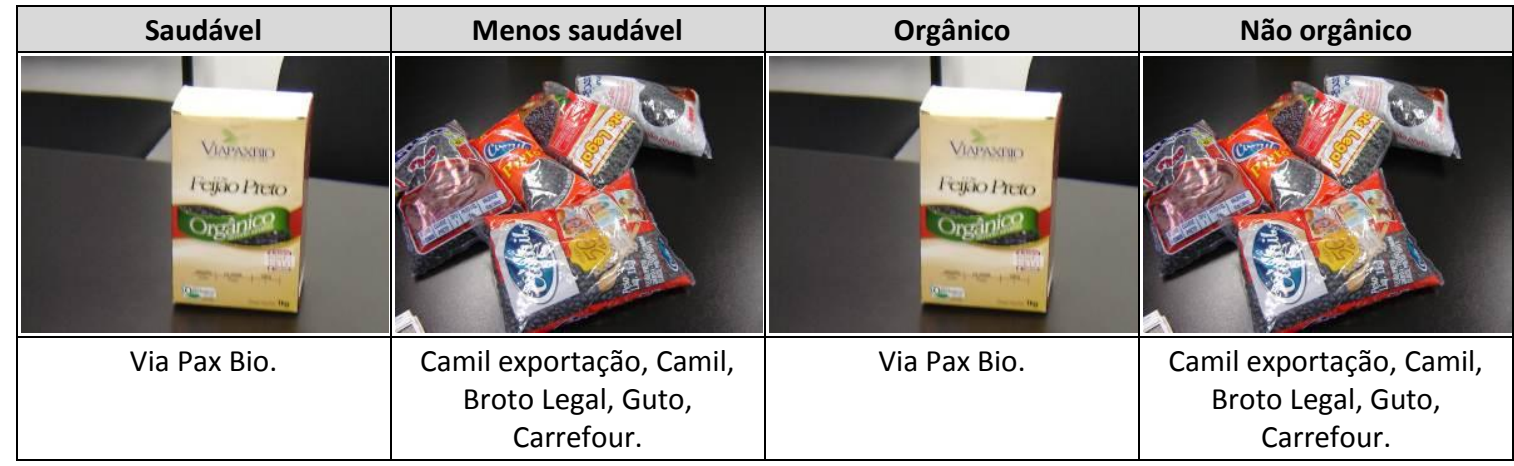

\section{PRODUTOS SEPARADOS POR CC13}

\section{Arroz Integral}

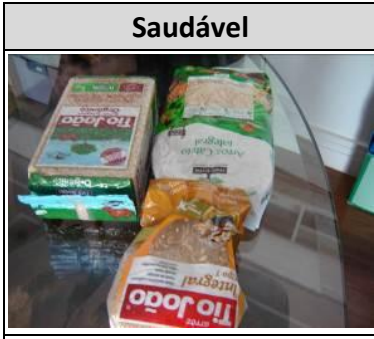

Tio João, Mãe Terra, Tio João orgânico

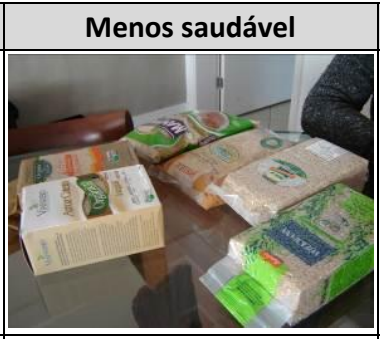

Maninho, Jasmine, Via Pax Bio, Organic, Korin, Volkmann

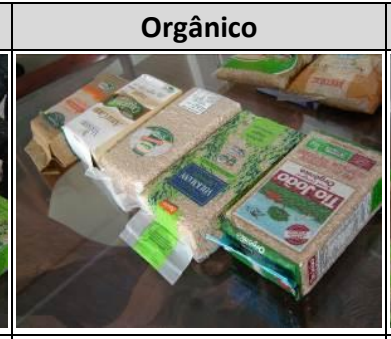

Organic, Volkmann, Korin, Tio João orgânico, Via Pax Bio

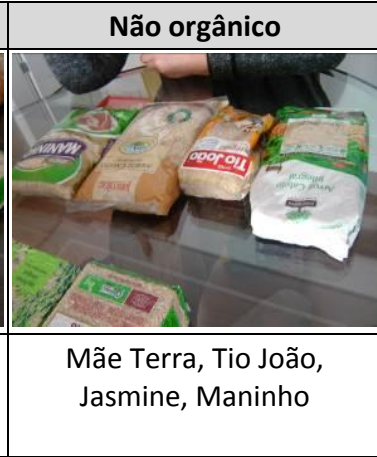

\section{Feijão Preto}

\begin{tabular}{|c|c|c|c|}
\hline Saudável & Menos saudável & Orgânico & Não orgânico \\
\hline & & \\
\hline
\end{tabular}

\section{PRODUTOS SEPARADOS POR CB18}

\section{Arroz Integral}

\begin{tabular}{|c|c|c|c|}
\hline Saudável & Menos saudável & Orgânico & Não orgânico \\
\hline & & & \\
& & & \\
\hline
\end{tabular}




\section{Feijão Preto}

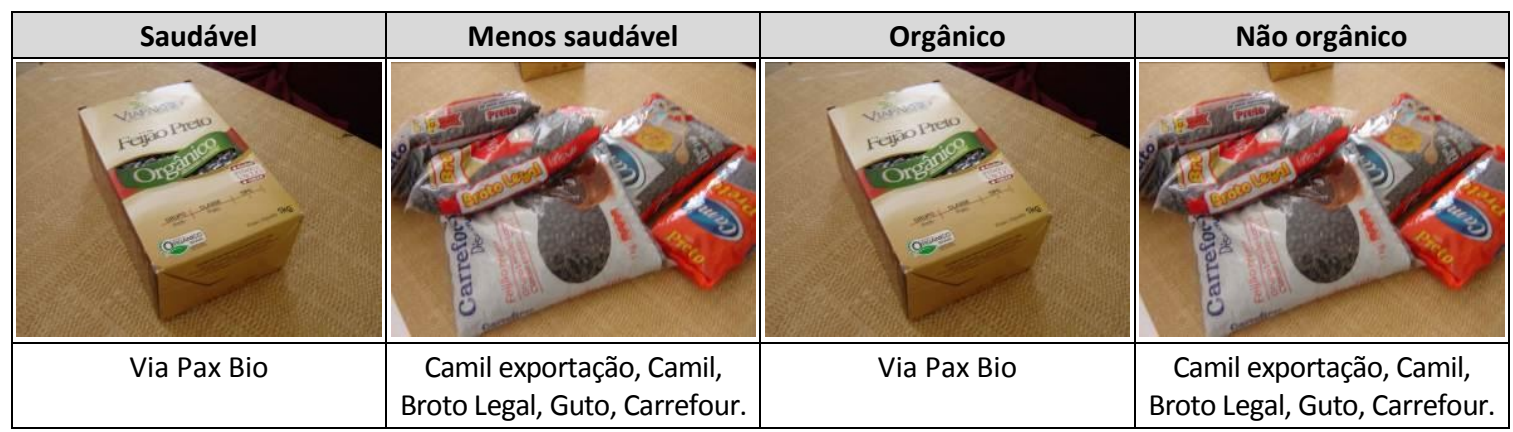

\section{PRODUTOS SEPARADOS POR CA21}

\section{Arroz Integral}

\begin{tabular}{|c|c|c|c|}
\hline Saudável & Menos saudável & Orgânico & Não orgânico \\
\hline & & & \\
\hline $\begin{array}{c}\text { Mãe Terra, Korin, Volkmann, } \\
\text { Tio João orgânico }\end{array}$ & Camil, Maninho, Tio João & $\begin{array}{c}\text { Organic, Volkmann, Korin, } \\
\text { Tio João orgânico, Via Pax } \\
\text { Bio }\end{array}$ & $\begin{array}{c}\text { Mãe Terra, Tio João, } \\
\text { Jasmine, Maninho, Camil }\end{array}$ \\
\hline
\end{tabular}

\section{Feijão Preto}

\begin{tabular}{|c|c|c|c|}
\hline Saudável & Menos saudável & Orgânico & Não orgânico \\
\hline & & & \\
\hline & & & \\
\hline
\end{tabular}

\section{PRODUTOS SEPARADOS POR CA31}

\section{Arroz Integral}

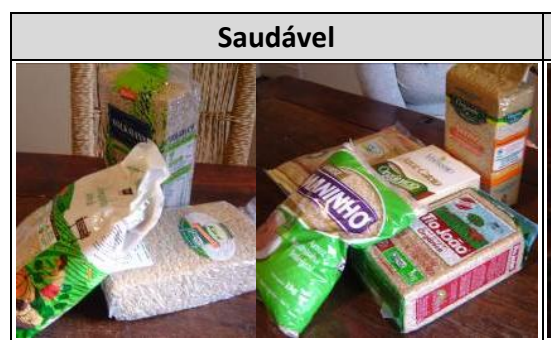

Maninho, Jasmine, Via Pax Bio Organic, Mãe Terra, Korin, Volkmann, Tío João orgânico

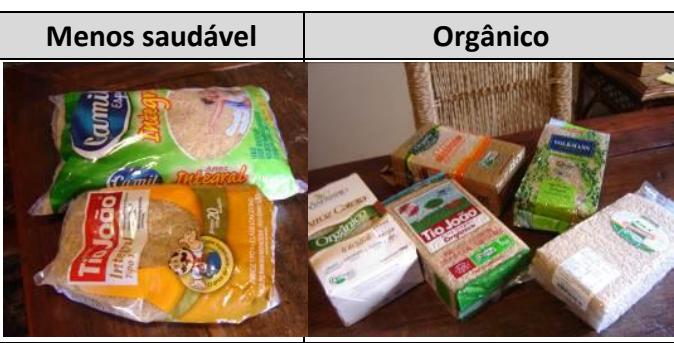

Tio João, Camil

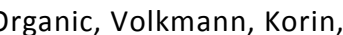

Tio João orgânico, Via Pax Bio

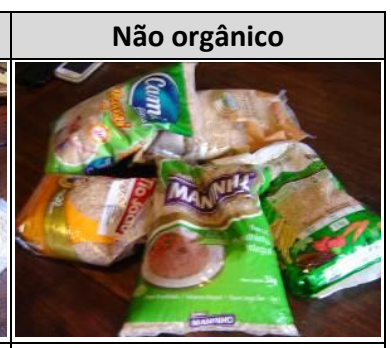

Mãe Terra, Tio João, Jasmine, Maninho, Camil 


\section{Feijão Preto}

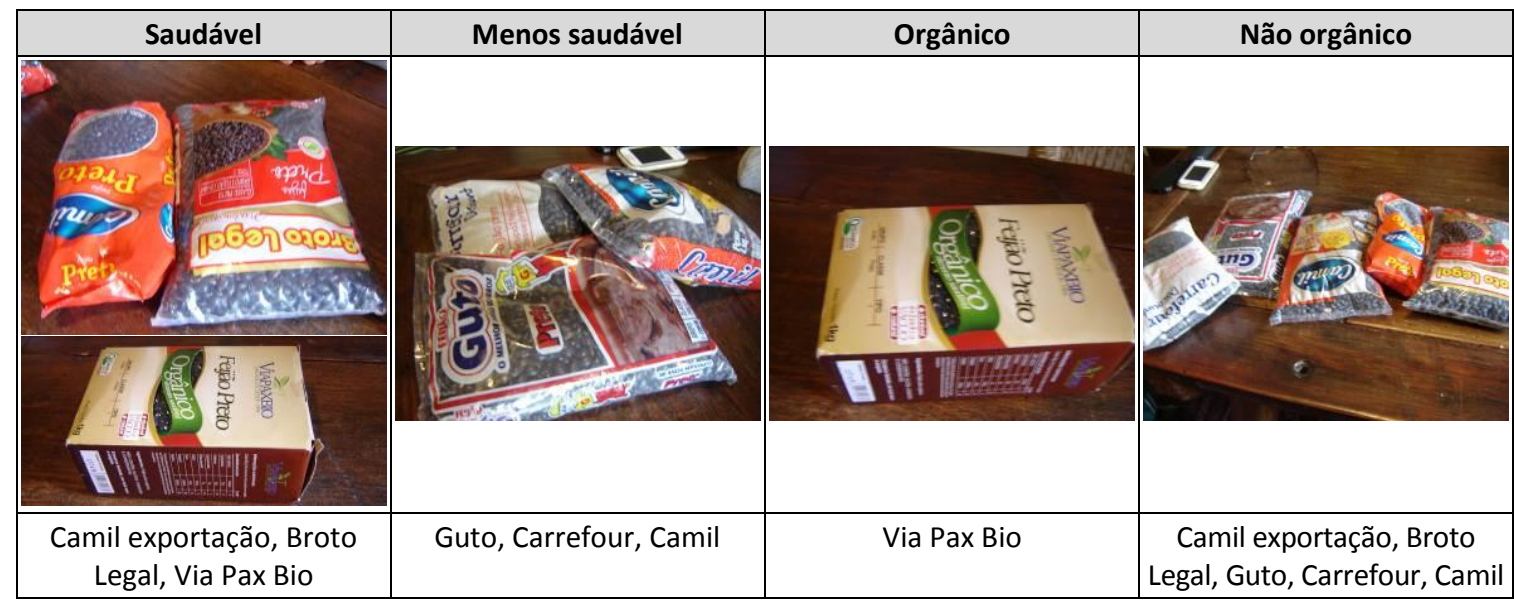

\section{PRODUTOS SEPARADOS POR CB32}

\section{Arroz Integral}

\begin{tabular}{|c|c|c|c|}
\hline Saudável & Menos saudável & Orgânico & Não orgânico \\
\hline & & & \\
\hline $\begin{array}{c}\text { Tio João, Jasmine, } \\
\text { Volkmann, Tio João } \\
\text { orgânico }\end{array}$ & $\begin{array}{c}\text { Camil, Maninho, Via Pax Bio, } \\
\text { Organic, Mãe Terra, Korin }\end{array}$ & $\begin{array}{c}\text { Organic, Volkmann, Korin, } \\
\text { Tio João orgânico, Via Pax } \\
\text { Bio }\end{array}$ & $\begin{array}{c}\text { Mãe Terra, Tio João, } \\
\text { Jasmine, Maninho, Camil }\end{array}$ \\
\hline
\end{tabular}

\section{Feijão Preto}

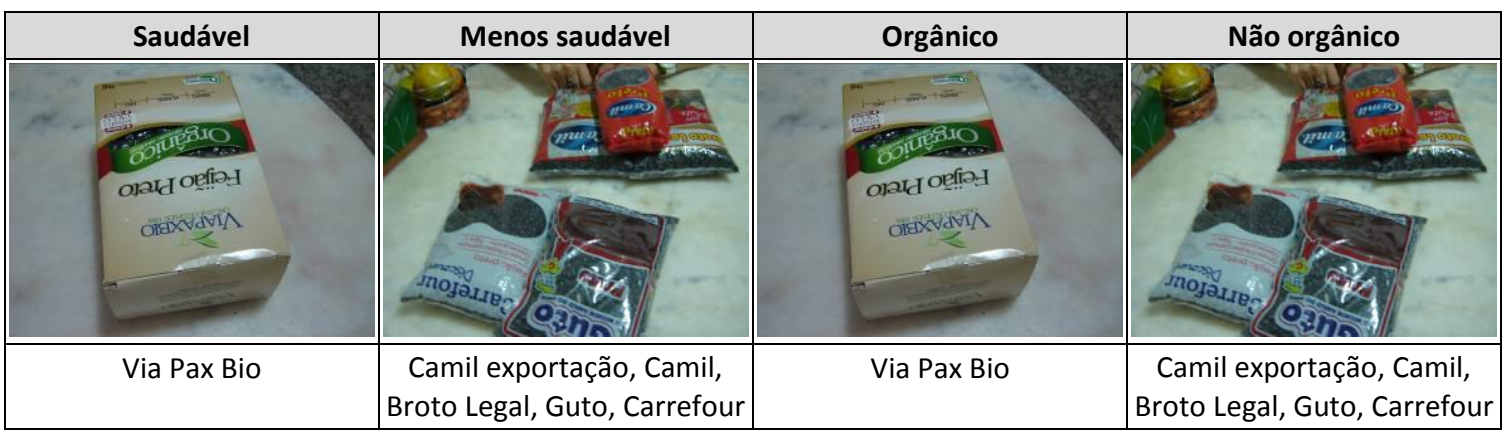

\section{F. SEPARAÇÃO DAS EMBALAGENS DO GRUPO 2}

\begin{tabular}{|l|l|}
\hline \multicolumn{2}{|l|}{ Grupo 2 - Pouco processados } \\
\hline Açúcar mascavo & Farinha de trigo integral \\
\hline $\begin{array}{l}\text { Mãe Terra, Via Pax Bio, Jasmine, Vitalin, Planeta Verde, Mais } \\
\text { Vitta, Viver Carrefour, Athenas, Doces Puxa Puxa }\end{array}$ & $\begin{array}{l}\text { Mãe Terra, Via Pax Bio, Mirella, Jasmine, Donna Benta, Mais } \\
\text { Vita }\end{array}$ \\
\hline
\end{tabular}




\section{PRODUTOS SEPARADOS POR CA02}

\section{Farinha de trigo integral}

\begin{tabular}{|c|c|c|c|}
\hline Saudável & Menos saudável & Orgânico & Não orgânico \\
\hline & & & \\
\hline
\end{tabular}

\section{Açúcar mascavo}

\begin{tabular}{|c|c|c|c|}
\hline Saudável & Menos saudável & Orgânico & Não orgânico \\
\hline $\begin{array}{c}\text { Mãe Terra, Via Pax Bio, } \\
\text { Planeta Verde. }\end{array}$ & $\begin{array}{c}\text { Jasmine, Vitalin, Mais Vitta, } \\
\text { Viver Carrefour, Athenas, } \\
\text { Doces Puxa Puxa. }\end{array}$ & $\begin{array}{c}\text { Mãe Terra, Via Pax Bio, } \\
\text { Planeta Verde. }\end{array}$ & $\begin{array}{c}\text { Jasmine, Vitalin, Mais Vitta, } \\
\text { Viver Carrefour, Athenas, } \\
\text { Doces Puxa Puxa. }\end{array}$ \\
\hline
\end{tabular}

\section{PRODUTOS SEPARADOS POR CCO6}

\section{Açúcar mascavo}

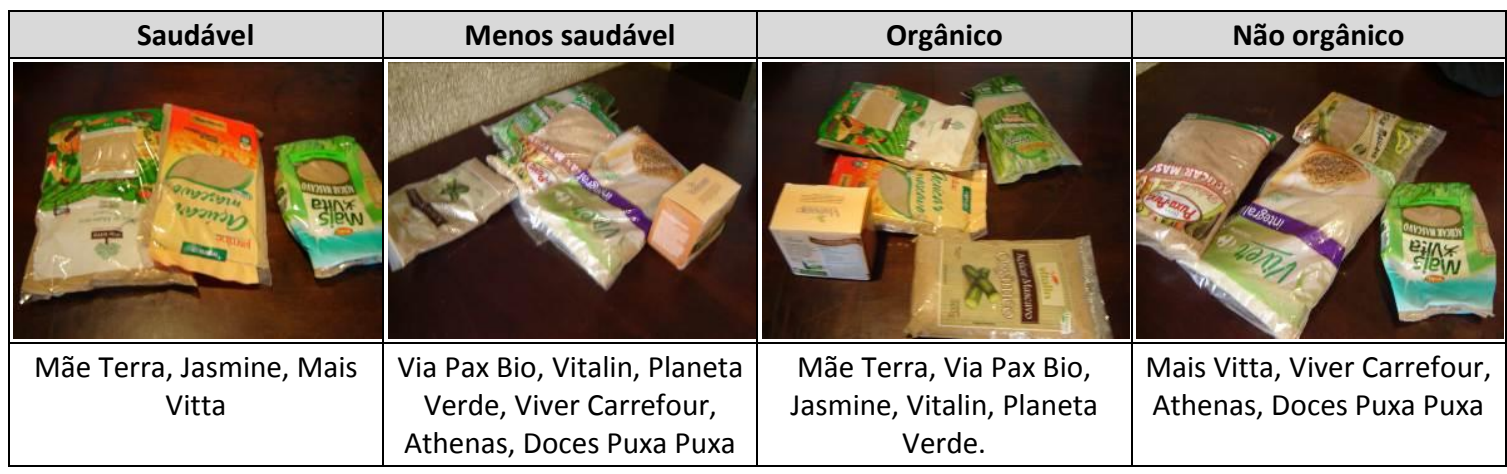

\section{Farinha de trigo integral}

\begin{tabular}{|c|c|c|c|}
\hline Saudável & Menos saudável & Orgânico & Não orgânico \\
\hline & & & \\
\hline $\begin{array}{c}\text { Mãe Terra, Jasmine, Mais } \\
\text { Vita, Donna Benta. }\end{array}$ & Mirella, Via Pax Bio & Mãe Terra, Via Pax Bio, & Mirella, Jasmine, Donna \\
& & Benta, Mais Vita. & Nenhuma \\
\hline
\end{tabular}


PRODUTOS SEPARADOS POR CA12

\section{Açúcar mascavo}

\begin{tabular}{|c|c|c|c|}
\hline Saudável & Menos saudável & Orgânico & Não orgânico \\
\hline $\begin{array}{c}\text { Mãe Terra, Via Pax Bio, } \\
\text { Jasmine, Vitalin, } \\
\text { Planeta Verde }\end{array}$ & $\begin{array}{c}\text { Mais Vitta, Viver Carrefour, } \\
\text { Athenas, Doces Puxa Puxa }\end{array}$ & $\begin{array}{c}\text { Mãe Terra, Via Pax Bio, } \\
\text { Jasmine, Vitalin, } \\
\text { Planeta Verde }\end{array}$ & $\begin{array}{c}\text { Mais Vitta, Viver Carrefour, } \\
\text { Athenas, Doces Puxa Puxa }\end{array}$ \\
\hline
\end{tabular}

\section{Farinha de trigo integral}

\begin{tabular}{|l|c|c|c|}
\hline Saudável & Menos saudável & Orgânico & Não orgânico \\
\hline & & & \\
\hline & & & \\
\hline Via Pax Bio, Mirella, Jasmine & $\begin{array}{c}\text { Mãe Terra, Donna Benta, } \\
\text { Mais Vita }\end{array}$ & Via Pax Bio, Mirella & $\begin{array}{c}\text { Mãe Terra, Jasmine, Donna } \\
\text { Benta, Mais Vita }\end{array}$ \\
\hline
\end{tabular}

\section{PRODUTOS SEPARADOS POR CA19}

\section{Açúcar mascavo}

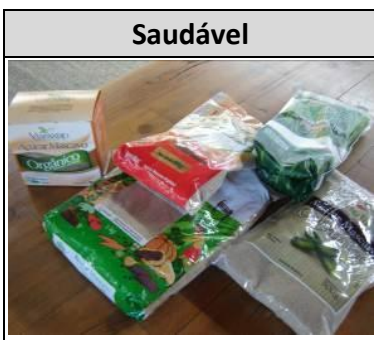

Via Pax Bio, Vitalin, Planeta Verde, Jasmine, Mãe Terra

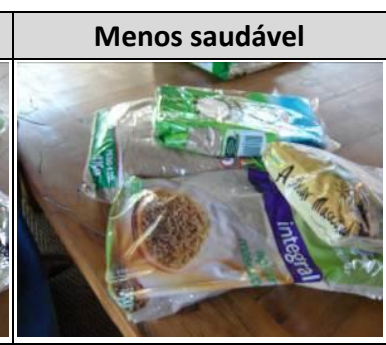

Doces Puxa Puxa, Mais

Vitta, Viver Carrefour, Athenas

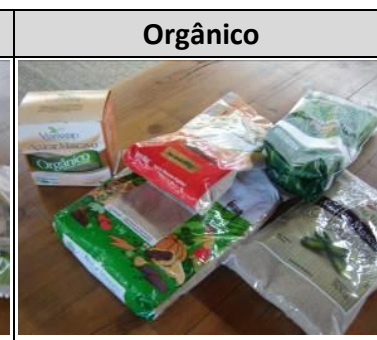

Via Pax Bio, Vitalin, Planeta Verde, Jasmine, Mãe Terra

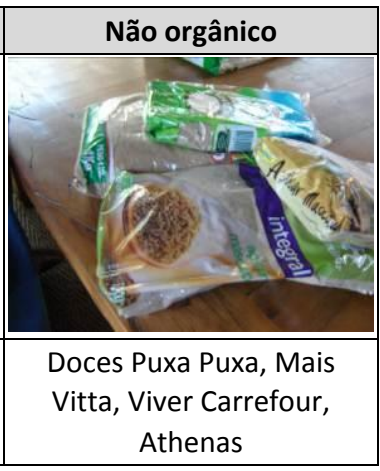

Farinha de trigo integral

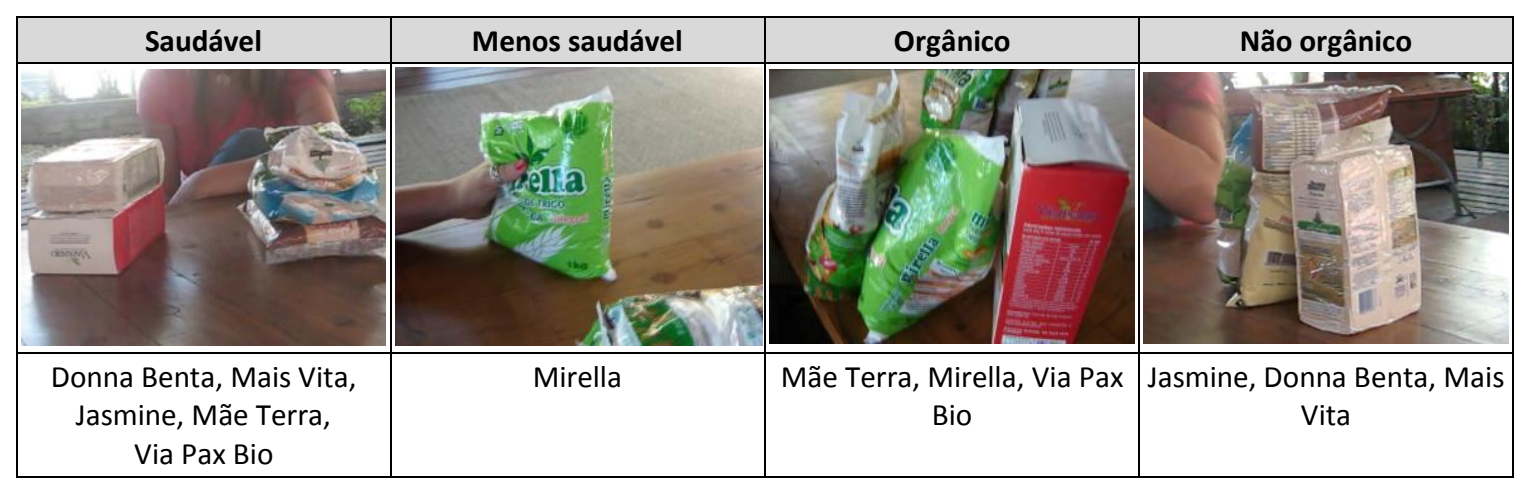




\section{PRODUTOS SEPARADOS POR CB27}

\section{Açúcar mascavo}

\begin{tabular}{|c|c|c|c|}
\hline Saudável & Menos saudável & Orgânico & Não orgânico \\
\hline & & \\
\hline $\begin{array}{c}\text { Viver Carrefour, Vitalin, } \\
\text { Planeta Verde, Jasmine, } \\
\text { Mãe Terra }\end{array}$ & $\begin{array}{c}\text { Doces Puxa Puxa, Mais } \\
\text { Vitta, Athenas, Via Pax Bio }\end{array}$ & $\begin{array}{c}\text { Via Pax Bio, Vitalin, Planeta } \\
\text { Verde, Jasmine, Mãe Terra }\end{array}$ & $\begin{array}{c}\text { Doces Puxa Puxa, Mais } \\
\text { Vitta, Viver Carrefour, } \\
\text { Athenas }\end{array}$ \\
\hline
\end{tabular}

\section{Farinha de trigo integral}

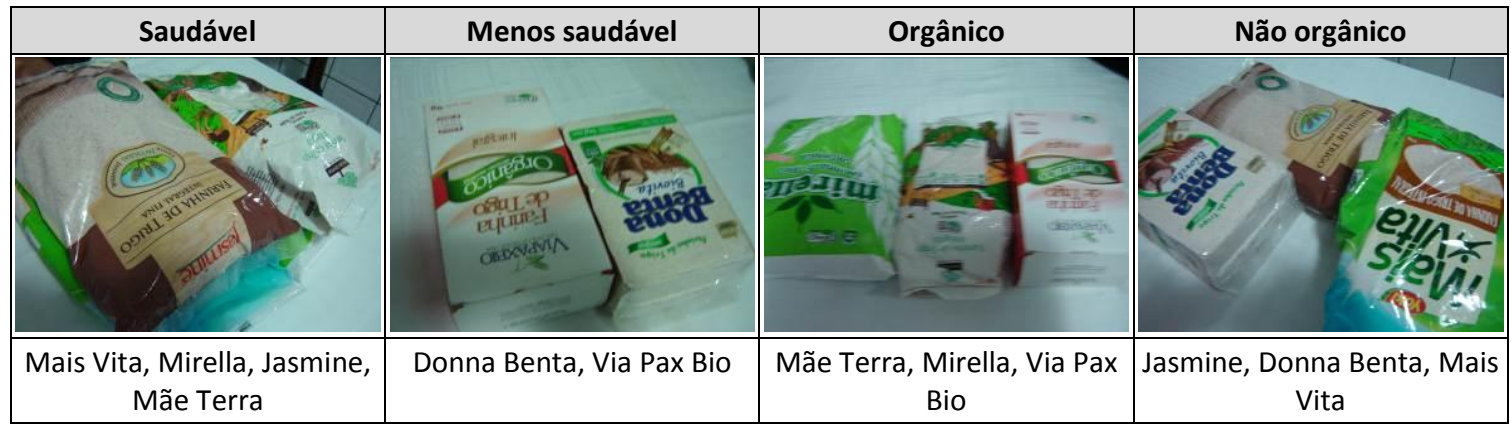

\section{PRODUTOS SEPARADOS POR CA28}

\section{Açúcar mascavo}

\begin{tabular}{|c|c|c|c|}
\hline Saudável & Menos saudável & Orgânico & Não orgânico \\
\hline & & & \\
\hline $\begin{array}{c}\text { Via Pax Bio, Vitalin, Planeta } \\
\text { Verde, Jasmine, Mãe Terra, } \\
\text { Athenas }\end{array}$ & $\begin{array}{c}\text { Doces Puxa Puxa, Mais } \\
\text { Vitta, Viver Carrefour }\end{array}$ & $\begin{array}{c}\text { Via Pax Bio, Vitalin, Planeta } \\
\text { Verde, Jasmine, Mãe Terra }\end{array}$ & $\begin{array}{c}\text { Doces Puxa Puxa, Mais } \\
\text { Vitta, Viver Carrefour, }\end{array}$ \\
\hline
\end{tabular}

\section{Farinha de trigo integral}

\begin{tabular}{|c|c|c|c|}
\hline Saudável & Menos saudável & Orgânico & Não orgânico \\
\hline & & & \\
\hline $\begin{array}{c}\text { Mais Vita, Jasmine, Mãe } \\
\text { Terra }\end{array}$ & $\begin{array}{c}\text { Mirella, Donna Benta, Via } \\
\text { Pax Bio }\end{array}$ & $\begin{array}{c}\text { Mãe Terra, Mirella, Via Pax } \\
\text { Bio }\end{array}$ & $\begin{array}{c}\text { Jasmine, Donna Benta, Mais } \\
\text { Vita }\end{array}$ \\
\hline
\end{tabular}


PRODUTOS SEPARADOS POR CA29

\section{Açúcar mascavo}

\begin{tabular}{|c|c|c|c|}
\hline Saudável & Menos saudável & Orgânico & Não orgânico \\
\hline & & & \\
\hline $\begin{array}{l}\text { Via Pax Bio, Vitalin, Planeta } \\
\text { Verde, Jasmine, Mãe Terra }\end{array}$ & $\begin{array}{c}\text { Doces Puxa Puxa, Mais } \\
\text { Vitta, Viver Carrefour, } \\
\text { Athenas }\end{array}$ & $\begin{array}{c}\text { Via Pax Bio, Vitalin, Planeta } \\
\text { Verde, Jasmine, Mãe Terra }\end{array}$ & $\begin{array}{c}\text { Doces Puxa Puxa, Mais } \\
\text { Vitta, Viver Carrefour, } \\
\text { Athenas }\end{array}$ \\
\hline
\end{tabular}

\section{Farinha de trigo integral}

\begin{tabular}{|c|c|c|c|}
\hline Saudável & Menos saudável & Orgânico & Não orgânico \\
\hline & & \\
\hline & & \\
\hline
\end{tabular}

\section{G.SEPARAÇÃO DAS EMBALAGENS DO GRUPO 3}

\begin{tabular}{|l|l|}
\hline Grupo 3 - Pronto consumo & \multicolumn{2}{|l|}{ Barra de cereais } \\
\hline Cookie & Monama, Native, Gran Pure Granola, Gran Pure Chocolate, \\
Mãe Terra, Native, Jasmine & Brgânico, Jasmine Integral, Vitao, Biosoft, Gran Pure, Taeq \\
organico, Taeq Aveia, Viver Carrefour, Kobber, Naturale, & Castanha, Nature Valley, Kellness, Quaker, Kobber granola, \\
Quaker & Kobber, Taeq granola, Taeq light, Ritter, Tia Sônia \\
\hline
\end{tabular}

\section{PRODUTOS SEPARADOS POR CA04}

\section{Cookies}

\begin{tabular}{|c|c|c|c|}
\hline Saudável & Menos saudável & Orgânico & Não orgânico \\
\hline & & & \\
\hline $\begin{array}{c}\text { Mãe Terra, Native, Jasmine, } \\
\text { Orgânico, Jasmine integral, } \\
\text { Kobber }\end{array}$ & $\begin{array}{c}\text { Vitao, Biosoft, Gran Pure, } \\
\text { Taeq orgânico, Taeq Aveia, } \\
\text { Viver Carrefour, Naturalle, } \\
\text { Quaker }\end{array}$ & $\begin{array}{c}\text { Mãe Terra, Native, Jasmine, } \\
\text { Orgânico, Taeq orgânico. }\end{array}$ & $\begin{array}{c}\text { Jasmine integral, Vitao, } \\
\text { Biosoft, Gran Pure, Taeq } \\
\text { Aveia, Viver Carrefour, } \\
\text { Kobber, Naturale, Quaker }\end{array}$ \\
\hline
\end{tabular}




\section{Barra de cereais}

\begin{tabular}{|c|c|c|c|}
\hline Saudável & Menos saudável & Orgânico & Não orgânico \\
\hline $\begin{array}{c}\text { Native, Nature Valley, } \\
\text { Jasmine coco, Mãe Terra, } \\
\text { Gran Pure orgânico. }\end{array}$ & $\begin{array}{c}\text { Monama, Gran Pure } \\
\text { Chocolate, Bio2, Jasmine } \\
\text { Cranberry, Kellness, Quaker, } \\
\text { Kobber granola, Kobber, } \\
\text { Taeq granola, Taeq light, } \\
\text { Ritter, Tia Sônia. }\end{array}$ & $\begin{array}{c}\text { Gran Pure orgânico, Native, } \\
\text { Monama, }\end{array}$ & $\begin{array}{c}\text { Gran Pure Chocolate, Bio2, } \\
\text { Mãe Terra, Jasmine } \\
\text { Cranberry, Jasmine Castanha, } \\
\text { Nature Valley, Kellness, } \\
\text { Quaker, Kobber granola, } \\
\text { Kobber, Taeq granola, Taeq } \\
\text { light, Ritter, Tia Sônia }\end{array}$ \\
\hline
\end{tabular}

\section{PRODUTOS SEPARADOS POR CB05}

\section{Cookies}

\begin{tabular}{|c|c|c|c|}
\hline Saudável & Menos saudável & Orgânico & Não orgânico \\
\hline & & & \\
\hline $\begin{array}{c}\text { Mãe Terra, Native, Jasmine } \\
\text { Orgânico, Taeq organico, } \\
\text { Taeq Aveia. }\end{array}$ & $\begin{array}{c}\text { Jasmine integral, Vitao, } \\
\text { Biosoft, Gran Pure, Viver } \\
\text { Carrefour, Kobber, Naturale, } \\
\text { Quaker. }\end{array}$ & $\begin{array}{c}\text { Mãe Terra, Native, Jasmine } \\
\text { Orgânico, Taeq orgânico, } \\
\text { Taeq Aveia. }\end{array}$ & $\begin{array}{c}\text { Jasmine integral, Vitao, } \\
\text { Biosoft, Gran Pure, Viver } \\
\text { Carrefour, Kobber, Naturale, } \\
\text { Quaker. }\end{array}$ \\
\hline
\end{tabular}

\section{Barra de cereais}

\begin{tabular}{|c|c|c|c|}
\hline Saudável & Menos saudável & Orgânico & Não orgânico \\
\hline & & & \\
\hline $\begin{array}{c}\text { Monama, Native, Gran Pure } \\
\text { Orgânico, Gran Pure } \\
\text { Chocolate, Bio2, Mãe Terra, } \\
\text { Taeq granola, }\end{array}$ & $\begin{array}{c}\text { Jasmine Cranberry, Jasmine } \\
\text { Castanha, Nature Valley, } \\
\text { Kellness, Quaker, Kobber } \\
\text { granola, Kobber, Taeq light, } \\
\text { Ritter, Tia Sônia }\end{array}$ & $\begin{array}{c}\text { Monama, Native, Gran Pure } \\
\text { Orgânico, Gran Pure } \\
\text { Chocolate, Bio2, Mãe Terra, } \\
\text { Taeq granola, }\end{array}$ & $\begin{array}{c}\text { Jasmine Cranberry, Jasmine } \\
\text { Castanha, Nature Valley, } \\
\text { Kellness, Quaker, Kobber } \\
\text { granola, Kobber, Taeq light, } \\
\text { Ritter, Tia Sônia }\end{array}$ \\
\hline
\end{tabular}




\section{PRODUTOS SEPARADOS POR CC11}

\section{Cookies}

\begin{tabular}{|c|c|c|c|}
\hline Saudável & Menos saudável & Orgânico & Não orgânico \\
\hline & & & \\
\hline $\begin{array}{c}\text { Mãe Terra, Native, Jasmine } \\
\text { Orgânico, Jasmine integral, } \\
\text { Biosoft, Gran Pure, Taeq } \\
\text { organico, Kobber, Natural. }\end{array}$ & $\begin{array}{l}\text { Quaker, Viver Carrefour, } \\
\text { Vitao, Taeq Aveia. }\end{array}$ & $\begin{array}{c}\text { Native, Mãe Terra, Jasmine } \\
\text { Orgânico, Jasmine integral, } \\
\text { Biosoft, Gran Pure. }\end{array}$ & $\begin{array}{l}\text { Vitao, Taeq organico, Taeq } \\
\text { Aveia, Viver Carrefour, } \\
\text { Kobber, Naturale, Quaker. }\end{array}$ \\
\hline
\end{tabular}

\section{Barra de cereais}

\begin{tabular}{|c|c|c|c|}
\hline Saudável & Menos saudável & Orgânico & Não orgânico \\
\hline $\begin{array}{c}\text { Kobber granola, Bio2, Gran } \\
\text { Pure orgânico, Quaker, } \\
\text { Native, }\end{array}$ & $\begin{array}{c}\text { Gasmine Coco, Tia Sônia, } \\
\text { Mãe Terra, Kellness, Nature } \\
\text { Valley, Monama, Bio2 } \\
\text { orgânico, Ritter, Jasmine } \\
\text { Cranberry, Taeq light, }\end{array}$ & $\begin{array}{c}\text { Kobber, Bio2, Gran Pure } \\
\text { orgânico, Native, Quaker, } \\
\text { Talight, Bio2 orgânico, } \\
\text { Jasmine Cranberry, } \\
\text { Monama, }\end{array}$ & $\begin{array}{c}\text { Kobber granola, Taeq } \\
\text { granola, Kellness, Gran Pure } \\
\text { Chocolate, Mãe Terra, Tia } \\
\text { Sônia, Jasmine Coco, Ritter, } \\
\text { Nature Valley, }\end{array}$ \\
\hline
\end{tabular}

\section{PRODUTOS SEPARADOS POR CB14}

\section{Cookies}

\begin{tabular}{|c|c|c|c|}
\hline Saudável & Menos saudável & Orgânico & Não orgânico \\
\hline $\begin{array}{c}\text { Mãe Terra, Native, Jasmine } \\
\text { Orgânico, Jasmine integral, } \\
\text { Vitao, Biosoft, Gran Pure, } \\
\text { Taeq Aveia, Viver Carrefour, } \\
\text { Kobber, Naturale }\end{array}$ & Quaker, Taeq organico, & $\begin{array}{c}\text { Mãe Terra, Native, Jasmine } \\
\text { Orgânico, Taeq orgânico. }\end{array}$ & $\begin{array}{c}\text { Jasmine integral, Vitao, } \\
\text { Biosoft, Gran Pure, Taeq } \\
\text { Aveia, Viver Carrefour, } \\
\text { Kobber, Naturale, Quaker }\end{array}$ \\
\hline
\end{tabular}




\section{Barra de cereais}

\begin{tabular}{|c|c|c|c|}
\hline Saudável & Menos saudável & Orgânico & Não orgânico \\
\hline $\begin{array}{c}\text { Monama, Native, Gran Pure } \\
\text { Granola, Bio2, Bio2 } \\
\text { orgânico, Mãe Terra, Nature } \\
\text { Valley, Kellness, Quaker, } \\
\text { Kobber granola, Kobber, } \\
\text { Taeq granola, Taeq light, } \\
\text { Ritter. }\end{array}$ & $\begin{array}{c}\text { Castanha, Tia Sônia, Gran } \\
\text { Pure Chocolate }\end{array}$ & Native, Gran Pure Granola, & $\begin{array}{c}\text { Gran Pure Chocolate, Bio2, } \\
\text { Mãe Terra, Jasmine } \\
\text { Cranberry, Jasmine } \\
\text { Castanha, Nature Valley, } \\
\text { Kellness, Quaker, Kobber } \\
\text { granola, Kobber, Taeq } \\
\text { granola, Taeq light, Ritter, } \\
\text { Tia Sônia }\end{array}$ \\
\hline
\end{tabular}

\section{PRODUTOS SEPARADOS POR CB2O}

\section{Cookies}

\begin{tabular}{|c|c|c|c|}
\hline Saudável & Menos saudável & Orgânico & Não orgânico \\
\hline $\begin{array}{c}\text { Mãe Terra, Native, Jasmine } \\
\text { Orgânico, Taeq orgânico, } \\
\text { Gran Pure }\end{array}$ & $\begin{array}{c}\text { Jasmine integral, Vitao, } \\
\text { Biosoft, Taeq Aveia, Viver } \\
\text { Carrefour, Kobber, Naturale, } \\
\text { Quaker }\end{array}$ & $\begin{array}{c}\text { Mãe Terra, Native, Jasmine } \\
\text { Orgânico, Taeq orgânico }\end{array}$ & $\begin{array}{c}\text { Jasmine integral, Vitao, } \\
\text { Biosoft, Taeq Aveia, Viver } \\
\text { Carrefour, Kobber, Naturale, } \\
\text { Quaker, Gran Pure }\end{array}$ \\
\hline
\end{tabular}

\section{Barra de cereais}

\begin{tabular}{|c|c|c|c|}
\hline Saudável & Menos saudável & Orgânico & Não orgânico \\
\hline $\begin{array}{c}\text { Monama, Native, Gran Pure } \\
\text { Granola, Gran Pure } \\
\text { Chocolate, Bio2, Bio2 } \\
\text { orgânico, Mãe Terra }\end{array}$ & $\begin{array}{c}\text { Jasmine Cranberry, Jasmine } \\
\text { Castanha, Nature Valley, } \\
\text { Kellness, Quaker, Kobber } \\
\text { granola, Kobber, Taeq } \\
\text { granola, Taeq light, Ritter, } \\
\text { Tia Sônia }\end{array}$ & $\begin{array}{c}\text { Monama, Native, Gran Pure } \\
\text { Granola, Bio2 orgânico. }\end{array}$ & $\begin{array}{c}\text { Gran Pure Chocolate, Bio2, } \\
\text { Mãe Terra, Jasmine } \\
\text { Cranberry, Jasmine } \\
\text { Castanha, Nature Valley, } \\
\text { Kellness, Quaker, Kobber } \\
\text { granola, Kobber, Taeq } \\
\text { granola, Taeq light, Ritter, } \\
\text { Tia Sônia. }\end{array}$ \\
\hline
\end{tabular}




\section{PRODUTOS SEPARADOS POR CC23}

\section{Cookies}

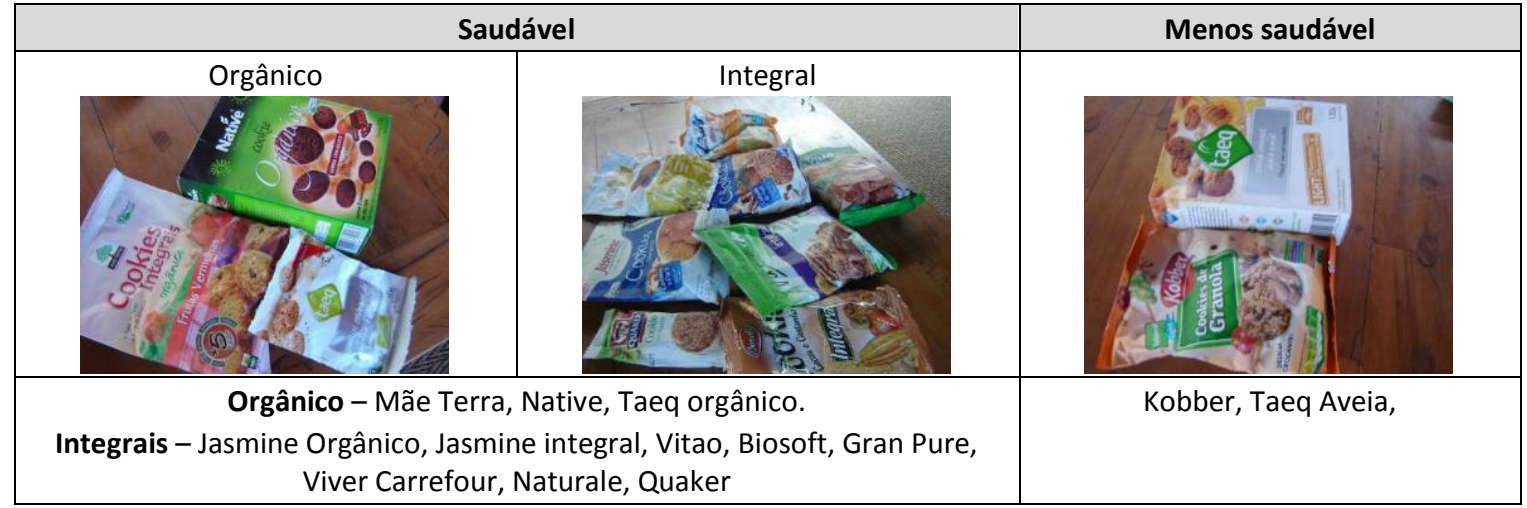

\begin{tabular}{|c|c|c|}
\hline Orgânico & \multicolumn{2}{|c|}{ Não orgânico } \\
\hline Mãe Terra, Native, Taeq orgânico. & Jasmine Orgânico, Jasmine integral, Vitao, Biosoft, Gran Pure, Viver Carrefour, \\
\hline \multicolumn{2}{|c|}{ Naturale, Quaker, Kobber, Taeq Aveia, } \\
\hline
\end{tabular}

\section{Barra de cereais}

\begin{tabular}{|c|c|c|}
\hline Saudável & Menos saudável & $\begin{array}{c}\text { Separação final começando pelo mais } \\
\text { saudável da esquerda para a direita. }\end{array}$ \\
\hline $\begin{array}{c}\text { Quaker, Ritter, Mãe Terra, Bio2 } \\
\text { orgânico, Bio2, Nature Valley, Taeq } \\
\text { granola, Taeq light, Native. }\end{array}$ & $\begin{array}{c}\text { Kobber granola, Kobber, Gran Pure } \\
\text { Granola, Gran Pure Chocolate, } \\
\text { Jasmine Castanha, Jasmine Cranberry, } \\
\text { Kellness, Monama, Tia Sônia }\end{array}$ & $\begin{array}{c}\text { Quaker, Ritter, Mãe Terra, Bio2 } \\
\text { orgânico, Bio2, Nature Valley, Taeq } \\
\text { granola, Taeq light, Native, Kobber } \\
\text { granola, Kobber, Gran Pure Granola, } \\
\text { Gran Pure Chocolate, Jasmine } \\
\text { Castanha, Jasmine Cranberry, } \\
\text { Kellness, Monama, Tia Sônia }\end{array}$ \\
\hline
\end{tabular}




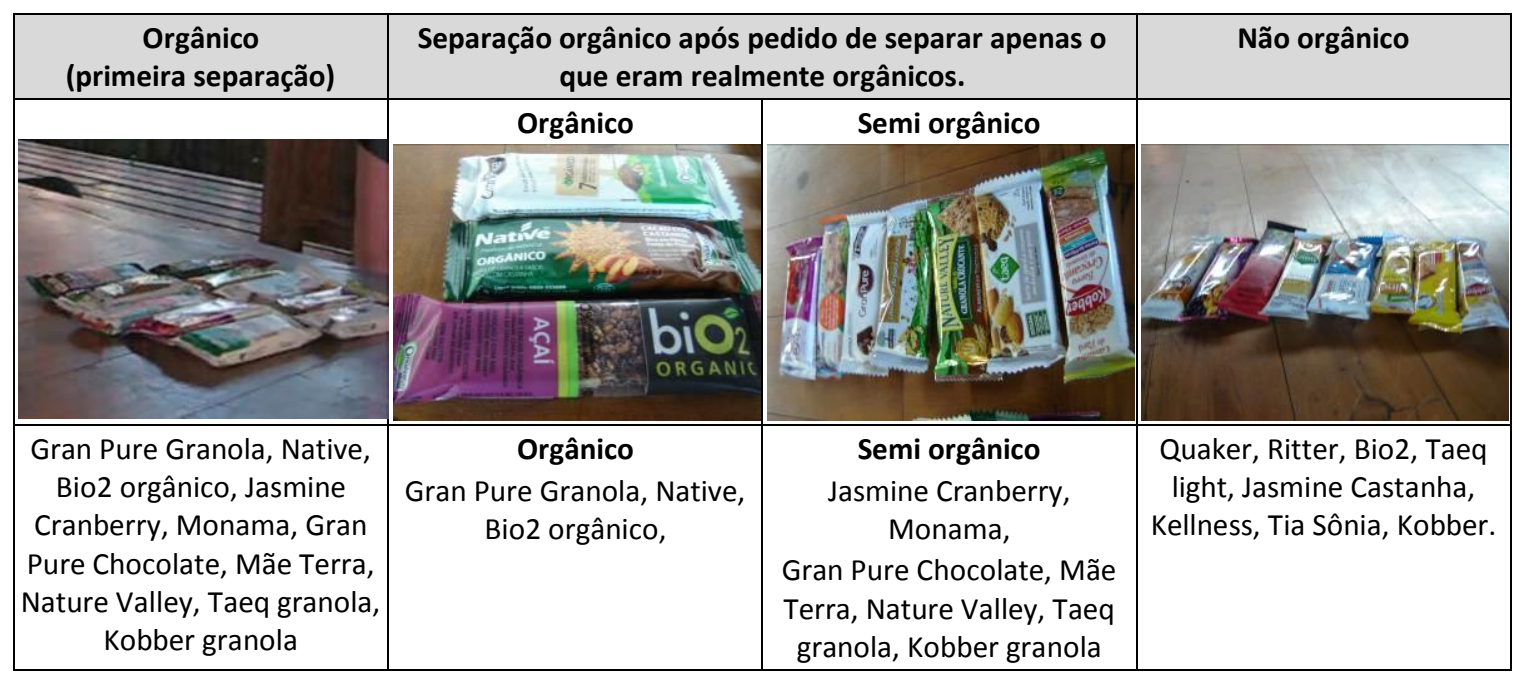

\section{PRODUTOS SEPARADOS POR CB24}

\section{Cookies}

\begin{tabular}{|l|l|l|l|}
\hline \multicolumn{1}{|c|}{ Saudável } & \multicolumn{1}{|c|}{ Menos saudável } & \multicolumn{1}{|c|}{ Orgânico } & \multicolumn{1}{|c|}{ Não orgânico } \\
\hline & &
\end{tabular}

\section{Barra de cereais}

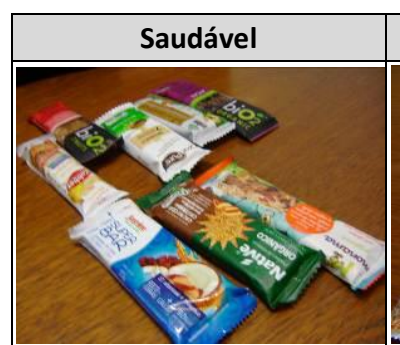

Monama, Native, Gran Pure Granola, Bio2, Bio2 orgânico, Mãe Terra, Jasmine Castanha, Kobber.

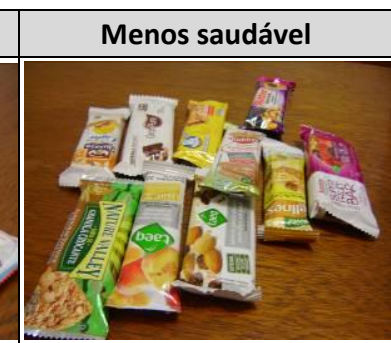

Jasmine Cranberry, Gran Pure Chocolate, Nature Valley, Kellness, Quaker, Kobber granola, Taeq granola, Taeq light, Ritter, Tia Sônia.

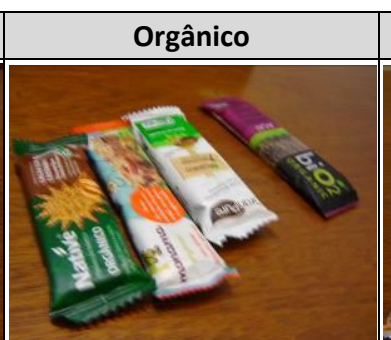

Não orgânico

Monama, Native, Gran Pure Jasmine Cranberry, Gran Pure Granola, Bio2 orgânico, Chocolate, Nature Valley, Kellness, Quaker, Kobber granola, Taeq granola, Taeq light, Ritter, Tia Sônia, Mãe Terra, Jasmine Castanha, Kobber, Bio2, 
PRODUTOS SEPARADOS POR CA26

\section{Cookies}

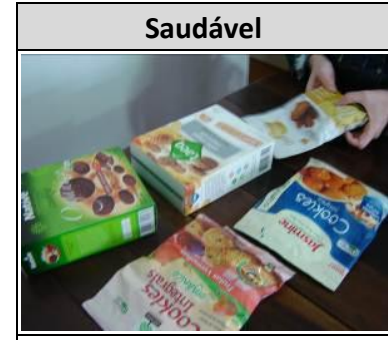

Mãe Terra, Native, Jasmine Orgânico, Gran Pure, Taeq Aveia,

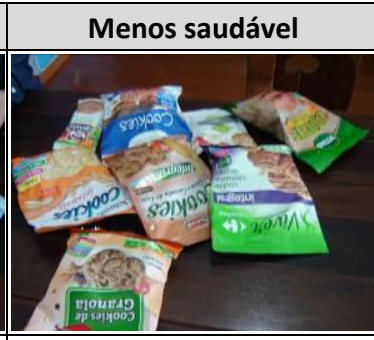

Jasmine integral, Vitao, Biosoft, Viver Carrefour, Kobber, Naturale, Quaker Taeq orgânico,

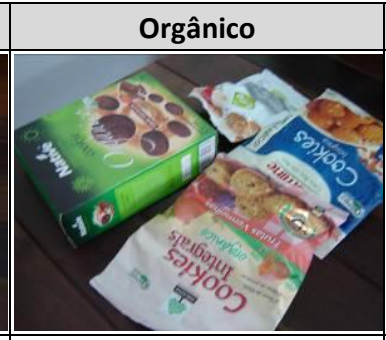

Mãe Terra, Native, Jasmine Orgânico, Taeq organico,

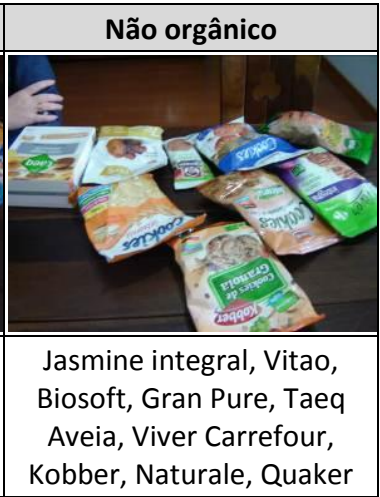

\section{Barra de cereais}

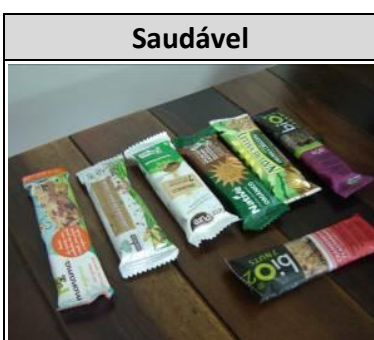

Monama, Native, Gran Pure Granola, Bio2, Bio2 orgânico, Mãe Terra, Nature Valley,

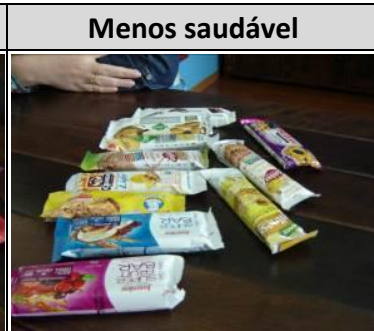

Gran Pure Chocolate, Jasmine Cranberry, Jasmine Castanha, Kellness, Quaker, Kobber granola, Kobber, Taeq granola, Taeq light, Ritter, Tia Sônia

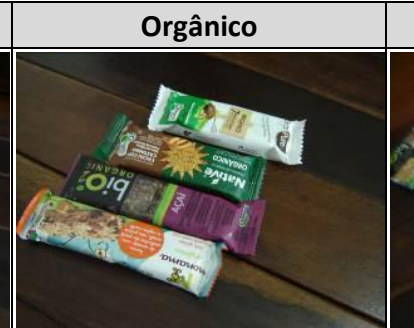

Monama, Native, Gran Pure Granola, Bio2 orgânico,
Não orgânico

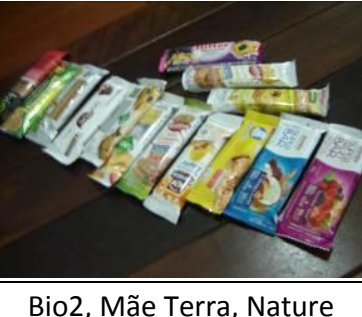

Valley,

Gran Pure Chocolate, Jasmine Cranberry, Jasmine Castanha, Kellness, Quaker, Kobber granola, Kobber, Taeq granola, Taeq light, Ritter, Tia Sônia

\section{H. SEPARAÇÃO DAS EMBALAGENS DO GRUPO 4}

\begin{tabular}{|l|l|}
\hline \multicolumn{2}{|l|}{ Grupo 4 - Preparo rápido para o consumo } \\
\hline Granola & Macarrão instantâneo \\
\hline $\begin{array}{l}\text { Mãe Terra, Monama, Native, Jasmine, Quaker, Kobber, } \\
\text { Vitao, Trio, Biosoft, Kellness, Cróqui }\end{array}$ & $\begin{array}{l}\text { Mãe Terra, Vilma Integral, Nissin, Nissin Mais, Vigor, } \\
\text { Panco, Maggi, Adria, Carrefour }\end{array}$ \\
\hline
\end{tabular}

PRODUTOS SEPARADOS POR CB01

\section{Granola}

\begin{tabular}{|c|c|c|c|}
\hline Saudável & Menos saudável & Orgânico & Não orgânico \\
\hline & & & \\
\hline Kobber, Trio & $\begin{array}{c}\text { Mãe Terra, Monama, Native, } \\
\text { Jasmine, Quaker, Vitao, } \\
\text { Biosoft, Kellness, Cróqui }\end{array}$ & Monama, Native & $\begin{array}{c}\text { Mãe Terra, Jasmine, Quaker, } \\
\text { Kobber, Vitao, Trio, Biosoft, } \\
\text { Kellness, Cróqui }\end{array}$ \\
\hline
\end{tabular}




\section{Macarrão}

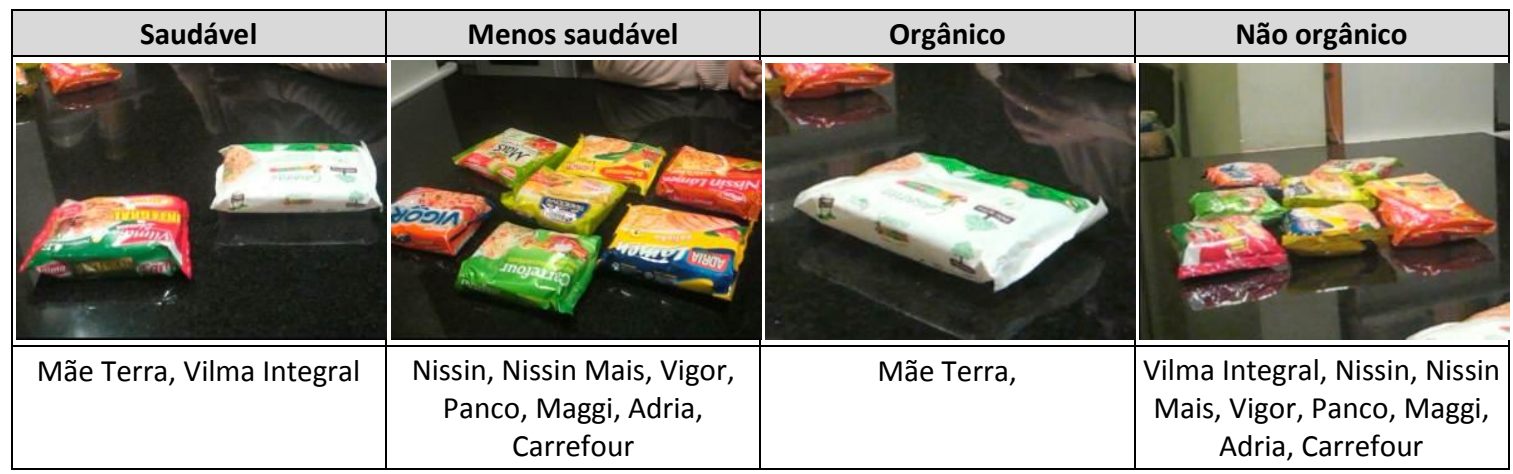

\section{PRODUTOS SEPARADOS POR CA15}

\section{Granola}

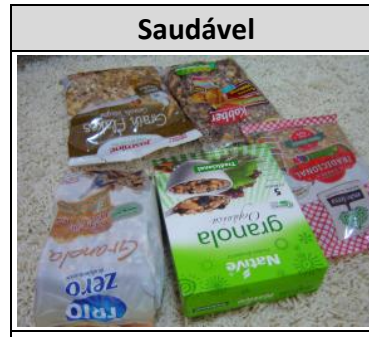

Native, Jasmine, Kobber, Trio, Mãe Terra

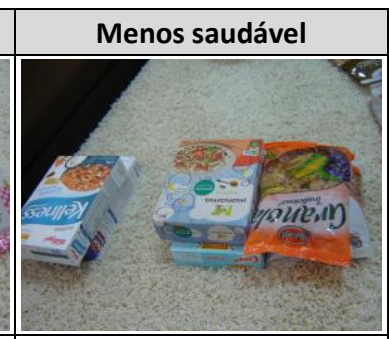

Kellness, Quaker, Vitao, Biosoft, Cróqui, Monama

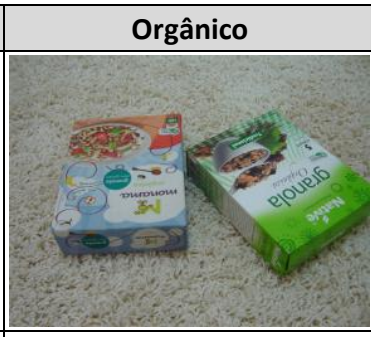

Monama, Native

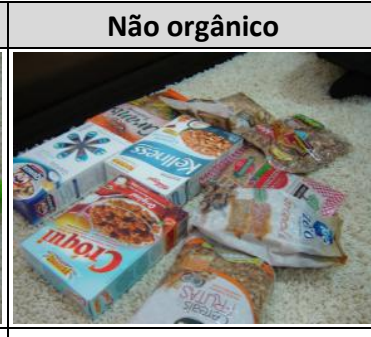

Jasmine, Kobber, Trio, Mãe Terra, Kellness, Quaker, Vitao, Biosoft, Cróqui

\section{Macarrão}

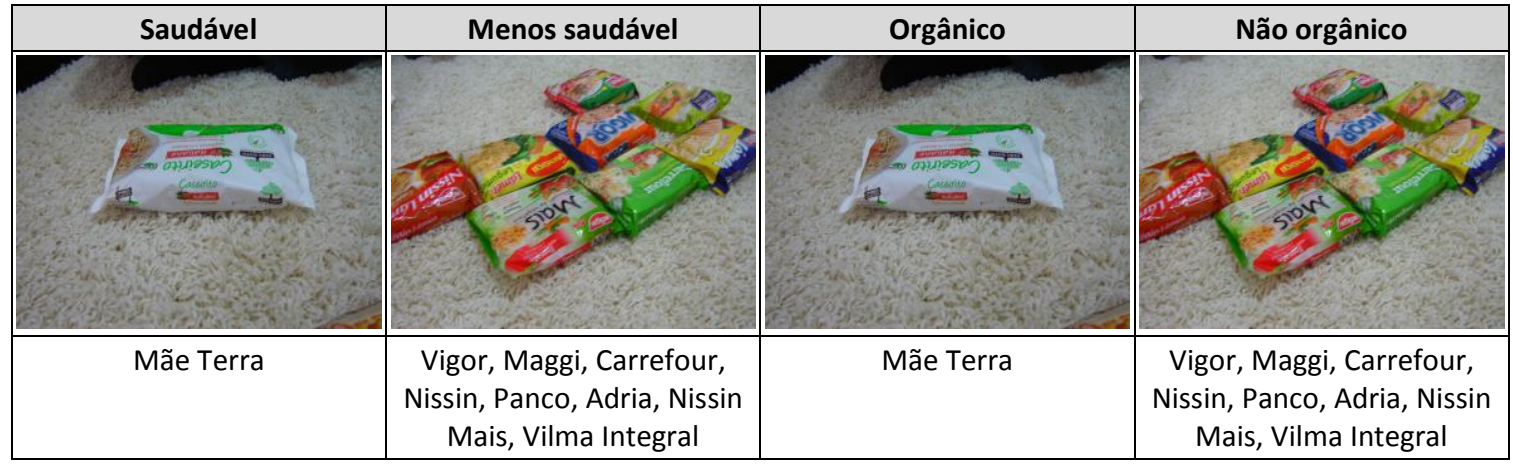

\section{PRODUTOS SEPARADOS POR CC16}

\section{Granola}

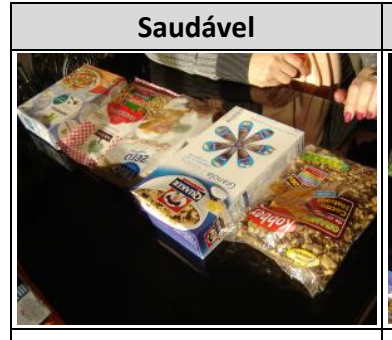

Trio, Mãe Terra, Monama, Quaker, Kobber

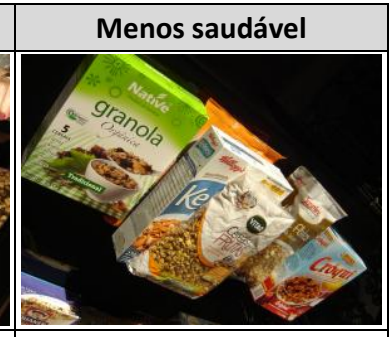

Kellness, Vitao, Biosoft, Cróqui, Native, Jasmine

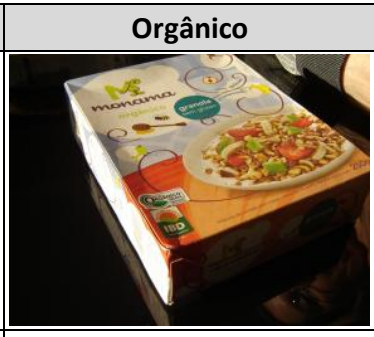

Monama

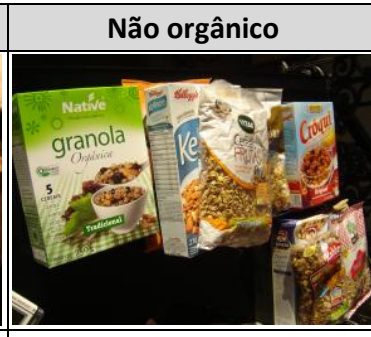

Trio, Mãe Terra, Quaker, Kobber, Kellness, Vitao, Biosoft, Cróqui, Native, Jasmine 


\section{Macarrão}

\begin{tabular}{|c|c|c|c|}
\hline Saudável & Menos saudável & Orgânico & Não orgânico \\
\hline $\begin{array}{c}\text { Adria, Nissin Mais, Vilma } \\
\text { Integral, Mãe Terra }\end{array}$ & $\begin{array}{c}\text { Vigor, Maggi, Carrefour, } \\
\text { Nissin, Panco }\end{array}$ & Mãe Terra & $\begin{array}{c}\text { Vigor, Maggi, Carrefour, } \\
\text { Nissin, Panco, Adria, Nissin } \\
\text { Mais, Vilma Integral }\end{array}$ \\
\hline
\end{tabular}

\section{PRODUTOS SEPARADOS POR CB17}

\section{Granola}

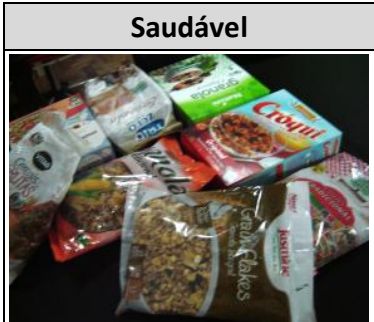

Vitao, Biosoft, Cróqui, Native, Jasmine, Trio, Mãe Terra, Monama

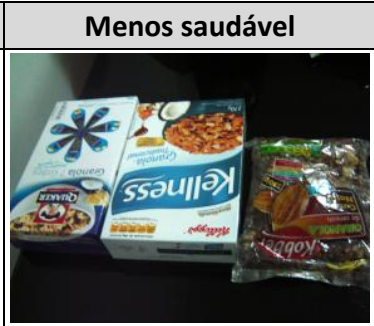

Kellness, Quaker, Kobber

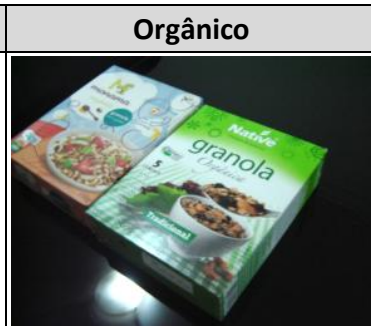

Monama, Native

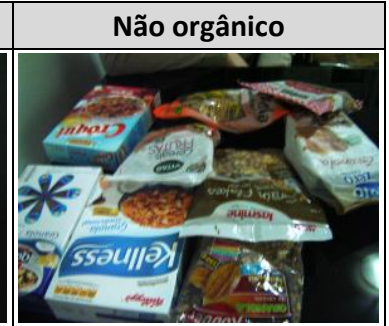

Vitao, Biosoft, Cróqui, Jasmine, Trio, Mãe Terra, Kellness, Quaker, Kobber

\section{Macarrão}

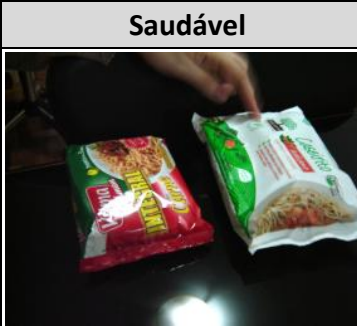

Mãe Terra, Vilma Integral

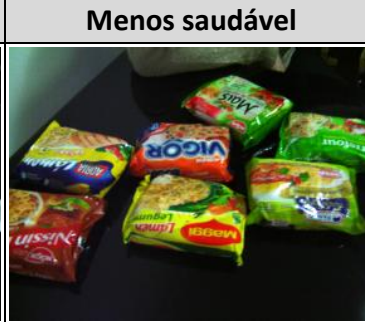

Vigor, Maggi, Carrefour, Nissin, Panco, Adria, Nissin Mais.

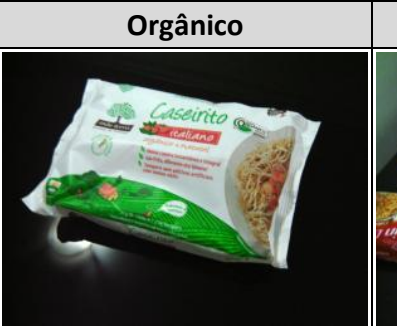

Mãe Terra

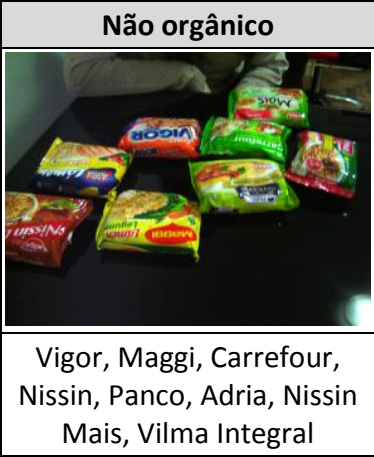

\section{PRODUTOS SEPARADOS POR CB22}

\section{Granola}

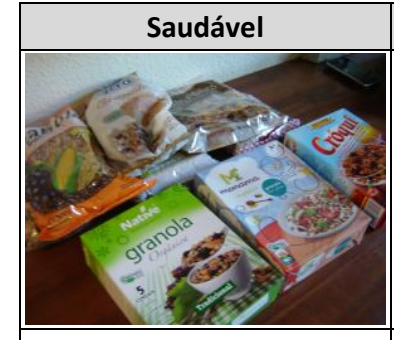

Vitao, Biosoft, Cróqui, Native, Jasmine, Kobber, Trio, Mãe Terra, Monama

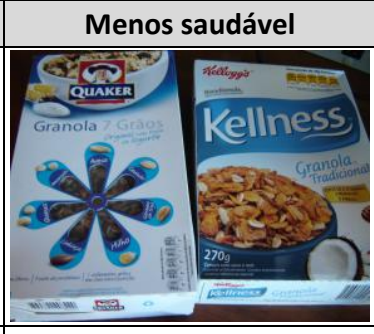

Kellness, Quaker

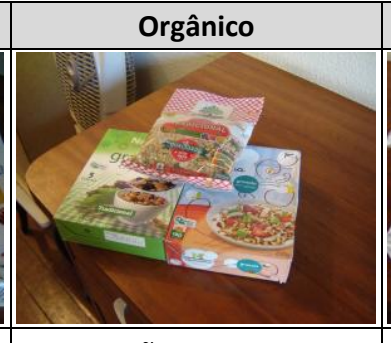

Native, Mãe Terra, Monama

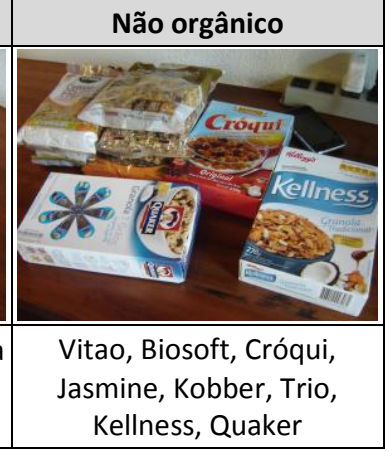




\section{Macarrão}

\begin{tabular}{|c|c|c|c|}
\hline Saudável & Menos saudável & Orgânico & Não orgânico \\
\hline & & & \\
\hline $\begin{array}{c}\text { Mãe Terra, Nissin Mais, } \\
\text { Vilma Integral }\end{array}$ & $\begin{array}{c}\text { Vigor, Maggi, Carrefour, } \\
\text { Nissin, Panco, Adria }\end{array}$ & Mãe Terra & $\begin{array}{c}\text { Vigor, Maggi, Carrefour, } \\
\text { Nissin, Panco, Adria, Nissin } \\
\text { Mais, Vilma Integral }\end{array}$ \\
\hline
\end{tabular}

\section{PRODUTOS SEPARADOS POR CA25}

\section{Granola}

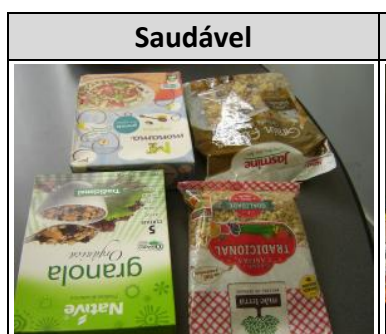

Native, Jasmine, Mãe Terra,

Monama

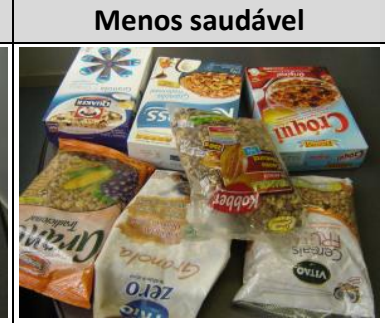

Kellness, Quaker, Vitao Biosoft, Cróqui, Kobber, Trio

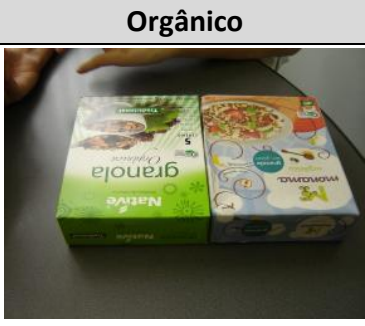

Native, Monama

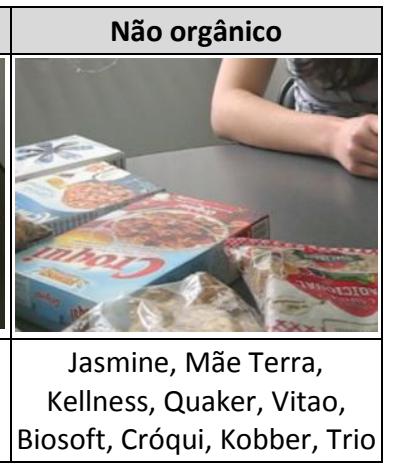

\section{Macarrão}

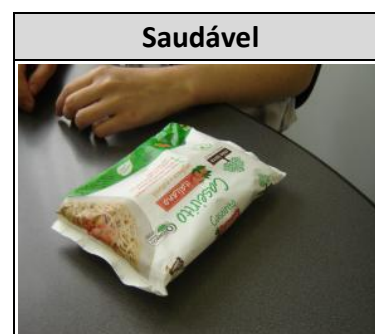

Mãe Terra

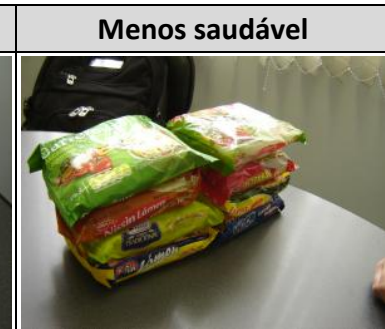

Vigor, Maggi, Carrefour, Nissin, Panco, Adria, Nissin Mais, Vilma Integral

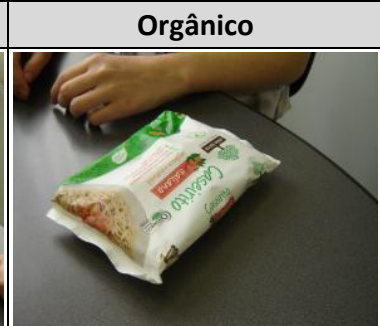

Mãe Terra

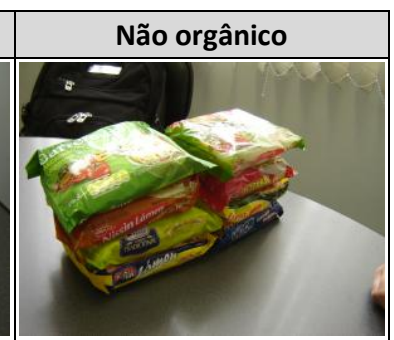

Vigor, Maggi, Carrefour, Nissin, Panco, Adria, Nissin Mais, Vilma Integral

\section{PRODUTOS SEPARADOS POR CC3O}

\section{Granola}

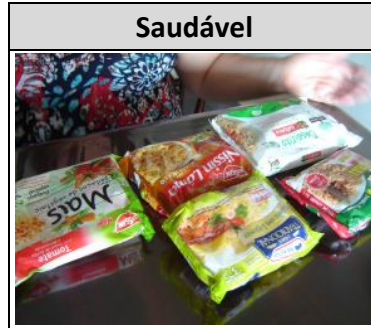

Nissin, Panco, Nissin Mais, Vilma Integral, Mãe Terra

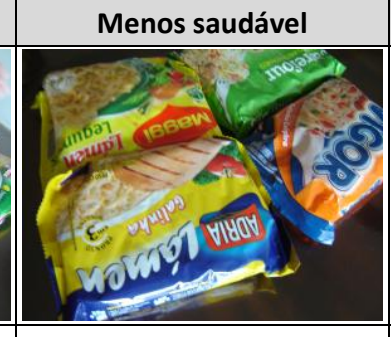

Adria, Vigor, Maggi, Carrefour

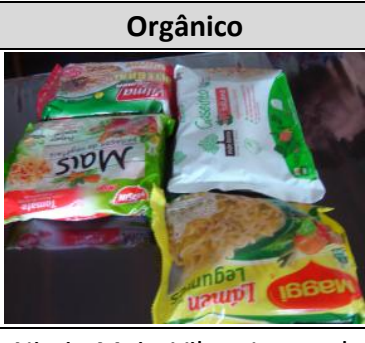

Nissin Mais, Vilma Integral, Mãe Terra, Maggi

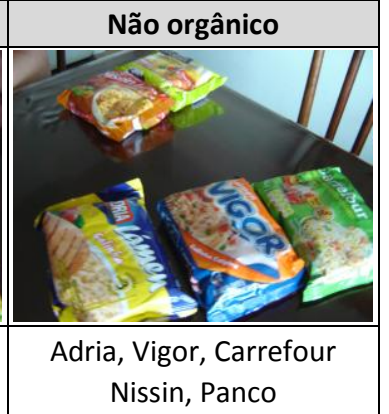




\section{Macarrão}

\begin{tabular}{|c|c|c|c|}
\hline Saudável & Menos saudável & Orgânico & Não orgânico \\
\hline $\begin{array}{c}\text { Kellness, Quaker, Cróqui, } \\
\text { Native, Jasmine, Kobber, } \\
\text { Monama }\end{array}$ & $\begin{array}{c}\text { Vitao, Biosoft, Trio, Mãe } \\
\text { Terra }\end{array}$ & $\begin{array}{c}\text { Quaker, Cróqui, Native, } \\
\text { Monama }\end{array}$ & $\begin{array}{c}\text { Jasmine, Kobber, Vitao, Trio, } \\
\text { Biosoft, Kellness, Mãe Terra }\end{array}$ \\
\hline
\end{tabular}

\section{DADOS DAS ENTREVISTAS COM ARROZ INTEGRAL}

\section{Arroz integral}

O número da primeira linha, de cada planilha, identifica o entrevistado

\section{Separação como mais saudável}

\begin{tabular}{|l|c|c|c|c|c|c|c|c|}
\hline observações durante a separação & 2 & 6 & 12 & 19 & 27 & 28 & 29 & $\begin{array}{c}\text { soma } \\
\text { consumidores }\end{array}$ \\
\hline olhou a tabela nutricional & & & & & & 1 & 1 & 2 \\
\hline olhou a parte de trás da embalagem & & 1 & & & & 1 & 1 & 3 \\
\hline ficou em dúvida com alguma marca & & & & & & & \\
\hline Tio João & & & & & 1 & & \\
\hline
\end{tabular}

\begin{tabular}{|l|l|l|l|l|l|l|l|l|}
\hline Separação saudável & 2 & 6 & $\mathbf{1 2}$ & $\mathbf{1 9}$ & $\mathbf{2 7}$ & $\mathbf{2 8}$ & $\mathbf{2 9}$ & $\begin{array}{c}\text { Soma } \\
\text { consumidores }\end{array}$ \\
\hline Camil & & & & & & & & 0 \\
\hline Maninho & & & & & & 1 & & \multicolumn{2}{|c|}{1} \\
\hline Tio João & & & 1 & & & & 1 & 2 \\
\hline Jasmine & & & & & 1 & 1 & 1 & 3 \\
\hline Via Pax Bio & 1 & & & 1 & 1 & 1 & & \\
\hline Organic & 1 & & & 1 & 1 & 1 & & \\
\hline Mãe Terra & 1 & & 1 & & 1 & 1 & & 4 \\
\hline Korin & 1 & 1 & & 1 & 1 & 1 & & 4 \\
\hline Volkmann & 1 & 1 & & 1 & 1 & 1 & 1 & 5 \\
\hline Tio João orgânico & 1 & & 1 & 1 & 1 & 1 & 1 & 6 \\
\hline
\end{tabular}

\begin{tabular}{|c|c|c|c|c|c|c|c|c|}
\hline Critérios separação arroz como saudável & 2 & 6 & 12 & 19 & 27 & 28 & 29 & soma menções \\
\hline informações na frente & & & & & & 1 & & 1 \\
\hline elemento gráfico & 1 & & & & & & & 1 \\
\hline papel & 1 & & & & & & & 1 \\
\hline apelo visual & 1 & & & & & & & 1 \\
\hline organização informações & & & & & & 1 & & 1 \\
\hline quantidade de embalagem & & 1 & & & & & & 1 \\
\hline gosto pessoal & 1 & & & & & & & 1 \\
\hline texto & & & & & & & 2 & 2 \\
\hline tabela nutricional & & & & & & & 2 & 2 \\
\hline embalagem a vácuo & 1 & & & 2 & & & & 3 \\
\hline tipo de produto & & & & 2 & & & 1 & 3 \\
\hline pesquisou sobre a empresa & & & 1 & & 2 & & & 3 \\
\hline produção & 1 & & 2 & & & & & 3 \\
\hline
\end{tabular}




\begin{tabular}{|c|c|c|c|c|c|c|c|c|}
\hline costuma comprar & 3 & & & & 1 & & & 4 \\
\hline integral & 1 & 1 & & & & 1 & 4 & 7 \\
\hline composição nutricional & & 1 & & & & & 6 & 7 \\
\hline biodinâmico & 2 & 4 & & 1 & & 1 & & 8 \\
\hline orgânico & 4 & 2 & & 3 & 1 & & 1 & 11 \\
\hline sabor & & & & & & & 12 & 12 \\
\hline marca & 3 & 1 & 3 & & 2 & & 4 & 13 \\
\hline
\end{tabular}

\begin{tabular}{|l|c|c|c|c|c|c|c|c|}
\hline Critérios separação arroz como menos saudável & $\mathbf{2}$ & $\mathbf{6}$ & $\mathbf{1 2}$ & $\mathbf{1 9}$ & $\mathbf{2 7}$ & $\mathbf{2 8}$ & $\mathbf{2 9}$ & soma menções \\
\hline calorias & & & & & & & 1 & 1 \\
\hline gosto pessoal & & & 1 & & & & & 1 \\
\hline parboilizado & 1 & & & & & 1 & & 1 \\
\hline produção & & & & & & 1 & & 1 \\
\hline aparência & & & 2 & & & & & 1 \\
\hline elemento textual & & & 2 & & & & 7 & 2 \\
\hline marca desconhecida & & & 9 \\
\hline
\end{tabular}

\section{Separação como orgânico}

\begin{tabular}{|l|c|c|c|c|c|c|c|c|}
\hline observações durante a separação & $\mathbf{2}$ & $\mathbf{6}$ & $\mathbf{1 2}$ & $\mathbf{1 9}$ & $\mathbf{2 7}$ & $\mathbf{2 8}$ & $\mathbf{2 9}$ & $\begin{array}{c}\text { soma } \\
\text { consumidores }\end{array}$ \\
\hline encontrou algum depois de olhar uma segunda vez & & 1 & & & & & & 1 \\
\hline Dúvida com Mãe Terra & & 1 & & & & & 1 & 2 \\
\hline Dúvida com Jasmine & & 1 & & & & 1 & 2 \\
\hline olhou primeiro no grupo de saudáveis & 1 & & 1 & 1 & 1 & & 4 \\
\hline
\end{tabular}

\begin{tabular}{|l|l|l|l|l|l|l|l|l|}
\hline Separação Orgânico & $\mathbf{2}$ & $\mathbf{6}$ & $\mathbf{1 2}$ & $\mathbf{1 9}$ & $\mathbf{2 7}$ & $\mathbf{2 8}$ & $\mathbf{2 9}$ & $\begin{array}{c}\text { soma } \\
\text { consumidores }\end{array}$ \\
\hline Mãe Terra & & & & & & & & \multicolumn{2}{|c|}{0} \\
\hline Tio João & & & & & & & & \\
\hline Jasmine & & & & & & & & \\
\hline Maninho & & & & & & & & \\
\hline Camil & & & & & & & & \\
\hline Organic & 1 & 1 & 1 & 1 & 1 & 1 & 1 & 0 \\
\hline Volkmann & 1 & 1 & 1 & 1 & 1 & 1 & 1 & 7 \\
\hline Korin & 1 & 1 & 1 & 1 & 1 & 1 & 1 & 7 \\
\hline Tio João orgânico & 1 & 1 & 1 & 1 & 1 & 1 & 1 & 7 \\
\hline Via Pax Bio & 1 & 1 & 1 & 1 & 1 & 1 & 1 & 7 \\
\hline
\end{tabular}

\begin{tabular}{|l|c|c|c|c|c|c|c|c|}
\hline Critérios separação arroz como orgânico & $\mathbf{2}$ & $\mathbf{6}$ & $\mathbf{1 2}$ & $\mathbf{1 9}$ & $\mathbf{2 7}$ & $\mathbf{2 8}$ & $\mathbf{2 9}$ & soma menções \\
\hline integral & & & & & 1 & & 1 \\
\hline seção como desenvolvemos & & & & & & 1 & & 1 \\
\hline biodinâmico & & & & & & 1 & 1 \\
\hline marca & & & & & 1 & & 1 \\
\hline splash & & & & & & 1 & & 1 \\
\hline faixa & & & 1 & & & & & \\
\hline segurança & 2 & & & & & & & 1 \\
\hline apelo visual & & & & & 2 & 1 & & \\
\hline outros selos certificação & 2 & & 3 & 1 & & & & \\
\hline embalagem a vácuo & & 1 & & & 3 & 2 & 3 & 6 \\
\hline selo SisOrg & 4 & 1 & 1 & 2 & 1 & 6 & 6 & 9 \\
\hline orgânico & & & 21 \\
\hline
\end{tabular}




\begin{tabular}{|l|c|c|c|c|c|c|c|c|}
\hline Critérios separação arroz como não orgânico & $\mathbf{2}$ & $\mathbf{6}$ & $\mathbf{1 2}$ & $\mathbf{1 9}$ & $\mathbf{2 7}$ & $\mathbf{2 8}$ & $\mathbf{2 9}$ & soma menções \\
\hline palavra integral & & & & & & 1 & & 1 \\
\hline falta do selo SisOrg & & & & & & & 1 & 1 \\
\hline preço & & & & & 1 & & & 1 \\
\hline marca desconhecida & & & & & & & 3 & 3 \\
\hline falta da palavra orgânico & & 3 & & & & 1 & 3 & 7 \\
\hline
\end{tabular}

\section{Arroz integral Mãe Terra}

\begin{tabular}{|l|c|c|c|c|c|c|c|c|}
\hline Já comprou este produto ou de outro sabor? & 2 & 6 & 12 & 19 & 27 & 28 & 29 & $\begin{array}{c}\text { soma } \\
\text { consumidores }\end{array}$ \\
\hline já viu e não comprou & & 1 & & & & & 1 & 2 \\
\hline comprou porque conhece a marca & 1 & & 1 & & 1 & 1 & & 4 \\
\hline Motivo por não ter comprado & & & & & & & & \\
\hline costuma comprar de outra marca & & 1 & & & & & & 1 \\
\hline compra arroz à granel & & & & & & & 1 & 1 \\
\hline não compra esse tipo de produto & & & 1 & 1 & & & & 2 \\
\hline
\end{tabular}

\begin{tabular}{|c|c|c|c|c|c|c|c|c|}
\hline $\begin{array}{l}\text { Aspectos positivos da embalagem de arroz integral Mãe } \\
\text { Terra }\end{array}$ & 2 & 6 & 12 & 19 & 27 & 28 & 29 & soma menções \\
\hline embalagem & & & & & & & 1 & 1 \\
\hline tabela nutricional & & & & 1 & & & & 1 \\
\hline cor & & & & & & & 1 & 1 \\
\hline legibilidade & & 1 & & & & & & 1 \\
\hline reciclagem & & 1 & & & & & & 1 \\
\hline embalagem saquinho & & & 1 & & & & & 1 \\
\hline quantidade de embalagem & & 1 & & & & & & 1 \\
\hline composição nutricional & & & 1 & & & & & 1 \\
\hline produção & & 1 & & & & & & 1 \\
\hline fonte de algum nutriente & & & & 2 & & & & 2 \\
\hline seção sobre nós & 1 & & 1 & & & & & 2 \\
\hline outros selos certificação & & & & & 2 & & & 2 \\
\hline abrir e fechar & & 2 & & & & & & 2 \\
\hline sentir o produto & 1 & & 1 & & & & & 2 \\
\hline aproveitamento embalagem & 2 & & & & & & & 2 \\
\hline sabor & & & & & & & 2 & 2 \\
\hline integral & & & & 2 & & 1 & & 3 \\
\hline nome & 1 & & & & & 2 & & 3 \\
\hline selo SisOrg & & & & & 3 & & & 3 \\
\hline apelo visual & 1 & & & 1 & & & 1 & 3 \\
\hline organização informações & 1 & & & 2 & & & & 3 \\
\hline pouco ou sem algo na composição & & & 1 & 3 & & & & 4 \\
\hline receita & 1 & & 2 & 1 & & & & 4 \\
\hline marca Mãe Terra & 1 & & & 1 & & 1 & 2 & 5 \\
\hline ver o produto & & & 3 & 2 & & & & 5 \\
\hline informações na frente & 1 & 2 & & 3 & & & & 6 \\
\hline remete a algo bom & 2 & 1 & & 1 & & & 3 & 7 \\
\hline ilustração & 3 & 2 & 1 & 1 & & 1 & 5 & 13 \\
\hline
\end{tabular}




\begin{tabular}{|c|c|c|c|c|c|c|c|c|}
\hline ser não orgânico & & & 1 & & & & & 1 \\
\hline tabela nutricional & & & & 1 & & & & 1 \\
\hline receita & & 1 & & & & & & 1 \\
\hline preparo básico & & & 1 & & & & & 1 \\
\hline plástico & & & & & & & 1 & 1 \\
\hline tipografia & & & & & & 1 & & 1 \\
\hline cor & & & 1 & & & & & 1 \\
\hline abrir e fechar & & & & & & & 2 & 2 \\
\hline tamanho da porção & & & 2 & & & & & 2 \\
\hline organização informações & & & & 2 & & & & 2 \\
\hline legibilidade & & 2 & & & & & & 2 \\
\hline ver pouco o produto & & & 2 & & & & & 2 \\
\hline embalagem saquinho & & & 2 & & & 1 & & 3 \\
\hline resistência da embalagem & & & 2 & & & 1 & & 3 \\
\hline sódio & & 1 & 1 & & 3 & & & 5 \\
\hline gosto & & & 1 & 4 & & & & 5 \\
\hline preço & 1 & & & & 4 & 1 & & 6 \\
\hline preparo & & & 6 & & & & & 6 \\
\hline aparência & & & 5 & & 1 & 3 & & 9 \\
\hline
\end{tabular}

\section{J. DADOS DAS ENTREVISTAS COM FEIJÃO PRETO}

\section{Feijão preto}

O número da primeira linha, de cada planilha, identifica o entrevistado

\section{Separação como mais saudável}

\begin{tabular}{|l|c|c|c|c|c|c|c|c|}
\hline observações durante a separação & $\mathbf{9}$ & $\mathbf{1 0}$ & $\mathbf{1 4}$ & $\mathbf{1 8}$ & $\mathbf{2 1}$ & $\mathbf{3 1}$ & $\mathbf{3 2}$ & soma consumidores \\
\hline olhou a tabela nutricional & & & & & & & 1 & 1 \\
\hline Olhou a parte de trás da embalagem & & & & & & & 1 & 1 \\
\hline
\end{tabular}

\begin{tabular}{|l|c|c|c|c|c|c|c|c|}
\hline Separação saudável & $\mathbf{9}$ & $\mathbf{1 0}$ & $\mathbf{1 4}$ & $\mathbf{1 8}$ & $\mathbf{2 1}$ & $\mathbf{3 1}$ & $\mathbf{3 2}$ & soma consumidores \\
\hline Guto & & & & & & & & 0 \\
\hline Carrefour & & & & & & & & \\
\hline Camil & & & 1 & & & & & 0 \\
\hline Camil exportação & & & 1 & & & 1 & & 1 \\
\hline Broto Legal & & & 1 & & 1 & 1 & & 2 \\
\hline Via Pax Bio & 1 & 1 & & 1 & 1 & 1 & 1 & 3 \\
\hline
\end{tabular}

\begin{tabular}{|l|l|l|l|l|l|l|l|c|}
\hline Critérios separação feijão como mais saudável & $\mathbf{9}$ & $\mathbf{1 0}$ & $\mathbf{1 4}$ & $\mathbf{1 8}$ & $\mathbf{2 1}$ & $\mathbf{3 1}$ & $\mathbf{3 2}$ & \multicolumn{2}{|c|}{ soma menções } \\
\hline outros selos de certificação & & & & & 1 & & & 1 \\
\hline faixa & & & & & & 1 & & 1 \\
\hline foto & & & & & & 1 & & 1 \\
\hline organização das informações & 1 & & & & & & & \\
\hline legibilidade & & & & & & 1 & & 1 \\
\hline parece caseiro & 1 & & & & & & & \\
\hline embalagem a vácuo & & & & & & & 1 & 1 \\
\hline site & & & & 1 & & & & 1 \\
\hline costuma comprar & & & & & & 2 & & 1 \\
\hline embalagem & & \\
\hline
\end{tabular}




\begin{tabular}{|c|c|c|c|c|c|c|c|}
\hline sem agrotóxico & & & & 2 & & & 2 \\
\hline reciclagem & & & & & & 2 & 2 \\
\hline marca & 1 & & & 2 & & & 3 \\
\hline tipo de produto & & & 2 & & & 1 & 3 \\
\hline produção & 2 & 1 & & & & & 3 \\
\hline tamanho da porção & & & & & 1 & 3 & 4 \\
\hline composição nutricional & & & & & & 7 & 7 \\
\hline palavra orgânico & 2 & 3 & 5 & 1 & 1 & & 12 \\
\hline
\end{tabular}

\begin{tabular}{|l|c|c|c|c|c|c|c|c|}
\hline Critérios separação feijão como menos saudável & $\mathbf{9}$ & $\mathbf{1 0}$ & $\mathbf{1 4}$ & $\mathbf{1 8}$ & $\mathbf{2 1}$ & $\mathbf{3 1}$ & $\mathbf{3 2}$ & soma menções \\
\hline elemento textual & & & & & & & 1 & 1 \\
\hline sem glúten & & & & & & & 1 & 1 \\
\hline marca & 1 & & & & & & & 1 \\
\hline organização informações & & & & & & 1 & & 1 \\
\hline parece mais industrial & & & & & & 1 & & 1 \\
\hline produção & & & & & 1 & & & 1 \\
\hline aditivos & 1 & & & & & & & 1 \\
\hline agrotóxicos /pesticidas & 1 & 1 & & & & & & 2 \\
\hline natural & & & 2 & & & & & 2 \\
\hline embalagem feia & & & & & & & 3 & 3 \\
\hline marca descohecidas & & & & 1 & & & 3 & 4 \\
\hline preço & & & & & & & 4 & 4 \\
\hline
\end{tabular}

\section{Separação como orgânico}

\begin{tabular}{|l|c|c|c|c|c|c|c|c|}
\hline observações durante a separação & 9 & 10 & 14 & $\mathbf{1 8}$ & $\mathbf{2 1}$ & $\mathbf{3 1}$ & $\mathbf{3 2}$ & soma consumidores \\
\hline olhou primeiro no grupo de saudáveis & 1 & 1 & & 1 & 1 & 1 & 1 & 6 \\
\hline
\end{tabular}

\begin{tabular}{|l|c|c|c|c|c|c|c|c|}
\hline Separação orgânico & $\mathbf{9}$ & $\mathbf{1 0}$ & $\mathbf{1 4}$ & $\mathbf{1 8}$ & $\mathbf{2 1}$ & $\mathbf{3 1}$ & $\mathbf{3 2}$ & soma consumidores \\
\hline Camil exportação & & & 1 & & & & & 1 \\
\hline Camil & & & 1 & & & & & \\
\hline Broto Legal & & & 1 & & & & & \\
\hline Guto & & & 1 & & & & & 1 \\
\hline Carrefour & & & 1 & & & & & 1 \\
\hline Via Pax Bio & 1 & 1 & 1 & 1 & 1 & 1 & 1 & 1 \\
\hline
\end{tabular}

\begin{tabular}{|l|c|c|c|c|c|c|c|c|}
\hline Critérios separação feijão como orgânico & $\mathbf{9}$ & $\mathbf{1 0}$ & $\mathbf{1 4}$ & $\mathbf{1 8}$ & $\mathbf{2 1}$ & $\mathbf{3 1}$ & $\mathbf{3 2}$ & soma menções \\
\hline embalagem & & & & & & 1 & & 1 \\
\hline segurança & & & 1 & & & & & 1 \\
\hline produção & & & & & & & 1 & 1 \\
\hline marca & & & & & & 1 & 1 & 2 \\
\hline natural & & 2 & & & & & & 2 \\
\hline faixa & & & & & & & 3 & 3 \\
\hline selo SisOrg & & 1 & & 1 & 1 & & 1 & 4 \\
\hline fechada a vácuo & & & 4 & & & 1 & & 5 \\
\hline palavra orgânico & 3 & 2 & & 3 & 1 & 2 & 5 & 16 \\
\hline
\end{tabular}

\begin{tabular}{|l|c|c|c|c|c|c|c|c|}
\hline Critérios separação feijão como não orgânico & 9 & 10 & 14 & 18 & 21 & 31 & 32 & soma menções \\
\hline embalagem & & & & & & & 1 & 1 \\
\hline palavra orgânico & & & & & & & 1 & 1 \\
\hline
\end{tabular}


seção sobre nós

outros selos certificação

Feijão preto Via Pax Bio

\begin{tabular}{|l|c|c|c|c|c|c|c|c|}
\hline Já comprou este produto ou de outro sabor? & $\mathbf{9}$ & $\mathbf{1 0}$ & $\mathbf{1 4}$ & $\mathbf{1 8}$ & $\mathbf{2 1}$ & $\mathbf{3 1}$ & $\mathbf{3 2}$ & soma consumidores \\
\hline Já comprou este produto ou de outro sabor & 1 & & & & 1 & & & \\
\hline Motivo por não ter comprado & & & & & & & & \\
\hline Nunca viu & & 1 & 1 & 1 & & 1 & 1 & 2 \\
\hline caro & 1 & & & & & & & 5 \\
\hline
\end{tabular}

\begin{tabular}{|c|c|c|c|c|c|c|c|c|}
\hline $\begin{array}{l}\text { Aspectos positivos da embalagem de feijão preto Via Pax } \\
\text { Bio }\end{array}$ & 9 & 10 & 14 & 18 & 21 & 31 & 32 & soma menções \\
\hline caixa & & & & & 1 & & & 1 \\
\hline guardar a embalagem & & & 1 & & & & & 1 \\
\hline manuseio & & & & & & & 1 & 1 \\
\hline outros selos certificação & & & & & & 1 & & 1 \\
\hline passa credibilidade & 1 & & & & & & & 1 \\
\hline passa cuidado & 1 & & & & & & & 1 \\
\hline produção & & & 1 & & & & & 1 \\
\hline selo SisOrg & & & & & & & 1 & 1 \\
\hline sem glúten & & 1 & & & & & & 1 \\
\hline tabela nutricional & & & & 1 & & & & 1 \\
\hline tinta & & & & & 1 & & & 1 \\
\hline ver o produto & & & & & & & 1 & 1 \\
\hline cor & 2 & & & & & & & 2 \\
\hline marca Via Pax Bio & 2 & & & & & & & 2 \\
\hline nome & & & & & & 2 & & 2 \\
\hline palavra natural & & & & & & 2 & & 2 \\
\hline segurança & 2 & & & & & & & 2 \\
\hline sentir o produto & & & & & 2 & & & 2 \\
\hline tipografia & & & 1 & & 1 & & & 2 \\
\hline informações na frente & & & & 3 & & & & 3 \\
\hline reciclagem & & & & & & & 3 & 3 \\
\hline receita & & 1 & 1 & 1 & & & & 3 \\
\hline tipo de produto & & & & & & 2 & 1 & 3 \\
\hline papel & 2 & & & & 2 & & & 4 \\
\hline seção institucional & & & 3 & & & 1 & 1 & 5 \\
\hline apelo visual & 2 & & & 1 & & & 3 & 6 \\
\hline fechado a vácuo & 1 & & 2 & 3 & & 1 & & 7 \\
\hline palavra orgânico & 2 & 2 & & 2 & & 2 & & 8 \\
\hline legibilidade & & 3 & 3 & & 3 & & & 9 \\
\hline organização das informações & & & 1 & 3 & 4 & 1 & 1 & 10 \\
\hline
\end{tabular}

\begin{tabular}{|l|l|l|l|l|l|l|l|l|}
\hline $\begin{array}{l}\text { Aspectos negativos da embalagem de feijão preto Via } \\
\text { Pax Bio }\end{array}$ & $\mathbf{9}$ & $\mathbf{1 0}$ & $\mathbf{1 4}$ & $\mathbf{1 8}$ & $\mathbf{2 1}$ & $\mathbf{3 1}$ & $\mathbf{3 2}$ & soma menções \\
\hline palavra orgânico & & & & & & 1 & & 1 \\
\hline saudável & 1 & & & & & & & 1 \\
\hline seção sobre nós & & & & & & 2 & & 1 \\
\hline composição nutricional & & & 1 & & & 1 & & 2 \\
\hline cor & & & & & & 1 & 1 & 2 \\
\hline marca desconhecida & & \\
\hline
\end{tabular}




\begin{tabular}{|l|l|l|l|l|l|l|l|l|} 
nome & & & & & & 2 & & 2 \\
\hline organização informações & & 2 & & & & & & 2 \\
\hline plástico & & & & & 2 & & & 2 \\
\hline ambientalmente correto & & & & & 3 & & & 3 \\
\hline ver o produto & & & & & & 3 & & 3 \\
\hline excesso de embalagem & & & & & 3 & 1 & & 4 \\
\hline preço & 3 & & & & & & 2 & 5 \\
\hline lacre & & 1 & 3 & & 2 & 3 & & 9 \\
\hline
\end{tabular}

\section{K. DADOS DAS ENTREVISTAS COM AÇÚCAR MASCAVO}

\section{Açúcar mascavo}

O número da primeira linha, de cada planilha, identifica o entrevistado

\section{Separação como mais saudável}

\begin{tabular}{|l|c|c|c|c|c|c|c|c|}
\hline observações durante a separação como mais saudável & $\mathbf{2}$ & $\mathbf{6}$ & $\mathbf{1 2}$ & $\mathbf{1 9}$ & $\mathbf{2 7}$ & $\mathbf{2 8}$ & $\mathbf{2 9}$ & soma consumidores \\
\hline olhou a tabela nutricional & & & & & & 1 & & 1 \\
\hline Olhou a parte de trás da embalagem & & & & & & 1 & & 1 \\
\hline Ficou em dúvida por causa da textura & & & & & & & 1 & 1 \\
\hline
\end{tabular}

\begin{tabular}{|l|c|c|c|c|c|c|c|c|}
\hline Separação saudável & $\mathbf{2}$ & $\mathbf{6}$ & $\mathbf{1 2}$ & $\mathbf{1 9}$ & $\mathbf{2 7}$ & $\mathbf{2 8}$ & $\mathbf{2 9}$ & soma consumidores \\
\hline Doces Puxa Puxa & & & & & & & & 0 \\
\hline Mais Vitta & & 1 & & & & & & 1 \\
\hline Viver Carrefour & & & & & 1 & & & 1 \\
\hline Athenas & & & & & & 1 & & 1 \\
\hline Via Pax Bio & 1 & & 1 & 1 & & 1 & 1 & 5 \\
\hline Vitalin & 1 & & 1 & 1 & 1 & 1 & 1 & 6 \\
\hline Planeta Verde & 1 & & 1 & 1 & 1 & 1 & 1 & 6 \\
\hline Jasmine & 1 & 1 & 1 & 1 & 1 & 1 & 1 & 7 \\
\hline Mãe Terra & 1 & 1 & 1 & 1 & 1 & 1 & 1 & 7 \\
\hline
\end{tabular}

\begin{tabular}{|l|c|c|c|c|c|c|c|c|}
\hline Critérios separação açúcar como saudável & 2 & 6 & 12 & 19 & 27 & 28 & 29 & soma menções \\
\hline ilustração & & & & & & 1 & & 1 \\
\hline tato & & & & & 1 & & & 1 \\
\hline costuma comprar & & 2 & 1 & & & & & 1 \\
\hline embalagem & & 1 & 1 & & & & & 2 \\
\hline palavra integral & & 1 & 1 & & & & & 2 \\
\hline marca conhecida & 1 & & & & & 1 & & 2 \\
\hline natural & & & & 3 & & & & 2 \\
\hline produção & 4 & & & & & & & 3 \\
\hline nome & & 1 & 2 & & & & 1 & 4 \\
\hline marca Jasmine & & 1 & 1 & & & & 2 & 4 \\
\hline tipo de produto & & & & & & 5 & & 4 \\
\hline sem algo na composição & 4 & & & & & & 2 & 5 \\
\hline palavra Natural & & 1 & 3 & & & 2 & & 6 \\
\hline marca Mãe Terra & & & & & & 8 & & 6 \\
\hline enriquecimento & & & & & & 17 & & 8 \\
\hline composição nutricional & 2 & 1 & & 4 & & 10 & 2 & 19 \\
\hline palavra orgânico & & & 6 & & 3 & 9 & 1 & 19 \\
\hline aparência & & \\
\hline
\end{tabular}




\begin{tabular}{|l|l|l|l|l|l|l|l|c|}
\hline Critérios separação açúcar como menos saudável & 2 & 6 & 12 & 19 & 27 & 28 & 29 & soma menções \\
\hline elemento textual & 1 & & & & & 1 \\
\hline organização informações & 1 & & & & & & 1 \\
\hline outras marcas & & & & & & 2 & & 2 \\
\hline ilustração & & & & & 2 & & 2 \\
\hline tipo de produto & 1 & & & & & 2 & & 2 \\
\hline nome & & & 2 & & & & 1 & 3 \\
\hline marca Carrefour & & & & & 3 & & 3 \\
\hline menos minerais & & & & & 3 & & 3 \\
\hline enriquecimento & & & 1 & & 4 & 2 & & 3 \\
\hline aparência & & 7 & 2 & & & & & 7 \\
\hline marca desconhecida & 1 & & & 2 & & 6 & 1 & 9 \\
\hline não está escrito orgânico
\end{tabular}

\section{Separação como Orgânico}

\begin{tabular}{|l|c|c|c|c|c|c|c|c|}
\hline observações durante a separação & 2 & 6 & 12 & 19 & $\mathbf{2 7}$ & $\mathbf{2 8}$ & $\mathbf{2 9}$ & soma consumidores \\
\hline olhou primeiro no grupo de saudáveis & 1 & 1 & 1 & & & 1 & & 4 \\
\hline encontrou algum depois de olhar uma segunda vez & & & 1 & & 1 & & & 2 \\
\hline
\end{tabular}

\begin{tabular}{|l|c|c|c|c|c|c|c|c|}
\hline Motivos separação orgânico & $\mathbf{2}$ & $\mathbf{6}$ & $\mathbf{1 2}$ & $\mathbf{1 9}$ & $\mathbf{2 7}$ & $\mathbf{2 8}$ & $\mathbf{2 9}$ & soma consumidores \\
\hline selo Sisorg & 1 & 1 & & & 1 & 1 & 1 & 5 \\
\hline selo IBD & 1 & & 1 & & & 1 & & 3 \\
\hline palavra orgânico & 1 & 1 & 1 & 1 & 1 & & 1 & 6 \\
\hline
\end{tabular}

\begin{tabular}{|l|c|c|c|c|c|c|c|c|}
\hline Motivos separação não orgânico & 2 & $\mathbf{6}$ & $\mathbf{1 2}$ & $\mathbf{1 9}$ & $\mathbf{2 7}$ & $\mathbf{2 8}$ & $\mathbf{2 9}$ & soma consumidores \\
\hline Não viu nada escrito & 1 & 1 & 1 & 1 & 1 & 1 & 1 & 7 \\
\hline
\end{tabular}

\begin{tabular}{|l|c|c|c|c|c|c|c|c|}
\hline Separação Orgânico & $\mathbf{2}$ & $\mathbf{6}$ & $\mathbf{1 2}$ & $\mathbf{1 9}$ & $\mathbf{2 7}$ & $\mathbf{2 8}$ & $\mathbf{2 9}$ & soma consumidores \\
\hline Mais Vitta & & & & & & & & 0 \\
\hline Viver Carrefour & & & & & & & & \\
\hline Athenas & & & & & & & & 0 \\
\hline Doces Puxa Puxa & & & & & & & & 0 \\
\hline Jasmine & 1 & 1 & 1 & 1 & 1 & 1 & 1 & 0 \\
\hline Vitalin & 1 & 1 & 1 & 1 & 1 & 1 & 1 & 7 \\
\hline Planeta Verde & 1 & 1 & 1 & 1 & 1 & 1 & 1 & 7 \\
\hline Mãe Terra & 1 & 1 & 1 & 1 & 1 & 1 & 1 & 7 \\
\hline Via Pax Bio & 1 & 1 & 1 & 1 & 1 & 1 & 1 & 7 \\
\hline
\end{tabular}

\begin{tabular}{|l|c|c|c|c|c|c|c|c|}
\hline Critérios separação açúcar como orgânico & 2 & 6 & 12 & 19 & 27 & 28 & 29 & soma menções \\
\hline palavra integral & & 1 & & & & & & 1 \\
\hline embalagem a vácuo & & & & & & & 1 & 1 \\
\hline aparência & & & 1 & & & & & \\
\hline natural & 2 & & & & & & & \\
\hline palavra saudável & & & & & & 2 & 2 \\
\hline slogan & & 1 & & & & 1 & & 2 \\
\hline outros selos certificação & & & & & & & 2 & 2 \\
\hline faixa verde & 1 & & 2 & & & & 2 \\
\hline palavra Natural & & & 3 \\
\hline
\end{tabular}




\begin{tabular}{|l|c|c|c|c|c|c|c|c|} 
produção & 5 & & & 2 & & & & \multicolumn{2}{|c|}{7} \\
\hline selo SisOrg & & 1 & & & 4 & 4 & 1 & 10 \\
\hline palavra orgânico & 2 & 3 & 8 & 3 & & 3 & 1 & 20 \\
\hline
\end{tabular}

\begin{tabular}{|l|c|c|c|c|c|c|c|c|}
\hline Critérios separação açúcar como não orgânico & 2 & 6 & 12 & 19 & 27 & 28 & 29 & soma menções \\
\hline palavra natural & & & & & 1 & & & 1 \\
\hline marca desconhecida & & 1 & & & & & & 1 \\
\hline organização informações & & & 1 & & & & & 1 \\
\hline tipografia & & & 2 & & & & & 2 \\
\hline não está escrito orgânico & 1 & 1 & 2 & & & & & 4 \\
\hline
\end{tabular}

Açúcar mascavo Mãe Terra

\begin{tabular}{|l|c|c|c|c|c|c|c|c|}
\hline Já comprou este produto ou de outro sabor? & 2 & 6 & 12 & 19 & 27 & 28 & 29 & soma consumidores \\
\hline Já comprou este produto & & 1 & & & & 1 & 1 & 3 \\
\hline preço & & & & & & 1 & & 1 \\
\hline marca conhecida & & 1 & & & & 1 & 1 & 3 \\
\hline Motivo por não ter comprado & 2 & 6 & 12 & 19 & 27 & 28 & 29 & soma consumidores \\
\hline nunca viu & & & & 1 & & & & 1 \\
\hline falta de interesse & & & 1 & & & & & 1 \\
\hline não compra açúcar mascavo & 1 & & & & 1 & & & 2 \\
\hline
\end{tabular}

\begin{tabular}{|c|c|c|c|c|c|c|c|c|}
\hline $\begin{array}{l}\text { Aspectos positivos da embalagem de açúcar mascavo } \\
\text { Mâe Terra }\end{array}$ & 2 & 6 & 12 & 19 & 27 & 28 & 29 & soma menções \\
\hline sem agrotóxico & 1 & & & & & & & 1 \\
\hline nome & & & & & & & 1 & 1 \\
\hline slogan & 1 & & & & & & & 1 \\
\hline abrir e fechar & & & & & 1 & & & 1 \\
\hline sentir o produto & & & & & 1 & & & 1 \\
\hline segurança / resistência & & & & & & 1 & & 1 \\
\hline tipo de produto & & & & & & & 1 & 1 \\
\hline ingrediente & & & & & & 1 & & 1 \\
\hline preço & & & & & & 1 & & 1 \\
\hline seção institucional & 1 & & & & & . & 1 & 2 \\
\hline seção sobre nós & & & & & & 1 & 1 & 2 \\
\hline receita & & & & & & 1 & 1 & 2 \\
\hline cor & & 1 & & & 1 & & & 2 \\
\hline cheiro & & & 1 & & 1 & & & 2 \\
\hline embalagem saquinho & & & & & 1 & 1 & & 2 \\
\hline design & 2 & & & & & & & 2 \\
\hline enriquecimento & & & & & & 2 & & 2 \\
\hline tabela nutricional & & & 1 & & & 2 & & 3 \\
\hline ilustração & & 3 & & & & & & 3 \\
\hline produção & 3 & & & & & & & 3 \\
\hline aparência & & 1 & 2 & & & & & 3 \\
\hline palavra orgânico & & & & 1 & & 2 & 1 & 4 \\
\hline selo SisOrg & 2 & & & & & & 2 & 4 \\
\hline organização informações & & & 1 & 1 & & 2 & & 4 \\
\hline ver o produto & & & 3 & 1 & & 2 & & 6 \\
\hline remete a algo bom & 4 & & 1 & & & 1 & & 6 \\
\hline marca Mãe Terra & & 1 & & & & 1 & 6 & 8 \\
\hline
\end{tabular}




\begin{tabular}{|c|c|c|c|c|c|c|c|c|}
\hline $\begin{array}{l}\text { Aspectos negativos da embalagem de açúcar mascavo } \\
\text { Mâe Terra }\end{array}$ & 2 & 6 & 12 & 19 & 27 & 28 & 29 & soma menções \\
\hline embalagem & & & & & & 1 & & 1 \\
\hline receita & & 1 & & & & & & 1 \\
\hline plástico & & & & & & 1 & & 1 \\
\hline abrir e fechar & & & & & & 1 & & 1 \\
\hline legibilidade & & & & & 1 & & & 1 \\
\hline tipo de produto & & & & & & & 1 & 1 \\
\hline gosto pessoal & & & & & 1 & & & 1 \\
\hline elemento textual & & & & & 1 & & 1 & 2 \\
\hline selo SisOrg & & & 1 & 1 & & & & 2 \\
\hline ilustração & 2 & & & & & & & 2 \\
\hline pouca visibilidade & & & & & 2 & & & 2 \\
\hline elemento gráfico & & & & & 3 & & & 3 \\
\hline tipografia & & & 1 & & 2 & & & 3 \\
\hline aparência & & & 4 & & & & & 4 \\
\hline embalagem saquinho & 1 & 1 & & 2 & & 1 & & 5 \\
\hline segurança & 3 & & & & & 2 & & 5 \\
\hline reciclagem & & & 6 & & & & & 6 \\
\hline organização informações & & 1 & & 1 & 1 & & 4 & 7 \\
\hline
\end{tabular}

\section{DADOS DAS ENTREVISTAS COM FARINHA DE TRIGO INTEGRAL}

\section{Farinha de trigo integral}

O número da primeira linha, de cada planilha, identifica o entrevistado

\section{Separação como mais saudável}

\begin{tabular}{|l|c|c|c|c|c|c|c|c|}
\hline observações durante a separação & $\mathbf{2}$ & $\mathbf{6}$ & $\mathbf{1 2}$ & $\mathbf{1 9}$ & $\mathbf{2 7}$ & $\mathbf{2 8}$ & $\mathbf{2 9}$ & soma consumidores \\
\hline olhou a tabela nutricional & 1 & & & & 1 & & 2 \\
\hline olhou a farinha & & 1 & 1 & 1 & & & 3 \\
\hline Olhou a parte de trás da embalagem & 1 & & & & 1 & 1 & 3 \\
\hline Ficou em dúvida por causa de alguma informação & $\mathbf{2}$ & $\mathbf{6}$ & $\mathbf{1 2}$ & $\mathbf{1 9}$ & $\mathbf{2 7}$ & $\mathbf{2 8}$ & $\mathbf{2 9}$ & soma consumidores \\
\hline Padrões de informações diferentes & 1 & & & & & & 1 \\
\hline porções diferentes na tabela & 1 & & & & & & \\
\hline
\end{tabular}

\begin{tabular}{|l|c|c|c|c|c|c|c|c|}
\hline Separação saudável & $\mathbf{2}$ & $\mathbf{6}$ & $\mathbf{1 2}$ & $\mathbf{1 9}$ & $\mathbf{2 7}$ & $\mathbf{2 8}$ & $\mathbf{2 9}$ & soma consumidores \\
\hline Donna Benta & & & & $\mathbf{1}$ & & & & 1 \\
\hline Mais Vita & & & & 1 & 1 & & & 2 \\
\hline Mirella & 1 & 1 & 1 & & 1 & & & 4 \\
\hline Jasmine & & & 1 & 1 & 1 & 1 & & 4 \\
\hline Mãe Terra & 1 & & & 1 & 1 & 1 & & 4 \\
\hline Via Pax Bio & 1 & 1 & 1 & 1 & & 1 & 1 & 6 \\
\hline
\end{tabular}

\begin{tabular}{|l|c|c|c|c|c|c|c|c|}
\hline Critérios separação farinha como saudável & $\mathbf{2}$ & $\mathbf{6}$ & $\mathbf{1 2}$ & $\mathbf{1 9}$ & $\mathbf{2 7}$ & $\mathbf{2 8}$ & $\mathbf{2 9}$ & soma menções \\
\hline seção contato & & & & & & & 1 & 1 \\
\hline qualidade & 1 & & & & & & 1 \\
\hline legibilidade & & 2 & & & & & 2 \\
\hline ingrediente & & & & & & 2 & 2 \\
\hline organização informações & 2 & 1 & & & & & 3 \\
\hline
\end{tabular}




\begin{tabular}{|c|c|c|c|c|c|c|c|c|}
\hline ver o produto & & & & 3 & & & & 3 \\
\hline tipo de produto & & & & & & 2 & 1 & 3 \\
\hline aparência & & & & & 3 & & & 3 \\
\hline palavra integral & 4 & & 1 & 1 & & & & 6 \\
\hline outros selos certificação & 6 & & & & & & & 6 \\
\hline embalagem a vácuo & 4 & & & 1 & & 1 & 3 & 9 \\
\hline palavra orgânico & 1 & & 1 & 1 & & & 7 & 10 \\
\hline marca & 7 & 5 & & & & & & 12 \\
\hline selo SisOrg & 18 & & & & & 2 & & 20 \\
\hline composição nutricional & 7 & & 4 & & & 12 & & 23 \\
\hline Critérios separação farinha como menos saudável & 2 & 6 & 12 & 19 & 27 & 28 & 29 & soma menções \\
\hline legibilidade & 1 & & & & & & & 1 \\
\hline glúten & 1 & & & & & & & 1 \\
\hline enriquecimento & & & & & & 2 & & 2 \\
\hline corante e conservante & 2 & & & & & & & 2 \\
\hline embalagem & 2 & & & & & 1 & & 3 \\
\hline marca & 1 & & 1 & & & 1 & & 3 \\
\hline não ver o produto & & & 1 & 2 & & & & 3 \\
\hline resistência & 4 & & & & & & & 4 \\
\hline não fechada a vácuo & & & 5 & & & 1 & & 6 \\
\hline composição nutricional & 7 & & 1 & & & & & 8 \\
\hline aparência & & & 6 & & 3 & & & 9 \\
\hline
\end{tabular}

\section{Separação como orgânico}

\begin{tabular}{|l|c|c|c|c|c|c|c|c|}
\hline observações durante a separação & 2 & 6 & 12 & 19 & $\mathbf{2 7}$ & $\mathbf{2 8}$ & $\mathbf{2 9}$ & soma consumidores \\
\hline olhou primeiro no grupo de saudáveis & 1 & 1 & 1 & 1 & 1 & & 1 & 6 \\
\hline ficou em dúvida por causa da marca & $\mathbf{2}$ & $\mathbf{6}$ & $\mathbf{1 2}$ & $\mathbf{1 9}$ & $\mathbf{2 7}$ & $\mathbf{2 8}$ & $\mathbf{2 9}$ & soma consumidores \\
\hline Mãe Terra & & & & 1 & & & & 1 \\
\hline Jasmine & & & & 1 & & & & 1 \\
\hline Mais Vita & & & & 1 & & & & 1 \\
\hline
\end{tabular}

\begin{tabular}{|l|c|c|c|c|c|c|c|c|}
\hline Separação orgânico & $\mathbf{2}$ & $\mathbf{6}$ & $\mathbf{1 2}$ & $\mathbf{1 9}$ & $\mathbf{2 7}$ & $\mathbf{2 8}$ & $\mathbf{2 9}$ & soma consumidores \\
\hline Jasmine & & $\mathbf{1}$ & & & & & & 1 \\
\hline Donna Benta & & 1 & & & & & & \multicolumn{2}{|c|}{1} \\
\hline Mais Vita & & 1 & & & & & & 1 \\
\hline Mãe Terra & 1 & 1 & & 1 & 1 & 1 & 1 & 6 \\
\hline Mirella & 1 & 1 & 1 & 1 & 1 & 1 & 1 & 7 \\
\hline Via Pax Bio & 1 & 1 & 1 & 1 & 1 & 1 & 1 & 7 \\
\hline
\end{tabular}

\begin{tabular}{|l|c|c|c|c|c|c|c|c|}
\hline Critérios separação farinha como orgânico & $\mathbf{2}$ & $\mathbf{6}$ & $\mathbf{1 2}$ & $\mathbf{1 9}$ & $\mathbf{2 7}$ & $\mathbf{2 8}$ & $\mathbf{2 9}$ & soma menções \\
\hline informações na frente & & & & & & & 1 & 1 \\
\hline reciclagem & & & & & 1 & & & 1 \\
\hline outros selos certificação & & & & & & 2 & & 2 \\
\hline faixa & & & 1 & & & & 1 & 2 \\
\hline integral & & 1 & & 2 & & & & 3 \\
\hline selo SisOrg & 2 & & & & 2 & 11 & & 15 \\
\hline palavra orgânico & 2 & 2 & 7 & 5 & 1 & 2 & 5 & 24 \\
\hline
\end{tabular}


falta da palavra orgânico

palavra integral

sem o selo SisOrg

2

\begin{tabular}{|l|l|}
1 & 1 \\
1 & \\
4 &
\end{tabular}

2

Farinha integral Via Pax Bio

\begin{tabular}{|l|c|c|c|c|c|c|c|c|}
\hline Já comprou este produto ou de outro sabor? & $\mathbf{2}$ & $\mathbf{6}$ & $\mathbf{1 2}$ & $\mathbf{1 9}$ & $\mathbf{2 7}$ & $\mathbf{2 8}$ & $\mathbf{2 9}$ & soma menções \\
\hline Já viu e não comprou. & & & & & & 1 & & \\
\hline Motivo por não ter comprado & $\mathbf{2}$ & $\mathbf{6}$ & $\mathbf{1 2}$ & $\mathbf{1 9}$ & $\mathbf{2 7}$ & $\mathbf{2 8}$ & $\mathbf{2 9}$ & soma menções \\
\hline Nunca viu & 1 & 1 & 1 & 1 & 1 & & 1 & 6 \\
\hline Não tem no supermercado que costuma ir & & & & & & 1 & & 1 \\
\hline
\end{tabular}

\begin{tabular}{|c|c|c|c|c|c|c|c|c|}
\hline $\begin{array}{l}\text { Aspectos positivos da embalagem de farinha integral Via } \\
\text { Pax Bio }\end{array}$ & 2 & 6 & 12 & 19 & 27 & 28 & 29 & soma menções \\
\hline embalagem & 1 & & & & & & & 1 \\
\hline informações na frente & & 1 & & & & & & 1 \\
\hline selo SisOrg & 1 & & & & & & & 1 \\
\hline tipografia & & & & & & 1 & & 1 \\
\hline design & 1 & & & & & & & 1 \\
\hline fácil de guardar & & & & & & 1 & & 1 \\
\hline separação material para reciclagem & & & 1 & & & & & 1 \\
\hline palavra integral & 1 & & & & & & 1 & 2 \\
\hline sem corante ou conservante & & & & & & 2 & & 2 \\
\hline organização das informações & & & & & 2 & & & 2 \\
\hline ver o produto & & 1 & 1 & & & & & 2 \\
\hline enriquecimento do produto & & & & & & 2 & & 2 \\
\hline seção institucional & 1 & & & & & 1 & & 2 \\
\hline contato & & & & & & 2 & & 2 \\
\hline legibilidade & & & & & 3 & & & 3 \\
\hline receita & & & 1 & & & 2 & & 3 \\
\hline biodinâmico & & & & & & 4 & & 4 \\
\hline faixa verde & & & & 2 & & & 2 & 4 \\
\hline apelo visual & 4 & & & & & & & 4 \\
\hline resistência da embalagem & & & & 1 & & 4 & & 5 \\
\hline tabela nutricional & 1 & & 3 & & & 2 & 1 & 7 \\
\hline fechada a vácuo & & 2 & & 2 & & & 3 & 7 \\
\hline palavra orgânico & 2 & & & & & 2 & 7 & 11 \\
\hline
\end{tabular}

\begin{tabular}{|c|c|c|c|c|c|c|c|c|}
\hline $\begin{array}{l}\text { Aspectos negativos da embalagem de farinha integral Via } \\
\text { Pax Bio }\end{array}$ & 2 & 6 & 12 & 19 & 27 & 28 & 29 & soma menções \\
\hline palavra orgânico & 1 & & & & & & & 1 \\
\hline texto institucional longo & & & & & & & 1 & 1 \\
\hline falta uma foto de pão & & 1 & & & & & & 1 \\
\hline difícil abrir & & & 1 & & & & & 1 \\
\hline lacre & & & 1 & & & & & 1 \\
\hline organização das informações & & & & & & & 2 & 2 \\
\hline fechado a vácuo & & & & & 2 & 1 & & 3 \\
\hline nome Via Pax Bio & 3 & & & & 1 & & & 4 \\
\hline não ver o produto & & & 1 & & 4 & & & 5 \\
\hline excesso de embalagem & & & & & & 5 & & 5 \\
\hline
\end{tabular}




\section{DADOS DAS ENTREVISTAS COM COOKIE}

\section{Cookie}

O número da primeira linha, de cada planilha, identifica o entrevistado

\section{Separação como mais saudável}

\begin{tabular}{|l|c|c|c|c|c|c|c|c|c|}
\hline observações durante a separação & 4 & 5 & 11 & 14 & 20 & 23 & 24 & 26 & soma consumidores \\
\hline olhou a tabela nutricional & & 1 & & 1 & & & & & 2 \\
\hline Ficou em dúvida com alguma marca & 4 & 5 & 11 & 14 & 20 & 23 & 24 & 26 & soma consumidores \\
\hline Gran Pure & & & & & & & 1 & & 1 \\
\hline Taeq & & & & 1 & & & & & 1 \\
\hline Taeq orgânico & & & & & 1 & 1 & & & \\
\hline Jasmine integral & & 1 & & & & & 1 & & 2 \\
\hline Ficou em dúvida por causa de alguma informação & 4 & 5 & 11 & 14 & 20 & 23 & 24 & 26 & soma consumidores \\
\hline light ou diet & & & 1 & & & & & & 2 \\
\hline
\end{tabular}

\begin{tabular}{|c|c|c|c|c|c|c|c|c|c|}
\hline Separação saudável & 4 & 5 & 11 & 14 & 20 & 23 & 24 & 26 & soma consumidores \\
\hline Quaker & & & & & & 1 & & & 1 \\
\hline Vitao & & & & 1 & & 1 & & & 2 \\
\hline Viver & & & & 1 & & 1 & & & 2 \\
\hline Biosoft & & & 1 & 1 & & 1 & & & 3 \\
\hline Taeq Aveia & & 1 & & 1 & & & & 1 & 3 \\
\hline Kobber & 1 & & 1 & 1 & & & & & 3 \\
\hline Naturale & & & 1 & 1 & & 1 & & & 3 \\
\hline Taeq orgânico & & 1 & 1 & & 1 & 1 & & & 4 \\
\hline Jasmine integral & 1 & & 1 & 1 & & 1 & 1 & & 5 \\
\hline Gran Pure & & & 1 & 1 & 1 & 1 & & 1 & 5 \\
\hline Native & 1 & 1 & 1 & 1 & 1 & 1 & & 1 & 7 \\
\hline Jasmine orgânico & 1 & 1 & 1 & 1 & 1 & 1 & 1 & 1 & 8 \\
\hline Mãe Terra & 1 & 1 & 1 & 1 & 1 & 1 & 1 & 1 & 8 \\
\hline Critérios separação cookie como saudável & 4 & 5 & 11 & 14 & 20 & 23 & 24 & 26 & soma menções \\
\hline seção institucional & & & & & & 1 & & & 1 \\
\hline informações na frente & & & & 1 & & & & & 1 \\
\hline tipografia & & & & & & 1 & & & 1 \\
\hline apelo visual & & & & & & 1 & & & 1 \\
\hline organização das informações & & & & & & & 1 & & 1 \\
\hline passa credibilidade & & & & & & & 1 & & 1 \\
\hline acabamento opaco da embalagem & & & & & & 1 & & & 1 \\
\hline palavra light ou zero & & & 2 & & & & & & 2 \\
\hline selo SisOrg & & 2 & & & & & & & 2 \\
\hline legibilidade & & & & & & 2 & & & 2 \\
\hline sabor & & & 1 & & & & & 1 & 2 \\
\hline qualidade & 2 & & & & & & & & 2 \\
\hline fonte de algum nutriente & & 2 & 1 & & & & & & 3 \\
\hline cor & & & & & & 3 & & & 3 \\
\hline marca & 2 & 1 & & & & & & 1 & 4 \\
\hline gosto pessoal & & & & & & & & 5 & 5 \\
\hline pouco ou sem algo na composição & & 2 & & 4 & & & & & 6 \\
\hline ingrediente & & & 4 & 3 & & 1 & 1 & 1 & 10 \\
\hline composição nutricional & & 5 & & 5 & & 2 & & 2 & 14 \\
\hline
\end{tabular}


palavra integral

palavra orgânico

\begin{tabular}{|l|l|l|l|l|l|l|l|}
1 & 1 & 3 & 1 & 1 & 8 & & 2 \\
2 & 3 & 1 & 1 & 2 & 5 & 1 & 5
\end{tabular}

17

20

\begin{tabular}{|c|c|c|c|c|c|c|c|c|c|}
\hline Critérios separação cookie como menos saudável & 4 & 5 & 11 & 14 & 20 & 23 & 24 & 26 & soma menções \\
\hline ambientalmente correto & & 1 & & & & & & & 1 \\
\hline acabamento sem brilho & & & & & & 1 & & & 1 \\
\hline foto & & & & & & & 1 & & 1 \\
\hline palavra saudável & & 1 & & & & & & & 1 \\
\hline pouco ou sem algo na composição & & & & 1 & & & & & 1 \\
\hline tipografia & & & & & & 1 & & & 1 \\
\hline cor & & & & & & 2 & & & 2 \\
\hline legibilidade & & & & & & 2 & & & 2 \\
\hline organização informações & & & & & & 2 & & & 2 \\
\hline preparo & & & & & & & 3 & & 3 \\
\hline aditivos & & & & & & & 3 & 1 & 4 \\
\hline palavra integral & & & & & & & & 5 & 5 \\
\hline palavra orgânico & 1 & 2 & & 1 & 1 & & & & 5 \\
\hline marca desconhecida & 5 & & & & & & 1 & & 6 \\
\hline palavra light ou zero & & & & & & 6 & 3 & 1 & 10 \\
\hline composição nutricional & 1 & 2 & 2 & 7 & & & & & 12 \\
\hline ingrediente & 1 & & 4 & 1 & & 1 & 6 & 3 & 16 \\
\hline
\end{tabular}

Separação como orgânico

\begin{tabular}{|l|c|c|c|c|c|c|c|c|c|}
\hline observações durante a separação & 4 & 5 & 11 & 14 & 20 & 23 & 24 & 26 & soma consumidores \\
\hline olhou primeiro no grupo de saudáveis & 1 & & & 1 & 1 & 1 & 1 & 1 & 6 \\
\hline ficou em dúvida por causa da marca & 4 & $\mathbf{5}$ & $\mathbf{1 1}$ & $\mathbf{1 4}$ & $\mathbf{2 0}$ & $\mathbf{2 3}$ & $\mathbf{2 4}$ & $\mathbf{2 6}$ & soma consumidores \\
\hline Mãe Terra & & & 1 & & & & & & 1 \\
\hline Gran Pure & & & & & 1 & & & & 1 \\
\hline Jasmine & 1 & & & & & & 1 & & \\
\hline Biosoft & & & 1 & & & & & & 2 \\
\hline
\end{tabular}

\begin{tabular}{|l|l|l|l|l|l|l|l|l|c|}
\hline Separação orgânico & $\mathbf{4}$ & $\mathbf{5}$ & $\mathbf{1 1}$ & $\mathbf{1 4}$ & $\mathbf{2 0}$ & $\mathbf{2 3}$ & $\mathbf{2 4}$ & $\mathbf{2 6}$ & soma consumidores \\
\hline Kobber & & & & & & & & & 0 \\
\hline Naturale & & & & & & & & & 0 \\
\hline Quaker & & & & & & & & & 0 \\
\hline Vitao & & & & & & & & & \\
\hline Viver & & & 1 & & & & & & \\
\hline Biosoft & & & 1 & & & & & & \\
\hline Gran Pure & & & 1 & & & & & & 1 \\
\hline Jasmine integral & & 1 & & & & & & & \\
\hline Taeq Aveia & 1 & 1 & 1 & 1 & 1 & & 1 & 1 & 1 \\
\hline Jasmine orgânico & 1 & 1 & & 1 & 1 & 1 & 1 & 1 & 7 \\
\hline Taeq orgânico & 1 & 1 & 1 & 1 & 1 & 1 & 1 & 1 \\
\hline Native & 1 & 1 & 1 & 1 & 1 & 1 & 1 & 1 \\
\hline Mãe Terra & & & 8 \\
\hline
\end{tabular}

\begin{tabular}{|l|c|c|c|c|c|c|c|c|c|}
\hline Critérios separação cookie como orgânico & 4 & 5 & 11 & 14 & 20 & 23 & 24 & 26 & soma menções \\
\hline palavra integral & & & & & & & & 1 & 1 \\
\hline sem algo na composição & & & & & & & 1 & & 1 \\
\hline
\end{tabular}




\begin{tabular}{|c|c|c|c|c|c|c|c|c|c|}
\hline marca Taeq & & 1 & & & & & & & 1 \\
\hline marca Native & 1 & & & & & & & 1 & 2 \\
\hline marca Jasmine & 3 & & & & & & & & 3 \\
\hline marca & & & & & & & & 5 & 5 \\
\hline ingrediente & & & 7 & & & & & & 7 \\
\hline marca Mãe Terra & & & & & & 2 & 5 & 1 & 8 \\
\hline selo SisOrg & 2 & 3 & & 4 & 7 & 1 & & 3 & 20 \\
\hline palavra orgânico & 3 & 4 & & 6 & 5 & 5 & 7 & 4 & 34 \\
\hline
\end{tabular}

\begin{tabular}{|l|c|c|c|c|c|c|c|c|c|}
\hline Critérios separação cookie como não orgânico & $\mathbf{4}$ & $\mathbf{5}$ & $\mathbf{1 1}$ & $\mathbf{1 4}$ & $\mathbf{2 0}$ & $\mathbf{2 3}$ & $\mathbf{2 4}$ & $\mathbf{2 6}$ & soma menções \\
\hline palavra light ou zero & & & & & & & 1 & & 1 \\
\hline ingrediente & & & & & & & 1 & & 1 \\
\hline selo SisOrg & & 1 & & 1 & & & & & 2 \\
\hline falta da palavra orgânico & 3 & 3 & & 6 & 1 & 1 & 2 & & 16 \\
\hline
\end{tabular}

\section{Cookies integrais Mãe Terra}

\begin{tabular}{|l|c|c|c|c|c|c|c|c|c|}
\hline Já comprou este produto ou de outro sabor? & $\mathbf{4}$ & $\mathbf{5}$ & $\mathbf{1 1}$ & $\mathbf{1 4}$ & $\mathbf{2 0}$ & $\mathbf{2 3}$ & $\mathbf{2 4}$ & $\mathbf{2 6}$ & soma consumidores \\
\hline Já comprou este produto ou de outro sabor & 1 & 1 & 1 & & & & 1 & & 4 \\
\hline Motivo da compra & & & & & & & & & \\
\hline orgânico & & & & & & & 1 & & 1 \\
\hline grãos & & & & & & & 1 & & 1 \\
\hline pouco sódio & 1 & & & & & & & & 1 \\
\hline marca conhecida & 1 & & & & & & 1 & & 2 \\
\hline parecer apetitoso & & 1 & 1 & & & & & & 2 \\
\hline Já viu e não comprou. & & & & 1 & & & & & 1 \\
\hline
\end{tabular}

\begin{tabular}{|l|c|c|c|c|c|c|c|c|c|}
\hline $\begin{array}{l}\text { Aspectos positivos da embalagem de cookie integral Mãe } \\
\text { Terra }\end{array}$ & $\mathbf{4}$ & $\mathbf{5}$ & $\mathbf{1 1}$ & $\mathbf{1 4}$ & $\mathbf{2 0}$ & $\mathbf{2 3}$ & $\mathbf{2 4}$ & $\mathbf{2 6}$ & soma menções \\
\hline fonte de fibras e proteínas & & $\mathbf{1}$ & & & & & & & 1 \\
\hline seção cartilha de princípios & & & & & & & 1 & & 1 \\
\hline selo SisOrg & & & 1 & & & & & 1 \\
\hline tipografia & & & & & & & 1 & & 1 \\
\hline cor & & 1 & & & & & & & 1 \\
\hline apelo visual & 1 & & & & & & & & 1 \\
\hline abrir e fechar & & & & & & 1 & & & 1 \\
\hline tamanho da porção & & & 1 & & & & & & 1 \\
\hline segurança / resistência & & 1 & & & & & & & 1 \\
\hline saudável & & & & & 2 & & & 2 \\
\hline organização informações & & & & & & 2 & & & 2 \\
\hline legibilidade & 1 & 1 & & & & & & & 2 \\
\hline composição nutricional & & 1 & & & & 1 & & & 2 \\
\hline produção & & & & 1 & & & 1 & & 2 \\
\hline natural & & 2 & & & & 1 & & & 3 \\
\hline seção institucional & & & 3 & & & & & & 3 \\
\hline foto & & 1 & 1 & & 1 & 2 & & & 5 \\
\hline remete a algo bom & & & 1 & 3 & & & & & 6 \\
\hline palavra integral & & & & & 1 & 5 & 6 \\
\hline splash & & & & \\
\hline ilustração & & & & \\
\hline sabor & & & & \\
\hline
\end{tabular}




\begin{tabular}{|l|c|c|c|c|c|c|c|c|c|}
\hline marca Mãe Terra & 2 & & & & & & 2 & 4 & 8 \\
\hline pouco ou sem algo na composição & 2 & 7 & & & & & & & \\
\hline ingredientes & & 2 & & 4 & 1 & 2 & 2 & 1 & 9 \\
\hline palavra orgânico & 3 & 1 & 1 & 4 & 3 & & 2 & 3 & 12 \\
\hline
\end{tabular}

\begin{tabular}{|c|c|c|c|c|c|c|c|c|c|}
\hline $\begin{array}{l}\text { Aspectos negativos da embalagem de cookie integral } \\
\text { Mãe Terra }\end{array}$ & 4 & 5 & 11 & 14 & 20 & 23 & 24 & 26 & soma menções \\
\hline tabela nutricional & & & & & & 1 & & & 1 \\
\hline splash & & & & & & & & 1 & 1 \\
\hline plástico & & & & & & & & 1 & 1 \\
\hline cor & & & & & & & & 1 & 1 \\
\hline ilustração & & & & & & 1 & & & 1 \\
\hline visibilidade & 1 & & & & & & & & 1 \\
\hline embalagem saquinho & & & & & & 1 & & & 1 \\
\hline ingrediente & & 1 & & & & & & & 1 \\
\hline aditivos & & & & & & & 1 & & 1 \\
\hline palavra integral & & & & & & & 1 & 1 & 2 \\
\hline fonte de fibras e proteína & & & & & & & 2 & & 2 \\
\hline tipografia & & & & & & & & 2 & 2 \\
\hline foto & 2 & & & & & & & & 2 \\
\hline abrir e fechar & & & & & & 2 & & & 2 \\
\hline legibilidade & & & 2 & & & & & & 2 \\
\hline composição nutricional & & 1 & & & & & & 1 & 2 \\
\hline apelo visual & & & & & & & & 3 & 3 \\
\hline resistência & & & 3 & & & & & & 3 \\
\hline tamanho da porção & 1 & & & & & 3 & & & 4 \\
\hline sabor & & & & 3 & & & 2 & & 5 \\
\hline organização informações & & & & & 1 & & 3 & 2 & 6 \\
\hline
\end{tabular}

\section{N. DADOS DAS ENTREVISTAS COM BARRA DE CEREAIS}

\section{Barra de cereais}

O número da primeira linha, de cada planilha, identifica o entrevistado

\section{Separação como mais saudável}

\begin{tabular}{|l|c|c|c|c|c|c|c|c|c|}
\hline observações durante a separação & $\mathbf{4}$ & $\mathbf{5}$ & $\mathbf{1 1}$ & $\mathbf{1 4}$ & $\mathbf{2 0}$ & $\mathbf{2 3}$ & $\mathbf{2 4}$ & $\mathbf{2 6}$ & soma consumidores \\
\hline olhou a tabela nutricional & & $\mathbf{1}$ & & & & & & & 1 \\
\hline ficou em dúvida por causa da marca & $\mathbf{4}$ & $\mathbf{5}$ & $\mathbf{1 1}$ & $\mathbf{1 4}$ & $\mathbf{2 0}$ & $\mathbf{2 3}$ & $\mathbf{2 4}$ & $\mathbf{2 6}$ & soma consumidores \\
\hline Bio2 açai & & & 1 & & & & & & 1 \\
\hline Bio2 Cranberry & & & 1 & & & & 1 & & 2 \\
\hline Mãe Terra & & & & & 1 & & & 1 & 2 \\
\hline Gran Pure & & & & & & & & & \\
\hline Ritter & & & & & & & 1 & & 1 \\
\hline Kellnes & & 1 & 1 & & & & & & 2 \\
\hline Nature Valley & & 1 & & & & & & & 1 \\
\hline Taeq granola & & & & & 1 & & & & 1 \\
\hline Gran Pure Chocolate & & 1 & & & 1 & & & 1 & 3 \\
\hline Jasmine Frutas vermelhas & & & & & 1 & & 1 & & 2 \\
\hline
\end{tabular}




\begin{tabular}{|c|c|c|c|c|c|c|c|c|c|}
\hline Jasmine frutas vermelhas & & & & & & & & & 0 \\
\hline Tia Sônia & & & & & & & & & 0 \\
\hline Kellness & & & & 1 & & & & & 1 \\
\hline Jasmine coco & 1 & & & & & & 1 & & 2 \\
\hline Kobber Granola & & & 1 & 1 & & & & & 2 \\
\hline Taeq light & & & & 1 & & 1 & & & 2 \\
\hline Ritter & & & & 1 & & 1 & & & 2 \\
\hline Gran Pure Chocolate & & 1 & & 1 & 1 & & & & 3 \\
\hline Quaker & & & 1 & 1 & & 1 & & & 3 \\
\hline Kobber Banana & & & 1 & 1 & & & 1 & & 3 \\
\hline Nature Valley & 1 & & & 1 & & 1 & & 1 & 4 \\
\hline Taeq Integral granola & & 1 & 1 & 1 & & 1 & & & 4 \\
\hline Monama & & 1 & & 1 & 1 & & 1 & 1 & 5 \\
\hline Gran Pure orgânico & 1 & 1 & 1 & & 1 & & 1 & 1 & 6 \\
\hline Bio2 Açaí orgânico & & 1 & & 1 & 1 & 1 & 1 & 1 & 6 \\
\hline Bio2 Cranberry & & 1 & 1 & 1 & 1 & 1 & 1 & 1 & 7 \\
\hline Mãe Terra & 1 & 1 & & 1 & 1 & 1 & 1 & 1 & 7 \\
\hline Native & 1 & 1 & 1 & 1 & 1 & 1 & 1 & 1 & 8 \\
\hline
\end{tabular}

\begin{tabular}{|l|c|c|c|c|c|c|c|c|c|}
\hline Critérios separação Barra como saudável & $\mathbf{4}$ & $\mathbf{5}$ & $\mathbf{1 1}$ & $\mathbf{1 4}$ & $\mathbf{2 0}$ & $\mathbf{2 3}$ & $\mathbf{2 4}$ & $\mathbf{2 6}$ & soma menções \\
\hline sem adição de açúcar & & & $\mathbf{1}$ & & & & & & 1 \\
\hline sem glúten & & & & $\mathbf{1}$ & & & & & 1 \\
\hline natural & & & & & & & 1 & & 1 \\
\hline remete a natural & & & & & & 2 & & & 2 \\
\hline apelo visual & & & & & 2 & & & & 2 \\
\hline produção & & & & 1 & & & 1 & & 2 \\
\hline sabor & & & & & & 2 & & & 2 \\
\hline ver o produto & 3 & & & & & & & & 3 \\
\hline gosto pessoal & & 1 & & 1 & & 1 & & & 3 \\
\hline palavra natural & & & 2 & & & & & 2 & 4 \\
\hline calorias & 3 & & & & & & & 1 & 4 \\
\hline costuma comprar & & 2 & 1 & 1 & & & & & 4 \\
\hline sem algo na composição & & 1 & 2 & & & & 1 & & 4 \\
\hline tipo de produto & & 3 & & 3 & 2 & 5 & 2 & 1 & 16 \\
\hline palavra orgânico & & 1 & 3 & 8 & & 2 & 2 & 2 & 18 \\
\hline ingrediente & 1 & 3 & & & & 7 & 4 & 4 & 19 \\
\hline marca & & & \\
\hline
\end{tabular}

\begin{tabular}{|l|c|c|c|c|c|c|c|c|c|}
\hline Critérios separação Barra como menos saudável & $\mathbf{4}$ & $\mathbf{5}$ & $\mathbf{1 1}$ & $\mathbf{1 4}$ & $\mathbf{2 0}$ & $\mathbf{2 3}$ & $\mathbf{2 4}$ & $\mathbf{2 6}$ & soma menções \\
\hline embalagem & & & $\mathbf{1}$ & & & & & & 1 \\
\hline elemento textual & & & & & 1 & & & & 1 \\
\hline organização informações & & & & & & & & 1 & 1 \\
\hline legibilidade & 1 & & & & & & & & 1 \\
\hline costuma comprar & & & & & 1 & & & & 1 \\
\hline produção & & & & & 1 & & & & 1 \\
\hline química & 2 & & & & & & & & 2 \\
\hline gosto pessoal & & & & & & & 1 & 1 & 2 \\
\hline natural & & & & & & & & 3 & 3 \\
\hline palavra light ou zero & & & & & 1 \\
\hline
\end{tabular}




\begin{tabular}{|c|c|c|c|c|c|c|c|c|c|}
\hline remete a algo ruim & & & & 1 & & & 3 & & 4 \\
\hline calorias & & & 4 & & & & & & 4 \\
\hline palavra orgânico & 1 & 1 & & & & & 1 & 2 & 5 \\
\hline marca desconhecida & & & & 3 & 2 & 4 & 1 & & 10 \\
\hline aditivos & & 9 & & 2 & & & & 3 & 14 \\
\hline ingrediente & 1 & 1 & 4 & 11 & & 1 & 7 & 10 & 35 \\
\hline
\end{tabular}

\section{Separação como orgânico}

\begin{tabular}{|l|c|c|c|c|c|c|c|c|c|}
\hline observações durante a separação & $\mathbf{4}$ & $\mathbf{5}$ & $\mathbf{1 1}$ & $\mathbf{1 4}$ & $\mathbf{2 0}$ & $\mathbf{2 3}$ & $\mathbf{2 4}$ & $\mathbf{2 6}$ & soma consumidores \\
\hline olhou primeiro no grupo de saudáveis & 1 & 1 & & 1 & 1 & 1 & 1 & & 6 \\
\hline ficou em dúvida por causa da marca & 1 & & & 1 & & & & 1 & 3 \\
\hline Mãe Terra & 1 & & & 1 & 1 & & 1 & 1 & 5 \\
\hline Gran Pure & & & & & & & & & \\
\hline Gran Pure Chocolate & & & & & & & & 1 & 1 \\
\hline Jasmine & 1 & & & & & & 1 & & 2 \\
\hline Bio2 açaí & & & 1 & 1 & 1 & & & & 3 \\
\hline Bio2 cranberry & & & & & & & 1 & 1 & 2 \\
\hline Taeq granola & & & & & 1 & & & & 1 \\
\hline ficou em dúvida por ter ingredientes orgânicos & & 1 & 1 & & & & & & 2 \\
\hline
\end{tabular}

\begin{tabular}{|l|c|c|c|c|c|c|c|c|c|}
\hline Separação Orgânico & $\mathbf{4}$ & $\mathbf{5}$ & $\mathbf{1 1}$ & $\mathbf{1 4}$ & $\mathbf{2 0}$ & $\mathbf{2 3}$ & $\mathbf{2 4}$ & $\mathbf{2 6}$ & soma consumidores \\
\hline Jasmine coco & & & & & & & & & 0 \\
\hline Kellness & & & & & & & & & 0 \\
\hline Ritter & & & & & & & & & 0 \\
\hline Tia Sônia & & & & & & & & 0 \\
\hline Nature Valley & & & & & 1 & & & 1 \\
\hline Quaker & & & 1 & & & & & & 1 \\
\hline Kobber Granola & & & & & 1 & & & 1 \\
\hline Kobber Banana & & & 1 & & & & & & 1 \\
\hline Taeq light & & & 1 & & & & & & 1 \\
\hline Gran Pure Chocolate & & 1 & & & & 1 & & & 2 \\
\hline Bio2 Cranberry & & 1 & & & & 1 & & & 2 \\
\hline Mãe Terra & & & 1 & & & 1 & & & 2 \\
\hline Jasmine frutas vermelhas & & 1 & & & & 1 & & & 2 \\
\hline Taeq Integral granola & & & 1 & 1 & 1 & 1 & 1 & 1 & 6 \\
\hline Bio2 Açaí orgânico & 1 & 1 & 1 & 1 & 1 & 1 & 1 & 1 & 8 \\
\hline Native & 1 & 1 & 1 & 1 & 1 & 1 & 1 & 1 & 8 \\
\hline Gran Pure orgânico & 1 & 1 & 1 & 1 & 1 & 1 & 1 & 1 & 8 \\
\hline Monama & & & & & 2 \\
\hline
\end{tabular}

\begin{tabular}{|l|c|c|c|c|c|c|c|c|c|}
\hline Critérios separação Barra como orgânico & $\mathbf{4}$ & $\mathbf{5}$ & $\mathbf{1 1}$ & $\mathbf{1 4}$ & $\mathbf{2 0}$ & $\mathbf{2 3}$ & $\mathbf{2 4}$ & $\mathbf{2 6}$ & soma menções \\
\hline sem açúcar & & & & & & 1 & & & 1 \\
\hline palavra natural & & & & & & 1 & & & 1 \\
\hline sabor & & & & & & 1 & & & 1 \\
\hline natural & & & 2 & & & 1 & & & 3 \\
\hline selo SisOrg & 1 & & & & & & 3 & & 4 \\
\hline palavra integral & & & & 1 & & 4 & & & 5 \\
\hline ingrediente & & & 2 & & & 4 & & & 6 \\
\hline marca & & 5 & & & & 2 & & & 7 \\
\hline
\end{tabular}




\begin{tabular}{|l|l|l|l|l|l|l|l|l|c|}
\hline Critérios separação Barra como não orgânico & $\mathbf{4}$ & $\mathbf{5}$ & $\mathbf{1 1}$ & $\mathbf{1 4}$ & $\mathbf{2 0}$ & $\mathbf{2 3}$ & $\mathbf{2 4}$ & $\mathbf{2 6}$ & soma menções \\
\hline selo SisOrg & $\mathbf{1}$ & & & & & & & 1 \\
\hline tipografia & & & & & & 1 & & & 1 \\
\hline aditivos & & & & & & 2 & & & \\
\hline palavra light ou zero & & & & 1 & & & & 1 & \\
\hline marca & & & & & & 3 & & & \\
\hline composição nutricional & & 2 & 2 & 1 & & & 1 & & \\
\hline ingrediente & 5 & & & 7 & 1 & & 4 & 3 & 3 \\
\hline falta da palavra orgânico & & & \\
\hline
\end{tabular}

\section{Barra de cereais Monama}

\begin{tabular}{|c|c|c|c|c|c|c|c|c|c|}
\hline Já viu este ou outro produto Monama? & 4 & 5 & 11 & 14 & 20 & 23 & 24 & 26 & soma consumidores \\
\hline Já viu e não comprou. & & & & & & & & 1 & 1 \\
\hline Motivo por não ter comprado & & & & & & & & & 0 \\
\hline não conhecia a marca & & & & & & & & 1 & 1 \\
\hline $\begin{array}{l}\text { Aspectos positivos da embalagem de barra de cereais } \\
\text { Monama }\end{array}$ & 4 & 5 & 11 & 14 & 20 & 23 & 24 & 26 & soma menções \\
\hline elemento textual & & & & & & & 1 & & 1 \\
\hline selo IBD & & 1 & & & & & & & 1 \\
\hline ilustração & & & & 1 & & & & & 1 \\
\hline remete a algo caseiro & & & & & & & 1 & & 1 \\
\hline composição nutricional & & 1 & & & & & & & 1 \\
\hline qualidade & & & & & & 1 & & & 1 \\
\hline natural & & & & 1 & & & & & 1 \\
\hline tabela nutricional & & & & 1 & 1 & & & & 2 \\
\hline apelo visual & & 1 & & 1 & & & & & 2 \\
\hline produção & & & & & & 2 & & & 2 \\
\hline cor & & & & 2 & 1 & & & & 3 \\
\hline legibilidade & & 1 & & & 2 & & & & 3 \\
\hline pouco ou sem algo na composição & 2 & & & & & & & 2 & 4 \\
\hline selo SisOrg & 1 & 1 & & & 2 & & & & 4 \\
\hline organização informações & & & & 4 & 1 & & & & 5 \\
\hline palavra orgânico & 2 & . & 3 & & 2 & & 2 & 2 & 11 \\
\hline ingrediente & 6 & 2 & 3 & 4 & & 2 & 2 & 4 & 23 \\
\hline $\begin{array}{l}\text { Aspectos negativos da embalagem de barra de cereais } \\
\text { Monama }\end{array}$ & 4 & 5 & 11 & 14 & 20 & 23 & 24 & 26 & soma menções \\
\hline dá vontade comer & & & 1 & & & & & & 1 \\
\hline foto & & & 1 & & & & & & 1 \\
\hline tipo de produto & & & & & & 1 & & & 1 \\
\hline cor & 1 & & & & & & & 1 & 2 \\
\hline ilustração & & & 2 & & & & & & 2 \\
\hline aditivos & 1 & & & & & & 1 & & 2 \\
\hline composição nutricional & & 1 & & & & 1 & & & 2 \\
\hline nome & & & & & & 3 & & & 3 \\
\hline organização informações & & & & & 3 & & & & 3 \\
\hline selo SisOrg colado & & & & & & 4 & & & 4 \\
\hline apelo visual & 2 & & 3 & & & & & & 5 \\
\hline marca desconhecida & 1 & & 1 & & & 1 & 1 & 2 & 6 \\
\hline não remete a saudável & & & 2 & & & 2 & 1 & 1 & 6 \\
\hline
\end{tabular}




\section{O.DADOS DAS ENTREVISTAS COM GRANOLA}

\section{Granola}

O número da primeira linha, de cada planilha, identifica o entrevistado

Separação como mais saudável

\begin{tabular}{|l|c|c|c|c|c|c|c|c|}
\hline observações durante a separação & 1 & 13 & 16 & 17 & 22 & 25 & 30 & soma consumidores \\
\hline olhou a tabela nutricional & & 1 & & & 1 & 1 & & 3 \\
\hline Olhou a parte de trás da embalagem & & 1 & & & 1 & 1 & & 3 \\
\hline Ficou em dúvida com alguma marca & 1 & 1 & & 1 & 1 & & & 4 \\
\hline Monama & & 1 & & & & & & 1 \\
\hline Native & & & & & 1 & & & 1 \\
\hline Mãe Terra & & & & & & 1 & & 1 \\
\hline Quaker & 1 & & & & & & & 1 \\
\hline Kobber & & & 1 & & & & & 1 \\
\hline Cróqui & & & 1 & 1 & 1 & & & 3 \\
\hline Jasmine & & & & & & 1 & & 1 \\
\hline Ficou em dúvida por causa de alguma informação & 1 & 13 & 16 & 17 & 22 & 25 & 30 & soma consumidores \\
\hline light ou diet & 1 & & & & & & & 1 \\
\hline integral & & & & & & & & \\
\hline pela aparência da embalagem & & 1 & & & 1 & & & 2 \\
\hline
\end{tabular}

\begin{tabular}{|c|c|c|c|c|c|c|c|c|}
\hline Separação saudável & 1 & 13 & 16 & 17 & 22 & 25 & 30 & soma consumidores \\
\hline Kellness & & & & & & & 1 & 1 \\
\hline Quaker & & & 1 & & & & 1 & 2 \\
\hline Vitao & & & & 1 & 1 & & & 2 \\
\hline Biosoft & & & & 1 & 1 & & & 2 \\
\hline Cróqui & & & & 1 & 1 & & 1 & 3 \\
\hline Native & & 1 & & 1 & 1 & 1 & 1 & 5 \\
\hline Jasmine & & 1 & & 1 & 1 & 1 & 1 & 5 \\
\hline Kobber & 1 & 1 & 1 & & 1 & & 1 & 5 \\
\hline Trio & 1 & 1 & 1 & 1 & 1 & & & 5 \\
\hline Mãe Terra & & 1 & 1 & 1 & 1 & 1 & & 5 \\
\hline Monama & & & 1 & 1 & 1 & 1 & 1 & 5 \\
\hline
\end{tabular}

\begin{tabular}{|l|c|c|c|c|c|c|c|c|}
\hline Critérios separação granola como mais saudável & $\mathbf{1}$ & $\mathbf{1 3}$ & $\mathbf{1 6}$ & $\mathbf{1 7}$ & $\mathbf{2 2}$ & $\mathbf{2 5}$ & $\mathbf{3 0}$ & \multicolumn{2}{c|}{ soma menções } \\
\hline fonte de fibras & & & & & & 1 & & 1 \\
\hline slogan & & & & & & & 1 & 1 \\
\hline splash & & 1 & & & & & & 1 \\
\hline legibilidade & & 1 & & & & & 1 \\
\hline acabamento opaco da embalagem & & & & & 1 & & \\
\hline reciclagem & & 1 & & & & & & \\
\hline preço & & & & 1 & & 1 & & \\
\hline natural & & & & 2 & & & & \\
\hline seção institucional & & 2 & & & & & & \\
\hline nome & & & 1 & & & 1 & & 2 \\
\hline cor & & & \\
\hline apelo visual & & & \\
\hline
\end{tabular}




\begin{tabular}{|c|c|c|c|c|c|c|c|c|}
\hline sabor & & & & & & & 2 & 2 \\
\hline passa a ideia de natural & & 2 & & 1 & & & & 3 \\
\hline forma de preparo & & & 1 & & & & 2 & 3 \\
\hline aditivos & & 2 & & & & 1 & & 3 \\
\hline ver ou sentir o produto & & 1 & 4 & & & & & 5 \\
\hline palavra light ou zero & 4 & & 1 & 2 & & & & 7 \\
\hline palavra integral & & & & 5 & & 3 & 1 & 9 \\
\hline tipo de produto & 1 & 2 & & & 1 & 5 & 1 & 10 \\
\hline marca & 2 & & 3 & 5 & 3 & 5 & & 18 \\
\hline palavra orgânico & & 1 & 3 & 2 & 3 & 10 & 2 & 21 \\
\hline pouco ou sem algo na composição & & 1 & 1 & 1 & & 20 & 2 & 25 \\
\hline ingrediente & & & 15 & 3 & 1 & 17 & 3 & 39 \\
\hline
\end{tabular}

\begin{tabular}{|l|c|c|c|c|c|c|c|c|}
\hline Critérios separação granola como menos saudável & $\mathbf{1}$ & $\mathbf{1 3}$ & $\mathbf{1 6}$ & $\mathbf{1 7}$ & $\mathbf{2 2}$ & $\mathbf{2 5}$ & $\mathbf{3 0}$ & soma menç̃̃es \\
\hline acabamento & & $\mathbf{1}$ & & & & & & 1 \\
\hline cor & 1 & & & & & & 1 \\
\hline elemento textual & & & & & 1 & & & 1 \\
\hline fonte de vitaminas & & 1 & & & & & 1 \\
\hline palavra light ou zero & & & & & & 1 & 1 \\
\hline papel reciclado & 1 & & & & & & 1 \\
\hline sabor & & & & & & 1 & 1 \\
\hline segurança & & 1 & & & & & & 1 \\
\hline selo SisOrg & & & & & 1 & & 1 \\
\hline composição nutricional & & 1 & 1 & & & & & 2 \\
\hline palavra artificial & & 2 & & & & & & 2 \\
\hline parece velho & & 2 & & & & & & 2 \\
\hline pouco ou sem algo & & 1 & & & & 1 & & 2 \\
\hline legibilidade & & 3 & & & & & & 3 \\
\hline química & & & & & 2 & 2 & & 4 \\
\hline palavra orgânico & & & & & 6 & & 6 \\
\hline ver o produto & & & 3 & & 3 & & & 6 \\
\hline marca & & & 2 & 4 & 6 & & & 12 \\
\hline aditivos & 4 & & & & 8 & 1 & 13 \\
\hline ingrediente & & & & & & 20 \\
\hline
\end{tabular}

\section{Separação como orgânico}

\begin{tabular}{|l|c|c|c|c|c|c|c|c|}
\hline observações durante a separação & 1 & 13 & 16 & 17 & 22 & 25 & 30 & soma consumidores \\
\hline olhou primeiro no grupo de saudáveis & & 1 & 1 & 1 & 1 & 1 & 1 & 6 \\
\hline ficou em dúvida por causa da marca & & & & & & 1 & 1 & 2 \\
\hline Mãe Terra & & & & 1 & & 1 & & 2 \\
\hline Quaker & & & & & & & 1 & 1 \\
\hline
\end{tabular}

\begin{tabular}{|l|c|c|c|c|c|c|c|c|}
\hline Separação orgânico & 1 & 13 & 16 & 17 & 22 & 25 & 30 & soma consumidores \\
\hline Jasmine & & & & & & & & 0 \\
\hline Kobber & & & & & & & & 0 \\
\hline Vitao & & & & & & & & 0 \\
\hline Trio & & & & & & & & 0 \\
\hline Biosoft & & & & & & & & 0 \\
\hline Kellness & & & & & & & & 0 \\
\hline
\end{tabular}




\begin{tabular}{|l|c|c|c|c|c|c|c|c|} 
Mãe Terra & & & & & 1 & & & 1 \\
\hline Quaker & & & & & & & 1 & 1 \\
\hline Cróqui & & & & & & & 1 & 1 \\
\hline Native & 1 & 1 & & 1 & 1 & 1 & 1 & 6 \\
\hline Monama & 1 & 1 & 1 & 1 & 1 & 1 & 1 & 7 \\
\hline
\end{tabular}

\begin{tabular}{|l|c|c|c|c|c|c|c|c|}
\hline Critérios separação granola como orgânico & 1 & 13 & 16 & 17 & $\mathbf{2 2}$ & $\mathbf{2 5}$ & $\mathbf{3 0}$ & soma menções \\
\hline elemento textual & & & & & 1 & & & 1 \\
\hline palavra natural & & & & & & & 1 & 1 \\
\hline seção institucional & & & & & & 1 & & 1 \\
\hline ilustração & & & & & & & 1 & 1 \\
\hline ingrediente & & & & & & & 1 & 1 \\
\hline produção & & 2 & & & & & & 2 \\
\hline selo IBD & & & 2 & & & 2 & & 4 \\
\hline marca Mãe Terra & & & & & 4 & 2 & & 6 \\
\hline selo SisOrg & & & 3 & & & 4 & & 7 \\
\hline palavra orgânico & 4 & 3 & 3 & 3 & 4 & 2 & 1 & 20 \\
\hline
\end{tabular}

\begin{tabular}{|l|c|c|c|c|c|c|c|c|}
\hline Critérios separação granola como não orgânico & 1 & 13 & 16 & 17 & 22 & 25 & 30 & soma menções \\
\hline palavra integral & & 1 & & & & & & 1 \\
\hline palavra natural & & 1 & & & & & & 1 \\
\hline sem a palavra orgânico & 1 & 3 & & & 1 & 1 & 1 & 7 \\
\hline
\end{tabular}

\section{Granola Monama}

\begin{tabular}{|l|c|c|c|c|c|c|c|c|}
\hline Já comprou este produto ou de outro sabor? & 1 & 13 & 16 & 17 & 22 & 25 & 30 & soma consumidores \\
\hline Nunca viu & 1 & 1 & 1 & 1 & 1 & 1 & 1 & 7 \\
\hline
\end{tabular}

\begin{tabular}{|c|c|c|c|c|c|c|c|c|}
\hline Aspectos positivos da embalagem da granola Monama & 1 & 13 & 16 & 17 & 22 & 25 & 30 & soma menções \\
\hline embalagem & & & & & & & 1 & 1 \\
\hline tabela nutricional & & & 1 & & & & & 1 \\
\hline informações o painel frontal & & & & 1 & & & & 1 \\
\hline splash & & & & 1 & & & & 1 \\
\hline segurança & & & & & & & 1 & 1 \\
\hline composição nutricional & & & & & & 1 & & 1 \\
\hline gosto & & & 1 & & & & & 1 \\
\hline seção institucional & & & 2 & & & & & 2 \\
\hline selo IBD & 1 & & & & & 1 & & 2 \\
\hline cor & & 1 & & & 1 & & & 2 \\
\hline foto & & & & & & & 2 & 2 \\
\hline reciclagem & & 1 & 1 & & & & & 2 \\
\hline marca empresa menor & & & 1 & & & 2 & & 3 \\
\hline selo SisOrg & 1 & & & 1 & 1 & & & 3 \\
\hline apelo visual & & 1 & & 1 & & & 1 & 3 \\
\hline organização informações & 1 & & & & 5 & & & 6 \\
\hline remete a algo bom & 1 & & 3 & 3 & & & & 7 \\
\hline ilustração & & 1 & 4 & & 3 & & 1 & 9 \\
\hline ingrediente & & & 6 & & & 4 & 1 & 11 \\
\hline palavra orgânico & & & 3 & 3 & 3 & 3 & 1 & 13 \\
\hline papel & 3 & 1 & 1 & & 4 & 6 & & 15 \\
\hline
\end{tabular}




\begin{tabular}{|c|c|c|c|c|c|c|c|c|}
\hline Aspectos negativos da embalagem da granola Monama & 1 & 13 & 16 & 17 & 22 & 25 & 30 & soma menções \\
\hline legibilidade (contraste cor) & & 1 & & & & & & 1 \\
\hline marca desconhecida & & & & 1 & & & & 1 \\
\hline qualidade & & & & & & 1 & & 1 \\
\hline design & 1 & & & & & 1 & & 2 \\
\hline ingrediente & & & & & & 2 & & 2 \\
\hline não remete a saudável & & & & & & 2 & & 2 \\
\hline caixa & & & & 3 & & & & 3 \\
\hline embalagem sem cabamento & & & 3 & & & & & 3 \\
\hline cor & & 1 & 1 & & & 2 & & 4 \\
\hline não ver o produto & & & & 4 & & & & 4 \\
\hline apelo visual & 3 & 3 & & & & & & 6 \\
\hline ilustração & & 1 & & & & 5 & & 6 \\
\hline material & 1 & & 3 & & & 3 & & 7 \\
\hline embalagem parece infantil & & 4 & & & & 3 & & 7 \\
\hline embalagem frágil & 3 & 2 & 2 & & & 1 & & 8 \\
\hline
\end{tabular}

\section{P. DADOS DAS ENTREVISTAS COM MACARRÃO INSTANTÂNEO}

\section{Macarrão instantâneo}

O número da primeira linha, de cada planilha, identifica o entrevistado

\section{Separação como mais saudável}

\begin{tabular}{|l|c|c|c|c|c|c|c|c|}
\hline observações durante a separação & 1 & 15 & 16 & 17 & 22 & 25 & 30 & soma consumidores \\
\hline olhou a tabela nutricional & & & 1 & & & 1 & & 2 \\
\hline Olhou a parte de trás da embalagem & 1 & & 1 & 1 & & 1 & & 4 \\
\hline Ficou em dúvida com alguma marca & 1 & 15 & 16 & 17 & 22 & 25 & 30 & soma consumidores \\
\hline Vilma Integral & & & & & 1 & 1 & & 2 \\
\hline Panco & & & & 1 & & & & 1 \\
\hline Carrefour & & & & 1 & & & & 1 \\
\hline Nissin Mais & & & 1 & 1 & 1 & & & 3 \\
\hline Ficou em dúvida por causa de alguma informação & 1 & 15 & 16 & 17 & 22 & 25 & 30 & soma consumidores \\
\hline light em sódio & & & & & & 1 & & 1 \\
\hline cor da embalagem & & & & 1 & 1 & & & 2 \\
\hline Cor verde & & & & 1 & & & & 1 \\
\hline pela aparência da embalagem & & & & & 1 & & & 1 \\
\hline
\end{tabular}

\begin{tabular}{|l|c|c|c|c|c|c|c|c|}
\hline Separação saudável & 1 & 15 & 16 & 17 & 22 & $\mathbf{2 5}$ & $\mathbf{3 0}$ & soma consumidores \\
\hline Vigor & & & & & & & & 0 \\
\hline Maggi & & & & & & & & 0 \\
\hline Carrefour & & & & & & & & 0 \\
\hline Nissin & & & & & & & 1 & 1 \\
\hline Panco & & & & & & & 1 & 1 \\
\hline Adria & & & 1 & & & & & 1 \\
\hline Nissin Mais & & & 1 & & 1 & & 1 & 3 \\
\hline Vilma Integral & 1 & & 1 & 1 & 1 & & 1 & 5 \\
\hline Mãe Terra & 1 & 1 & 1 & 1 & 1 & 1 & 1 & 7 \\
\hline
\end{tabular}




\begin{tabular}{|c|c|c|c|c|c|c|c|c|}
\hline Critérios separação macarrão como mais saudável & 1 & 15 & 16 & 17 & 22 & 25 & 30 & soma menções \\
\hline embalagem & & 1 & & & & & & 1 \\
\hline palavra light ou zero & 1 & & & & & & & 1 \\
\hline cor & & & & & 1 & & & 1 \\
\hline foto & & & & & 1 & & & 1 \\
\hline natural & & 1 & & & & & & 1 \\
\hline tabela nutricional & & & & & & 2 & & 2 \\
\hline aditivos & & 1 & & & & 2 & & 3 \\
\hline slogan & & & & 1 & 1 & 1 & 1 & 4 \\
\hline outros selos certificação & & & & & & 4 & & 4 \\
\hline palavra orgânico & & 2 & & & 1 & & 2 & 5 \\
\hline selo SisOrg & & & & & & 5 & & 5 \\
\hline remete a algo bom & & & & 4 & 1 & & & 5 \\
\hline Mãe Terra & & 2 & 1 & 2 & 1 & & & 6 \\
\hline ingrediente & 1 & & & & 1 & & 5 & 7 \\
\hline composição nutricional & & & 6 & 1 & & & & 7 \\
\hline pouco ou sem algo & & 1 & 2 & & & 7 & & 10 \\
\hline palavra integral & 1 & & & 2 & 4 & 3 & 2 & 12 \\
\hline forma preparo & & 1 & 3 & 1 & 2 & 6 & & 13 \\
\hline
\end{tabular}

\begin{tabular}{|l|l|l|l|l|l|l|l|c|}
\hline Critérios separação macarrão como menos saudável & $\mathbf{1}$ & $\mathbf{1 5}$ & $\mathbf{1 6}$ & $\mathbf{1 7}$ & $\mathbf{2 2}$ & $\mathbf{2 5}$ & $\mathbf{3 0}$ & \multicolumn{2}{c|}{ soma menções } \\
\hline elemento textual & & & & & 1 & & & 1 \\
\hline palavra orgânico & & & & & 1 & & & \\
\hline marca & & & & 1 & & & 1 \\
\hline cor & & & & & & 1 & & \\
\hline não passa credibilidade & & & & & & 1 & & \\
\hline gosto & & 1 & & & & & & \\
\hline aditivos & & & & & & 2 & & 1 \\
\hline pouco ou sem algo na composição & 2 & 3 & & & 4 & 1 & & \\
\hline ingrediente & 2 & 6 & 1 & 5 & 1 & 3 & 1 & 1 \\
\hline tipo de produto & 2 & 1 & 9 & & 1 & 10 & & 19 \\
\hline composição nutricional & & & 23 \\
\hline
\end{tabular}

\section{Separação como orgânico}

\begin{tabular}{|l|c|c|c|c|c|c|c|c|}
\hline observações durante a separação & 1 & 15 & 16 & 17 & 22 & 25 & 30 & soma consumidores \\
\hline olhou primeiro no grupo de saudáveis & 1 & 1 & 1 & 1 & 1 & 1 & 1 & 7 \\
\hline ficou em dúvida por causa da marca & 1 & 15 & 16 & 17 & 22 & 25 & 30 & soma consumidores \\
\hline Mãe Terra & & & & & & & & \\
\hline Vilma Integral & & 1 & & 1 & & & & 2 \\
\hline Panco & & & & & & & & \\
\hline Nissin Mais & & & & 1 & & & 1 & 2 \\
\hline encontrou algum depois de olhar uma segunda vez & & & & & & & 1 & 1 \\
\hline
\end{tabular}

\begin{tabular}{|l|c|c|c|c|c|c|c|c|}
\hline Separação orgânico & 1 & 15 & 16 & 17 & 22 & 25 & 30 & soma consumidores \\
\hline Nissin & & & & & & & & 0 \\
\hline Vigor & & & & & & & & 0 \\
\hline Panco & & & & & & & & \\
\hline Adria & & & & & & & & 0 \\
\hline Carrefour & & & & & & & & 0 \\
\hline
\end{tabular}




\begin{tabular}{|l|l|l|l|l|l|l|l|l|l|}
\hline Vilma Integral & & & & & & & 1 & & 1 \\
\hline Nissin Mais & & & & & & & 1 & 1 \\
\hline Maggi & & & & & & & 1 & 1 \\
\hline Mãe Terra & 1 & 1 & 1 & 1 & 1 & 1 & 1 & 7 \\
\hline
\end{tabular}

\begin{tabular}{|l|c|c|c|c|c|c|c|c|}
\hline Critérios separação macarrão como orgânico & 1 & 15 & $\mathbf{1 6}$ & $\mathbf{1 7}$ & $\mathbf{2 2}$ & $\mathbf{2 5}$ & $\mathbf{3 0}$ & soma menções \\
\hline palavra natural & & & & 1 & & & & 1 \\
\hline outros selos certificação & & & & & & 1 & & 1 \\
\hline remete a orgânico & & & & 1 & & & & 1 \\
\hline aditivos & & 1 & & & & & & 1 \\
\hline palavra integral & & 1 & & & & & 1 & 2 \\
\hline pouco ou sem algo na composição & & 2 & & & & & & 2 \\
\hline selo SisOrg & 1 & & & & & 1 & & 2 \\
\hline preparo & & 2 & & & & & & 2 \\
\hline slogan & & 2 & 1 & & 1 & & & 4 \\
\hline ingrediente & & & & & & & 4 & 4 \\
\hline palavra orgânico & & 2 & 2 & 3 & 1 & & 1 & 9 \\
\hline
\end{tabular}

\begin{tabular}{|l|c|c|c|c|c|c|c|c|}
\hline Critérios separação macarrão como não orgânico & 1 & $\mathbf{1 5}$ & $\mathbf{1 6}$ & $\mathbf{1 7}$ & $\mathbf{2 2}$ & $\mathbf{2 5}$ & $\mathbf{3 0}$ & soma menções \\
\hline palavra orgânico & & & 1 & & & & & 1 \\
\hline palavra integral & & 1 & & & & & & 1 \\
\hline selo SisOrg & 1 & & & & & & & 1 \\
\hline composição nutricional & & 1 & & & & & & 1 \\
\hline aditivos & & 1 & & 1 & & & & 2 \\
\hline
\end{tabular}

\section{Macarrão Caseirito Mãe Terra}

\begin{tabular}{|l|c|c|c|c|c|c|c|c|}
\hline Já comprou este produto ou de outro sabor? & 1 & 15 & 16 & 17 & 22 & 25 & 30 & soma consumidores \\
\hline Já comprou este produto ou de outro sabor & & & & & 1 & & & 1 \\
\hline marca conhecida & & & & & 1 & & & 1 \\
\hline orgânico & & & & & 1 & & & 1 \\
\hline Já viu e não comprou. & & 1 & 1 & & & & & 2 \\
\hline Motivo por não ter comprado & 1 & 15 & 16 & 17 & 22 & 25 & 30 & soma consumidores \\
\hline não compra macarrão instantâneo & & 1 & & & & & & 1 \\
\hline no dia não estava procurando miojo & & & 1 & & & & & 1 \\
\hline caro & & & 1 & & & & & 1 \\
\hline nunca viu & 1 & & & 1 & & 1 & & 3 \\
\hline
\end{tabular}

\begin{tabular}{|l|c|c|c|c|c|c|c|c|}
\hline Aspectos positivos da embalagem de macarrão Caseirito & $\mathbf{1}$ & $\mathbf{1 5}$ & $\mathbf{1 6}$ & $\mathbf{1 7}$ & $\mathbf{2 2}$ & $\mathbf{2 5}$ & $\mathbf{3 0}$ & soma menções \\
\hline palavra natural & & & & 1 & & & & 1 \\
\hline slogan & & & & & & 1 & & 1 \\
\hline informações na frente & & & & 1 & & & & 1 \\
\hline selo SisOrg & & & & & & 1 & & 1 \\
\hline plástico & & & & & 1 & & & 1 \\
\hline legibilidade & & & & & & 1 & & 1 \\
\hline design & & & & & & 1 & & 1 \\
\hline composição nutricional & & & & & 1 & & & 1 \\
\hline gosto pessoal & & & & 1 & & & & 1 \\
\hline qualidade do produto & & & & & & 1 & 1 & 2 \\
\hline nome & & & \\
\hline
\end{tabular}




\begin{tabular}{|c|c|c|c|c|c|c|c|c|}
\hline outros selos certificação & & & & & & 2 & & 2 \\
\hline apelo visual & 2 & & & & & & & 2 \\
\hline sentir produto & & 2 & & & & & & 2 \\
\hline acabamento & & 2 & & & & & & 2 \\
\hline resistência & & & & & & & 2 & 2 \\
\hline ingrediente & & & & & & 2 & & 2 \\
\hline sabor & & & & & & 1 & 1 & 2 \\
\hline aparência do macarrão & & & & 2 & & & & 2 \\
\hline elemento textual & 1 & & 2 & & & & & 3 \\
\hline ilustração & & & & & & 3 & & 3 \\
\hline porção & & & 1 & & 2 & & & 3 \\
\hline marca Mãe Terra & & & & 1 & 1 & & 2 & 4 \\
\hline palavra integral & & & 1 & 1 & & 3 & & 5 \\
\hline cor & & 2 & & & 2 & 1 & & 5 \\
\hline natural & & 1 & & 1 & 1 & & 2 & 5 \\
\hline remete a algo bom & & 2 & 1 & 2 & 1 & & & 6 \\
\hline preparo & & 1 & & 1 & & 2 & 2 & 6 \\
\hline palavra orgânico & & 2 & 1 & 1 & 1 & 3 & & 8 \\
\hline pouco ou sem algo na composição & & 2 & & 2 & & 5 & 1 & 10 \\
\hline organização informações & & 4 & & 12 & 2 & & & 18 \\
\hline
\end{tabular}

\begin{tabular}{|c|c|c|c|c|c|c|c|c|}
\hline Aspectos negativos da embalagem de macarrão Caseirito & 1 & 15 & 16 & 17 & 22 & 25 & 30 & soma menções \\
\hline elemento textual & & 1 & & & & & & 1 \\
\hline falta palavra light ou zero & & & & 1 & & & & 1 \\
\hline tabela nutricional & & 1 & & & & & & 1 \\
\hline foto & 1 & & & & & & & 1 \\
\hline organização informações & & 1 & & & & & & 1 \\
\hline resistência da embalagem & 1 & & & & & & & 1 \\
\hline bandeja & 1 & & & & & & & 1 \\
\hline gosto & & & & & 1 & & & 1 \\
\hline preço & & & 1 & & & & & 1 \\
\hline aparência & 1 & & & & & & & 1 \\
\hline legibilidade & & 2 & & & & & & 2 \\
\hline visibilidade do produto & & & & 2 & & & & 2 \\
\hline aproveitamento embalagem & 2 & & & & & & & 2 \\
\hline tipo de produto & & & & & & 2 & & 2 \\
\hline natural & & & & 2 & & & & 2 \\
\hline pouco ou sem algo na composição & & & & & & 3 & & 3 \\
\hline porção & & & & & 3 & & & 3 \\
\hline ingrediente & & & & & & 4 & 1 & 5 \\
\hline remete a algo ruim & & & & & 5 & 2 & & 7 \\
\hline
\end{tabular}




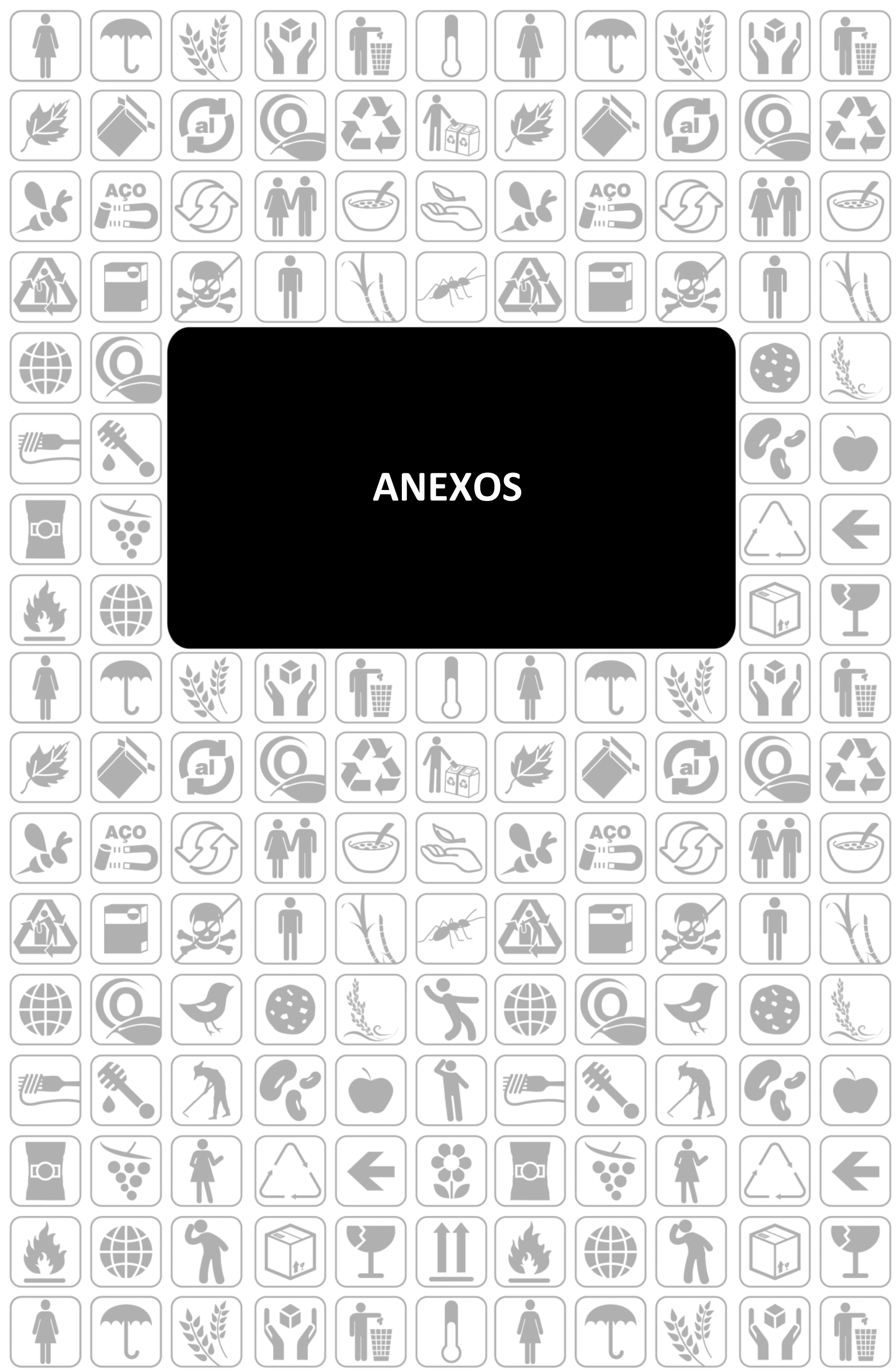




\section{A. EMBALAGENS MÃE TERRA}

Painel frontal da embalagem do arroz integral Mãe Terra

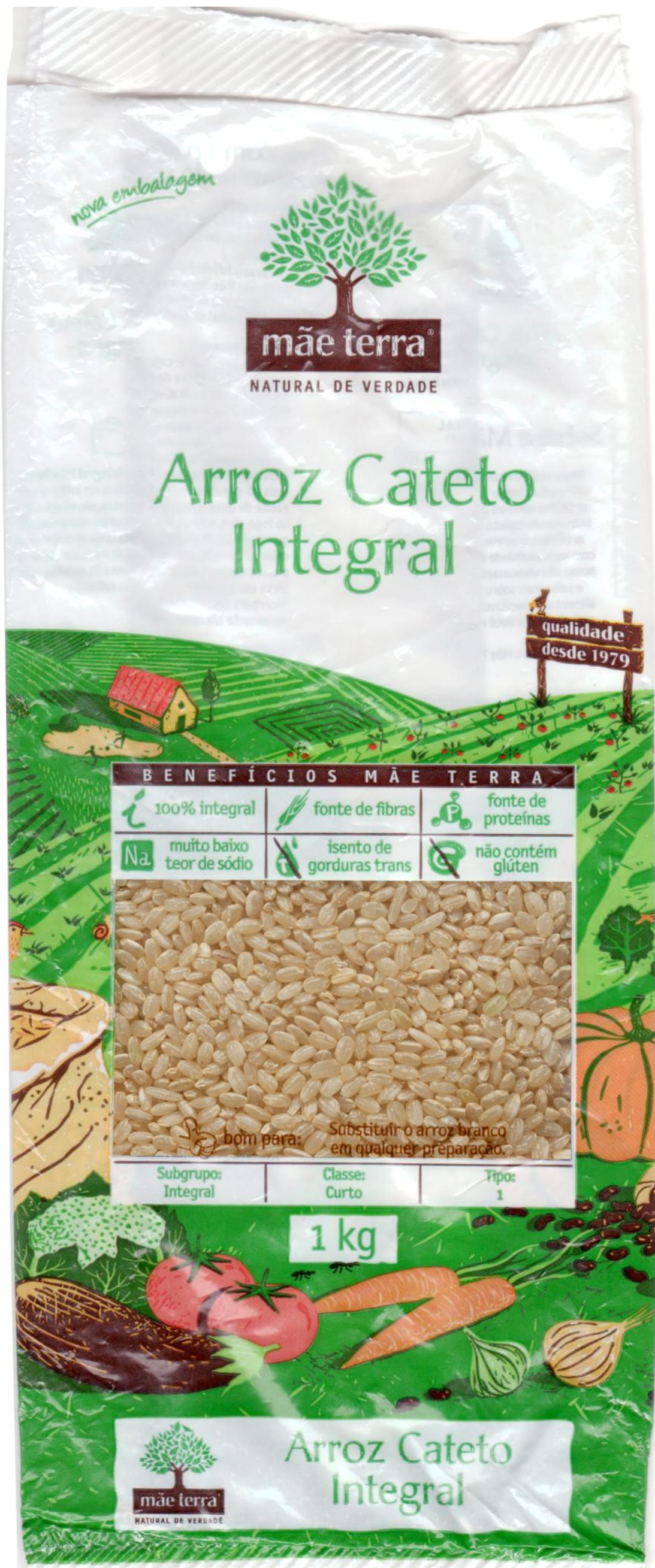


Painel traseiro

da embalagem do arroz integral Mãe Terra

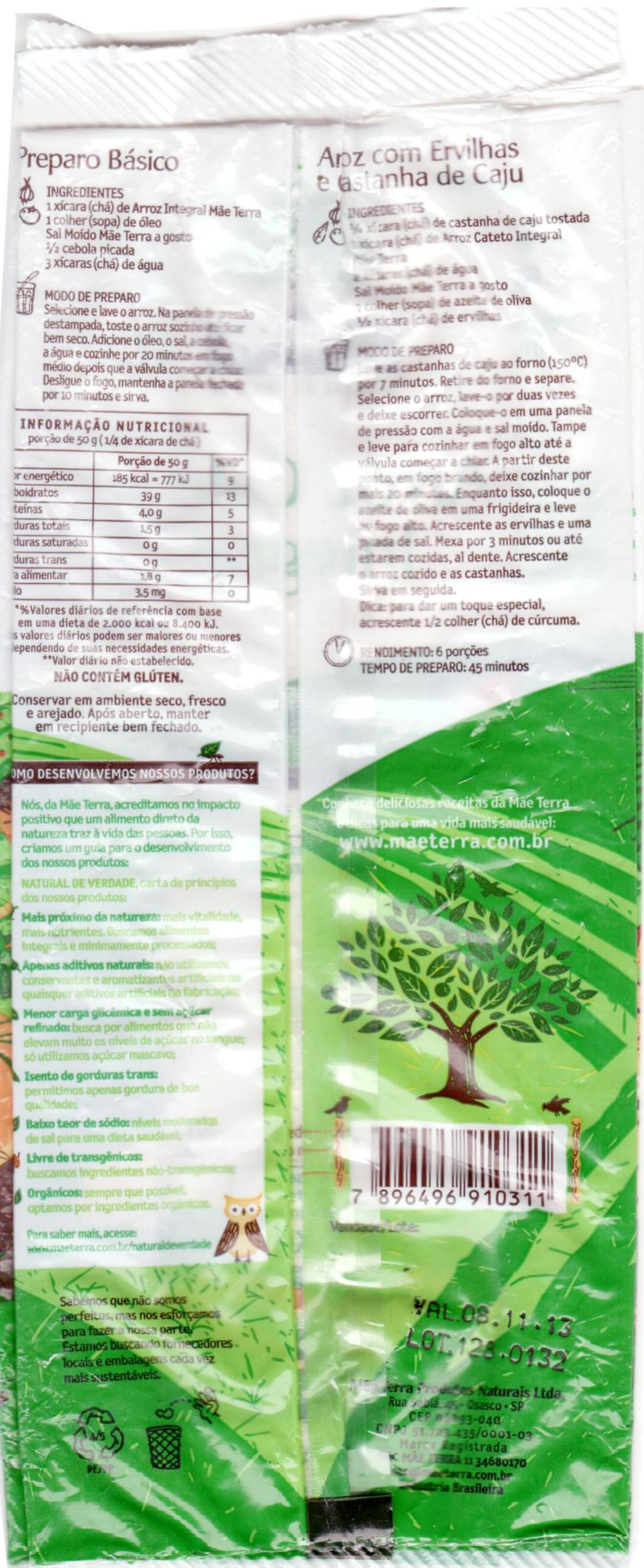


Painéis lateral esquerdo e direito da embalagem do arroz integral Mãe Terra

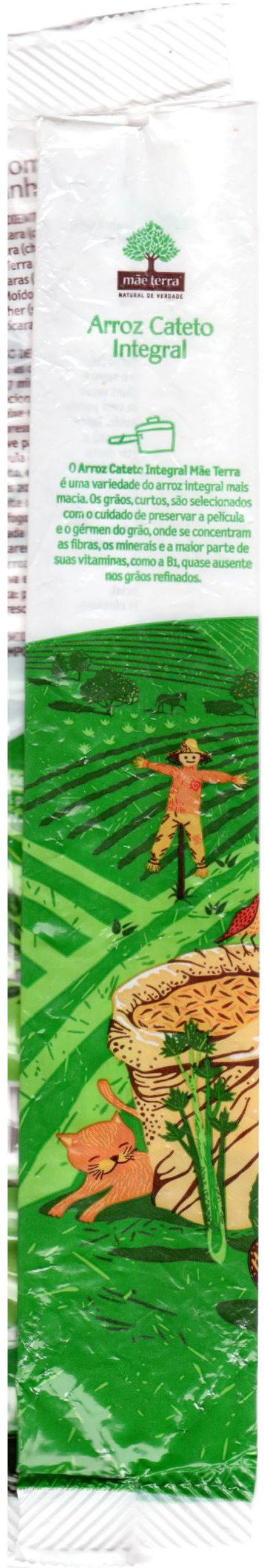

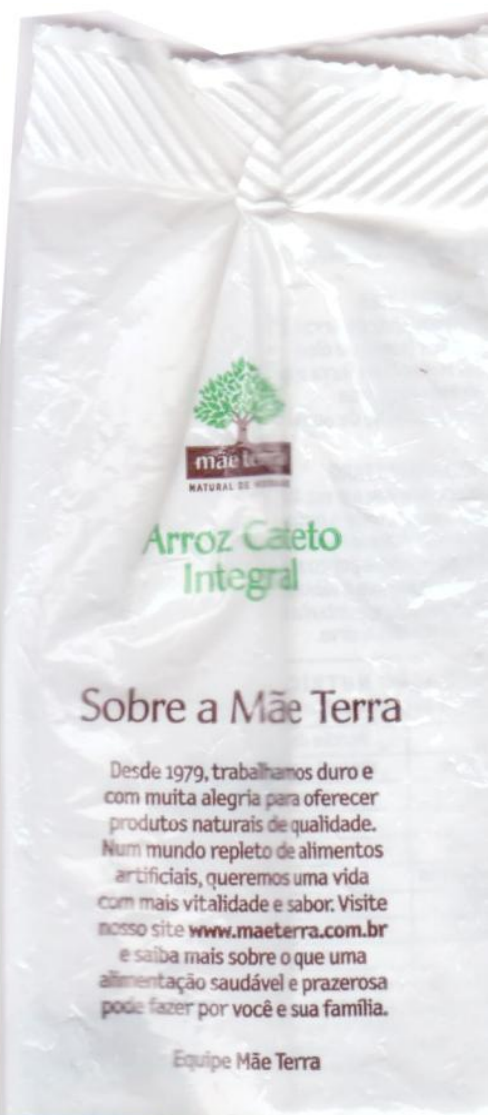

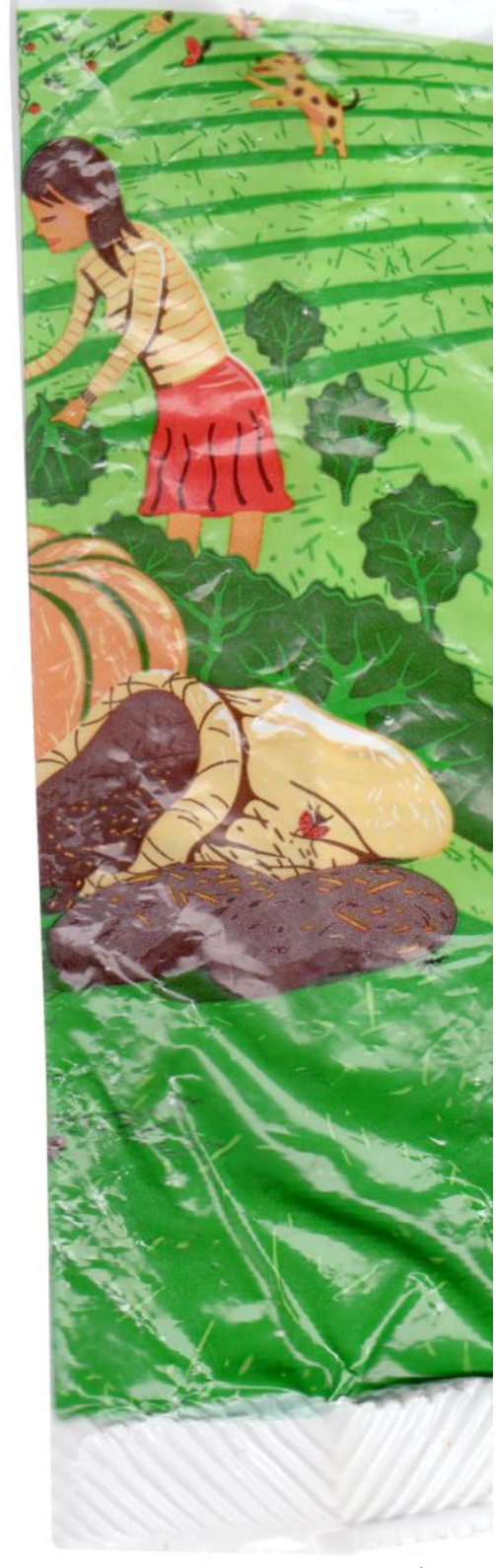


Painel frontal da embalagem de açúcar mascavoMãe Terra

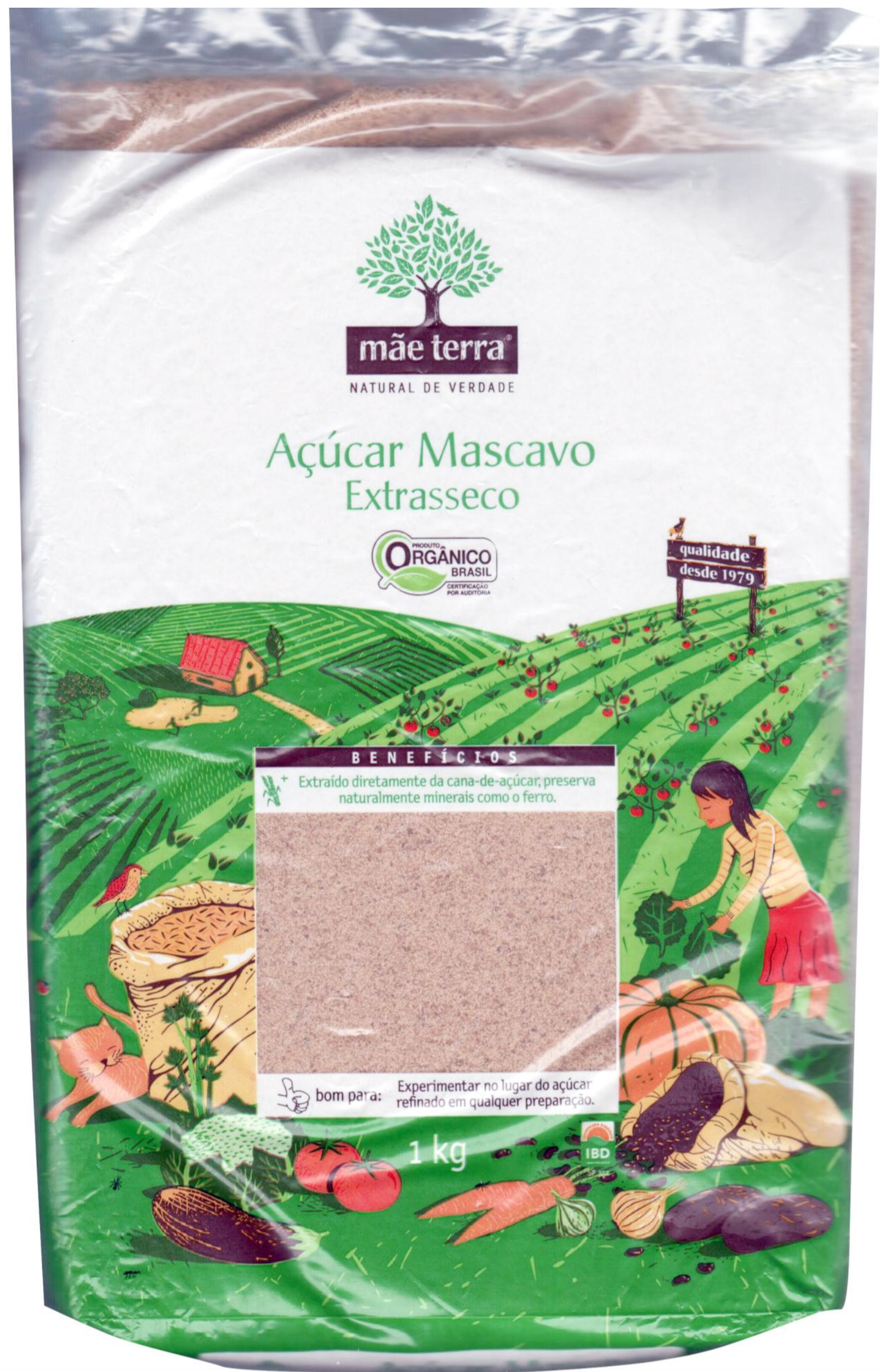


Painel traseiro da embalagem de açúcar mascavoMãe Terra

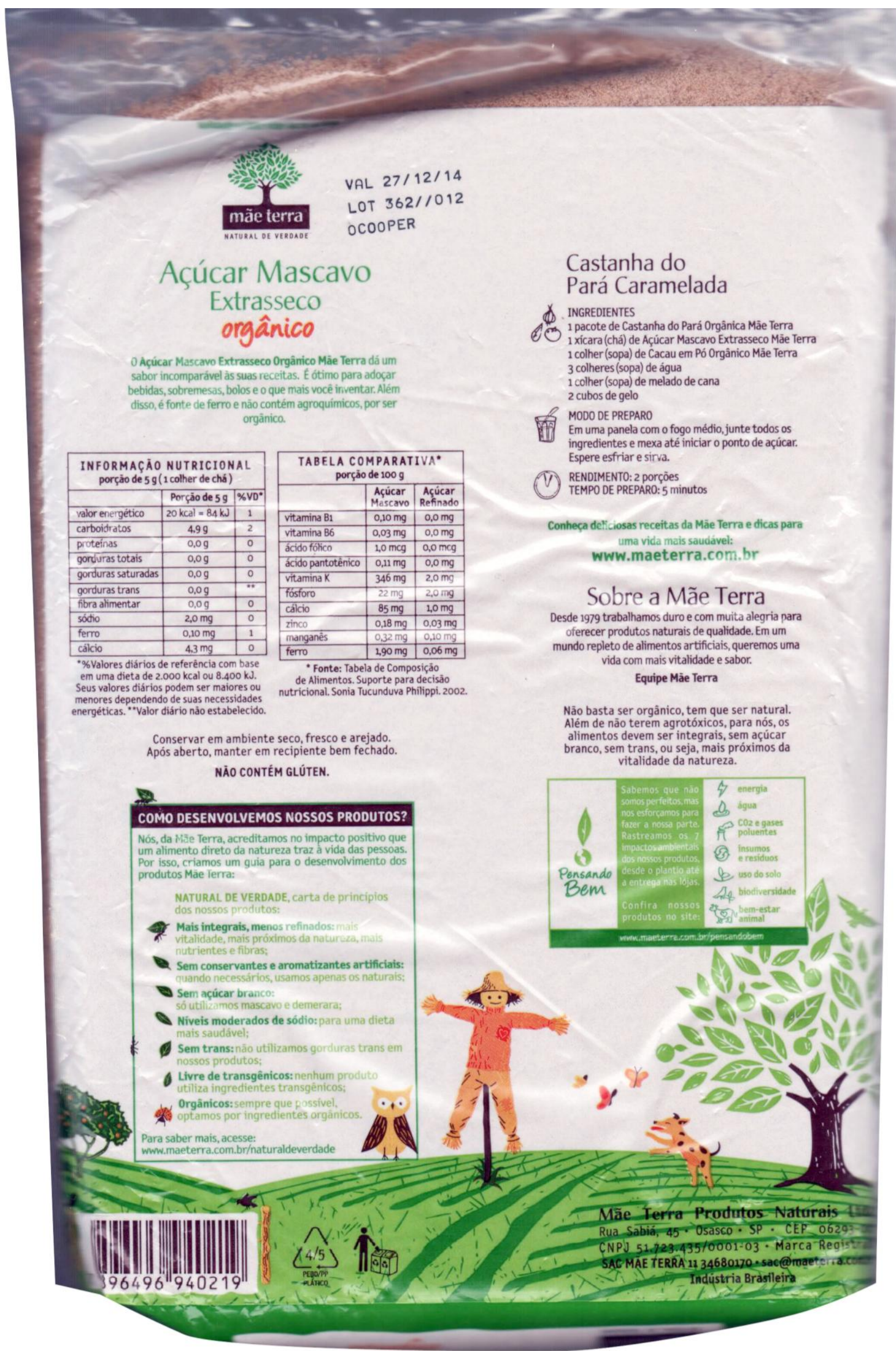




\section{Base}

da embalagem

de açúcar mascavo

Mãe Terra

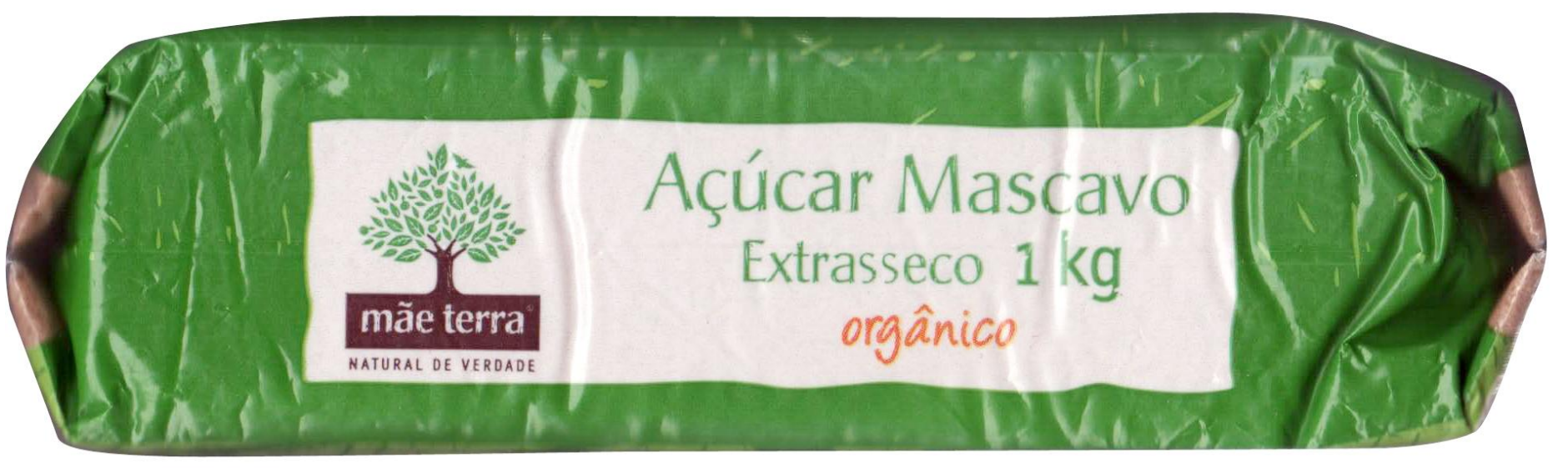


Painel frontal

da embalagem de

farinha de trigo integral Mãe Terra

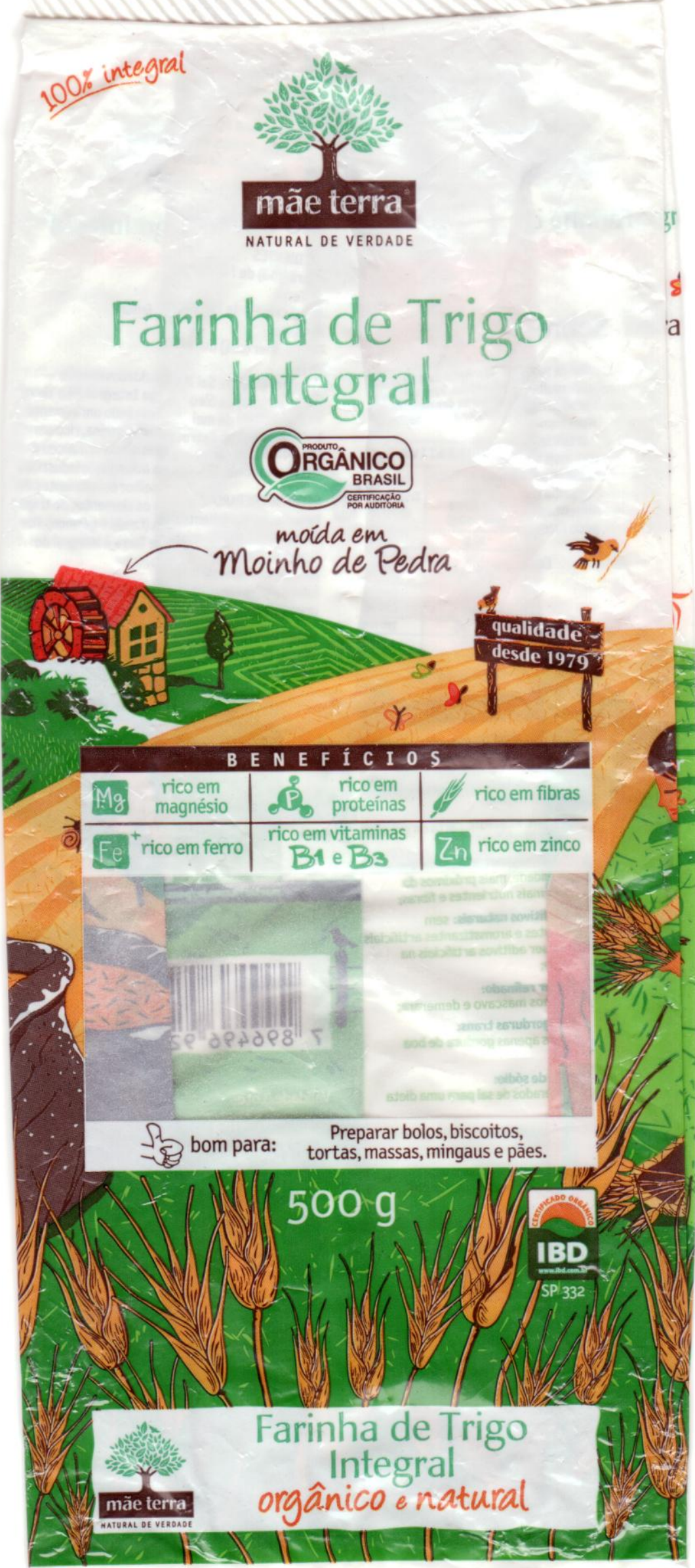


Painel frontal

da embalagem de

farinha de trigo integral Mãe Terra

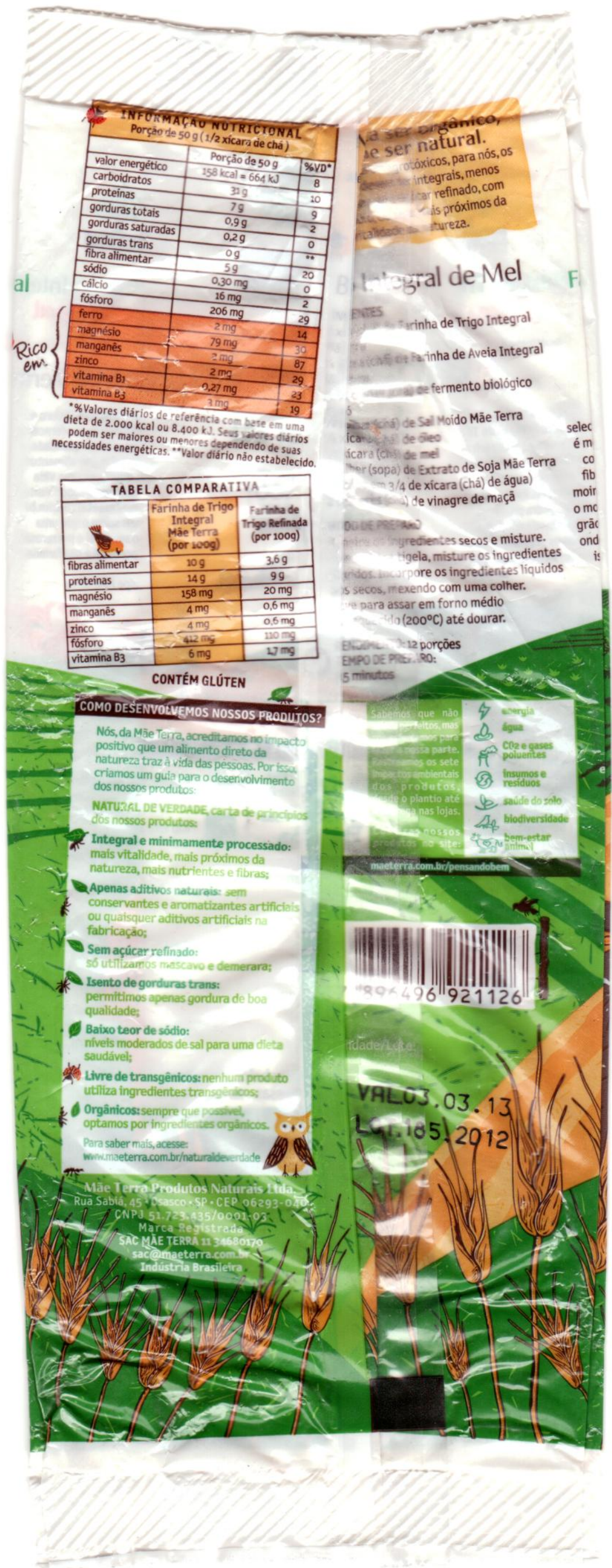


Painéis laterais esquerdo e direito da embalagem de

farinha de trigo integral Mãe Terra

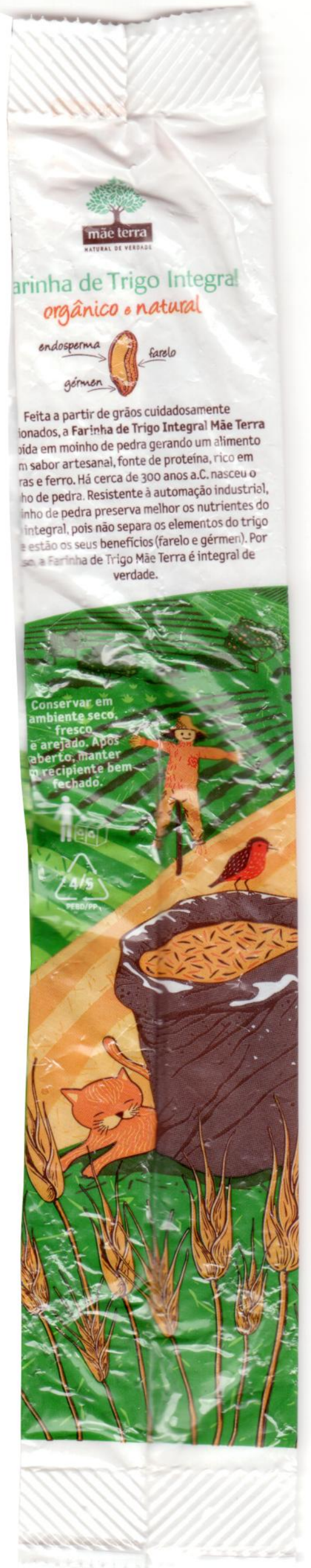

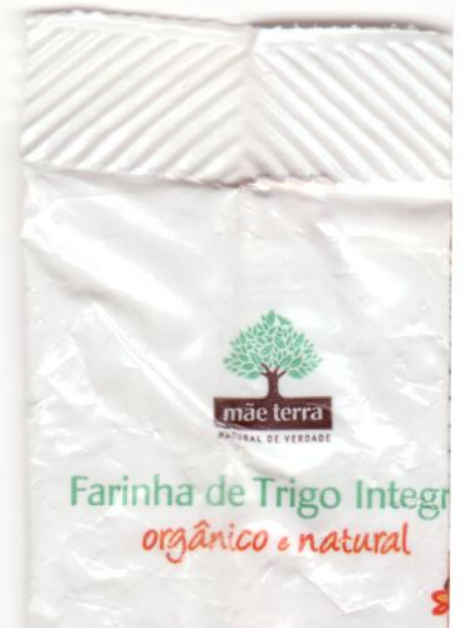

Sobre a Mãe Terra

Desde 1979 , trabalhamos duroe com muita alegria para oferecer produtos naturais de qualidade. Num mundo repleto de alimentos Num mundo repleto de alimentos
artificiais, queremos uma vida com mais vitalidade e sabor. Visite nosso site inww.maeterra.com.br e saiba mais sobre o que uma alimentacio saudávele prazo pode fazer por você e sua famíita. Eqripe Mảe Terra
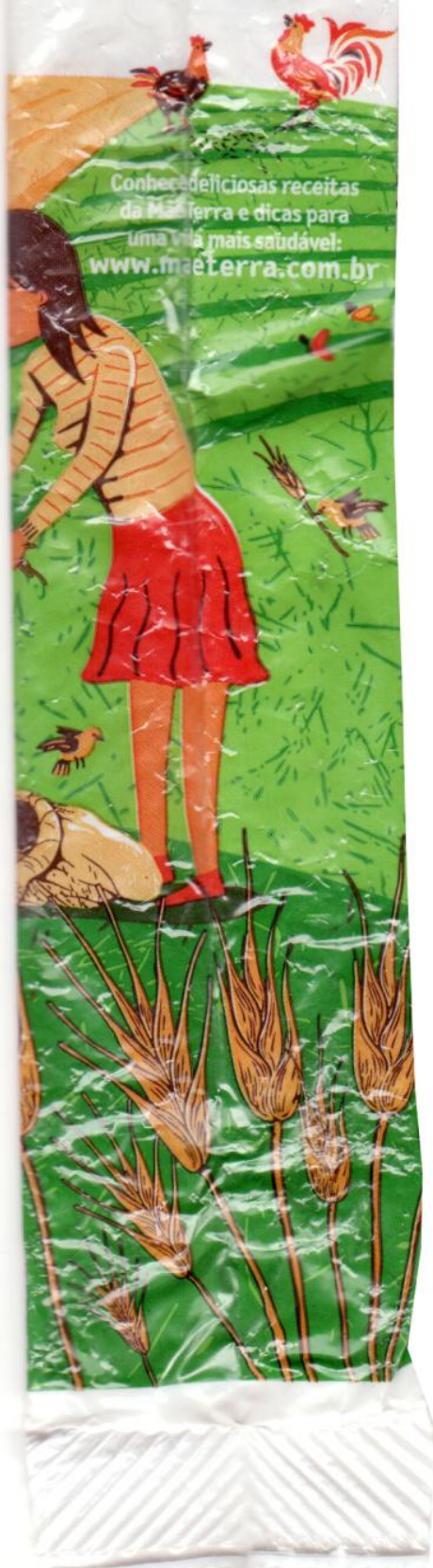
Painel frontal

da embalagem de

Cookies Integrais

Mãe Terra

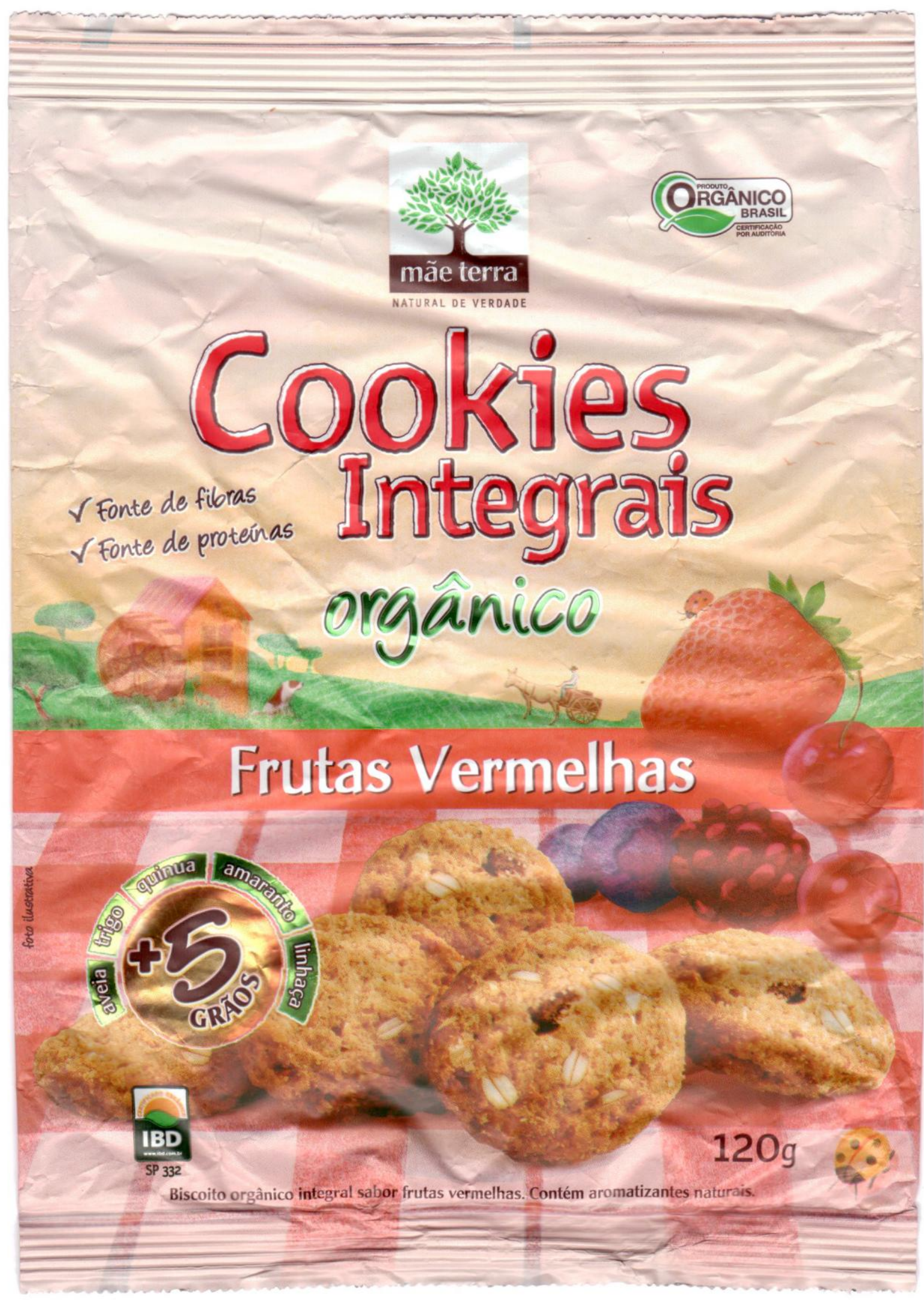


Painel traseiro

da embalagem de

Cookies Integrais

Mãe Terra

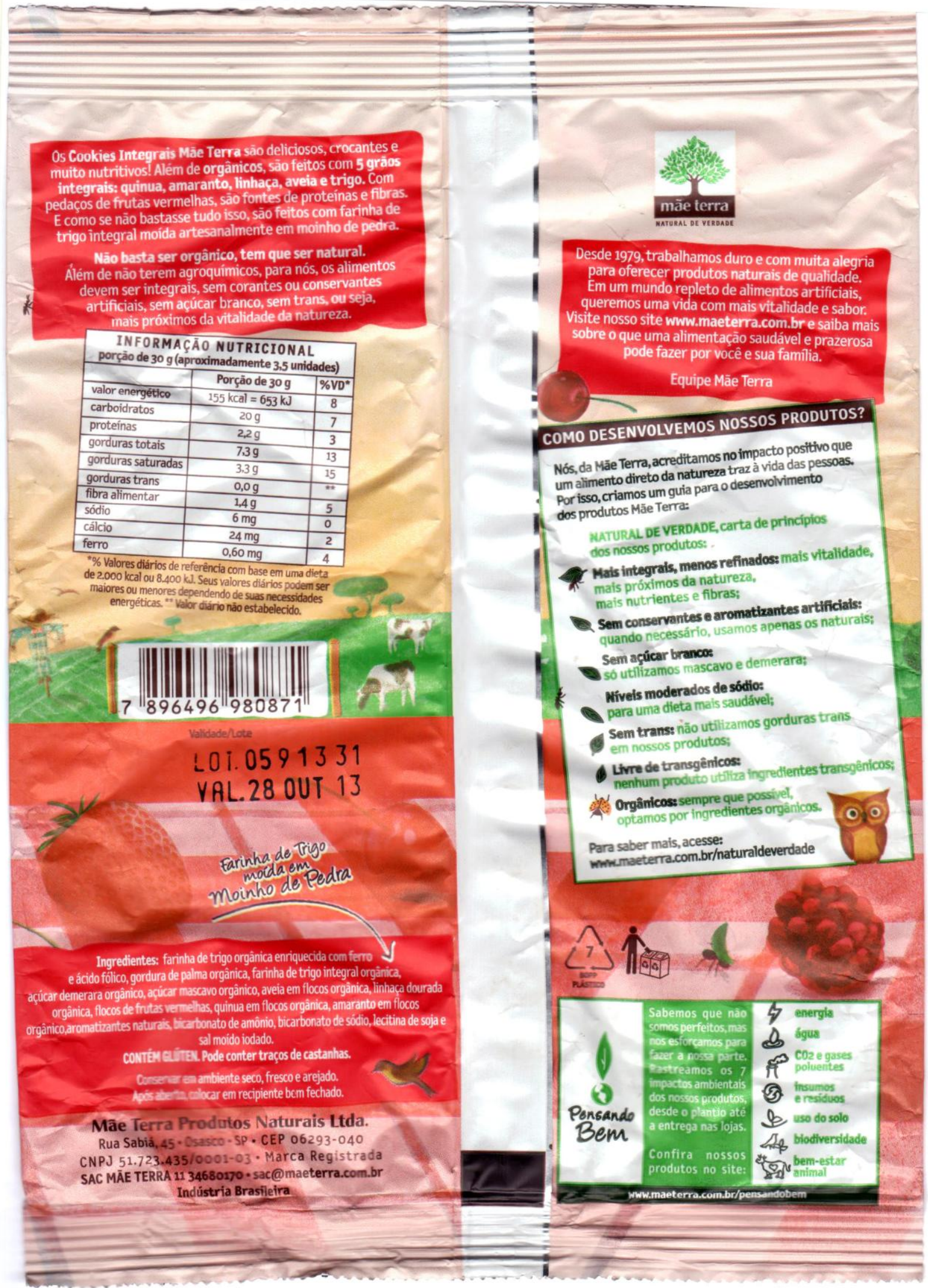


Painéis frontal e traseiro

da embalagem de

barra de cereais

Mãe Terra

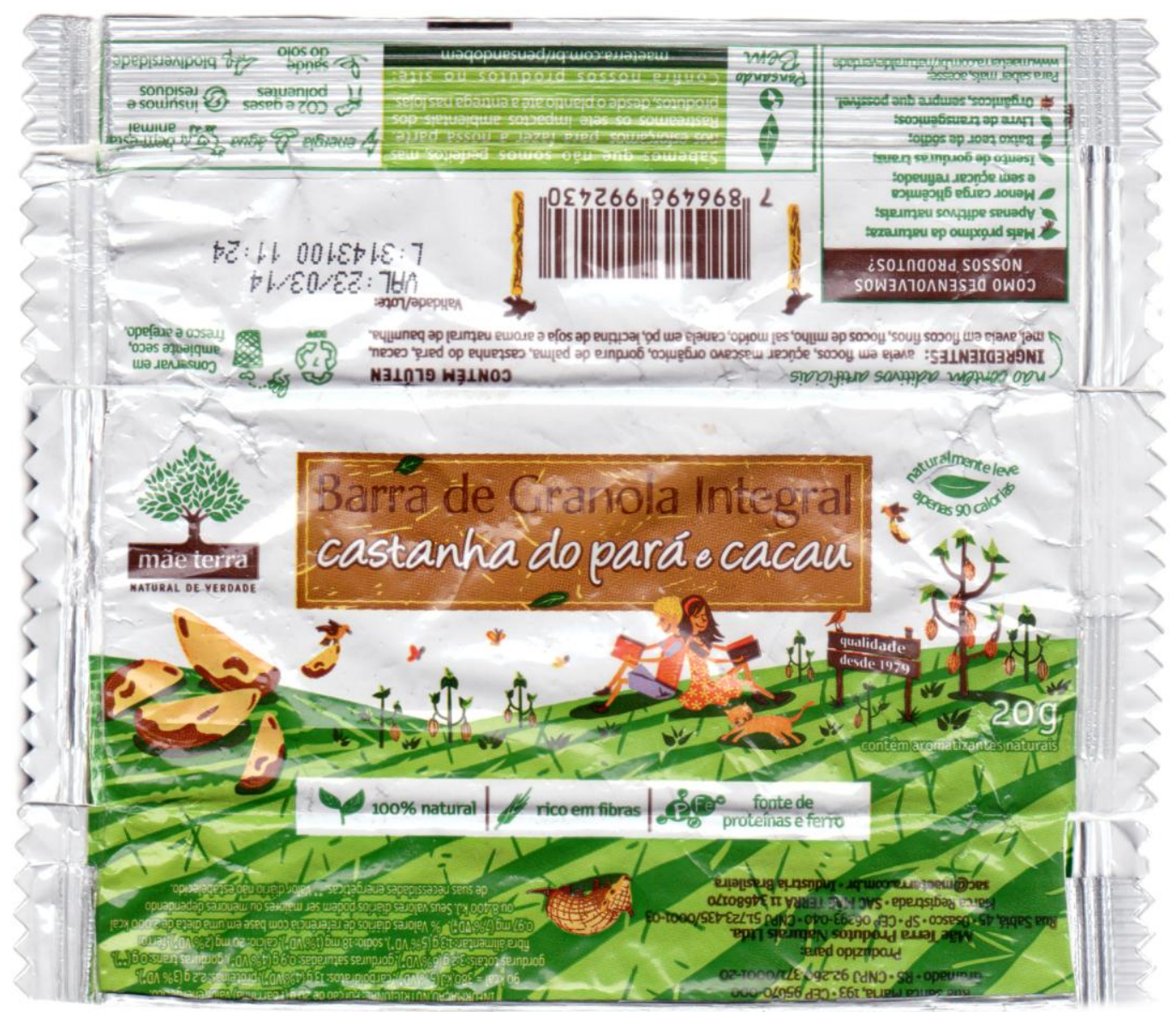


Painel frontal

da embalagem de

granola

Mãe Terra

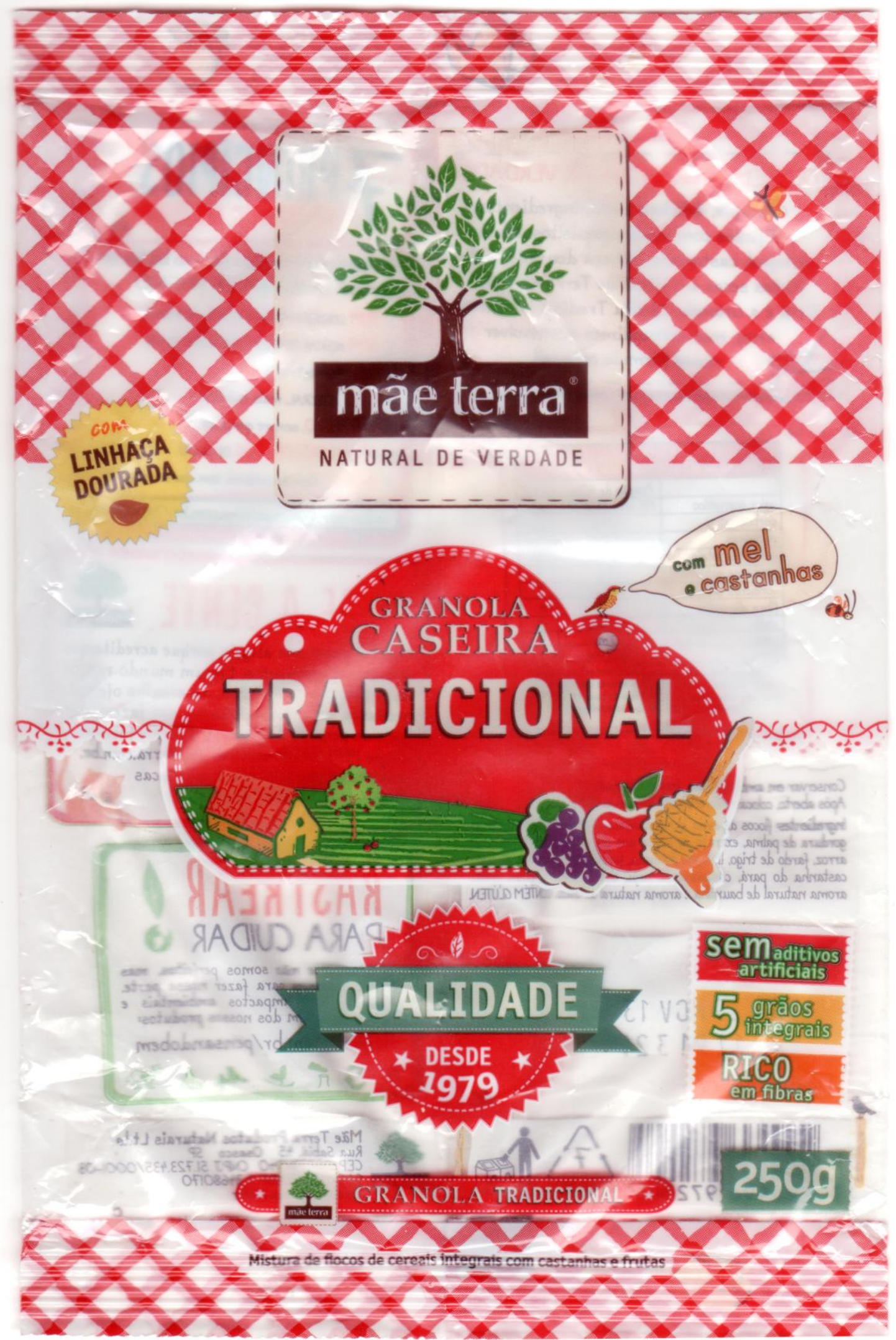


Painel traseiro

da embalagem de

granola

Mãe Terra

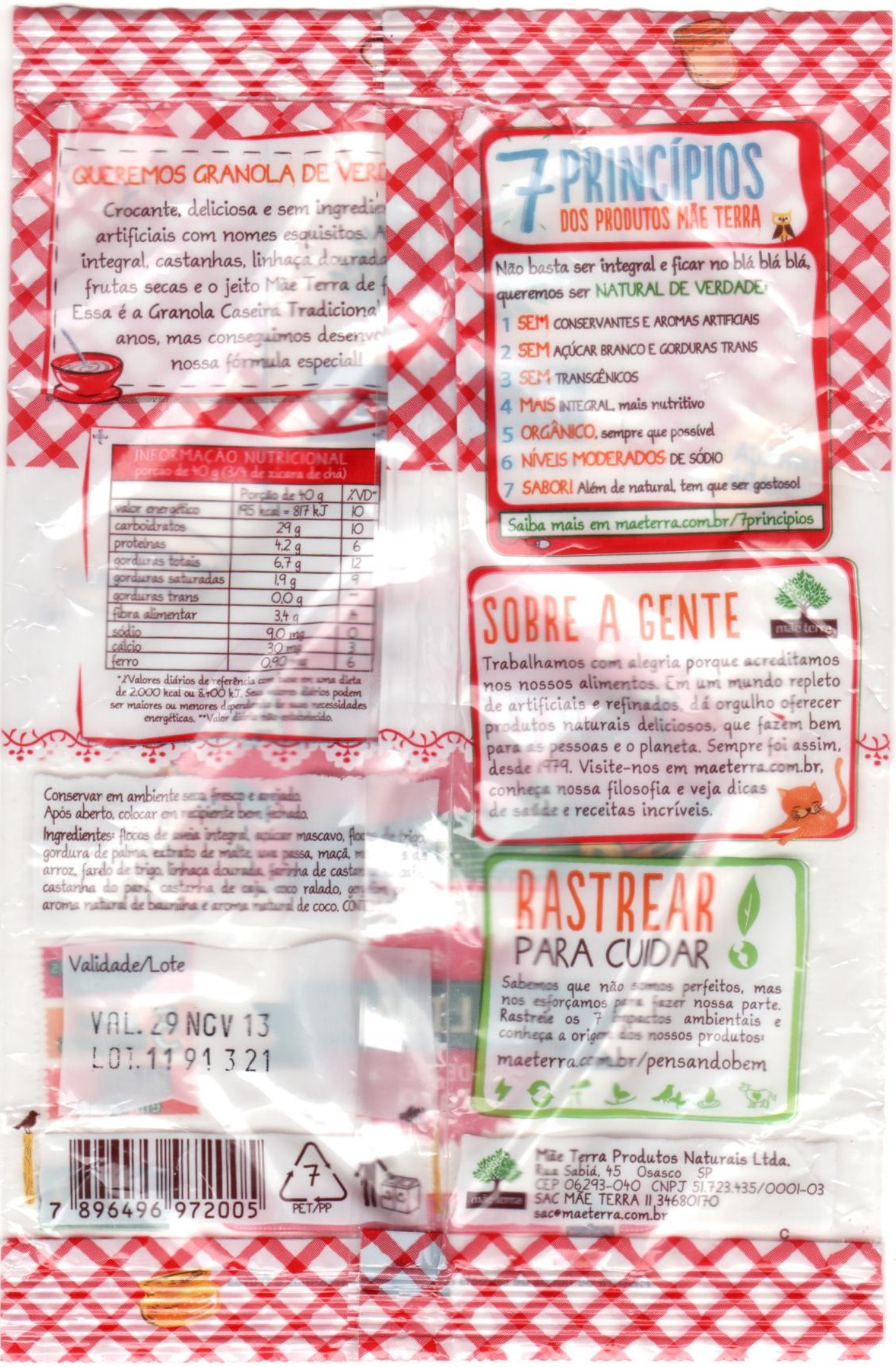


Painéis frontal e traseiro

da embalagem de

macarrão Caseirito

Mãe Terra

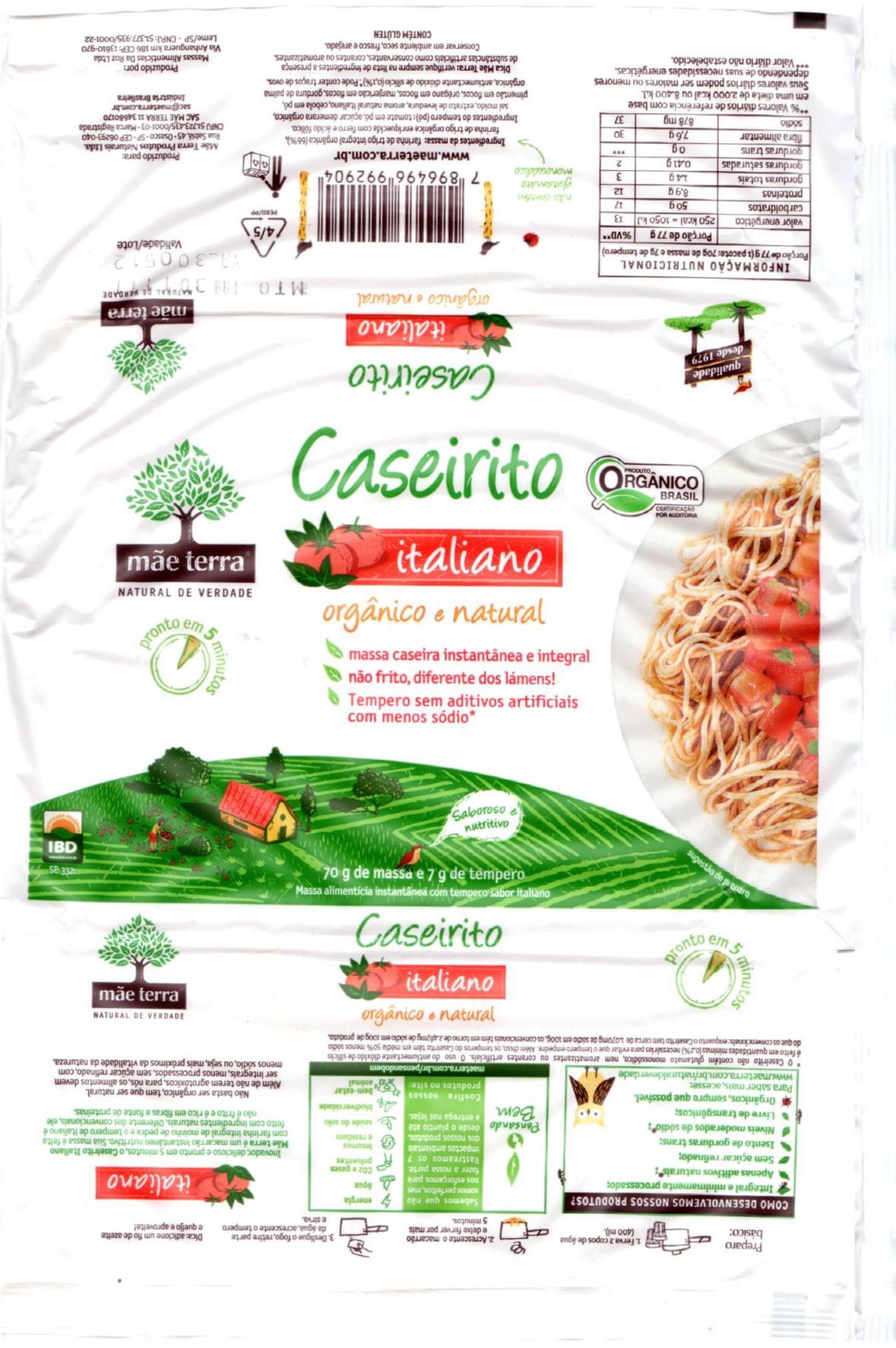




\section{B. EMBALAGENS MONAMA}

Painéis frontal e traseiro

da embalagem de

barra de cereais

Monama

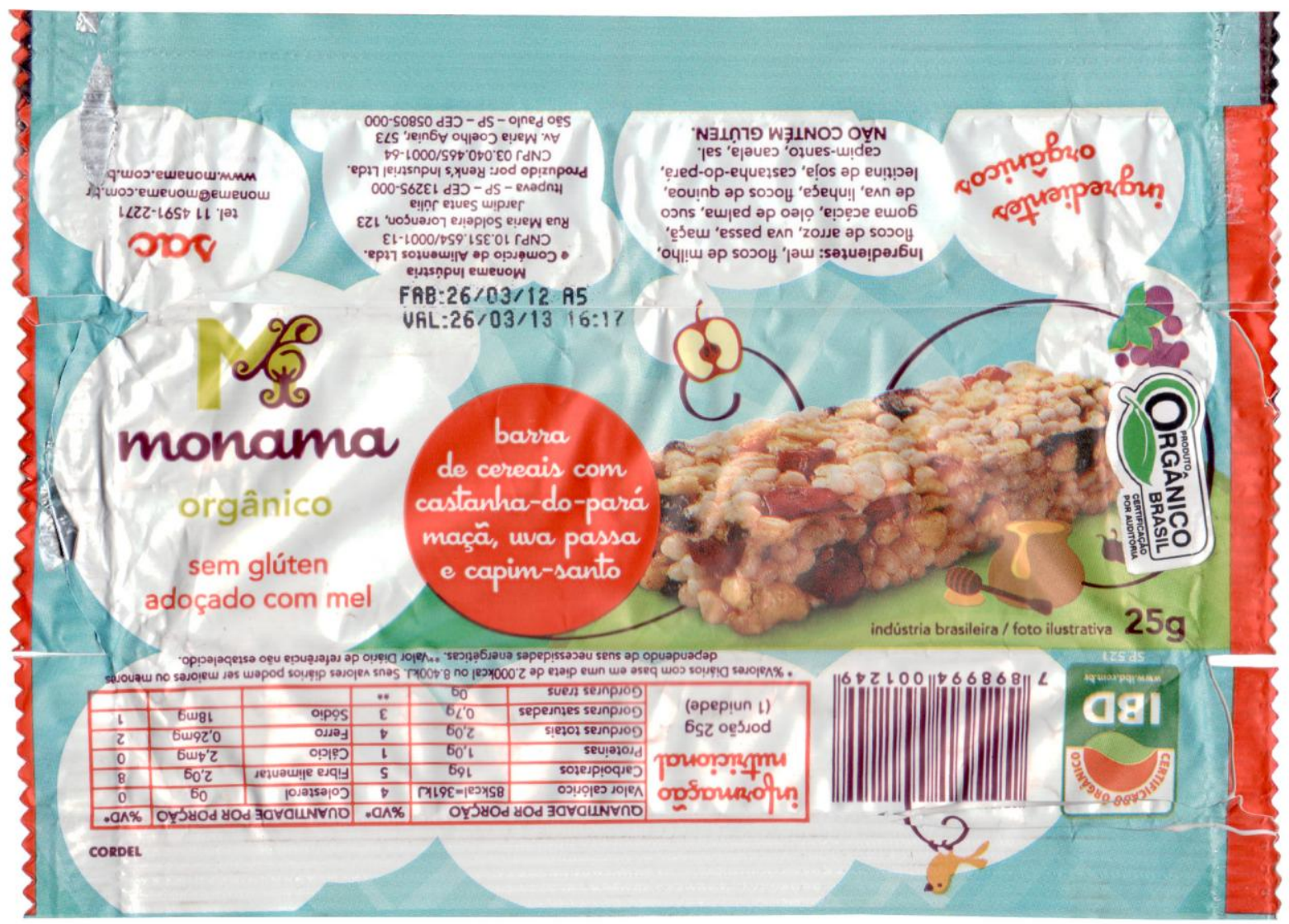


Painéis lateral esquerdo, frontal e tampa da embalagem de

granola

Monama

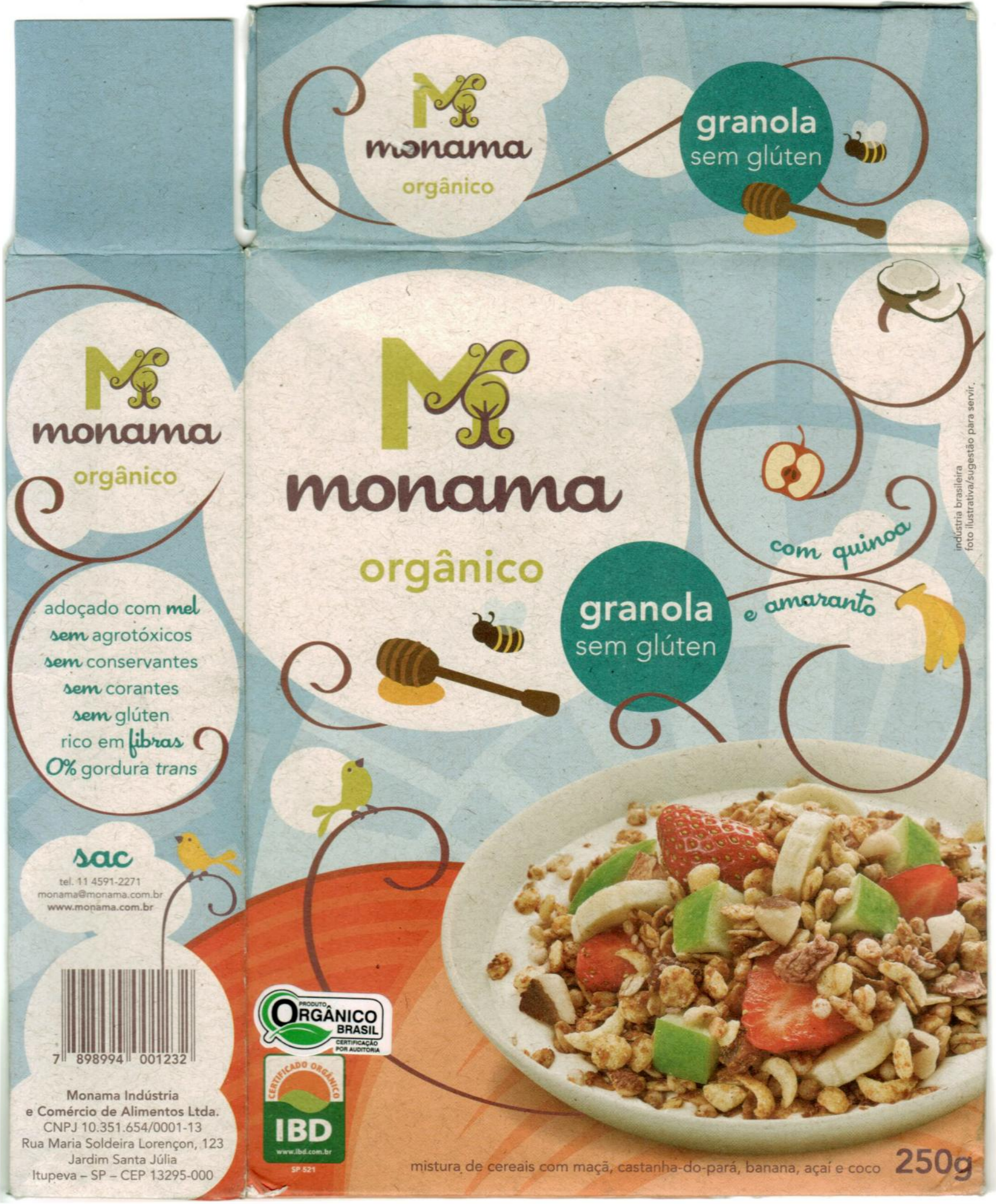


Painéis lateral direito e traseiro

da embalagem de

granola

Monama

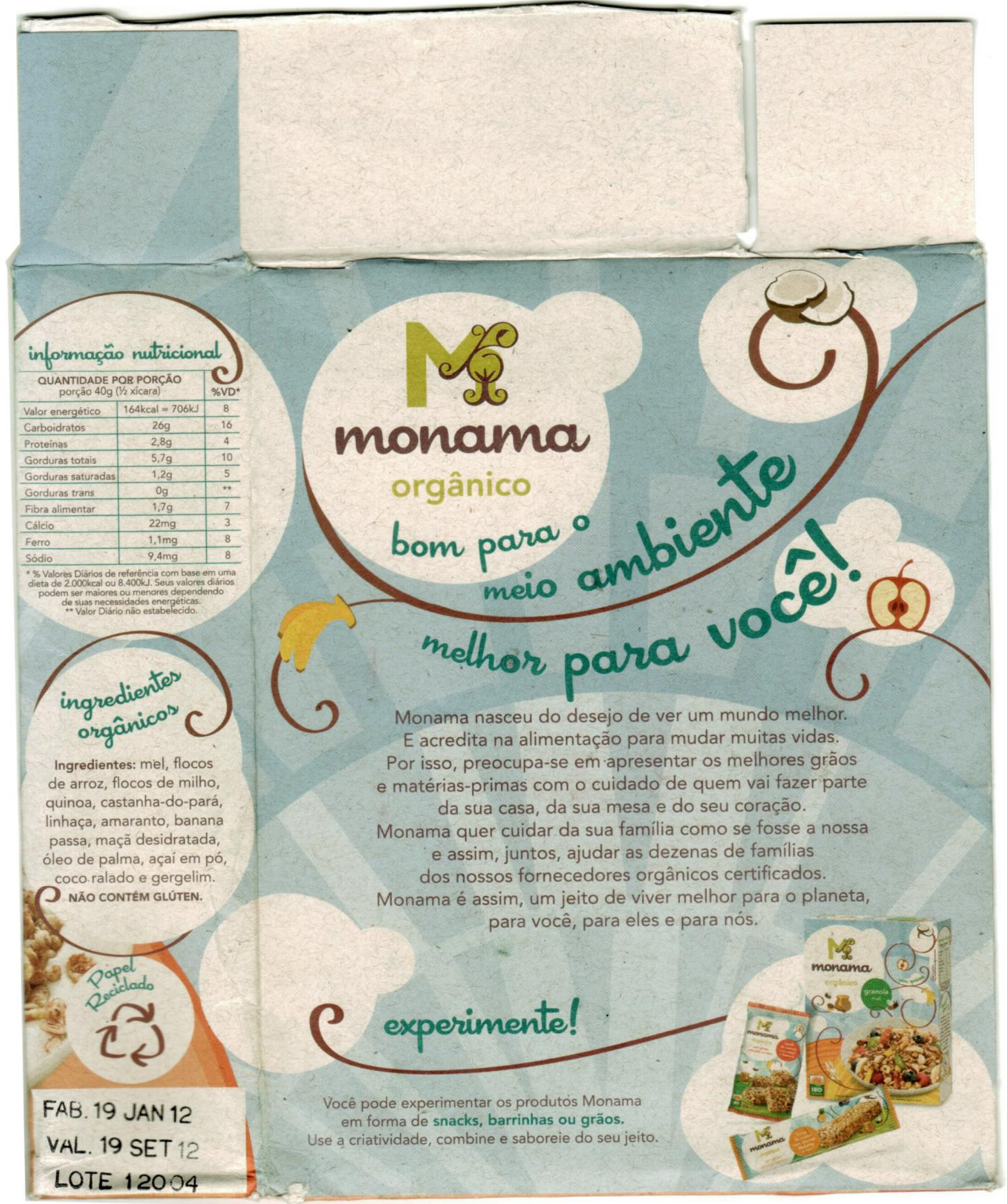


Base

da embalagem de

granola

Monama

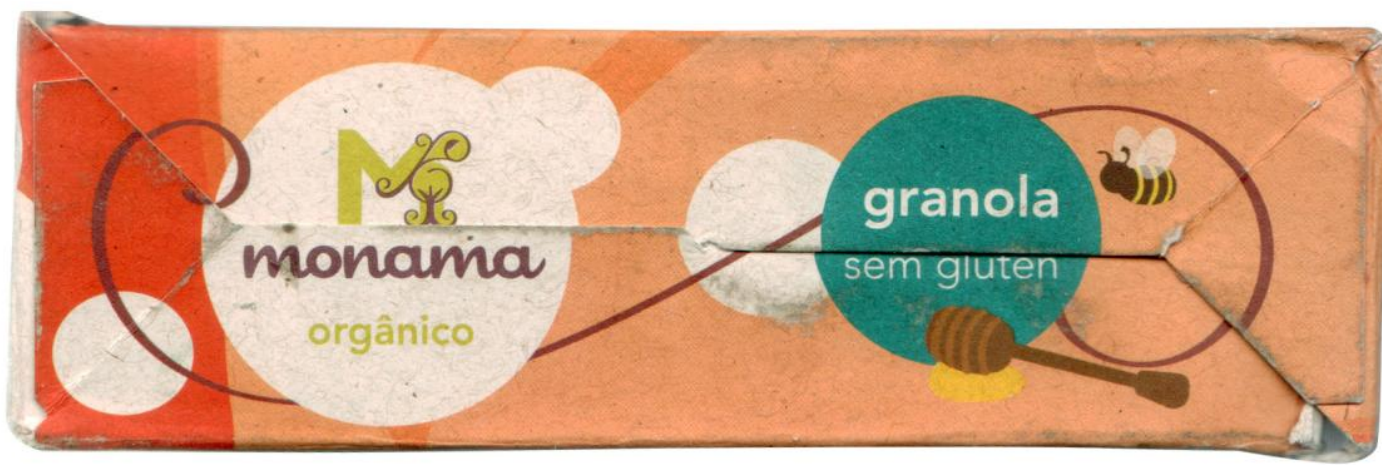




\section{EMBALAGENS VIA PAX BIO}

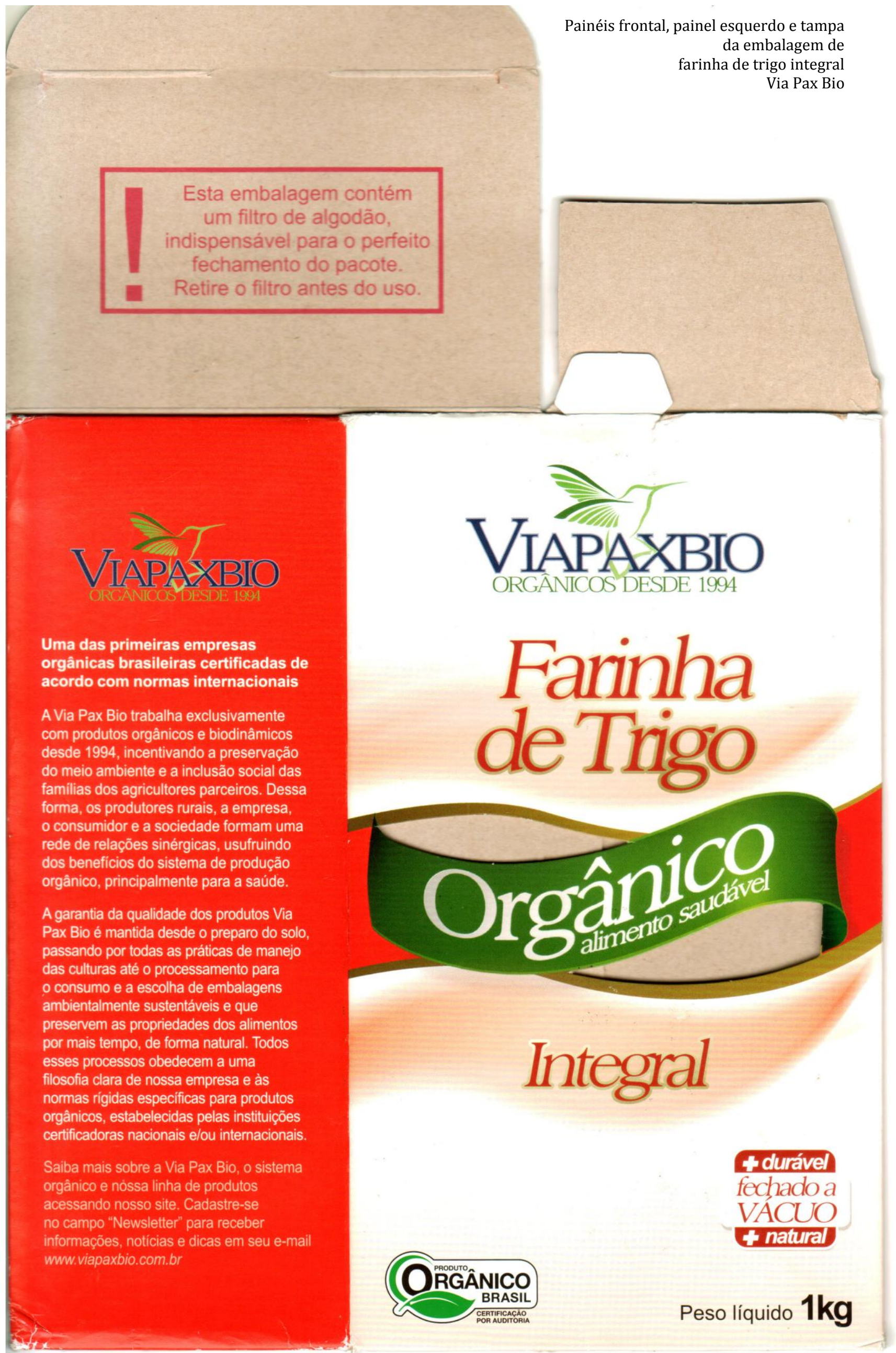


Painéis frontal, painel esquerdo e tampa

da embalagem de

farinha de trigo integral

Via Pax Bio

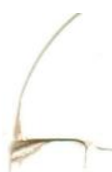

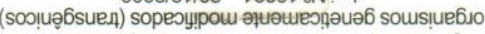

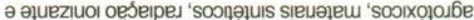

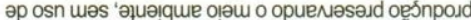

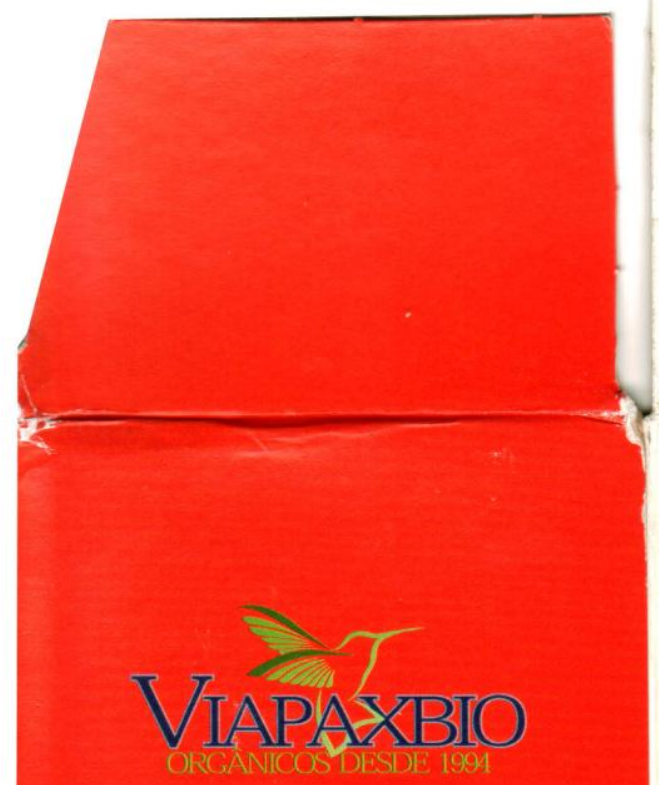

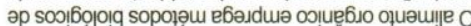

\section{OIdXYdVI}

Informações nutricionais

Cada $20 \mathrm{~g}$ ( 1 colher de sopa) contém em média:

Quantidade por porção

$\% \mathrm{VD}^{*}$

Valor calórico

Carboidratos

Proteinas

Gorduras totais

Gorduras saturadas

Gorduras trans

Colesterol

Fibra alimentar

Cálcio

Ferro

Sódio

Potássio

Fósforo

Tiamina

Riboflavina

*Valores diários de referência com base em uma dieta de

$2.000 \mathrm{kcal}$ ou $8.400 \mathrm{~kJ}$. Seus valores diários podem ser maiores

ou menores dependendo de suas necessidades energéticas.

"VD não estabeleciido. "'Valores nāo significativos.

Ingredientes: Farinha de trigo integral fina orgânica.

CONTÉM GLÚTEN. SEM CORANTES E SEM CONSERVANTES.

Conserve fechado, em local seco e arejado.

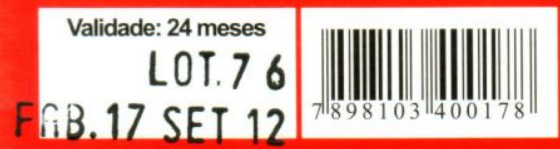

\section{A Farinha de Trigo} Integral Via Pax Bio é obtida da moagem dos grãos de trigo orgânico selecionados. Rica em proteína e fibras, a farinha integral confere mais valor nutritivo a pães, bolos e outras receitas.

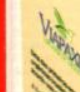

VIAPAXBIO

Farinha de Trig

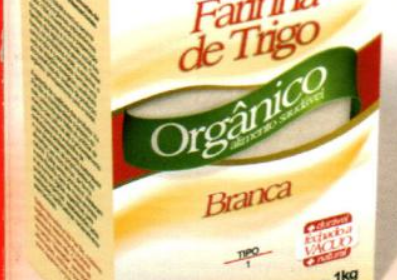

Veja mais receitas em nosso site: www.viapaxbio.com.br

Conheça também a Farinha de Trigo Branca Orgânica Via Pax Bio

\section{Biscoito de Trigo Integral Orgânico}

Ingredientes

- 6 xícaras de Farinha de Trigo Integral Orgânica Via Pax Bio

- 1 colher (chá) de sal marinho

- 1/3 xícara de mel orgânico

$-1 / 2$ xícara de castanhas

- 3 bananas orgânicas amassadas, ou 3

maçãs orgânicas raladas

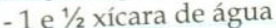

Preparo

Misture a farinha de trigo peneirada à água até a massa ficar homogênea. o sal, o mel, as bananas e por ( Colocar ultimo, as castanhas, numa fôrma untara variar pode-se acrescentar frutas secas. Bom apetite! 
Base

da embalagem de

farinha de trigo integral

Via Pax Bio

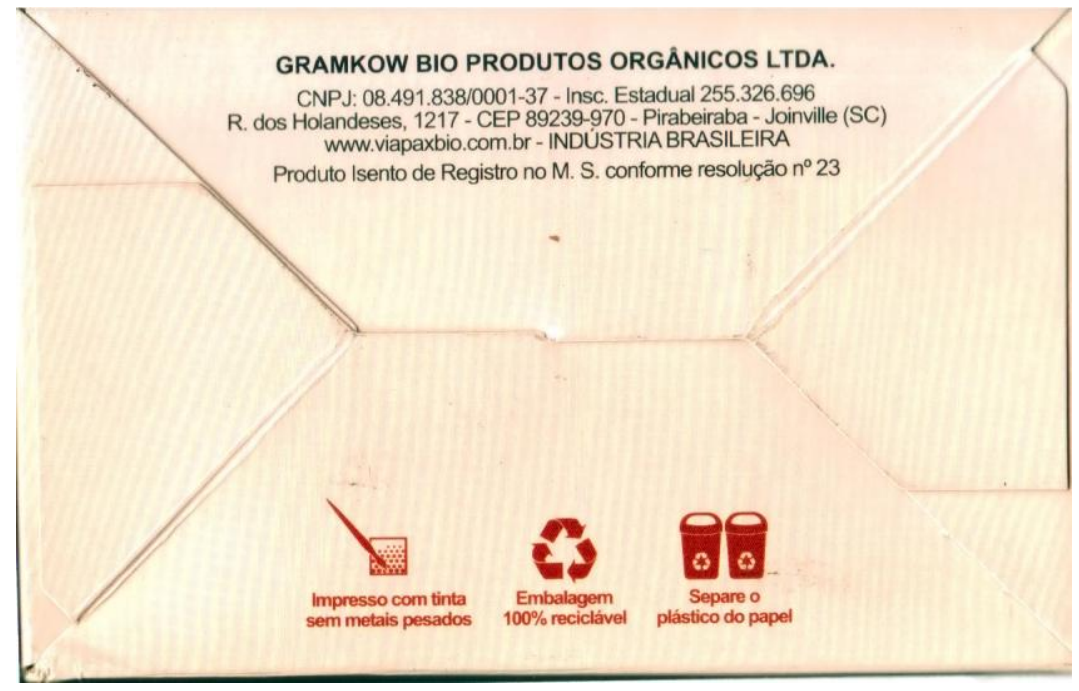

Base

da embalagem de

feijão preto

Via Pax Bio

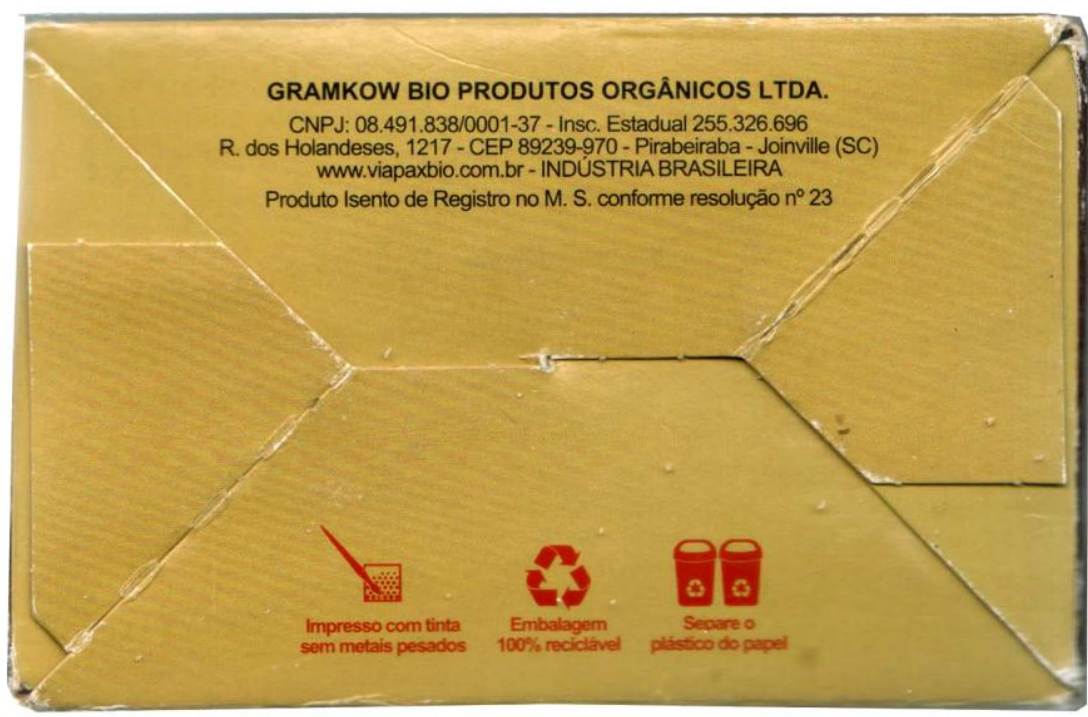


Painéis esquerdo e frontal da embalagem de feijão preto Via Pax Bio

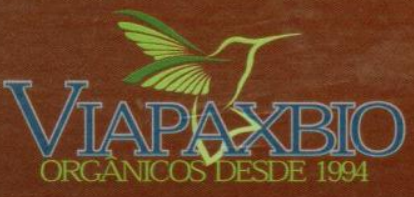

Uma das primeiras empresas orgânicas brasileiras certificadas de acordo com normas internacionais

A Via Pax Bio trabalha exclusivamente com produtos orgânicos e biodinâmicos desde 1994, incentivando a preservação do meio ambiente e a inclusão social das famílias dos agricultores parceiros. Dessa forma, os produtores rurais, a empresa, o consumidor e a sociedade formam uma rede de relações sinérgicas, usufruindo dos benefícios do sistema de produção orgânico, principalmente para a saúde.

A garantia da qualidade dos produtos Via Pax Bio é mantida desde o preparo do solo, passando por todas as práticas de manejo das culturas até o processamento para o consumo e a escolha de embalagens ambientalmente sustentáveis e que preservem as propriedades dos alimentos por mais tempo, de forma natural. Todos esses processos obedecem a uma filosofia clara de nossa empresa e às normas rígidas especíicas para produtos orgânicos, estabelecidas pelas instituições certificadoras nacionais e/ou internacionais.

Saiba mais sobre a Via Pax Bio, o sistema orgânico e nossa linha de produtos acessando nosso site. Cadastre-se no campo "Newsletter" para receber informações, noticias e dicas em seu e-mail www. viapaxbio.com.br

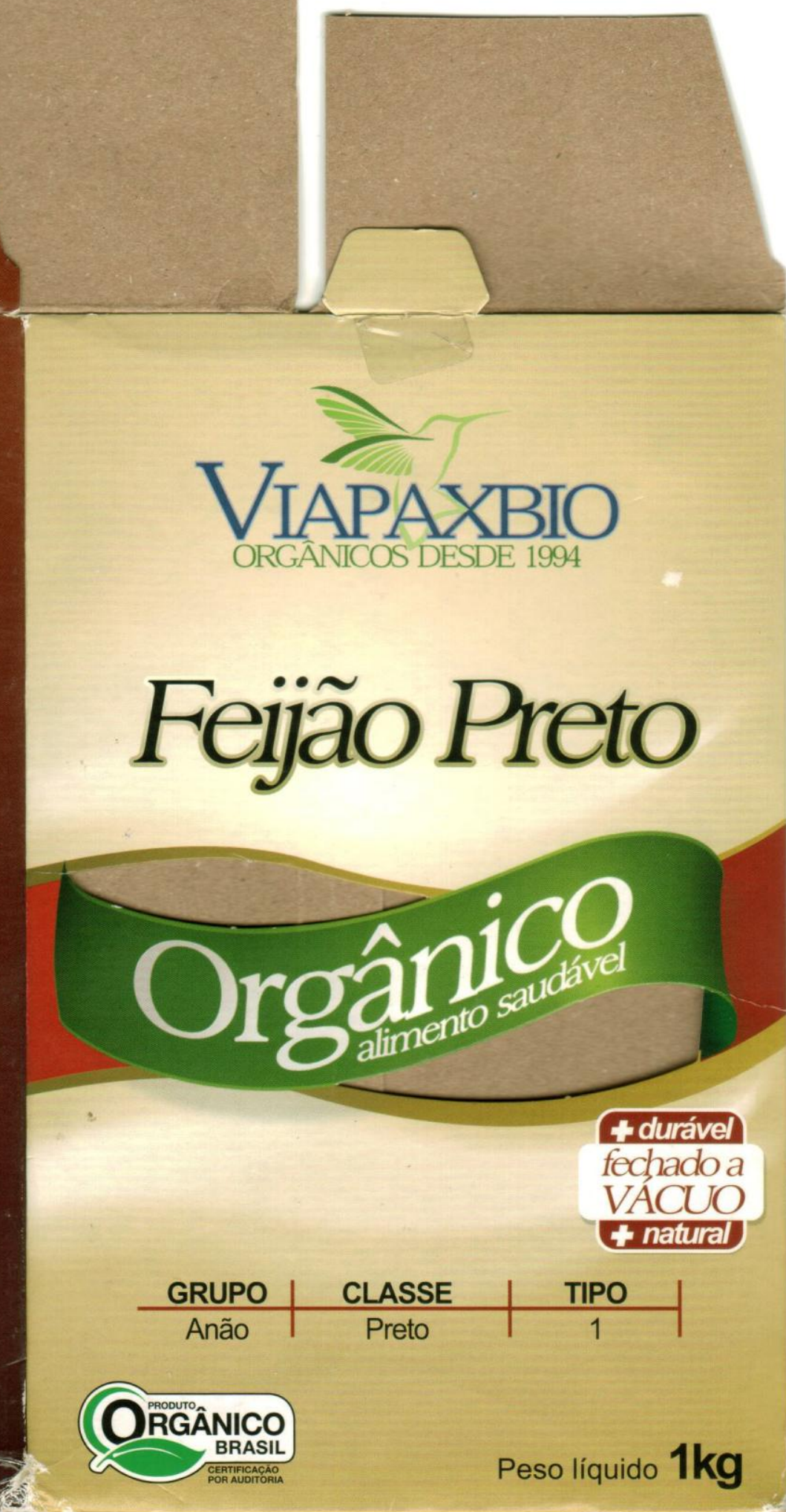


Painéis direito, traseiro e tampa

da embalagem de

feijão preto

Via Pax Bio

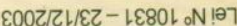

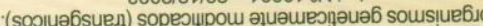

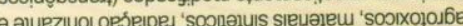

әр osn wes 'əిuəique olau o opuenesasd oésnpoud

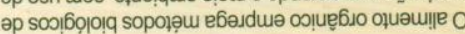

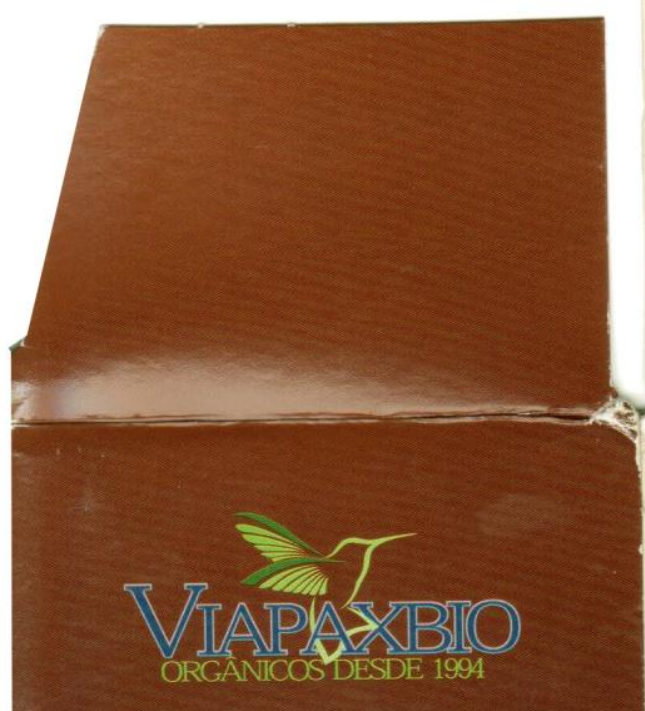

Informações nutricionais

Cada $50 \mathrm{~g}$ ( $1 / 2$ xicara de chá) contém em média:

Quantidade por porção $\% \mathrm{VD}^{*}$

\begin{tabular}{l|c|r}
\hline Valor calórico & $172 \mathrm{kcal}$ & 9 \\
\hline Carboidratos & $31 \mathrm{~g}$ & 8 \\
\hline Proteinas & $10 \mathrm{~g}$ & 19 \\
\hline Gorduras totais & $1 \mathrm{~g}$ & 2 \\
\hline Fibra alimentar & $7 \mathrm{~g}$ & 20 \\
\hline Cálcio & $73 \mathrm{mg}$ & 9 \\
\hline Ferro & $2 \mathrm{mg}$ & 14 \\
\hline Potássio & $724 \mathrm{mg}$ & 39 \\
\hline Fósforo & $235 \mathrm{mg}$ & 29 \\
\hline
\end{tabular}

* Valores diários de referência com base em uma dieta de $2.000 \mathrm{kcal}$ ou $8.400 \mathrm{~kJ}$. Seus valores diários podem ser maiores ou menores dependendo de suas necessidades energéticas.

Ingredientes: Feijão preto orgânico.

NÃO CONTÉM: GLÚTEN, CORANTES E CONSERVANTES.

Conserve fechado, em local seco e arejado.

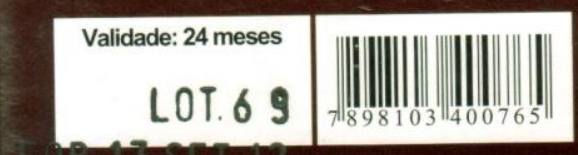

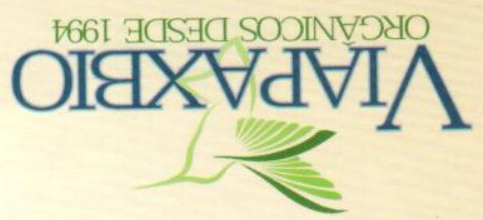

\section{O Feijão Preto Via}

Pax Bio é cultivado preservando a água e os solos das propriedades, a saúde do agricultor $e$ a sua saúde. $O$ controle das pragas $e$ doenças é feito de forma natural $e$ a integridade dos grãos é garantida naturalmente pela embalagem a vácuo. Este tipo de feijão é muito apreciado em caldos e no preparo da tradicional feijoada brasileira.

\section{visingere}
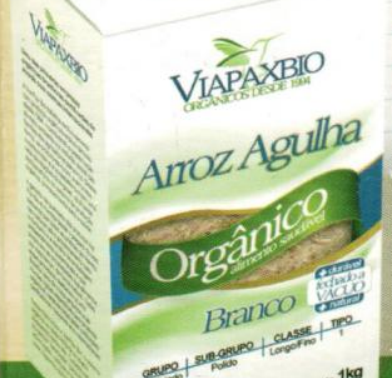

\section{Feijão Vegetariano Orgânico}

Ingredientes

$500 \mathrm{~g}$ de Feijão Preto Orgânico

Via Pax Bio

-2 beringelas orgânicas

1 pimentão verde orgânico

- 1 pimentão amarelo orgânico

- 1 abobrinha orgânica

- 3 cenouras orgânicas

- 1 couve-flor ou brócolis orgânico

- 1 cebolas grandes orgânicas

cominho (a gosto)

-1 tablete de caldo de legumes

\section{Preparo}

Cozinhar o feijão em água como de costume. Cortar os legumes em cubos. costume. Cortar ostiver macio, acrescentar Quando o feijäo estiver macio, acr mais 15 os legumes e deixar cozinhar por mais minutos ou até os legumes estarem al dente". Tempere com os temperos de sua preferência. Bom apetite!

Conheça também o Arroz Agulha Branco Orgânico Via Pax Bio E-mail:sac@viapaxbio.com.b Cx. Postal 7.240 - CEP 89239-970 - Joinville - Santa Catarina SAC 


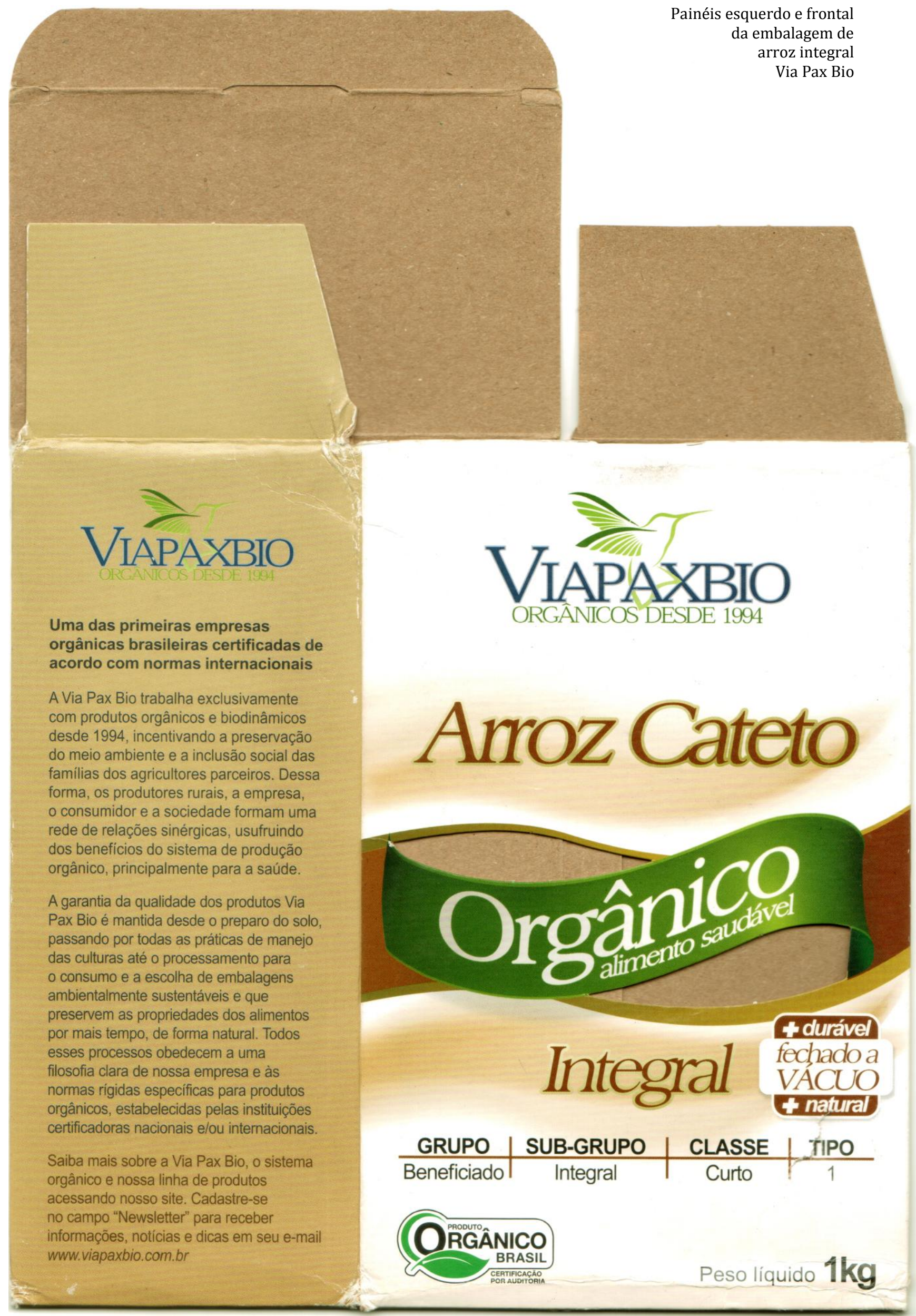


Painéis direito, traseiro e tampa

da embalagem de

arroz integral

Via Pax Bio

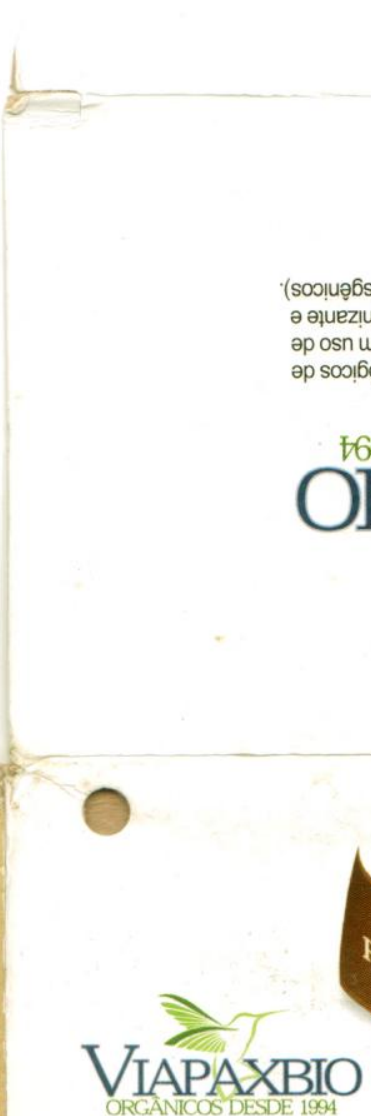

O Arroz Cateto Integral Via Pax Bio preserva o

valor nutritivo que está na película escura que reveste o grão, sendo considerado um alimento vivo. $O$ alto valor nutricional dos grãos, ricos em amido, proteínas, carboidratos e fibras e a vitalidade das sementes orgânicas são essenciais numa programação alimentar saudável. 0 arroz cateto é muito usado para risotos e na culinária oriental.

* Valores diários de referência com base em uma dieta de $2.000 \mathrm{kcal}$ ou $8.400 \mathrm{~kJ}$. Seus valores diários podem ser maiores ou menores dependendo de suas necessidades energéticas. "VD não estabelecido.

Ingredientes: Arroz cateto integral orgânico.

NÃO CONTÉM: GLÚTEN, CORANTES E CONSERVANTES

Conserve fechado, em local seco e arejado.

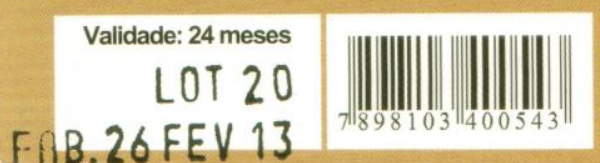

\section{visneres: \\ Jysingen}

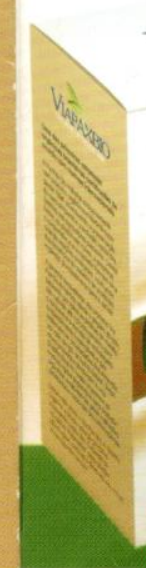

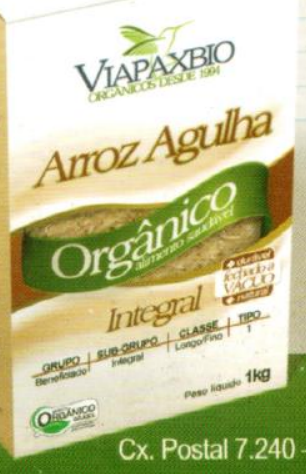

$\varepsilon 00 Z Z L / \varepsilon Z-1 \varepsilon 80 L \mathrm{~N} 127$ (5)

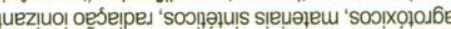

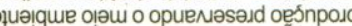

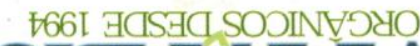
OIAXVdVI $\Lambda$

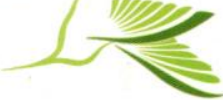

\section{Risotto de funghi}

\section{Ingredientes}

-1 litro de caldo de galinha

$-1 / 2$ xícara de funghi secchi, de preferência italianos, lavados e deixados de molho em $1 / 2$ xícara de água, por 2 horas.

- 1 cebola orgânica picada

- 2 xícaras de Arroz Cateto Integral

Orgânico Via Pax Bio

$-1 / 2$ xícara de leite

$-1 / 2$ xícara de vinho branco seco

-4 colheres (sopa) de manteiga

\section{Preparo}

Doure a cebola em 3 colheres (sopa) de manteiga. Junte $o$ arroz e frite ligeiramente. Adicione $o$ vunho e deixe evaporar. Junte o leite, mexendo vinho e deixe eva o arroz com um pouco da água dos funghi. Em seguida, passe a regar com o de galinha. Quando o arroz estiver al dente, junte os funghi, que deverão estar moles. Corrija junte os funghi, que deverano o tempero se necessario. Continue mex macio. acrescentando o caldo até 0 arroz ficar misture Apague o fogo, junte a manteiga restan bem e sirva em seguida. Bom apetite

Conheça também o Arroz Agulha Integral Orgânico Via Pax Bio

Fone: (47) 3418-0121 -mail: sac@viapaxbio.com br 
Base

da embalagem de

arroz integral

Via Pax Bio

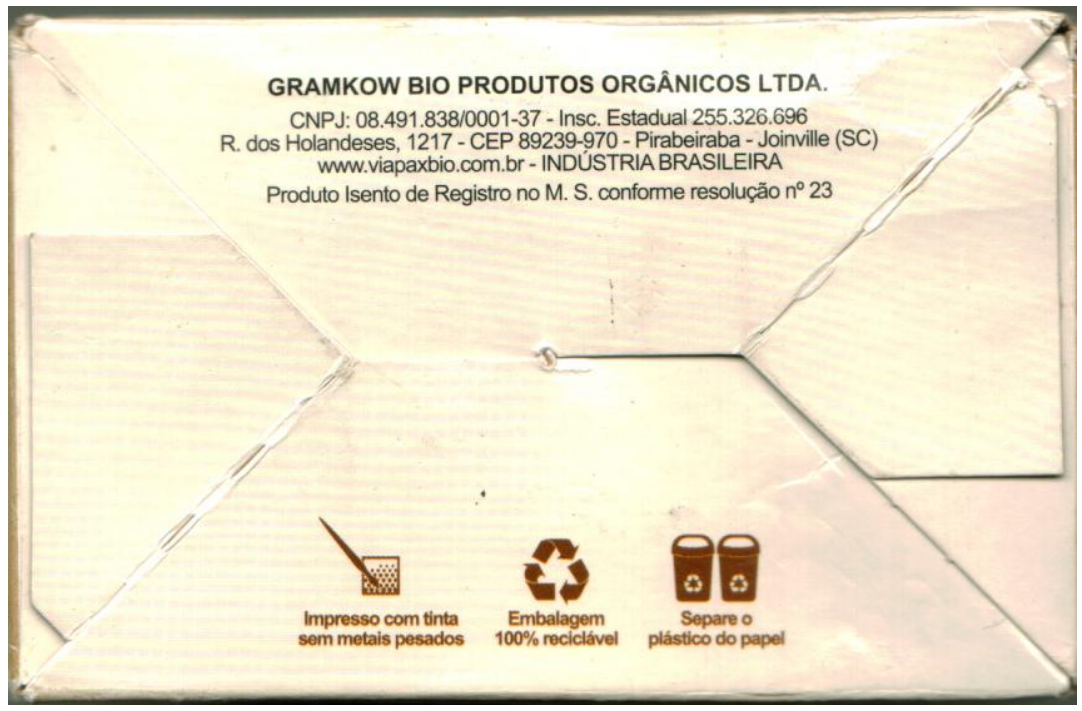

Base

da embalagem de

açúcar mascavo

Via Pax Bio

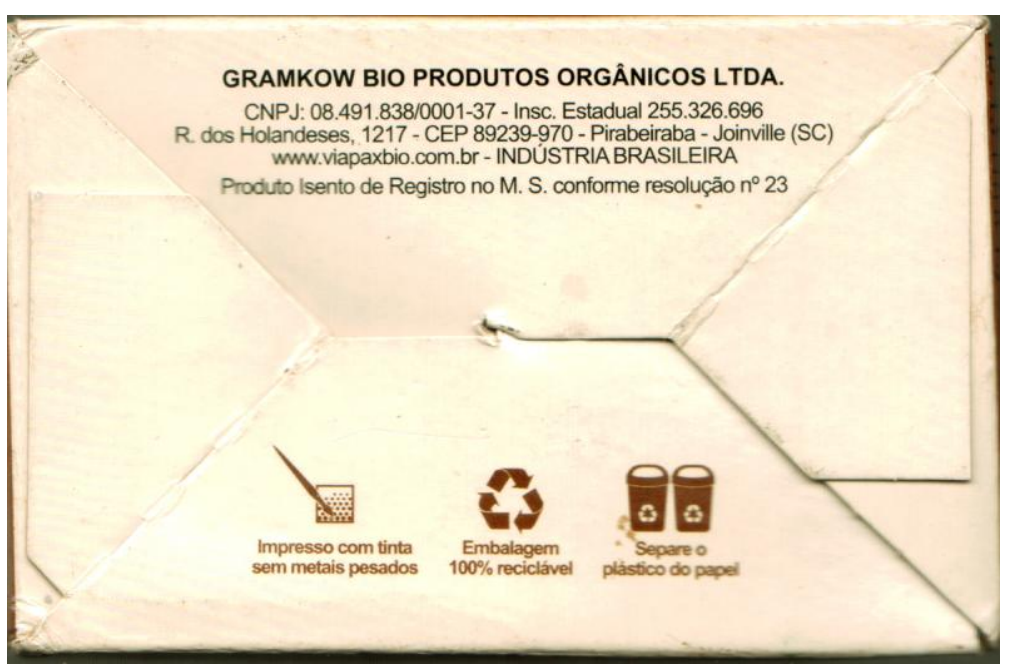


Painéis esquerdo e frontal

da embalagem de

açúcar mascavo

Via Pax Bio

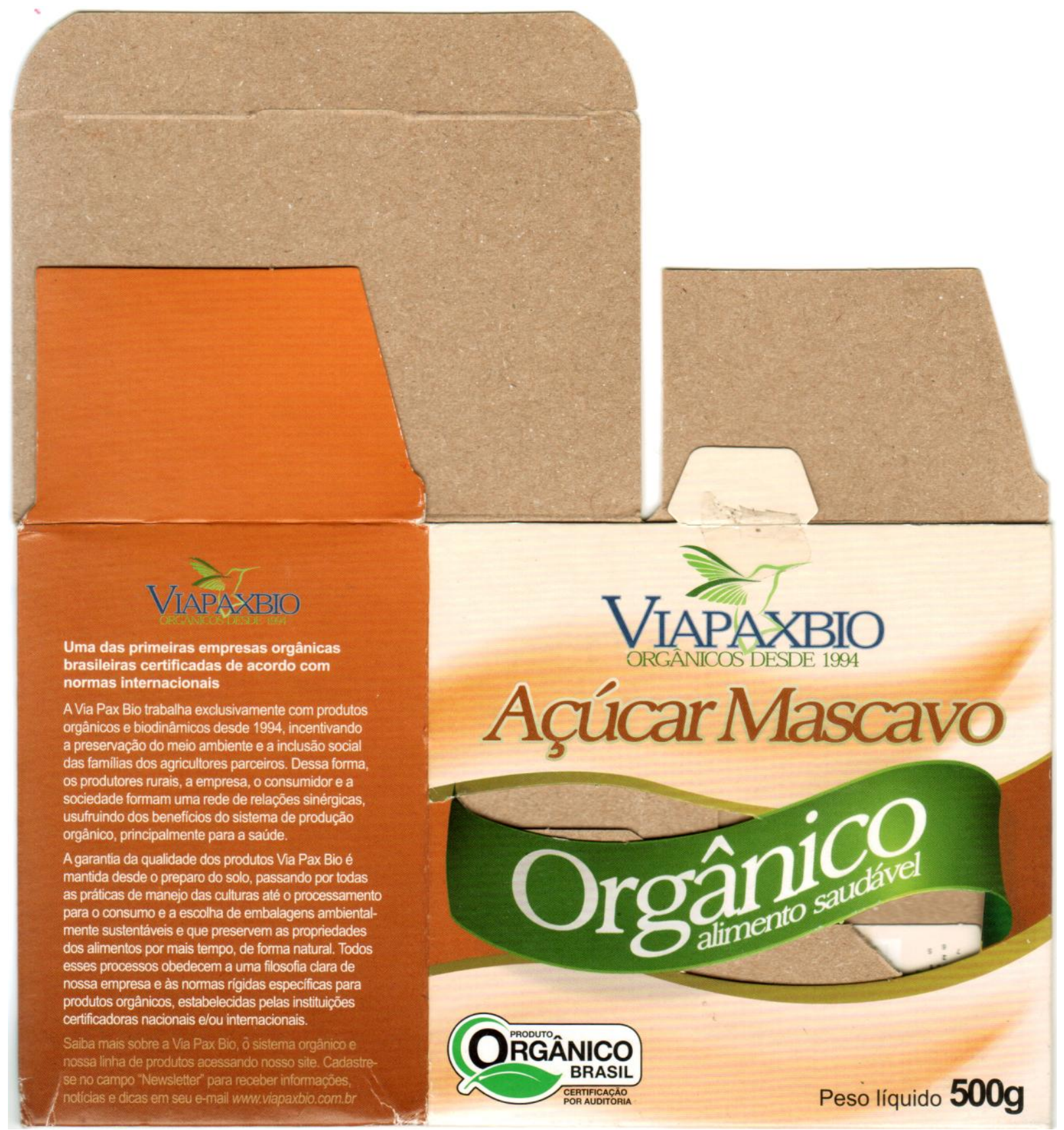


Painéis direito, traseiro e tampa

da embalagem de

açúcar mascavo

Via Pax Bio

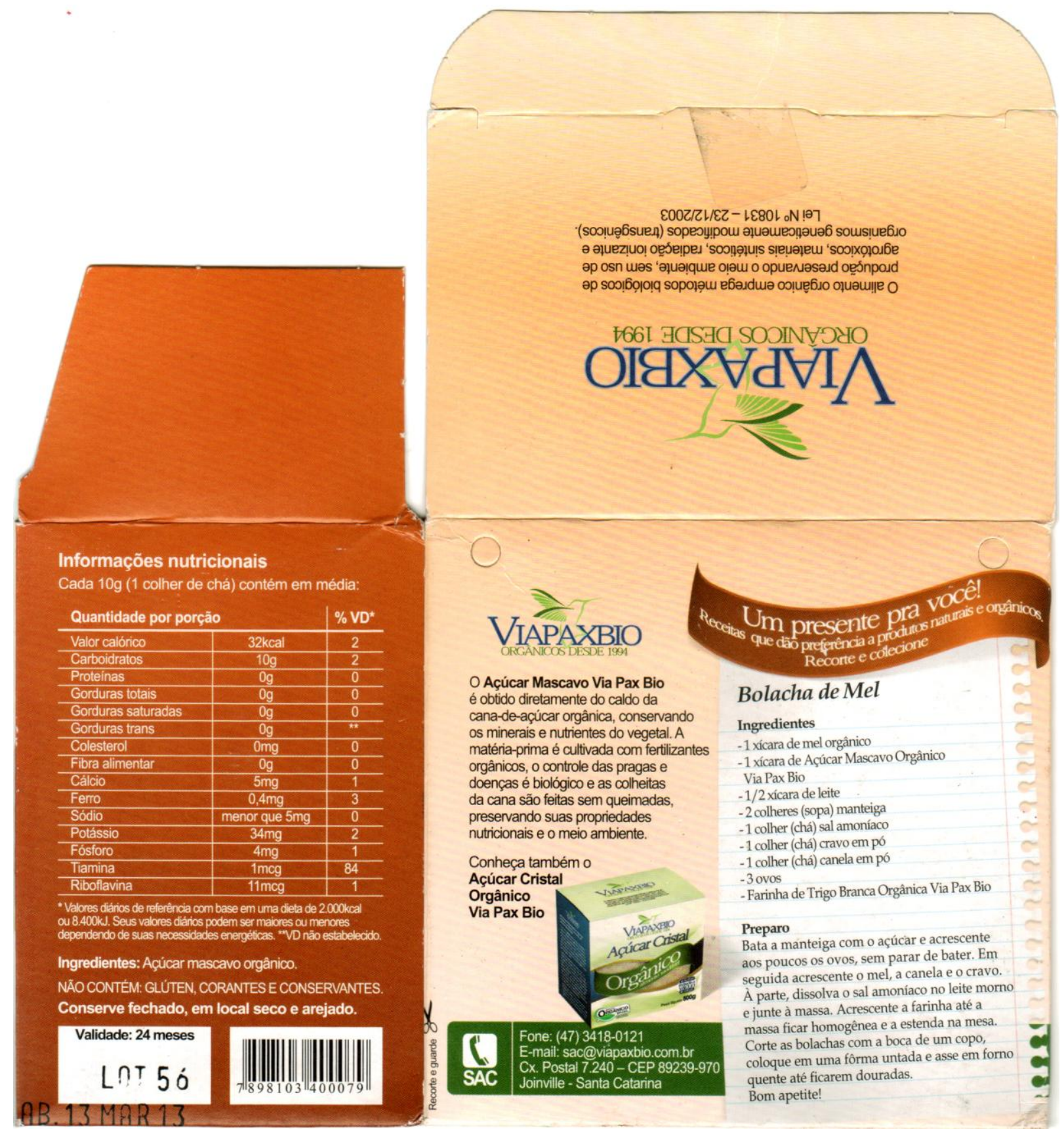

